Rodrigo Cristiano Queiroz

\title{
Oscar Niemeyer e Le Corbusier: Encontros
}

Tese apresentada para o Programa de Pós-Graduação da Faculdade de Arquitetura e Urbanismo da Universidade de São Paulo para a obtenção do título de Doutor Área de Concentração: Projeto de Arquitetura

Orientador: Prof.Dr. Lucio Gomes Machado

São Paulo 
Autorizo a reprodução e divulgação total ou parcial deste trabalho por qualquer meio convencional ou eletrônico, para fins de estudo e pesquisa, desde que citada a fonte.

assinatura:

e-mail: roqueiro@usp.br

\begin{tabular}{|l} 
Queiroz, Rodrigo Cristiano \\
Oscar Niemeyer e Le Corbusier: encontros / Rodrigo \\
Cristiano Queiroz. --São Paulo, 2007. \\
457 p. : il. \\
Tese (Doutorado - Área de Concentração: Projeto de \\
Arquitetura) - FAUUSP. \\
Orientador: Lucio Gomes Machado \\
1.Arquitetura moderna 2.Projeto de arquitetura 3.Niemeyer, \\
Oscar, 1907- 4.Le Corbusier, 1887-1965 I.Título \\
\end{tabular}


para Adal, Má e Bel 



\section{Agradecimentos}

Aos interlocutores do Rio de Janeiro:

Ana Lucia Niemeyer

Cêça Guimaraens

Ítalo Campofiorito

Maria Elisa Costa

Maria Cristina Cabral

Marlice N. S. de Azevedo

Oscar Niemeyer

Aos interlocutores de São Paulo:

Agnaldo Farias

Aline Nassarala Regino

Ciro Pirondi

Eduardo de Jesus Rodrigues

Ellen Cesonis

Francisco Segnini Jr.

Gabriel Borba

Heliana Comin Vargas

Hugo Segawa

José Tadeu de Azevedo Maia

Juliana Grenfell

Julio Roberto Katinsky

Lucio Gomes Machado

Marco Antonio Alves do Valle

Marcos Azevedo Acayaba

Maria Isabel Imbronito

Marlene Milan Acayaba

Miguel Alves Pereira

Mônica Junqueira de Camargo

Nestor Goulart Reis Filho

Oreste Bortolli Jr.

Paula Katakura

Paulo Julio V. Bruna

Percival Tirapeli

Rafael Perrone

Silvio Soares Macedo

Sylvio Barros Sawaya 


\section{resumo}

A leitura comparativa das arquiteturas de Oscar Niemeyer e Le Corbusier aponta para a existência de um diálogo.

Os três encontros ocorridos entre os arquitetos em 1936 no Rio de Janeiro, em 1947 em Nova York e 1955 em Paris prestam-se como cenário para uma troca de experiências estéticas caracterizada por uma relação de influência e contra-influência.

Nos projetos que sucedem seu primeiro encontro com Le Corbusier na cidade do Rio de Janeiro em 1936, Niemeyer estrutura sua própria linguagem no instante em que, expande à escala do edifício, os elementos de caráter compositivo que Le Corbusier preserva internos a um esquema plástico-gráfico de matriz pictórica.

A crescente emancipação da forma de traçado curvilíneo com relação aos pressupostos puristas apregoados por Le Corbusier em seus projetos realizados durante a década de 1920, além de representar a autonomia formal da arquitetura de Oscar Niemeyer, sinaliza uma perspectiva plástica para a própria obra de Le Corbusier, justamente no momento em que o arquiteto franco-suíço, em 1947, na cidade de Nova York, é apresentado, pelas mãos do arquiteto brasileiro, às fotografias dos edifícios da Pampulha.

No início de 1955, ano em que inicia uma severa auto-crítica com relação aos seus procedimentos projetuais, Niemeyer realiza sua primeira viagem à Europa e reencontra Le Corbusier, dessa vez, no atelier do "mestre" em Paris. Ao ser apresentado aos estudos de Le Corbusier para os palácios de Chandigarh, Niemeyer encontra o nexo entre síntese plástica e monumentalidade que será incorporado em seus projetos para os palácios de Brasília.

Oscar Niemeyer arma seu universo estético a partir de um raciocínio dialético que oscila entre o respeito e a ruptura com relação aos postulados corbusianos. Ao extravasar a dimensão expressiva da plástica arquitetônica para além dos parâmetros reguladores dos modelos de Le Corbusier, Niemeyer revigora os sentidos da superfície, da forma e do espaço na arquitetura moderna, assimilando o projeto como um desenho da própria paisagem. 


\section{abstract}

The comparison between Oscar Niemeyer's and Le Corbusier's architectures points out to the existence of a dialog.

The three meetings that took place in Rio de Janeiro in 1936, New York in 1947 and Paris in 1955, provides a scenario for an aesthetic interchange of experiences, characterized by a relation of influence and counter-influence.

In the works that come after Niemeyer's first meeting with Le Corbusier in the city of Rio de Janeiro in 1936, he structures his own language at the same time that he expands and reaches the building scale, the compounded elements Le Corbusier preserved inside a plastic/graphic scheme of pictorial source.

The growing curved line trace freedom with regard to the purist presupposes divulged by Le Corbusier in his projects realized during the 1920's, besides representing the formal autonomy of Niemeyer's architecture, points to a plastic perspective in Le Corbusier's own works, just in the moment when the French-Swiss architect in 1947, in New York city, is introduced, through the Brazilian architect, to Pampulha building photographs.

Early of 1955, the year he initiates a strong self-criticism of his design procedures, Niemeyer travels to Europe for the first time and meets Le Corbusier again, at the "master's" atelier in Paris. Introduced to Le Corbusier's plan for Chandigarh Palaces, Niemeyer finds the connection between plastic syntheses and monumentality, which would be incorporated in his works for Brasilia Palaces.

Oscar Niemeyer builds his aesthetic universe from a dialectical thought that oscillates between respect and rupture with regard to the Corbusian postulates. Extroverting the expressive dimension of architecture plastics to beyond the regulator parameters of Le Corbusier's models, Niemeyer revives the surface, form and space senses in modern architecture, incorporating the design project as a drawing from landscape itself. 


\section{sumário}

11 introdução

\section{o encontro de 1936: formação}

21 Ministério da Educação e Saude e a Universidade do Brasil

21 Antecedentes à segunda visita de Le Corbusier ao Rio de Janeiro

50 Segundo "O risco original de Le Corbusier"

85 Universidade do Brasil

107 Pavilhão do Brasil na Feira Internacional de Nova York

130 O Pavilhão do Brasil e a desfiguração do volume corbusiano

\section{Pampulha}

151 Cassino

162 O Cassino da Pampulha e a ruptura com o raciocínio pictórico de Le Corbusier

185 Casa de Baile e Hotel Resort

208 Curva sobre curva e a relação entre lâmina e plataforma

227 Iate Clube e Golfe Clube

241 Entre as "modernidades" de Le Corbusier e Lucio Costa

254 O desenho moderno e a superfície da memória

283 Igreja de São Francisco de Assis

291 Modernidade e religiosidade 


\section{o encontro de 1947: contra influência}

303 A sede da Organização das Nações Unidas em Nova York

315 A igreja de São Francisco de Assis de Oscar Niemeyer, a capela de Ronchamp de Le Corbusier e o crustáceo apanhado na praia de Long Island

329 A capela de Le Corbusier em Ronchamp e os templos de Oscar Niemeyer em Brasília

339 Os projetos de Le Corbusier e Oscar Niemeyer para os padres Dominicanos em Sainte-Baume

351 Le Corbusier e a ruptura com a membrana purista: O Carpenter Center e o Pavilhão de Congressos em Estrasburgo

367 Le Corbusier e "as premisssas de um Novo Barroco vindo de fora”

\section{o encontro de 1955: síntese e monumentalidade}

383 Do Museu de Arte de Caracas Brasília

391 Revisão crítica de Oscar Niemeyer: dos projetos realizados a partir de 1954 ao "Depoimento" de 1958

397 A viagem de Niemeyer à Europa e o encontro com Le Corbusier em Paris

403 Chandigarh e Brasília

443 considerações finais

451 bibliografia 



\section{introdução}

O extremo teor de inventividade impregnado na proficiência plástica que caracteriza a arquitetura de Oscar Niemeyer possui um elevado teor de sedução que, a primeira vista, nos afasta de sua real compreensão.

O presente trabalho se presta a tarefa de desvelar parte do raciocínio encoberto pela sombra da figura do gênio que promove a "invenção" como matriz geradora de sua arquitetura. Ao resguardar sua intensa reflexão cotidiana, que assimila a tentativa como processo de trabalho, Niemeyer compõe um personagem que sustenta seu próprio mito.

Quando adjetiva sua arquitetura como fruto de uma inspiração que remonta "a curva livre e sensual (...) que encontro nas montanhas de meu país" e no "corpo da mulher preferida", Niemeyer preserva incógnito o eixo estruturador de sua própria linguagem.

Algumas das indagações que instigaram a proposição da tese emergiram das dúvidas que permaneceram suspensas após o término de minha Dissertação de Mestrado, intitulada O Desenho de um Processo: os estudos de Oscar Niemeyer para o edifício do Congresso Nacional de Brasilia ${ }^{2}$.

Os estudos de Niemeyer para o Congresso Nacional, nem de longe, lembram o vigor e a síntese característicos dos desenhos que ilustram suas publicações e conferências, mas representam a intensidade da dúvida, do erro, presentes em desenhos onde a linha pura e contínua - típica da certeza presente na obra pronta - dá lugar a uma sucessão de esboços sobrepostos, onde a angústia da tentativa deixa aflorar, não mais a representação de um projeto concluído e depurado pelo tempo, mas um meticuloso processo de trabalho.

Nesses estudos, Niemeyer percorre em revista sua própria obra, em um exercício especulativo sobre diversas soluções aplicadas em projetos anteriores, como os volumes trapezoidais para as assembléias, à semelhança do próprio auditório do Ministério da Educação e Saúde, e as coberturas

1. Fragmentos do "Poema da Curva" in Minha Arquitetura (NIEMEYER, 2000:17)

2. QUEIROZ, Rodrigo C. O Desenho de um processo: os estudos de Oscar Niemeyer para o edifício do Congresso Nacional de Brasília. São Paulo, Dissertação de Mestrado, ECA-USP, 2003. 
côncavas, que recuperam gestos presentes em projetos como o Fluminense Iate Clube (1945) e a Biblioteca do Centro Tecnológico da Aeronáutica em São José dos Campos (1947). Por outro lado, em alguns esboços para o Congresso Nacional, Niemeyer lança mão de soluções formais que só seriam incorporadas de maneira definitiva em sua obra em projetos posteriores à experiência em Brasília, como a torre, cuja planta em forma de "olho" ecoará no projeto para a sede da CESP em São Paulo (1979), ou o embasamento caracterizado como um tronco de pirâmide raso, solução que encontrará rebatimento no Memorial JK em Brasília (1980).

A exaustiva reflexão sobre a relação entre forma e paisagem, revelada no conjunto de desenhos para o Congresso Nacional de Brasília, inspirou uma leitura sobre a obra de Oscar Niemeyer que tende a assimilá-la como conseqüência não apenas da mera "invenção", como apregoa o próprio arquiteto, mas como um modo de raciocínio pessoal, alicerçado por um exercício consciente de projeto inerente ao métier da profissão, instrumentalizado pelo seu próprio universo metodológico.

É evidente que, ao apontarmos para uma lógica criativa resguardada por trás da "invenção", não destituímos a obra de Niemeyer de sua incontestável potencialidade sensível, geradora de uma das maiores manifestações estéticas do século XX e que adentra o século XXI com uma intensidade de produção jamais vista em seus 73 anos de atividade profissional.

A primeira linha de raciocínio que estrutura a tese parte do cruzamento de algumas indagações que identificam, nos trabalhos de Oscar Niemeyer realizados no período compreendido entre os projetos para a Sede do Ministério da Educação e Saúde no Rio de Janeiro (1936) e os palácios de Brasília (1956/1960), um exercício projetual caracterizado pela livre interpretação do legado arquitetônico de Le Corbusier.

A leitura comparada das obras de Oscar Niemeyer e Le Corbusier, inseridas em um contexto espaço/tempo, nos permite estabelecer conexões que sinalizam para a existência de um diálogo construído por uma relação de influência e contra-influência.

A aferição dos procedimentos de projeto em ambos os arquitetos é balizada pela análise de duas trajetórias profissionais que se cruzam em três momentos distintos: nos encontros entre os arquitetos, ocorridos em 1936, na cidade do Rio de Janeiro, em 1947, na cidade de Nova York e em 1955, em Paris.

A análise cronológica das transformações ocorridas nos projetos de Oscar Niemeyer compreendidos entre 1936 e 1960, sinaliza para uma hipótese que enquadra grande parte da obra do arquiteto carioca realizada nesse período como uma incorporação autoral do vocabulário formal especulado por Le Corbusier em suas três fases: os exercícios acerca do purismo (1919/1929), o diálogo com o vernáculo (1930/1946) e a nova dimensão da expressão plástica associada a noção de arquitetura como monumento (1947/1965).

As questões levantadas na tese configuram-se como possibilidades de percepção que subsidiam uma leitura crítica sobre as obras de Oscar Niemeyer e Le Corbusier.

Como convite à leitura, apresentamos as cinco questões principais que sintetizam a tônica do trabalho: 
- A gênese plástica da arquitetura de Oscar Niemeyer pode ser compreendida como uma interpretação dos estilemas formais corbusianos?

- É possível formular uma leitura que aponte para a existência de uma metodologia de projeto em Niemeyer, estruturada pelo arranjo de um conjunto de formas (inspiradas no vocabulário corbusiano) que são agenciadas segundo uma estratégia de organização espacial?

- O projeto de Niemeyer para o Conjunto Arquitetônico da Pampulha (1940/1943) representa não apenas um exercício interpretação dos projetos puristas de Le Corbusier, mas também o instante de cisão com os ensinamentos do "mestre"?

- Poderia o projeto do Conjunto da Pampulha, juntamente com alguns projetos de Niemeyer realizados até 1955 , ter contribuído para o redirecionamento plástico da obra de Le Corbusier, diagnosticado nos projetos realizados entre 1947 e 1965 ?

- Os projetos de Oscar Niemeyer realizados a partir de 1955 (tomemos como exemplo os próprios palácios de Brasília), além de representarem a síntese de um exercício de auto-crítica com relação a sua obra pretérita, poderiam ser compreendidos como uma interpretação pessoal das experiências de Le Corbusier que incorporavam expressividade plástica e monumentalidade, como os projetos para os palácios de Chandigarh (1951/1955)?

A tarefa de clarificar essas questões exige a adoção de uma estrutura de raciocínio balizada pelo cruzamento de dois vetores de análise e interpretação: o projeto de arquitetura e a história.

Ao cotejarmos as obras de Oscar Niemeyer e Le Corbusier, observamos a possibilidade do estabelecimento de um panorama temporal dado pelos encontros entre os arquitetos, que se prestaram como cenário de fundo para a formulação da tese.

Os encontros ocorridos em 1936, 1947 e 1955 representam os momentos definidores de um diálogo que aflora nas obras de ambos os arquitetos, cuja direção muda de sentido em cada um dos encontros.

Tanto as intervenções realizadas por Niemeyer sobre os partidos propostos por Le Corbusier para a sede do Ministério da Educação e Saúde ${ }^{3}$, elaborados em sua visita ao Rio de Janeiro em 1936, como seus projetos para o Pavilhão do Brasil para a Feira Internacional de Nova $\operatorname{York}^{4}$ (1938/1939) e para o Conjunto Arquitetônico da Pampulha (1940/1943), ilustram um retórico procedimento de respeito e transgressão com os pressupostos estéticos presentes na produção de Le Corbusier realizada entre 1919 e 1930.

Em que pese o fato da aparente obediência com relação aos códigos corbusianos como o térreo livre, a fachada livre e o terraço-jardim, no projeto definitivo para a sede do MES Niemeyer não compreende o esquema arquitetônico de Le Corbusier como uma formulação retentora da noção de liberdade. Ao contrário, o arquiteto carioca assimila a própria elementariedade das soluções corbusianas como um esquema, cuja versatilidade permite a incorporação das mais diversas intervenções, sem perder seu vínculo com o ideário moderno desenhado pelo "mestre".

3. Seja no estudo para o terreno a beira-mar, seja na versão para o terreno do Morro do Castelo.

4. Realizado em parceria com Lucio Costa 
O princípio da retícula ortogonal de pilares, que Le Corbusier desloca de soluções como o esquema Dom-ino (1914) e as vilas puristas (1920/1929) para seus estudos para o MES, é sutilmente desfigurado na solução proposta por Niemeyer e equipe, realizada após o retorno do arquiteto franco-suíço para a Europa. Ao abrir em "leque" a retícula de pilares do salão de exposições do MES - insinuando uma continuidade visual do próprio volume transparente e suspenso do salão de exposições que interseciona parte do volume trapezoidal do auditório - Niemeyer não apenas rompe com a idéia de regularidade da retícula, como inverte a lógica da relação forma/estrutura, presente tanto nos exemplares puristas de Le Corbusier, como em suas duas versões para o MES, onde a tessitura de pilares se apresenta como um diagrama gráfico organizador da forma. Na proposta de Niemeyer ocorre o inverso: o desenho do tramo da estrutura se adapta à forma do edifício. ${ }^{5}$

Mesmo no tratamento dos volumes curvilíneos presentes no térreo e na cobertura do MES, é possível aferir esse exercício de ruptura com relação ao referencial corbusiano. Enquanto Le Corbusier, em projetos com a casa Savoye (1929), concebe os fechamentos encurvados - seja no térreo, no interior do volume, ou na cobertura - como um contorno exato, dado pela eleição de formas elípticas e derivadas de segmentos de cilindros, Niemeyer, no MES, substituí a curva inspirada na geometria pura por uma construção formal dada pela concordância entre arcos alternados, conferindo um sentido de sinuosidade e movimento aos volumes que Le Corbusier preserva subordinados a um raciocínio de matriz purista. ${ }^{6}$

Essas transgressões iniciais, deflagradas na consistente participação de Niemeyer no projeto definitivo para a sede do MES, por mais sutis que possam parecer, representam os primeiros passos do então jovem arquiteto rumo a sua autonomia plástica com relação ao referencial corbusiano.

No projeto para o Pavilhão do Brasil na Feira Internacional de Nova York, Niemeyer prossegue o exercício de ruptura com os códigos corbusianos iniciado no projeto do Ministério. Se, no MES, apenas um pequeno trecho da retícula de pilares do bloco de exposições se desalinha do tramo ortogonal, no Pavilhão do Brasil toda a retícula que estrutura o bloco de exposições acompanha a curvatura em "S" do volume horizontal e suspenso.

Os pequenos volumes do orquidário e do aquário, conectados por marquise curva, dispostos no jardim interno do Pavilhão, além de expressarem uma interpretação de Niemeyer sobre o vocabulário formal corbusiano - como a forma cilíndrica conectada a marquise sustentada em um par de colunas em "V", empregadas por Le Corbusier no projeto da sede o Exército da Salvação em Paris (1929) - representam uma versão embrionária de soluções que serão retomadas pelo arquiteto brasileiro em edifícios do Conjunto da Pampulha (1940/1943). ${ }^{7}$

Em seus projetos realizados durante a década de 1920, Le Corbusier assimila as formas

5. vide figuras. 42 e 51

6. vide figura 53

7. vide figura 125 
curvas como elementos compositivos que são posicionados segundo um senso de organização regido por um campo ortogonal maior, dado pelo contorno perimetral regular da construção, seja uma simples residência, ou um projeto de escala urbana. Nesses projetos, Le Corbusier transpõe, para a escala da arquitetura, a reflexão pictórica contida em suas pinturas puristas, onde a linha curva permanece inscrita no interior da forma regular da moldura, assim como se insere a uma trama de eixos ortogonais paralelos ao limite físico da composição. Le Corbusier preserva a curva como um componente interno a uma totalidade regular, devido a sua predileção pelo volume exterior de contorno puro. ${ }^{8}$

No Pavilhão do Brasil, Niemeyer exterioriza as formas curvilíneas que Le Corbusier preservava reclusas no interior de seus esquemas puristas. Mas devemos lembrar que, mesmo no Pavilhão, essas formas curvas autônomas, representadas pelo aquário e pelo viveiro de aves, ainda comportavam-se como elementos integrantes de uma totalidade maior, ao passo que, em Pampulha, a forma curva dilata-se assumindo a escala do próprio edifício, como podemos observar, por exemplo, no projeto para a Casa de Baile.'

Nesse sentido, poderíamos dizer que Niemeyer assimila a plástica corbusiana purista como um tema que é, ao mesmo tempo, absorvido e transgredido. Será justamente esse exercício de obediência e ruptura, dado pela paulatina emancipação da forma curva com relação ao esquema regulador purista, que caracteriza o período da obra de Oscar Niemeyer compreendido entre os projetos do MES e Pampulha.

A estratégia de Niemeyer dada pela expansão, à escala do edifico, daquelas formas que Le Corbusier mantém internas a uma estrutura racional, apresenta-se como um procedimento arquitetônico sem precedentes nos projetos de edifícios isolados realizados por Le Corbusier até 1947. Nesse mesmo ano, passados onze anos da segunda visita de Le Corbusier ao Rio de Janeiro, ambos os arquitetos se reencontram em território norte-americano, na cidade de Nova York, por ocasião do projeto para a Sede da Organização das Nações Unidas.

O encontro de 1947 pode ser reconhecido como um instante de inflexão da relação "mestre/discípulo" estabelecida no primeiro encontro entre Le Corbusier e Oscar Niemeyer em 1936, no Rio de Janeiro.

Em Nova York, Le Corbusier não estava mais diante daquele interessado "aprendiz" que o acompanhou durante sua permanência em solo carioca em 1936. Encontrava um arquiteto que já gozava de certo prestígio internacional devido à repercussão do projeto do Pavilhão do Brasil em Nova York, que expandiu as divisas, não apenas de sua arquitetura, mas da própria arquitetura moderna brasileira, fato que despertou o interesse da crítica internacional, culminando na famosa exposição Brą̧il Builds, sediada nos salões do Museu de Arte Moderna de Nova York em 1943.

Nesse reencontro, Le Corbusier é apresentado, pelas mãos do próprio Niemeyer, aos proje-

8. vide figura 176

9. vide figura 205 
tos do jovem arquiteto brasileiro realizados após o encontro de 1936. Niemeyer leva à Nova York, as fotografias dos edifícios da Pampulha que, naquela ocasião, já haviam sido concluídos. ${ }^{10}$

(...) Não sei por quê, lembrei-me de outro encontro que tivemos em 1947 - em Nova York, quando Le Corbusier, examinando fotografias de meus trabalhos, comentou: 'Você faz o barroco com o concreto armado', acrescentando indulgente: 'Mas o faz muito bem' (NIEMEYER apud XAVIER, 2003:248).

Le Corbusier reconhece a inegável paternidade das soluções formais que caracterizam os edifícios da Pampulha. Por outro lado, a l atente liberdade de concepção, que transforma em edifício aqueles elementos formais que Le Corbusier relega a uma condição quase ornamental, pode ser compreendida como uma perspectiva para a própria arquitetura do mestre franco-suíço.

O projeto para o Cassino da Pampulha ${ }^{11}$ (1940) representa o exato momento da dúvida que pendula entre o respeito e a transgressão. Em um mesmo objeto, Niemeyer incorpora tanto a noção de volume puro e suspenso, estruturado por retícula interna à sua projeção - aos moldes da casa Savoye (1929) - como extravasa essa mesma membrana reguladora, ao expor o volume ovóide do salão de dança. A dilatação exterior daquelas formas anteriormente inscritas em um perímetro ortogonal pode ser aferida em projetos posteriores de Le Corbusier como o Carpenter Center em Harvard ${ }^{12}$ (1961/1964) e o Palácio de Congressos em Estrasburgo (1964). Será justamente, durante o reencontro com Niemeyer em Nova York, que Le Corbusier realiza os esboços iniciais daquele projeto que representaria uma nova perspectiva para a plástica arquitetônica em sua obra: a Capela de Notre-Dame du-Haut em Ronchamp.

O projeto para o Conjunto da Pampulha pode ser reconhecido tanto como uma interpretação autônoma dos estilemas compositivos de Le Corbusier - que são expandidos à escala do edifício - como uma resposta a própria estanqueidade redutora da expressão plástica presente nos exemplares puristas do "mestre".

Grande parte dos projetos de Niemeyer que sucedem sua primeira experiência em Belo Horizonte sintetizam uma prática caracterizada pela assimilação das soluções empregadas em Pampulha como elementos integrantes de um universo de formas adaptáveis aos mais diversos programas. Esse exercício de incorporação de soluções consagradas, à serviço de uma aparente trivialidade projetual, transforma a obra-prima em mero recurso formal polivalente.

O exaustivo redesenho do vocabulário formal lançado em Pampulha confere um certo teor de arbitrariedade a alguns projetos realizados por Niemeyer entre 1943 e 1954, cuja aparente subjetividade no emprego das formas consagradas em Pampulha sinalizava para um suposto desgaste daquelas soluções formais que, pelo menos à margem da Lagoa da Pampulha, possuíam o frescor da novidade.

10. devemos lembrar que o catálogo da exposição Brą̧il Builds (1943) apresentava parte dos edifícios da Pampulha ainda em fase de construção. O projeto para a Igreja de São Francisco de Assis não integrava o referido catálogo.

11. vide figura 485

12. vide figura 490 
Na opinião de Mario Pedrosa,

(...) iria caber a Niemeyer, o mais fecundo inventor de formas de nossa arquitetura, o inesgotável improvisador de soluções, o 'playboy' endiabrado, reagir primeiro que todos contra o demônio da originalidade e a faceirice da improvisação (PEDROSA apud XAVIER, 2003:243).

Em 1955, Niemeyer reencontra Le Corbusier, dessa vez, em seu atelier situado na rue de Sèvres 35 em Paris. Nesse terceiro encontro, a direção do diálogo retoma o sentido que caracterizou o primeiro encontro entre os arquitetos em 1936.

Em Paris, Niemeyer se debruça novamente sobre os ensinamentos do "mestre". Dessa vez, diferentemente do encontro em solo carioca - onde o "discípulo" estrutura sua linguagem, ao decifrar o potencial plástico ocultado no interior dos estilemas puristas do "mestre" - Niemeyer encontra na arquitetura de Le Corbusier o vetor de síntese para uma linguagem que, em alguns casos, se reduzia a sucessivos decalques distorcidos das soluções empregadas em Pampulha.

O itinerário compreendido pela diversidade plástica, que brotava do vocabulário formal gestado em Pampulha, à unidade, ao mesmo tempo concisa e monumental, presente em projetos como o Museu de Arte de Caracas (1955) e os palácios de Brasília (1956/1960), possui no encontro entre os arquitetos em Paris, seu seminal ponto de inflexão.

Passados dezenove anos do encontro no Rio de Janeiro, diante dos estudos de Le Corbusier para os palácios de Chandigarh, Niemeyer reincorpora o papel daquele mesmo "discípulo atento" e vislumbra uma nova direção para sua própria trajetória que, já no ano seguinte, em 1956, nos primeiros estudos para os palácios da nova capital do Brasil ${ }^{13}$, amalgamava a urgente noção de síntese plástica à idéia de monumento.

Se, por um lado, podemos aferir na obra de Niemeyer, compreendida entre os projetos do Ministério da Educação e Saúde (1936) e dos palácios de Brasília (1956/1960), um rebatimento do arcabouço formal corbusiano, por outro lado, devemos afirmar que Niemeyer confere uma autonomia estética à sua obra, justamente por desfigurar o raciocínio aplicado por Le Corbusier nas dimensões da superfície, da forma e do espaço.

Quando rompe com a tradição cubista, presente na construção plástica de Le Corbusier, Niemeyer inverte a própria lógica material da forma corbusiana que assume o volume como foco da concepção arquitetônica.

Ao tornar exposta a espessura que confere o perfil à forma - como no terraço vazado do Pavilhão do Brasil, nas abóbadas sucessivas da Igreja de São Francisco de Assis ou nos palácios de Brasília - Niemeyer transfere para a construção a tensão gráfica pertinente ao seu próprio desenho, que incorpora arquitetura, espaço e paisagem como uma coisa só. Talvez nesse diálogo com o lugar, intermediado pelo desenho, resida um possível legado eclipsado pelo gênio de Oscar Niemeyer.

13. Niemeyer inicia os projetos para os palácios da nova capital federal antes mesmo da proclamação do resultado final do concurso para o Plano Piloto, vencido por Lucio Costa em 1957. 



\section{o encontro de 1936: formação}





\title{
Ministério da Educação e Saúde e a Universidade do Brasil
}

\section{Antecedentes à segunda visita de Le Corbusier ao Rio de Janeiro}

\begin{abstract}
(...) Meu primeiro contato com Le Corbusier foi em 1936, quando convocado pelo ex-ministro Gustavo Capanema, passou alguns dias entre nós. Naquela ocasião fui-lhe útil como desenhista, fazendo algumas perspectivas para os projetos que elaborou. Recordo a maneira afetuosa com que nos distinguia e uma carta que, de volta à França enviou a Lúcio Costa, na qual, de passagem, fazia referência a meu respeito, episódio sem a menor importância, mas que naquele momento - eu vinha de sair da escola - serviu-me de grande incentivo (NIEMEYER apud CORONA, 2001:24, grifo nosso).
\end{abstract}

O projeto para a sede do Ministério da Educação e Saúde ilustra um dos episódios mais emblemáticos da arquitetura moderna no Brasil. Os dez anos, compreendidos entre o lançamento do concurso (1935) e a inauguração do edifício (1945), representam o período ${ }^{1}$ em que Oscar Niemeyer estrutura sua linguagem, em um gradativo processo de autonomia e independência em relação aos cânones corbusianos e ao legado tradicionalista de Lucio Costa.

Em 05 de julho de 1935, dezoito dias após o início do julgamento dos 34 anteprojetos para a sede do MES, a comissão julgadora ${ }^{2}$ classifica três ${ }^{3}$ projetos para uma segunda etapa: Pax de Archimedes Memória, Alfa de Rafael Galvão e Mário Fertin e Minerva de Gerson Pinheiro. Em 08 de julho de 1935, é realizada uma nova reunião dos membros da comissão julgadora, quando os membros do júri decidem que somente seriam promovidos para a segunda fase os projetos que obtivessem o mínimo de três votos.

Os projetos Pax (Rafael Galvão) e Minerva (Arquimedes Memória) obtiveram quatro votos e o projeto $A l f a$ (Gerson Pinheiro) apenas dois votos. Devido ao empate na primeira colocação, Gustavo Capanema, como quinto elemento do júri, foi convocado para dar seu voto de desempate. Curiosamente, o Ministro confia seu voto ao projeto Alfa que, até então, estaria desclassificado,

1. Nesse período de dez anos (1935/1945), Niemeyer realizará projetos que serão definidores de sua arquitetura: Obra do Berço e Maternidade (1937), Pavilhão do Brasil e Grande Hotel de Ouro Preto (1938/1939), Estádio Nacional (1940/1941), conjunto da Pampulha (1940/1943), restaurante-garagem de barcos na Lagoa Rodrigo de Freitas e Fluminense Iate Clube (1945) 2. Comissão julgadora com posta por Eduardo Souza Aguiar (engenheiro do Mesp) Natal Paladini (Escola Politécnica), Salvador Batalha (representante do Instituto Central de arquitetos), Adolfo Morales de los Rios Filho (Escola Nacional de Belas Artes) e Gustavo Capanema (Ministro da Educação e Saúde).

3. Segundo o edital do concurso, cinco projetos deveriam ser classificados para segunda fase.

21 o encontro de 1936: formação 

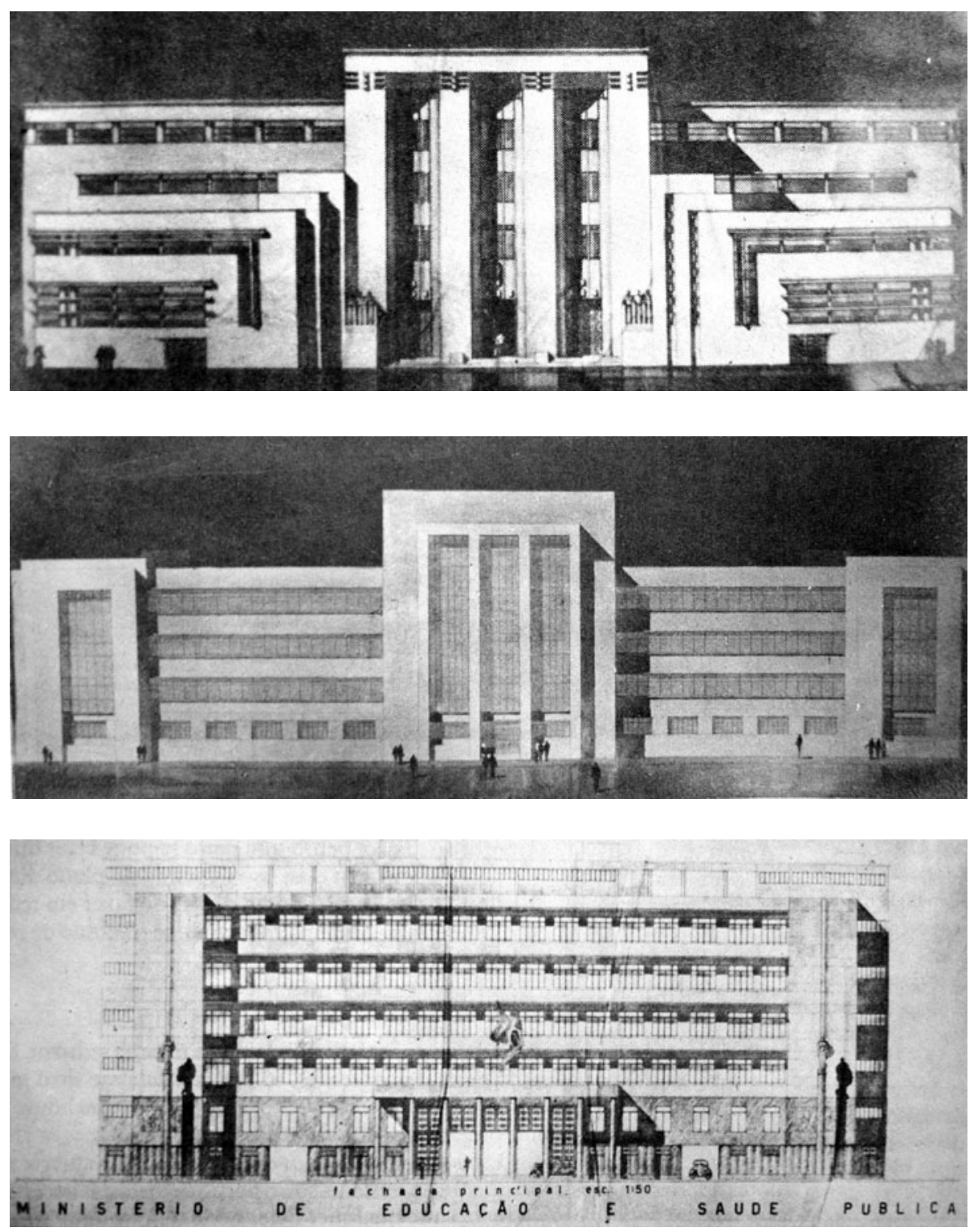

[01] Projeto para a sede do MES classificado em primeiro lugar - Arquimedes Memória - 1935 (LISSOVSKY, 1996:17)

[02] Projeto para a sede do MES classificado em segundo lugar - Rafael Galvão e Mário Fertin - 1935 (LISSOVSKY, 1996:18)

[03] Projeto para a sede do MES classificado em terceiro lugar - Gerson Pinheiro - 1935

(LISSOVSKY, 1996:19) 
mas que, com o voto de Capanema, atinge o número mínimo de votos para promoção à segunda fase. [1], [2], [3] O Ministro Capanema, com essa atitude, se exime da responsabilidade sobre a classificação dos projetos na primeira fase do concurso, além de evitar um inconveniente estremecimento nas relações com a "cúpula moderna" de seu gabinete, caso externasse predileção pelas soluções acadêmicas com feições marajoara e art decó presentes nos projetos de Arquimedes Memória e de Rafael Galvão.

Como quinto elemento do júri, Capanema possuía o poder de escolher o projeto vencedor, entre os projetos de Memória e Galvão, na primeira fase. Sua escolha pelo projeto de Gerson Pinheiro indica uma posição contrária à vigência acadêmica presente nos projetos empatados na primeira colocação. O projeto de Pinheiro era o único entre os três classificados que possuía alguma filiação com os estilemas modernos: contorno puro, ausência de ornatos e uso de pilotis. A escolha de Capanema desvia da grande evidência os projetos de aspecto acadêmico e introduz na disputa um concorrente, pelo menos em linhas gerais, "moderno".

Os meses compreendidos entre a publicação do resultado da primeira fase do concurso e a proclamação do resultado final, após a nova entrega dos três projetos para aferição em segunda fase, foram um período de turbulência. Em ata lavrada em 01 de outubro de 1935, o projeto de Arquimedes Memória é proclamado vencedor do certame e os projetos de Rafael Galvão e Gerson Pinheiro obtêm segunda e terceira colocações respectivamente. A organização do concurso sofre severas críticas por parte dos arquitetos modernos desclassificados, que publicavam sua indignação na Revista da Diretoria de Engenharia da Prefeitura do Distrito Federal.

Em setembro de 1935, são publicados na Revista da Diretoria de Engenharia da Prefeitura do Distrito Federal dois projetos com características modernas desclassificados pela comissão julgadora na primeira fase do concurso para a sede do MES: os projetos das equipes de Affonso Eduardo Reidy e de Jorge Moreira. O teor de descontentamento com relação aos procedimentos de avaliação dos projetos e ao resultado do concurso é um traço flagrante na publicação:

Foram apresentados 34 projetos, já tendo sido realizado o julgamento da primeira prova.

A comissão julgadora, entretanto, classificou apenas três projetos.

Até a presente data não foi divulgado o laudo da comissão esclarecendo as razõ es que a levaram a desclassificar os 31 anteprojetos.

Lamentamos que não tenham sido expostos os trabalhos após o julgamento, como aliás é hábito fazer-se em todos os concursos de arquitetura. A exposição, além de ser uma satisfação devida aos concorrentes e ao público, seria uma boa oportunidade para se aquilatar o grau de adiantamento de nossos arquitetos e as diversas tendências da arquitetura em nosso meio (Revista da Diretoria de Engenharia da PDF, 1936 apud LISSOVSKY, 1996:15).

Além dos projetos de Reidy e Moreira, a Revista de Engenharia publica o projeto vencedor do concurso para a Caixa de Aposentadoria de Praga ${ }^{5}$, que, apesar de ter sido contratado e exe-

4. Carlos Drummond de Andrade, Mário de Andrade, Rodrigo Melo Franco de Andrade e Manuel Bandeira.

5. Projeto de autoria de Havlicek e Honzik.

23 o encontro de 1936: formação 
cutado, adotou uma solução contrária aos parâmetros presentes no edital do concurso ${ }^{6}$. Tratavase de um exemplar ideal na árdua missão de advogar em favor da arquitetura moderna, mesmo em um concurso que indicava, pelo menos para os modernos, se encaminhar para um desfecho indesejável. Ao publicar os três projetos juntos, a Revista de Engenharia posiciona-se contrária ao privilégio de projetos com características acadêmicas pela comissão julgadora do concurso para a sede do MES e se presta como um referencial de conduta para os arquitetos brasileiros. $\mathrm{O}$ artigo vencedor do concurso para a Caixa de Aposentadoria de Praga, extraído da revista L'Architecture d'Aujourd'hui, fora traduzido por Affonso Eduardo Reidy. Segue trecho do mesmo:

As condições eram bastante penosas por ter a municipalidade fixado a forma do bloco. Este deveria ser tradicional (...) e de fisionomia acadêmica (...)

Os arquitetos sabem, por excelência, que desprezar tais disposições significa, quase sempre, naufragar com o seu projeto (...) ficamos persuadidos de que a solução funcional seria impossível sem a abolição das condições prescritas. (...) propusemos ao Instituto um projeto desprezando completamente todas aquela condições e respeitando somente o desenvolvimento natural do plano. Nossos concorrentes, arquitetos mais reverentes, temendo a recusa da municipalidade, procuraram encerrar o programa do quadro tradicional.(...)

(...) Os espaços das áreas internas, ordinariamente sombrios e perdidos, nós os damos ao público, anexando-os às ruas e parques (Revista da Diretoria de Engenharia da PDF, 1936 apud LISSOVSKY, 1996:15, grifo nosso).

A Revista de Engenharia, na época sob a direção de Carmem Portinho, adota uma estratégia precisa na tentativa de reverter o cenário configurado após o anúncio do vencedor para o MES: como não possuía poderes legais para impugnar o concurso, pautava seus argumentos na ausência de informações que justificassem a eliminação de 31 dos 34 projetos entregues para o concurso. A edição de setembro de 1935, associada ao declarado descontentamento da intelectualidade moderna que, inclusive, ocupava o próprio gabinete de Capanema, colocou o ministro em uma situação de desconforto. Ele tinha plena consciência de que o projeto vencedor não possuía as qualidades estéticas e simbólicas para representar tanto o Ministério como, principalmente, sua gestão renovadora.

Capanema, prevendo o rumo inevitavelmente desastroso do resultado do concurso e solidário à reação contrária por parte dos "modernos", convida Lucio Costa para a realização de um novo projeto para a sede do MES, antes mesmo da proclamação do resultado final. Em carta escrita em 26 de junho de $1936^{7}$, Lucio Costa informa Le Corbusier sobre a realização do projeto

6. A ocupação periférica do lote e o uso de pátio central.

7. No livro Le Corbusier e o Brasil (SANTOS: 1987,142) a carta redigida por Lucio Costa para Le Corbusier está publicada como sendo escrita na data de 26 de janeiro de 1936. Trata-se um suposto mal entendido. Em diversos trechos da carta, Lucio Costa tece comentários sobre as correspondências trocadas entre Le Corbusier e Monteiro de Carvalho, escritas em 21 e 30 de março de 1936: “(...) as sementes de que fala a Monteiro ainda não germinaram (...)”, nesse trecho, Lucio Costa se refere ao início da carta escrita por Le Corbusier para Monteiro datada de 30 de março de 1936: “(...) Teria chegado a hora em que as sementes plantadas na América do Sul começaria(sic) a germinar(...)”. Em outro trecho da carta, Lucio Costa escreve que 
a ser desenvolvido por ele, juntamente com uma equipe de cinco jovens arquitetos:

Salvo uma ou outra, talvez as sementes de que fala a Monteiro ainda não germinaram.

(...) Passaram-se quatro anos no ostracismo. Em setembro de 35 fui chamado ao Ministério da Educação.

O fato é que o Ministro Capanema tem como chefe de gabinete Carlos Drummond de Andrade: um poeta

(...) Tendo, ao que parece, tomado conhecimento de minha aventura na Escola, ele interveio em meu favor junto ao Ministro - resumindo: fui colocado em contato com este que, aborrecido com o resultado de um concurso que organizara para a construção do novo edifício de seu Ministério - o projeto classificado em primeiro lugar era simplesmente banal - encomendou-me, a mim e a outros cinco arquitetos, cujos nomes você já sabe, um novo projeto (COSTA 1936 apud SANTOS, 1987:142, grifo nosso).

$\mathrm{Na}$ carta, Lucio Costa comenta sobre o convite, ainda informal, feito em setembro de 1935. Fica assim comprovado que Capanema já articulava com Costa os procedimentos para a realização de um novo projeto, antes mesmo da proclamação do resultado final do concurso - sinal de que nenhum dos três projetos classificados representava a imagem desejada por ele para seu Ministério. Para tornar possível a realização desse projeto moderno, Capanema articulou com os diversos campos da política e da sociedade, seja na solicitação de um parecer detalhado ao engenheiro Saturnino de Brito sobre a proposta de Archimedes Memória (a fim de desqualificála tecnicamente e, assim, ter argumentos concretos para a proposição de um novo projeto); seja na intervenção junto ao Presidente Getúlio Vargas, externando a insatisfação com os projetos classificados para a segunda fase do concurso e solicitando a autorização para a contratação de Lucio Costa; seja também pelo contato feito a Lucio Costa - por indicação de Carlos Drumond de Andrade - mesmo antes do anúncio da vitória de Memória.

Em 25 de março de 1936, passados quase seis meses do contato inicial, Lucio Costa é convidado oficialmente por Capanema para a realização de um novo projeto para a sede do MES.

Para amainar a impressão de arbitrariedade que poderia ser alardeada pelo convite à Costa, Capanema já havia sugerido a montagem de uma equipe composta por arquitetos modernos. $\mathrm{O}$ argumento de que o critério para a montagem da equipe de Costa foi a escolha dos arquitetos participantes do concurso com projetos modernos pode ser questionado, na medida em que arquitetos como Olavo Redig, Attílio Correia Lima e o próprio Gerson Pinheiro, autores de projetos modernos para o MES, não foram nomes lembrados por Costa.

Lucio Costa escolhe aqueles arquitetos que, além de terem participado do concurso com projetos modernos, possuíam algum vínculo pessoal com o arquiteto.

Em depoimento concedido a Lauro Cavalcanti, Lucio Costa justifica a escolha dos

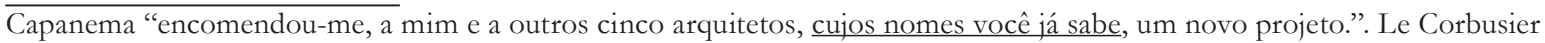
tomou conhecimento dos nomes dos integrantes da equipe que realizaria o novo projeto para o MES pela carta redigida por Monteiro, datada de 21 de março de 1936: “(...) Os dois (Lucio Costa e Carlos Leão) assim como um grupo de camaradas modernistas “à la Corbusier”, entre os quais Affonso REIDY, Jorge MOREIRA, Oscar NIEMEYER, Ernani VASCONCE$\underline{\mathrm{LOS}}$, etc. pensam que o Ministro poderia convidá-lo para dar um curso (...)”

Devido às comparações dos conteúdos das cartas, acreditamos que a data de 26 de junho de 1936, que consta no livro Colunas da Educaşão (LISSOVSKY, SÁ:1996:93), corresponda à data real do envio da carta de Lucio Costa à Le Corbusier.

25 o encontro de 1936: formação 

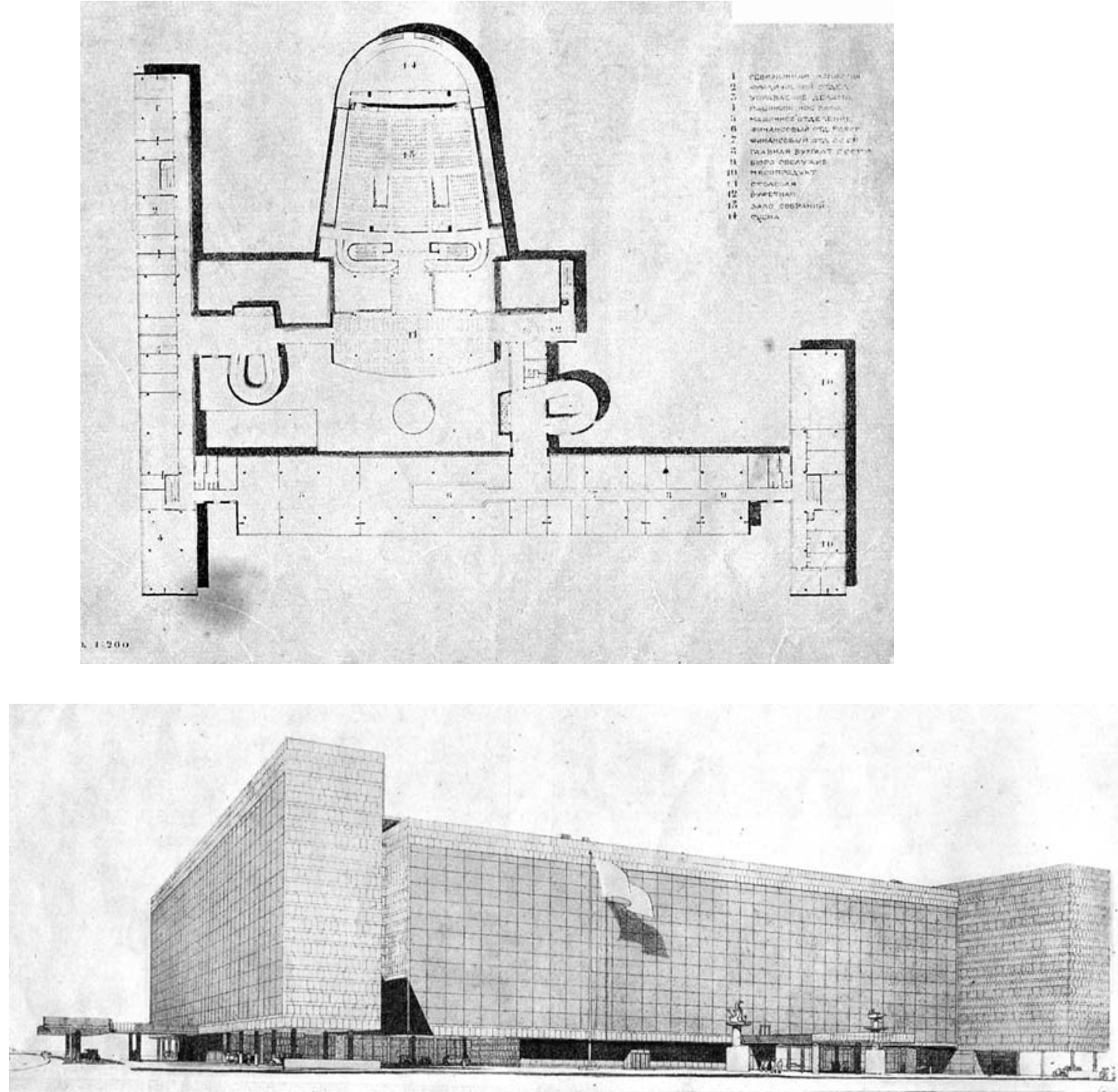

[04] Palácio Centrosoyus - Moscou - LC - planta 5o pavimento - versão preliminar - 1928/1929 (BOESIGER, 1946:37)

[05] Palácio Centrosoyus - Moscou - LC - perspectiva - versão preliminar - 1928/1929

(BOESIGER, 1946:34) 
membros da equipe que realizariam o novo projeto para o MES:

O Carlos Leão, pessoa culta e fina, chamei porque era meu sócio e amigo. Affonso Reidy e Jorge Moreira, colegas na ENBA ${ }^{8}$, haviam apresentado bons projetos. Moreira disse que só aceitaria colaborar caso viesse também o Ernani. Oscar, colaborador meu, argumentou que também mereceria estar no grupo (COSTA 1989 apud CAVALCANTI, 2006:42, grifo nosso).

O projeto elaborado pela equipe liderada por Costa, em linhas gerais, configura-se como uma variação sobre o partido arquitetônico comum às propostas das equipes de Affonso Reidy e Jorge Moreira, caracterizados por um bloco perimetral em " $U$ " com o auditório localizado no interior do pátio aberto, no eixo de simetria situado entre as alas gêmeas.

Lucio Costa e equipe preservam a configuração do "U”, mas o auditório migra do interior do pátio aberto para o exterior. Há um espelhamento do volume do auditório em seu eixo de simetria transversal. Aquilo que, em Reidy e Moreira, era um volume contido no interior do "U", na versão da equipe de Costa assume nítida presença exterior.

Os projetos de Reidy e Moreira apresentados no concurso para o MES possuem uma clara influência do projeto de Le Corbusier para o Palácio Centrosoyus em Moscou (1929). Os três projetos caracterizam-se pela implantação de três lâminas em "U" que abrigam o volume do auditório no vazio resultante da praça interior. [04], [05], [06], [07], [08], [09]

$\mathrm{Na}$ proposta apresentada pela equipe de Reidy, o desenho do "U” não é tão evidente como nos projetos de Le Corbusier e Jorge Moreira. As lâminas estão dispostas em forma de "H" assimétrico e o corredor de circulação da lâmina perpendicular está praticamente alinhado ao meio da lâmina maior.

No projeto de Moreira, o "U” formado pelas alas que abrigam as repartições é regular e o auditório - localizado no eixo de simetria da composição - possui contorno retangular, enquanto que no projeto de Reidy o auditório é caracterizado por um volume trapezoidal.

Em carta endereçada a Le Corbusier, datada de 21 de março de 1936 - quatro dias antes do convite oficial de Capanema a Costa para a realização do novo projeto do MES - Monteiro de Carvalho, arquiteto de tradicional família carioca que havia mantido contato com Le Corbusier em 1929, por ocasião de sua primeira visita ao Brasil, discorre sobre a realização de um projeto moderno para a sede do MES e sobre o projeto para a cidade universitária para a Universidade do Brasil. Nessa mesma carta, Monteiro aproveita para aventar a possibilidade de uma segunda visita de Le Corbusier ao Brasil para a realização de algumas conferências e de um possível parecer sobre o projeto dos jovens arquitetos para a Universidade do Brasil. Segue trecho da carta:

Acabo de receber a visita de um jovem arquiteto que me contou coisas muito interessantes sobre as quais prometi lhe escrever. Ele o conheceu durante sua passagem brilhante por aqui; creio que na época era ainda aluno da Escola de Belas Artes; chama-se Carlos Leão (...); ele trabalha com Lucio Costa, que para mim é o mais criativo dentre os jovens arquitetos brasileiros. Naturalmente os dois são grandes admira-

8. Escola Nacional de Belas Artes do Rio de Janeiro.

27 | o encontro de 1936: formação 

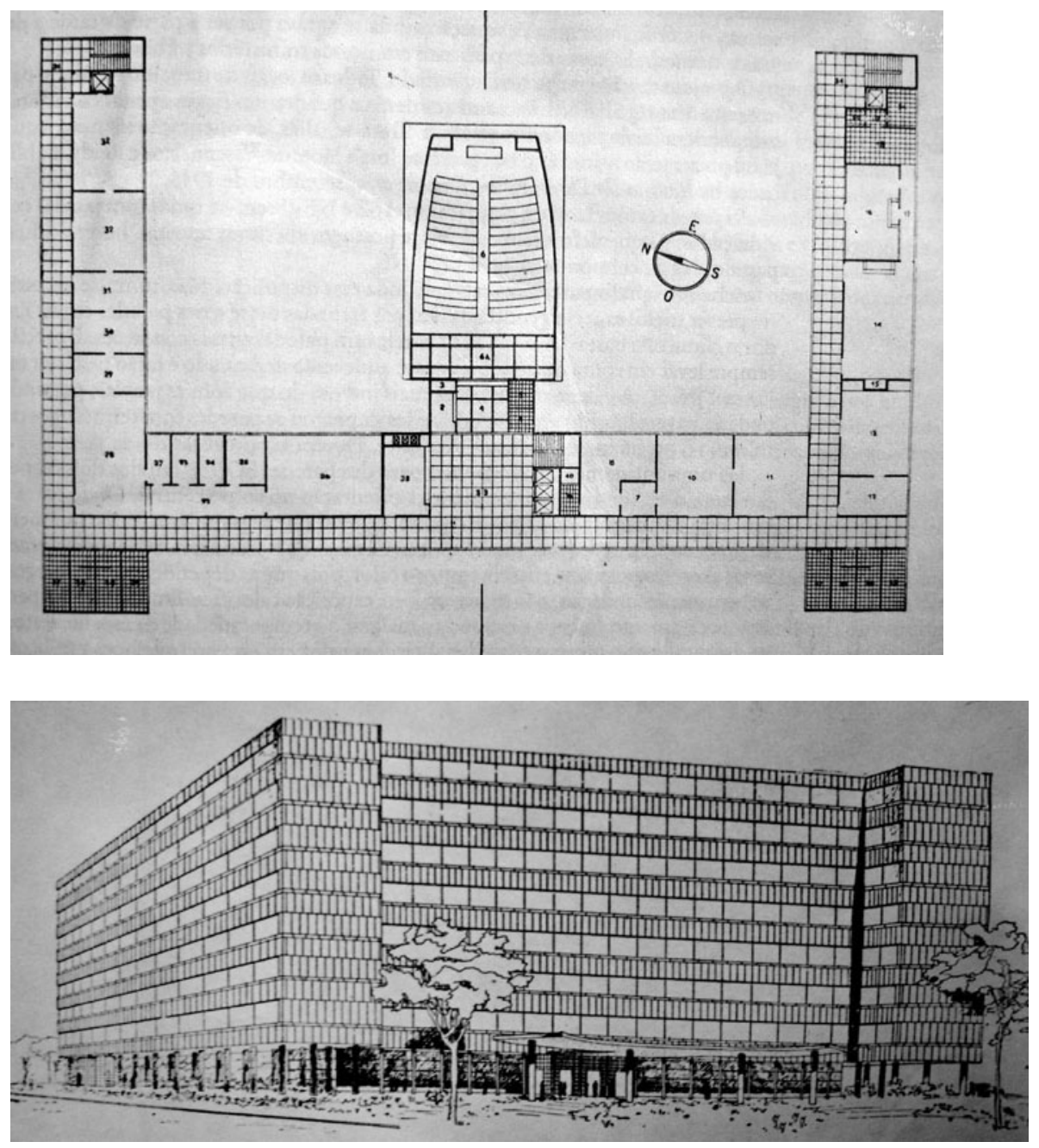

[06] Projeto para a sede do MES - concurso - Jorge Moreira e Ernani Vasconcelos - planta 3o pavimento - 1935 (LISSOVSKY, 1996:77

[07] Projeto para a sede do MES - concurso - Jorge Moreira e Ernani Vasconcelos - perspectiva - 1935 (LISSOVSKY, 1996:76) 
dores de Le Corbusier. Acabam de ser contratados para fazer o projeto do novo Ministério da Educação Pública, por que convenceram o Ministro a fazer um projeto (...). Como estão em contato com o Ministro Capanema, ao mesmo tempo em que falaram muito de você, criticaram Piacentini, que o mesmo Ministro fizera vir ao Rio para fazer o projeto da cidade universitária (...) como hoje o nacionalismo está na moda, foi votada uma lei impedindo os arquitetos estrangeiros de trabalhar aqui. (...) Os dois (Lucio Costa e Carlos Leão) assim como um grupo de camaradas modernistas "à la Corbusier", entre os quais Affonso REIDY, Jorge MOREIRA, Oscar NIEMEYER, Ernani VASCONCELOS, etc. pensam que o Ministro poderia convidá-lo para dar um curso de dois a três meses na Escola de Belas Artes e, uma vez aqui, provavelmente o Ministro pedirá também seu parecer sobre a Cidade Universitária e será mais fácil arrumar as coisas para que você possa ao menos dirigir o projeto aproveitando os jovens brasileiros. (...) O Brasil nunca teve uma arquitetura própria; é o país ideal para uma arquitetura internacional; aliás, o espírito brasileiro está sempre aberto para receber tudo que há de bom e avançado no mundo (MONTEIRO apud SANTOS, 1987:134, grifo nosso).

Monteiro de Carvalho, em nenhum momento da carta endereçada à Le Corbusier, faz qualquer menção a uma suposta consultoria sobre o novo projeto do MES. O convite para a confecção de um parecer e a futura direção de um projeto com os arquitetos brasileiros recai sobre o projeto da Cidade Universitária da Universidade do Brasil. Carvalho apenas menciona que os arquitetos brasileiros haviam sido contratados por Capanema para a elaboração do "novo Ministério da Educação Pública” e, inclusive, já comunica sobre a composição da equipe montada por Lucio Costa, constituída por Affonso Eduardo Reidy, Jorge Machado Moreira, Ernani Vasconcelos, Oscar Niemeyer, além do próprio Lucio Costa.

Passados nove dias, em 30 de março de 1936, Le Corbusier envia uma carta a Monteiro Carvalho, na qual o arquiteto não apenas responde às suas indagações como expõe algumas condições para que sua segunda visita ao Brasil se efetive:

Fiquei muito contente com sua carta de 21 de março. Teria chegado a hora em que as sementes plantadas na América do Sul começariam a germinar?

Esta carta comporta vários pontos:

1. O essencial é minha eventual participação na construção do novo Ministério da Educação.

Você sabe que fiz o Ministério da Indústria Leve em Moscou [Palácio Centrosoyus], para 3500 funcionários (...) mas talvez não seja uma referência para o Rio de Janeiro.

(...) tendo em vista suas novas leis de proteção nacionalista, estou perfeitamente disposto a guardar o anonimato se isso puder ser útil.

2. sua carta levanta a questão da Cidade Universitária do Rio. Aí também o problema me interessa enormemente e tenho algumas idéias, (...) Ora, tenho idéias bem modernas sobre a concepcão de uma cidade universitária. Vivo constantemente com jovens de todos os tipos, conheci-os no mundo inteiro. Em minha última viagem aos USA falei nas maiores universidades do país. Conheço todas as instalações lá feitas e posso pretender que não haja arquiteto melhor preparado do que eu para levar a cabo tal empreendimento. Portanto, aqui também, minha plena aceitação das condições que vocês quiserem.

3. O último ponto de sua carta fala de um convite do Ministro da Educação para dar um curso de dois a três meses na Escola de Belas Artes do Rio. É extremamente tentador pois amo a sua cidade, mas o período é longo e creio que minha intervenção poderia ser infinitamente mais curta.(...)

Meu caro Monteiro, arranje tudo isso (LE CORBUSIER apud SANTOS, 1987:135, grifo nosso).

29 o encontro de 1936: formação 

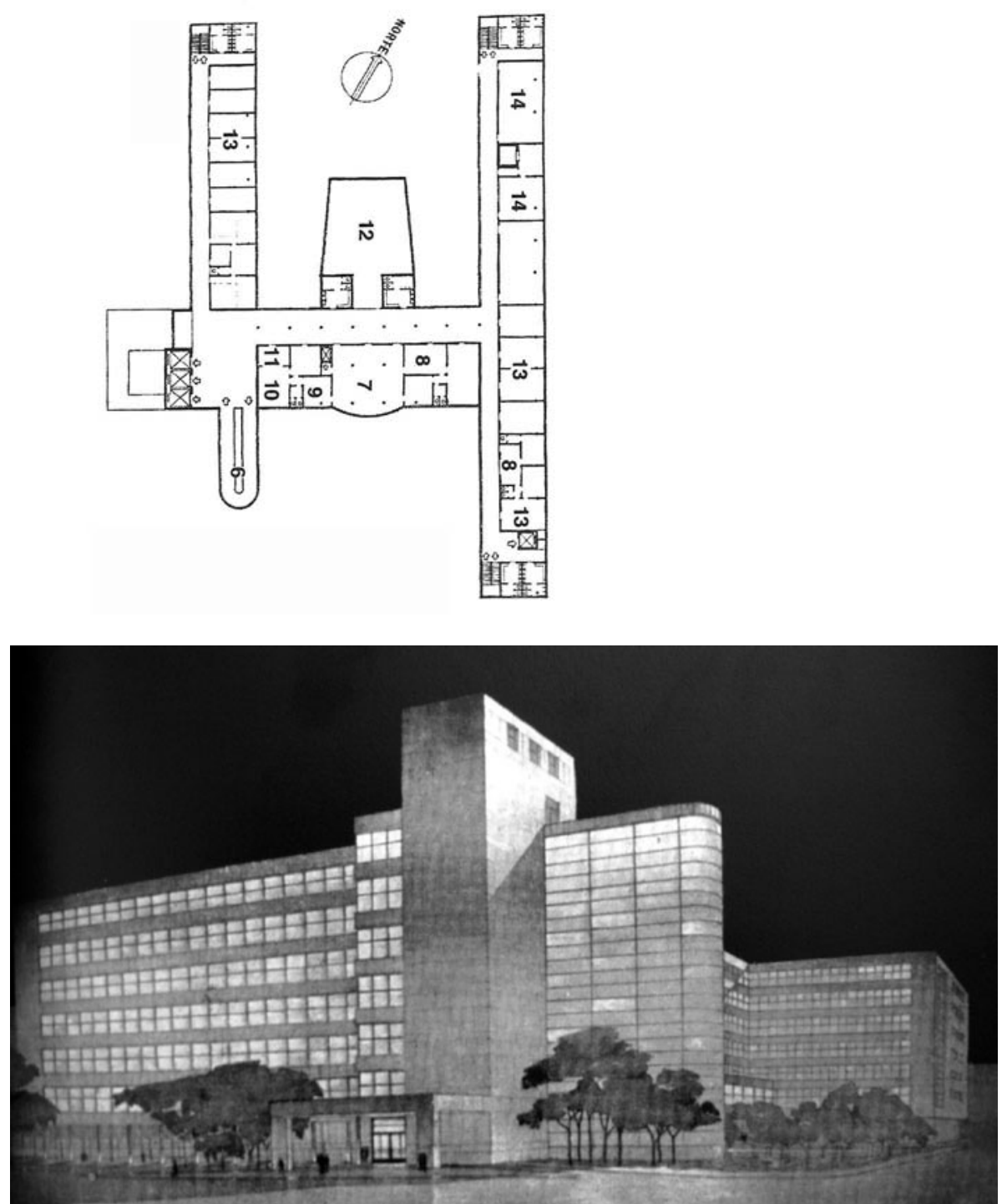

[08] Projeto para a sede do MES - concurso - Affonso Eduardo Reidy - planta 2o pavimento - 1935 (BONDUKI, 2000:50)

[09] Projeto para a sede do MES - concurso - Affonso Eduardo Reidy - perspectiva - 1935 (BONDUKI, 2000:51) 
A carta de Le Corbusier à Monteiro de Carvalho é uma revelação. Primeiramente, é possível perceber que, até então, não havia sido levantada a hipótese da participação de Le Corbusier no projeto do MES. É o próprio arquiteto que, logo no início da carta, coloca sua participação no referido projeto como condição fundamental para sua segunda viagem ao Rio de Janeiro.

Para justificar sua participação no projeto do MES, Le Corbusier demonstra sua experiência em projetos de edifícios ministeriais ao citar o projeto do "Ministério da Indústria Leve em Moscou" (Palácio Centrosoyus), porém conclui que tal projeto "talvez não seja uma referência para o Rio de Janeiro”. Certamente, Le Corbusier imaginara para o Rio de Janeiro um edifício com características opostas ao Palácio Centrosoyus.

As lembranças de Le Corbusier de sua primeira visita ao Rio de Janeiro condicionariam uma solução mais aberta e generosa, com um diálogo mais estreito com a fascinante paisagem natural carioca. Mal sabia o arquiteto que, quando chegasse ao Rio de Janeiro, se depararia com uma proposta para o MES cujo referencial era exatamente uma síntese de seus projetos para o Palácio Centrosoyus em Moscou (1928/1929) e para a Liga das Nações em Genebra (1927/1929).

Para Le Corbusier, a configuração estanque e rebatida do Palácio Centrosoyus, dada pela composição ortogonal de volumes resultantes do limite da quadra, apresentava-se como uma solução pouco apropriada para a realidade carioca.

Quanto a sua participação no projeto da cidade Universitária, Le Corbusier adota uma conduta mais direta e objetiva, dizendo ser ele mesmo o arquiteto mais bem preparado para a realização de um projeto dessa categoria, mesmo não tendo ainda em seu currículo um projeto destinado a esse fim. Para Le Corbusier, sua experiência em visitar as diversas universidades americanas o credenciava à categoria de melhor arquiteto para "levar a cabo tal empreendimento".

Como já foi observado, o arranjo tipológico-formal que caracteriza o projeto de Le Corbusier para o Palácio Centrosoyus foi a solução adotada não apenas por Reidy e Moreira em seus respectivos projetos participantes (e igualmente desclassificados) do concurso para o MES, como também foi absorvido pela equipe de jovens arquitetos formada por Lucio Costa para a realização do novo projeto.

No instante em que recebe a primeira carta de Monteiro de Carvalho, Le Corbusier ainda não havia tomado nenhum contato com as diferentes versões modernas para a sede do MES. Quando Le Corbusier, em carta de resposta à Monteiro, descarta a transposição de uma solução como a do Palácio Centrosoyus para a realidade carioca, involuntariamente, de antemão, reprova também aquelas soluções modernas propostas pelos arquitetos brasileiros para o MES ${ }^{9}$, fato que, em um futuro breve, se concretizaria.

Devemos lembrar que o referencial corbusiano que rege tanto os projetos de Reidy e Moreira, como o projeto desenvolvido posteriormente pela equipe formada por Costa, estava presente nos dois grands travaux de Le Corbusier realizados entre 1927 e 1929, caracterizados pela

9. Sejam as propostas de Reidy e Moreira, seja a proposta desenvolvida posteriormente pela equipe de Costa.

31 o encontro de 1936: formação 



[10] Liga das Nações em Genebra - trecho da implantação - LC - 1927/1928

(BOESIGER, 1946 (4a edição) :173)

[11] Liga das Nações em Genebra - planta do balcão do salão de conferências - versão preliminar- LC - 1927/1928 (BOESIGER, 1946-4a edição:165) 
articulação de volumes retangulares implantados em " $U$ " e pela utilização do volume trapezoidal do auditório.

No projeto realizado pela equipe de Lucio Costa, a suposta inversão do salão de conferências - que tanto no Palácio Centrosoyus, como nas propostas de Reidy e Moreira, encontrava-se interno ao "U" - já estava presente no projeto de Le Corbusier para a Liga das Nações em Genebra (1927/1929) que, assim com a proposta elaborada pela equipe de Costa, consistia de uma composição onde o volume trapezoidal do salão de conferências está posicionado do lado externo do conjunto formado pelos blocos perpendiculares entre si. Essa não seria a única semelhança entre os projetos de Le Corbusier e da equipe de jovens arquitetos brasileiros. Em ambos os casos, o volume trapezoidal possui sua base menor voltada para a frente da composição. O contorno em planta dos dois salões de conferências (da Liga das Nações e do estudo realizado pela equipe de Costa) é caracterizado pelas bases encurvadas secantes às laterais em diagonal, diferentemente do Palácio Centrosoyus, cuja base menor possui curvatura concordante às paredes laterais do corpo trapezoidal.

Poderíamos dizer que a inversão do posicionamento do salão de conferências, presente no projeto da equipe de Lucio Costa, não se resume ao simples redesenho das propostas de Reidy e Moreira, tributárias ao projeto de Le Corbusier para o Palácio Centrosoyus, mas deve ser compreendida como a incorporação da solução de outro projeto de Le Corbusier: a Liga das Nações em Genebra. [10], [11], [12], [13]

Em seus depoimentos, Lucio Costa e Oscar Niemeyer sempre salientaram o papel fundamental da análise da arquitetura de Le Corbusier para o desenvolvimento de seus projetos, afirmando que os textos de Le Corbusier e, principalmente, a publicação de seus projetos - seja nos periódicos internacionais, seja na coleção Le Corbusier: Ouvre Complète - foram tratados como "sagrado catecismo". Segue trecho em que Niemeyer discorre sobre o assunto:

(...) Naquela época ainda caminhávamos na periferia da arquitetura. Tínhamos lido sua obra excepcional como sagrado catecismo, mas ainda não estávamos, como se verificou, integrados nos seus segredos e minúcias. E isso explica a suficiência de mestre com que afastou logo o projeto elaborado pelo Lucio para a sede daquele ministério, uma composição em "U", adotando solução diferente, a forma linear que caracterizava a maioria de seus projetos (Niemeyer 1998:90, grifo nosso).

O primeiro volume da coleção Le Corbusier: Ouvre Complète ${ }^{10}$, com primeira edição datada de 1930, apresenta os projetos realizados entre 1910 e 1929, entre os quais, os projetos da Liga das Nações em Genebra (1927) e do Palácio Centrosoyus em Moscou (1928/1929).

Para uma melhor compreensão da adoção dessas referencias pelos arquitetos brasileiros e sua antecipada rejeição por parte de Le Corbusier, devemos analisar as transformações ocorridas na obra do arquiteto franco-suíço nesse período de tempo compreendido entre a elaboração e

10. A coleção Le Corbusier: Ouvre Complète é constituída de oito volumes que apresentam os projetos em ordem cronológica, de 1910 a 1965. Costa.

33 o encontro de 1936: formação 


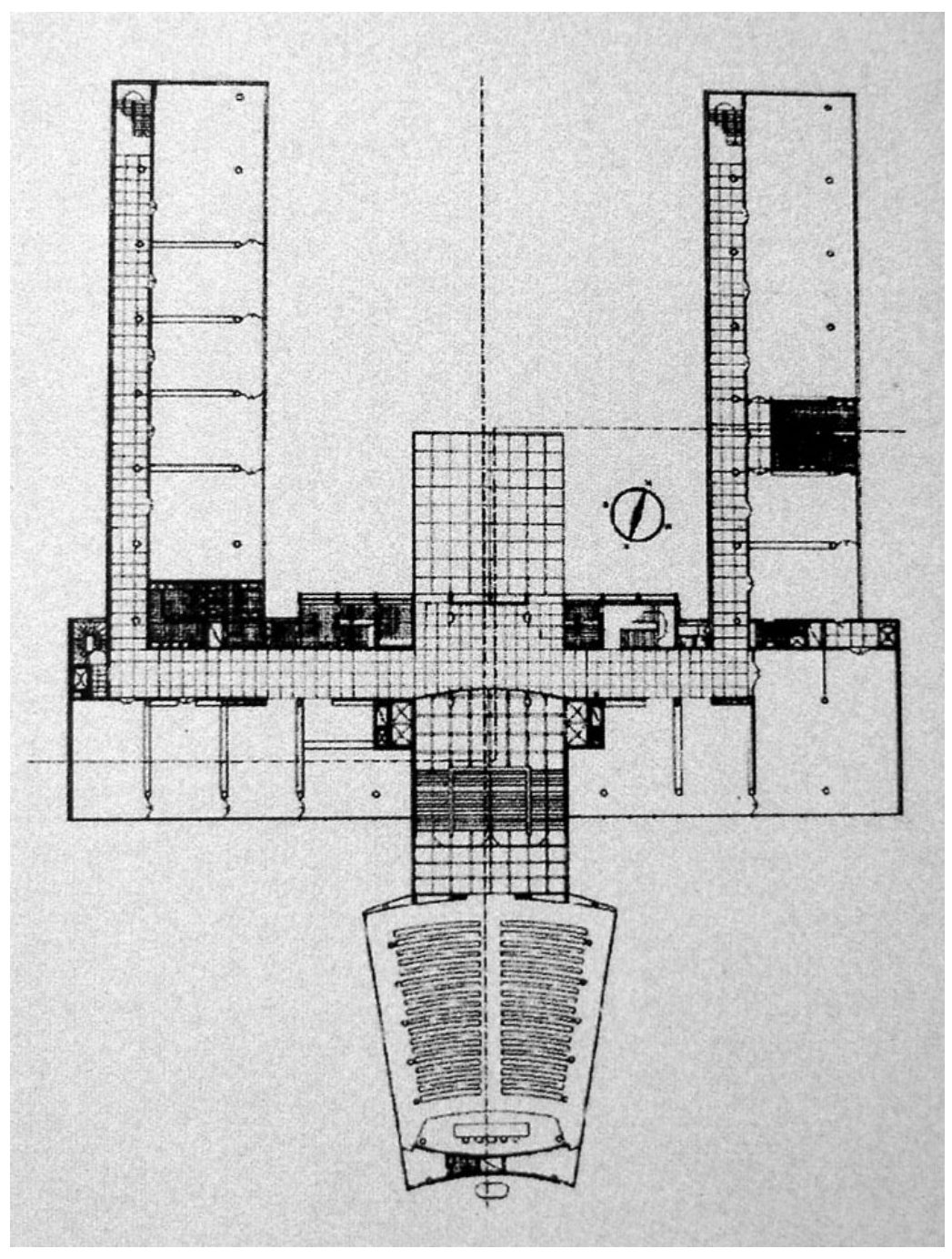

[12] Projeto para a sede do MES - concurso - Lucio Costa e equipe - planta 1o pavimento - 1935/1936 (BONDUKI, 2000:53)

[13] Projeto para a sede do MES - concurso - Lucio Costa e equipe - perspectiva praça em frente a R. Araújo Porto Alegre - 1935/1936 (BONDUKI, 2000:53)




publicação dos dois grands travaux (1927/1930) e a evolução dos projetos realizados pelos arquitetos brasileiros para a sede do MES (1935/1937).

Tanto Affonso Reidy e Jorge Moreira, em seus projetos individuais, como Costa e sua equipe no novo projeto do MES, debruçam-se sobre um referencial corbusiano que não só caracterizava os grands travaux, mas também se prestava como parâmetro para sua série de vilas puristas projetadas durante a década de 1920. Trata-se de um arranjo das formas no espaço (sejam os volumes regulares nos projetos urbanos, ou os fechamentos nas casas) dados por um senso de organização regido por um raciocínio eminentemente pictórico, onde uma estrutura formal reguladora organiza os parâmetros gráficos que balizam a composição do conjunto.

O componente liberto do conjunto (dado pela forma trapezoidal dos auditórios nos projetos de escala urbana e pelos fechamentos internos como banheiros, divisórias e caixas de escada nas vilas puristas), invariavelmente possui um posicionamento que segue os alinhamentos da membrana exterior, sejam as lâminas ortogonais nos grands travaux, seja o contorno regulador nas vilas puristas.

Alan Colquhoun, em seu ensaio intitulado As estratégias dos 'grands travaux', discorre sobre o princípio da "elementarização" presente nos projetos de Le Corbusier realizados durante a década de 1920:

O princípio compositivo essencial (Centrosoyus, Cité) é a elementarização, tal princípio distingue-os dos esquemas tradicionais com páteos internos fechados onde os volumes programáticos não são distintos uns dos outros. Nos grands travaux cada elemento do programa possui sua forma própria e é claramente distinto de seu vizinho. Os principais elementos são as lâminas ou os blocos lineares e as massas centroidais (contendo locais de assembléia). As lâminas são acopladas umas as outras em ângulos retos, formando páteos abertos (COLQUOUN, 2003:129, grifo nosso).

Para Colquhoun, nesses projetos Le Corbusier separa os componentes do programa a partir da distinção de suas diferentes intensidades plásticas: as lâminas ortogonais que abrigam os pequenos recintos do programa, ou os volumes trapezoidais que contém as grandes assembléias, chamadas pelo autor de "massas centroidais".

Devemos atentar para o fato de que os projetos de Le Corbusier adotados como referência para as diferentes versões modernas para o MES - realizadas antes de sua chegada ao Rio de Janeiro - representam um conjunto de soluções e procedimentos que, já nos primeiros anos da década de 1930, sofreriam um claro processo de transformação em três dimensões distintas, porém indissociáveis: a superfície, a forma e o espaço.

Logo nos primeiros anos da década de 1930, os projetos de Le Corbusier afastam-se de maneira gradual do estatuto tipológico-formal que caracterizou sua produção na década de 1920. O purismo estilizado das casas brancas e a organização ortogonal de peças laminares em contraste com os volumes trapezoidais das assembléias dão lugar a uma concepção estética que, paulatinamente, assimila materiais cuja natureza tátil e visual se distancia das superfícies opacas e cristalinas das casas brancas.

$$
35 \text { o encontro de 1936: formação }
$$


A partir de 1930, a forma em Le Corbusier se torna suporte para a matéria em seu estado bruto, sem o acabamento regularizador executado a posteriori, que se sobrepunha ao material de fechamento (bloco de concreto) com o objetivo de conferir um aspecto "purista" ao objeto.

Tanto em suas casas de campo (Errazuris - 1930, Mme. Mandrot - 1930-1931 e Mathes 1935), como em seus edifícios (Pavilhão Suíço na Universidade de Paris - 1930-1932, Porte Molitor em Paris - 1933, Edifício Clarté em Genebra - 1930-1932, Cité Refuge em Paris, 1932-1933) realizados a partir de 1930, a temática purista é substituída por um certo teor de rusticidade que se intensifica com o passar dos anos.

Elizabeth Harris, no livro Le Corbusier: Riscos Brasileiros, também sinaliza para esse período de transformação da arquitetura de Le Corbusier, que coincide com sua segunda visita ao Rio de Janeiro. Segue trecho:

Os primeiros cinco anos da década de 30 foram de intensa atividade. Com a Ville Savoye já em obras, Le Corbusier partiu para a planificação do Pavilhão Suíço, dos prédios de apartamentos Immeubles em Paris e das duas residências de fim-de-semana. A esse tempo começava a integrar materiais texturizados à sua arquitetura, contrastando superfícies polidas e brilhantes. (HARRIS, 1987:38).

E será justamente essa relação de contraste ente os materiais texturizados e cristalinos que caracterizará as diferentes propostas de Le Corbusier para o edifício do MES, seja na versão à beira-mar, seja na versão para o terreno definitivo.

Alan Colquhoun aponta algumas razões para a mudança presente nos projetos de Le Corbusier, ocorrida entre o final da década de 1920 e o início da década de 1930, onde a pictorialidade purista dá lugar a uma liberdade que, mesmo sutilmente, já se apropria da matéria vernácula. O autor coloca como uma das razões a suposta desilusão com os projetos de escala urbana, devido a pouca aceitação por parte dos governantes e industriais. Segue trecho do autor:

Apesar da causa imediata dessa mudança ter sido, sem dúvida, a escassez de aço no pós-guerra, ela também parece ter sido resultado de uma mudança de atitude já manifestada em seu trabalho da década de 1930. Pode-se fazer essa inferência não somente devido à introdução em suas pinturas da década de 1930 de "objetos de reação poética" - objets trouvés orgânicos e a figura feminina, mas também em razão do uso de materiais locais em seus edifícios - particularmente em uma serie de casas que projetou para áreas rurais [Errazuris, Mme. Mandrot e Mathes].

(...) parece ter sido o resultado de seu próprio fracasso em despertar o interesse do governo ou dos industriais pela produção de conjuntos habitacionais de massa (COLQUOHUN, 2003:170).

Como podemos perceber, há uma falha de sintonia entre a conduta apresentada nos projetos de Le Corbusier realizados a partir da década de 1930 e o referencial corbusiano adotado pelos arquitetos brasileiros nas diversas versões para a nova sede do MES. Fato que é compreensível se imaginarmos que, na primeira metade da década de 1930, os projetos de Le Corbusier representantes dessa "nova fase" ainda estavam em processo de execução, muitos deles ainda em desenvolvimento, motivo que justifica a suposta ausência de informação dos jovens arquitetos brasileiros que, muito provavelmente, ainda não haviam tomado contato com todos esses projetos 
da fase pós-purista de Le Corbusier.

O segundo volume de Le Corbusier: Ouvre Complète ${ }^{11}$ tem sua primeira publicação realizada em 1935, o mesmo ano em que os arquitetos brasileiros iniciam os estudos para o projeto do MES. Os projetos de Le Corbusier adotados como referenciais pelos jovens arquitetos brasileiros integravam o primeiro volume da Coleção Le Corbusier: Ouvre Complète ${ }^{12}$, que possui sua primeira edição datada de 1930, apresentando os projetos realizados entre 1910 e 1929, entre os quais, os projetos da Liga das Nações em Genebra e do Palácio Centrosoyus em Moscou, mas que, segundo Le Corbusier, "talvez não seja uma referência para o Rio de Janeiro".

A aferição das datas das publicações dos dois primeiros volumes de Le Corbusier: Ouvre Complète indica um distanciamento de seis anos entre as edições. Fato que, em princípio, nos permite supor que os arquitetos brasileiros, em 1935/1936, haviam tomado contato muito mais com a produção purista de Le Corbusier (presente no primeiro volume da publicação) do que com seus projetos caracterizados por uma temática material mais primitivista. Porém, tal colocação não possui argumentos suficientes para afirmar que a equipe de arquitetos brasileiros não possuía nenhum conhecimento sobre a fase pós-purista de Le Corbusier.

Ao cotejarmos o referencial corbusiano utilizado pela equipe brasileira com os projetos desenvolvidos por Le Corbusier no período em que realiza sua segunda visita ao Rio de Janeiro, diagnosticamos um flagrante desencontro: o "Le Corbusier" estudado pela equipe brasileira “como sagrado catecismo" não é o mesmo Le Corbusier que desembarcaria no Rio de Janeiro em 12 de julho de 1936, daí um dos motivos das divergências de Le Corbusier com relação ao estudo que já havia sido desenvolvido pela equipe de Lucio Costa.

Apesar de Costa e sua equipe estarem debruçados sobre o projeto da nova sede do MES desde setembro de 1935, será apenas em 25 de março de 1936 que Gustavo Capanema oficializa o convite que já havia sido oferecido a Lucio Costa havia quase seis meses.

No período compreendido entre os primeiros estudos para o projeto do MES (setembro de 1935) e o convite oficial de Capanema (marco de 1936), Lucio Costa escreve e publica na edição de janeiro de 1936 da Revista da Diretoria de Engenharia da Prefeitura do Distrito Federal, o texto intitulado Razões da Nova Arquitetura. O texto elaborado por Costa fundamentaria o ímpeto moderno latente no imaginário desses jovens arquitetos e que já se fazia presente nas novas proposições para o projeto do MES.

O texto Razões da Nova Arquitetura, face ao momento crucial de renovação da arquitetura brasileira, representava o mais legítimo argumento em defesa da arquitetura moderna. Os jovens

11. No segundo volume de Le Corbusier: Ouvre Complète publicado em 1935 são apresentados alguns dos projetos que caracterizam esse período de ruptura com o purismo e incursão na temática vernácula na escolha dos materiais construtivos e de revestimento. Seguem alguns projetos típicos desse período, publicados no segundo volume de sua Obra Completa: residência Errazuris no Chile (1929); residência da Mme. Mandrot em Le Prade, França; Pavilhão Suíço na Universidade de Paris (1930/1932); edifício de apartamentos em Porte Molitor em Paris (1933).

12. A coleção Le Corbusier: Ouvre Complète é constituída de oito volumes que apresentam os projetos em ordem cronológica, de 1910 a 1965.

37 | o encontro de 1936: formação 
arquitetos reunidos em torno de Lucio Costa entendiam o projeto do edifício do MES como a correspondência concreta, mesmo que ainda experimental, dos pressupostos presentes no fundamental texto de Costa.

Em seu texto, Lucio Costa acredita que a renovação moderna é tão intensa que, até mesmo o Renascimento, se comparado a ruptura moderna, reduzia-se a um "jogo pueril de intelectuais requintados". Segue trecho do autor:

Estamos vivendo, precisamente, um desses períodos de transição, cuja importância, porém, ultrapassa - pelas possibilidades de ordem social que encerra - a de todos aqueles que o precederam. As transformações se processam tão profundas e radicais que a própria aventura humanística do Renascimento, sem embargo de seu extraordinário alcance, talvez venha a parecer à posteridade, diante delas, um simples jogo pueril de intelectuais requintados (COSTA apud LISSOVSKY:1996, 46).

Segundo Lucio Costa, somente a renovação moderna poderia novamente lastrear de autenticidade uma arquitetura que se perdera em estilizações vazias. Para o autor:

(...) As construções atuais refletem, fielmente, em sua grande maioria, essa completa falta de rumo, de raízes. Deixemos, no entanto, de lado essa pseudo-arquitetura cujo único interesse é documentar, objetivamente, o incrível grau de imbecilidade a que chegávamos - porque ao lado dela existe, já perfeitamente constituída em seus exemplos fundamentais, em forma, disciplinada, toda uma nova técnica construtiva, paradoxalmente à espera da sociedade à qual, logicamente, deverá pertencer (idem, grifo nosso).

Em 15 de maio de 1936, Lucio Costa e equipe entregam a Capanema o novo anteprojeto para a sede do MES, acompanhado de extenso memorial descritivo ilustrado. Segue trecho do memorial:

(...) partido apresenta as seguintes vantagens: primeiro, o recuo do corpo principal torna possível apreender em um mesmo golpe de vista todo o conjunto do edifício, o que - respeitando o alinhamento - se não daria; segundo, os corpos laterais suspensos sobre pilotis não cortam a perspectiva - $\underline{\text { a vista prolonga-se }}$ desembaraçada através dos mesmos, por toda a quadra, de uma a outra rua, conseguindo-se assim agradável sensação de espaço e desafogo; (...) Procuramos atender as conveniências dos vários serviços - razão mesma de ser do edifício - respeitando, porém, os princípios racionais da nova técnica construtiva e acima deles, os princípios permanentes de proporção, ritmo, simetria, comuns a toda verdadeira arquitetura. Daí resultou, sem esforço, um edifício de linhas severas, de aspecto sóbrio e digno, não em 'determinado estilo' - o que seria lamentável - mas 'com estilo' no melhor sentido da palavra (COSTA apud LISSOVSKY:1996, 62, grifo nosso).

As colocações presentes no memorial elaborado por Lucio Costa e equipe ilustram o sutil limiar entre o compromisso com o estatuto da arquitetura moderna e um suposto respeito à estilística acadêmica.

A ruptura com a tipologia tradicional - das plantas caracterizadas pelos alinhamentos lindeiros à calçada, conformando um pátio interno - está presente em duas situações distintas: no 
"recuo do bloco principal” com relação ao alinhamento do lote que configura o afastamento necessário à apreensão de todo conjunto; e no uso de pilotis nas alas gêmeas que permite a transposição física e visual no nível do chão. Por outro lado, ao mencionar o respeito pelos "princípios permanentes de proporção, ritmo, simetria, comuns a toda verdadeira arquitetura", Costa e equipe externam um vínculo aos estilemas consagrados pelos projetos acadêmicos, como aqueles presentes nas propostas de Arquimedes Memória, Rafael Galvão e Gerson Pinheiro. [14], [15]

O projeto e o memorial descritivo desenvolvidos por Lucio Costa e equipe ainda deveriam passar pelos meticulosos pareceres de uma comissão técnica constituída por diversos profissionais, entre eles os engenheiros Sousa Aguiar, Saturnino de Brito e Domingos da Silva.

Ao confrontarmos os pareceres técnicos com a impecável réplica elaborada por Lucio Costa, podemos aferir com precisão esse momento histórico em que o establishment acadêmico se coloca como avaliador de uma proposta que apresenta, agora oficialmente, a "nova arquitetura".

O debate travado entre alguns dos pareceristas e a equipe de Costa ilustra o instante exato em que o paradigma acadêmico vigente sucumbe à argumentação precisa dos arquitetos modernos. De todos os pareceres, os de Saturnino de Brito e de Domingos da Silva assumem nítido destaque justamente pelos seus pontos de vista antagônicos.

Em seu parecer, Saturnino de Brito elabora um texto que, em extensão, supera o próprio memorial desenvolvido por Costa e equipe. Saturnino de Brito dedica grande parte de sua análise à discussão sobre a linguagem moderna à luz da estética e da filosofia: “(...) A arquitetura sendo 'a mais técnica das artes' (A. Comte), precisa, nos tempos modernos, a trama funcional das novas construções”.(1936 apud LISSOVSKY, 1996:69).

$\mathrm{O}$ autor parte da premissa da arquitetura moderna como condição para o pleno êxito de projetos com caráter público e forte apelo simbólico, características que se encaixam na proposta de Costa e equipe.

Não bastassem a clareza e a lucidez presentes no memorial descritivo que integrava o anteprojeto para o MES, o parecer de Saturnino de Brito não apenas reforça a necessidade latente da adoção da arquitetura moderna por parte da sociedade brasileira, como promove o projeto de Costa e equipe à condição de experimento exemplar. Em diversos momentos de seus parecer, Saturnino de Brito ressalta o alinhamento do novo projeto do MES às postulações presentes nos textos e nas obras de Le Corbusier:

Proscrevamos as ruas corredor, com seus perpétuos congestionamentos. Elevemos nossas construções sobre estacadas, em grandes volumes, em rendentes (...) O arauto da tendência é o arquiteto Le Corbusier, não se pode negar o gênio das idéias proclamadas (Idem).

Em seguida, Saturnino de Brito discorre com precisão sobre a incompatibilidade entre o gosto vigente da época e as propostas de Le Corbusier. O mais curioso é a atualidade do raciocínio presente nesse trecho. Inconscientemente, Saturnino de Brito, aponta para aquele fator que se prestava como argumento para a revisão crítica do próprio Le Corbusier que, naquele instante,

\footnotetext{
39 o encontro de 1936: formação
} 

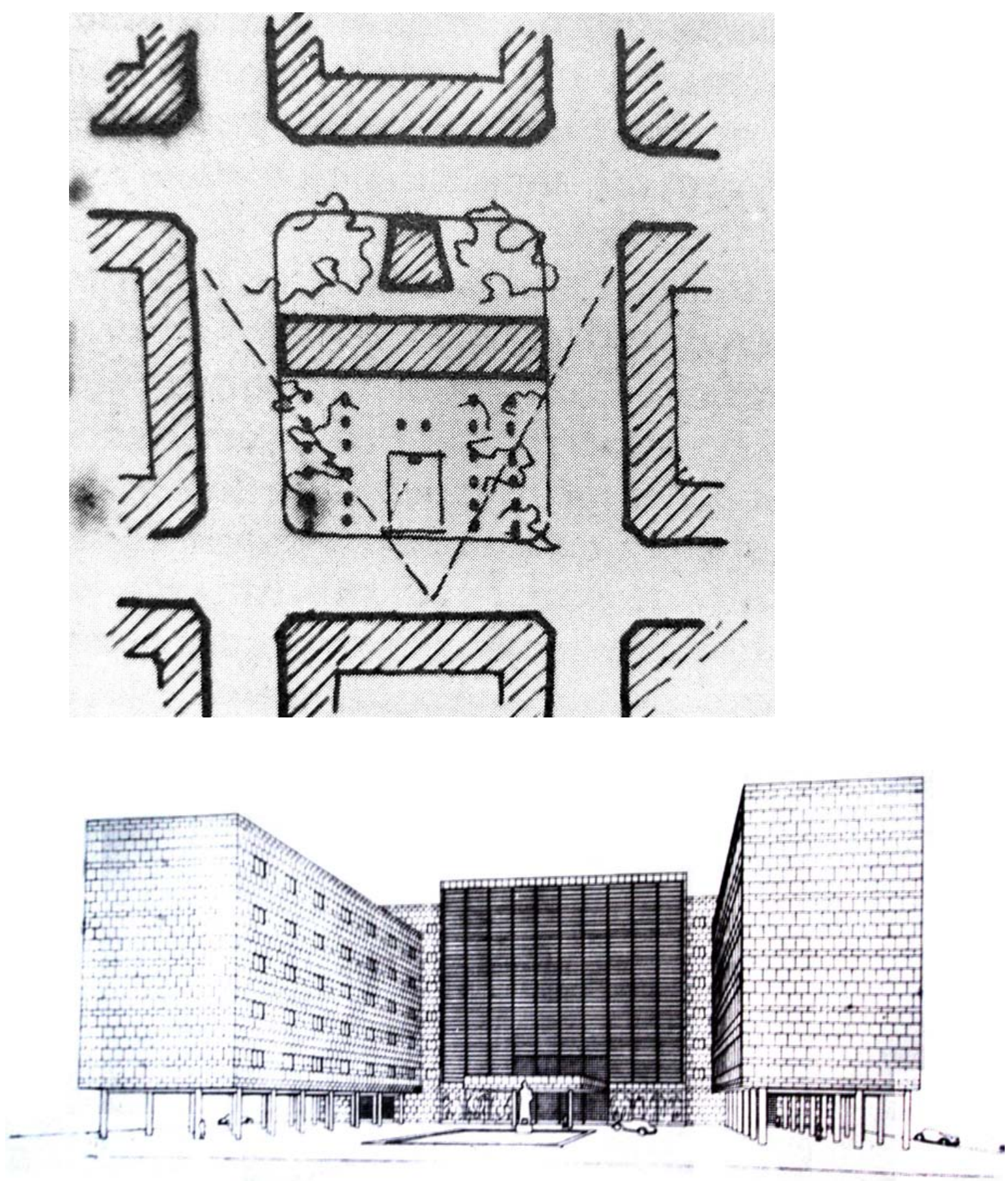

[14] Projeto para a sede do MES - concurso - Lucio Costa e equipe - esboço da ocupação da construção no pavimento térreo - 1935/1936

(LISSOVSKY, 1996:62)

[15] Projeto para a sede do MES - concurso - Lucio Costa e equipe - perspectiva R. Pedro Lessa - 1935/1936 (LISSOVSKY, 1996:64) 
se afastava do legado purista. Segue trecho do parecer:

Não se pode negar gênio às idéias proclamadas, porém se a arquitetura fosse limitar-se à mera produção de maquinas de habitar, perderia valores inestimáveis para a eclosão do sentimento do belo. É certamente por isso que os salões, os júris de arquitetura, as comissões municipais, embora saúdem o poeta de La ville $\mathrm{R} a$ dieuse, conservam-no no seu lugar de bardo arquitetônico, sem concretizar os planos (Idem, grifo nosso).

O parecer de Saturnino de Brito sofre grande influência do próprio texto Rąõos da Nova Arquitetura de Lucio Costa, publicado havia menos de seis meses. Em outro trecho do parecer, o autor discorre sobre a frivolidade das "construções futuristas e modernistas" e as compara à nova proposta para o MES, elogiada pelo seu extremo teor de autenticidade. Para legitimar seu posicionamento, Saturnino de Brito se respalda no texto Raðões da Nova Arquitetura:

Ao referir as tendências na arquitetura moderna, claro é que no nosso caso (edifício público) não cabe considerar as construções futuristas e modernistas, que constituem apenas um desvio momentâneo de senso estético. (...) Caso diverso, porém, é o da tendência que vimos tratando. Sua filiação ao passado encontra-se salientada em um artigo publicado na Revista da Diretoria de Engenharia, janeiro de 1936, pelo arquiteto Lucio Costa, um dos bons valores da geração atual de arquitetos. Esse artigo acentua como a arquitetura contemporânea continua a guiar-se 'pelos mesmos princípios e pelas mesmas leis que a do passado' e considera destituídas de toda a significação real as classificações apressadas e estanques, 'que pretendem ver em tal metamorfose irremediável conflito entre o passado e o futuro'. (...) Vê-se que o distinto arquiteto se filia à corrente que temos anotado como primeira tendência (Idem, grifo nosso).

Talvez o que mais chame a atenção no parecer de Saturnino de Brito não seja seu alinhamento aos discursos presentes tanto no texto de Lucio Costa como no memorial descritivo do novo projeto do MES. Gostaríamos de destacar a lucidez das idéias presentes nesse parecer que, ao mesmo tempo em que assimila o pensamento moderno em todas as suas nuances, desbasta alguns excessos com a clara intenção de moderar o caráter eminentemente doutrinário, presente nos discursos de Le Corbusier e de Lucio Costa.

Saturnino de Brito, em outro trecho de seu parecer, aponta o projeto de Le Corbusier para o Palácio Centrosoyus em Moscou como um claro referencial adotado pela equipe brasileira para a elaboração do edifício do MES. Em outro momento, o autor discorre sobre o projeto elaborado pela equipe de Jorge Moreira para o concurso do MES, também descrito pelo autor como um exemplar inspirado no projeto de Le Corbusier para Moscou. Saturnino de Brito compara os componentes formais e tipológicos comuns tanto ao Palácio Centrosoyus, como ao projeto realizado pela equipe brasileira e a proposta de Jorge Moreira.

Dentre os edifícios construídos, o que pertence inteiramente à tendência que primeiro indicamos é o Centrosoyus de Moscou, palácio central das cooperativas, projetado por Le Corbusier e Paul Jeanneret. (...) que, evidentemente, serviu de guia aos autores do projeto em exame. A identidade de aspecto, o partido geral e as colunatas estão na perspectiva apresentada como em La ville Radieuse.

É mais um testemunho de que o projeto para o Ministério da Educação se filia à tendência que já temos definido e que vimos ser minoritária na arquitetura dos dias de hoje.

41 o encontro de 1936: formação 


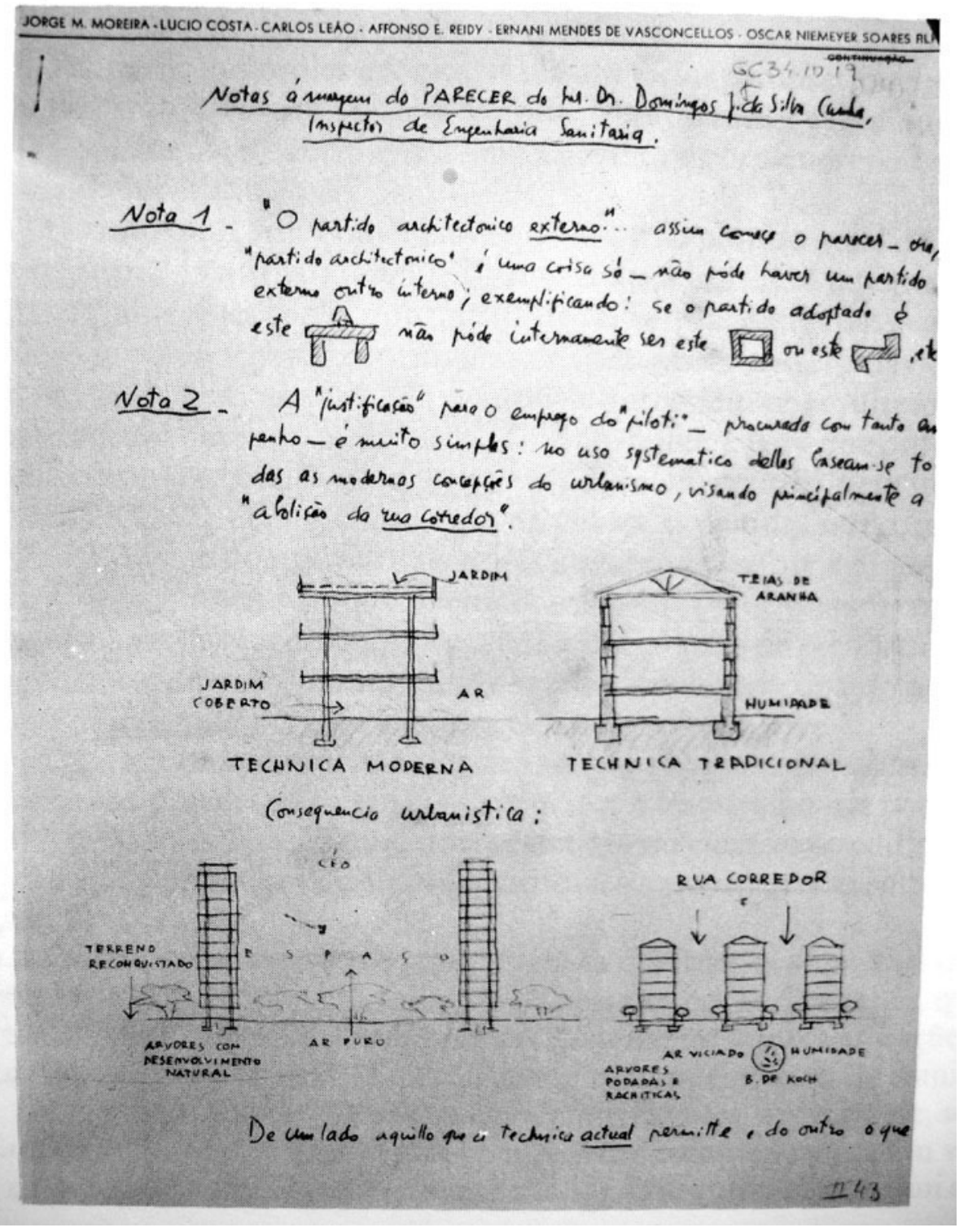

[16] Projeto para a sede do MES - concurso - Lucio Costa e equipe - desenho explicativo de Lucio Costa, realizado como resposta ao parecer de Domingos da Silva, Inspetor de Engenharia Sanitária - 1935/1936

(LISSOVSKY, 1996:85) 
Apesar de minoritária, ela é, porem, uma das tendências existentes e, desde que atenda aos requisitos essenciais, o projeto poderá ser executado tal qual foi o Centrosoyus, dependendo isto de uma questão de diretriz estética, como dissemos.

(...) Esse projeto Moreira-Vasconcelos obedeceu a inspiração do de Le Corbusier para o Centrosoyus de Moscou (...) Fazemos tais aproximações apenas para situar sem dúvida alguma o projeto no seio das correntes arquitetônicas modernas (...) (Idem, grifo nosso).

O parecer elaborado por Saturnino de Brito é um importante documento que ilustra a recepção da arquitetura moderna por parte de uma comissão técnica acostumada a tecer pareceres sobre projetos acadêmicos. Tal parecer não é apenas um criterioso voto de confiança em favor da arquitetura moderna brasileira, mas pode ser considerado uma brilhante análise desse período de transição e de ruptura entre modelos estéticos tão distintos: o classicismo da academia e a abstração moderna.

O parecer redigido por Domingos da Silva ${ }^{13}$, diversamente do parecer de Saturnino de Brito, desfere severas críticas contra o novo projeto do edifício do MES, sejam nos condicionantes estéticos ou técnicos. As diferenças entre os tratamentos das superfícies das alas gêmeas (pequenas aberturas retangulares em uma face, pele de vidro na outra), na opinião de Domingos da Silva (1936 apud LISSOVSKY, 1996:84), "produz contrastes muito violentos".

Domingos da Silva inicia seu parecer com uma análise do "partido arquitetônico externo" do projeto de Costa e equipe. Lucio Costa, em réplica recheada de croquis ilustrativos e didáticos, se dedica, não apenas a justificar as virtudes de seu projeto, mas expõe ao parecerista, alguns conceitos básicos da arquitetura. Costa afirma ser um contra-senso falar em "partido externo". Costa (Ibid., 85) explica que "partido architectônico é uma coisa só, não pode haver um partido interno e outro externo". [16]

Em outro ponto do parecer, Domingos da Silva (Ibid., 84) externa sua resistência com relação aos pilotis no pavimento térreo, “cuja justificação não se apresentará facilmente”. Para o autor, "a colunata do térreo seria perfeitamente indicada numa estação de estrada de ferro que deve atender em prazos curtos, as ondas de povo que a procuram".

Em outro momento de sua réplica ilustrada, Lucio Costa (Ibid., 85) se dedica a explicação do uso dos pilotis no térreo: “A 'justificativa' para o emprego do piloti - procurada com tanto empenho - é muito simples; no uso systemático delles baseam-se todas as modernas concepções do urbanismo, visando principalmente a 'abolição da rua corredor" ${ }^{\text {"14 }}$.

Apesar do projeto realizado pela equipe de Costa ter sido desconsiderado por Le Corbusier, por causa da adoção de um referencial equivocado (Centrosoyus), devemos assimilar o período compreendido entre o início do trabalho da equipe formada por Lucio Costa para a realização do novo projeto para a sede do MES (setembro de 1935) e a chegada de Le Corbusier ao Brasil (12 de julho de 1936) como um momento de ebulição do debate entre modernos e

13. Domingos J. Da Silva Cunha, Inspetor de Engenharia Sanitária.

14. Foi preservada a grafia original do documento.

43 o encontro de 1936: formação 
acadêmicos e de crucial importância para a afirmação da arquitetura moderna no Brasil. Em um período de dez meses, a vigência acadêmica perde campo para o pensamento moderno de maneira gradativa. Recapitulemos a ordem dos fatos:

- Setembro de 1935: Por intermédio de Carlos Drumond de Andrade, Capanema convoca Lucio Costa e solicita a formação de uma equipe de arquitetos para a elaboração de um novo projeto para o MES;

- 01 de outubro de 1935: Pouco tempo depois, o projeto acadêmico com ornamentação marajoara de Arquimedes Memória é proclamado vencedor do Concurso para a sede do MES. $\mathrm{O}$ arquiteto recebe o prêmio em dinheiro previsto no edital, porém não seria contratado para a elaboração do projeto real que, nesse instante, já era uma incumbência de Lucio Costa e equipe;

- Janeiro de 1936: Enquanto desenvolve o projeto para a nova sede do MES com a equipe de jovens arquitetos brasileiros, Lucio Costa publica aquele que seria reconhecido como o texto fundamental para afirmação da arquitetura moderna brasileira: Razões da Nova Arquitetura;

- 21 de março de 1936: Monteiro de Carvalho realiza o primeiro contato com Le Corbusier e expõe o desejo de trazê-lo ao Rio de Janeiro;

- 15 de maio de 1936: Lucio Costa e equipe entregam o projeto e o memorial descritivo ilustrado para a nova sede do MES. Trata-se de um documento que registra o esforço de argumentação daquela equipe de jovens arquitetos em defesa das postulações modernas;

- 04 de junho de 1936: O engenheiro Saturnino de Brito elabora um minucioso parecer sobre o projeto realizado pela equipe de Costa. O parecer expõe um otimismo realista não só sobre a proposta para o MES mas, principalmente, sobre a arquitetura moderna. Saturnino de Brito alinha-se às idéias contidas no texto Razões da Nova Arquitetura para a construção de argumentos consistentes em defesa da renovação na estética arquitetônica;

- 12 de julho de 1936: Le Corbusier desembarca no Rio de Janeiro.

Retomemos a análise dos conteúdos das cartas trocadas entre Monteiro de Carvalho e Le Corbusier. Monteiro envia uma carta a Le Corbusier em 08 de abril de 1936. O conteúdo versa principalmente sobre aspectos de ordem prática, como calendário, honorários e transporte. Em uma das passagens presentes na carta, Monteiro informa que os encaminhamentos políticos para a realização da Universidade do Brasil estavam adiantados, inclusive, com a Comissão do Plano da Universidade do Brasil já constituída. Caso Le Corbusier tivesse interesse em participar dessa comissão, deveria intervir diretamente junto ao Ministro Capanema. Segue trecho da carta:

Nossos amigos Lucio Costa e Carlos Leão disseram-me, ainda ontem, estarem certos de que, uma vez aqui, você conseguirá convencer o Ministro, que é jovem e inteligente, e que certamente encontrará um meio de aproveitá-lo, quer dizer, de colocá-lo na comissão. O projeto para o Ministério da Educação eles já o estão fazendo (CARVALHO apud SANTOS, 1987:136, grifo nosso).

A carta de Monteiro tem o claro objetivo de conduzir o foco de Le Corbusier para o projeto da Universidade do Brasil, propondo meios para que o "mestre" encontrasse um lugar 
na comissão formada por Capanema. Monteiro não realiza qualquer menção à possibilidade de Le Corbusier participar do projeto do edifício do MES; ao contrário, reafirma que o projeto do Ministério já está em pleno curso, nas mãos da equipe de Costa e Leão.

Le Corbusier responde à carta de Monteiro, com um claro tom de indignação com relação a sua "exclusão" do grupo de trabalhos para o projeto do edifício do MES e, em tom melancólico, quase apelativo, implora à Monteiro que lhe seja dada a oportunidade de projetar e construir algo em solo carioca, "de qualquer jeito".

1. Seus amigos LUCIO COSTA e CARLOS LEÃO parecem terem reservado só para eles o estabelecimento do projeto do Ministério da Educação. É isso mesmo? E não há nenhuma esperança para mim, como você me escrevera na primeira carta, onde parecia que eu devia colaborar com os dois colegas.

(...) é indispensável que possa trazer um trabalho prático de uma viagem assim, pois a profissão de profeta começa a ser um peso nas minhas costas e preciso ganhar minha vida. Sendo arquiteto e urbanista, é através do projeto de arquitetura e urbanismo que posso fazê-lo.

4. caso vá ao Rio de Janeiro, gostaria de entrar em contato com o Presidente [Getúlio Vargas], se possível para que ele coloque em estudos o meu famoso plano de 1929 que prevê a construção de um grande viaduto com 100m de altura, e habitações para 180 mil pessoas; grandes benefícios para a municipalidade que realizaria as obras em concreto armado do viaduto e que, em seguida, venderia os terrenos a serem construídos superpostos.

Meu caro Monteiro, compreenda-me: é necessário que eu construa, de qualquer jeito, senão, morrerei na pele de um teórico, o que me desagrada (LE CORBUSIER, 1936 apud SANTOS, 1987:137, grifo nosso).

O teor da carta que Le Corbusier escreve para Monteiro espelha a imagem de um artista em pleno desespero diante da perspectiva que aponta para mais uma atividade intelectual sem um final concreto. Primeiramente, Le Corbusier demonstra indignação ao saber que Costa e Leão estão desenvolvendo o projeto do MES à revelia do "mestre". Le Corbusier tenta persuadir Monteiro, dizendo que na correspondência datada de 21 de março de 1936 Monteiro de Carvalho havia dito que o arquiteto "devia colaborar com os dois colegas" (Costa e Leão) no projeto do edifício do MES. Em nenhuma passagem da carta redigida por Monteiro há qualquer menção sobre a possibilidade da participação de Le Corbusier no projeto do MES.

O fato de Le Corbusier canalizar esforços para participar do projeto do MES, enquanto sequer menciona o projeto da Universidade do Brasil, diz respeito a sua eminente necessidade de executar um projeto, muito mais do que simplesmente projetar. Para Le Corbusier, o edifício do MES tinha maiores chances de ser construído do que a Universidade do Brasil. Tratava-se de uma construção infinitamente menor, cujo empreendimento já estava totalmente encaminhado, com um quarteirão inteiro na região central do Rio de Janeiro destinado a receber tal construção. Adicione-se a isso o entusiasmo do Ministro Capanema, que não mediria esforços para ver seu "palácio moderno" construído.

Os argumentos de Le Corbusier em favor da realização de seus projetos não residem mais em fundamentações teóricas. Le Corbusier, tido pelos brasileiros como o mestre da arquitetura moderna, implora a Monteiro pela oportunidade de trabalho concreto em solo carioca.

\footnotetext{
45 o encontro de 1936: formação
} 
Em dois momentos da carta à Monteiro, Le Corbusier faz seu pedido em um tom que mistura ordenação e súplica: "E não há nenhuma esperança para mim?”, "a profissão de profeta começa a ser um peso nas minhas costas e preciso ganhar minha vida", "é necessário que eu construa, de qualquer jeito, senão, morrerei na pele de um teórico, o que me desagrada".

A situação de desespero é de tal ordem que Le Corbusier aventa, inclusive, a possibilidade de se retomar o plano urbanístico para a cidade do Rio de Janeiro, realizado havia sete anos em sua primeira visita à cidade, em 1929. O arquiteto solicita uma audiência com o Presidente Getúlio Vargas, para tentar convencê-lo da realização da proposta de 1929. Como argumento, Le Corbusier lança mão das supostas vantagens econômicas de seu projeto, discorrendo sobre possibilidade de se vender os "terrenos a serem construídos sobrepostos".

Em outra carta endereçada a Monteiro de Carvalho, Le Corbusier, em meio às reclamações quanto ao baixo honorário oferecido pelo governo brasileiro, reafirma a necessidade de vincular sua viagem não apenas as conferências, mas a projetos de arquitetura concretos. Segue trecho da carta datada de 05 de maio de 1936:

As conferências: Buenos Aires, em 1929, tinha-me pago três mil francos por conferência (dez conferências) e todas as despesas pagas de Paris a Paris. A remuneração de 30.000 francos, aproximadamente, que você me propõe, é portanto, inferior à que Buenos Aires me tinha pago em 1929, há sete anos atrás. $\underline{A}$ remuneração de 500 francos proposta por você me parece insuficiente.

(...) gostaria de ir fazer conferências no Rio, mas quero estar seguro de ter um serviço a executar (...) atualmente não posso mais me dar o trabalho de me deslocar exclusivamente para ir dar conferências. Já que expliquei: julgo que seria bem possível que achassem um meio de me confiar um estudo de um edifício ou de um plano urbanístico, seja no Rio, ou fora do Rio (...)

Rogo-lhe a gentileza de continuar a fazer o que é necessário para me permitir a realização de um trabalho de arquitetura no Brasil. Repito aqui mais uma vez que é isso que me interessa acima de tudo (LE CORBUSIER apud SANTOS, 1987:138, grifo nosso).

No transcorrer do tempo e das cartas, as súplicas transformam-se em imposições. Em suas cartas, Le Corbusier quase não se refere às conferências que seriam realizadas por ele no Rio de Janeiro. A idéia de trazer o "mestre" apenas para as conferências na ENBA ficava cada vez mais inviável. Sua vinda, definitivamente, deveria estar condicionada à realização de um projeto de arquitetura, de qualquer categoria, "seja no Rio ou fora do Rio".

As sucessivas cartas de Le Corbusier enviadas a Monteiro de Carvalho e Gustavo Capanema apenas reiteram a condição essencial para a vinda do arquiteto ao Rio de Janeiro: a elaboração de um projeto de arquitetura com chances efetivas de ser executado.

Em 05 de maio de 1936, Le Corbusier envia uma carta para Gustavo Capanema, cujo conteúdo versa sobre o cronograma da viagem, suas atribuições, seus honorários e, principalmente, sua participação efetiva nos projetos do MES e da Universidade do Brasil. Segue trecho da carta: 
Essa viagem parece ter como objetivo:

a) dar oito conferências de arquitetura e urbanismo na Escola de Belas Artes do Rio

b) dar meu parecer sobre o projeto de construção do Ministério da Instrução Pública.

c) dar igualmente minhas idéias sobre o projeto de construção da cidade universitária do Rio.

(...) Estimo que seria uma alegria para um arquiteto como eu encontrar a oportunidade de situar dentro dessa paisagem magnífica uma obra de maturidade capaz de demonstrar as possibilidades da arquitetura moderna.

(...) Cheguei a uma idade em que não posso me deslocar para tão longe para fazer pura e simplesmente conferências para estudantes. É indispensável que possa criar obras de arquitetura, pequenas ou grandes, mas significativas. (...) só posso ir ao Rio dar aulas de arquitetura e urbanismo se me for garantido formalmente que serei encarregado de um trabalho de arquitetura ou de urbanismo (...) (LE CORBUSIER apud LISSOVSKY, 1996:58-59).

$\mathrm{Na}$ carta endereçada a Capanema, Le Corbusier repete as solicitações (que agora se transformaram em condições) externadas a Monteiro. Mais uma vez, o arquiteto coloca como um dos objetivos de sua viagem o parecer sobre o projeto do MES. Reiteramos que em nenhuma passagem das cartas enviadas por Monteiro de Carvalho há a solicitação, ou mesmo o desejo, por um parecer de Le Corbusier sobre o projeto do edifício do MES. A essa altura dos acontecimentos, não havia mais separação entre as solicitações dos brasileiros e as condições do "mestre".

A capacidade de persuasão e o exercício da retórica em Le Corbusier são qualidades notáveis. $\mathrm{O}$ arquiteto manipula com habilidade as informações e as condiciona às suas intenções profissionais. Tudo isso através de poucas e curtas cartas enviadas de longe (Paris e Argélia).

Percebendo que, gradativamente, suas propostas ganhavam a simpatia da intelectualidade e do governo carioca, Le Corbusier, mesmo à distância, decide expandir um pouco mais os seus domínios. O arquiteto redige uma outra carta a Monteiro de Carvalho, datada de 15 de junho de 1936, dizendo que não se sentiria confortável participando da comissão da Universidade do Brasil juntamente com Marcelo Piacentini, arquiteto de linhagem acadêmica. Segue trecho:

Entre os dois nomes em confronto, o meu e do colega citado, há essa diferença fundamental que um representa o progresso da arquitetura e do urbanismo e o outro manifesta os poderes acadêmicos postos a serviço do aparato, do fausto em detrimento de tudo que é funcional, orgânico, biológico na arquitetura dos novos tempos.(...)

Você compreenderá, meu caro Monteiro, que estou um pouco contrariado de encontrar mais uma vez o academicismo no meu caminho.

(...) o pouco dinheiro que eu custaria ao Brasil representaria, do ponto de vista da evolução da causa mais essencial de um país, uma tal possibilidade de progresso, que essa despesa assim consentida traduzir-seia rapidamente em imensas economias e imensos benefícios, graças as idéias modernas da arquitetura. Dar essas idéias num curso de oito palestras na Universidade do Rio teria um efeito - estou certo - considerável sobre a juventude. (...)

É preciso acrescentar que o Rio é um lugar com uma natureza tão admirável que é preciso, para responder a esse esplendor natural, uma certa dose de lirismo plástico e - digo-o sem a menor modéstia - dentre os arquitetos do tempo moderno, sinto-me o único tão preparado para enfrentar tarefas tão delicadas. (LE CORBUSIER apud SANTOS, 1987:139-140, grifo nosso).

47 o encontro de 1936: formação 
Em sua derradeira carta a Monteiro de Carvalho, Le Corbusier expõe seu descontentamento em ter que participar da comissão para o plano da Universidade do Brasil juntamente com Piacentini. Para Le Corbusier seria incoerente que dois arquitetos de condutas ideológicas tão distantes compusessem uma mesma comissão. Tanto a experiência de Piacentini, como sua proximidade com o Ministro Capanema, poderiam configurar um obstáculo intransponível para objetivo de Le Corbusier, que desejava desenvolver o projeto da Universidade do Brasil, no máximo, na companhia dos jovens arquitetos brasileiros.

A carta redigida por Le Corbusier tem a clara intenção de, mais uma vez, persuadir Monteiro no sentido de obter garantias de que realizaria um projeto concreto no Rio de Janeiro, nem que para isso fosse necessária a dissolução da comissão que, em princípio, teria como dois de seus cinco componentes Le Corbusier e Marcelo Piacentini.

Le Corbusier tinha plena consciência de que, caso participasse de uma comissão de "notáveis" para o plano da Universidade do Brasil, suas chances de realizar o projeto seriam praticamente nulas. Nesse instante, a última coisa que Le Corbusier precisava seria a intervenção de interlocutores de filiação acadêmica, contrários à sua arquitetura. Daí o fato de Le Corbusier reiterar, em praticamente todas as correspondências, seu desejo de realizar um projeto juntamente com os jovens arquitetos brasileiros. Tratava-se de um grupo de arquitetos que Le Corbusier sabia que já estava devidamente domesticado, pois havia "lido sua obra excepcional como sagrado catecismo",15.

Em todas as correspondências anteriores, Le Corbusier nunca havia dado muita atenção, ou até mesmo comentado sobre as qualidades de suas conferências que seriam proferidas no Rio. Aliás, o arquiteto sempre as condicionou à realização de um projeto de arquitetura em solo carioca. Somente no instante em que o arquiteto se vê insatisfeito com os honorários propostos pelo governo brasileiro é que promove suas conferências com a intenção de justificar que o valor pedido por ele (mil francos por conferência) era a quantia justa de uma despesa pequenina, se comparada com as "imensas economias e imensos benefícios, graças às idéias modernas da arquitetura" que estariam contidas nas conferências.

Nessas correspondências, podemos perceber que os argumentos de Le Corbusier sempre estão atrelados a sua conveniência pessoal. Aquilo que, em um primeiro momento, poderia soar como um pedido, um gentil favor, em seguida, transformava-se em ordenação e condição para que sua vinda ao Rio de Janeiro pudesse se concretizar.

Le Corbusier finaliza sua última carta a Monteiro Carvalho com um parágrafo que sintetiza de maneira exemplar o seu comportamento nas correspondências anteriores. Para o arquiteto, a intensidade vigorosa da paisagem carioca só poderia dialogar com uma arquitetura que possuísse "uma certa dose de lirismo plástico" e, "sem a menor modéstia", Le Corbusier diz ser ele próprio, "dentre os arquitetos do tempo moderno", o único arquiteto "preparado para enfrentar tarefas tão delicadas".

15. (NIEMEYER, 1998:90) 
No parágrafo que encerra as trocas de correspondências referentes a sua segunda viagem ao Brasil, Le Corbusier resume com precisão todos os diálogos travados com Monteiro de Carvalho, Gustavo Capanema e Lucio Costa. Parece que todas as reivindicações, no fundo, queriam dizer a mesma coisa: seria a atuação profissional de Le Corbusier a única solução, não apenas para a Universidade do Brasil ou para o MES mas, devido ao flagrante desespero do "mestre", para qualquer tipo de questão que envolvesse arquitetura e urbanismo.

Após a apreciação das cartas, carregamos a impressão de que, para Le Corbusier, pouco importava o lugar, ou o tipo do problema. O ponto principal estava na descoberta de meios que transportassem sua arquitetura do universo teórico de seus livros e conferências para uma realidade concreta, seja ela qual fosse.

49 | o encontro de 1936: formação 


\section{Segundo o risco original de Le Corbusier ${ }^{16}$}

Le Corbusier, a bordo do dirigível Hindenburg, chega ao Rio de Janeiro em 12 de julho de 1936, onde permanece por quase cinco semanas, retornando a Paris no dia 15 de agosto do mesmo ano.

Carlos Leão, em entrevista a Elizabeth Harris, descreve o momento da chegada de Le Corbusier ao Rio de Janeiro:

(...) todos os arquitetos do projeto do Ministério se acotovelavam no hangar do Zepelim, situado a quarenta e cinco quilômetros do centro do Rio de Janeiro. A péssima aterrissagem do engenho preocupou os arquitetos, mas Le Corbusier foi o primeiro a descer e imediatamente pôs os arquitetos a trabalhar (LEÃO apud HARRIS, 1987:80).

Logo de saída, Le Corbusier posiciona-se contrário ao projeto realizado pela equipe de jovens arquitetos brasileiros, apelidando-o de "múmia". Le Corbusier desqualifica a simetria e a rigidez da composição que, por sua vez, baseou-se na organização hierarquizada de seu próprio projeto para o Palácio Centrosoyus. Devemos lembrar que Le Corbusier, já em sua primeira carta a Monteiro de Carvalho, considera o projeto do Palácio Centrosoyus como um referencial inadequado para esse tipo de situação.

A primeira atribuição dada a Le Corbusier no Rio de Janeiro seria a elaboração de um parecer sobre o projeto da equipe de Costa, a pedido do próprio Ministro Capanema.

Gustavo Capanema redige um simples questionário para tornar mais objetiva a aferição de Le Corbusier sobre o projeto brasileiro:

1. O senhor considera o projeto bom?; 2. O senhor considera o projeto ruim?; 3. Nesse caso, que orientação deveria seguir a comissão para apresentar um bom projeto?; 4. O senhor considera o projeto razoável?; 5. Nesse caso, quais são os seus defeitos e imperfeições, e que correções o senhor sugere a fim de que tais defeitos e imperfeições sejam corrigidos de forma a que o projeto possa ser considerado bom? (CAPANEMA 1936 apud HARRIS:1987,82).

16. Termo utilizado por Lucio Costa presente na placa inaugural do edifício do MES. 
Somente em 10 de agosto de 1936, passados quase um mês da recepção do questionário, Le Corbusier entrega o parecer ao Ministro Capanema. Os parágrafos iniciais são recheados de elogios à proposta brasileira. Segundo Le Corbusier, o projeto

(...) se processa sob uma forma sinfônica entre cheios e vazios, de matérias opacas ou transparentes, de formas redondas ou prismáticas etc. de excelente espírito", em outro trecho, o arquiteto chega a dizer que "este projeto pode ser classificado (...) dentre os melhores que já se fizeram até hoje, não importa em que país (LE CORBUSIER apud LISSOVSKY, 1996:109).

As críticas mais severas recairiam sobre a "simetria muito sistemática à esquerda e à direita do eixo da construção". Em um outro trecho, Le Corbusier ${ }^{17}$ justifica as limitações do projeto da equipe brasileira pelas restrições do lote urbano que “(...) se encontra em uma situação tal, que fui levado a perguntar ao ministro se a escolha do terreno destinado ao palácio era absolutamente definitiva ou se restava ainda alguma esperança de encontrar-se em outro lugar."

Tanto a rejeição da "múmia", como a predileção por uma solução laminar desvinculada do traçado tradicional da cidade do Rio de Janeiro, ilustram o período de transitoriedade que passava a própria obra de Le Corbusier: do afastamento das soluções hierarquizadoras da forma e do espaço - presentes no Palácio Centrosoyus em Moscou, na Liga das Nações em Genebra e diagnosticadas na própria "múmia" - à adoção dos blocos laminares que subvertem a lógica do quarteirão tradicional (blocos à rendent de projetos como a Ville Radieuse-1935).

Le Corbusier ${ }^{18}$ diz ter sido informado de “(...) que toda a liberdade ainda era possível” e seria essa tal liberdade que permitiu ao arquiteto “(...) procurar um outro terreno suscetível de sediar o palácio em condições suficientemente aceitáveis."

$\mathrm{Na}$ opinião do arquiteto, para o êxito da empreitada de Capanema, seria fundamental que se viabilizasse a mudança do terreno para uma situação mais favorável, com uma perspectiva desimpedida, voltada para o mar. Segue outro trecho do parecer de Le Corbusier ${ }^{19}$ :

(...) deplorável que a iniciativa do ministro submergisse num conjunto arquitetônico e urbanístico de tal natureza que de nenhuma maneira e apesar de toda a perfeição do prédio seria possível atingir uma impressão de nobreza e de grandiosidade. (...) Respondo isso: proponho não corrigir o projeto, que é excelente, mas sim substituir o terreno, que é ruim. (...) A localização equivale a mais da metade da concepção arquitetônica, ela é predominantemente decisiva.

Passados dez dias de buscas por uma situação mais adequada e de conversas com os departamentos competentes, Le Corbusier ${ }^{20}$ encontra um terreno disponível e o cobre de elogios, na clara intenção de persuadir Capanema a tomar uma decisão favorável à mudança de terreno.

17. Idem.

18. Idem.

19. Idem.

20. Ibid., p.111

51 o encontro de 1936: formação 

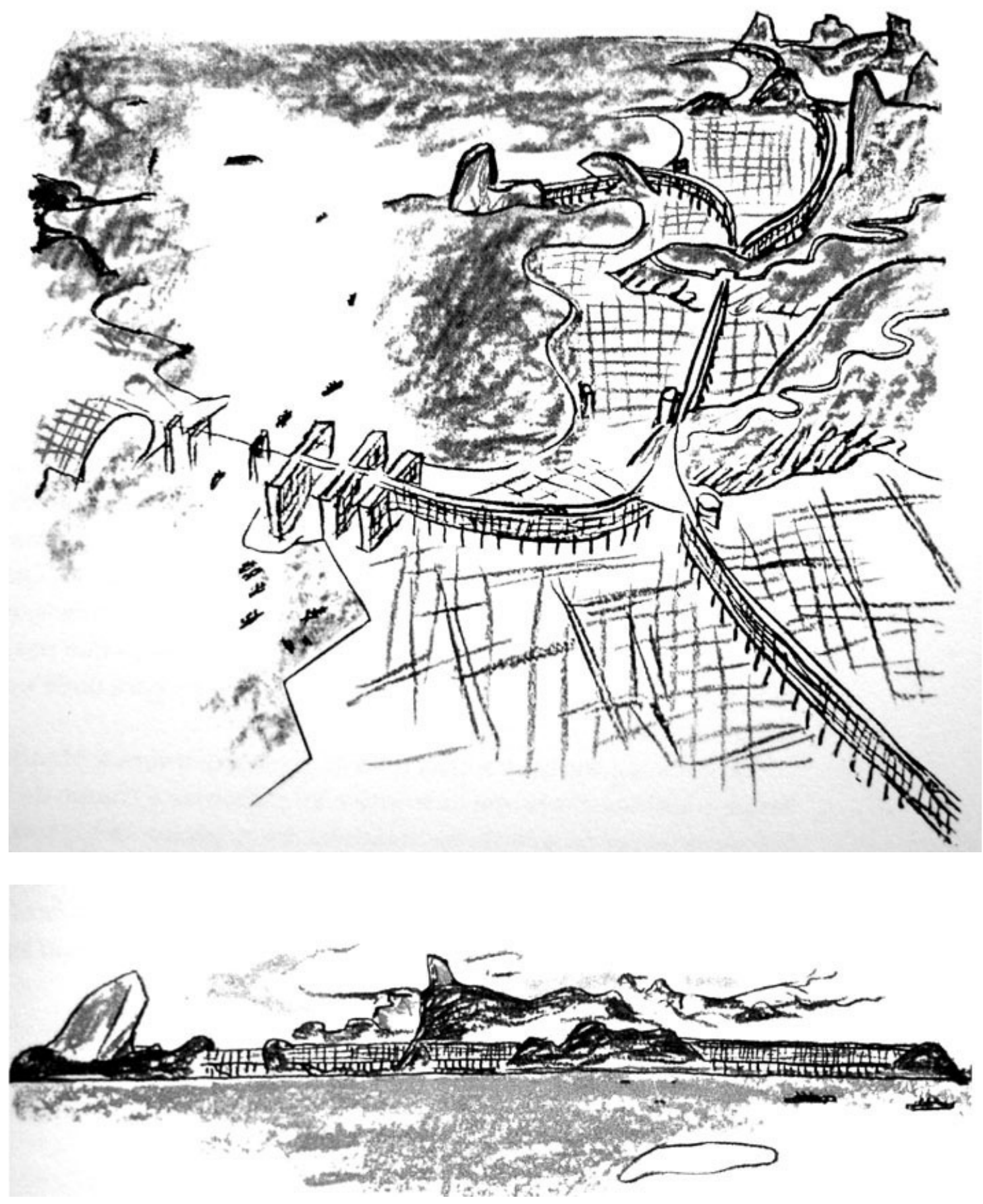

[17] Plano Urbanístico para o Rio de Janeiro - Le Corbusier - 1929

(LE CORBUSIER, 2004:237)

[18] Plano Urbanístico para o Rio de Janeiro - Le Corbusier - 1929

(LE CORBUSIER, 2004:237) 
(...) encontrei um terreno disponível, que é atualmente um dos mais belos do Rio. Esse terreno não tem comparação possível com o precedente. Ele está situado na orla marítima, sua perspectiva está assegurada pela presença do aeroporto que exige (...) uma vasta extensão de água que se estende a esse sítio para interditar qualquer construção.

O palácio, se construído sobre esse terreno, se encontraria no eixo visual da baía. O terreno está atualmente disponível.

Em um outro trecho do parecer, Le Corbusier justifica que o projeto desenvolvido para um terreno - até então, hipotético - situado na praia de Santa Luzia, não se tratava de um novo projeto, mas uma adaptação do projeto realizado pela equipe brasileira na quadra do Morro do Castelo. Segundo Le Corbusier ${ }^{21}$, as alas gêmeas e paralelas presentes no projeto elaborado pela equipe de Lucio Costa (os braços da "múmia"), se abririam no projeto à beira-mar, e a concepção em "U” se transformaria em uma única lâmina de nítida proporção horizontal.

O projeto da comissão de arquitetos pôde ser automaticamente adaptado a este terreno. Insisto no fato de que não se trata de um novo palácio, mas do mesmo, cujas alas simplesmente se abririam. (...) Outro elemento de grande importância é que o estacionamento para automóveis pôde ser agora criado, o que não seria possível no terreno precedente.

Le Corbusier resiste em considerar como base para o projeto a quadra vazia - conseqüência da urbanização da região onde antes existia o morro do Castelo. A luta travada por Le Corbusier para a mudança do terreno envolvia uma questão urbana que permeava o imaginário do arquiteto havia alguns anos. Para Le Corbusier, a fuga da malha tradicional da região central da cidade do Rio de Janeiro consistia em uma maneira de se afastar da estrutura urbana condicionada pelas "ruas corredor".

A horizontalidade do bloco linear proposto por Le Corbusier e equipe ${ }^{22}$ para um terreno fictício à beira-mar era incompatível com a realidade apresentada pela quadra localizada na área do desmonte do morro do Castelo, cujas dimensões (91,60m x 69m), para Le Corbusier, apresentavam-se extremamente reduzidas.

A cisão provocada por Le Corbusier, ao ignorar o sítio real e realizar uma proposta em terreno, até então, hipotético, ilustra muito mais do que uma simples troca de terrenos. Estavam em disputa, não apenas, duas concepções de arquitetura divergentes, mas duas idéias de cidades incompatíveis entre si: o academicismo francês do Plano Agache e a relação dialética de integralidade e independência entre os edifícios e os espaços públicos presente no próprio projeto urbanístico de Le Corbusier para a cidade do Rio de Janeiro, realizado em 1929. O projeto de Le Corbusier para uma situação à beira-mar formalizava-se como um eco de suas propostas urbanísticas para a cidade do Rio de Janeiro, realizadas havia menos de sete anos (dezembro de 1929). [17], [18]

21. Ibid., p.111

22. Inicialmente, a proposta da lâmina horizontal à beira-mar foi concebida para um terreno hipotético. Somente após dez dias de procura por um terreno com efetivo potencial para receber a sede do MES, é que o projeto implanta-se em uma situação real.

53 | o encontro de 1936: formação 



[19] Pavilhão Suíço na Universidade de Paris - Le Corbusier - 1930-1932

(BOESIGER, 1947:87)

[20] Pavilhão Suíço na Universidade de Paris - Le Corbusier - 1930-1932

(BOESIGER, 1947:86) 
A presença da paisagem natural, da água, do vazio e da perspectiva desimpedida da área envoltória foram alguns dos condicionantes da proposta urbana de Le Corbusier em 1929. Em 1936, quando retorna ao Rio de Janeiro com a incumbência de implantar um edifício dentro da trama urbana do centro da cidade, o arquiteto se vê impossibilitado de reatar esse estreito diálogo com a espacialidade generosa do encontro entre a montanha e o mar. A persistência em tentar transferir a localização do projeto é justificável: Le Corbusier desejava restabelecer os vínculos entre a paisagem carioca e sua aguçada percepção de arquiteto e artista.

Somente quando o projeto para uma hipotética versão do MES junto ao litoral já estava praticamente definido é que Le Corbusier encontra um terreno com chances reais de receber o referido edifício. $\mathrm{O}$ terreno escolhido pelo arquiteto ficava próximo à quadra original, distante apenas alguns quarteirões em direção à praia. A situação privilegiada à beira-mar tornava o edifício um marco horizontal em meio à fascinante paisagem da baía da Guanabara. Sua implantação, paralela à praia, permitia uma vista totalmente desimpedida para a mesma baía.

Além de uma reminiscência da experiência de 1929 (bloco horizontal voltado para o mar), a proposta de Le Corbusier para o terreno à beira-mar vem ao encontro das suas proposições pós-puristas. O volume puro com aberturas em fita (típica solução da década de 1920) é substituído pela lâmina horizontal única, com sua face sul envidraçada e envolvida por delgada membrana de pedra. Ao substituir os rasgos horizontais por extensos planos de vidro emoldurados por estreitas espessuras revestidas de pedra, Le Corbusier incorpora, na versão à beira-mar, as estratégias de manipulação da forma e da superfície que já estavam presentes em seus projetos realizados a partir de 1930: o Pavilhão Suíço da Universidade de Paris (1930-1932) e o edifício de apartamentos Clarté em Genebra (1930-1932). [19], [20]

O próprio tratamento dado às fachadas norte e sul, presentes no primeiro estudo de Le Corbusier para o MES, é uma clara transposição das soluções aplicadas no Pavilhão Suíço: fachada sul envidraçada, e a fachada norte revestida de pedra e com obstruções quadradas.

Por mais que Le Corbusier justifique o projeto do MES à beira-mar como uma transposição da "múmia" 23 para uma realidade mais arejada, percebemos que se trata de um outro projeto que não se restringe a simples abertura dos braços da "múmia".

Ao desenvolver com a equipe brasileira essa nova versão para o MES, Le Corbusier introduz esses jovens arquitetos aos novos pressupostos modernos que ultrapassam os conceitos do "esquema Dom-Ino" e da "máquina de morar" estudados por eles como "sagrado catecismo".

Ao que tudo indica, a jovem geração de arquitetos brasileiros havia bebido muito mais na fonte purista ${ }^{24}$ de Le Corbusier, do que no seu referencial de feição nativista. Com a participação no projeto à beira-mar, os arquitetos tomam contato com uma referência corbusiana que transcende a mera alusão ao plano urbanístico de 1929, e assume a matéria vernácula como superfície para o objeto moderno, cujas aberturas não se reduzem mais a obstrução compositiva das casas

23. Nome dado por Le Corbusier ao projeto realizado pela equipe de Lucio Costa para o terreno original. Devido a sua simetria e rigidez, o projeto brasileiro, segundo Le Corbusier, assemelhava-se a uma múmia com os braços erguidos para frente. 24. Basta observarmos os referenciais adotado para a "múmia”: Palácio Centrosoyus de Moscou e Liga das Nações em Genebra.

$$
55 \text { o encontro de 1936: formação }
$$



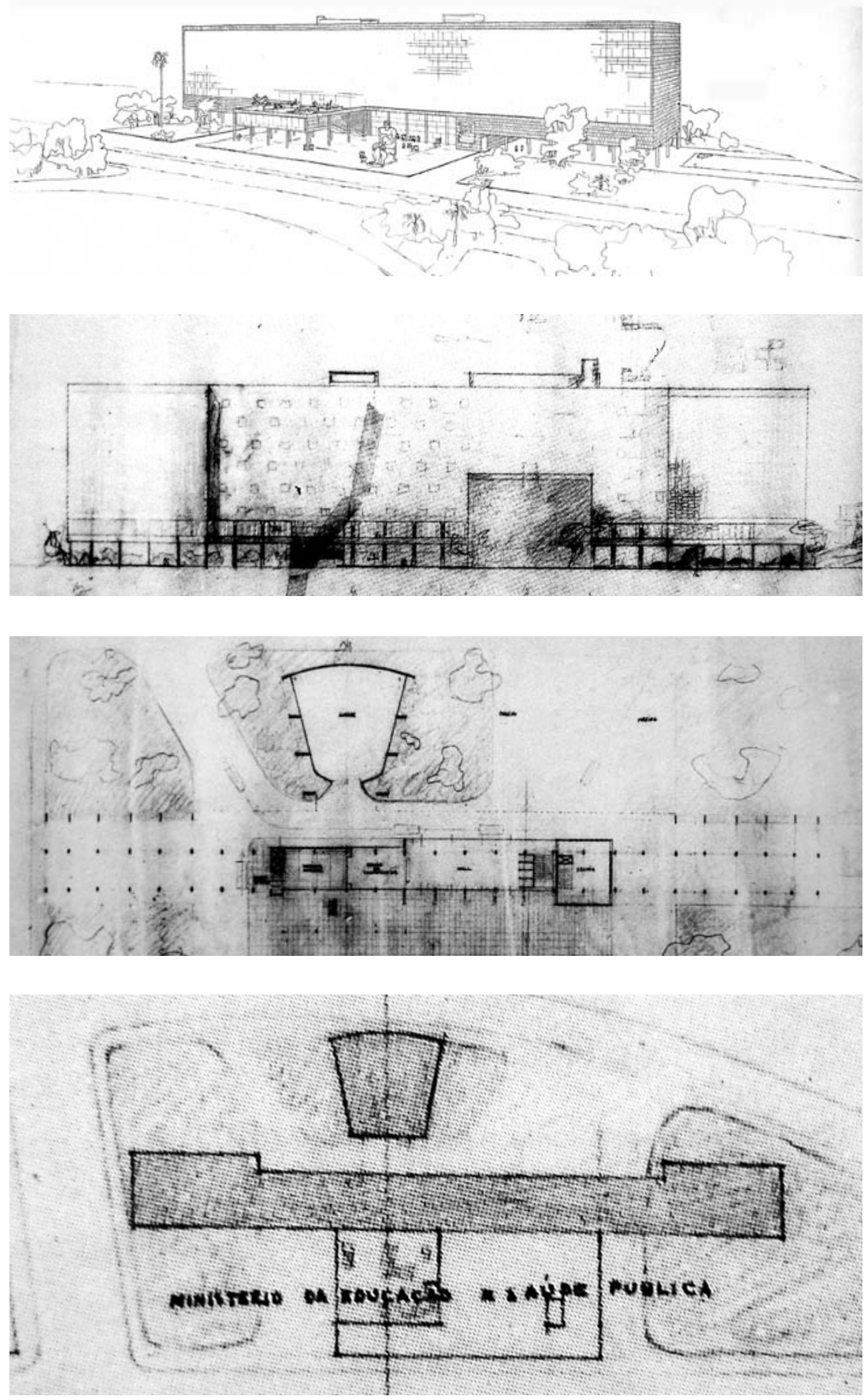

[21] Ministério da Educação e Saúde - Rio de Janeiro - versão a beira-mar - perspectiva - Le Corbusier e equipe brasileira - 1936. (PAPADAKI, 1950:51)

[22] Ministério da Educação e Saúde - Rio de Janeiro - versão a beira-mar - elevação posterior - Le Corbusier e equipe brasileira - 1936. (SANTOS, 1987:168)

[23] Ministério da Educação e Saúde - Rio de Janeiro - versão a beira-mar - planta térreo - Le Corbusier e equipe brasileira - 1936. (SANTOS, 1987:168)

[24] Ministério da Educação e Saúde - Rio de Janeiro - versão a beira-mar - implantação - Le Corbusier e equipe brasileira -1936. (SANTOS, 1987:165) 
brancas, mas se permitem integrais em uma monumental membrana transparente, ou singelas em pequenos quadrados alternados em zigue-zague sobre a superfície, agora revestida de pedra. A massa reguladora pintada de branco, presente nos exemplares corbusianos da década de 1920, dá lugar à adoção de superfícies embrutecidas.

A proposição de Le Cobusier para o edifício do MES na praia de Santa Luzia entraria em conflito com o referencial corbusiano que havia estruturado a formação daqueles jovens arquitetos, que transitava entre as composições puristas das casas brancas da década de 1920 e a organização hierarquizada do Palácio Centrosoyus. Os esquemas racionalizadores da forma e do espaço dão lugar a um experimento que, mesmo com um contorno elementar, estabelece um nexo tátil entre a arquitetura e a cultura do lugar.

No projeto à beira-mar, Le Corbusier e equipe concebem um conjunto caracterizado pela interseção perpendicular de dois volumes regulares: o bloco linear suspenso, paralelo à praia, que abriga os escritórios e as repartições, e o volume mais baixo, parcialmente suspenso, que abriga o salão de exposição e auditório.

$\mathrm{Na}$ versão para o MES realizada pela equipe brasileira e batizada de "múmia" por Le Corbusier, o bloco do salão de exposições e auditório também intercepta o volume em "U" que abriga as salas e trabalho e gabinetes. Porém, na "múmia", o bloco linear, perpendicular ao auditório trapezoidal, é dois pavimentos mais alto que as alas gêmeas, o que nos leva a crer que a proposta de Le Corbusier para a praia de Santa Luzia não é uma mera transposição da "múmia" que "abre os braços" em uma situação à beira-mar. $\mathrm{Na}$ "múmia" o volume trapezoidal do auditório é conectado ao bloco de exposições por sua base maior, sutilmente convexa. Há uma ruptura entre os volumes do bloco expositivo e do auditório. Na proposta para a praia, o volume do auditório também é trapezoidal, porém conecta-se ao bloco expositivo em sua base menor, conferindo um sentido de continuidade entre os volumes. [21], [22], [23], [24]

Em carta redigida em 11 de agosto de 1936, Gustavo Capanema elimina a possibilidade de se transferir a sede do MES para o terreno escolhido por Le Corbusier na praia de Santa Luzia e solicita que o arquiteto faça algumas considerações caso o edifício do MES seja mesmo construído no terreno original.

(...) Sobre o projeto existente, o senhor escreve: 'No caso de execução do dito projeto, teria eu algumas modificações de detalhes a introduzir que, na verdade, constituem nuanças. Essas nuanças adquirem grande importância no momento de execução'.

Como não tenho nenhuma certeza da realização da troca do terreno, por razões de ordem burocrática e outras, e ainda para prevenir tudo, peço-lhe que exponha essas 'algumas modificações de detalhes' às quais o senhor se refere.(...) (CAPANEMA apud LISSOVSKY, 1996:114).

Quatro dias antes de seu retorno a Paris, Le Corbusier recebe essa última incumbência de Capanema. O arquiteto não se restringirá à sugestão de modificações de detalhes sobre a "múmia". Ao contrário, Le Corbusier, prestes a voltar à Europa, realiza um segundo projeto para o MES, agora no terreno original, mesmo tendo declarado sua predileção por uma situação litorânea.

57 | o encontro de 1936: formação 

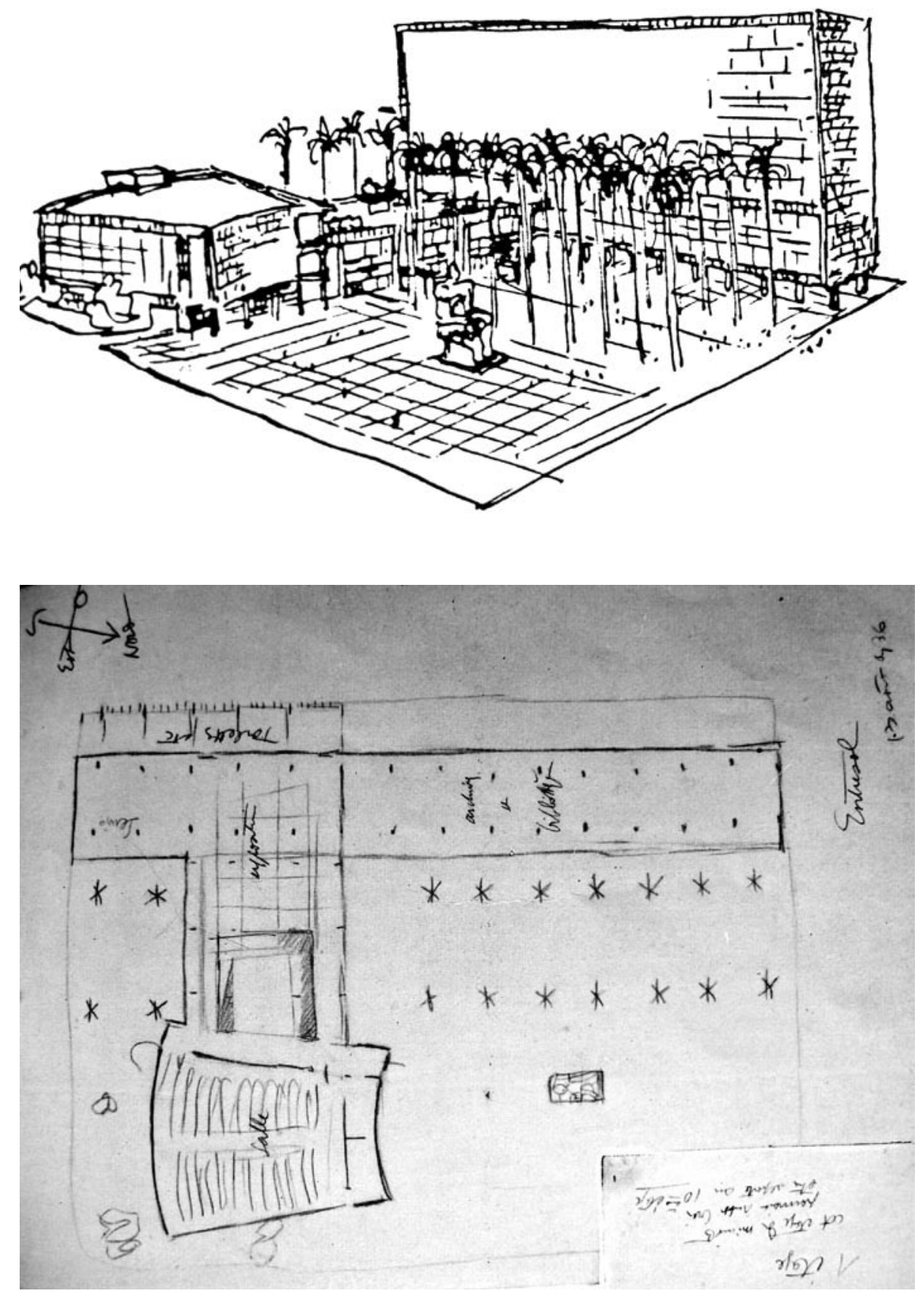

[25] Ministério da Educação e Saúde - Rio de Janeiro - estudo para o terreno definitivo - perspectiva - Le Corbusier - 1936. (SANTOS, 1987:173)

[26] Ministério da Educação e Saúde - Rio de Janeiro - estudo para o terreno definitivo - planta primeiro pavimento Le Corbusier - 1936. (Revista de Arquitetura e Urbanismo, julho/agosto 1939 p.546) 
Le Corbusier realiza uma transposição imediatista, contra sua vontade, do bloco linear à beira-mar para a quadra resultante do desmonte do morro do Castelo. Os dois sítios possuem características geográficas e geométricas distintas. Enquanto a quadra resultante do desmonte do morro do Castelo tem o formato retangular que mede $91,60 \mathrm{~m}$ por $69 \mathrm{~m}$, o terreno da praia de Santa Luzia possui o formato de um triângulo retângulo com hipotenusa em arco convexo, com sua base maior paralela à praia, medindo por volta de $180 \mathrm{~m}$. [25]

A adaptação do partido do projeto da praia de Santa Luzia não ocorrerá facilmente no terreno original. O bloco linear implantado no terreno à beira-mar mede por volta de 130 metros de comprimento, possuindo seis pavimentos-tipo. A proporção horizontal alcançada nesse estudo não será transportada para o terreno original que, em virtude do comprimento menor $(91,60 \mathrm{~m})$ comprometeria a proporção horizontal do bloco, mesmo que fossem adotados os mesmos seis pavimentos-tipo presentes na versão à beira-mar.

No terreno original, Le Corbusier localiza a lâmina de repartições e escritórios no sentido do comprimento do lote (alinhado à rua da Imprensa), na clara tentativa de resgatar pelo menos o sentido formal da solução litorânea.

Da mesma forma que o bloco linear da proposta para a praia de Santa Luzia não se encaixava no comprimento do terreno original, o bloco de exposições/auditório também sofreria cruciais alterações ao adaptar-se as dimensões do terreno original. Na versão à beira-mar, o volume perpendicular que intercepta a lâmina administrativa é constituído por um bloco retangular resultante da conexão do salão de exposições e do auditório. Devido à pouca largura do terreno original (69m), esse bloco mais baixo, perpendicular ao bloco administrativo, configura-se como uma construção em forma de "L", com o auditório perpendicular ao bloco de exposições e paralelo ao bloco administrativo.

A adaptação forçada do projeto da praia de Santa Luzia para o terreno original apresenta alguns desajustes flagrantes, como a orientação equivocada (leste-oeste) que tornaria inviável as grandes superfícies envidraçadas, desprovidas de proteção, previstas no estudo do arquiteto. A implantação da lâmina no lado mais comprido da quadra seria a única solução possível para que, pelo menos em parte, a horizontalidade do projeto a beira-mar fosse preservada, mesmo com o acréscimo de mais quatro pavimentos. [26], [27], [28], [29]

Le Corbusier não transpõe para o segundo estudo do MES os volumes encurvados presentes na cobertura no projeto implantado na praia de Santa Luzia. Essa subtração é um traço flagrante da tentativa frustrada de Le Corbusier de preservar a horizontalidade do projeto implantado à beira-mar.

Segue trecho em que Lucio Costa descreve o tortuoso processo de adaptação da solução da praia de Santa Luzia para o terreno original realizado por Le Corbusier:

Ele ainda tentou adaptar a sua concepção ao terreno original, surgindo então um impasse, porque sendo o lote mais estreito na desejada orientação sul não haveria como dispor, nessa orientação, a metragem total de piso requerida pelo programa, uma vez que então as autoridades da aeronáutica limitavam o gabarito

59 | o encontro de 1936: formação 



[27] Ministério da Educação e Saúde - Rio de Janeiro - estudo para o terreno definitivo - elevação R. Araújo Porto Alegre - Le Corbusier - 1936. (Revista de Arquitetura e Urbanismo, julho/agosto 1939 p.547)

[28] Ministério da Educação e Saúde - Rio de Janeiro - estudo para o terreno definitivo - elevação R. da Imprensa Le Corbusier - 1936. (Revista de Arquitetura e Urbanismo, julho/agosto 1939 p.547)

[29] Ministério da Educação e Saúde - Rio de Janeiro - estudo para o terreno definitivo - elevação Av. Graça Aranha Le Corbusier - 1936. (Revista de Arquitetura e Urbanismo, julho/agosto 1939 p.547) 
a dez pavimentos. Teve assim que implantar o bloco no sentido norte-sul, com as fachadas para leste e oeste, o que resultou numa composição algo contrafeita que não agradou nem a ele nem a nos (COSTA, 1995:136, grifo nosso).

$\mathrm{Na}$ incerteza de construir seu projeto ideal, Le Corbusier, em poucos dias, realiza o estudo para o terreno original e, em 15 de agosto de 1936, retorna à Paris.

Segundo Lucio Costa, dentre todas as contribuições deixadas por Le Corbusier no Rio de Janeiro em 1936, talvez a mais brilhante tenha sido o desabrochar do gênio de Oscar Niemeyer, jovem arquiteto de vinte e oito anos, adotado por Le Corbusier como um acompanhante, sempre à mão para a realização de suas belas perspectivas. Segue trecho em que Lucio Costa se refere à revelação de Oscar Niemeyer:

(...) Em quatro semanas [Le Corbusier] fez um projeto para a Cidade Universitária (...), fez seis ou sete conferências, fez um projeto para o Ministério, num terreno à beira-mar, e ainda procurou adaptar o projeto ao terreno definitivo, sem conseguir. E além de tudo nos deixou de quebra o Oscar Niemeyer. Porque ele não existia antes da vinda de Le Corbusier, não existia absolutamente. E veio a questão do trabalho do Ministério, depois eu o levei a Nova York, para o Pavilhão da Feira Internacional de 1939, veio a Pampulha. Foi a presença de Le Corbusier que o deixou, de quebra.(...)

Ele gostava do Oscar porque ele às vezes o ajudava a fazer os desenhos, ajudava a fazer as figuras que aparecem nas perspectivas. Dos vários arquitetos, tinha um - o Oscar - que toda hora estava à mão e pronto a fazer qualquer coisa. (...) O Oscar, na época, era tímido, não tinha a menor comunicação e recebeu aquilo em cheio, aquele oxigênio todo. Aí é que revelou o que era de fato, o que estava incubado (COSTA, 1995:152, grifo nosso).

Em texto intitulado Relato Pessoal, Lucio Costa explica o episódio do MES, do convite feito por Capanema em 1935 à inauguração do edifício, dez anos depois, em 1945. Em um momento do texto, Lucio Costa refere-se a Oscar Niemeyer como uma “dádiva” deixada por Le Corbusier.

(...) Contudo, apesar dessa frustração final ${ }^{25}$,ele ainda nos deixaria de quebra, sem querer - além dos planos para a Universidade, das aulas ao vivo e daquele risco fundamental ${ }^{26}-$, uma dádiva: foi durante esse curto mas assíduo convívio de quatro semanas que o gênio incubado de Oscar Niemeyer aflorou (COSTA, 1995:136, grifo nosso).

O Ministro Gustavo Capanema divide da mesma opinião de Lucio Costa, e confirma o papel de "sacristão" de Niemeyer, arquiteto que convertia em desenhos as idéias de Le Corbusier:

(...) quem era o enfant gaté de Le Corbusier era o Oscar Niemeyer. Como era jovem e desenhava muito bem, Oscar Niemeyer passou a ser o 'sacristão' de Le Corbusier. Ele não fazia nada sem o Oscar. O Oscar convertia logo suas idéias em desenhos (CAPANEMA apud CAVALCANTI, 1995:73, grifo nosso).

25. Lucio Costa refere-se ao projeto deixado por Le Corbusier para o terreno original como uma "frustração final".

26. Para Lucio Costa, o primeiro projeto do MES elaborado por Le Corbusier para o terreno da praia de Santa Luzia foi o "risco fundamental" que definiu o partido adotado por Oscar Niemeyer em seu estudo pessoal e que posteriormente foi assimilado como partido definitivo pela equipe de arquitetos que, em 05 de janeiro de 1937, apresentaria essa nova proposta à Capanema.

61 o encontro de 1936: formação 
O próprio Le Corbusier, de volta a Paris, em carta redigida a Lucio Costa em 21 de novembro de 1936, pergunta sobre o "valoroso Oscar e suas belas perspectivas" (LE CORBUSIER apud SANTOS, 1987:178).

Em resposta a Le Corbusier, Lucio Costa escreve uma carta onde discorre sobre sua influência sobre Niemeyer: “(...) Continue mandando notícias, isso significa bastante para todos nós. Seu P.S. deixou o Oscar 'emocionado' - ele está fazendo coisas lindas no momento - sua visita abriu os horizontes para ele” (LE CORBUSIER apud SANTOS, 1987:179).

Elizabeth Harris também aponta para a "transformação de Oscar Niemeyer" após a passagem de Le Corbusier pelo Rio de Janeiro.

(...) A princípio, a viagem de Le Corbusier ao Brasil parecera não ter causado grande impressão. No entanto, um arquiteto em particular, graças à visita do mestre, sofrera profunda transformação: Oscar Niemeyer acolhera de coração as idéias de Le Corbusier (HARRIS, 1987:117, grifo nosso).

Em seu livro Preocupações do Belo, Lauro Cavalcanti ressalta a "revelação" de Niemeyer após o contato com Le Corbusier em 1936, referindo-se a Le Corbusier e Niemeyer como "Moisés" e seu discípulo:

(...) Na historiografia arquitetônica, a "revelação" de Niemeyer, até então aluno medíocre e arquiteto discreto, é o ponto mágico de um momento mítico: Le Corbusier, como um Moisés, entrega as tábuas da "modernidade" a Oscar Niemeyer que, tocado pelo gênio do mestre, vê despertar a sua própria genialidade na conducão do projeto do MES, origem da arquitetura "moderna" brasileira, que obterá reconhecimento e prestigio internacionais (CAVALCANTI, 1995:73, grifo nosso).

Esse curto período do episódio do projeto do MES, compreendido entre o retorno de Le Corbusier a Paris, em 15 de agosto de 1936, e a apresentação para Capanema, em 05 de janeiro de 1937, de uma nova proposta para o edifício do MES contendo o partido do projeto definitivo ainda encontra-se em suspensão. Trata-se de um momento cercado de incertezas, onde os desencontros dos depoimentos e das análises históricas, associados à ausência de desenhos comprobatórios, ainda preservam enevoada uma das passagens mais intrigantes do episódio do MES: o percurso projetual ocorrido entre a apresentação a Capanema, em 19 de outubro de 1936, da proposta realizada pela equipe brasileira logo após a partida Le Corbusier, reconhecida como a "múmia" com sutis alterações, e a apresentação do estudo que continha o partido arquitetônico daquele que seria projeto definitivo, em 05 de janeiro de 1937.

Após o retorno de Le Corbusier a Paris, a equipe de jovens arquitetos brasileiros encontrava-se em um impasse que daria margem a escolhas distintas: ou esses arquitetos retomavam o projeto batizado por Le Corbusier como "múmia"; ou traduziriam o impacto da visita do "mestre" em um novo projeto.

A seguir, nos deteremos à comparação das dissonantes leituras sobre o projeto desenvolvido pela equipe brasileira em seguida à partida de Le Corbusier. Tanto os depoimentos 
desencontrados de Lucio Costa e Oscar Niemeyer, como as diferentes versões narradas por autores como Elizabeth Harris e Yves Bruand, ainda mantém suspensos alguns trechos cruciais de um projeto realizado há mais de setenta anos.

Segundo Lucio Costa, a reação imediata da equipe brasileira, após a partida de Le Corbusier, foi a retomada dos estudos para a "múmia": "Depois de sua partida nos atribuímos a tarefa de fazer novo projeto baseado na sua proposição original, ou seja, orientado mesmo para o sul e com a altura necessária (...)"(COSTA 1995:136, grifo nosso).

Divergindo da versão de Costa, Yves Bruand afirma que a equipe brasileira não retomou os estudos da "múmia", mas realizou uma síntese dos dois projetos realizados por Le Corbusier para o MES, adotando como referencial o estudo deixado para o terreno original, associado à aplicação de alguns princípios que regeram o estudo para o terreno à beira-mar. Para Bruand, o projeto realizado após a partida de Le Corbusier partia

(...) do esboço [de Le Corbusier] elaborado para o terreno original, Lucio Costa e equipe reexaminam o problema, empenhando-se em aplicar os princípios que haviam orientado Le Corbusier quando da elaboração do primeiro projeto [para a praia de Santa Luzia] (BRUAND 1999:85).

Elizabeth Harris, em seu livro Le Corbusier: Riscos Brasileiros diverge de Bruand e afirma que a equipe de jovens arquitetos brasileiros, após o retorno de Le Corbusier, retomou os estudos para a "múmia". Segue trecho da autora:

Após o regresso de Le Corbusier a Paris, os arquitetos brasileiros puseram de lado os seus esboços e voltaram ao conjunto original de planos para o sitio do Castelo, ao qual se referiam como múmia. (...) A equipe introduziu mudanças superficiais na múmia, seguindo as observações críticas de Le Corbusier, e submeteu os planos para a aprovação dois meses mais tarde, a 19 de outubro de 1936 (HARRIS 1987:117, grifo nosso).

Segundo Harris, em 19 de outubro de 1936, uma nova versão da "múmia" desenvolvida pela equipe brasileira passou por uma aprovação de Capanema. Para a autora, o projeto representava a "múmia" acrescida de "mudanças superficiais".

Mauricio Lissovsky e Paulo Sérgio Moraes de Sá, autores do livro Colunas da Educação: A construção do Ministério da Educação e Saúde, não corroboram com a versão apresentada por Bruand, alinhando-se a versão defendida por Harris.

Lissovsky e Sá desenvolvem uma apurada pesquisa que explica todo o episódio da construção do MES a partir da publicação, em ordem cronológica, dos documentos que registram todo o desenrolar dos acontecimentos. Os autores estruturam um raciocínio que considera a retomada da "múmia" por parte da equipe de arquitetos liderada por Lucio Costa após o retorno de Le Corbusier à Europa.

Em parecer redigido em 19 de outubro de $1936^{27}$, Gustavo Capanema executa uma análise

27. Data coincidente com a versão apresentada por Elizabeth Harris.

63 o encontro de 1936: formação 

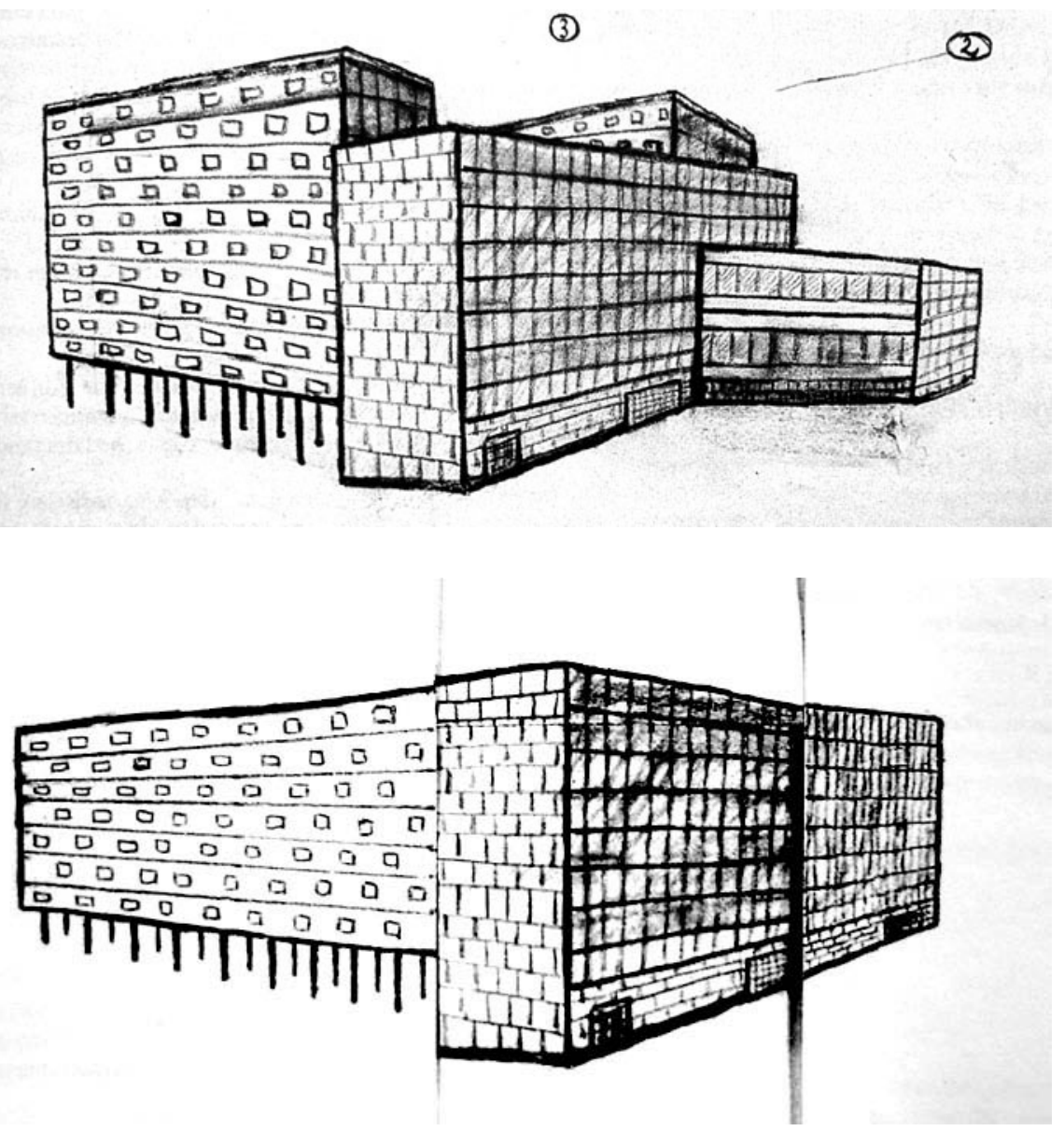

[30] Ministério da Educação e Saúde - Rio de Janeiro - estudo realizado pelo Ministro Gustavo Capanema - 1936. (LISSOVSKY, 1996:126)

[31] Ministério da Educação e Saúde - Rio de Janeiro - estudo realizado pelo Ministro Gustavo Capanema - 1936. (LISSOVSKY, 1996:126) 
sobre o estudo realizado pela equipe brasileira após a partida de Le Corbusier. Em vários trechos do parecer é possível diagnosticar as menções que Capanema faz sobre uma nova versão da "múmia" acrescida de sutis alterações. Seguem trechos do parecer de Capanema que fazem alusão a essa segunda versão para a "múmia":

(...) Aprovo o projeto com as seguintes observações:

(...) 2. Deve ser previsto o aumento do edifício, em altura, com tantos pavimentos a mais, quer no corpo $\underline{\text { central, }}$ quer nas alas laterais, quantos permitam a harmonia da perspectiva.

(...) 5. O corpo anexo, para salão de conferências, poderia ser localizado de um dos lados da parede que dá para o sul, conforme me alvitrou o próprio Lúcio Costa. Poderia ser colocado ao lado da rua da Imprensa. $\underline{\text { Isto tiraria ao conjunto um pouco da simetria, }}$ que foi objeto da crítica do sr. Le Corbusier, no seu parecer. Tal corpo poderia ter a forma retangular, solução melhor, como pareceu a Augusto Perret, que, ao ensejo de sua passagem pelo Rio de Janeiro, me fez verbalmente, a meu pedido, rápida crítica do projeto (...)

Resultaria dessa solução uma área retangular, compreendida entre o corpo central do edifício, o corpo anexo, a rua Pedro Lessa e a rua Graça Aranha, área que poderia ser transformada em jardim.

Outra solução que poderia ser examinada: suprimir o corpo anexo, trazendo-se o corpo central para mais perto da rua Pedro Lessa e aumentando o tamanho das alas laterais.

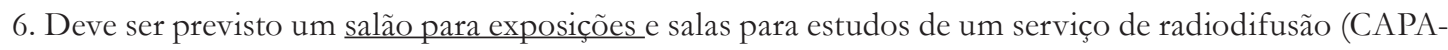
NEMA apud LISSOVSKY, 1996:127-128, grifo nosso).

Em 15 de outubro de 1936, quatro dias antes do parecer de Capanema, Washington Azevedo entrega ao Ministro um parecer sobre essa mesma versão sutilmente alterada da "múmia". Em diversos trechos do parecer, Azevedo comenta sobre os problemas presentes no estudo apresentado pelos arquitetos brasileiros.

(...) Foi tomado o partido de edificação em forma de "U" com salas para o lado de menor insolação. (...) não me parece mal a disposição do andar tipo: grandes salas (facilmente divisíveis), serviços concentrados em colunas verticais, elevadores reunidos.

O que me figura pouco aconselhável é o corpo anexo destinado à garage e a sala de conferências. (...) A garage (...) da forma que foi disposta, não atende às necessidades: dificuldade de circulação dos veículos, falta de espaço para manobras (...) (AZEVEDO apud LISSOVSKY, 1996:124-125, grifo nosso).

A presença de termos como "corpo central", "alas laterais", "simetria", "partido em forma de "U", nos dão claros indícios de que os pareceristas estavam diante de um estudo com as feições da "múmia" realizada pela equipe brasileira antes da chegada de Le Corbusier.

$\mathrm{O}$ aspecto mais interessante, presente nos dois pareceres, principalmente no parecer de Capanema, não é, nem tanto, a confirmação de que a equipe brasileira retomou o estudo da "múmia" após o retorno de Le Corbusier a Paris, mas sim as alterações de projeto sugeridas pelos pareceristas.

Em seu parecer, o Ministro Capanema, não apenas aponta deficiências no estudo, como propõe diversas alterações significativas no projeto, e que seriam atendidas no estudo que sucede a retomada da "múmia". Seguem algumas sugestões de Capanema para o edifício do MES:

- aumento do número de andares do "corpo central" e das "alas laterais";

65 o encontro de 1936: formação 

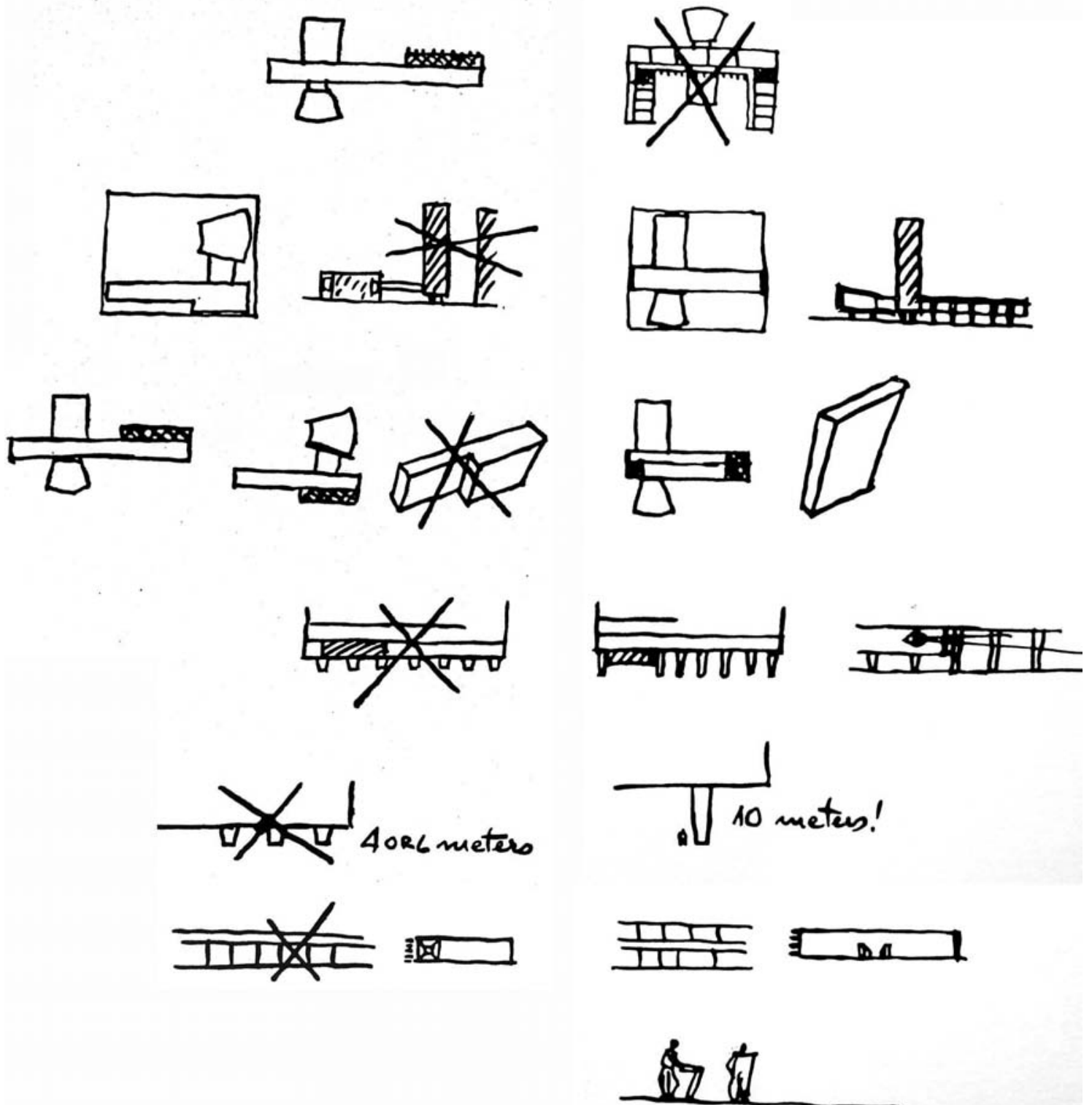

[32] Ministério da Educação e Saúde - croquis alusivos às transformações do projeto - Oscar Niemeyer (SANTOS, 1987:183) 
- transferência do salão de conferências para uma situação "ao lado da rua da Imprensa", eliminando a simetria indesejada do conjunto;

- a alteração do contorno trapezoidal do salão de conferências e a adoção do formato retangular;

- a previsão de uma praça/jardim de limite retangular voltada para a esquina formada pelas ruas Pedro Lessa e Graça Aranha, resultante do novo arranjo assimétrico do conjunto;

- aumento do comprimento das alas laterais em direção da r. Pedro Lessa; previsão de um salão de exposições.

Às sugestões de ordem projetual propostas por Gustavo Capanema acrescenta-se o conselho dado por Washington Azevedo de se rever o desenho do estacionamento localizado sob o salão de conferências.

De uma forma ou de outra, as alterações sugeridas por Capanema e Azevedo seriam assimiladas pela equipe liderada por Costa nos estudos posteriores a retomada da "múmia". Tratase de um dado inusitado a revelação de que algumas das diretrizes arquitetônicas e urbanísticas que regeram o projeto definitivo para o MES partiram de um parecer elaborado pelo próprio Ministro Capanema.

Não há registros, pelo menos nos trabalhos publicados sobre o MES, desse grupo de desenhos realizados pela equipe brasileira e que passaram pelos pareceres de Gustavo Capanema e Washington Azevedo. Os únicos desenhos que fazem menção ao estudo realizado pela equipe brasileira sobre o esquema da "múmia" saíram da mão do próprio Ministro Capanema, sob a forma de esboços extremamente precários. [30], [31]

As sugestões propostas por Capanema foram incorporadas a um segundo estudo realizado pela equipe brasileira após a partida de Le Corbusier e apresentado ao Ministro em 05 de janeiro de 1937,já com a feição do projeto definitivo para o edifício do MES.

Em carta enviada para Le Corbusier em 31 de dezembro de 1936, Lucio Costa se declara insatisfeito com a retomada do projeto da "múmia" e descreve a nova proposta concebida pela equipe de arquitetos, em uma só lâmina, seguindo os conselhos do "mestre".

(...) A idéia de fazer a 'múmia' depois de termos visto as coisas tão bonitas que o senhor fez não nos anima: estamos propondo a ele [Capanema] uma nova solução de um só bloco, como o senhor nos havia aconselhado - mas no sentido mais curto do terreno (S-S-E) e com o dobro de profundidade (COSTA apud SANTOS, 1987:179).

O período de dois meses, compreendido entre outubro e dezembro de 1936, ilustra o momento crucial de todo o episódio que envolve o projeto do edifício do MES, onde é definido o partido do projeto final. Nesse curto espaço de tempo, Lucio Costa e equipe desprezam a versão sutilmente modificada da "múmia" (cujos desenhos são desconhecidos) e elaboram uma nova proposta que em nada lembraria a simetria em " $U$ ” da proposição anterior. Será nesse exato instante - da rejeição do estudo apresentado a Capanema em 12 de outubro de 1936, à elaboração da nova proposta com o partido do projeto definitivo, entregue ao Ministro em 05 de janeiro de

$$
67 \text { | o encontro de 1936: formação }
$$


1937 - que ascenderá a figura do jovem arquiteto Oscar Niemeyer.

Elizabeth Harris, baseada em entrevista ${ }^{28}$ realizada com Carlos Leão, descreve a origem do projeto definitivo para o MES que sucedeu a retomada da "múmia":

(...) Durante o dia ele [Oscar Niemeyer] colaborava com as modificações da múmia, mas à noite passava horas desenhando um novo projeto, onde entravam os pontos essenciais dos projetos de Le Corbusier. Uma manhã, em dezembro de 1936, ele levou seus projetos para o estúdio e mostrou-os a Carlos Leão. Leão ficou sinceramente impressionado com a assimilação dos princípios de Le Corbusier pelo jovem arquiteto, conforme se evidenciava num notável design baseado nos estudos do mestre. Quando Lucio Costa chegou, Niemeyer pegou os planos e jogou-os pela janela, temeroso de que aquele o considerasse insolente por trabalhar sozinho num novo projeto. Leão falou a Lucio Costa sobre o surpreendente conjunto de projetos produzido por Niemeyer e insistiu com este para ir apanhá-los imediatamente. Niemeyer modificara ligeiramente o projeto para o sitio do Castelo com aspectos do plano para a praia de Santa Luzia e criou uma composição equilibrada, destinada ao plano piloto para a estrutura final (HARRIS 1987:117-118, grifo nosso).

Segue trecho em que o próprio Oscar Niemeyer confirma as informações dadas por Carlos Leão à Elizabeth Harris. Niemeyer descreve, não só os acontecimentos que o levaram a realizar, de maneira isolada, uma nova proposta para o MES, mas também as soluções sugeridas por ele e adotadas no projeto definitivo. [32]

Afastado o projeto do Lucio que lhe serviu de programa, Le Corbusier elaborou dois estudos: o primeiro, para o terreno ideal junto ao mar, o outro, para o local definitivamente escolhido no centro da cidade. E foi este último o projeto que passou a ser desenvolvido pela equipe organizada por Lucio, e de que eu fazia parte. Para mim, o primeiro estudo era muito melhor. E quando vi os desenhos do segundo projeto sendo concluídos, tentei, angustiado, uma idéia diferente, tendo como base seu primeiro projeto. Carlos Leão gostou dos croquis que eu desenhei; falou com o Lucio, eu os joguei pela janela - nunca me ocorrera vê-los aproveitados - Lucio mandou buscá-los e foram aprovados. Neles eu localizava o projeto de Le Corbusier no centro do terreno, abrindo o grande hall, fazendo com que a praça o invadisse de lado a lado, e o conjunto de exposições e auditórios, mais independentes, voltados para o exterior.

Mas, com a minha colaboração é, não raro, exagerada ou minimizada, lembro outras coisas por mim sugeridas, com a eliminação das saliências previstas na fachada posterior para a localização dos sanitários; a adoção do corredor central em vez da circulação singela; a exclusão da primeira placa de brise-soleil junto ao peitoril. Lembro que o Jorge Moreira não gostou de minha proposta. "Lucio", disse ele, o projeto já está quase pronto. "Tudo desenhado", mas o Lucio manteve sua opinião e a minha sugestão foi aprovada. Não fosse ele, é bom lembrar, o que estaria construído seria o segundo projeto de Le Corbusier, e a fachada protegida por brises verticais, como as da ABI, como senti em alguns desenhos e croquis (Niemeyer 1998:91-92, grifo nosso).

Os dois relatos apresentados acima mostram que Niemeyer se encontrava em um impasse que precisava ser equacionado: ou o arquiteto sucumbia ao modelo acadêmico da composição simétrica em "U” da "múmia", ou assimilava os pressupostos modernos presentes nos estudos

$\overline{28 .}$ entrevista realizada em junho de 1981.

o encontro de 1936: formação| 68 
de Le Corbusier para o MES.

A idéia de modernidade contida no raciocínio que concebeu a "múmia" já estava defasada em relação ao modelo corbusiano apresentado aos jovens arquitetos no Rio de Janeiro. A modernidade tributária aos grands travaux de Le Corbusier da década de 1920 como o Palácio Centrosoyus (1929-1930) que estava impregnada na "múmia" apresentava-se muito mais como um retrocesso do que como um avanço, principalmente, quando comparada com os estudos realizados por Le Corbusier para o MES, onde o desenho do edifício já não é mais perimetral ao desenho da quadra; ao contrário, desenvolve-se autônomo ao traçado tradicional. Elevado sobre pilotis, o edifício devolve o chão à cidade, e as transposições extravasam as "ruas corredor" que dão lugar ao vazio, conseqüência do adensamento em lâminas independentes do contorno da quadra.

Por mais que as decisões que nortearam o partido definitivo do edifício do MES sejam atribuídas a Niemeyer, sua paternidade corbusiana é inegável, o que torna imprudente qualquer colocação que afirme, categoricamente, que o projeto do edifício do MES seja um exemplar autêntico da arquitetura moderna brasileira (se é que podemos falar nesses termos). Contudo, os desenhos deixados por Le Corbusier eram preliminares e as alterações sugeridas por Oscar Niemeyer extremamente significativas, o que nos leva a crer que se tratava de uma relação entre um tipo e um modelo.

As recomendações deixadas por Le Corbusier em sua segunda viagem ao Rio de Janeiro, seja nos esboços para o MES, nas conferências ou nos pareceres, extrapolam o âmbito especifico do projeto do edifício e informam muito mais sobre um conjunto de procedimentos postuladores de um tipo de edifício, do que sobre o projeto de um edifício em si. Já o projeto definitivo do MES, conformado nas soluções propostas por Niemeyer, representa a transformação do tipo em modelo, que, por sua vez, apresenta particularizações que o próprio tipo não considerava. A transposição desse conjunto de idéias constituidoras do tipo corbusiano para o edifício construído, retrata a interpretação desses pressupostos transformados em edifício. Nesse sentido, é possível concluir que o projeto definitivo do edifício do MES representa uma contribuição genuína - em um primeiro momento, de Niemeyer e, em seguida da equipe de arquitetos brasileiros - sobre um esquema proposto por Le Corbusier.

Para a inauguração do edifício do MES, Lucio Costa redige um texto que está gravado na pedra que reveste o hall principal no pavimento térreo. Segue a transcrição do texto:

Sendo Presidente da República Getúlio Vargas e Ministro de Estado da Educação e Saúde Gustavo Capanema, foi mandado construir êste edifício para Sede do Ministério da Educação e Saúde projetado pelos arquitetos Oscar Niemeyer, Afonso Reidy, Jorge Moreira, Carlos Leão, Lucio Costa e Hernani Vasconcelos, segundo risco original de Le Corbusier, 1937, 1945. (COSTA apud Lissowsky, 1996:214)

Não discordamos do texto de Lucio Costa, apenas acrescentaríamos a informação de que o projeto da equipe brasileira foi realizado "segundo o risco original de Le Corbusier" para um outro projeto, implantado em um outro lugar, no caso, o estudo feito para a Praia de Santa Luzia.

69 | o encontro de 1936: formação 

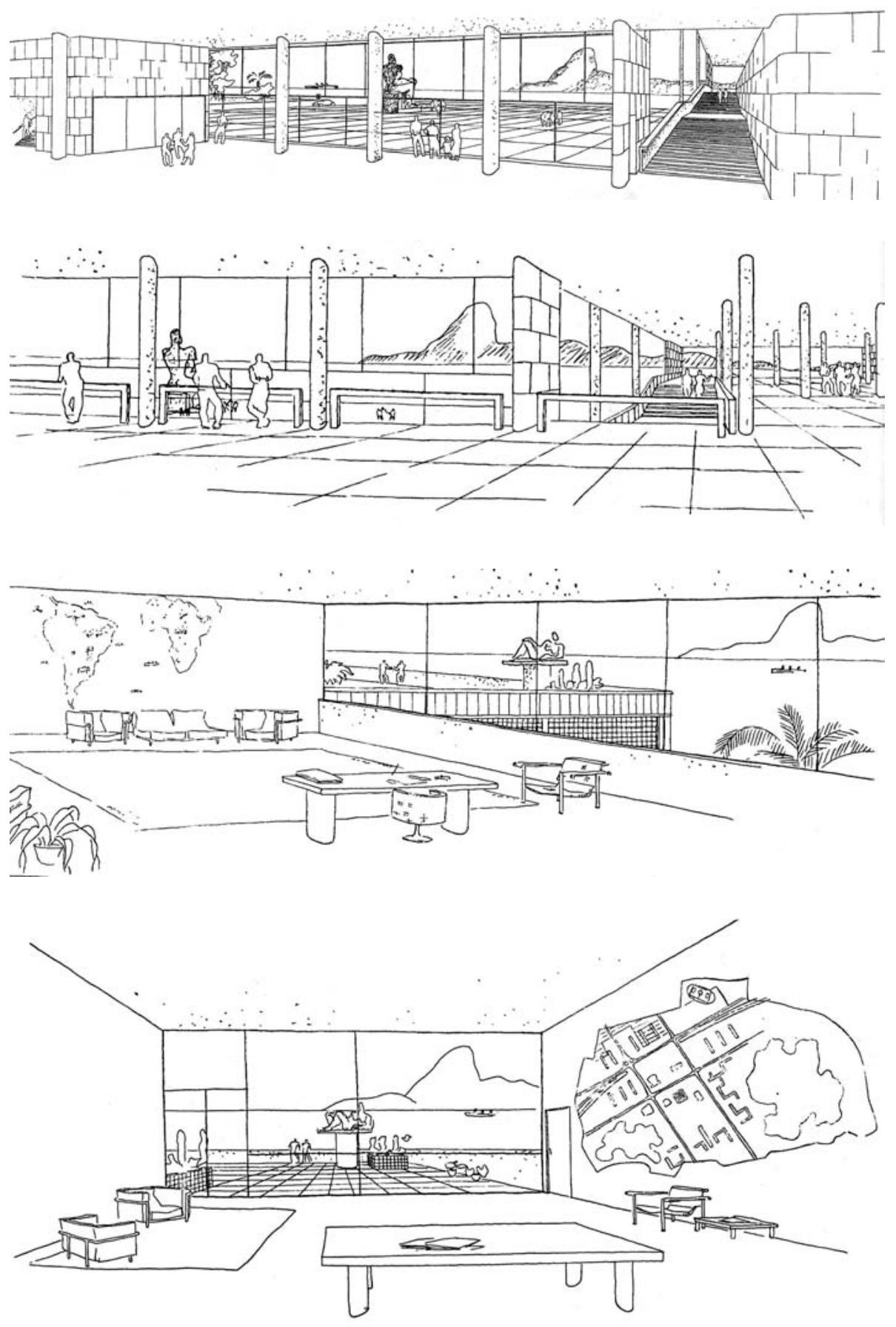

[33] Ministério da Educação e Saúde - versão à beira-mar - Le Corbusier e equipe brasileira - perspectiva interna salão de acesso - desenho Oscar Niemeyer (BILL, 1947:80)

[34] Ministério da Educação e Saúde - versão à beira-mar - Le Corbusier e equipe brasileira - perspectiva interna salão do primeiro andar - desenho Oscar Niemeyer (BILL, 1947:80)

[35] Ministério da Educação e Saúde - versão à beira-mar - Le Corbusier e equipe brasileira - perspectiva interna gabinete do Ministro Gustavo Capanema - desenho Oscar Niemeyer (BILL, 1947:80)

[36] Ministério da Educação e Saúde - versão à beira-mar - Le Corbusier e equipe brasileira - perspectiva interna sa sala de espera do gabinete do Ministro Gustavo Capanema (à direita, fixado na parede, o projeto de Le Corbusier para a Universidade do Brasil - desenho Oscar Niemeyer (BILL, 1947:79) 
No final do texto gravado na parede do MES, Lucio Costa coloca as datas "1937-1945", dando a impressão de que o projeto do MES começou em 1937. Sabemos que a proposta definitiva foi realizada entre outubro e dezembro de 1936 mas, propositalmente, ao ignorar o ano de 1936, Lucio Costa, pelo menos nas inscrições da placa inaugural, subtrai da história oficial a presença de Le Corbusier no Rio de Janeiro.

Os desenhos de Niemeyer que, posteriormente, foram adotados por Lucio Costa e equipe e como partido para o projeto definitivo do MES, não se baseavam no estudo feito por Le Corbusier para a quadra do Morro do Castelo, mas no seu primeiro estudo feito para o terreno localizado na Praia de Santa Luzia. Segundo Niemeyer, seus desenhos caracterizavam-se por "uma idéia diferente, tendo como base seu primeiro projeto".

Com essas colocações, não resta dúvida de que o edifício construído do MES é um projeto de autoria exclusiva da equipe de jovens arquitetos. O risco revelador ${ }^{29}$ de Niemeyer assimila o risco original de Le Corbusier, não como uma solução de projeto, mas como um esquema formal que, por basear-se em pressupostos estandartizados, se permite adaptar às circunstâncias mais distintas.

Talvez o fato de Niemeyer ser o mais jovem arquiteto do grupo seja um dos fatores que o fizeram incorporar esse corbusianismo atualizado com uma percepção mais aberta, mais receptiva, sem o excessivo respeito aos modelos corbusianos sacralizados da década de 1920.

O estreito convívio entre Niemeyer e Le Corbusier, durante as semanas em que o "mestre" esteve no Rio de Janeiro, teve um papel fundamental na futura recepção de seus ensinamentos, que não estão presentes apenas no discurso. Estão no projeto e principalmente no desenho.

Niemeyer desenhou grande parte das perspectivas para Le Corbusier. Essa relação com o desenho foi fundamental para a assimilação do conteúdo da arquitetura. Ao dedicar-se ao desenho de uma perspectiva interna ${ }^{30}$, o arquiteto assimila as minúcias, não apenas do projeto, mas do raciocínio do arquiteto que idealiza aqueles espaços: as aberturas, os enquadramentos, as relações de proporção, o posicionamento mais adequado do indivíduo dentro do projeto, a intenção por detrás do desenho. [33], [34], [35], [36]

Apesar dos dois estudos de Le Corbusier versarem sobre uma suposta evolução da axialidade em "U" que caracteriza a "múmia", algumas soluções de projeto dão indícios de que o desejo por uma síntese horizontal e suspensa em lâmina única ainda esbarrava em algumas escolhas que diluíam a intensidade moderna dos projetos.

Na elaboração do partido definitivo para o MES, Niemeyer não realiza apenas uma síntese de dois modelos do "mestre" (para a praia de Santa Luzia e para o terreno original). O arquiteto incorpora os pressupostos corbusianos a partir de um exercício de depuração da forma arquitetônica, dado por um procedimento ambíguo, caracterizado tanto pela reverência como pela ruptura.

29. Risco que revela o "gênio encubado" de Oscar Niemeyer (COSTA, 1995:136).

30. Como podemos observar nas perspectivas internas que ilustram os salões presentes na proposta de Le Corbusier para a praia de Santa Luzia.

71 o encontro de 1936: formação 



[37] Ministério da Educação e Saúde estudo da versão definitiva - planta pavimento tipo - equipe brasileira - desenho Oscar Niemeyer (Revista de Arquitetura e Urbanismo, julho/agosto 1939 p.544)

[38] Ministério da Educação e Saúde - versão de Le Corbusier para o terreno definitivo - planta pavimento tipo - desenho Oscar Niemeyer (Revista de Arquitetura e Urbanismo, julho/agosto 1939 p. 544)

[39] Ministério da Educação e Saúde bloco vertical de contorno regular (exclusão das saliências presentes nos estudos de Le Corbusier) - vista R. da Imprensa - 1936 - equipe brasileira (foto: Rodrigo Queiroz)

o encontro de 1936: formação 72 
Ao mesmo tempo em que preserva intactos os cincopontos inscritos na arquitetura corbusiana, Niemeyer intervem nas dimensões da forma e do espaço, a partir de um raciocínio, até então, sem precedentes na obra de Le Corbusier.

Nos dois estudos de Le Corbusier para o MES, o bloco de escritórios se posiciona como um "fundo" para o bloco perpendicular que avança em direção à praça vazia (seja a quadra triangular da praia de Santa Luzia, ou a quadra retangular do morro do Castelo). Niemeyer inverte a condição de "fundo" do edifício, ao transferi-lo do alinhamento da calçada para o meio do terreno.

A horizontalidade que caracterizava as propostas anteriores de Le Corbusier é abandonada no estudo realizado por Niemeyer, que prevê a implantação do bloco administrativo no sentido da largura da quadra.

Na proposta de Niemeyer, o bloco administrativo assume a condição de um objeto pleno na quadra. Tanto a relação figura-fundo entre o bloco administrativo e o bloco de exposição e conferências, como a hierarquização das fachadas presente nas propostas de Le Corbusier é transgredida. O conceito de frente e fundo desaparece justamente pelo fato do edifício estar implantado no meio do terreno, desafogando ambas as elevações.

Nos estudos de Le Corbusier, o bloco administrativo é uma barra horizontal implantada como fundo e enquadramento da perspectiva que se descortina de uma plataforma vazia. No estudo de Niemeyer, esse mesmo bloco é encarado como um objeto autônomo no meio do lote. Para essa transposição, faz-se necessária uma revisão sobre a condição urbana e plástica desse objeto. Nesse instante, Niemeyer modela a lâmina corbusiana na intenção de eliminar uma reminiscência acadêmica (hierarquização das fachadas) que, em um objeto disposto no meio da quadra vazia, comprometeria a plena leitura da forma em todas as suas perspectivas.

A solução encontrada por Niemeyer e pela equipe brasileira foi a transposição da circulação, da extremidade para o eixo longitudinal da planta, além do aumento considerável da largura da planta retangular, fator que permitiu que as salas fossem abertas para ambas as faces do volume. [37], [38], [39]

Nas versões de Le Corbusier, o bloco horizontal possui duas protuberâncias laterais em sua face posterior. Niemeyer elimina essas saliências e define a planta do pavimento tipo como um retângulo regular. Conseqüentemente, o volume que nos estudos de Le Corbusier era recortado, na proposta de Niemeyer apresenta-se como um objeto de geometria elementar.

Apesar do partido claramente dividido em dois blocos, nas duas propostas de Le Corbusier a autonomia dos volumes que estruturam o conjunto é comprometida. O arquiteto organiza uma composição a partir da interseção de dois volumes perpendiculares entre si: o bloco administrativo como uma lâmina horizontal e o bloco que compreende os salões de exposição e conferência como um volume mais baixo e perpendicular ao bloco maior. Ao adotar os volumes interceptados, Le Corbusier retira a possível potencialidade formal de ambos os volumes, tornando inviável a construção de visuais integrais que enquadrem os volumes em sua totalidade.

Niemeyer compreende a interseção entre os volumes perpendiculares nos estudos de Le

$$
73 \text { o encontro de 1936: formação }
$$



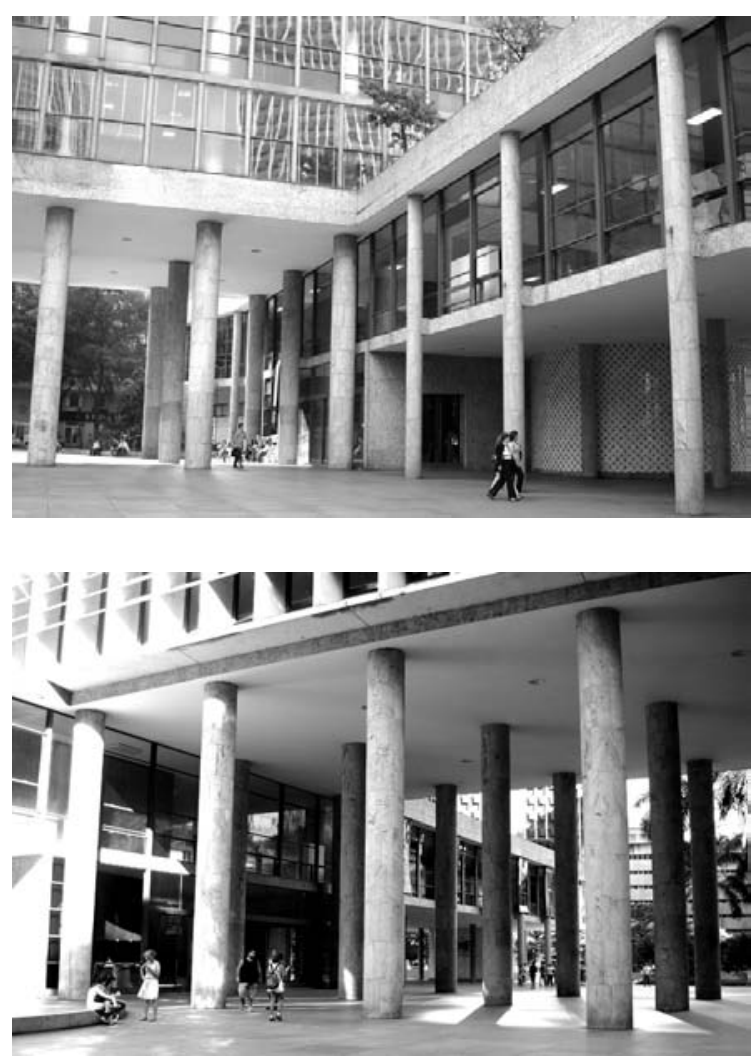

[40] Ministério da Educação e Saúde - perspectiva para a R. Araújo Porto Alegre (transposição do bloco de exposições sob o bloco de escritórios) - equipe brasileira (foto: Rodrigo Queiroz)

[41] Ministério da Educação e Saúde - perspectiva para a R. Pedro Lessa (transposição do bloco de exposições sob o bloco de escritórios) - 1936 - equipe brasileira (foto: Rodrigo Queiroz)


[42] Ministério da Educação e Saúde - abertura em leque da trama de pilares do bloco de exposições que se encaixa no volume trapezoidal do auditório - 1936 - equipe brasileira (foto: Rodrigo Queiroz)

[43] Ministério da Educação e Saúde - junção entre o volume transparente do salão de exposição e o volume trapezoidal do auditório - 1936 - equipe brasileira (foto: Rodrigo Queiroz) 
Corbusier como um ruído passível de solução. A interseção em Le Corbusier transforma-se em sobreposição em Niemeyer, que eleva a altura dos pilotis do bloco administrativo, igualando-a a altura do bloco compreendido pelos salões de exposição e conferência. Com essa solução, desaparece a interseção de volumes presente nos estudos de Le Corbusier.

Enquanto que nas propostas de Le Corbusier essa relação de independência entre os volumes era apenas sugerida, no estudo de Niemeyer a autonomia de cada componente é tanto física como visual.

Na solução de Niemeyer, o bloco compreendido pela junção do dos salões de exposição e de conferência assume um sentido de continuidade e unidade que inexiste nas propostas de Le Corbusier, justamente pelo fato de que, em Le Corbusier, o bloco de exposições e conferência passa "por dentro" da lâmina administrativa, enquanto que em Niemeyer os volumes preservam suas naturezas geométricas individuais. [40], [41]

Em Niemeyer, esse conjunto que passa sob o volume principal não é formado pela mera junção da forma retangular do salão de exposições à forma trapezoidal do salão de conferências. No instante em que os dois volumes se encontram, a linha de pilares periféricos do salão de exposições abre-se em leque, "abraçando" o volume trapezoidal do auditório. Com esse artifício, não apenas a horizontalidade do conjunto é reforçada, como a materialidade estanque do volume do auditório é, em parte, diluída, pois se encontra parcialmente abrigada pela pele transparente do salão de exposições que inflete-se em sutil diagonal para abrigar o volume trapezoidal. [42]

Com o rompimento da trama regular de pilares, estão transgredidas tanto a lógica corbusiana que rege as relações entre as massas puras no espaço como a própria regra do esquema Dom-Ino. A trama se sujeita à forma arquitetônica no momento em que a seqüência de pilares se abre para receber o volume trapezoidal do auditório. Nesse instante, inverte-se um pressuposto corbusiano da forma que se condiciona à retícula regular de pilares. No caso do projeto brasileiro, a retícula é esgarçada para adaptar-se à forma. [43]

Essa ruptura com a regularidade da retícula assumirá um grau de liberdade cada vez maior nos projetos de Niemeyer que sucedem a experiência do MES, como no salão de exposições do Pavilhão do Brasil na Feira Internacional de Nova York (1938), caracterizado por uma sutil curvatura em "S". Essa delicada sinuosidade da retícula já estava presente, inclusive, na proposta de Niemeyer classificada em segundo lugar no concurso para o Pavilhão ${ }^{31}$.

A proposta de Niemeyer e equipe, apresentada em 05 de janeiro de 1937, por mais que possa ser compreendida como um redesenho dos estudos de Le Corbusier para o MES, assimila as recomendações prescritas por Capanema em seu parecer de 19 de outubro de 1936. Nesse sentido, poderíamos dizer que Niemeyer atende as sugestões de Capanema, a partir de uma interpretação pessoal do ideário corbusiano. [44], [45]

Todas as recomendações indicadas por Capanema em seu parecer foram atendidas no estudo realizado por Niemeyer que, posteriormente, seria adotado pela equipe brasileira. $\mathrm{O}$ "au-

31. A análise dos projetos de Niemeyer para o Pavilhão do Brasil encontra-se no capítulo Pavilhão do Brasil na Feira de Nova York.

75 o encontro de 1936: formação 

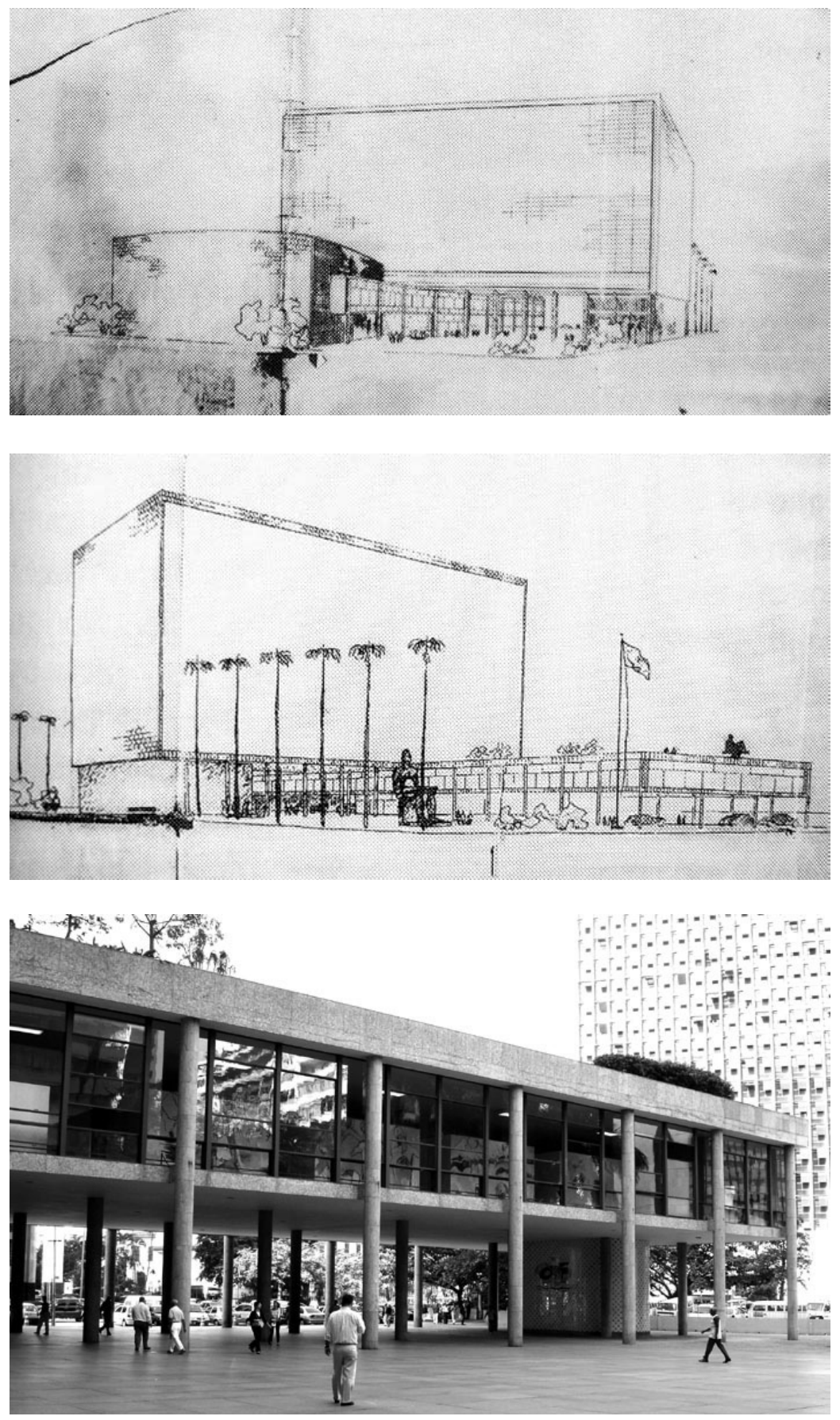

[44] Ministério da Educação e Saúde - estudo entregue pela equipe brasileira em 05 de dezembro de 1936 - realizado a partir das alterações propostas por Oscar Niemeyer (primeira aparição do partido definitivo) - perspectiva esquina da R. Araújo Porto Alegre com Av. Graça Aranha (DECKKER, 2001:39)

[45] Ministério da Educação e Saúde - estudo entregue pela equipe brasileira em 05 de dezembro de 1936 - realizado a partir das alterações propostas por Oscar Niemeyer (primeira aparição do partido definitivo) - perspectiva esquina da Av. Graça Aranha com Pedro Lessa (DECKKER, 2001:39)

[46] Ministério da Educação e Saúde - bloco de exposições com o acréscimo de mais dois módulos que avançam em direção da R. Pedro Lessa que foi interrompida nesse trecho (foto: Rodrigo Queiroz) 
mento do número de andares do corpo central"; a "transferência do salão de conferências para uma situação ao lado da rua da Imprensa" sugerida pelo Ministro é atendida por Niemeyer, no instante em que o arquiteto localiza o corpo horizontal compreendido pelos salões de exposições e conferência ladeando a rua da Imprensa. A sugestão de Capanema para que fosse realizada uma "alteração do contorno trapezoidal do salão de conferências e a adoção do formato retangular (...)e a previsão de um salão de exposições” se traduz no momento em que o salão transparente retangular abraça o volume trapezoidal do auditório, ocultando parte do volume em seu interior. O desejo de Capanema por "uma praça/jardim de limite retangular voltada para a esquina formada pelas ruas Pedro Lessa e Graça Aranha” estava contemplada na proposta de Niemeyer que localiza o "T" em uma posição que mantém livre exatamente o retângulo descrito por Capanema e que, em um futuro breve, seria ocupado pelos jardins do jovem paisagista Roberto Burle Marx. Em outra sugestão, Capanema propõe o "aumento do comprimento das alas laterais na direção da rua Pedro Lessa". Ao observarmos a evolução dos estudos realizados sobre o partido definitivo, percebemos que foi adicionado mais dois módulos reticulares ao bloco retangular do salão de exposições em seu sentido sul, em direção à rua Pedro Lessa. Tal acréscimo de área só foi possível graças ao fechamento dessa rua, que permitiu que o bloco expositivo se prolongasse por mais vinte metros. [46]

Ao cotejarmos as sugestões de Gustavo Capanema com as soluções atribuídas a Niemeyer, realizadas à revelia da equipe brasileira, percebemos uma clara relação de correspondência entre os desejos do Ministro e as proposições do jovem arquiteto. Nesse sentido, poderíamos dizer que Niemeyer não apenas estabelece alternadas referências e rupturas com os códigos corbusianos, mas também adapta o projeto às novas diretrizes apontadas por Capanema.

Nessa primeira proposta apresentada a Capanema em 05 de janeiro de 1937 ainda não estavam presentes os volumes encurvados localizados no térreo e na cobertura do MES, e o bloco principal possuía apenas dez pavimentos. Somente em uma fase adiantada do projeto é que, por sugestão de Capanema, seriam acrescentados mais quatro pavimentos, totalizando catorze andares-tipo. Esses elementos encurvados no térreo e na cobertura aparecem na medida em que os estudos para o MES assumem contornos definitivos. [47], [48], [49]

Esses componentes sinuosos que foram assimilados no desenrolar dos estudos do MES - apesar de se configurarem como um traço flagrante de liberdade plástica em sintonia com a regularidade do conjunto - já eram utilizados por Le Corbusier ${ }^{32}$ em seus projetos de residências realizados na década de 1920, seja externamente, na cobertura, ou no interior dos volumes puros.

A curva nos projetos puristas de Le Corbusier, como nas “casas brancas”, é compreendida como uma instância de liberdade sob a contensão geométrica do contorno exterior. $\mathrm{O}$ arquiteto constrói a curva com os parâmetros da geometria exata, constituída ou pela concordância de quadrantes circulares (semi-círculo, ou quarto-de-círculo), ou pelo traçado de parábolas regu-

32. No capítulo Cassino abordaremos em profundidade a curva pictórica nos projetos puristas de Le Corbusier.

77 | o encontro de 1936: formação 

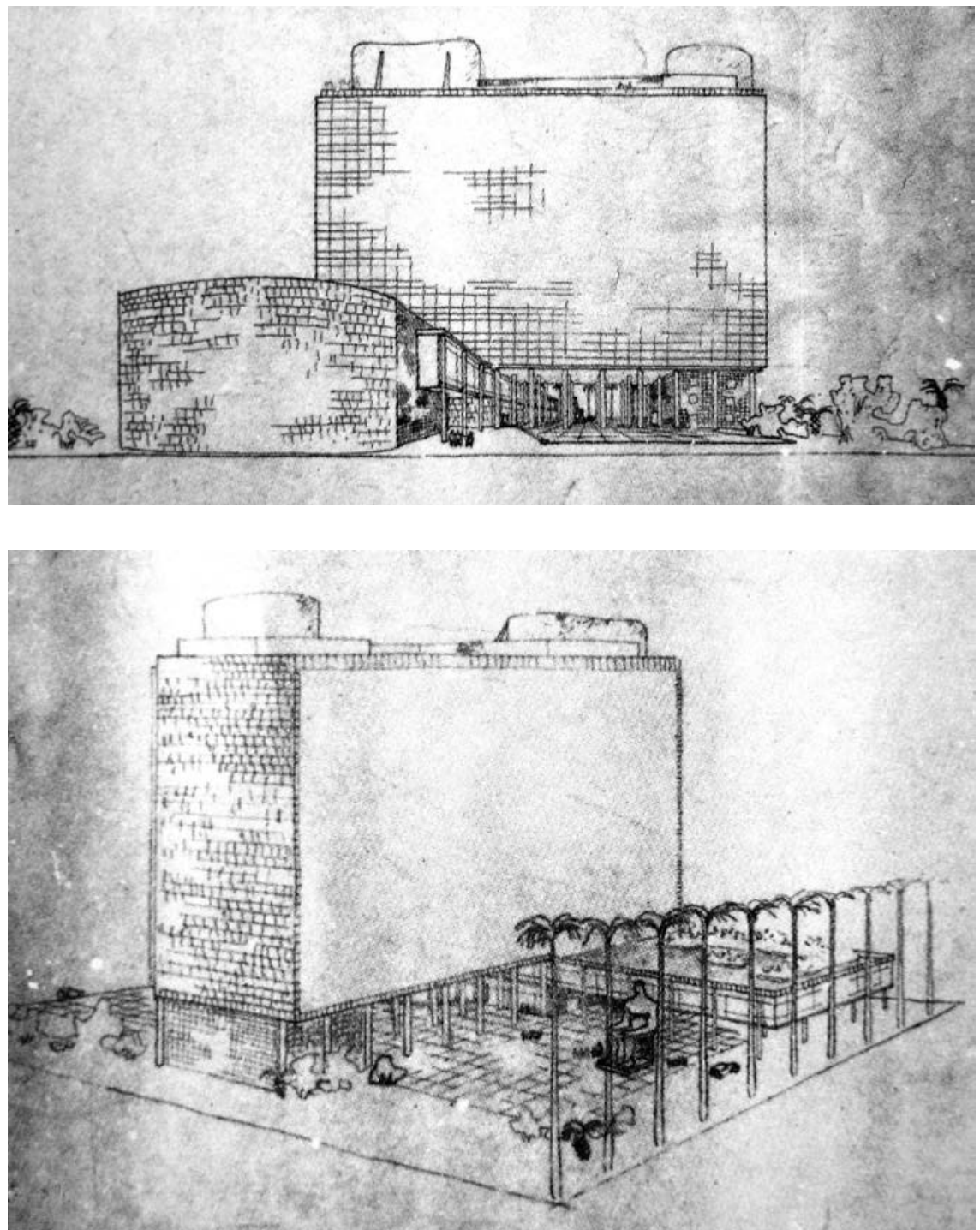

[47] Ministério da Educação e Saúde - segundo estudo realizado pela equipe brasi-

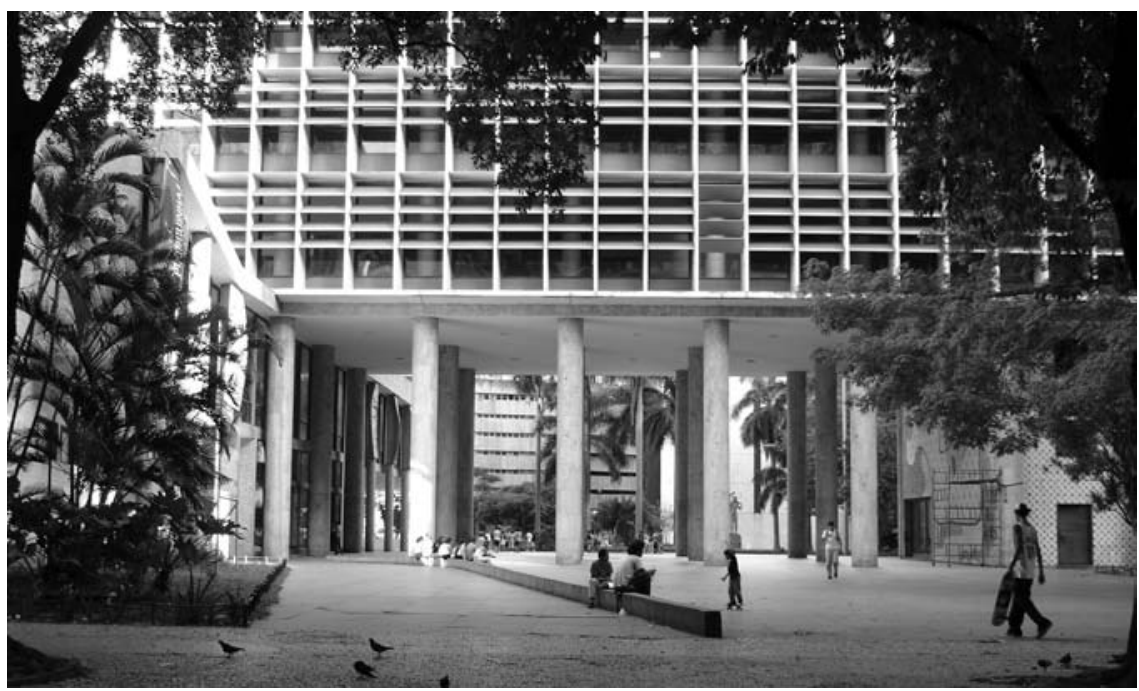
leira - 1937 - perspectiva R. Araújo Porto Alegre (DECKKER, 2001:178)

[48] Ministério da Educação e Saúde - segundo estudo realizado pela equipe brasileira - 1937 - perspectiva Av. Graça Aranha com R. Pedro Lessa (DECKKER, 2001:178)

[49] Ministério da Educação e Saúde - vista R. Araújo Porto Alegre (foto: Rodrigo Queiroz) 
lares. No projeto para a casa Savoye (1929), Le Corbusier dispõe os componentes encurvados nos três pavimentos da residência: em semi-círculo transparente no térreo; em semi-circulo que abriga a caixa de escada no pavimento intermediário; e em traçados ovais e semi-circulares nos pára-ventos da cobertura.

No projeto do MES, esses elementos encurvados alinham-se às soluções corbusianas, muito mais no sentido de sua dimensão pictórica do que de sua dimensão plástica. As formas livres presentes no térreo e na cobertura do MES ilustram a primeira ocorrência da curva na arquitetura de Niemeyer e, já nesse primeiro projeto, o desenho da curva assume um movimento que diverge da curva corbusiana, experimentando traçados sinuosos, mesmo que timidamente. Nas formas oblongas do MES, a regularidade geométrica da curva corbusiana dá lugar a um movimento ondulante que concorda "curvas e contra-curvas".

No pavimento térreo, sob a projeção do salão de exposições, encontram-se dois volumes de traçado curvo: o volume de planta oval que abriga a escada helicoidal de acesso ao salão de exposições e o volume de traçado oblongo que contém o vestiário e escada de serviço. $\mathrm{Na}$ cobertura do edifício administrativo estão implantados outros dois volumes encurvados com a mesma natureza geométrica daqueles encontrados no térreo: um volume de planta oval destinado ao reservatório de água e um volume de planta oblonga que abriga a casa-de-máquinas dos elevadores. [50], [51], [52], [53]

Assim como as formas curvas presentes na casa Savoye, as formas livres do Ministério são interiores ao perímetro do edifício, seja na cobertura ou no térreo. Essa configuração estabelece uma relação de dualidade entre o todo retentor de contorno regular e a forma livre interna à forma pura. Tal relação é percebida nos desenhos das plantas, onde o perfil exterior dos objetos assume a condição de moldura que abriga e organiza a composição das formas curvas.

Devemos lembrar que, tanto o uso da cerâmica esmaltada e pintada que reveste as formas encurvadas no térreo, como a escolha pelo granito apicoado que reveste as espessuras das lajes, os pilotis e as empenas laterais do bloco principal foram sugestões expressas de Le Corbusier para o projeto a beira-mar e que são transpostas para o projeto definitivo no Morro do Castelo. Nesse sentido, podemos afirmar que, não apenas na dimensão da forma, mas também na dimensão da superfície, o projeto do MES corresponde aos apontamentos de Le Corbusier. [54], [55]

A matéria vernácula como superfície da forma moderna talvez seja a instância maior do lastro de autenticidade da arquitetura moderna brasileira. Porém, devemos apontar que, pelo menos no projeto do MES, tido como projeto fundador de nossa arquitetura moderna, a adoção da matéria tradicional como cobertura para a forma moderna (pedra apicoada e cerâmica pintada) foi uma sugestão proveniente de um olhar estrangeiro.

Segue trecho em que Lucio Costa credita a Le Corbusier a idéia de utilizar tanto a pedra como os azulejos no edifício do MES:

(...) Eu pretendia usar aquele arenito de Ipanema, de São Paulo. É o material da mapoteca do Itamaraty (...) É uma pedra cor de palha queimada. Mas ele [Le Corbusier] disse, olhando o gnaiss dos enquadramentos antigos: 'Esse granito é tão bonito que parece de onça. Vocês deveriam botar aî'.

79 | o encontro de 1936: formação 



[50] Ministério da Educação e Saúde - projeto definitivo - cobertura - equipe brasileira (WISNIK, 2001:59)

[51] Ministério da Educação e Saúde - projeto definitivo - planta térreo - equipe brasileira (WISNIK, 2001:59)
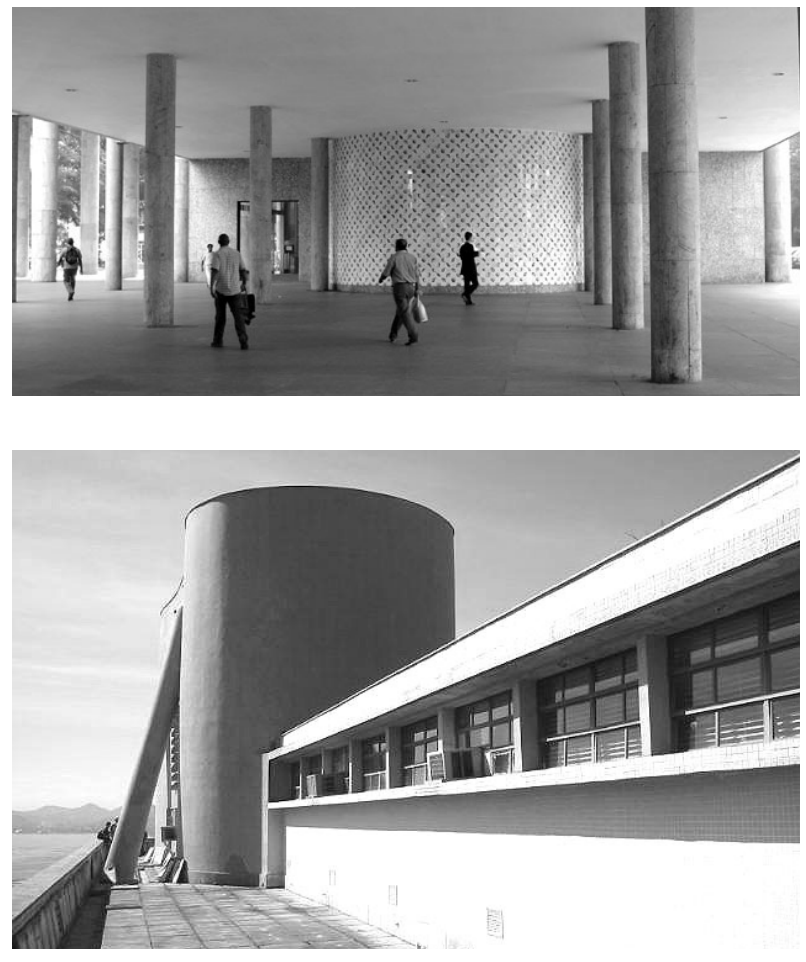

[52] Ministério da Educação e Saúde - volume de planta oblonga da casa de máquinas na cobertura (foto: Rodrigo Queiroz)

[53] Ministério da Educação e Saúde - volume de planta oval revestido de cerâmica pintada que abriga a escada helicoidal que ascende ao salão de exposições (foto: Rodrigo Queiroz) 
(...) Os azulejos eram uma tradição. Aqueles silhares enormes nas igrejas dos séculos XVII e XVIII, em toda a parte, salvo em Minas (COSTA 1995:146).

Como vimos no depoimento de Costa, coube ao próprio Le Corbusier a sugestão do uso desses elementos tradicionais (pedra e cerâmica pintada) no projeto do MES. Não se tratava de uma sugestão aclimatada à ambiência carioca. Devemos lembrar que, desde os primeiros anos da década de 1930, Le Corbusier dedicava-se à fusão entre a forma moderna e a superfície nativa, vide as casas de campo projetadas na primeira metade da década de 1930 (Errazuris 1930 - Mandrot 1930-1931 e Mathes 1935). A própria adoção da cerâmica como matéria de revestimento das "formas livres" - que caracterizará algumas versões e o projeto definitivo do MES - já havia sido especulada por Le Corbusier no projeto do Exército da Salvação em Paris (1930) na forma cilíndrica posicionada ao lado do acesso principal.

Além da cerâmica pintada e do granito apicoado, a equipe brasileira incorporará o bloco quadrado de vidro (tijolo de vidro), outro material adotado por Le Corbusier, tanto no estudo do MES na praia de Santa Luzia como em projetos anteriores, como o edifício de apartamentos Clarté em Genebra (1930-1932); a Cité Refuge (1932-1933), o Pavilhão Suíço (1930-1932) e o edifício de apartamentos Molitor (1933), esses três últimos construídos em Paris. [56], [57]

No projeto de Le Corbusier para um edifício de apartamentos na Argélia (1933) já estavam presentes, não apenas a forma curva na cobertura, como a superfície tramada de brises horizontais que também seria adotada no MES.

Nos dois estudos realizados para o MES, Le Corbusier propõe a utilização de brises horizontais fixos nas extremidades laterais da elevação posterior do bloco horizontal. O projeto definitivo para o MES adota a solução dos brises horizontais presentes nos experimentos de Le Corbusier. Porém, no projeto brasileiro, os brises são móveis, adequando o sombreamento a cada estação do ano e, diferentemente da proposta de Le Corbusier, ocupam toda a face do bloco principal. Contemporâneo ao projeto e a construção do MES, Niemeyer realiza o projeto da Obra do Berço (1937), onde já se encontram, quase que experimentalmente, os brises articuláveis, nesse caso, posicionados na vertical. [58]

Quando Niemeyer propõe "a exclusão da primeira placa de brise-soleil junto ao peitoril”" dos andares tipo do bloco administrativo do MES, o arquiteto abranda a homogeneidade monótona da fachada, rompendo com a uniformidade formada pela superfície perfurada que contém os brises. Com a eliminação da fileira de brises inferiores em cada pavimento tipo, penumbras geométricas se desenham na fachada devido a profundidade dessas células, o que resulta em uma superfície dinâmica que assume diferentes padronagens do transcorrer de um único dia. [59]

No projeto para o MES, Oscar Niemeyer realiza sua primeira interpretação autoral sobre a obra do "mestre". A proposta de Niemeyer não deve ser reconhecida como mera transposição para o terreno original do estudo de Le Corbusier para a Praia de Santa Luzia Ao contrário, as qualidades das intervenções de Niemeyer para o MES recaem muito mais sobre as sucessivas rupturas com o modelo corbusiano do que sobre os pressupostos modernos que são preservados. Niemeyer transgride o esquema proposto por Le Corbusier, mas ao mesmo tempo o utiliza

81 | o encontro de 1936: formação 

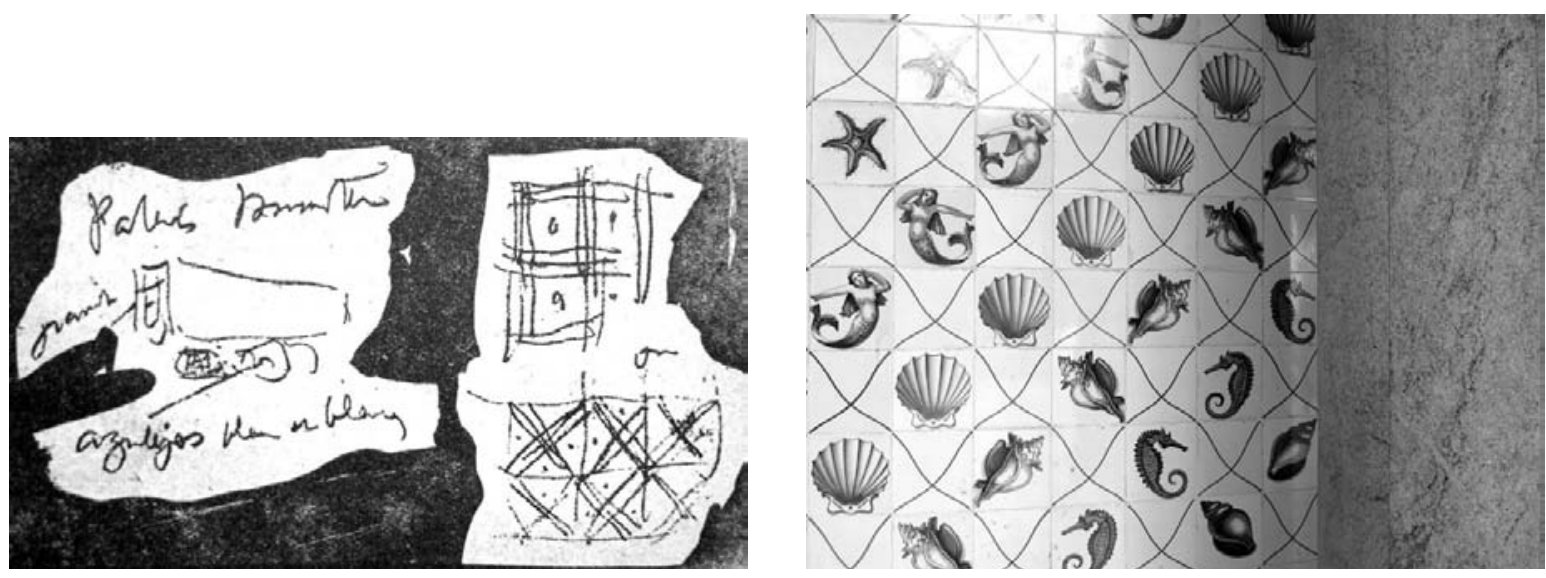

[54] Ministério da Educação e Saúde - esboços de Le Corbusier indicando a pedra apicoada e a cerâmica pintada como revestimentos externos (SANTOS, 1987:167)

[55] Ministério da Educação e Saúde - a relação entre a cerâmica pintada que reveste as alvenarias externas e a pedra apicoada que reveste os pilotis. (foto: Rodrigo Queiroz
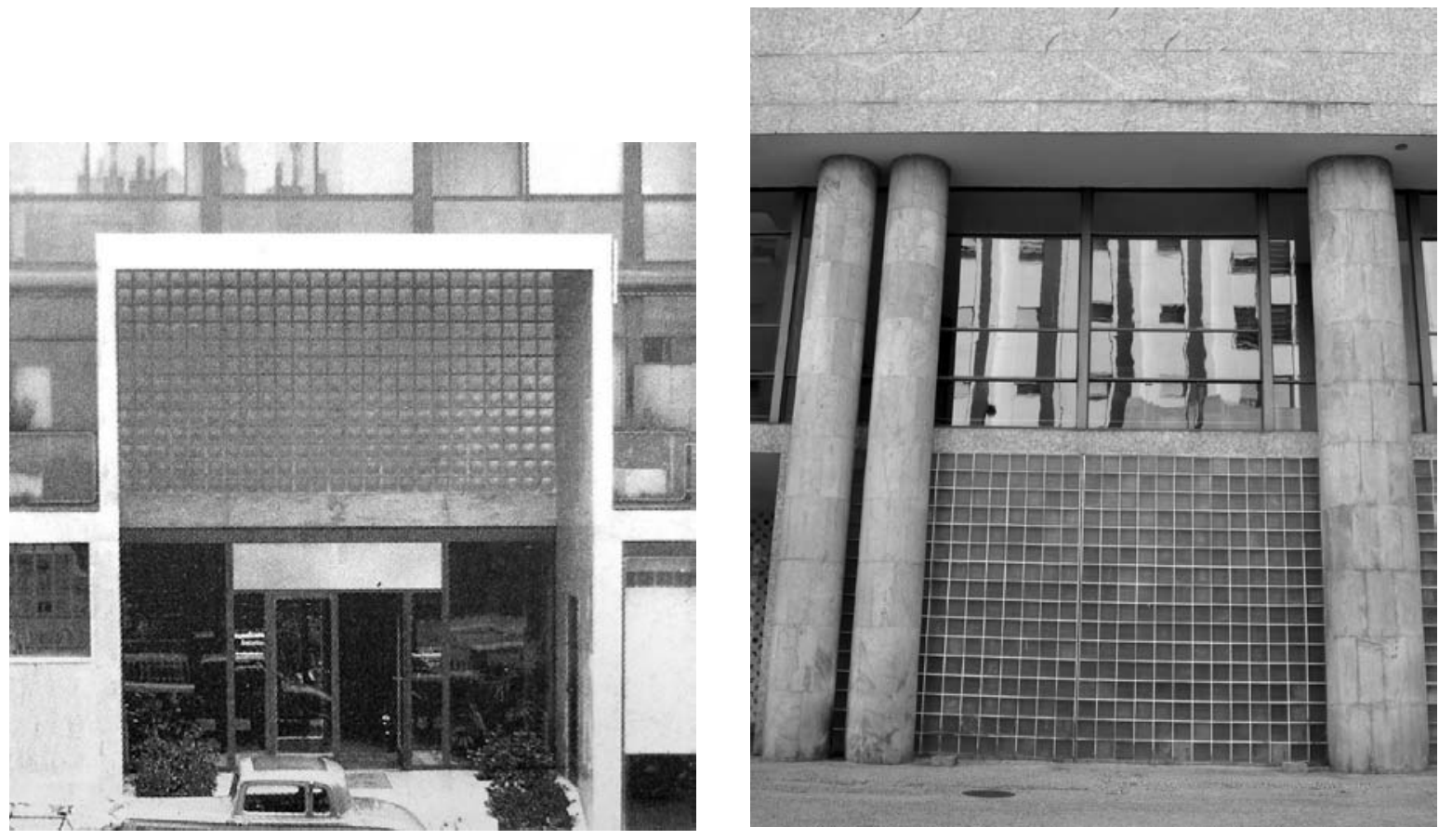

[56] Edifício de apartamentos Clarté em Genebra - Le Corbusier - 1930-1932 (BOESIGER, 1947:71)

[57] Ministério da Educação e Saúde - fechamento em tijolo de vidro da parede do lobby voltada para a R. da Imprensa (foto: Rodrigo Queiroz) 
como suporte para sua própria liberdade.

O projeto para o MES, assim como os projetos iniciais de Niemeyer, pode ser reconhecido como um pêndulo que oscila entre o respeito pela obra do "mestre" e o ímpeto de liberdade que ainda se encontrava recoberto de sutilezas: a curvatura ondulante dos volumes oblongos, o afrouxamento da retícula estrutural do salão de exposições e a transposição plena dos volumes perpendiculares que caracterizam o projeto. $\mathrm{Na}$ medida em que os projetos evoluem, a liberdade assume uma autonomia cada vez maior, até o ponto em que o respeito ao corbusianismo se vê eclipsado pela forma livre.

Do projeto do MES ao projeto da Igreja de São Francisco de Assis na Pampulha, observamos com nitidez esse processo dialético que transita entre o respeito e a ruptura com os cânones puristas de Le Corbusier. A cada projeto, o tributo perde espaço para a liberdade, sem com isso perder o foco do referencial corbusiano.

Em um primeiro momento, no MES, o afastamento de pressupostos como o esquema Dom-ino ainda está sutilmente insinuado. No Pavilhão do Brasil, a dissolução da retícula regular confere a gestualidade em "S" do próprio bloco de exposições. No Cassino da Pampulha, Niemeyer extrapola para o meio externo a forma livre que, para Le Corbusier, está invariavelmente abrigada no interior da forma regular. $\mathrm{Na}$ Casa de Baile, a forma livre que no Cassino ainda preserva uma conexão com a forma regular, assume a autonomia do próprio edifício, representado por dois volumes curvos conectados por marquise sinuosa. Na Igreja de São Francisco, toda e qualquer menção ao purismo e ao esquema Dom-ino desaparece, a forma não é mais conseqüência do arranjo de lajes e pilares. O edifício é conseqüência de um gesto contínuo, sem interrupção, como o próprio desenho de Niemeyer.

83 o encontro de 1936: formação 

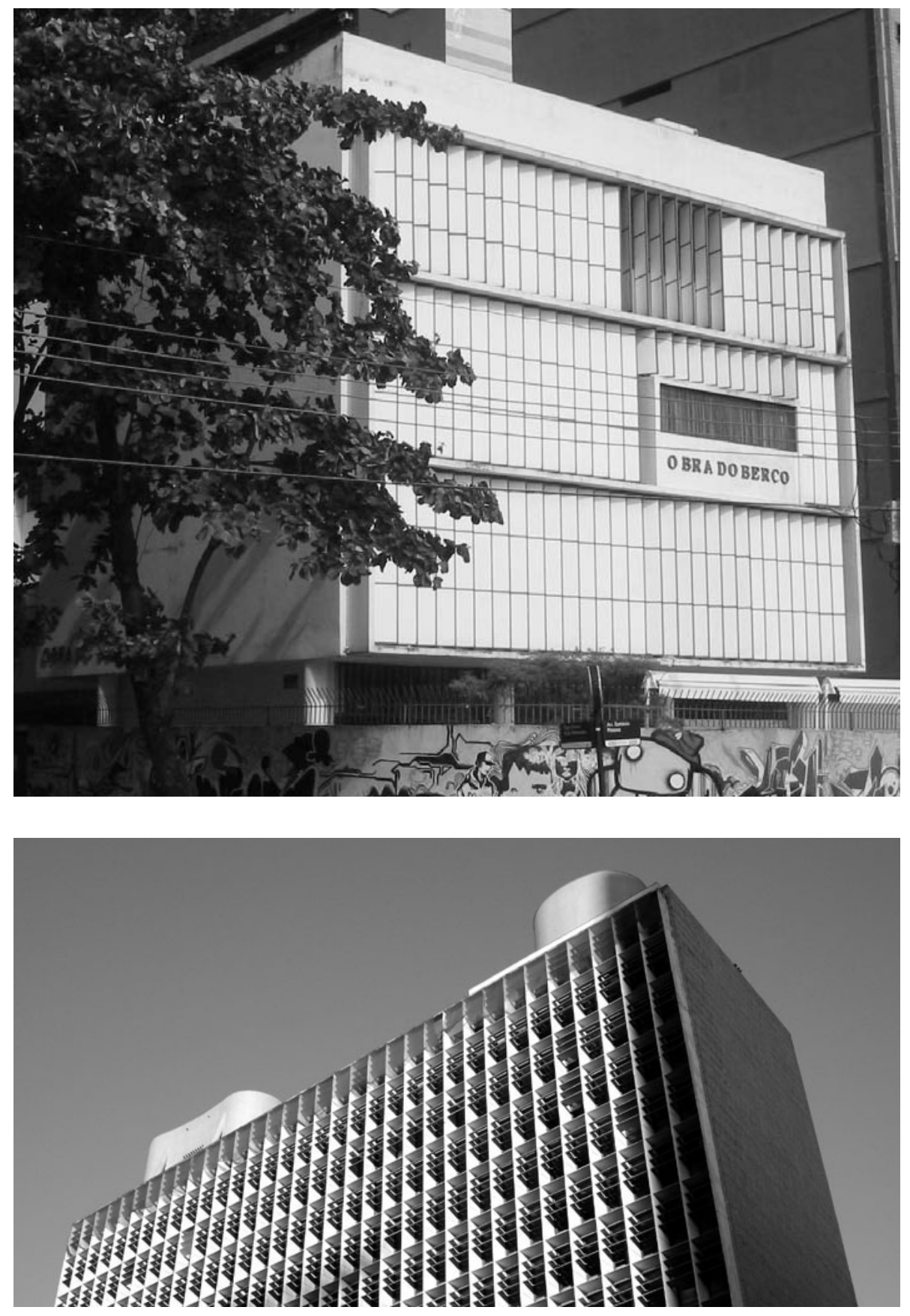

[58] Obra do Berço - 1937 - Oscar Niemeyer (foto: Rodrigo Queiroz)

[59] Ministério da Educação e Saúde - brises móveis e formas curvas na cobertura (foto: Rodrigo Queiroz) 


\section{Universidade do Brasil}

Como podemos observar nas cartas trocadas entre Monteiro de Carvalho e Le Corbusier, a motivação original para a vinda do arquiteto ao Rio de Janeiro não era sua participação no projeto do edifício do MES. O convite recaia sobre o desejo de um parecer de Le Corbusier sobre o projeto da Cidade Universitária da Universidade do Brasil que já havia sido objeto de discussão com arquitetos como Alfredo Agache e Marcelo Piacentini.

Por indicação e Alfred Agache o projeto da Cidade Universitária deveria ser realizado na Praia Vermelha. Posteriormente a localização seria substituída por uma área próxima à Quinta da Boa Vista, cujo acesso ao centro do Rio de Janeiro era facilitado. Foram desenvolvidos três projetos diferentes para o mesmo terreno: o de Marcelo Piacentini; o de Le Corbusier; e o da equipe organizada por Lucio Costa.

Com a chegada de Piacentini na cidade do Rio de Janeiro em agosto de 1935 para o início dos trabalhos para o projeto da Cidade Universitária, é desencadeada uma reação nacionalista apoiada em lei que proibia o exercício de atividades de profissionais liberais estrangeiros no país. As reações desfavoráveis com relação à contratação de Piacentini obrigam o Ministro Gustavo Capanema a nomear uma nova comissão, composta apenas por profissionais brasileiros, entre eles Washington Azevedo, Paulo Fragoso, Ângelo Bruhns, Firmino Saldanha e Lucio Costa.

Nos projetos de Piacentini, de Le Corbusier e da equipe de Lucio Costa, o campus universitário se desenvolve em um eixo praticamente perpendicular à linha férrea, o que não significa que os projetos sejam, nem de longe, parecidos.

Marcelo Piacentini propõe um eixo que passa pelos pátios internos de diversas construções simétricas de feição acadêmica. Le Corbusier, juntamente com a equipe de arquitetos brasileiros, concebe um eixo na mesma direção daquele proposto por Piacentini, mas não se configura como um eixo físico nem um eixo visual: o arquiteto alinha as principais edificações do campus (grande auditório, Museu do Conhecimento e o Hospital para mil leitos) sobre um eixo virtual. O eixo, que na versão de Le Corbusier, é ocupado pelas três construções mais significativas do conjunto, na versão realizada pela equipe de Costa após o retorno de Le Corbusier para a Europa, apresenta-se desimpedido e ladeado por construções laminares paralelas entre si e perpendiculares

85 | o encontro de 1936: formação 

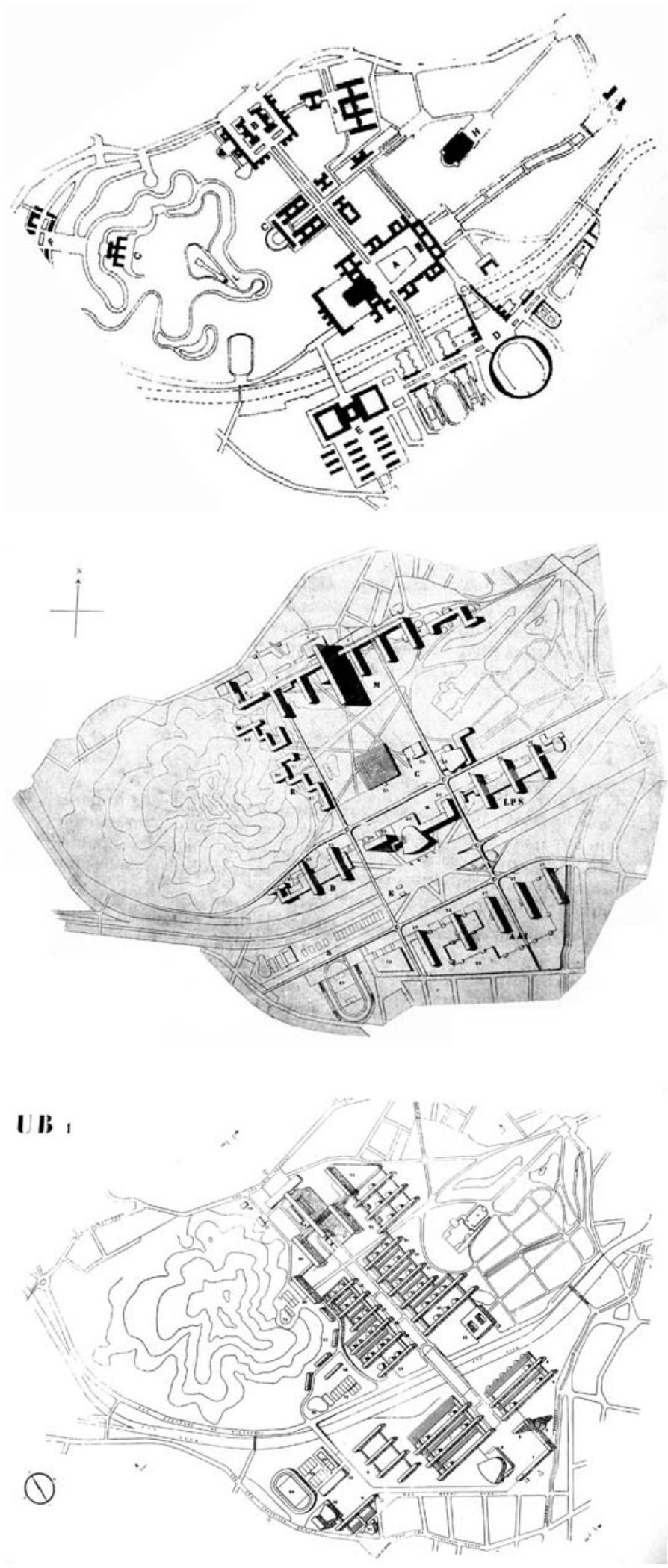

[60] Plano para a Universidade do Brasil projeto Marcelo Piacentini - 1936 (CARRILHO:2002, 264)

[61] Plano para a Universidade do Brasil projeto Le Corbusier e equipe brasileira - 1936 (GOROVITZ, 1993:34)

[62] Plano para a Universidade do Brasil projeto Lucio Costa e equipe - 1936 (GOROVITZ, 1993:43) 
ao eixo principal. [60], [61], [62]

Durante sua passagem pelo Rio de Janeiro, Le Corbusier é consultado por Gustavo Capanema sobre o projeto para o novo campus. A equipe de arquitetos brasileiros que colabora com Le Corbusier para o projeto da Cidade Universitária difere, em parte, daquela que desenvolveu o projeto para o MES: Ernani Vasconcelos é excluído e somam-se aos demais membros da equipe de Lucio Costa os arquitetos José de Sousa Reis, Fernando Saldanha e Ângelo Bruhns ${ }^{33}$.

Assim como o estudo do arquiteto para uma versão edifício do MES à beira-mar remontava a sua experiência urbana realizada nessa mesma cidade havia sete anos (1929), a proposta de Le Corbusier para a Cidade Universitária pode ser considerada como um novo arranjo de soluções que já haviam sido especuladas pelo arquiteto em projetos anteriores.

Componentes de três projetos distintos são revisitados de maneira flagrante na proposta de Le Corbusier: as assembléias trapezoidais do Palácio dos Sovietes (1931); a planta em espiral quadrada do Museu Mundial (1929) e do Museu de Arte Contemporânea de Paris (1931); e os blocos à rendent da Ville Radieuse. [63], [64], [65], [66]

Para Elizabeth Harris:

(...) O plano de Le Corbusier [para a cidade universitária] derivava da cidade universitária constante do projeto do Mundaneum (1929), que constituía um anexo ao plano para a Liga das Nações (1927). (...) O plano de Le Corbusier para a cidade universitária era um desdobramento do plano Mundaneum, edifício de seis torres dispostas à maneira de um silo quadrado, ligado a um teatro trapezoidal e formando uma série de estruturas elevadas anexas. (HARRIS 1987:100)

Cecília Rodrigues dos Santos reconhece o projeto de Le Corbusier para a Cidade Universitária na Universidade do Brasil como

(...) uma espécie de colagem de vários temas arquitetônicos-urbanísticos anteriores desenvolvidos por Le Corbusier. O esquema do Mundaneum é retomado no Museu do Conhecimento, a plasticidade e a invenção estrutural do Centrosoyus reaparecem no Auditório Máximo, o sistema de blocos interligados da Ville Radieuse é empregado para a maioria das instalações do campus (...). (SANTOS 1987:113)

Tanto no projeto do Mundaneum (1929) como no projeto para a Cidade Universitária da Universidade do Brasil, Le Corbusier adota condutas semelhantes na organização de suas formastipo no espaço. Em ambos os projetos, a composição do conjunto é organizada a partir de um foco central dado por um edifício de proporções monumentais que, no caso, possui a mesma forma em planta e abriga o mesmo programa. No Mundaneum, o objeto que rege a organização do espaço é o Museu Mundial, que possui planta em forma de espiral quadrada, exatamente como o Museu do Conhecimento da Universidade do Brasil que, da mesma maneira, também possui posição de destaque na organização do conjunto. [67]

Le Corbusier aplica no projeto da Cidade Universitária um conjunto de convenções que englobam as estratégias compositivas de ocupação do espaço, associadas à articulação

33. (Cf. HARRIS, 1987:100).

87 o encontro de 1936: formação 

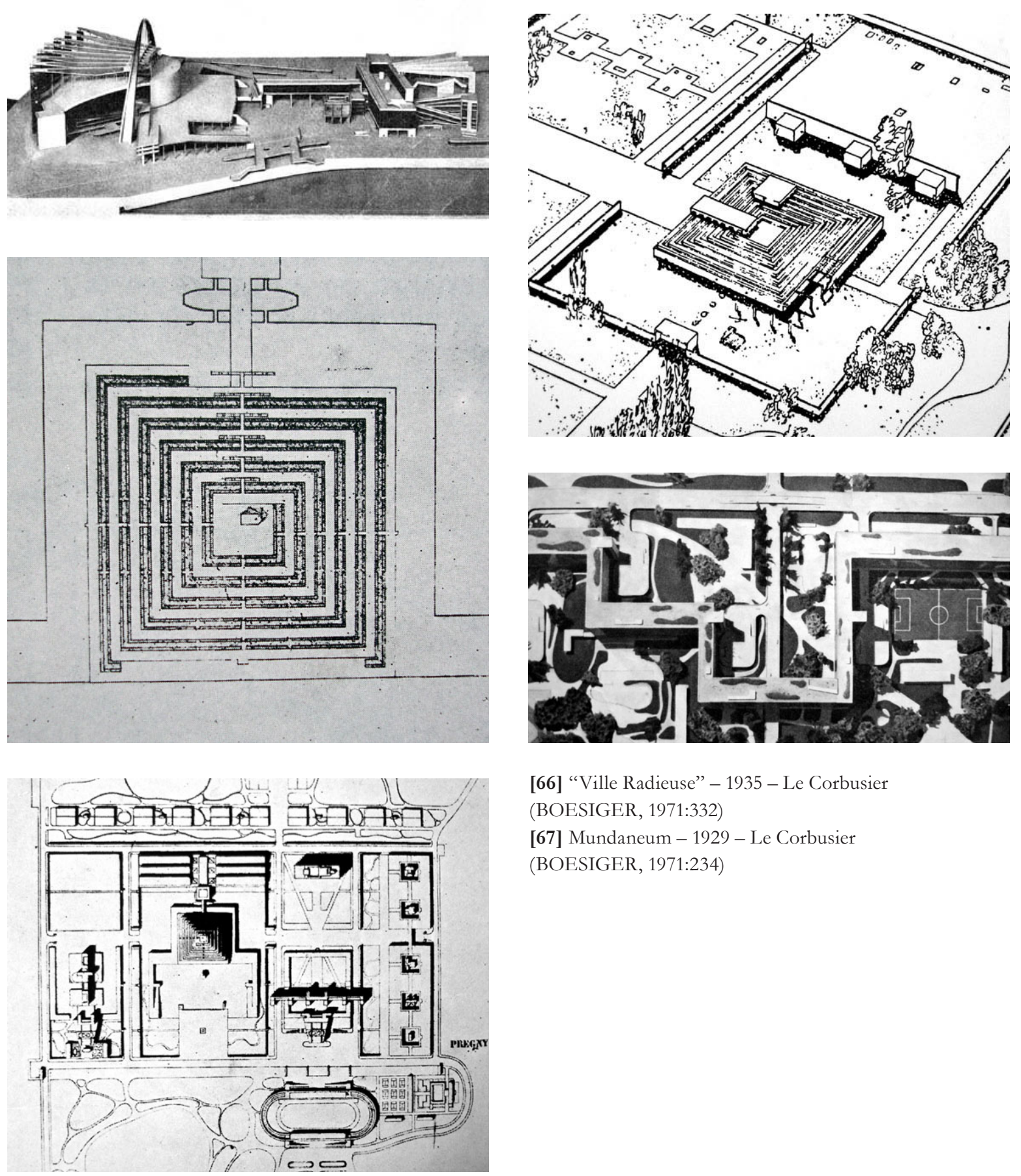

[66] "Ville Radieuse" - 1935 - Le Corbusier

(BOESIGER, 1971:332)

[67] Mundaneum - 1929 - Le Corbusier

(BOESIGER, 1971:234)

[63] Palácio dos Sovietes - 1931 - Le Corbusier (BOESIGER, 1971:109)

[64] Museu Mundial - 1929 - Le Corbusier

(BOESIGER, 1971:235)

[65] Museu de Arte Contemporânea de Paris - 1931 Le Corbusier

(BOESIGER, 1971:235) 
de soluções formais, que nada mais são do que soluções tipológicas que sofrerão poucas alterações no decorrer dos projetos.

No projeto para a Cidade Universitária da Universidade do Brasil, assim como no Mundaneum, Le Corbusier elabora um conjunto constituído por três tipos básicos que vinculam forma e programa: a espiral quadrada do Museu; os volumes trapezoidais dos auditórios e os volumes regulares de planta retangular (lâminas delgadas no projeto carioca - blocos com pátio interno no Mundaneum). Trata-se muito mais de um vocabulário de tipos do que de um repertório de formas, característica oposta a de Oscar Niemeyer que possui um repertório de formas adaptáveis à maioria dos programas a que se destinam.

No Mundaneum, o Museu Mundial possui o formato piramidal escalonado, devido ao fato de que a espiral quadrada ascende verticalmente, resultando em um volume em forma de "zigurate”. No Museu do Conhecimento da Cidade Universitária, o arquiteto adota a mesma planta em espiral quadrada, porém o volume é regular e horizontal, aos moldes do projeto do Museu de Arte Contemporânea de Paris (1931). Esses volumes achatados de planta quadrada e suspensos sobre pilotis figuram como a solução para diversos projetos de museus de Le Corbusier, não apenas o Museu de Arte Contemporânea de Paris (1931) e o Museu do Conhecimento da Universidade do Brasil (1936), como também o Museu do Crescimento Ilimitado (1939), o Museu de Ahmedabad na Índia (1954), o Museu de Arte de Tokyo (1957/1959) e o Centro Internacional de Arte de Erienbach nos arredores de Frankfurt (1963). [68]

A idéia de conjunto no projeto de Le Corbusier para a Cidade Universitária assume uma concepção que diverge da proposta desenvolvida pela equipe de Lucio Costa. São duas concepções distintas: a estruturação do espaço a partir do objeto na proposta de Le Corbusier e a estruturação do espaço a partir do conjunto na proposta de Lucio Costa.

No projeto de Le Corbusier para a Cidade Universitária, o espaço principal é construído pela disposição em linha dos três edifícios mais significativos do conjunto: o Museu do Conhecimento, o Grande Auditório e o Hospital. Ao implantar essas três construções alinhadas sobre um eixo retilíneo, os componentes principais do projeto não são revelados em uma única mirada, ao contrário, faz-se necessário o deslocamento físico para a construção dos diferentes visuais que, no máximo, enquadram os edifícios dois a dois. [69]

Le Corbusier discorre sobre o papel do deslocamento na percepção da arquitetura:

(...) A arquitetura árabe nos ensina algo precioso. É andando que podemos apreciá-la, com os pés: é andando, se deslocando que se percebe a ordenação da arquitetura. É um princípio contrário à arquitetura barroca, sobre papel, ao redor de um ponto teórico. Eu prefiro os ensinamentos da arquitetura árabe (LE CORBUSIER apud GOROVITZ, 1993:68-69, grifo nosso).

\section{Para Matheus Gorovitz:}

A percepção de conjunto [na proposta de Le Corbusier] se dá por um processo de reconstituição de fragmentos de percepção que se adquire ao longo de deslocamentos. A construção dos espaços e, conseqüentemente, das visuais é conseqüência da presença de (...) módulos isolados ou agrupados e articulados,

89 o encontro de 1936: formação 

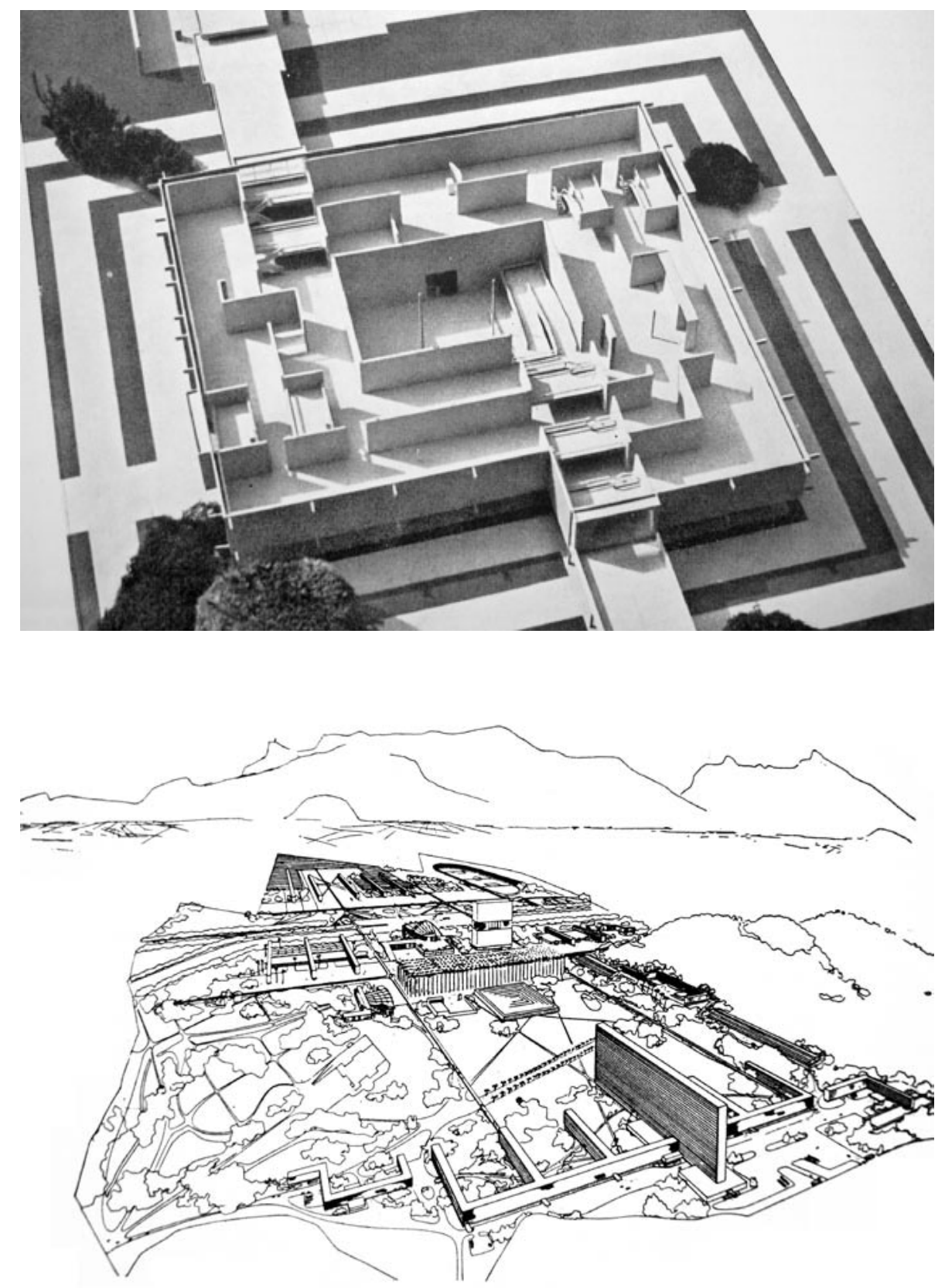

[68] Museu do Crescimento Ilimitado - 1935 - Le Corbusier (BOESIGER, 1971:235)

[69] Plano para a Universidade do Brasil perspectiva geral - projeto Le Corbusier e equipe brasileira - 1936

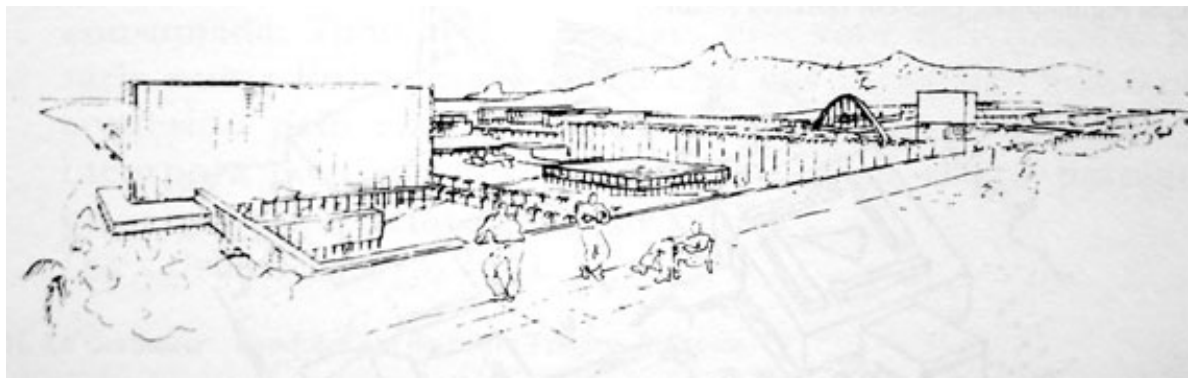

(GOROVITZ, 1993:37)

[70] Plano para a Universidade do Brasil - perspectiva - projeto Le Corbusier e equipe brasileira - 1936

(GOROVITZ, 1993:54) 
formando conjunto, igualmente autônomos (GOROVITZ 1993:33-67).

A autonomia plástica de cada um dos edifícios principais do projeto de Le Corbusier é reforçada pela adoção de módulos espaciais individualizados. Em Le Corbusier, a centralidade da composição é dada pelo objeto e não pelo vazio. Trata-se de um procedimento clássico incorporado a uma noção moderna de forma e espaço. Talvez a diferença fundamental entre as propostas de Le Corbusier e de Lucio Costa resida no papel dado ao objeto na construção do espaço. Essa não é uma observação que recai apenas sobre as diferentes "cidades universitárias" de Le Corbusier e Lucio Costa. Na verdade, as diferenças contidas nessas propostas ilustram posturas divergentes no que diz respeito à relação entre o objeto arquitetônico e o lugar, e ao significado de conjunto arquitetônico.

Para justificar a postura clássica de Le Corbusier na organização das formas no espaço, Elizabeth Harris, alinha sua proposta à Acrópole grega:

(...) Como na Acrópole, a paisagem circundante rodeava os edifícios, enquanto o campus oferecia uma perspectiva diversa a partir de cada um dos edifícios. Por outro lado, a orientação axial guiava os estudantes, ao longo das passagens para pedestres e carros, de um grupo de faculdades para outro (HARRIS 1987:100, grifo nosso).

Na proposta de Le Corbusier, observa-se uma clara hierarquização do gradiente expressivo dos edifícios, não apenas nas diferentes intensidades da forma, mas também nas suas disposições no espaço. Le Corbusier estrutura sua composição de maneira a estabelecer uma relação de contraste entre o edifício protagonista (Museu do Conhecimento) e os objetos que abrigam os programas que se repetem (salas de aula e alojamentos), que assumem a condição de fundo para o objeto centralizador. [70]

O eixo virtual formado pelo Hospital de mil leitos, o Museu do Conhecimento e o Grande Auditório cruza o vazio contido em uma implantação em "C" configurada pela presença de formas laminares delgadas: edifícios de cursos ${ }^{34}$ (blocos isolados conectados por marquise), os clubes e residências dos professores (blocos "dobrados" à rendent como na Ville Radieuse).

Se, no projeto do MES, Niemeyer teve papel fundamental na sua concepção final, no projeto da Cidade Universitária é a figura de Lucio Costa que assume nítido destaque.

Marco do Valle, em sua tese intitulada Desenvolvimento da forma e procedimentos de projeto na arquitetura de Oscar Niemeyer (1935-1998) aponta para as diferentes leituras que Lucio Costa e Oscar Niemeyer executam sobre a obra de Le Corbusier ao enfrentarem problemas distintos, seja Niemeyer no projeto do MES, seja Lucio Costa no projeto para a Cidade Universitária. Segue trecho do autor:

(...) Ao compararmos as soluções de Lúcio Costa no projeto da Cidade Universitária a partir das soluções de Le Corbusier com a solução de Oscar Niemeyer para o Mesp em relação ao mestre (...) poderemos entender não somente suas diferenças (...), mas também como os caminhos dos dois arquitetos seriam complementares

34. Faculdades de Medicina; Filosofia, Ciências e Letras; Direito; Arquitetura; Artes e Engenharia.

91 o encontro de 1936: formação 

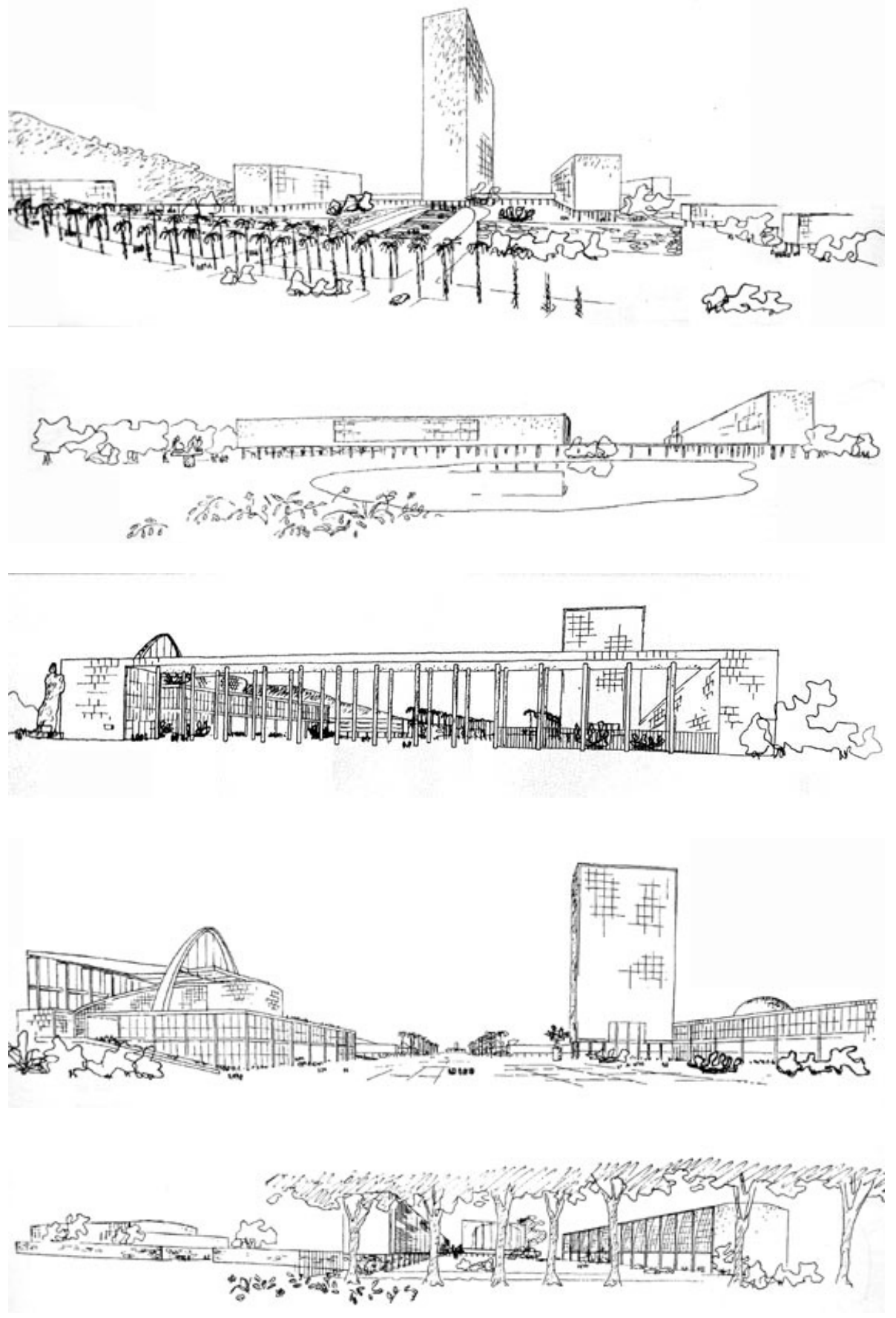

[71] Universidade do Brasil - Praça do Hospital - Lucio Costa e equipe -1936

(COSTA, 1995:185)

[72] Universidade do Brasil - Praça do Museu - Lucio Costa e equipe $-1936$

(COSTA, 1995:186)

[73] Universidade do Brasil - Pórtico de Entrada (Grande Auditório, Reitoria e Planetário) - Lucio Costa e equipe $-1936$

(COSTA, 1995:184)

[74] Universidade do Brasil - Praça de Entrada (Grande Auditório, Reitoria e Planetário) - Lucio Costa e equipe $-1936$ (COSTA, 1995:184)

[75] Universidade do Brasil - Praça da Escola de Música - Lucio Costa e equipe -1936 (COSTA, 1995:187) 
em suas potencialidades. Lúcio Costa se destacará em seu projeto urbanístico para a Cidade Universitária, sendo que suas intervenções plásticas em relação aos edifícios foi bastante reduzida, e Oscar Niemeyer foi dominante na solução plástica de implantação do edifício do Mesp (VALLE 2000:65, grifo nosso).

Valle diagnostica as potencialidades de Costa e Niemeyer ao interpretar os diferentes comportamentos dos arquitetos que enfrentam problemas distintos, o que permitiu o florescimento de habilidades também distintas: as dimensões urbana de Lucio Costa e plástica de Niemeyer.

Para Gorovitz, Lucio Costa "estabelece entre as partes do projeto uma relação de hierarquia” (GOROVITZ 1993:80). Valle completa o raciocínio de Gorovitz e anuncia que essa relação de hierarquia entre as partes, presente na proposta de Costa, estabelece um "contraste com o projeto de Le Corbusier, no qual o sistema de módulos individualizados é fortalecido pela plástica dos edifícios" (VALLE 2000:65). Corroboramos com ambos os autores, porém, acreditamos que a força da "plástica dos edifícios" de Le Corbusier também é geradora de uma "relação de hierarquia" entre os componentes do conjunto ${ }^{35}$. Em Le Corbusier, essa "relação de hierarquia" caracteriza o todo, enquanto que, em Lucio Costa, essa mesma relação é explorada em espaços separados, como podemos observar nas diferentes praças compostas por elementos formalmente hierarquizados: a praça da Faculdade de Medicina; a praça do Museu; a praça compreendida entre o Grande Auditório (projeto que foi reservado a Le Corbusier) e o planetário; e a praça da Música, resultante do espaço formado pela implantação dos edifícios da escola de Música, da Sala de Música de Câmara e do Teatro. [71], [72], [73], [74], [75]

Devemos considerar que o teor do gradiente de intensidade formal que caracteriza essa "relação de hierarquia" na proposta de Costa e equipe apresenta-se de maneira extremamente abrandada, se comparado com a versão de Le Corbusier para a Cidade Universitária. No estudo de Lucio Costa, os edifícios não assumem posição de destaque por sua individualidade plástica, ao contrário, o arquiteto privilegia os pátios abertos como estruturadores da composição de núcleos distintos, porém conectados por dois eixos que se cruzam. A comparação entre os cortes de escala urbana das duas propostas é fundamental para a compreensão das diferentes concepções sobre a relação entre o todo e o específico e entre o conjunto e a paisagem.

Se Le Corbusier desenha o eixo virtual com a implantação dos objetos principais, Lucio Costa age de maneira inversa, desobstruindo o eixo de qualquer obstáculo que dificulte a mirada. Poderíamos redefini-los como o eixo volumétrico de Le Corbusier e o eixo vazio de Lucio Costa.

Sobre as diferenças e afinidades entre as propostas de Le Corbusier e Lucio Costa, Gorovitz aponta que

(...) Enquanto no projeto Le Corbusier o eixo principal é um eixo virtual, apenas sugerido pelo alinhamento dos edifícios que a ele se subordinam, no projeto Lucio Costa o eixo se consubstancia como fenômeno, cuja apreensão é fruto de uma experiência sensível: "uma seqüência de impressões", conforme nos esclarece a memória do projeto (GOROVITZ 1993:56, grifo nosso).

35. A hierarquização das formas no espaço em Le Corbusier será retomada na análise dos diferentes projetos para a sede da ONU, propostos por Le Corbusier e Oscar Niemeyer.

93 o encontro de 1936: formação 

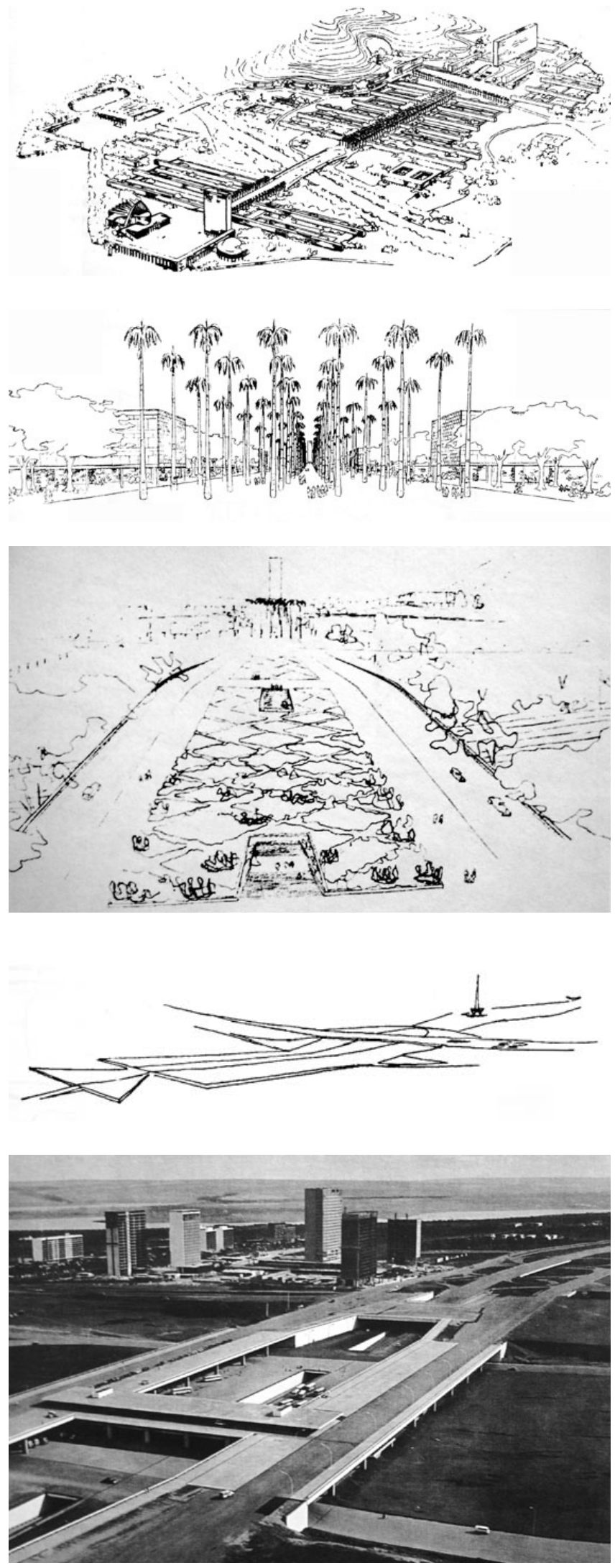

[76] Universidade do Brasil - perspectiva do conjunto - Lucio Costa e equipe - 1936 (COSTA, 1995:172)

[77] Universidade do Brasil - Alameda Central "Prenúncio do Eixo Monumental de Brasília" Lucio Costa e equipe - 1936.

(COSTA, 1995:185)

[78] Universidade do Brasil - plataforma sobre estrada de ferro - Lucio Costa e equipe - 1936 (GOROVITZ, 1993:73)

[79] Plano Piloto de Brasília - Eixo Rodoviário sobre Eixo Monumental - Lucio Costa - 1957 (COSTA, 1995:288)

[80] Brasília - rodoviária - Lucio Costa - 1958 (WISNIK, 2001:108) 
Apesar das diferenças entre as propostas de Le Corbusier e Lucio Costa poderem se caracterizar como uma "inversão", alguns elementos presentes na proposta de Costa remetem-se claramente ao estudo de Le Corbusier: a localização dos edifícios dos cursos de Artes, Arquitetura e Engenharia em uma porção do terreno localizada do outro lado da via férrea, ao extremo sul do conjunto; o Hospital concebido como uma lâmina delgada de grande comprimento implantada sobre o eixo principal e localizado na extremidade norte do campus.

Em carta enviada para Le Corbusier em 31 de dezembro de 1936, Lucio Costa discorre sobre seu projeto para a Cidade Universitária e aponta algumas diferenças com relação ao projeto do "mestre", e ainda revela que o Grande Auditório seria uma "encomenda" designada ao experiente colega.

(...) No dia 12 de outubro apresentamos a Capanema nosso ante-projeto que, em consequiência do seu, adotava entretanto um partido por assim dizer oposto - adaptando-se às circunstâncias: em lugar de uma vista imediata e grandiosa de todo o conjunto, impressões que se desenvolvem sucessivamente durante 0 percurso do campus. Dentro dos nossos limites e na "nossa escala", o projeto está bom. Incorporamos desde agora ao projeto - a fim de tornar possível, mais tarde uma "encomenda" - seu auditório (COSTA apud SANTOS, 1987:179, grifo nosso).

$\mathrm{Na}$ carta, Lucio Costa distingue as escalas dos estudos, referindo-se à escala do projeto realizado pela equipe brasileira como "nossa escala". Com essa colocação, Lucio Costa relativiza a vigência da monumentalidade clássica de Le Corbusier, colocando a incompatibilidade entre as "escalas" como a diferença crucial entre os projetos. Nessa carta, Lucio Costa assume um claro posicionamento de autonomia com relação a Le Corbusier. O produto desses raciocínios distintos está exposto, com todos os seus atributos, nos dois projetos para a cidade universitária: o objeto como instância centralizadora da composição em Le Corbusier e a síntese entre intimismo e monumentalidade em Lucio Costa. [76]

Em seu livro de memórias, Lucio Costa se refere ao eixo central de seu projeto, ladeado pelas lâminas paralelas das escolas, como sendo um "Prenúncio do Eixo Monumental de Brasília" (COSTA 1995:185). Diversas das decisões tomadas no projeto do Plano Piloto de Brasília podem ser reconhecidas como redesenhos amadurecidos da Cidade Universitária. Passados praticamente vinte e um anos, no projeto do Plano Piloto de Brasília, o arquiteto revisita o desenho das perspectivas lineares, seus eixos e sua hierarquização em grupamentos isolados que caracterizaram a Cidade Universitária. [77]

Assim como na Cidade Universitária do Brasil, o Plano Piloto de Brasilia é conseqüência do cruzamento de dois eixos: um linear, cívico, monumental e finito e outro, rodoviário, contínuo e dinâmico, desenhado em sutil curvatura. No cruzamento desses eixos, em ambos os projetos, Lucio Costa desenha transposições que permitem a fluidez física e visual dos dois eixos. Porém, as transposições se invertem nos dois projetos. Enquanto na Cidade Universitária o eixo principal prossegue em plataforma suspensa sobre o eixo rodo-ferroviário de traçado encurvado, no Plano Piloto de Brasília o Eixo Rodoviário (também encurvado, nesse caso, chamado de "asa") cruza o Eixo Monumental por cima, também em plataforma, que no caso de Brasília é a

$$
95 \text { o encontro de 1936: formação }
$$



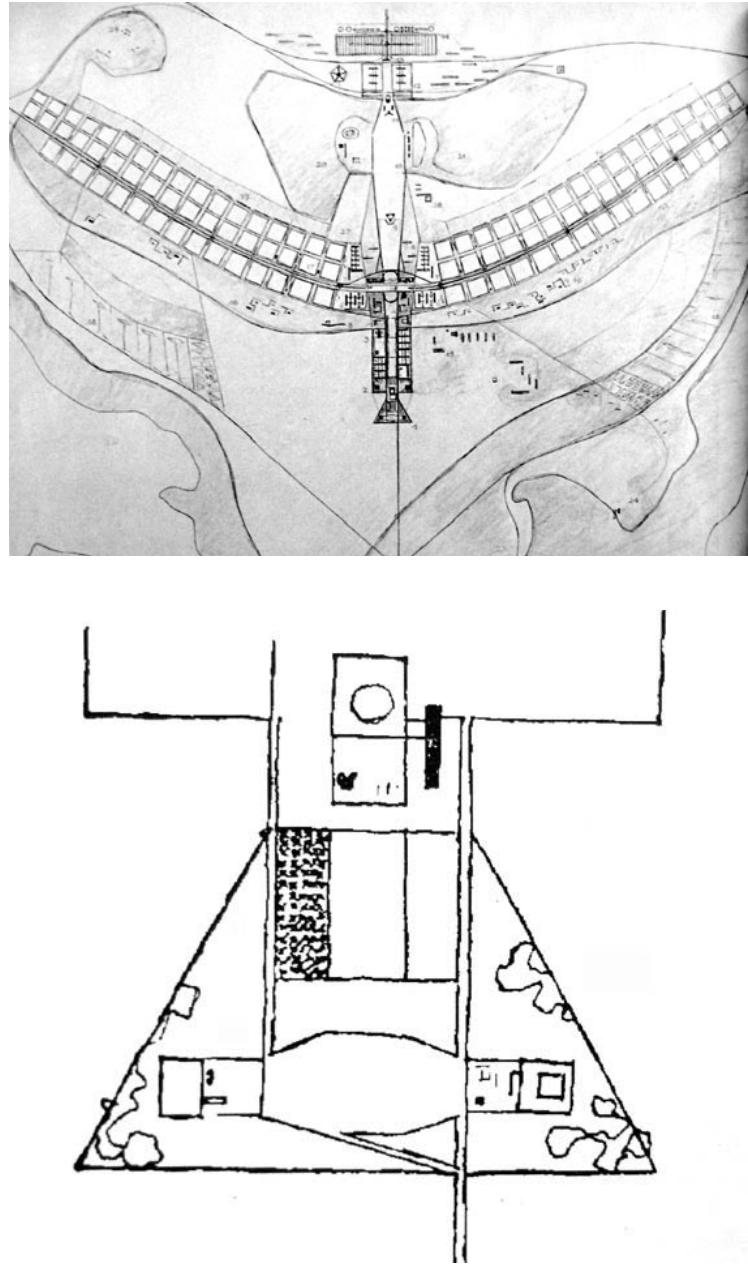

[81] Plano Piloto de Brasília - plano geral - Lucio Costa $-1957$

(TIRAPELI, 2000:248)

[82] Plano Piloto de Brasília - Praça dos Três Poderes implantação - Lucio Costa - 1957

(COSTA, 1995:288)

[83] Brasília - Praça dos Três Poderes - projeto definitivo - implantação - Oscar Niemeyer - 1958

(Revista MÓDULO n.09 - fevereiro/1958, p.17)


[84] Plano Piloto de Brasília - Praça dos Três Poderes perspectiva - Lucio Costa - 1957

(COSTA, 1995:306)

[85] Brasília - Praça dos Três Poderes - projeto definitivo - maquete - Oscar Niemeyer - 1957

(COSTA, 1995:306) 
própria rodoviária. [78], [79], [80]

Talvez a semelhança mais evidente entre os dois projetos seja a implantação dos blocos laminares paralelos entre si e perpendiculares ao eixo principal, sejam os blocos dos cursos na Cidade Universitária, sejam os edifícios ministeriais que configuram a Esplanada dos Ministérios. [81]

Os vazios espaçados em diversos momentos do eixo principal, que na Cidade Universitária conformam as diferentes praças (Medicina, Museu e Reitoria), também estão presentes no projeto de Lucio Costa para o Plano Piloto de Brasília, tanto no estudo entregue no concurso, como no projeto executado. Alguns desses espaços vazios, além de romperem com a rigidez da disposição dos blocos ministeriais, permitem a construção de perspectivas fundamentais para a percepção do conjunto, como é o caso dos vazios defronte aos Palácios do Itamaraty e da Justiça que tornam arejadas as miradas, independentemente de sua direção, seja "para o Palácio” ou “do Palácio”. Essa estratégia repete-se na Catedral Metropolitana de Brasília e nos Setores Culturais Norte e Sul, ocupados respectivamente pelo Teatro Cláudio Santoro (1968) e pelo Museu da República (2003). [82], [83], [84], [85]

Apesar das semelhanças na ordenação dos objetos na Cidade Universitária e no Plano Piloto de Brasília, há uma inversão do foco das duas grandes praças. Enquanto na Cidade Universitária a grande praça constituída pelos edifícios da Reitoria, Planetário e Grande Auditório configura um espaço de partida - caracterizado, inclusive pela presença do pórtico de entrada - de onde se inicia o promenade físico e visual, em Brasília, a Praça dos Três Poderes configura um espaço de chegada onde culmina o percurso do Eixo Monumental. [86], [87]

Mesmo que ambas as praças estejam em situações antagônicas, Lucio Costa elege objetos que possuem a mesma natureza formal para conformá-las. Na praça da Reitoria, o arquiteto arremata uma das laterais com um bloco delgado de proporção vertical articulado a outro volume, caracterizado por uma plataforma suspensa encimada por um domo opaco. No memorial ilustrado apresentado por Lucio Costa para o concurso do Plano Piloto de Brasília, os desenhos que representam a Praça dos Três Poderes ilustram o Congresso Nacional como uma torre de planta retangular conectada a uma plataforma horizontal que serve de embasamento para uma calota. Conscientemente ou não, o arquiteto elege as mesmas formas como elementos estruturadores de uma mesma configuração espacial para uma praça de dimensões monumentais, seja ela de partida ou de chegada. [88], [89]

Tanto na planta como na perspectiva integrante do memorial ilustrado do Plano Piloto de Brasília, Lucio Costa desenha um campo retangular preenchido por trama de palmeiras imperiais, situado lateralmente ao triângulo virtual que delimita a Praça dos Três Poderes. Abaixo da perspectiva, Lucio Costa faz menção a origem da idéia da utilização das palmeiras imperiais dispostas em retícula: "fórum de palmeiras imperiais proposto em 1936 por Le Corbusier" (COSTA 1995:288). O arquiteto refere-se as palmeiras propostas por Le Corbusier no seu projeto para a Cidade Universitária da Universidade do Brasil.

No projeto de Le Corbusier, a trama de palmeiras assume o papel de fundo para o $\mathrm{Mu}$ seu do Conhecimento, separando-o, visualmente, do Grande Auditório implantado no mesmo

\footnotetext{
97 | o encontro de 1936: formação
} 

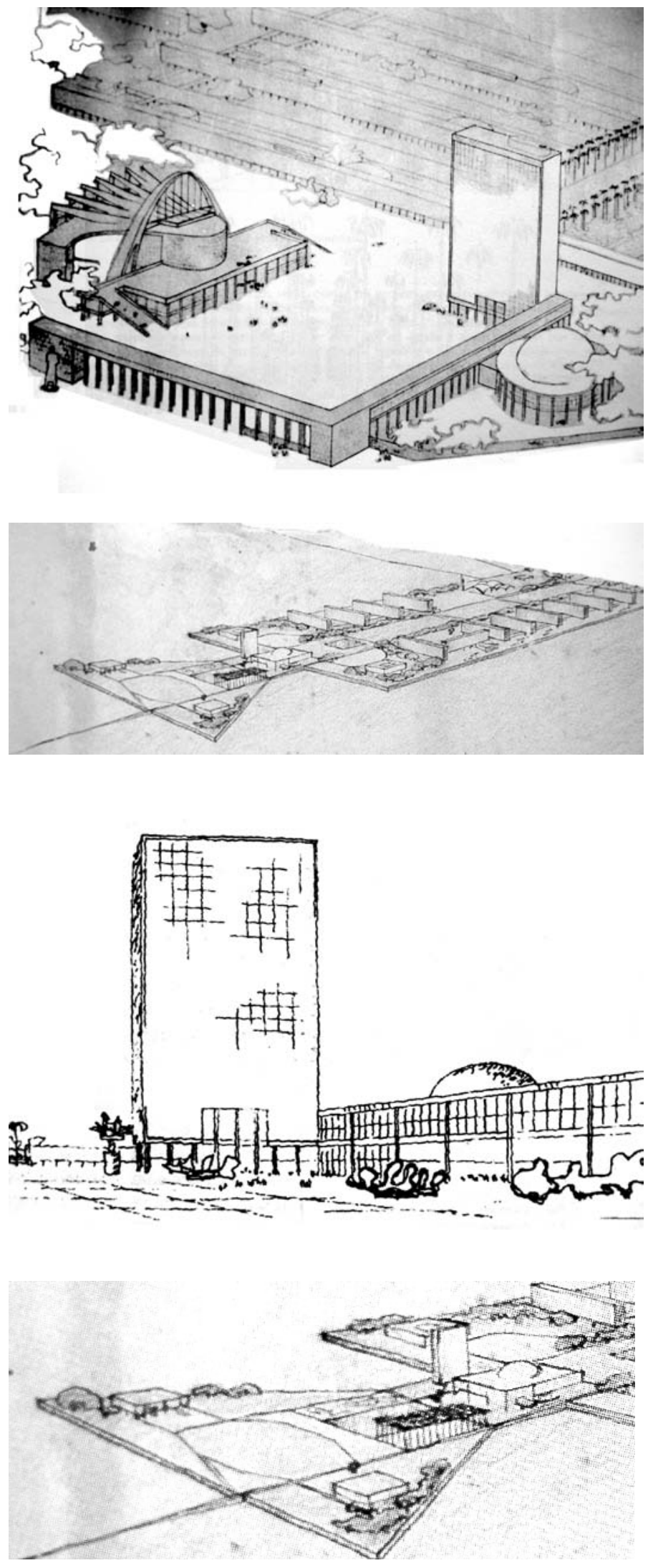

[86] Universidade do Brasil - Praça de acesso - Grande Auditório, Reitoria e Planetário perspectiva - Lucio Costa e equipe - 1936 (GOROVITZ, 1993:83)

[87] Plano Piloto de Brasília - Eixo Monumental - perspectiva - Lucio Costa - 1957 (COSTA, 2002:sn)

[88] Universidade do Brasil - Praça de chegada - Planetário - Lucio Costa e equipe - 1936 (COSTA, 1995:184)

[89] Plano Piloto de Brasília - Praça dos Três Poderes - perspectiva - Lucio Costa - 1957 (COSTA, 2002:sn) 
alinhamento. Na proposta de Lucio Costa para a Praça dos Três Poderes, a praça retangular de palmeiras imperiais preenche uma das laterais do espaço, arrematando a visada que enquadra o Congresso Nacional e o Supremo Tribunal Federal. Lucio Costa lança mão do mesmo renque de palmeiras, porém o implanta em uma posição que o distingue da proposta de Le Corbusier. O mesmo fórum de Palmeiras que, para Le Corbusier, emoldura o objeto, para Lucio Costa emoldura o conjunto, justamente por preencher o fundo que enquadra os dois edifícios. [90], [91]

Ao cotejarmos as diferentes implantações dos fóruns de palmeiras imperiais, não nos deparamos apenas com organizações de espaço distintas entre si. $\mathrm{Na}$ verdade, essa comparação ilustra com precisão as diferentes percepções de Lucio Costa e Le Corbusier sobre o diálogo entre objeto e paisagem. Em Lucio Costa, o vazio é a instância visual fundamental para a constituição do conjunto arquitetônico, enquanto que, para Le Corbusier, o objeto protagonista (no caso o Museu do Conhecimento) cumpre o papel de elemento estruturador do conjunto, sendo compreendido somente a partir da interação de duas instâncias distintas: o movimento e o tempo.

A configuração do espaço em Oscar Niemeyer pode ser entendida como uma síntese das concepções de espaço em Lucio Costa e em Le Corbusier. Ao mesmo tempo em que Niemeyer incorpora a noção de conjunto arquitetônico e "unidade arquitetural" presente em Lucio Costa, o arquiteto estabelece uma clara relação hierárquica entre os objetos integrantes de seus conjuntos arquitetônicos, aos moldes da concepção de Le Corbusier. Porém, assim como para Lucio Costa, para Niemeyer o vazio será um componente fundamental na organização dessas formas no espaço. [92], [93], [94]

Em síntese, poderíamos dizer que Niemeyer incorpora na espacialidade de Lucio Costa as formas-tipo de Le Corbusier. Mas em Niemeyer essas formas-tipo não estarão necessariamente vinculadas ao programa contido dentro delas. Essas formas são interpretadas como soluções adaptáveis aos mais diversos programas. Ao assimilar as soluções corbusianas como formas, independentemente de seu conteúdo, Niemeyer rompe a relação direta entre forma e função que caracteriza as formas-tipo de Le Corbusier.

Uma dessas formas-tipo utilizadas por Le Corbusier em seu projeto da Cidade Universitária também estaria presente no projeto de Lucio Costa. O volume do Grande Auditório - cuja matriz está no projeto do Palácio dos Sovietes em Moscou - é extremamente semelhante nos dois projetos, caracterizado por um volume trapezoidal com a cobertura da platéia pendurada em vigas aparentes dispostas em leque, e a cobertura do palco atirantada em cabos fixados em um arco que envolve todo o volume do palco.

Caso Lucio Costa e equipe fossem contratados para a realização do projeto da Cidade Universitária, reservariam o projeto do edifício do Grande Auditório para Le Corbusier. Daí a semelhança tão flagrante entre as propostas de Lucio Costa e Le Corbusier para o Grande Auditório. No caso do projeto de Lucio Costa, se tratava muito mais de uma homenagem do que de uma referência absorvida.

Niemeyer assimila as formas-tipo apresentadas por Le Corbusier no projeto da Cidade

$$
99 \text { | o encontro de 1936: formação }
$$




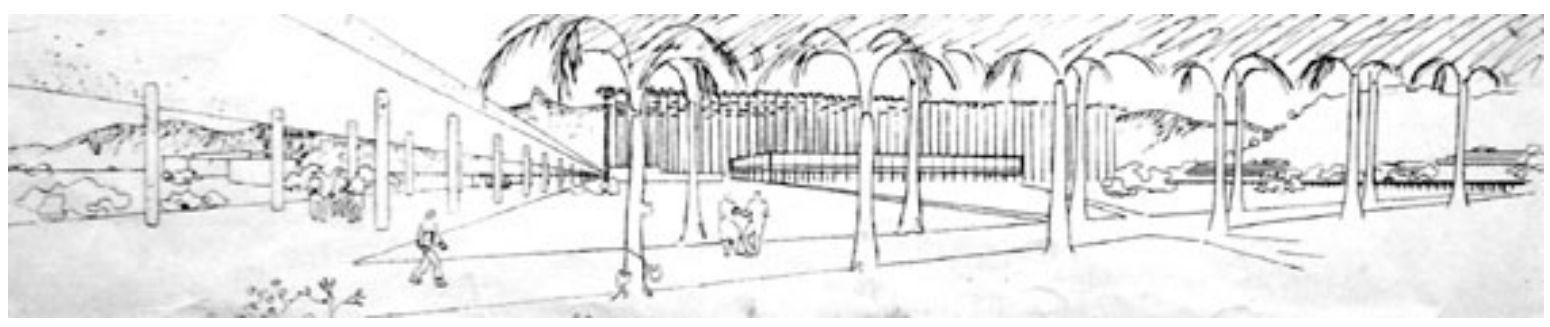

[90] Universidade do Brasil - Museu do Conhecimento e fórum de palmeiras imperiais - Le Corbusier - 1936 (GOROVITZ, 1993:54)
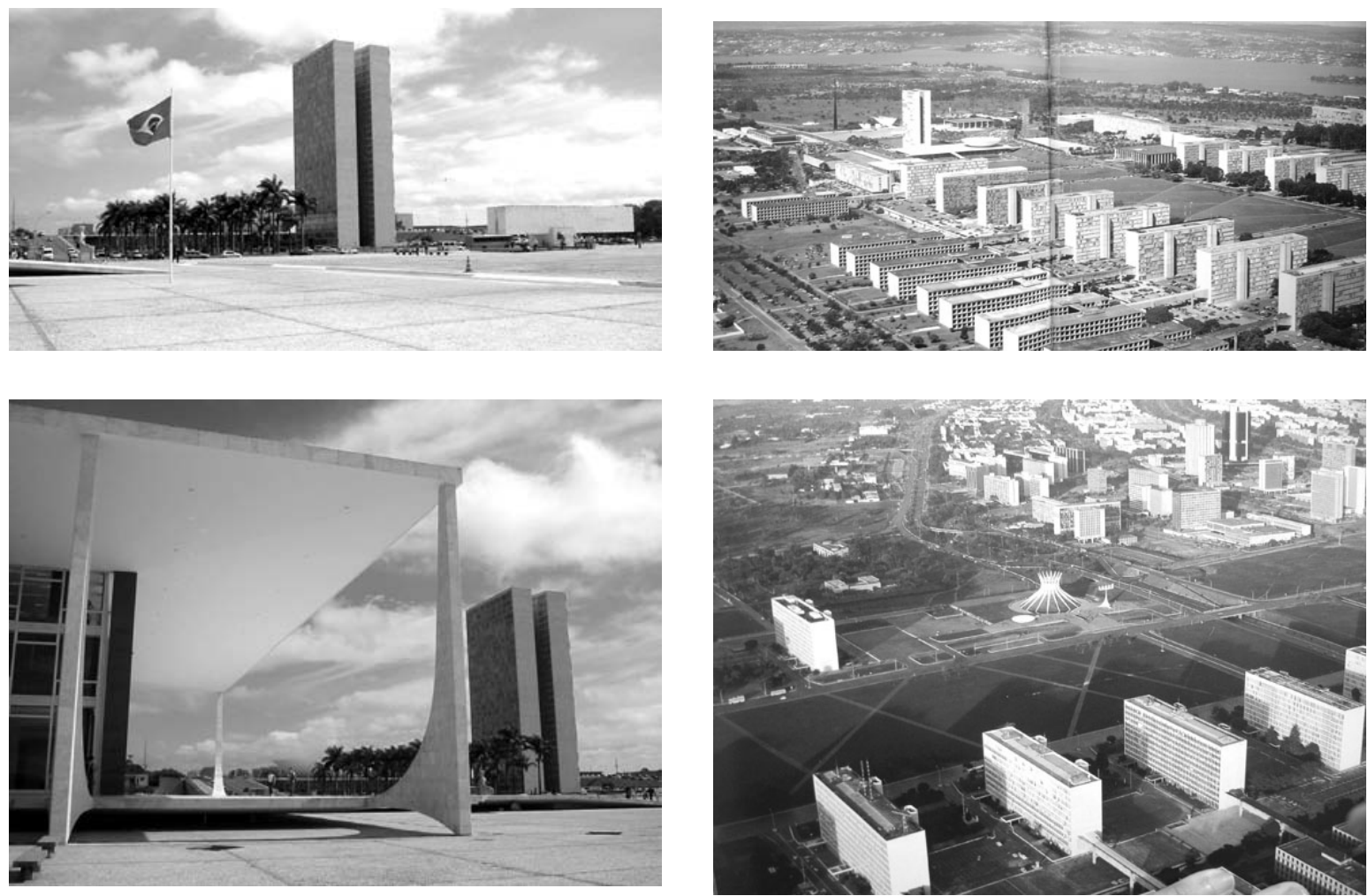

[91] Brasília - Praça dos Três Poderes - Congresso Nacional e fórum de palmeiras imperiais - Oscar Niemeyer - 1958. (Foto: Rodrigo Queiroz)

[92] Brasília - Praça dos Três Poderes - Supremo Tribunal Federal com o fórum de palmeiras imperiais e o Congresso Nacional ao fundo - Oscar Niemeyer - 1958.

(Foto: Rodrigo Queiroz)

[93] Brasília - Esplanada dos Ministérios e Praça dos Três Poderes - Oscar Niemeyer - 1958 (TIRAPELI, 2000:258-259)

[94] Brasília - Esplanada dos Ministérios e Catedral Metropolitana - Oscar Niemeyer - 1958

(TIRAPELI, 2000:255) 
Universitária a partir de um raciocínio que decompõe essas formas em componentes passíveis de transitar nos mais diversos programas. O arco com tirantes, presente nos auditórios de Le Corbusier para o Palácio dos Sovietes e para a Cidade Universitária, será utilizado por Niemeyer como estrutura de sustentação da cobertura da arquibancada do Estádio Nacional no Rio de Janeiro. Niemeyer transpõe o componente corbusiano para um outro contexto, mas preserva seu nexo funcional. Nesse mesmo projeto, a arquibanca em forma de "ferradura aberta" faz menção ao projeto de Le Corbusier para o Estádio para 100.000 pessoas para o Centro Nacional de Lazer Popular (1936). [95], [96], [97], [98]

Segundo Kenneth Frampton:

O estádio de Niemeyer é a síntese de dois notáveis projetos de Le Corbusier: o Palácio dos Sovietes (1931) e o Centro Nacional de Lazer Popular, com capacidade para 100.000 pessoas.

(...) Como alternativa à solução para a estrutura da cobertura do estádio proposta por Le Corbusier, Niemeyer optou por uma cobertura suspensa por cabos sobre as arquibancadas, com cabos pendurados no arco hiperbólico de 300 metros.

(...) A influência corbusiana também se estende ao caráter monumental dos arcos hiperbólicos. Como em sua proposta para o Palácio dos Sovietes que se presta como um símbolo cívico a grande distância, como as cúpulas e os domos das cidades medievais (FRAMPTON apud BRILLEMBOURG, 2004:45).

O volume trapezoidal com vigas invertidas na cobertura presente nos dois projetos de Le Corbusier para os auditórios do Palácio dos Sovietes e da Cidade Universitária será retomado por Niemeyer no projeto para o Teatro Municipal de Belo Horizonte (1943). Entretanto, nesse caso, Niemeyer não pendura a cobertura com tirantes como Le Corbusier, apenas lança mão das vigas invertidas posicionadas em leque ${ }^{36}$. [99]

Tanto na Cidade Universitária como em Brasília, Lucio Costa se exime da responsabilidade de conferir expressão ao objeto arquitetônico. Se em Brasília, a expressão ficou a cargo de Oscar Niemeyer, o mesmo não pode ser dito na Cidade Universitária. A atuação de Niemeyer durante a segunda passagem de Le Corbusier no Brasil está claramente vinculada ao projeto para a sede do MES, enquanto que sua participação no projeto da Cidade Universitária se restringe, basicamente, aos desenhos das perspectivas e ao projeto do Clube dos Estudantes. Lucio Costa refere-se às perspectivas para a Cidade Universitária como sendo "ampliações desenhadas por Oscar, então colaborador da equipe, com auxilio de epidiascópio [projetor de imagens] segundo indicações minhas" (COSTA 1995:185).

No projeto do Clube dos Estudantes da Cidade Universitária ${ }^{37}$, Niemeyer executa uma síntese pessoal de algumas estratégias que já haviam sido utilizadas por Le Corbusier. Como já informamos, Niemeyer não se apropria do repertório formal corbusiano de maneira literal. Ao contrário, Niemeyer confere um novo desenho às diversas soluções corbusianas que são reconstituídas a partir de um arranjo que incorpora elementos de diversos projetos como

36. (Cf.: VALLE, 2000:69).

37. O projeto de Niemeyer para o Clube dos Estudantes da Universidade do Brasil será retomado no capítulo Pavilhão do Brasil na Feira de Nova York.

101 o encontro de 1936: formação 

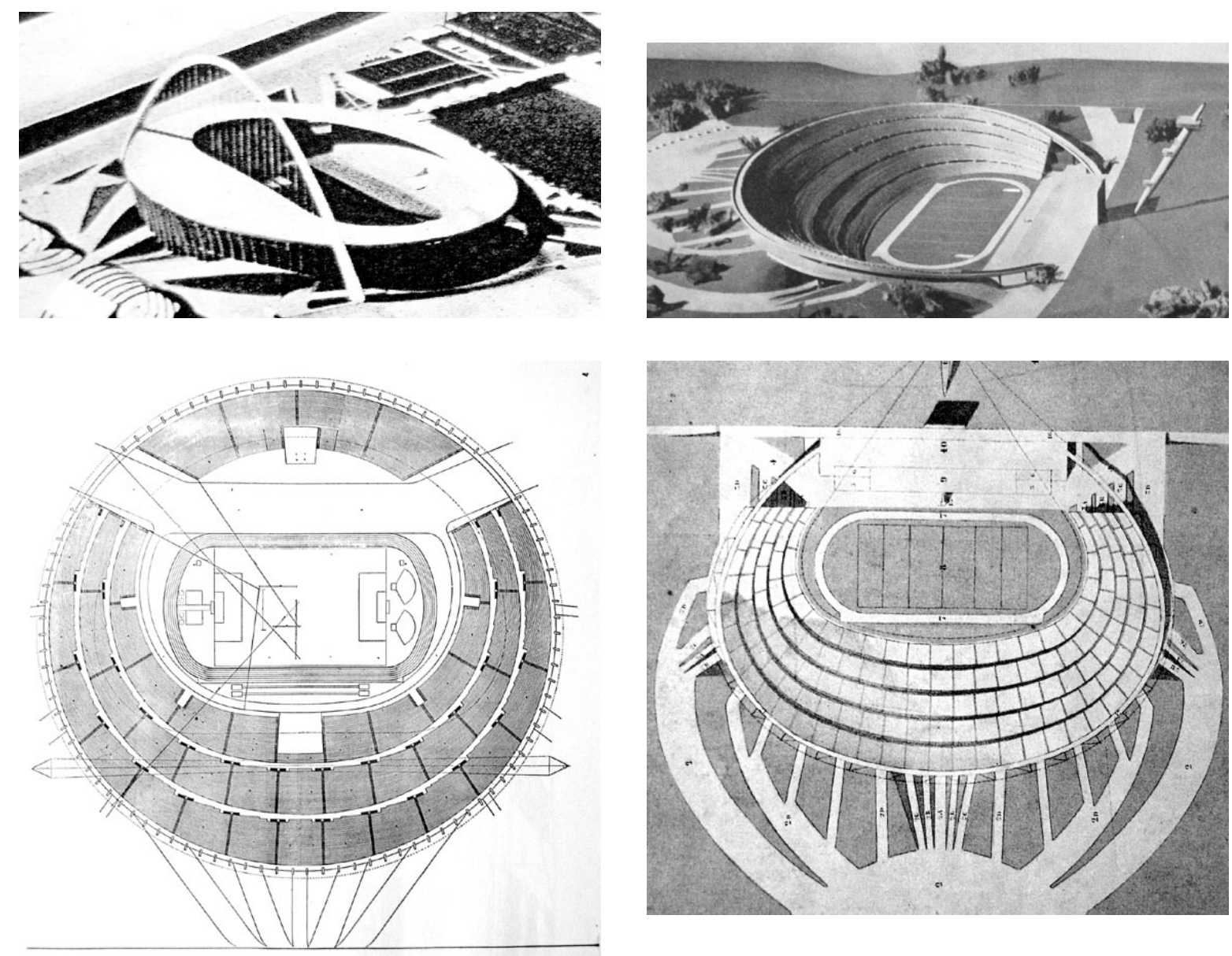

[95] Estádio Nacional - maquete - Oscar Niemeyer - 1941 (PAPADAKI, 1950:46)

[96] Estádio Nacional - planta - Oscar Niemeyer - 1941 (PAPADAKI, 1950:41)

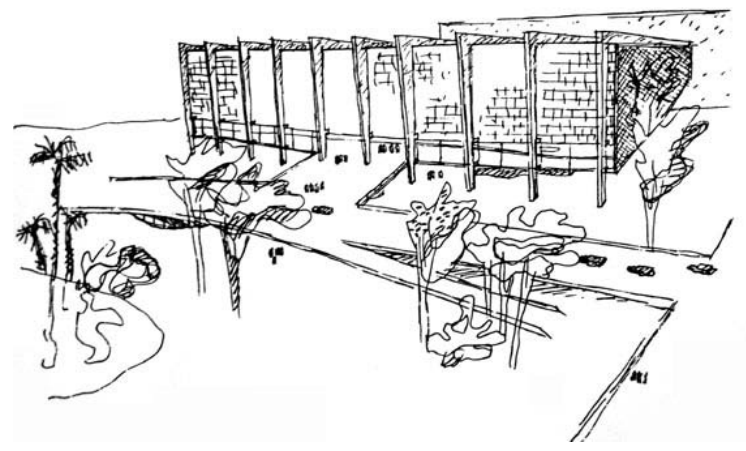

[97] Estádio para 100.000 pessoas - maquete - Le Corbusier - 1936

(BILL, 1947:93)

[98] Estádio para 100.000 pessoas - planta - Le Corbusier $-1936$

(BILL, 1947:92)

[99] Teatro Municipal de Belo Horizonte - perspectiva Oscar Niemeyer - 1943 (PAPADAKI, 1950:113) 
componentes de um projeto único.

A horizontalidade do volume do Clube dos Estudantes faz eco ao primeiro projeto de Le Corbusier para o MES, localizado na praia de Santa Luzia. Por outro lado, Niemeyer rompe com a rigidez do volume, ao desenhar os terraços abertos e a plataforma elevada, presentes em projetos de Le Corbusier como as casas Citrohan e a casa Stein. Porém, as casas corbusianas estão desprovidas da horizontalidade que caracteriza o Clube dos Estudantes que, por sua vez, possui um jogo de cheios e vazios que inexiste no primeiro projeto de Le Corbusier para o MES. Como vemos, Niemeyer assimila a arquitetura de Le Corbusier na dimensão da estratégia formal e não na dimensão da forma do objeto em si. [100], [101], [102]

Esse processo de interpretação das soluções corbusianas, passa pela subversão da condição formal dessas soluções. Niemeyer rompe com a estanqueidade de matriz cubista que caracteriza os projetos de Le Corbusier, ao desfigurar o volume puro. Tanto nas casas Citrohan e Stein, como no primeiro estudo de Le Corbusier para o MES, a forma pura é configurada tanto pelo contorno do volume como pelos desenhos de suas aberturas.

Nas casas Citrohan e Stein, Le Corbusier opera a partir de estratégias de subtração e adição onde a condição do objeto como um "sólido" é preservada, independentemente da liberdade pulsante nesse jogo compositivo de cheios e vazios. Esse sentido estanque presente nas propostas de Le Corbusier não é conseqüência apenas da solução formal adotada, mas da maneira como o arquiteto intervém na forma. As aberturas horizontais (só possíveis pelo advento da estrutura independente) comportam-se como uma operação compositiva sobre a superfície do volume, compreendendo a face do volume como um suporte bidimensional para uma ação de raiz pictórica.

No projeto para o Clube dos Estudantes, assim como no MES, Niemeyer rompe com raciocínio purista presente nos referenciais corbusianos. Ao alastrar as aberturas ao limite físico da forma, Niemeyer dilui o volume, que agora é conseqüência de um contorno quase linear e sem espessura.

Se Le Corbusier desenha a abertura como uma intervenção sobre o volume, Niemeyer expande a abertura ao seu limite, transformando o volume em membrana. Em Niemeyer, a abertura "em fita" dos exemplares puristas de Le Corbusier dá lugar ao vazio conformado pelo contorno das delgadas espessuras dos planos de fechamento do edifício.

Estamos diante de ênfases distintas: enquanto Le Corbusier opera a forma para afirmá-la como suporte para uma ação compositiva quase que a posteriori, Niemeyer redesenha as soluções corbusianas na intenção, justamente, inverter a natureza plástica de suas configurações, porém sem nunca negá-las. Por mais que a intervenção de Niemeyer demonstre uma autonomia sobre os ensinamentos do "mestre", o referencial estará sempre presente.

No projeto de Le Corbusier para a casa Citrohan, o volume principal está apoiado diretamente sobre a plataforma. No Clube dos Estudantes, Niemeyer suspende os volumes, liberando o piso da plataforma e conferindo uma autonomia plástica a cada um dos componentes do projeto.

103 | o encontro de 1936: formação 

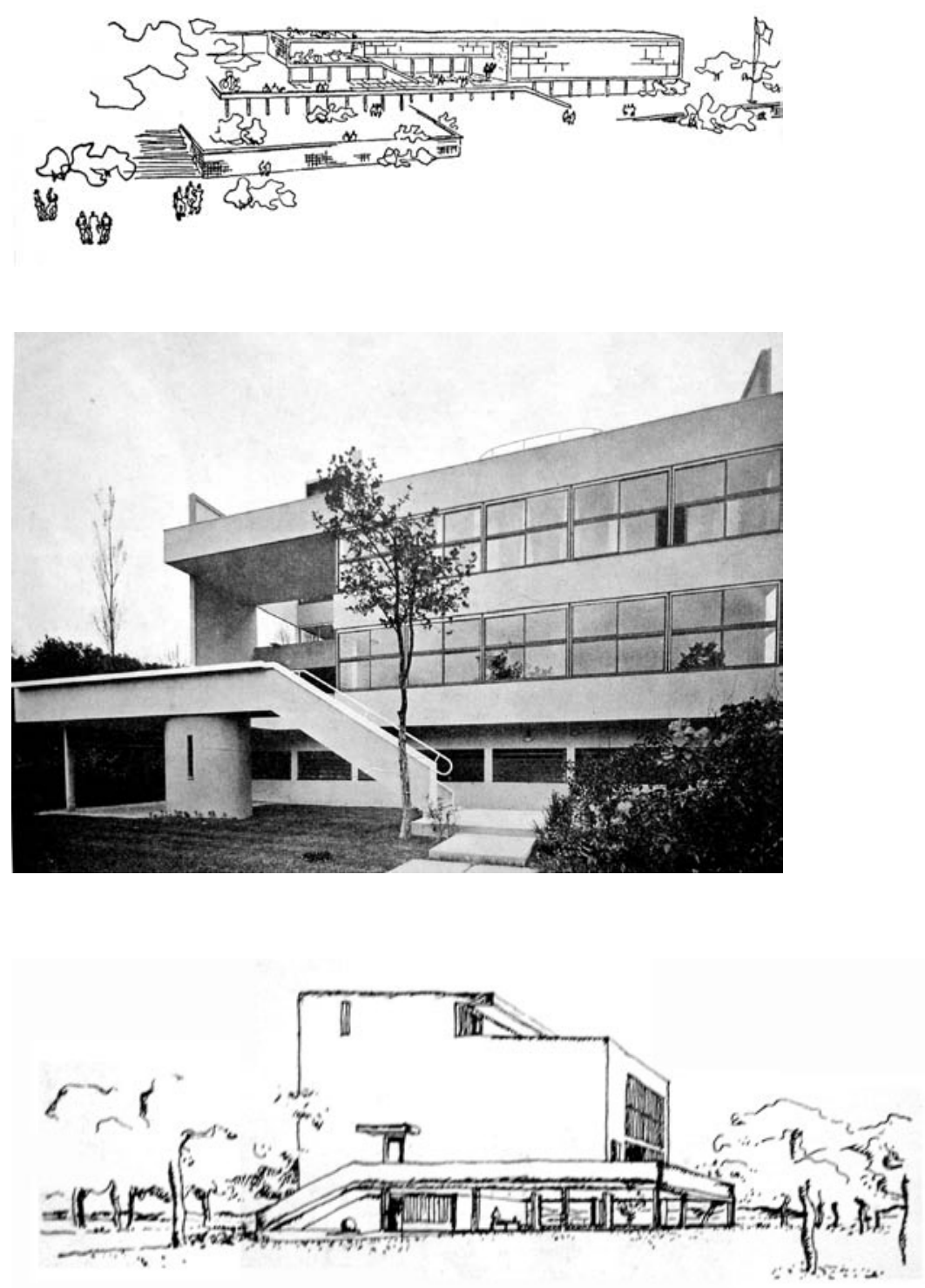

[100] Universidade do Brasil - Clube dos Estudantes - perspectiva - Oscar Niemeyer - 1936 (COSTA, 1995:187)

[101] Casa Stein - Le Corbusier - 1927

(BOESIGER, 1946:146)

[102] Casa Citrohan - perspectiva - Le Corbusier - 1922

(BOESIGER, 1946:46) 
Essa apropriação do referencial corbusiano, presente de maneira exemplar no projeto do Clube dos Estudantes, é fundamental para a compreensão do significado da liberdade na arquitetura de Oscar Niemeyer. Não se trata de uma liberdade medida pelo grau de expressão da forma arquitetônica, mas de uma liberdade que desenha uma nova espacialidade, não apenas moderna, mas única. 



\section{Pavilhão do Brasil na Feira Internacional de Nova York}

O projeto para o Pavilhão do Brasil para a Feira Internacional de Nova York de 1939 foi objeto de concurso em fevereiro de 1938, sendo Lucio Costa proclamado o arquiteto vencedor. Costa abdica do direito de desenvolver seu projeto e prefere convidar Oscar Niemeyer, autor do projeto classificado em segundo lugar, para a elaboração de um novo projeto, a ser realizado em conjunto.

O primeiro lugar no concurso para o projeto do Pavilhão do Brasil não é a primeira vitória de Lucio Costa em certames dessa categoria. O projeto vencedor do concurso para o pavilhão brasileiro na Feira Internacional da Philadelphia, de 1926, também foi de autoria de Lucio Costa. Apesar da vitória para o pavilhão de 1926, o projeto de Costa não foi executado.

Após a avaliação dos projetos concorrentes, a comissão julgadora do concurso para o Pavilhão Brasileiro da Feira de Nova York, presidida pelo arquiteto Ângelo Bruhns, destaca em sua ata de julgamento, os condicionantes que dirigiram a escolha dos projetos de Lucio Costa e Oscar Niemeyer, primeiro e segundo colocados, respectivamente. Segue trecho da ata:

A questão não deveria se orientar pela imitação de detalhes da arquitetura tradicional ou autóctone, mas por uma forma arquitetônica capaz de traduzir a expressão do ambiente brasileiro e, mais ainda, uma forma arquitetônica preferivelmente contemporânea, em virtude do fato da exposição de Nova York ter estabelecido como tema o mundo de amanhã (...) (BRUHNS apud CARRILHO, 2002:200, grifo nosso).

O comentário presente em ata oficial revela que a intenção do concurso não era a de premiar um projeto que mimetizasse elementos literais de uma arquitetura do período colonial, mais ligada à tradição vernacular. Tratava-se do momento de se encontrar a expressão que revelasse uma brasilidade sem a necessidade da incorporação de uma temática vinculada a um passado caracterizado pela ação genuína do homem sobre a paisagem brasileira.

A preocupação em conceber uma "forma arquitetônica (...) preferivelmente contemporânea (...) capaz de traduzir a expressão do ambiente brasileiro”, presente em ata oficial, deixa claro o interesse e a necessidade de se estruturar uma linguagem que plasmasse um ideário vernacular a uma estética eminentemente moderna.

107 | o encontro de 1936: formação 



[103] Pavilhão do Brasil em Nova York - 1938 - planta térreo - Lucio Costa e Oscar Niemeyer (UNDERWOOD, 2002:53)

[104] Pavilhão do Brasil em Nova York - 1938 - planta pav. superior - Lucio Costa e Oscar Niemeyer (UNDERWOOD, 2002:53)


[105] Pavilhão do Brasil em Nova York - bloco de exposições (Revista Arquitetura e Urbanismo - maio/junho 1939:477) [106] Pavilhão do Brasil em Nova York - bloco de exposições (Revista Arquitetura e Urbanismo - maio/junho 1939:476) 
Ao abrir mão do direito de desenvolver o projeto sozinho, Lucio Costa apenas reafirma seu ponto de vista que reconhece o gênio emergente de Niemeyer, diagnosticado e promovido já no projeto do Ministério da Educação e Saúde em 1936.

Lucio Costa relata que o contato de Niemeyer com Le Corbusier em 1936 teve um papel crucial em sua formação e no florescimento de sua arquitetura. Segundo Costa: "foi durante esse curto, mais assíduo convívio de quatro semanas que o gênio encubado de Oscar Niemeyer aflorou" (COSTA 1995:136, grifo nosso).

Em um texto sobre Pavilhão do Brasil, Lucio Costa justifica a presença de Niemeyer:

Levei o Oscar comigo para Nova York a fim de elaborarmos novo projeto para o Pavilhão do Brasil na Feira Mundial de 1939, porque foi depois da vinda de Le Corbusier em 36, por iniciativa minha, que a sua criatividade se revelou subitamente, com grande força inventiva; entendi então que era o momento dele desabrochar e ser reconhecido internacionalmente (COSTA 1995:190, grifo nosso).

O Pavilhão Brasileiro representa o encontro de duas correntes que, ao debruçarem sobre um problema em comum, formalizam um nexo que legitimaria a arquitetura moderna brasileira: a tradição de Costa e a liberdade de Niemeyer.

A experiência do Pavilhão do Brasil ocorre em seguida à realização do projeto para a sede do Ministério da Educação e Saúde (1936), projeto que exercerá um papel fundamental na concepção do Pavilhão Brasileiro.

Tanto o vínculo à tradição presente em Costa, como o ímpeto de liberdade, ainda encubado em Niemeyer, são submetidos a um agenciamento das operações arquitetônicas tributárias às soluções canônicas que definiram as estratégias de Le Corbusier em diversos projetos, como as "casas brancas" da década de 1920, mais precisamente as casas Stein (1927) e Savoye (1929), o projeto do Pavilhão L'Esprit Nouveau (1925) e o próprio estudo feito pelo arquiteto para uma versão do edifício do MES, implantada à beira-mar (1936).

Costa e Niemeyer incorporam os modelos do "mestre" a partir de uma operação que transgride as máximas corbusianas. O Pavilhão do Brasil subverte as configurações de volume e de espaço que, em Le Corbusier, se reportam a uma lógica inerente as suas experiências pictóricas de filiação purista ${ }^{38}$.

O Pavilhão do Brasil representa um desdobramento autônomo de alguns estilemas presentes no projeto para a sede do Ministério da Educação e Saúde. O arranjo dado pela relação forma/espaço presente no MES, apesar de caracterizar-se como uma solução que claramente se distancia da estanqueidade cubista do objeto corbusiano, apresenta-se como um passo preliminar, ainda contido, estancado, porém necessário, para se encontrar a liberdade presente na forma, na matéria e na transparência do pavilhão brasileiro.

As soluções presentes no MES, que serão diagnosticadas no Pavilhão do Brasil, versam mais sobre a intervenção da equipe brasileira do que, propriamente, sobre os estudos realizados 38. (Cf.: VALLE, 2000: 99-109).

109 | o encontro de 1936: formação 

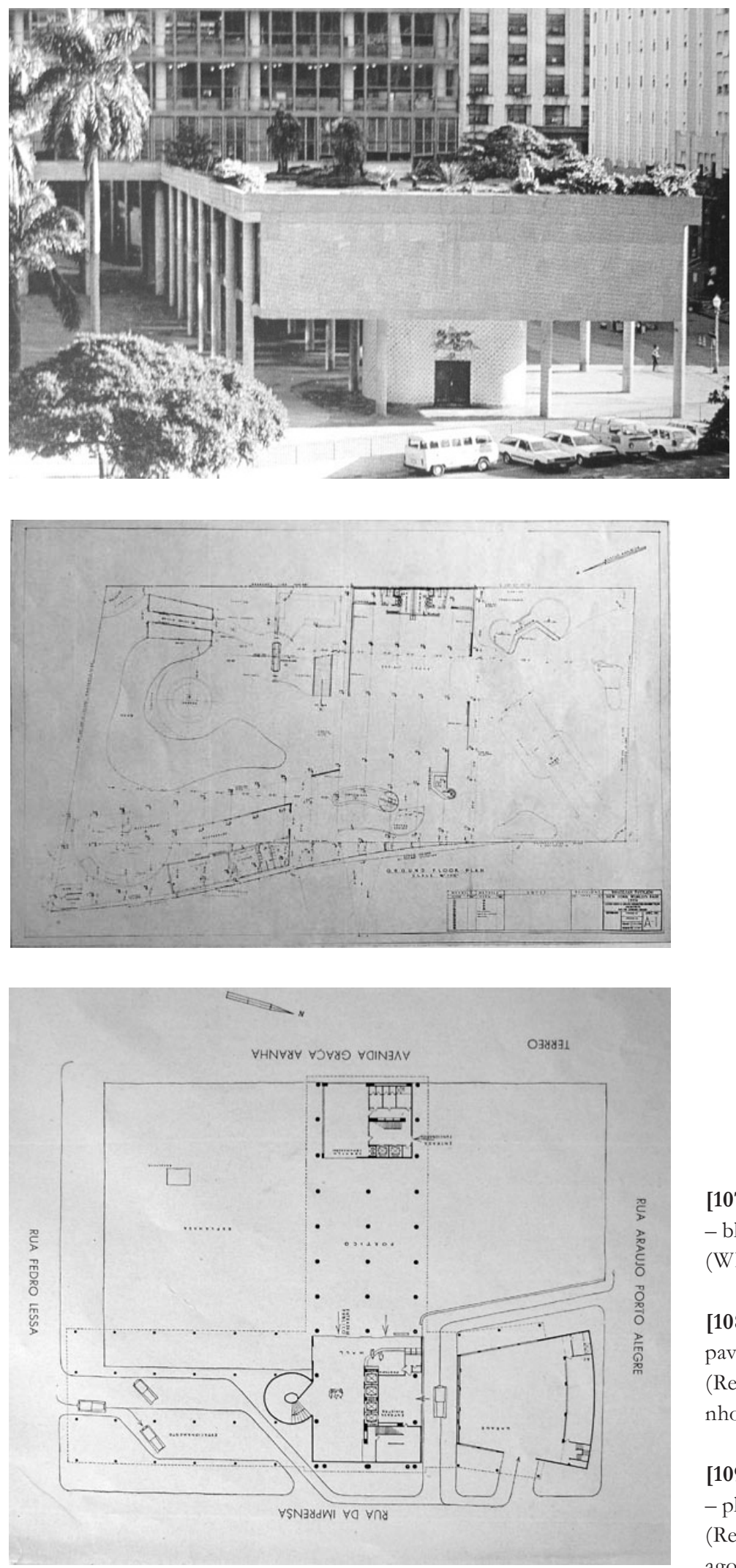

[107] Ministério da Educação e Saúde - 1936 - bloco de exposições

(WISNIK, 2001:53)

[108] Pavilhão do Brasil em Nova York - planta pav. térreo

(Revista Arquitetura e Urbanismo - maio/junho 1939:473)

[109] Ministério da Educação e Saúde - 1936 - planta pav. térreo

(Revista Arquitetura e Urbanismo - julho/ agosto 1939:22) 
por Le Corbusier.

O projeto do Pavilhão de Costa e Niemeyer ${ }^{39}$ consiste em uma construção de três pavimentos, com planta em forma de "L", além de três pequenos volumes isolados: aquário, orquidário e viveiro. O lado maior do "L" é configurado por um bloco horizontal com planta em suave curvatura. Suas faces maiores possuem tratamentos antagônicos: a face voltada para a rua é cega, já a face voltada para o jardim é envidraçada. O bloco encurvado abriga os espaços expositivos, restaurante e pista de dança. Seu apêndice perpendicular é um generoso terraço aberto que abriga o auditório e recebe a rampa em "S" que ascende do solo ${ }^{40}$. [103], [104]

A solução da implantação em "L" propicia o aparecimento de um espaço aberto para a acolher o jardim e o lago, ao mesmo tempo em que resguarda o bloco expositivo do Pavilhão Brasileiro da maciça massa construída do Pavilhão Francês implantado ao lado.

Segundo Lucio Costa:

(...) diante da massa pesada, mais alta e muito maior do Pavilhão Francês, nosso vizinho, impôs-se a adoção de um partido diferente, leve e vazado, que, em vez de se deixar absorver, contrastasse com ele. Daí também o recuo do corpo principal da construção e o aproveitamento da curva graciosa do terreno (COSTA 1995:192, grifo nosso).

No projeto do pavilhão brasileiro, o corpo horizontal em curva do bloco de exposições estabelece um diálogo com bloco homônimo presente no projeto definitivo do MES. A solução do volume horizontal suspenso, interno ao renque de pilares periféricos exteriores ao fechamento de vidro, está presente nos dois projetos de blocos expositivos, tanto no do Pavilhão do Brasil, como no do MES. [105], [106], [107]

Não serão apenas as características formais externas que aproximarão os blocos de exposições do Pavilhão Brasileiro e do MES. Ao recuar o bloco de exposições e liberar parte do lote para o jardim com o lago, orquidário e aquário, Costa e Niemeyer não apenas afastam parte do Pavilhão Brasileiro do volumoso Pavilhão Francês, como permitem que visuais enquadrem todo o conjunto e o vazio, conseqüência da implantação em "L". Essa mesma intenção está presente na implantação do bloco expositivo do MES, caracterizado por um volume horizontal suspenso e retangular, implantado próximo do limite do lote, nitidamente desalinhado do eixo de simetria do terreno. O deslocamento permite que o bloco de exposições do MES incorpore o vazio a sua frente (que se abre para a Rua Graça Aranha) como um recuo necessário para a plena compreensão do conjunto formando pelo bloco expositivo e pela lâmina de escritórios. [108], [109]

Apesar da referência ao bloco de exposições do MES ser patente no recinto homônimo do Pavilhão, devemos observar que, ao adotar o bloco em curva, o projeto de Costa e Niemeyer conferirá um aspecto sinuoso à retícula estrutural que é base fundamental para a planta-livre e

39. "O projeto do Pavilhão Brasileiro na Feira Internacional de Nova York de 1939, foi projetado por Lucio Costa e Oscar Niemeyer com a colaboração dos arquitetos Paul Lester Wiener (interiores) e Thomas Price (paisagismo).” (VALLE, 2000:13).

40. (Cf.: CAVALCANTI, 2006:177).

111 | o encontro de 1936: formação 

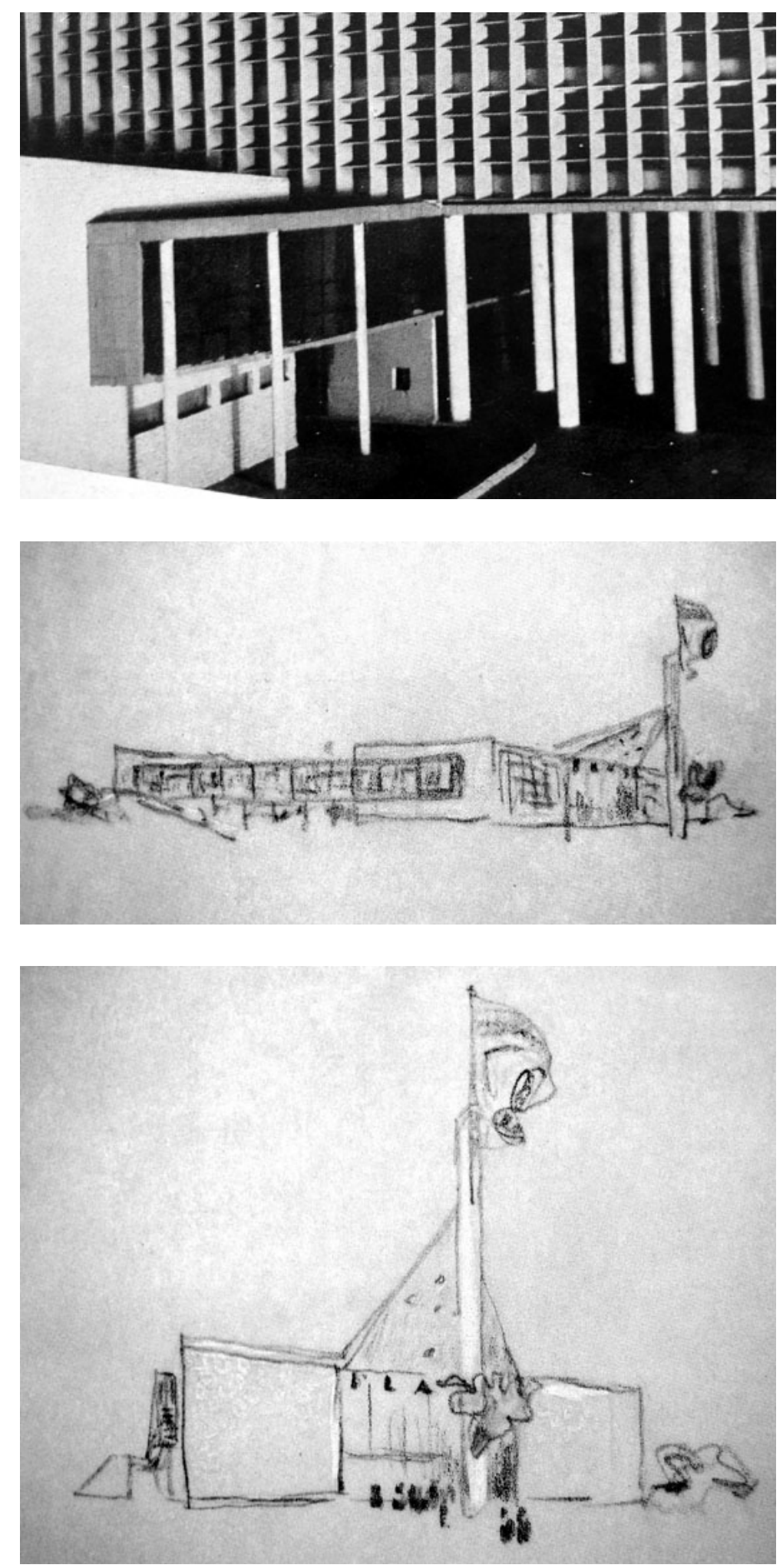

[110] Ministério da Educação e Saúde - 1936 - bloco de exposições e auditório (Revista Arquitetura e Urbanismo julho/agosto 1939:551)

[111] Pavilhão do Brasil em Nova York - 1938 - bloco de exposições - proposta vencedora - Lucio Costa. (COSTA, 2002:21)

[112] Pavilhão do Brasil em Nova York - 1938 - acesso principal - proposta vencedora - Lucio Costa. (COSTA,2002:21) 
para a fachada-livre.

Sobre a relação entre o projeto do MES e o Pavilhão do Brasil, Marcos Carrilho afirma que:

As variações proporcionadas pelo sistema da estrutura independente foram intensamente exploradas. De um lado, a caixa fechada se projetava suspensa em balanço, de outro, se abria integralmente para o jardim, por meio de um pano de vidro recuado ligeiramente em relação à estrutura, permitindo que as colunas surgissem livres e sem interrupção, a exemplo da solução adotada para a sala de exposições do MES, e marcassem o seu ritmo, desenvolvendo-se na dimensão de toda a altura do edifício (CARRILHO, 2002:202, grifo nosso).

No projeto realizado por Lucio Costa, classificado em primeiro lugar, também é possível observar a presença do bloco de exposições em forma de um volume retangular horizontal e suspenso. A solução de Costa para o bloco de exposições rebaterá na proposta conjunta realizada com Niemeyer, porém com algumas alterações. [110], [111], [112]

$\mathrm{Na}$ proposta de Lucio Costa, o volume que abriga os espaços expositivos possui sua face transparente voltada para fora, característica que não corresponde à solução definitiva, cuja face externa é cega.

O bloco de exposições da proposta de Costa assemelha-se à solução desenvolvida para o bloco de exposições do MES. Em ambos os projetos, o volume transparente suspenso "abraça" o auditório, representado por um volume trapezoidal opaco implantado diretamente sobre o solo.

O desenho de Lucio Costa indica que o bloco de exposições está ancorado em dois volumes opacos. Em uma extremidade o bloco expositivo conecta-se ao auditório; na outra extremidade, próxima da face principal do Pavilhão, o bloco suspenso se funde ao volume que representa o acesso principal demarcado por marquise triangular, cuja aresta mais alta encontrase sustentada pelo mastro da bandeira do Brasil.

Em um dos croquis de Lucio Costa para o Pavilhão é possível notar a presença da superfície retangular preenchida pelos cobogós exatamente como na versão definitiva, concebida posteriormente. A rampa externa, presente no projeto definitivo, já integrava o projeto de Lucio Costa. Não era em "S" e nem estava na frente da elevação principal. Ao contrário, era paralela ao salão de exposições e desenvolvia-se em um único e retilíneo lance.

A versão de Lucio Costa pode ser compreendida como uma transposição do salão de exposições do MES para uma realidade diversa da Esplanada do Castelo. O desdobramento em fachada rebatida, tendo como eixo de simetria o mastro da bandeira do Brasil, nos dá pistas de uma certa incongruência entre a modernidade corbusiana presente no salão de exposições e a axialidade clássica que caracteriza a elevação principal do Pavilhão.

No instante em que Costa se vê desvinculado do alicerce corbusiano, o arquiteto retoma um raciocínio tradicional que parecia não corresponder à liberdade moderna presente na referência clara ao mestre franco-suíço, no bloco de exposições.

No projeto de Oscar Niemeyer, classificado em segundo lugar, podemos observar uma série de características que migrarão para o projeto definitivo realizado em parceria com

113 o encontro de 1936: formação 

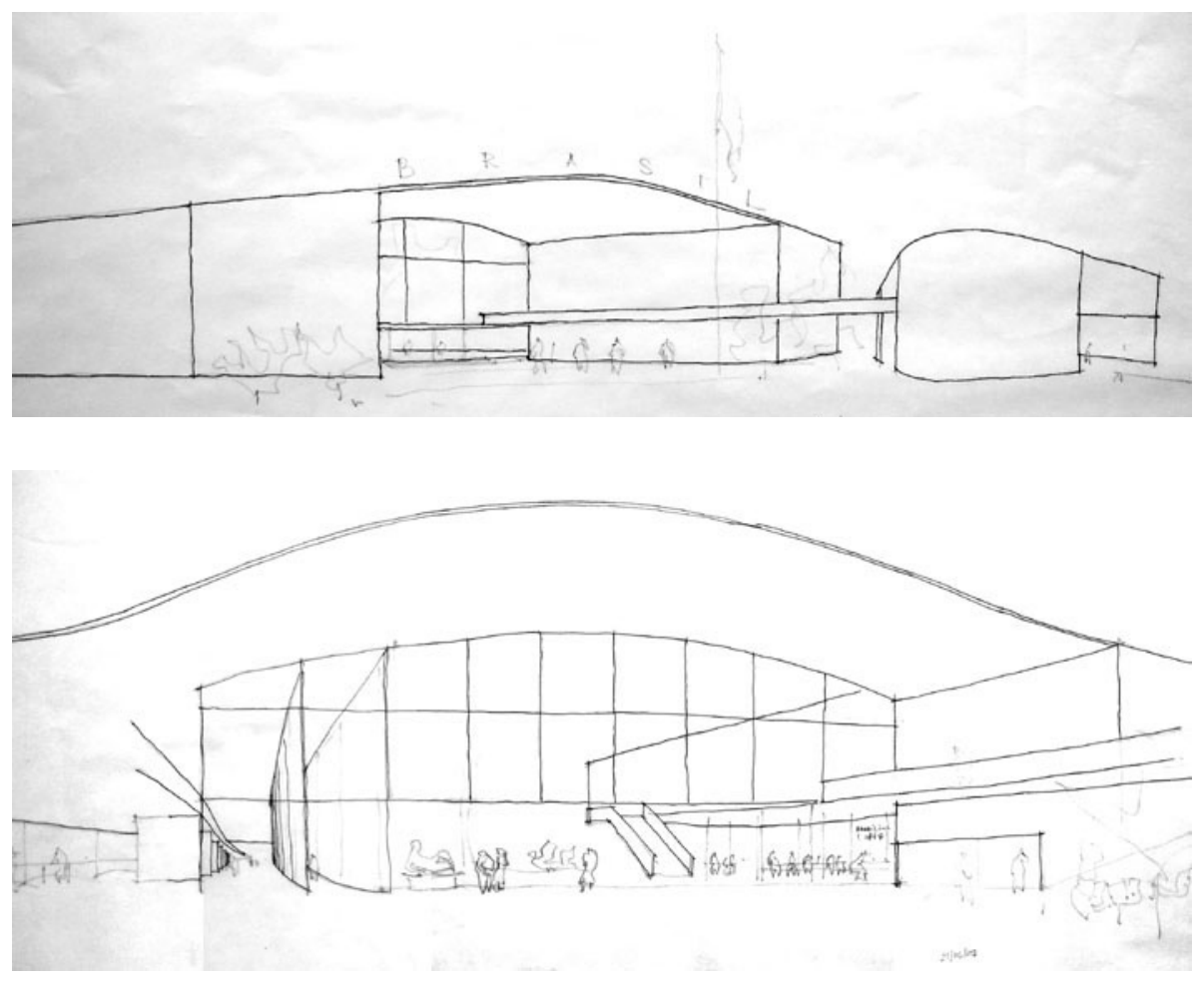

[113] Pavilhão do Brasil em Nova York - 1938 - perspectiva do conjunto - proposta classificada em segundo lugar Oscar Niemeyer

(Desenho de Rodrigo Queiroz traçado sobre cópia heliográfica pertencente ao acervo da Casa de Lucio Costa)

[114] Pavilhão do Brasil em Nova York - 1938 - perspectiva da entrada - proposta classificada em segundo lugar Oscar Niemeyer

(Desenho de Rodrigo Queiroz traçado sobre cópia heliográfica pertencente ao acervo da Casa de Lucio Costa) 
Lucio Costa. Enquanto o projeto de Lucio Costa possui uma aparência volumétrica estanque ${ }^{41}$, a versão de Niemeyer é caracterizada por uma volumetria vazada na porção que marca o acesso principal. [113], [114]

$\mathrm{Na}$ proposta de Niemeyer, uma cobertura em abóbada abatida abriga o salão de entrada do Pavilhão. Uma passarela suspensa rasga o grande vazio da entrada e conduz a um auditório externo, cuja volumetria trapezoidal com base menor em curva convexa é idêntica àquela presente no projeto definitivo. O auditório externo, ilustrado na versão de Niemeyer classificada em segundo lugar, será transposto para o interior do grande terraço coberto e suspenso na proposta realizada em parceria com Costa.

O bloco expositivo em forma de barra encurvada em sutil "S", presente no projeto final, já era parte integrante na proposta de Niemeyer. Em uma das perspectivas é possível observar o peitoril do mezanino a desenvolver-se em suave ondulação. A locação de uma escada de único lance, exposta no jardim interno, é outro elemento comum tanto à versão de Niemeyer como ao projeto definitivo.

Poderíamos definir o projeto final para o Pavilhão do Brasil como uma versão híbrida, que assimila elementos e características dos dois projetos realizados em separado por Costa e Niemeyer, ilustrando a síntese de algumas condições presentes nos raciocínios dos arquitetos: o compromisso com o legado corbusiano e com elementos de uma arquitetura "autêntica" presente em Lucio Costa, e o ímpeto de liberdade na forma e no espaço presente em Niemeyer.

Sobre a solução final para o projeto do Pavilhão, Lucio Costa, em uma correção manuscrita sobre a "memória descritiva" do projeto, declara: "Desenho e projeto de Oscar Niemeyer, utilizou apenas meu partido anterior - pilotis, rampa e quebra-sol" (COSTA apud XAVIER, 1962/2007:95, grifo nosso).

A definição de Costa é clara. O arquiteto explica de maneira precisa o seu papel e a parcela de contribuição de Oscar Niemeyer no projeto final. O partido que caracteriza a versão de Costa é o mesmo da proposta definitiva: dois blocos perpendiculares, sendo o bloco principal, mais largo e vazado, reservado ao espaço de recepção, e o volume que abriga os espaços de exposição, estreito, longo e sobre pilotis, localizado à esquerda do bloco principal.

A rampa presente na proposta definitiva (que na versão de Costa é reta e paralela ao bloco de exposições e que inexiste na versão de Niemeyer), assumirá um traçado ondulante em planta, e estará localizada na elevação principal do Pavilhão. Os quebra-sóis retangulares, presentes na versão de Costa (pelo menos em um dos desenhos) não aparecem na versão de Niemeyer, mas estarão presentes na elevação principal do projeto final.

No Pavilhão do Brasil, a trama estrutural acompanha a sutil curvatura do bloco de exposições. Essa escolha de Costa e Niemeyer nos dá uma clara pista de que a estrutura segue a forma, ao contrário dos exemplares corbusianos que derivam do Esquema Dom-Ino, onde a retícula de pilares permanece inflexível, independentemente dos traçados em planta dos fechamentos

41. Justamente por confiar no esquema Dom-Ino presente no bloco de exposições do MES e transpô-lo para o Pavilhão do Brasil.

115 o encontro de 1936: formação 

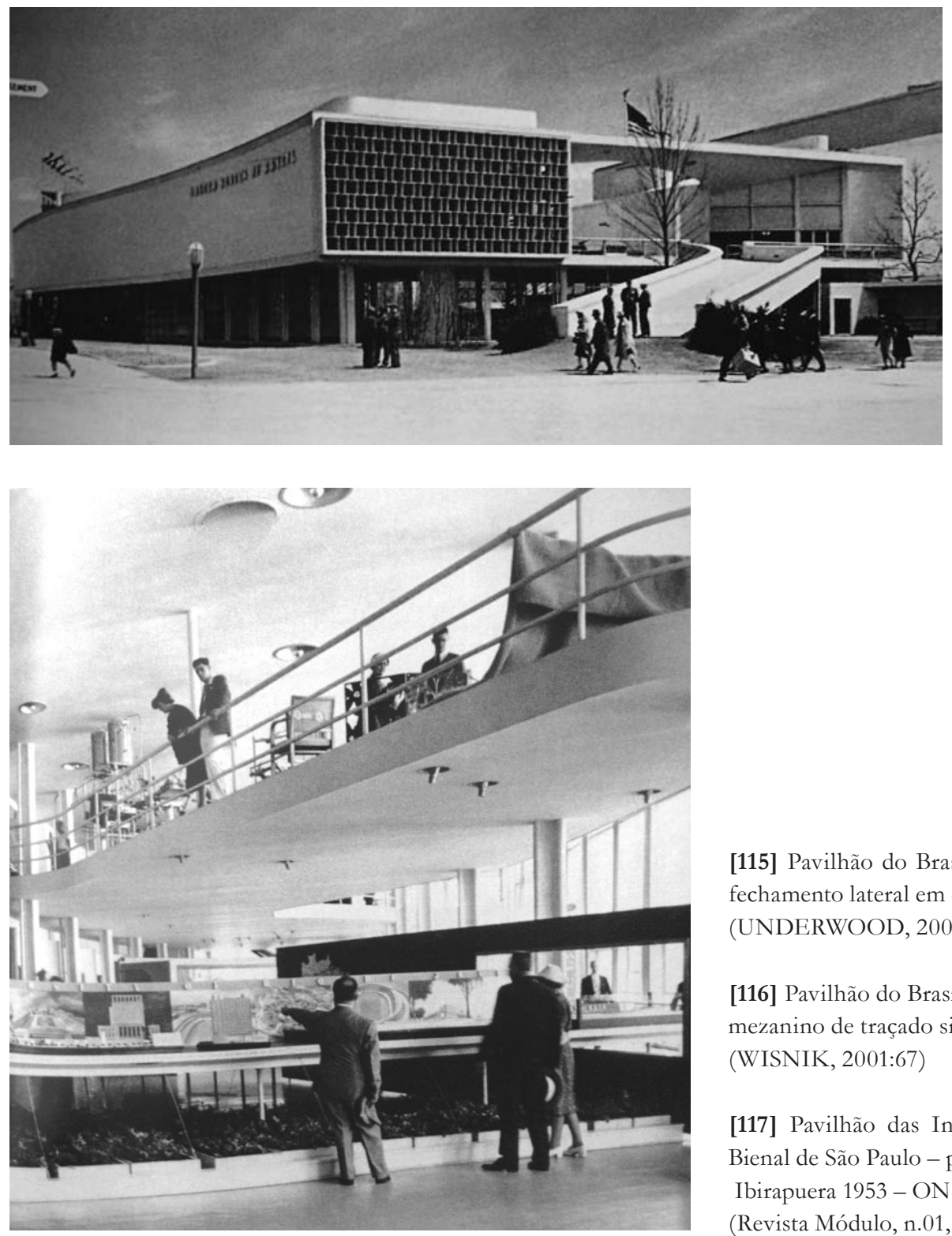

[115] Pavilhão do Brasil em Nova York - 1938 fechamento lateral em curva e acesso em rampa (UNDERWOOD, 2002:51)

[116] Pavilhão do Brasil em Nova York mezanino de traçado sinuoso (WISNIK, 2001:67)

[117] Pavilhão das Industrias - atual Fundação Bienal de São Paulo - planta sobreloja - Parque Ibirapuera 1953 - ON

(Revista Módulo, n.01, março/1955, p.29)

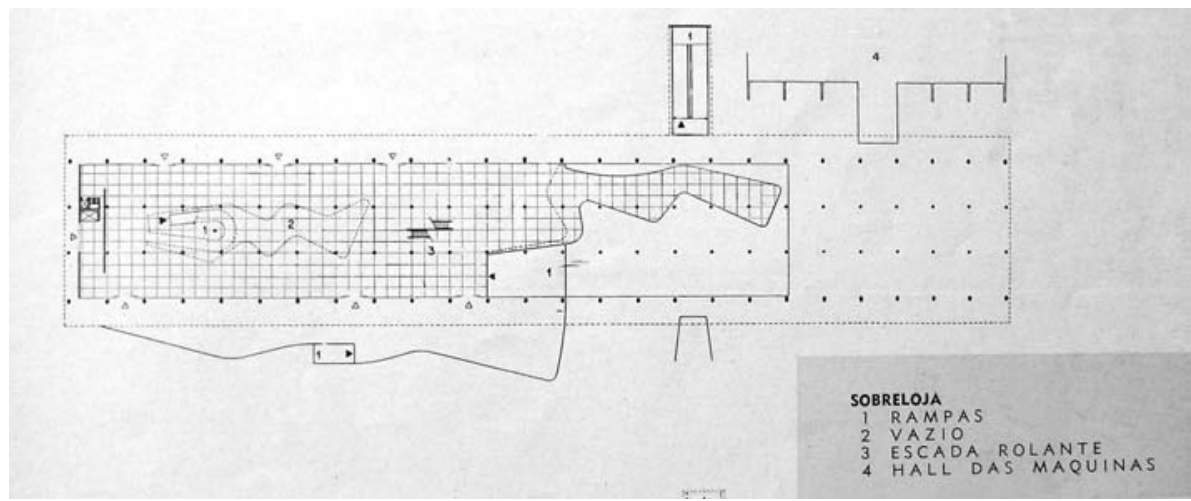

o encontro de 1936: formação| 116 
internos e externos.

Em Le Corbusier, a retícula de pilares é um índice ortogonal que baliza a organização interior do volume de contorno puro, ao mesmo tempo em que - por sua lógica e ritmo - evidencia a liberdade dos paramentos encurvados contidos no interior do volume purista.

O diálogo com a obra de Le Corbusier presente no Pavilhão do Brasil é pontuado por uma seqüência de afirmações e negações caracterizadas, por um lado, pela aceitação de soluções canônicas e, por outro, por intervenções que transgridem a lógica corbusiana.

A face do bloco de exposições voltada para o lago artificial e jardim é caracterizada por uma superfície transparente com os pilares periféricos externos à face de vidro, solução que remonta a proposta da equipe brasileira para a sede do MES. Na face voltada para a rua, oposta àquela que se abre para o jardim, Costa e Niemeyer adotam uma solução inversa. Todo o pavimento superior está resguardado por uma fachada cega que reforça a curvatura do bloco em virtude dos pilares estarem contidos em seu interior.

Com esse artifício, toda a face encurvada do bloco de exposições pode ser percebida como um único plano contínuo. Nessa situação, os arquitetos corroboram com a estratégia de Le Corbusier de afastar a estrutura para o interior do volume e assim propiciar a "fachada livre". [115]

No projeto do Pavilhão do Brasil, podemos observar três configurações distintas para a curva: a curva exterior presente no bloco de exposições que caracteriza contorno do objeto; a curva interior, presente no rasgo sinuoso que descreve o vazio entre o mezanino e o primeiro pavimento do bloco de exposições; e a curva compositiva, presente nos objetos e nos paramentos internos à projeção do contorno exterior, como a parede da pista de dança, o balcão do bar, o balcão do cafezinho e o próprio auditório, contido na porção vazada, perpendicular ao bloco de exposições.

A obstrução em recorte ondulante da laje de piso do terceiro pavimento do bloco de exposições pode ser compreendida como a primeira ocorrência desse tipo de operação na obra de Niemeyer. O recorte sinuoso da laje do mezanino, no caso do Pavilhão do Brasil, potencializa a dinâmica da apreensão do espaço interno que dialoga com a gestualidade exterior do objeto.

Em diversos projetos de Niemeyer que sucedem a experiência do Pavilhão podemos observar esse tipo de solução. Talvez o exemplar mais conhecido seja o Pavilhão das Industrias (atual Pavilhão Ciccillo Matarazzo), edifício integrante do conjunto arquitetônico do Parque Ibirapuera (1951/1954) que, assim como o Pavilhão do Brasil, possui sua laje rasgada por movimento sinuoso. [116], [117]

Tanto o rasgo do mezanino como os fechamentos encurvados contidos no interior do Pavilhão do Brasil incorporam as características presentes nos projetos de Le Corbusier realizados durante a década de 1920 que, por sua vez, dialogam com as suas experiências pictóricas de cunho purista ${ }^{42}$.

No projeto do Pavilhão do Brasil, a curva é conseqüência da ação motora de um gesto contínuo, plena antítese à curva caracterizada por arcos circulares e parabólicos presentes nas

42. A relação entre a curva pictórica presente nas vilas de Le Corbusier e a curva aberta e exterior de Niemeyer será abordada no capítulo Cassino.

117 | o encontro de 1936: formação 

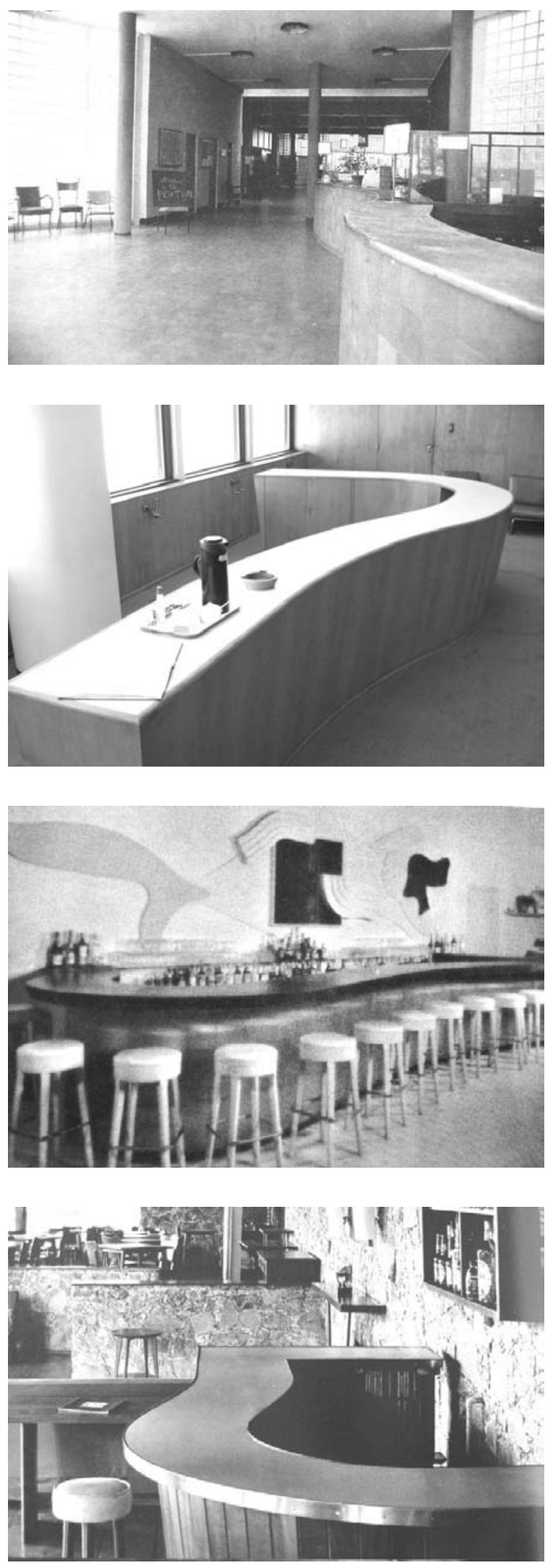

[118] Exército da Salvação (Cite Refuge) - balcão da recepção - 1929 - LC

(BAKER, 1996:07)

[119] Balcão da recepção do salão de exposições - MES $-1936$

(Foto: Rodrigo Queiroz)

[120] Balcão do bar - Pavilhão do Brasil - 1938 (CAVALCANTI, 2006:180)

[121] Balcão do bar - Hotel São Clemente - Nova Friburgo - 1944/1945 - Lucio Costa (WISNIK, 2001:84) 
casas de Le Corbusier da década de 1920.

No Pavilhão, Niemeyer e Costa interpretam de maneira pessoal as qualidades geométricas que conferem um sentido puro aos modelos de Le Corbusier, através da distensão horizontal do objeto e da eliminação da superfície exterior que caracteriza a forma pura.

Para Luiz Recamán,

(...) o pavilhão de Nova Iorque inspira-se nesse interessante jogo formal interno das vilas corbusianas, mas ultrapassa-as ao romper com a "célula" modular. Novamente, é pura excepcionalidade, retirando, do esquema corbusiano, o seu potencial plástico e expressivo, em que nem o volume prismático continente resiste a essa apropriação (RECAMÁN 2002:130, grifo nosso).

Ao comparar o Pavilhão do Brasil com as vilas corbusianas, Recamán aponta para uma questão crucial para a compreensão da liberdade formal presente no Pavilhão e posteriormente nos edifícios do Conjunto da Pampulha: a ruptura da célula purista de Le Corbusier.

Quando os componentes encurvados (viveiro, orquidário e aquário) extravasam para o exterior dos limites de fechamento do Pavilhão, a condição plástico-pictórica dos componentes encurvados presentes nas casas brancas de Le Corbusier, assume um grau de autonomia e liberdade que, à primeira vista, será incompatível com os pressupostos puristas que regem as experiências do mestre franco-suíço.

Os paramentos e os objetos curvos contidos no interior do Pavilhão do Brasil podem ser reconhecidos como redesenhos de soluções presentes no $\mathrm{MES}^{43}$, mas também se prestarão como modelos para alguns projetos de Niemeyer que sucedem a experiência americana.

O balcão do bar do Pavilhão do Brasil possui traçado em "S" semelhante àquele presente no hall do salão de exposição do MES (1936), que também encontrará rebatimento no balcão do bar do Park Hotel São Clemente em Nova Friburgo, projeto de Lucio Costa (1944/1945). Porém, quando observamos o balcão projetado por Le Corbusier para o hall de entrada da Cité Refuge (1929), compreendemos a direção do diálogo estabelecido entre os arquitetos brasileiros e o "mestre". O balcão serpenteante revestido em madeira clara, característico do Pavilhão, do MES e do Park Hotel, já estava presente no edifício parisiense de Le Corbusier. [118], [119], [120], [121]

No Pavilhão, os volumes encurvados da pista de dança e do auditório - independentes da trama estrutural formada por pilares metálicos de secção “i” - sintetizam a preocupação em estabelecer o contraste entre as superfícies curvas contidas no interior e o perfil exterior do edifício que, apesar de assumir sutil curvatura no corpo que contém o mezanino, não chega a ofuscar as formas o auditório e da pista de dança ${ }^{44}$.

O restaurante-dançante de traçado circular, presente no térreo do bloco de exposições do Pavilhão, será solução recorrente em outros projetos de Niemeyer, como nos restaurantesdançantes presentes no Cassino e na Casa de Baile da Pampulha, cujos desenhos são próximos

43. Presentes principalmente na casa de máquinas da cobertura e no balcão do salão de exposições.

44. No capítulo Casa de Baile e Hotel Resort será retomado o tema da planta circular.

119 | o encontro de 1936: formação 



[122] Pavilhão do Brasil em Nova York - 1938/1939 - ballroom e restaurante circular (CAVALCANTI, 2006:180)

[123] Cassino da Pampulha - 1940 - ballroom e restaurante circular- ON

(Foto: Rodrigo Queiroz)

[124] Casa de Baile - Pampulha - 1942 - ballroom e restaurante circular - ON

(Foto: Rodrigo Queiroz) 
ao do Pavilhão do Brasil. Trata-se de um modelo que associa a forma à sua função: planta circular com as mesas em posição periférica e o centro do círculo reservado à dança.

A adoção dos planos encurvados transparentes, resultantes da justaposição de esbeltas réguas verticais de vidro, presentes nos projetos de Niemeyer, demonstra uma relação com a caixilharia em semi-círculo da casa Savoye de Le Corbusier (1929).

Tanto no Cassino como na Casa de Baile, Niemeyer exterioriza a forma (quase) circular que define o espaço de dança do Pavilhão do Brasil. Gradativamente, nos projetos de Niemeyer que sucedem a experiência de Nova York, as formas curvas serão transportadas do interior dos volumes para o meio externo. [122], [123], [124]

O projeto do Pavilhão do Brasil representa o exato instante em que Niemeyer inicia o procedimento de emancipação das formas encurvadas que, em Le Corbusier, permanecem internas ao campo pictórico, tanto na pintura, como no desenho em planta. No Pavilhão do Brasil, o volume do ballroom está enclausurado no interior de um volume maior que caracteriza, formalmente, o edifício.

No Cassino da Pampulha, Niemeyer dá continuidade ao raciocínio libertador presente no Pavilhão, exteriorizando a forma de matriz circular que abriga o ballroom. Porém, mesmo no Cassino, essa autonomia da forma livre passa por um processo de diálogo e enfrentamento dos pressupostos corbusianos. Niemeyer mantém uma conexão que une a forma circular (salão de baile) a um volume de matriz racionalista (salão de jogos). Uma considerável evolução pode ser verificada no projeto para a Casa de Baile, onde o volume de planta circular conecta-se a um outro volume apenas por marquise sinuosa.

O projeto para o Cassino da Pampulha pode ser compreendido como um estágio intermediário entre a forma circular interna ao volume do edifício presente no Pavilhão do Brasil e a forma circular externa que, juntamente com a marquise sinuosa, caracteriza a Casa de Baile. [125], [126], [127]

No projeto para o Pavilhão do Brasil, Niemeyer especula a emancipação da forma livre, ainda em escala doméstica, mas que será reconhecida de maneira definitiva em Pampulha. Os volumes do viveiro, do orquidário e do aquário, dispostos externos ao volume do Pavilhão já prenunciam a exteriorização das formas livres que não mais se restringem ao interior da projeção de formas regulares, como nos exemplares puristas de Le Corbusier.

Sobre o contraste entre esses componentes curvilíneos exteriores e a geometria do Pavilhão, Luiz Recamán postula que:

À fluidez da volumetria externa do bloco principal contrapõe-se a fragmentação dos elementos curvos próximos, mas independentes, que não procuram continuidade (rampa, auditório, pista de dança, aviário e caixa d’água). É como se os anexos corbusianos, de formas livres em relação ao rigor prismático da lâmina, se apresentassem todos justapostos, em menor escala, não como contraposição ao módulo - agora inexistente - mas buscando a tensão entre si, propondo como tema sua desarmonia (RECAMÁN 2002:133, grifo nosso).

121 o encontro de 1936: formação 



[125], [126], [127]: Plantas do Pavilhão do Brasil; do Cassino e da Casa de Baile da Pampulha. [125] (UNDERWOOD, 2002:53); [126] (PAPADAKI, 1950:72); [127] (UNDERWOOD, 2002:64) 
Poderíamos adicionar à colocação de Recamán o fato de que esses componentes curvos presentes no Pavilhão e elencados pelo autor, além de representarem um redesenho dos "anexos corbusianos", extrapolam a condição hermética da composição corbusiana que distribui esses "anexos" internos ao perímetro exterior do edifício, invariavelmente, representado por um contorno puro.

Seja uma caixa de escada, um lavabo ou um pára-vento na cobertura, para Le Corbusier, esses elementos ordenam-se a partir de um senso de organização pictórico, onde o traçado gráfico, em planta, flerta com o raciocínio da pintura.

Esse diálogo purista que Le Corbusier executa entre aquilo que contém e aquilo que está contido - presente nas casas brancas da década de 1920 - segue a relação entre a moldura regular do quadro que limita o campo de ação do arranjo de componentes figurativos como pratos, copos, garrafas e violões.

Ao expelir parte desses "elementos curvos" para o exterior do Pavilhão, Niemeyer subverte um dos paradigmas do purismo corbusiano. A curva que Le Corbusier mantém encapsulada no interior da planta/moldura, no Pavilhão assume o papel de um objeto pleno na paisagem, mesmo que, nesse instante, ainda esteja reduzido a um componente apequenado, comparado a escala do edifício.

Será justamente esse movimento libertador, presente do Pavilhão - ainda de maneira encubada e quase experimental - que promoverá a forma livre à condição de objeto exterior. Os projetos de Niemeyer que sucedem a experiência americana ${ }^{45}$ darão vazão a esse desejo de libertação e emancipação das formas curvas, originalmente redesenhadas dos exemplares puristas de Le Corbusier.

Apesar da exteriorização das formas livres, os volumes do orquidário, aquário e viveiro, devido as suas dimensões modestas, não caracterizam o edifício do Pavilhão enquanto forma e imagem. Diferentemente dos edifícios da Pampulha, no projeto do Pavilhão essas formas autônomas são apêndices libertos que organizam os espaços vazios da praça de chegada (viveiro) e do jardim (orquidário e aquário).

O viveiro, constituído por duas formas cilíndricas irregulares conectadas, encontra-se na entrada do Pavilhão, à direita da rampa de acesso, no mesmo lugar em que Niemeyer havia disposto o auditório, em sua proposta individual. Já o aquário cilíndrico, interligado ao orquidário retangular por marquise, está implantado na porção contida pela própria forma "L" do Pavilhão.

Em uma perspectiva de Niemeyer que representa o jardim interno do Pavilhão, é possível observar a presença do conjunto dado pela forma circular conectada por marquise sinuosa ao volume de planta trapezoidal que abriga o orquidário. Essa perspectiva ilustra a primeira ocorrência da utilização do pilar em "V" nos projetos de Niemeyer. Trata-se de um par de pilares tubulares que sustenta a marquise de conexão dos dois volumes.

Essa solução dos pilares tubulares em "V" como apoio para marquise já havia sido espe-


plantas do Pavilhão do Brasil, do Cassino e da Casa de Baile da Pampulha.

123 o encontro de 1936: formação 

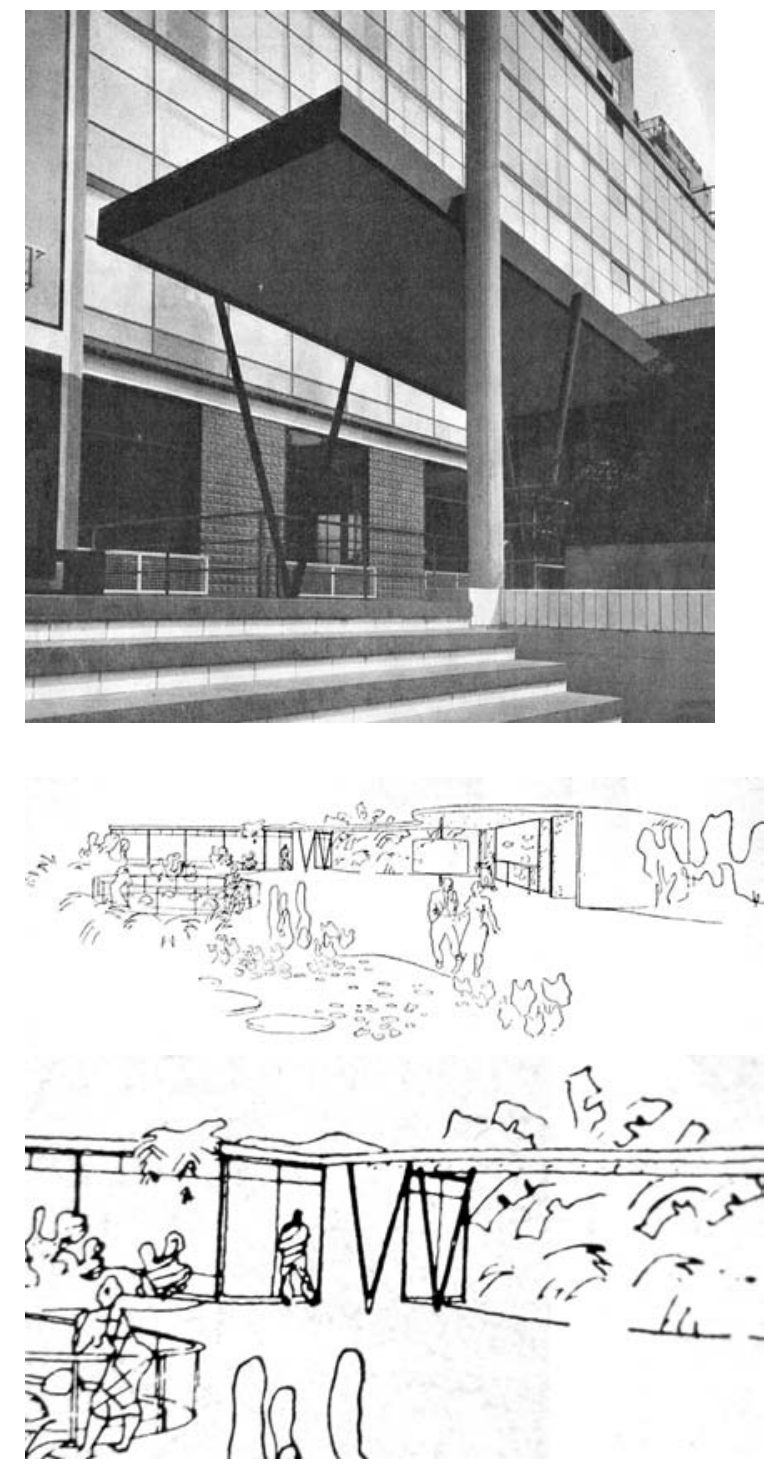

[128] Cité Refuge - Paris - marquise e pilar em "V" -

Le Corbusier - 1929

(BOESIGER, 1971:115)

[129] Pavilhão do Brasil na Feira Internacional de Nova York - 1929 - perspectiva do jardim interno e detalhe do par de pilares em "V" sob a marquise de conexão entre o orquidário e o aquário - Oscar Niemeyer e Lucio Costa

(Revista Arquitetura e Urbanismo, maio/junho 1939:472)
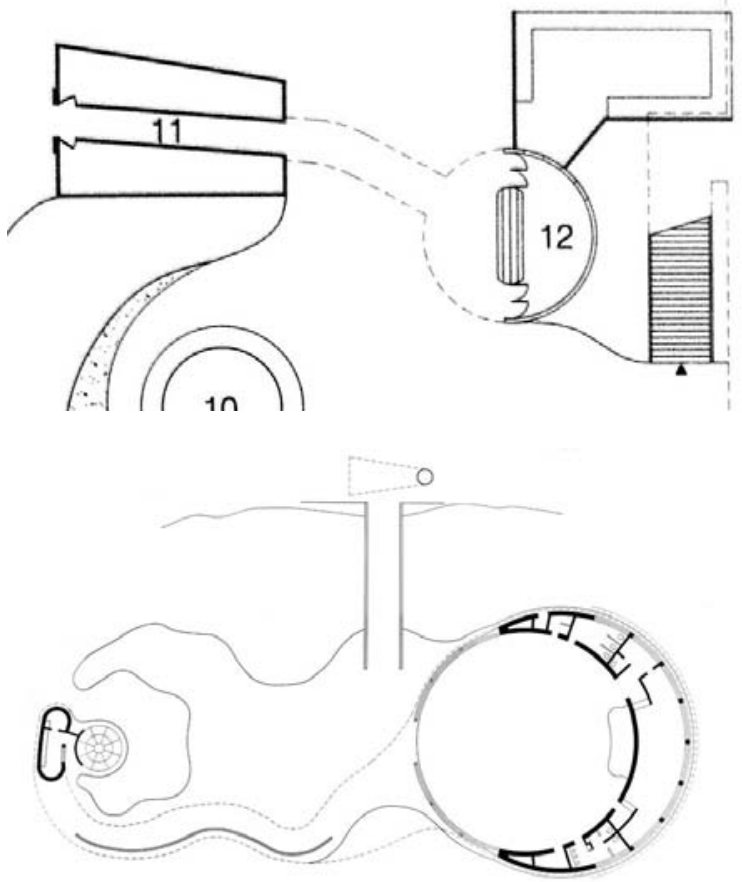

[130] Pavilhão do Brasil em Nova York - 1938 - fragmento da planta - orquidário e aquário

(UNDERWOOD, 2002:53)

[131] Casa de Baile - Pampulha - 1942 - planta - ON

(UNDERWOOD, 2002:64) 
culada por Le Corbusier na entrada principal do edifício do Exército da Salvação ${ }^{46}$ (1929) e será retomada por Niemeyer na marquise de entrada do Cassino da Pampulha. [128], [129]

O conjunto formado pelo orquidário e aquário do Pavilhão já esboça a solução que estará presente na Casa de Baile da Pampulha: volume raso de planta circular conectado a outro por marquise sinuosa. [130], [131]

Em um projeto de Affonso Eduardo Reidy para um bar em praça pública na Av. Afonso Vizeu, no bairro da Tijuca, Rio de Janeiro (1939), podemos identificar a clara referência ao conjunto formado pelo orquidário e aquário do Pavilhão do Brasil. Assim como no projeto de Niemeyer e Costa, a proposta de Reidy é caracterizada pela adoção de um volume trapezoidal e outro circular, conectados por marquise sinuosa. [132], [133], [134]

$\mathrm{Na}$ proposta de Reidy, uma outra marquise em forma de barra encurvada se desenvolve como uma ramificação da cobertura circular que abriga as mesas do bar. Esse trecho encurvado adicional - que também abriga mesas - é sustentado por um par de colunas metálicas tubulares em "V'.

Se, por um lado, o projeto do bar de Reidy inspira-se no conjunto formado pelo orquidário e aquário do Pavilhão, sua marquise de traçado encurvado e independente, apoiada sobre pilotis em "V" reaparecerá, em uma conjuntura diversa, na marquise de entrada do projeto de Niemeyer para o Cassino da Pampulha (1940). A marquise do Cassino possui traçado trapezoidal com um desenvolvimento sinuoso em suas extremidades. Assim como no exemplar de Reidy, o piloti em "V" do Cassino apóia justamente um dos trechos encurvados da marquise. [135]

O passo dado por Niemeyer no Pavilhão será definidor da experiência traçada em Pampulha, onde o arquiteto estrutura uma pesquisa que encontra a chave para a emancipação da forma arquitetônica justamente no instante em que compreende o potencial plástico de elementos que Le Corbusier condena a condição de apêndice expressivo ${ }^{47}$.

No bloco de acesso do Pavilhão, Niemeyer inscreve o volume trapezoidal do auditório e a superfície de elementos vazados em uma delgada moldura retangular que é definida como um contorno, uma membrana suspensa.

À primeira vista, nos enganamos ao compreender o terraço do Pavilhão do Brasil apenas como uma moldura retangular. Fato que é plenamente justificável, pois se trata de um projeto que é estudado a partir dos registros da época, sendo que, as fotografias, em sua imensa maioria, registram somente a face externa do terraço.

Um olhar mais apurado perceberá que a cobertura do auditório do Pavilhão do Brasil não é horizontal, mas inclinada. Não há qualquer indício de fresta entre a cobertura "horizontal" do Pavilhão e a cobertura inclinada do auditório.

Mas afinal, como um volume retangular vazado (terraço coberto) abriga um outro volume trapezoidal menor com cobertura inclinada (auditório) e perfeitamente encaixado do volume

46. A relação entre as experiências de Le Corbusier e Oscar Niemeyer com os pilares tubulares em "V" será abordada no capítulo Cassino.

47. A relação entre a curva purista de Le Corbusier e a curva gestual de Oscar Niemeyer será abordada no capítulo Cassino

125 | o encontro de 1936: formação 



[132] Bar na Praça Afonso Viseu - Tijuca planta - Affonso Eduardo Reidy - 1939

(BONDUKI, 2000:70)

[133] Bar na Praça Afonso Viseu - Tijuca perspectiva - Affonso Eduardo Reidy - 1939

(BONDUKI, 2000:70)

[134] Bar na Praça Afonso Viseu - Tijuca maquete - Affonso Eduardo Reidy - 1939 (BONDUKI, 2000:70)

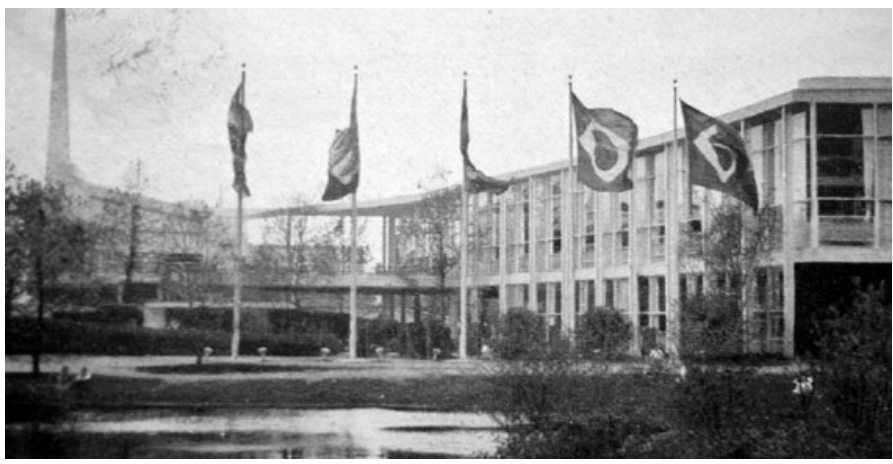

[135] Cassino da Pampulha - marquise de acesso - ON - 1940

(foto: Rodrigo Queiroz)

[136] Pavilhão do Brasil em Nova York - volume trapezoidal do auditório com cobertura inclinada conectado ao bloco expositivo por marquise que sofre ligeira torção

(Revista Arquitetura e Urbanismo - maio/junho 1939:476) 
vazado maior?

Para conseguir tal efeito, Costa e Niemeyer executam uma torção na laje de cobertura do terraço que, ao mesmo tempo em que acompanha o alinhamento horizontal na fachada principal, acompanha a inclinação da cobertura do auditório na face oposta.

Esse dado indica que a cobertura do Pavilhão do Brasil não é plana. Na verdade, trata-se de um plano irregular, torcido, que é horizontal apenas enquanto cobre o bloco de exposições e inclina-se em sutil declive em direção do jardim interno no instante em que cobre o terraço aberto, justamente para acomodar o volume trapezoidal de cobertura inclinada.

Enquanto a elevação principal do Pavilhão do Brasil é caracterizada por um retângulo vazado e suspenso, sua face oposta, voltada para o jardim, constitui-se por um volume trapezoidal interligado por marquise recortada em curva, ao volume que abriga o bloco de exposições. [136], [137], [138]

O volume do auditório do Pavilhão não chega a tocar o fechamento lateral do generoso terraço, cujo contorno exterior desenvolve-se sem interrupção. Esse artifício também é aplicado por Niemeyer no projeto para o Iate Clube da Pampulha (1940), onde uma das laterais da elevação principal do volume trapezoidal vazado é preservada vazia, a seqüência de brises verticais da fachada é interrompida e não encontra a empena lateral do volume suspenso. O contorno trapezoidal segue pleno, sem interferência, autônomo aos fechamentos, seja o caixilho integral ou o brise vertical. [139]

Em um dos diversos estudos realizados para o projeto do Congresso Nacional de Brasília (1957), Niemeyer retoma a solução da abertura que atinge o limite das espessuras das lajes e das empenas laterais, diagnosticado no Pavilhão do Brasil e no Iate Clube da Pampulha. No estudo do Congresso, Niemeyer revê uma solução próxima daquela presente no Iate Clube. Trata-se de um volume com cobertura inclinada, onde a seqüência de brises verticais não chega a tocar o fechamento lateral configurado como parte da borda que compreende todo o contorno do objeto. [140]

No Pavilhão do Brasil, Niemeyer desenvolve um sistema compositivo complexo que funde duas estratégias projetuais distintas: a relação entre o corpo horizontal, suspenso e transparente com o volume trapezoidal fechado, presente nas diferentes versões para o edifício do MES, realizadas a partir da chegada de Le Corbusier, e a exteriorização de elementos curvilíneos que Le Corbusier, em seus projetos puristas, preserva inscritos à projeção do contorno exterior do edifício. Niemeyer processa esse duplo referencial formal a partir de um raciocínio que inverte sua natureza geométrica.

No projeto do MES, Le Corbusier manipula formas regulares no espaço a partir de uma organização que mantém intacta a autonomia de cada objeto. No Pavilhão, Niemeyer desmembra a lógica purista que preserva a integridade geométrica da forma. Ao subtrair uma das faces do volume que caracteriza o bloco-terraço, Niemeyer retira do objeto seu próprio sentido de volume. É essa intervenção que, apesar de ordenar-se pelos pressupostos corbusianos, rompe com sua lógica de concepção da forma.

127 | o encontro de 1936: formação 



[137] Pavilhão do Brasil em Nova York - volume trapezoidal do auditório com cobertura inclinada escada de acesso ao jardim.

(Revista Arquitetura e Urbanismo - maio/junho 1939:477)

[138] Pavilhão do Brasil em Nova York: perspectiva interna do mezanino de traçado curvilíneo, de onde se avista o auditório com cobertura inclinada.

(COSTA, 2002:20)

[139] Iate Clube da Pampulha ON - 1942

(PAPADAKI, 1950:83)

[140] estudo para o Congresso Nacional de Brasília - ON - 1957.

(KATINSKY, 1990:s.n.) 
A seguir abordaremos o projeto do Pavilhão do Brasil como uma inversão da plástica corbusiana, onde Oscar Niemeyer e Lucio Costa, ao alastrarem a dimensão da abertura ao limite da forma, transgridem a idéia de volume presente nos referenciais de Le Corbusier como o Pavilhão L’Esprit Nouveau (1922) e a Casa Stein (1927). 


\section{O Pavilhão do Brasil e a desfiguração do volume corbusiano}

O projeto do Pavilhão do Brasil na Feira Internacional de Nova York representa o exato instante em que os códigos corbusianos, assimilados e aplicados no projeto do edifício do Ministério da Educação e Saúde, sofrem um gradual processo de transformação.

O volume vazado e aéreo que abriga os acessos, o terraço e o auditório do Pavilhão do Brasil (perpendicular ao bloco curvo fechado que contém exposição, restaurante e pista de dança) pode ser compreendido como uma extensão lateral dos planos de piso e de cobertura do bloco de exposições.

O piso do pavimento superior do bloco de exposições do Pavilhão do Brasil extravasa para além dos domínios dos fechamentos exteriores encurvados e assume a função de um generoso terraço, enquanto que a laje de cobertura desenvolve-se em curva, até encontrar a contra-curva volumétrica do auditório.

O terraço do Pavilhão define-se como uma única peça vazada - apenas moldura, vazio e cobogó - que se contrapõe ao bloco encurvado. Enquanto o bloco de exposições caracteriza-se por uma volumetria clara, envidraçado de um lado e cego do outro, o bloco-terraço incorpora o vazio, como um estreito contorno que abriga o terraço e o volume do auditório.

No bloco-terraço do Pavilhão do Brasil, a dimensão do rasgo em fita, típico das soluções de Le Corbusier, alastra-se ao limite físico do volume, restando apenas as espessuras. O sentido de volume é transgredido, e o que vemos é simplesmente o vazio contido entre os planos exteriores verticais e horizontais. Aquilo que para Le Corbusier era invólucro, no Pavilhão, torna-se superfície bidimensional. Perde-se a noção do dentro e do fora.

Enquanto Le Corbusier realiza uma abertura que enfatiza o caráter puro do volume, Niemeyer expande a abertura ao limite do próprio volume. A matéria da face é subtraída, só restando uma delgada membrana. É um contorno esguio que preserva a sutileza de um elegante desenho. [141]

A leitura visual do projeto é orquestrada por um movimento que parafraseia a ação motora do traço do arquiteto: a linha horizontal do chão, de repente, ascende em diagonal sinuosa; em seguida, retoma sua condição horizontal, mas não é mais chão, é terraço que se estende 
e contorna os limites laterais, e continua em horizontal - agora é cobertura. Enfim o percurso se fecha, conseqüência desse traço contínuo que desenha com linha a membrana envoltória e vazada, sutil reminiscência das especulações puristas de Le Corbusier. [142]

No Pavilhão, o perfil da rampa que se prolonga e contorna o edifício funciona como uma esbelta moldura que enquadra penumbra e luz.

A pronunciada distensão horizontal do pavilhão certamente contribui para essa leitura visual contínua do projeto, que permite percebê-lo, ao mesmo tempo, como forma vazada e como gesto regulador. Essa não será a primeira vez que Niemeyer enfrentará o problema da diluição do volume através da manipulação de prismas horizontais vazados.

Projetos como o edifício da Maternidade da associação beneficente da Obra do Berço (1937) e o Clube dos Estudantes da Universidade do Brasil (1936) são fundamentais para a compreensão do percurso de Niemeyer até o Pavilhão do Brasil.

O prisma longilíneo suspenso da Maternidade preserva características presentes no estudo de Le Corbusier para uma proposta que previa a implantação do edifício do MES em uma situação a beira-mar, caracterizado por um volume retangular de dilatada proporção horizontal envolto em uma membrana de granito apicoado.

Apesar do eminente aspecto prismático da Maternidade, as espessuras dos planos envoltórios saltam aos olhos, exatamente como no primeiro estudo de Le Corbusier para o MES. As espessuras das lajes e das empenas laterais envolvem todo o corpo prismático da Maternidade. Preserva-se a silhueta exterior do volume como moldura, mesmo no instante em que envolve o trecho cego da fachada. [143], [144]

Os pára-ventos da cobertura da Maternidade remetem às formas encurvadas presentes nas coberturas de projetos como a casa Savoye, o estudo de Le Corbusier para o MES no terreno a beira-mar e a versão definitiva do MES realizada pela equipe brasileira.

No projeto do MES, as formas da cobertura são volumes fechados, porém de contorno ondulatório, ao passo que, na casa Savoye, são planos curvos abertos cujo desenho remete a segmentos de circunferência e de elipse. Na Maternidade, Niemeyer funde o perfil ondulatório do volume presente na cobertura do MES com o traçado aberto inerente à casa Savoye.

O projeto de Oscar Niemeyer para o Clube dos Estudantes da Universidade do Brasil, assim como o estudo de Le Corbusier para o MES, a Maternidade e o Pavilhão do Brasil, também se caracteriza como um volume retangular, horizontal e suspenso, delimitado por membrana envoltória que abriga aberturas integrais. [145], [146]

O próprio sentido de continuum dado pelo desenvolvimento da escada que se transforma em piso do terraço, presente no Clube dos Estudantes, pode ser diagnosticado no Pavilhão, onde a rampa, em diagonal encurvada, prossegue e desenha a linha de piso do terraço coberto.

No Clube, assim como no Pavilhão, Niemeyer concebe o volume a partir do desenvolvimento de um traço que começa na linha horizontal do chão, se inclina e envolve o conjunto. A espessura da borda torna-se evidente, dado o contraste com o fechamento transparente ou com o vazio que resguarda um jardim coberto. $\mathrm{O}$ arquiteto confere sentido gráfico ao objeto

131 | o encontro de 1936: formação 



[141] Pavilhão do Brasil em Nova York - 1938 - perspectiva - ON e Lucio Costa (PAPADAKI, 1950:13)

[142] Pavilhão do Brasil em Nova York - 1938 - ON e Lucio Costa

(PAPADAKI, 1950:12) 
vazado que não se caracteriza pela perfuração, pelo rasgo em fita, presente nas "vilas corbusianas". No Clube a abertura compreende toda a face. O volume pode ser reconhecido quase como uma dobradura, um invólucro subtraído de suas faces.

Enquanto no Pavilhão de Nova York é a rampa que inicia o percurso do plano que se recorta e sofre dobras e rasgos, no projeto para o Clube dos Estudantes é a escada de acesso que cumpre esse papel. Essa mesma escada desdobra-se em uma generosa plataforma - instância reguladora da relação entre o volume e o chão - também presente no projeto da Maternidade com a clara intenção de estabelecer uma proporção agradável entre as alturas dos pilotis e do volume retangular suspenso, preservando a integridade de ambos.

Assim como no Pavilhão de Nova York, no Clube dos Estudantes da Universidade do Brasil o trecho vazio que abriga o terraço - compreendido apenas pelos planos horizontais de piso e de cobertura e pela empena lateral - encontra-se em uma das extremidades do volume devassado. A eleição de um trecho lateral extremo para locação de um instante vazio não é aleatória. Neste caso, Niemeyer reforça ainda mais o teor vazado desses projetos. Valoriza-se o caráter de membrana dos fechamentos externos, onde se percebe, além das espessuras, as faces internas dos planos de fechamento laterais e de cobertura.

Ao manter vazia a porção lateral da fachada, Niemeyer induz nossa percepção a apreender o objeto em um percurso visual dado pela moldura. Em projetos como o Pavilhão do Brasil, o Clube dos Estudantes, a Maternidade e o Iate Clube, Niemeyer evidencia uma posição peculiar ao absorver os preceitos canônicos de Le Corbusier como a planta-livre, o térreo-livre e a fachada-livre. Porém, diversamente de Le Corbusier, Niemeyer deseja diluir a volumetria ao invés de enfatizá-la e, para atingir esse objetivo, dilata a abertura ao limite físico da face do objeto. $\mathrm{O}$ volume é anulado na medida em que Niemeyer preserva apenas uma moldura, um perímetro regulador que abriga em seu interior a marcação vertical dos brises, a transparência dos caixilhos e próprio vazio.

Projetos de Le Corbusier como o Pavilhão L'Esprit Nouveau ${ }^{48}$ (1925) e a casa Stein (1927) já anunciam algumas características que estarão presentes no projeto do Pavilhão brasileiro, principalmente a dualidade entre a superfície escavada e a superfície preenchida pela caixilharia, presentes na face do objeto retangular suspenso.

O projeto do protótipo de Le Corbusier para o Salão de Outono de 1925 guarda características comuns com o projeto ianque de Niemeyer e Costa: ambos são pavilhões, são construções com a peculiar condição efêmera e fugaz de desaparecer.

A idéia de suspensão do pavilhão francês, dada pela existência de uma estreita fresta entre o objeto e o chão, permite que o contorno do invólucro vazado seja compreendido em toda a sua integridade.

No projeto protótipo, Le Corbusier dispõe no pavimento inferior, além da cozinha e do estar, um generoso terraço-jardim. O pavimento superior é ocupado pelos dormitórios dispostos

48. O projeto do Pavilhão L’Esprit Nouveau é uma versão prototípica de uma célula de habitação dos Immueble-Villa (1922), edifícios de habitação onde cada unidade possui as características de uma pequena casa com jardim.

133 o encontro de 1936: formação 



[143] MES (versão a beira-mar) 1936 - LC; [144] Maternidade 1937 - ON; [145] Clube dos Estudantes - 1937 $-\mathrm{ON}$

[146] Pavilhão do Brasil em Nova York - 1938 - ON e Lucio Costa

[143] (PA PA D A K I, 1950:51); [144] (VALLE, 2000); [145] (VALLE, 2000:141); [146] (PAPADAKI, 1950:13) 
sobre a cozinha. A laje desse pavimento não ocupa todo o perímetro da planta, mantendo o estar com pé-direito duplo. [147], [148]

A combinação dos recintos resulta em um paralelepípedo de sutil proporção horizontal, limitado em suas bordas horizontais por vigas de cobertura e viga peitoril de igual altura, o que confere unidade ao volume.

A porção escavada do objeto abriga o jardim que ocupa uma área maior na fachada do que a porção envidraçada que contém o estar com pé-direito duplo. Apesar do uso da pele de vidro enfatizar a transparência, a trama retangular marcada pelos perfis de ferro pintados de preto do caixilho possui forte apelo gráfico.

Para dramatizar a oposição entre o trecho escavado do jardim e o trecho envidraçado do estar, Le Corbusier executa uma obstrução circular na laje que cobre o jardim. Enquanto no trecho encaixilhado há penumbra, no vazio do jardim há luz.

As características descritas acima para ilustrar o Pavilhão L'Esprit Nouveau coincidem com as características presentes no Pavilhão Brasileiro: o volume suspenso; o perfil regulador que desenha a superfície que envolve o objeto; a antítese entre o escavado (terraço aberto) e a superfície tramada (recinto fechado); o contraste entre o terraço banhado por luz natural e o recinto escuro abrigado por uma superfície de desenho reticular; a interrupção de trecho da laje do pavimento superior para duplicar o pé-direito do piso inferior; o recorte encurvado na laje de cobertura do terraço suspenso. [149]

No Pavilhão de Nova York, uma superfície de elementos vazados é emoldurada entre o piso e a cobertura do terraço. Esse tratamento, ao mesmo tempo em que reporta a uma tradição construtiva do período colonial brasileiro, dialoga com a trama de perfis pretos que desenham o caixilho do Pavilhão L'Esprit Nouveau.

A superfície reticulada de elementos vazados do Pavilhão brasileiro projeta-se para além do alinhamento do "bloco-terraço", como um quadro que se encaixa à moldura do edifício. Essa estratégia também está presente na superfície de brises móveis do projeto definitivo para o MES, onde a trama vazada dos brises se sobrepõe à fachada transparente.

A amarração alternada dos elementos vazados dinamiza a composição desses elementos que, por estarem desalinhados uns dos outros, impossibilitam a formação de linhas verticais na fachada, o que poderia ser prejudicial à intenção explícita de horizontalidade expressa no projeto. A própria saliência dos elementos vazados potencializa o contraste entre o elemento escavado e o elemento acrescido.

O Pavilhão de Nova York guarda semelhanças com o Pavilhão L'Esprit Nouveau no agenciamento de espaços que contrastam entre si por terem tratamentos opostos, com as superfícies, ora abertas, ora fechadas por tessitura reticular.

Assim como o Pavilhão L'Esprit Nouveau, o projeto de Le Corbuiser para a casa Stein (1927) também guarda um rol de semelhanças com o Pavilhão de Costa e Niemeyer.

A elevação posterior da casa Stein possui paralelo no projeto do Pavilhão L'Esprit Nouveau, no qual Le Corbusier sinaliza com a mesma proposta da porção escavada em contraposição à

135 | o encontro de 1936: formação 

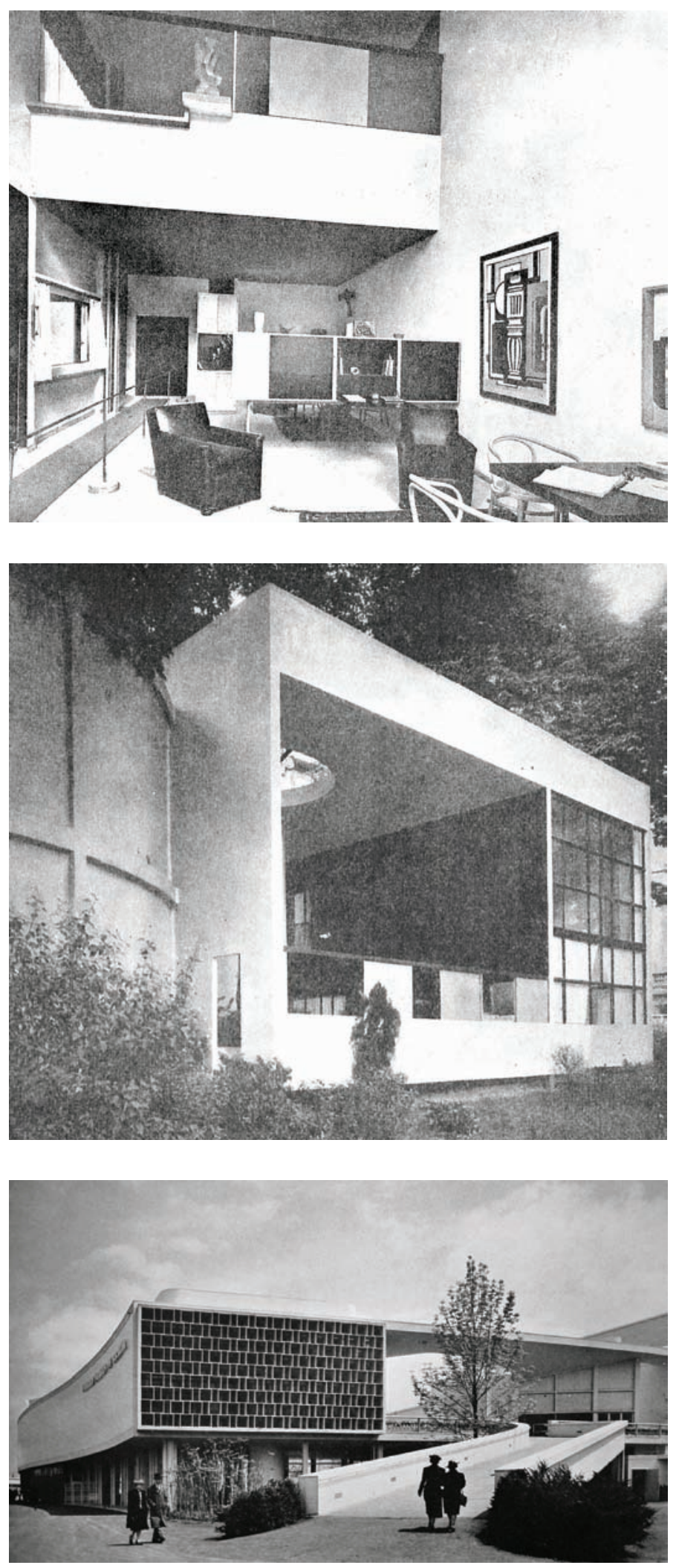

[147] Pavilhão L'Esprit Nouveau - 1925 - LC (BOESIGER, 1971:29)

[148] Pavilhão L'Esprit Nouveau - 1925 - LC (BOESIGER, 1971:27)

[149] Pavilhão do Brasil em Nova York - 1938 - ON e Lucio Costa (PAPADAKI, 1950:12) 
porção envidraçada. [150]

No projeto da casa Stein, Le Corbusier não insinua: realmente suspende o volume maior. A sombra do bloco principal projetada no bloco térreo dos dormitórios é o índice visual que torna evidente a emancipação do volume superior.

Os princípios de estrutura independente e fachada livre, tão apregoados por Le Corbusier, esbarram em uma sutil contradição no projeto da casa Stein. A retícula de pilares contida no interior das plantas do primeiro e segundo pavimentos alinha-se a parede que contém as aberturas dos dormitórios no pavimento térreo, o que nos indica que a disposição dessas aberturas é conseqüência da dimensão dos vãos entre os pilares. Conclui-se que, nesse caso, a estrutura não é independente da fachada que, por sua vez, não é livre.

Os tratamentos da volumetria e das superfícies da casa Stein se aproximam das operações realizadas pelos arquitetos brasileiros no projeto do Pavilhão do Brasil.

Tanto o Pavilhão do Brasil como a casa Stein são compreendidos a partir das seguintes características: volume parcialmente escavado; seu trecho vazio retangular abriga um generoso terraço, cujo peitoril é a continuidade da circulação vertical - externa à projeção do volume - que ascende em diagonal do chão ao piso do terraço. [151]

A escada da casa Stein, ao mesmo tempo em que corresponde à rampa do Pavilhão brasileiro - dado o desenho contínuo do peitoril - também pode encontrar paralelo na escada que conecta o terraço elevado ao jardim interno no Pavilhão do Brasil, que, de forma idêntica à casa Stein, se posiciona externa à projeção do volume e paralela a fachada.

Não serão apenas os aspectos exteriores que relacionarão a casa Stein com o Pavilhão brasileiro. O agenciamento dos paramentos encurvados presentes no interior da casa concebida por Le Corbusier se aproxima do aspecto dado aos fechamentos curvos presentes no Pavilhão. A parede curva do auditório preserva o mesmo alinhamento com relação à fachada diagnosticado na planta casa Stein. A própria curvatura em "U” aberto, conseqüência da concordância entre retas e arco, é muito similar entre a sala de jantar de Le Corbuiser e o auditório de Niemeyer. [152], [153]

No auditório do Pavilhão do Brasil, Niemeyer lança mão da típica volumetria trapezoidal preconizada por Le Corbusier (Centrosoyus, Liga das Nações, MES) ao mesmo tempo em que interpreta a forma livre contida no interior das vilas puristas.

O volume trapezoidal que, para Le Corbusier, trata-se de um objeto exterior destinado a abrigar auditórios e assembléias, para Niemeyer, no Pavilhão, apresenta-se como um gesto encurvado que assume dois papéis distintos: para quem olha a face principal é interno ao volume virtual do terraço do Pavilhão; para quem observa do lado oposto, no jardim interno, é um volume trapezoidal com cobertura inclinada.

Nesse caso, há a manutenção da forma tipológica do auditório, mas a escala e a condição na qual ele se insere diverge tanto das experiências puristas de Le Corbusier nas casas brancas, como dos canônicos volumes trapezoidais de projetos como o Palácio Centrosoyus.

Em Niemeyer, a peça curva do auditório do Pavilhão desempenha a mesma função que

137 | o encontro de 1936: formação 

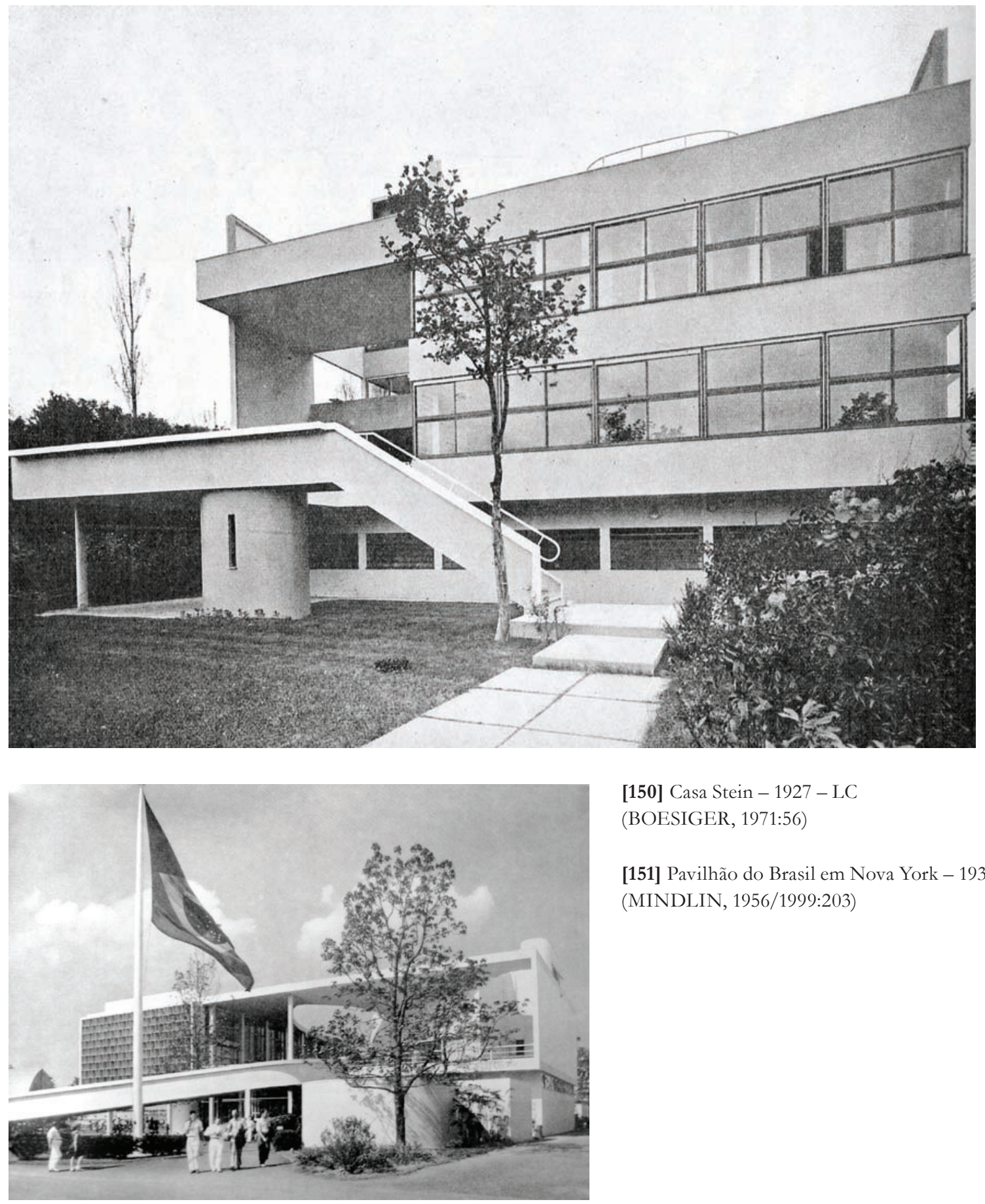

[150] Casa Stein - 1927 - LC

(BOESIGER, 1971:56)

[151] Pavilhão do Brasil em Nova York - 1938 (MINDLIN, 1956/1999:203) 
a parede curva da sala de jantar da casa Stein. A diferença crucial é que, no Pavilhão do Brasil, a forma curva não será espiada pela fresta desenhada pela janela em fita, típica dos exemplares corbusianos, mas está descoberta. É interna, mas integra visualmente o meio externo, justamente pelo fato de que Niemeyer alastra a abertura ao limite do volume que contém o auditório.

Não bastasse toda a transformação que o projeto do Pavilhão de Nova York executa sobre a regra corbusiana, diluindo o volume purista a uma esbeltez que é quase linha, ocorre nesse projeto o prenuncio de uma ação projetual que emancipará definitivamente a obra de Niemeyer com relação aos pressupostos de Le Corbusier: a transposição da forma livre - que em Le Corbusier encontra-se contida no interior da forma pura - para o meio externo.

O processo de emancipação da forma livre com relação ao esquema purista de Le Corbusier ocorre de maneira gradual na obra de Niemeyer. O Pavilhão do Brasil representa uma primeira experiência que terá desdobramento no primeiro edifício que Niemeyer elabora para o Conjunto da Pampulha: o Cassino.

Para o arquiteto, antropólogo e escritor Lauro Cavalcanti,

(...) o Pavilhão do Brasil, apesar de usar o vocabulário básico de Le Corbusier, antecipou futuras tendências, com a liberdade de sua rampa, flexibilidade de volumes, proteção da insolação com elementos fixos, uso da curva como elemento expressivo e indistinção de espaço interno e externo. Começou nesse projeto o estabelecimento de uma linguagem brasileira própria, independente e autônoma da matriz européia (CAVALCANTI 2006:184, grifo nosso).

O Pavilhão do Brasil - primeiro projeto que exprime a liberdade de Niemeyer - nos faz compreender uma estratégia dialética que, ao mesmo tempo em que subverte a configuração dos exemplares canônicos de Le Corbusier, preserva um compromisso com a linguagem moderna, tributária ao esquema Dom-Ino.

O raciocínio de Niemeyer resulta em uma operação que, por vezes, é adjetivada como fluida, leve, vazada, suspensa, delgada, horizontal, distendida, aérea, etc. Mas, todas essas leituras e qualificações sintetizam a intenção de transgressão do espaço corbusiano ${ }^{49}$, reconhecido pela sua pedagogia hierarquizadora, alicerçada pela tríade organiz̧ação-forma-programa.

Ao eliminar grandes porções de matéria das faces do volume, Niemeyer rompe com a estanqueidade do objeto puro, tornando exterior uma espacialidade que Le Corbusier mantinha interiorizada, mesmo com a adoção das janelas em fita, presentes nas "casas brancas" da década de 1920.

Ao subtrair a face opaca e alastrar a abertura ao limite da face do objeto, Niemeyer não apenas escancara o volume e o espaço cubista de Le Corbusier, como permite que a forma livre - que nos exemplares de Le Corbusier está enclausurada - se transfira para o meio externo e assuma a autonomia de um objeto na paisagem.

49. (Cf.: RECAMÁN, 2002:140).

139 | o encontro de 1936: formação 



[152] Casa Stein - 1927 - planta primeiro pavimento - LC

(BOESIGER, 1971:56)

[153] Pavilhão do Brasil - 1938 - trecho da planta do primeiro pavimento

(UNDERWOOD, 2002:53) 


\section{Pampulha}

"Para mim, Pampulha foi o começo da minha vida de arquiteto. E com que entusiasmo começava!” (NIEMEYER, 1998:94).

Em 1940, Oscar Niemeyer é convidado pelo Governador de Minas Gerais, Benedito Valadares, para realizar o projeto de um Cassino nas redondezas da cidade de Belo Horizonte. Apesar do convite a Niemeyer ser conseqüência da indicação do Ministro Gustavo Capanema, devemos lembrar que o jovem arquiteto não era um profissional estranho a Valadares pois, no ano anterior, Niemeyer havia realizado o projeto para o Grande Hotel de Ouro Preto, encomenda do próprio Governador.

Segundo Yves Bruand, Niemeyer recebe de Valadares o convite para projetar o Cassino em uma de suas estadas em Belo Horizonte durante os encontros e reuniões para o projeto do Grande Hotel de Ouro Preto. Segue trecho do autor:

(...) por sugestão do SPHAN, aceita pelo Governador de Minas Gerais, Benedito Valadares, (Niemeyer) foi encarregado em 1940 do projeto de um Hotel na histórica cidade de Ouro Preto, onde se pretendia incrementar o turismo. Durante uma das estadas de Niemeyer em Belo Horizonte, o Governador, que pretendia construir um Cassino na montanha que domina a cidade trocou idéias com ele a respeito (BRUAND 1981:28, grifo nosso).

Pela colocação de Bruand, percebemos que, em um primeiro momento, Niemeyer recebera a incumbência de projetar um único edifício, no caso o Cassino, em um sítio diverso daquele em que, futuramente, se implantaria o Conjunto da Pampulha.

Em outro trecho, Bruand credita a Niemeyer tanto a idéia de se transferir o projeto do Cassino da "montanha que domina a cidade" para as imediações da Lagoa da Pampulha, como a proposta de um conjunto arquitetônico voltado ao ócio e ao lazer, tendo o Cassino como um dos edifícios integrantes.

Niemeyer, tal qual Le Corbusier em 1936, quando do projeto do Ministério, declarou de imediato que o local não era conveniente e propôs um outro, às margens do lago artificial construído no bairro da Pampulha, nos arredores da capital, esboçando o projeto de um edifício que poderia ser o primeiro de um

141 | o encontro de 1936: formação 
futuro conjunto de repouso e lazer para os habitantes de Belo Horizonte. O prefeito da cidade, Juscelino Kubitschek, entusiasmou-se com o projeto e decidiu realizá-lo imediatamente (Idem).

A partir da colocação de Bruand, percebemos que o legado deixado por Le Corbusier para Niemeyer em 1936 iria além da institucionalização dos estilemas modernos nas escalas da superfície, da forma e do espaço.

As semelhanças das atitudes de Le Corbusier no Rio de Janeiro e de Niemeyer em Pampulha não se reduzem a uma suposta postura visionária que ignora as condições reais de inserção do projeto e que propõe o projeto em uma situação ideal. Muito mais do que tomar uma atitude semelhante à do mestre franco-suíço, Niemeyer, em Pampulha, ao sugerir a realização, não mais do edifício isolado, mas de um conjunto à beira da lagoa, assimila a mesma percepção corbusiana que induzia a realização do projeto do MES, não na quadra do morro do Castelo, mas em uma nova configuração à beira-mar.

Ao ignorar o terreno real para a construção do MES e se voltar para o desenvolvimento de uma proposta pessoal em um sítio em frente ao mar - a revelia, tanto da equipe brasileira, como do próprio Ministro Gustavo Capanema - Le Corbusier expõe sua predileção por um contexto que privilegiaria o edifício enquanto forma arquitetônica inserida na paisagem, a partir de um jogo de distanciamento e proximidade dado, principalmente, por sua relação com o mar.

Notem que as intenções de Le Corbusier e Niemeyer se aproximam. Em ambos os casos, os arquitetos descartam a proposta original e desenvolvem uma proposta de projeto que assimila o vazio "natural" ${ }^{50}$ da paisagem como campo ideal para a plena acomodação física e visual do objeto arquitetônico.

Tanto Le Corbusier no Rio de Janeiro (1936) como Niemeyer em Pampulha (1940) transportam a "realidade" para uma situação que atende a um desejo por uma visualidade aberta num ambiente "ideal". Talvez a grande diferença entre as duas condutas é a de que Niemeyer tenha conseguido convencer as autoridades locais para a transferência do projeto, diferentemente de Le Corbusier, cuja proposta para a praia de Santa Luzia não foi suficientemente sedutora a ponto de fazer com que Capanema mudasse de idéia.

Os condicionantes do projeto para o Conjunto da Pampulha forneceriam para Niemeyer um tema (lugar e programa) aberto e flexível o suficiente para que suas experiências formais iniciadas no MES e enfrentadas, mesmo que timidamente, no Pavilhão - assumissem uma escala de liberdade ainda maior.

O afastamento do contexto urbano da cidade de Belo Horizonte, associado a um suposto afrouxamento dos programas (o jogo, o esporte, a dança e a oração) permite que Niemeyer opere com plena autonomia as formas dos edifícios e suas relações entre si e com a paisagem.

50. Enquanto a natureza na qual se insere a proposta de Le Corbusier para o edifício do MES à beira-mar é original, a "natureza" da lagoa é artificial. O curioso é que, passados alguns anos, o sítio escolhido por Le Corbusier na praia de Santa Luzia, também seria alvo da intervenção geográfica do homem: a construção do aterro do Flamengo. No lugar onde havia o trecho de mar em frente a proposta de Le Corbusier para o MES, hoje existe o edifício do Museu de Arte Moderna do Rio de Janeiro. 
O campo estruturador do conjunto é a própria Lagoa da Pampulha. Niemeyer dispõe os edifícios à margem e voltados para da lagoa. As idéias de conjunto e de unidade arquitetônica só são perceptíveis de maneira tão intensa em Pampulha justamente pelo fato de que a lagoa assume um papel duplo: afastamento e reflexão.

Para Niemeyer, o vazio é um elemento fundamental para que possamos compreender a "unidade arquitetural" que permite, em uma mesma mirada, a assimilação das relações de contraposição e complementaridade entre os edifícios integrantes de um conjunto arquitetônico.

Em projetos como a Praça dos Três Poderes (1958), a Universidade de Constantine (1969), o Memorial da América Latina (1986/87) e o Caminho Niemeyer (1997/2003) reconhecemos com clareza as estratégias que Niemeyer adota para dispor as formas na paisagem e no campo bidimensional que desenha o chão. Nos projetos citados, o vazio é o elemento estruturador da construção do espaço. A distância entre os objetos que compõem o conjunto é fundamental, não apenas para a construção das visuais arejadas que abrangem grupos de edificações, mas também para que percebamos cada edifício em sua própria unidade.

Em Pampulha, a lagoa cumpre o papel da praça vazia. O afastamento necessário para a apreensão do conjunto é dado pela água. Diferentemente das praças de piso opaco (mosaico português ou placas de concreto), a "praça" em Pampulha é espelho que reflete arquitetura e paisagem.

Em um de seus comentários sobre o projeto e a construção da Pampulha, Niemeyer relata a sensação de observar as construções refletidas na lagoa: "Quantas vezes visitamos a obra de Pampulha! Quantas vezes fomos de lancha para vê-la de longe a se refletir nas águas da lagoa. E JK não se continha: 'Que beleza! Vai ser o bairro mais bonito do mundo."' (NIEMEYER 1998:93-94, grifo nosso).

O promenade architectural em Pampulha é tanto visual como físico. O contorno sinuoso da Lagoa exige que essa relação de unidade entre os edifícios seja revelada aos poucos, em um sucessivo jogo de descobertas, dado, não apenas pela visão ma,s também, pelo movimento.

Devemos observar ainda que o contorno orgânico da Lagoa da Pampulha em nada lembra as implantações ortogonais dos conjuntos, posteriormente realizados por Niemeyer. O promenade visual que enquadra os edifícios como limites laterais e de fundo nas construções das perspectivas de projetos como o Memorial da América Latina inexiste na Pampulha.

A idéia de unidade arquitetônica no conjunto da Pampulha subverte a relação de figura/ fundo dada por edifícios de intensidades formais distintas, onde a concisão de um ou de vários potencializa o gesto liberto que caracteriza o objeto protagonista.

Ao todo, Niemeyer desenvolve o projeto de sete edificações na área envoltória à Lagoa da Pampulha: o Cassino, a Casa de Baile, o Iate Clube, o Golfe Clube, o Hotel, a Igreja de São Francisco de Assis e a residência de fim-de-semana de Juscelino Kubitschek, então prefeito de Belo Horizonte. De todos os projetos, apenas o Hotel não foi construído. O Golfe Clube não se encontra à margem da lagoa como os demais edifícios, e atualmente abriga a adminstração do Zoológico da cidade de Belo Horizonte.

143 | o encontro de 1936: formação 


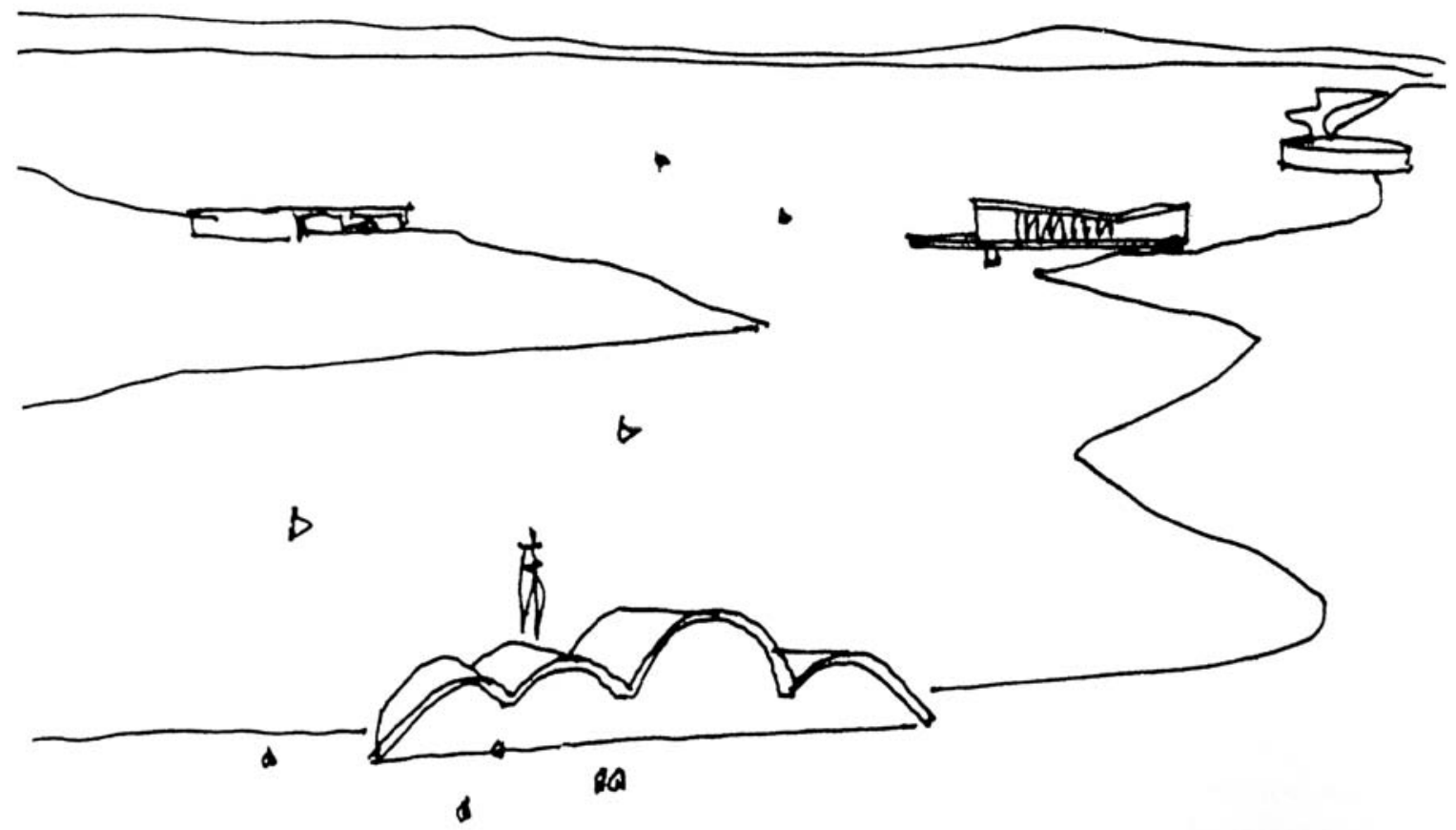

[154] Conjunto Arquitetônico da Pampulha - perspectiva - ON (1940/1943) (CORONA, 2001:32) 
Na maioria dos desenhos de Niemeyer que ilustram o projeto do conjunto da Pampulha, estão representados apenas o Cassino, a Casa de Baile, o Iate Clube e a Igrejinha, sendo essa última, invariavelmente, colocada em primeiro plano. O arquiteto suprime tanto o Golfe Clube como a residência de JK não apenas do desenho, mas também de seus depoimentos. Niemeyer considera como objetos integrantes do conjunto apenas aqueles edifícios caracterizados por uma intensidade plástica sem antecedentes em sua obra pretérita. [154]

O Golfe Clube, além de não integrar o "promenade aquático” possui uma solução formal idêntica à da residência de Oswald de Andrade e Tarsila do Amaral (1938). A residência de JK está voltada para a lagoa, porém, situa-se do outro lado da via marginal, além de tratar-se de uma propriedade particular que incorpora o telhado invertido, elemento que caracteriza o Iate Clube. Todos os edifícios considerados por Niemeyer como componentes do "conjunto" estão implantados na porção de terra que se desenvolve entre a lagoa e a via marginal, exceto a Casa de Baile, localizada em uma ilhota artificial que emerge de uma lagoa também artificial.

Os desenhos das formas dos quatro edifícios que constituem o conjunto são ancorados por um outro desenho, o da geografia. Assim como cada um dos objetos possui uma característica formal única, suas implantações apresentam o mesmo teor de singularidade: o destacado promontório que recebe o conflituoso Cassino, resultado do enfrentamento entre a forma regular do salão de jogos e a forma livre do salão de dança; a sinuosa ilhota que acomoda a ondulante Casa de Baile; a plataforma do Iate que, como um pier, avança em direção à lagoa; e o adro da Igrejinha, que, voltado para a lagoa, dá as costas para a rua, configurando um vazio/praça fundamental para a plena leitura da parábola que cobre a nave.

Como podemos perceber, o conjunto da Pampulha está longe de ser apenas uma exemplar coleção de edifícios com forte carga autoral. Niemeyer alinhava uma estratégia em que a unidade arquitetural transcende a forma, fundindo o estético ao simbólico.

Os edifícios incorporam papéis que se traduzem na linguagem do objeto e no comportamento com relação ao lugar: o Cassino com a espacialidade inebriante e sedutora da ambiência do jogo, elevada, distante, mas ao mesmo tempo voltada para os edifícios que, em sua frente, do lado oposto da lagoa, promovem o deleite do físico: a Casa de Baile, cuja graciosidade do gesto em curvas alternadas abriga o movimento da dança, e o Iate Clube, pulsante, dinâmico, e transparente, atirando-se sobre a água. Em primeiro plano, propositalmente afastada, encontrase a Igreja de São Francisco, lugar de oração que serenamente se acomoda no chão, com uma delicadeza tal, que não sabemos se emerge ou se pousa.

Em Pampulha, a unidade arquitetônica transcende a forma, está na superfície. Em que pese a autonomia dos diversos perfis dos edifícios do conjunto, Niemeyer elege poucos materiais que desempenharão as mesmas funções em todos os edifícios: a pedra apicoada que reveste os pilotis cilíndricos e as bordas que exteriorizam as delgadas espessuras dos contornos dos edifícios; o azulejo pintado que reveste as paredes exteriores abrigadas sob a projeção do volume/ plano sustentado por pilotis, tais como as paredes curvilíneas que abrigam os vestiários tanto do Cassino, como da Casa de Baile e do Iate Clube; e o caixilho desenhado em réguas verticais,

145 | o encontro de 1936: formação 
encurvado nos "ballrooms" do Cassino e da Casa de Baile e planificado na vertical nas elevações principais no Iate Clube de da Igreja de São Francisco.

No conjunto da Pampulha, cada um dos edifícios possui autonomia formal própria, seja o volume regular escavado e extravasado do Cassino; a planta circular e a marquise sinuosa da casa de Baile; o volume com cobertura invertida, suspenso e parcialmente transparente do Iate Clube; ou as abóbadas sucessivas que aterrissam diretamente no solo da Igreja de São Francisco de Assis.

Os edifícios da Pampulha representam a oportunidade de expansão em escala e proporção dos componentes encurvados e de função compositiva presentes em projetos que antecedem a experiência mineira: o projeto definitivo do MES (1936) e o projeto para o Pavilhão de Nova York (1938).

Os volumes ovais e oblongos revestidos de azulejo ou pastilha presentes no térreo e na cobertura do MES, juntamente com as formas curvas presentes no Pavilhão ${ }^{51}$, encontram no projeto do conjunto da Pampulha a oportunidade de expandirem-se em escala e proporção, assumindo a configuração do próprio edifício.

Os edifícios do conjunto da Pampulha não representam apenas a extroversão plena dos componentes "ornamentais" presentes no MES e no Pavilhão do Brasil, mas ilustram a emancipação, à escala do edifício, dos elementos que Le Corbusier condena à condição de componente em alguns de seus projetos: o caixilho curvo da Casa Savoye (1929); a marquise e o pilar em "V" do edifício do Exército da Salvação (1929); o telhado em cobertura invertida da casa Errazuris (1930); as abóbadas sucessivas presentes nos projetos da casa Monol (1919) e de seu atelier particular (1929).

Projetos como o MES, o Pavilhão do Brasil e o conjunto da Pampulha nos mostram que as intervenções que Niemeyer realiza sobre os códigos corbusianos ocorrem de maneira constante e gradual. Em um primeiro momento, no MES (1936), a constância da retícula de pilares é interrompida, se inflexiona para acomodar em seu interior o volume trapezoidal do auditório. No Pavilhão do Brasil (1938), o bloco expositivo - que no MES é um volume regular - encurvase em suave "S" e a retícula, antes ortogonal, acompanha a curvatura do bloco expositivo: indício claro de que a forma do edifício condiciona a forma da estrutura. Os volumes de traçado curvilíneo, localizados na cobertura ou sob a projeção do edifício no MES, no Pavilhão migram para o exterior, esboçando um primeiro desejo de autonomia da forma livre com relação à contensão da forma retentora.

No conjunto da Pampulha (1940), as formas que no Pavilhão ainda expressavam-se timidamente, assumem a condição plena de um edifício inserido na paisagem. ${ }^{52}$

Segundo Luiz Recamán, as volumetrias encurvadas do Pavilhão do Brasil, em Pampulha

51. O fechamento circular do ballroom/restaurante; a forma cilíndrica e a marquise curva do conjunto formado pelo orquidário e aquário; as formas circulares justapostas do viveiro e o fechamento arqueado do auditório.

52. A análise da evolução das formas e dos desenhos do MES à Pampulha está abordada em pormenor nos capítulos Pavilhão do Brasil na Feira de Nova York, Cassino e Casa de Baile e Hotel Resort. 
transformam-se em "volumes edifício":

A situação peculiar e de aparente autonomia artística que cerca o projeto (da Pampulha) desenvolve, em algum sentido, a excepcionalidade do projeto do Pavilhão, cuja pesquisa volumétrica poderá agora se expandir em volumes edifício (RECAMAN 2002:151, grifo nosso).

Independentemente do processo gradativo de emancipação e autonomia da forma em Niemeyer ser diagnosticado em intensidades graduais no MES, no Pavilhão e em Pampulha, devemos compreender o próprio conjunto da Pampulha como um experimento onde a intensidade da liberdade formal também é gradativa: da conflituosa relação entre o volume regular insinuado do salão de jogos e o volume de planta oval, expelido, mas ainda conectado, no Cassino; da separação plena das formas curvilíneas interligadas apenas por marquise sinuosa da Casa de Baile; culminando nas abóbadas da Igreja de São Francisco, onde toda e qualquer reminiscência ao arranjo de planos, vigas e pilares, tributários ao esquema Dom-ino e redesenhados no Cassino, na Casa de Baile e no Iate Clube desaparece, e o que vemos é um objeto conseqüência de um perfil contínuo que emerge em diagonal do chão, se desenvolve em abóbadas aéreas e retorna inclinado ao chão.

O conjunto da Pampulha, além de representar a exteriorização plena dos elementos de escala compositiva presentes tanto em diversos projetos de Le Corbusier, como no MES e no Pavilhão, ilustrará a gênese de parte do repertório formal que caracterizará toda a obra de Oscar Niemeyer.

Sobre a hipótese da existência de um repertório formal restrito que condiciona as soluções formais de Niemeyer, gostaríamos de citar as colocações de alguns autores que se dedicaram à análise e a discussão da forma em Niemeyer a partir da consideração da existência de um repertório formal restrito.

Para Marco do Valle

Niemeyer se baseia no repertório de formas e procedimentos de Le Corbusier e realiza uma recriação ou redesenho deles, chegando a um repertório particular, que forma seu próprio repertório formal. (...) Portanto, é no conjunto da Pampulha que, com extrema habilidade, desenvolve seu conjunto universo inicial, estabelece suas primeiras formas escolhidas da arquitetura corbusiana, e também cria por procedimentos projetuais de sua expressão pessoal, por meio de reajustes formais do repertório corbusiano, novos redesenhos, que se caracterizam como o encontro e a consciência do arquiteto com o estabelecimento de sua própria linguagem (VALLE 2000:133-134, grifo nosso).

Na opinião de Luiz Recamán, os edifícios da Pampulha representam

(...) a definição de alguns modelos de estruturas-forma que serão incessantemente reutilizados a partir daí, adaptados a qualquer arquitetura. (...) A emergência desses modelos por sobre quaisquer condicionantes sociais ou geográficas permitirá uma espécie de neutralização histórico-espacial das soluções, que assumem assim o caráter de tipos pré-arquitetônicos. Não definem nem unidades funcionais nem estruturais propriamente, mas uma solução formal-estrutural que pode ser utilizada, como o foi, em diferentes

147 | o encontro de 1936: formação 
escalas, funções, contextos urbanos e culturais. (...) Sem estabelecer vínculos extrínsecos de qualquer natureza, as estruturas-forma da Pampulha revelam a cada reaparição, o descompromisso de toda a ordem a que vieram dar expressão (RECÁMAN 2002:151, grifo nosso).

\section{Segundo Edson Mahfuz, a obra de Oscar Niemeyer}

(...) fornece mais do que suficientes evidências de que Oscar Niemeyer trabalha com um repertório formal e compositivo relativamente fechado, partes do qual são aplicadas em todos os seus projetos. Além disso, vários elementos desse repertório se desenvolvem através da adaptação, transformação e/ou inversão de elementos, estratégias compositivas extraídas da obra de Le Corbusier.(...)

(...) Niemeyer emprega um método que consiste na aplicação de um número limitado de estratégias compositivas e elementos de composição a todos os tipos de programa, escolhendo dentro do universo finito do seu repertório as estratégias e elementos que lhe parecam mais apropriados a cada caso.

(...) O que num primeiro momento é invenção (como as formas criadas na Pampulha), logo a diante se torna convenção e passa a ser parte de um repertório (MAHFUZ, 2002: 122-133, grifo nosso).

As afirmações de Valle, Recamán e Mahfuz são, ao mesmo tempo, coincidentes e complementares.

Valle atesta que a obra de Niemeyer é conseqüência da manipulação de um repertório formal restrito, oriundo de um redesenho de elementos presentes na arquitetura de Le Corbusier. Segundo o autor, Pampulha representa o "conjunto universo inicial" desse grupo de elementos estruturadores da linguagem formal de Niemeyer.

A colocação de Recamán, além de reafirmar o ponto de vista de Valle, reconhece os elementos formais da Pampulha como sendo "tipos pré-arquitetônicos" ou "estruturas-forma" que, por sua "neutralização" e simplicidade plástica, permitem adaptar-se a todo e qualquer tipo de programa.

O "repertório fechado" ou o "universo finito" diagnosticado por Mahfuz alinha-se às posições de Valle e Recamán, que afirmam a existência de um repertório formal delimitado na obra de Oscar Niemeyer, e também apontam Pampulha como a gênese desse conjunto de formas.

Os três autores atestam a mesma afirmação, isto é, a existência de um repertório formal na obra de Niemeyer, tendo sua primeira aparição efetiva no projeto do conjunto da Pampulha, mas cada um deles irá batizar a descoberta com nomeações distintas: o "conjunto universo inicial” de Valle, os "tipos pré-arquitetônicos" e as "estruturas-forma” de Recamán e os "repertório fechado" e "universo finito" de Mahfuz. No fundo, as diferentes nomenclaturas adotadas pelos autores definem um mesmo argumento que deseja clarificar uma lógica plástica por trás de uma trajetória profissional que está em sua oitava década de trabalho incessante e que, segundo o próprio Niemeyer, segue uma única premissa elementar: "arquitetura é invenção".

Mahfuz sinaliza para uma segunda estratégia compositiva na obra de Niemeyer, acrescentando um novo dado nas postulações que compreendem a obra de Niemeyer como o redesenho de um repertório formal fechado. Para o autor, Niemeyer manipula seu repertório formal a partir de uma estratégia de manipulação dessas formas no espaço.

Segundo Mahfuz, além da estratégia formal: 
É também significativa nessa estratégia a tendência a contrastar espaços secundários e repetitivos - usualmente ortogonais e seguindo as direções da malha estrutural - com os espaços hierarquicamente mais importantes. Esses são tratados como objetos especiais e recebem formas únicas, não ortogonais (MAHFUZ, 2002:122, grifo nosso).

O autor expande o entendimento da obra de Niemeyer para além da forma. Para Mahfuz, tão fundamental quanto a forma é o esquema de organização que a posiciona no espaço.

No capítulo Pampulha, caberá à presente pesquisa desenvolver uma análise pormenorizada não apenas da transposição das soluções corbusianas para o universo formal de Niemeyer, mas também dos procedimentos adotados pelo arquiteto brasileiro que legitimarão sua autonomia com relação aos pressupostos do "mestre".

Em que consiste esse redesenho das formas corbusianas em Niemeyer? A operação de Niemeyer não deve ser reduzida a mera transposição para a escala do edifício dos elementos arquitetônicos que Le Corbusier preserva como instrumentos de composição com um "todo" maior, invariavelmente de contorno purista.

É evidente que a obra de Oscar Niemeyer não se reduz ao mero redesenho de soluções corbusianas e que seus projetos não são a simples consequência do arranjo de um conjunto mínimo de formas. Pampulha não representa apenas um grupo de soluções formais versáteis, adaptáveis a todo e qualquer tipo de lugar e programa.

Pampulha consiste de um raciocínio que funde forma e programa a partir da transgressão da condição hermética que caracteriza a concepção estanque dos experimentos corbusianos resultantes da intervenção na forma pura, seja ela subtrativa ou aditiva.

Le Corbusier processa a forma a partir de uma operação "pictórica” que, por mais contundente que seja, não retira do objeto sua feição purista. Por outro lado, Niemeyer em Pampulha, desaparece com a idéia da criação como uma intervenção sobre um esquema estruturador que deve ser preservado para que um suposto ideal de pureza seja atendido.

Trata-se de posturas diametralmente opostas. Enquanto Le Corbusier "intervem na forma", como uma ação quase a posteriori, Niemeyer "manipula a forma" com um grau de liberdade que não encontra precedentes nas obras de Le Corbusier realizadas até a metade da década de 1940. Essas duas condutas distintas representam a diferença crucial entre os raciocínios de Le Corbusier e Oscar Niemeyer.

Para Niemeyer, a superfície, a forma e o espaço assumem significados distintos daqueles que regem o raciocínio de Le Corbusier. Tanto o aspecto purista das superfícies brancas das casas da década de 1920, como a presença da memória contida nas superfícies em madeira ou pedra das casas da década de 1930, para Niemeyer serão reconhecidos como dados de um raciocínio pictórico. Prova disso é a maneira como Niemeyer irá transitar com extrema liberdade na utilização dos materiais, sejam os acabamentos "regularizadores", sejam os materiais embrutecidos.

Em Pampulha, as superfícies brancas de Le Corbusier dão lugar à adoção dos azulejos estampados e as pastilhas-mural, cujas reflexões difusas sugerem uma "imaterialidade" contrária à opacidade regular das vilas puristas da década de 1920.

149 | o encontro de 1936: formação 
Enquanto Le Corbusier desenha a abertura como uma obstrução "em fita" de um volume de contorno regular, Niemeyer expande a abertura ao limite físico da forma e da matéria, preservando não mais o volume, como Le Corbusier, mas somente o contorno, a espessura. Com essa operação de Niemeyer, o volume transforma-se em uma delgada superfície de abrigo, que se aproxima muito mais da esbeltez gráfica do seu próprio desenho do que do seu referencial corbusiano.

Niemeyer realiza uma inversão que transfigura tanto o esquema Dom-Ino como os "cinco pontos" de Le Corbusier. Será justamente essa estratégia de estruturar uma poética própria a partir de uma leitura particular sobre os códigos corbusianos que fará com que o "discípulo" atinja uma autonomia com relação ao "mestre", logo no primeiro projeto que dá condições ao jovem arquiteto de alçar um vôo livre e solo.

A seguir, abordaremos em separado cada um dos edifícios do conjunto da Pampulha em uma análise desses componentes formais que se transferem dos projetos de Le Corbusier para o cenário mineiro. 


\section{Cassino}

O Cassino da Pampulha é o primeiro dos seis edifícios projetados por Oscar Niemeyer para o, até então, longínquo bairro localizado nos arredores de Belo Horizonte. ${ }^{53}$

O projeto do Cassino (1940), indica um desdobramento de alguns procedimentos adotados por Niemeyer, tanto no Ministério da Educação e Saúde (1936), como no Pavilhão do Brasil para a Feira Internacional de Nova York (1938). As formas encurvadas que no MES permaneciam internas a projeção do perfil exterior do edifício, no Pavilhão já se encontravam expostas, mesmo que de maneira ainda tímida. No Cassino, Niemeyer dá continuidade a esse itinerário caracterizado pelas sucessivas rupturas sobre os cânones corbusianos, com a intenção de promover à dimensão de edifício as formas que Le Corbusier preserva reduzidas à uma composição de raiz pictórica.

Nesse percurso de contínuas transgressões sobre os paradigmas puristas de Le Corbusier, o projeto do Cassino da Pampulha exprime, como nenhum outro projeto de Niemeyer, o exato limiar entre o respeito e a libertação. Por mais que reconheçamos no Cassino da Pampulha uma evidente evolução da forma livre, principalmente quando comparado ao MES e ao Pavilhão do Brasil, não podemos deixar de identificar a inegável referência feita aos exemplares puristas de Le Corbusier, mais precisamente a casa Savoye (1929).

Essa delicada escolha entre a confortável continuidade respeitosa a um modelo vigente e o rompimento com os paradigmas constituidores desse mesmo modelo é um traço de comportamento presente nos procedimentos adotados por Niemeyer no Cassino. Essa dúvida intensa ocorre em momentos definidores das obras de diversos artistas, como Piet Mondrian, que no percurso traçado da figuração à abstração realiza pinturas que relutam em se desvencilhar do tema, mas já apresentam uma clara inclinação à composição abstrata. Dentro da obra de

53. Edifícios projetados por Oscar Niemeyer pertencentes ao conjunto arquitetônico da Pampulha: Cassino; Casa de Baile; Hotel Resort; Iate Clube; Golfe Clube e Igreja de São Francisco de Assis - dos seis edifícios projetados, apenas o Hotel Resort não foi construído. Além dos seis edifícios que compõem o conjunto da Pampulha, Oscar Niemeyer realizou o projeto de duas residências no bairro da Pampulha: residência de fim-de-semana de Juscelino Kubitschek (1943) e a residência Alberto Simão (1954).

151 o encontro de 1936: formação 
Niemeyer, o Cassino da Pampulha representa esse exato ponto de inflexão.

Por mais que o MES e o Pavilhão do Brasil já apontassem para uma intenção de liberdade sobre os códigos corbusianos, devemos lembrar que ambos os projetos foram elaborados em equipe $^{54}$. O Cassino foi o primeiro projeto em que Niemeyer teve condições plenas de alçar um vôo solo com total liberdade, mas, mesmo assim, o comprometimento com os ensinamentos do "mestre" ainda se traduzia de maneira literal.

No Cassino, Niemeyer estabelece uma organização de três blocos volumetricamente autônomos (salão de jogos; salão de dança, restaurante e bloco de serviços), porém conectados entre si. Tanto o salão de jogos como o bloco de serviço - apesar das sucessivas rupturas com os pressupostos corbusianos - ainda preservam a feição purista dos exemplares de Le Corbusier. Ao passo que o salão de dança, configurado como um volume transparente de planta ovalada, representa o exato instante em que a forma curva, reclusa ao interior dos projetos puristas de Le Corbusier exterioriza-se, mas preserva conexão com o salão de jogos.

Podemos compreender o Cassino como um estágio intermediário entre as sutis volumetrias encurvadas esparramadas dentro e fora do Pavilhão do Brasil e gesto pleno que desenha a sinuosidade da Casa de Baile.

Segundo Luiz Recamán:

(...) o Cassino é o elo entre o momento de concentração forçada dos elementos em busca de autonomia (no Pavilhão) e sua dispersão total, sua independentização. (...) O caminho a seguir, depois dessa experiência, será a liberação dos volumes em edifícios separados, tarefa realizada nos outros projetos desse conjunto (RECAMÁN 2002:152, grifo nosso).

O projeto para o Cassino da Pampulha ilustra o instante em que Niemeyer enfrenta os códigos corbusianos $^{55}$ presentes nas casas projetadas entre 1925 e 1929 e não os assimila como soluções formais, mas os considera como procedimentos de projeto.

Em uma primeira visada do Cassino, a referência que salta aos olhos é da casa Savoye (1929), devido à presença, quase que didática, de elementos da morada corbusiana transportados para o cenário mineiro.

A forma regular suspensa sobre pilotis, presente na casa Savoye, é violada por Niemeyer no Cassino. Le Corbusier enfatiza a idéia de suspensão, dividindo o projeto da casa Savoye em três partes: o térreo vazio e transparente; o volume retangular suspenso rasgado por janelas em fita e as formas encurvadas na cobertura. Niemeyer manipula com liberdade essa relação entre o que está suspenso e o que está acolhido no térreo, porém a referência à divisão em três partes, presente na casa Savoye, ainda se preserva no Cassino.

O volume puro, que na casa Savoye de Le Corbusier, é o todo retentor que abriga em seu interior tanto as divisões internas como o reticulado de pilares, no Cassino assume o papel de um

54. Em que pese o fato de que Lucio Costa atribui à Niemeyer o projeto do Pavilhão do Brasil.

55. O conceito do esquema Dom-Ino (1914) presente em projetos como o Pavilhão l'Esprit Nouveau (1925); a instituição dos cinco pontos: térreo livre, planta livre, fachada livre, janela horizontal e o terraço jardim. 
componente articulador (salão de jogos) que, além de desfigurar a estanqueidade purista da casa Savoye, conecta-se a outros dois volumes externos (salão de baile e pavilhão de serviços). O passo seguinte ao projeto do Cassino será a exteriorização total da forma livre, que ocorre no próprio Conjunto da Pampulha, no projeto da Casa de Baile, onde a forma circular (restaurante e pista de dança), parcialmente transparente, é expelida por completo.

$\mathrm{Na}$ face destinada ao acesso principal do Cassino, o caixilho extravasa o limite do pavimento térreo e ascende até tocar a face inferior da laje de cobertura, interrompendo o plano cego que corresponde ao mezanino do salão de jogos. [155]

O volume "suspenso", que é efetivo em Le Corbusier, é apenas sugerido no Cassino, e assume configurações antagônicas em suas faces perpendiculares: é cego na face leste (acesso) e aberto na face sul, mas ao invés de adotar janela em fita de Le Corbusier, constitui-se por uma abertura integral que se alastra ao limite físico do próprio objeto, preservando apenas as espessuras dos fechamentos externos e das lajes de piso e de cobertura, como nos projetos da Maternidade e do Pavilhão do Brasil. [156], [157]

Com essas decisões de projeto, Niemeyer rompe com a condição hermética do perfil regulador do volume corbusiano, contrariando a lógica purista presente na casa Savoye.

Para enfatizar a dualidade entre a opacidade do volume suspenso e a transparência das réguas cristalinas que ascendem verticalmente, Niemeyer suprime qualquer tipo de abertura na porção do volume suspenso (mezanino do salão de jogos) presente na elevação principal.

O diálogo entre cheios e vazios no Cassino assume uma autonomia que transcende as experiências de Le Corbusier em projetos como o Pavilhão L'Esprit Nouveau e as casas Stein e Savoye. Na face principal do Cassino, Niemeyer, diferentemente de Le Corbusier, não subtrai a matéria contida na face do volume, mas retira parte do próprio volume suspenso, que é interrompido no instante em que se alinha ao acesso principal.

No Pavilhão L'Esprit Nouveau e nas casas Stein e Savoye, Le Corbusier retira matéria, porém preserva o perímetro do volume, mantendo o seu sentido "puro". A idéia de sólido suspenso presente na casa Savoye é diluída no Cassino, cujo volume superior sofre recortes que rompem com o sentido geométrico que caracterizaria um sólido regular fechado.

O fechamento encaixilhado no pavimento térreo do Cassino insinua a idéia de térreolivre presente na casa Savoye. No projeto de Le Corbusier, o caixilho em semi-círculo irregular contido sob a projeção do volume retangular suspenso, preserva enclausurada apenas uma parte do pavimento térreo, ocupado pelo reticulado de pilares e pela membrana transparente.

No projeto de Niemeyer, a referência ao térreo-livre é mais cenográfica do que literal. O pavimento térreo do salão de jogos do Cassino é envolvido por caixilharia transparente dividida em estreitas réguas verticais transparentes com uma das arestas em quarto-de-circulo recuada sob a projeção do mezanino. Apesar das evidentes diferenças, é inevitável a associação com o projeto de Le Corbusier para a casa Savoye. [158], [159]

O uso de rampas em dois lances alternados, contidas no interior do volume no salão de jogos do Cassino parafraseia a rampa ortogonal aos fechamentos externos da casa Savoye.

153 | o encontro de 1936: formação 

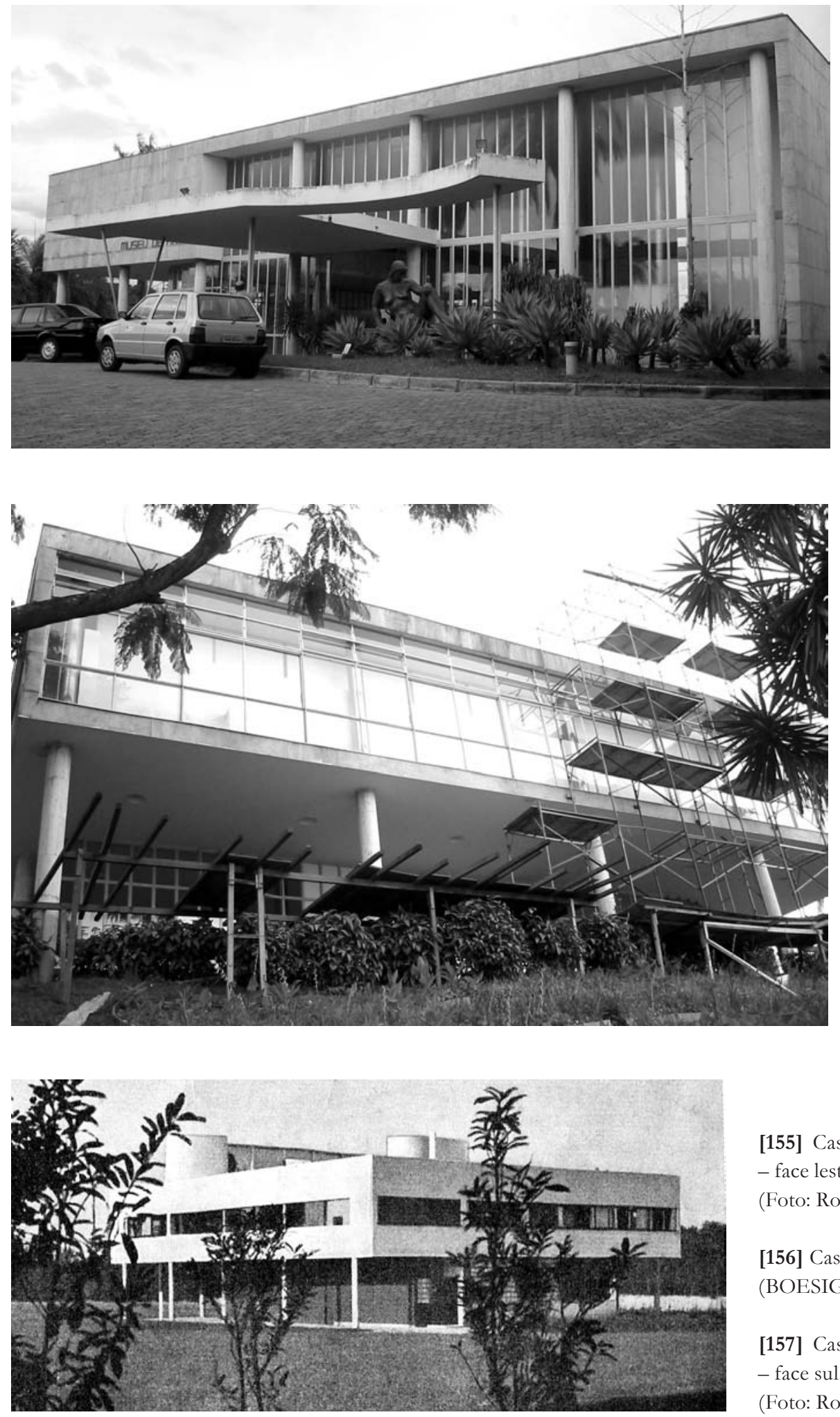

[155] Cassino da Pampulha - 1940 - face leste - ON

(Foto: Rodrigo Queiroz)

[156] Casa Savoye - 1929 - LC

(BOESIGER, 1971:58)

[157] Cassino da Pampulha - 1940 - face sul - ON

(Foto: Rodrigo Queiroz) 
No Cassino, de maneira diversa da casa Savoye, o percurso em rampa que permite o promenade só é possível graças ao generoso trecho em pé-direito triplo que caracteriza o espaço de acolhimento do edifício. [160], [161]

Segundo Edson Mahfuz:

(...) Aqui, a rampa, colocada em posição central, análoga à rampa da Ville Savoye, "articula o espaço como a estrutura de um jogo elaborado", assumindo uma condição protagônica. O "objeto especial" - neste caso o volume curvilíneo do restaurante e teatro - que no precedente corbusiano era sempre contido pelo volume prismático, "migra" para o exterior do edifício, estabelecendo uma tensão entre os dois componentes básicos (MAHFUZ, 2002:123, grifo nosso).

Segue trecho em que Kenneth Frampton aponta as diferenças entre as rampas do Cassino de Niemeyer e da casa Savoye de Le Corbusier:

Outra diferença oriunda do partido é o papel desempenhado pela rampa: no desenho de Le Corbusier ela sobe pelo eixo central do prédio por uma fenda estreita e revela seu potencial plástico apenas no terraço onde o dinamismo das formas figurativas se torna visível com a rampa culminando no solário da cobertura. A rampa do Cassino de Niemeyer desempenha um papel totalmente diferente, uma vez que permanece solta no meio de um generoso foyer enquanto sobe para promover acesso ao teatro atrás do prisma e às salas de jogos no primeiro andar, esse ultimo tem a planta em "L" e observa a rampa enquanto ascende em meio às colunas soltas no foyer (FRAMPTON apud BRILLENBOURG, 2004:44).

Ao conceber o salão de jogos como um volume quase oco ocupado por mezanino e rampa, Niemeyer ilustra aquela que será a tônica de seu raciocínio no projeto do Cassino: mantém-se fiel ao vocabulário corbusiano, porém subverte a lógica purista no agenciamento desses elementos, concebendo uma obra que, ao mesmo tempo em que incorpora a pesquisa de Le Corbusier, propõe uma revisão de seus paradigmas ao compreender o objeto, não como um bólido puro, mas como uma organização exterior nitidamente hierarquizada.

Ao exteriorizar os pilares na fachada principal do Cassino, Niemeyer rompe a lógica da retícula de pilotis que caracteriza a casa Savoye: livres no pavimento térreo e contidos no interior da forma pura suspensa. Na casa Savoye, a contensão da trama de pilares no interior da forma retangular é fundamental para que seja preservada a idéia da fachada livre. Com esse artifício, a fachada torna-se suporte para uma interferência compositiva, na qual os "rasgos em fita" não se sujeitam à estrutura.

Quando no Cassino, Niemeyer inverte a lógica retícula-membrana presente na casa Savoye. $\mathrm{O}$ arquiteto não se afasta totalmente das soluções corbusianas, ao contrário, irá de encontro à primeira proposta de Le Corbusier para a sede do MES no terreno à beira-mar (1936), que em seguida foi incorporada na solução definitiva concebida pela equipe brasileira (1936/1937) e que, posteriormente, foi retomada no projeto do Pavilhão do Brasil na Feira de Nova York (1938).

A solução da fileira de pilares alinhados externamente à cortina de vidro da elevação principal do Cassino já estava presente no primeiro estudo de Le Corbusier para o edifício do MES. A perspectiva do edifício - provavelmente, desenhada pelo próprio Niemeyer - ilustra com niti-

155 | o encontro de 1936: formação 

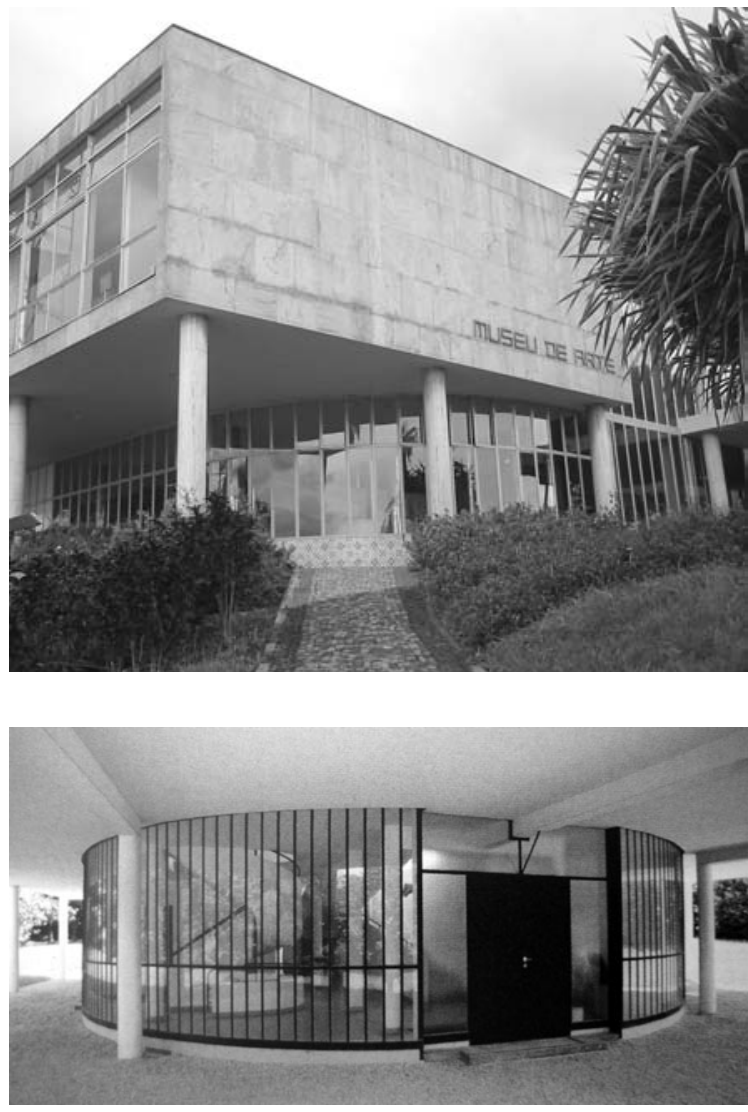

[158] Cassino da Pampulha - 1940 - caixilho em quarto-decírculo no térreo - ON

(Foto: Rodrigo Queiroz)

[159] Casa Savoye - 1929 - caixilho em semi-círculo irregular no térreo - LC

(SBRIGLIO, 2005:17)


[160] Casa Savoye - ambiente interno - 1929 - LC (SBRIGLIO, 2005:65)

[161] Cassino da Pampulha - 1940 - salão de jogos - ON (Foto: Rodrigo Queiroz) 
dez a exteriorização de uma fileira de pilares no pavimento térreo do bloco principal.

Para Recamán é como se a fachada do Cassino "fosse ela mesma os pilotis de um edifício inexistente” (RECAMÁN 2002:154). O autor compreende a porção envidraçada da elevação principal do Cassino como uma transposição da solução corbusiana para a entrada principal do MES. Acrescentamos à colocação de Recamán o fato de que a leitura sobre o projeto do MES, presente no Cassino, ultrapassa o projeto de Le Corbusier para o estudo na Praia de Santa Luzia. Esses tais "pilotis de um edifício inexistente" descritos pelo autor já estavam presentes no salão de exposições do edifício do MES que foi construído na Esplanada do Castelo, com os pilotis exteriores ao volume transparente, cuja cobertura avança sobre o alinhamento da caixilharia, até apoiar-se nesses pilares, exatamente como no Cassino da Pampulha. [162], [163], [164]

A configuração da vista principal do Cassino é conseqüência dessas experiências sucessivas de Niemeyer que incorporam características de diversos projetos: a idéia de suspensão da casa Savoye e o modelo dos salões de exposições com pilares externos presente nas diferentes versões para o edifício do MES e no Pavilhão do Brasil.

A escada externa que se integra em sutil tangente ao volume oval e transparente da pista de dança do Cassino, também ilustra uma recorrência ao projeto de Le Corbusier para o MES. Em ambos os casos, o fechamento envidraçado em estreitas réguas verticais aumenta de altura, gradativamente, acompanhando o desenho em diagonal da escada, até encontrar o solo. [165], [166]

O acesso principal do Cassino é protegido por marquise trapezoidal sustentada por pilares metálicos tubulares, um deles em "V". Sua base maior possui uma extensão encurvada que serve de abrigo à escultura de Zamoysk.

$\mathrm{Na}$ marquise do Cassino, Niemeyer une duas soluções corbusianas que não estão presentes na casa Savoye: a marquise arqueada e o piloti em "V". As marquises encurvadas como elemento de proteção e de indicação do acesso principal à edificação aparecem na obra de Le Corbusier em projetos como o Palácio Centrosoyus (1929). O pilar em "V" metálico que apóia a marquise do Cassino já está presente do edifício Cité Refuge (Exército da Salvação - 1929). No projeto de Le Corbusier, o pilar em "V" também sustenta uma marquise, porém, diferentemente do Cassino, a marquise de Le Corbusier é retangular e inclinada, solução que seria incorporada por Niemeyer ainda no projeto da Pampulha. A marquise que abriga o acesso à Igreja de São Francisco de Assis é inclinada e apoiada sobre pilares em "V" encurvados que tangenciam a face inferior da marquise. Quando Niemeyer encurva o apoio, dilui seu próprio sentido estrutural. A função portante do pilar passa desapercebida, pois seu desenho sublima a lógica da peça como matéria que sofre compressão. [167], [168], [169], [170], [171], [172]

Apesar das diversas citações à obra de Le Corbusier presentes no Cassino, o projeto de Niemeyer está longe de ser compreendido como mera manipulação das soluções corbusianas.

Para Lauro Cavalcanti, “(...) o Cassino apresenta, concomitantemente, uma adesão aos princípios corbusianos e a procura de uma expressão mais livre e sensual" (CAVALCANTI 2006:200).

O mérito do projeto do Cassino não se encontra nos redesenhos "de efeito" de um discí-

157 | o encontro de 1936: formação 

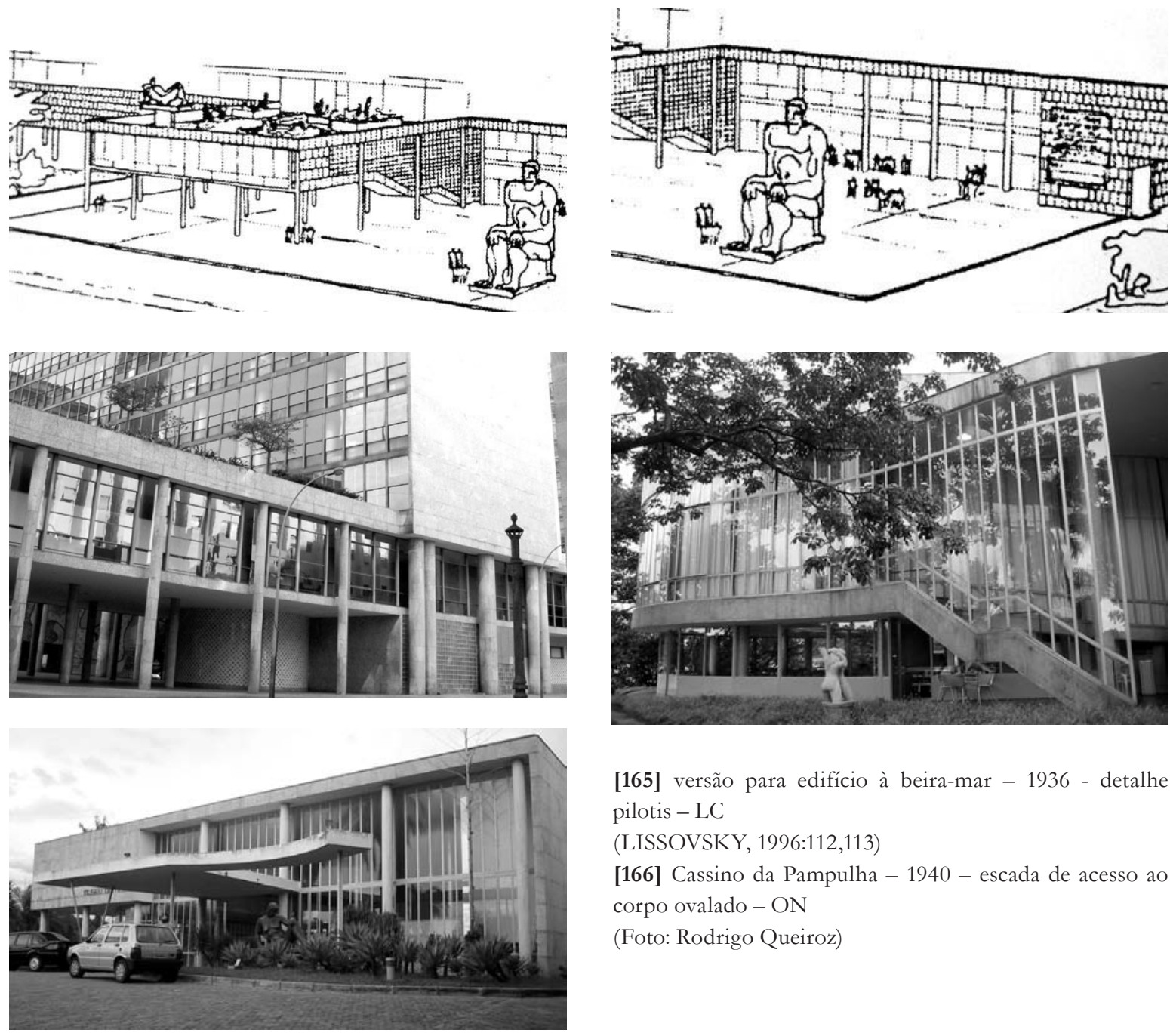

[165] versão para edifício à beira-mar - 1936 - detalhe pilotis - LC

(LISSOVSKY, 1996:112,113)

[166] Cassino da Pampulha - 1940 - escada de acesso ao corpo ovalado - ON

(Foto: Rodrigo Queiroz)

[162] MES - versão para terreno a beira-mar - 1936 - detalhe bloco de exposições - LC

(LISSOVSKY, 1996:112,113)

[163] MES (projeto definitivo - bloco de exposições) - 1936 - equipe brasileira

(Foto: Rodrigo Queiroz)

[164] Cassino da Pampulha - 1940 - entrada principal $-\mathrm{ON}$

(Foto: Rodrigo Queiroz) 
pulo atento. Sua virtude aflora no instante em que Niemeyer enfrenta, não apenas a linguagem de Le Corbusier, mas o seu modo de raciocínio.

A seguir, abordaremos o projeto do Cassino a partir de uma leitura que o compreende não apenas como um desdobramento dos exemplares puristas de Le Corbusier, mas como uma evolução do próprio raciocínio corbusiano, balizado pelos seus códigos pictóricos que são transpostos da pintura para a arquitetura, onde tanto a tela como a planta são assimiladas não como mero suporte, mas como campo organizado a partir da composição de elementos estruturadores: o seu próprio limite físico, sua subdivisão em retícula, e a disposição dos componentes encurvados internos a esse campo gráfico. A disposição dos elementos na pintura e na arquitetura obedece tanto aos limites perpendiculares desse campo (seja a moldura ou as paredes externas em planta), como ao reticulado estruturador (seja a quadrícula irregular da pintura, ou a trama de pilares em planta).

No projeto do Cassino da Pampulha, Niemeyer assimila esse conjunto de parâmetros a partir de um posicionamento que, ao mesmo tempo em que incorpora, relativiza essas máximas corbusianas. Apesar das flagrantes transgressões presentes no Cassino, talvez a mais significativa - e que abre uma perspectiva definitiva para toda a obra de Niemeyer - seja justamente a ruptura do campo purista de Le Corbusier. 

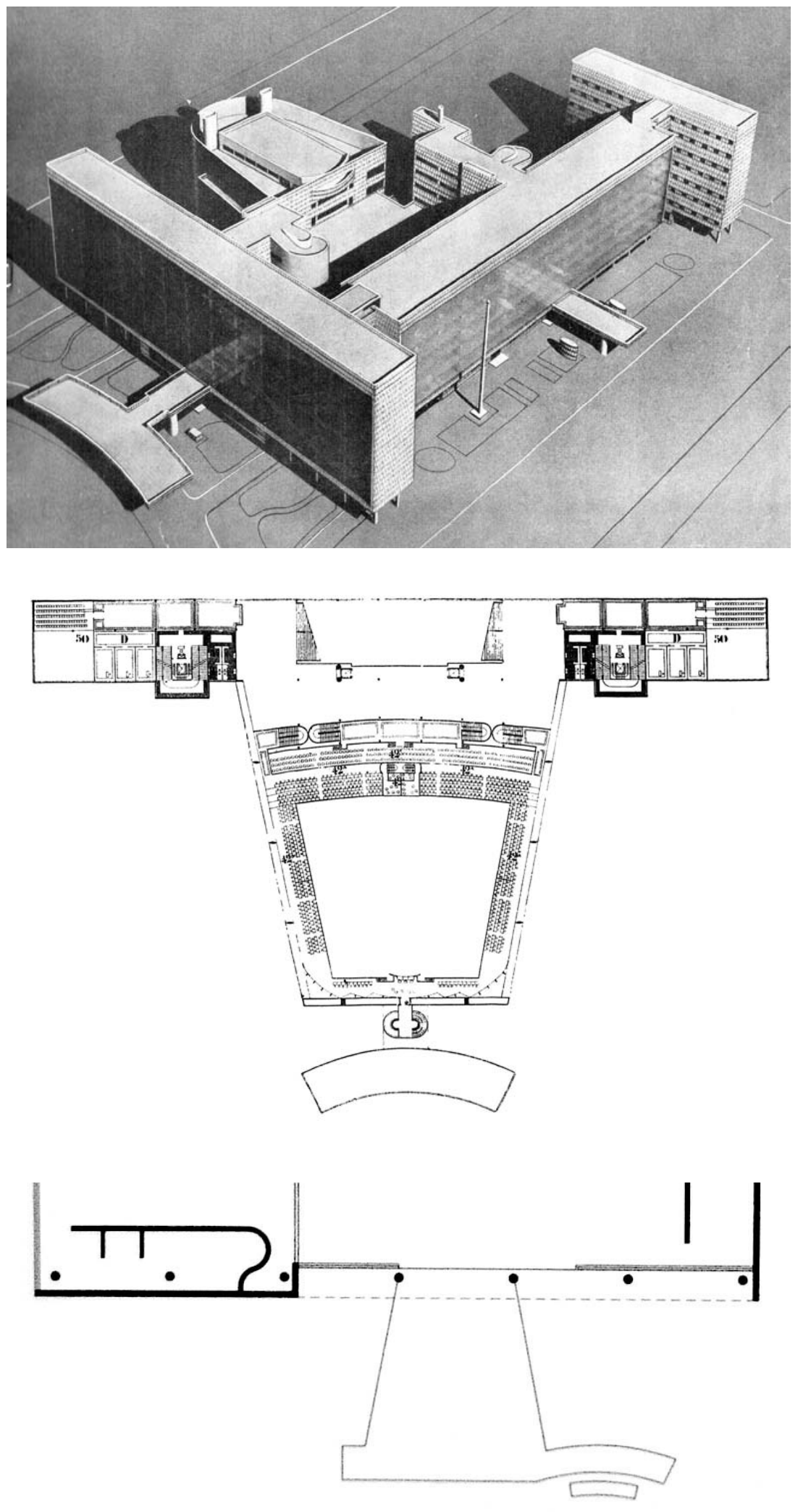

[167] Palácio Centrosoyus - 1929 - maquete - marquise encurvada - LC

(BOESIGER, 1971:102)

[168] Liga das Nações em Genebra - 1927 - auditório e bloco encurvado - LC

(BOESIGER:1994:52)

[169] Cassino da Pampulha - 1940 - detalhe marquise encurvada - ON

(UNDERWOOD, 2002:61) 



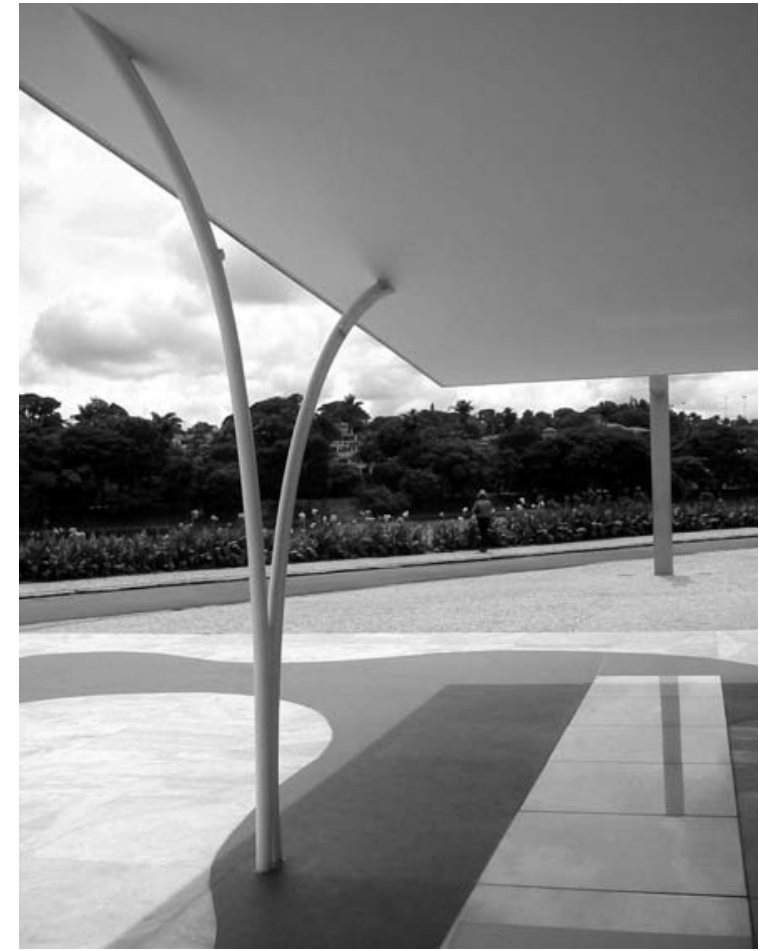

[170] Cite Refuge - 1929 - marquise inclinada e pilar em "V" - LC (BOESIGER, 1971:115)

[171] Cassino da Pampulha - 1940 - marquise encurvada e pilar em "V" - ON (GOODWIN, 1943:s.n.)

[172] Igreja de São Francisco de Assis - Pampulha - 1943 - marquise inclinada e pilar em "V" - ON (Foto: Rodrigo Queiroz) 


\section{O Cassino da Pampulha e a ruptura com o raciocínio pictórico de Le Corbusier}

No projeto do Cassino da Pampulha, Niemeyer exterioriza aquilo que Le Corbusier protege. A disposição do volume ovóide da pista de dança - externo, porém conectado ao volume retangular do salão de jogos - ilustra o instante em que o jovem arquiteto brasileiro, aos trinta e dois anos de idade, enfrenta o esquema corbusiano e transgride a regra da forma pura que limita a expansibilidade da forma livre. Em Le Corbusier, a forma curva, invariavelmente abrigada pelo perímetro regulador do volume exterior, se presta como índice visual que, por contraste, potencializa a própria pureza do objeto exterior.

O projeto de Le Corbusier para a casa Savoye (1929) sintetiza a aplicação dos "cinco pontos" (térreo livre, planta livre, fachada livre, janela horizontal e terraço jardim) estabelecidos como parâmetros estético-tecnológicos que permitem que a arquitetura assimile a problemática da arte moderna, a partir da compreensão do objeto arquitetônico como um volume abstrato que, apesar de escavado, preserva sua integridade geométrica.

Em seu ensaio intitulado Arquitetura e engenharia: Le Corbusier e o paradoxo da razão, Alan Colquhoun discorre sobre os "cinco pontos" e expõe o sentido compositivo de raiz pictórica presente no agenciamento dos espaços contidos no interior da forma pura.

(...) Os cinco pontos para uma nova arquitetura reinterpretam os elementos arquitetônicos tradicionais segundo essa dialética. Em primeiro lugar, a planta e os volumes internos são liberados das restrições de estrutura e assumem configurações exigidas pela utilidade e conveniência. Ao mesmo tempo, tal liberdade permite que esses volumes assumam uma importância antropomórfica por meio de metáforas visuais, de uma maneira que esteja intimamente relacionada aos objetos representados nas pinturas puristas (COLQUHOUN 2004:119-120, grifo nosso).

Os projetos de Le Corbusier contemporâneos a casa Savoye ${ }^{56}$ possuem uma filiação estética que expressa um claro diálogo com suas composições pictóricas. Nos estudos para a casa Savoye, o arquiteto exercita a manipulação dos elementos curvilíneos interiores a um limite retangular.




A tradução arquitetônica da experiência de Le Corbusier presente em suas composições puristas ocorre em duas vias: no desenho em planta e na volumetria da obra construída.

Alan Colquhoun, em outro ensaio intitulado $A$ importância de Le Corbusier, indica a relação entre pintura e arquitetura nos projetos de Le Corbusier da década de 1920, e credita a sua experiência pictórica a origem dos paramentos curvos contidos no interior de perímetros regulares que definem o perfil exterior da maioria dos objetos arquitetônicos concebidos por Le Corbusier naquele período:

A analogia entre as casas de Le Corbusier e sua própria pintura purista é mais literal e figural do que a analogia com o cubismo como um todo. Em ambos os casos (pintura e arquitetura), uma estrutura "platônica" regular define um campo em relação ao qual inúmeros objetos são dispostos - garrafas, copos, cachimbos na pintura; escadarias, banheiros, corredores, closets nas casas. Objetos e espaços normalmente assumem a forma de recipientes ocos cujas superfícies curvadas convexas se projetam no campo neutro e a ele se conectam.(...)

A disposição de volumes arquitetônicos somente poderia ter uma analogia direta com um tipo de pintura: a natureza-morta. Os objetos de uma natureza-morta não somente são suscetíveis a um alto grau de abstração sem perder a capacidade de serem reconhecidos (uma propriedade essencial do cubismo que o distingue da pintura abstrata), mas também possuem certa variedade de conotações que os relacionam ao conteúdo de uma casa.(...)

Eles podem ser dispostos como for desejado e, portanto, representam a noção de liberdade do artista. A liberdade de disposição dos objetos determinada pela tecnologia, sobre a qual Le Corbusier insistia, é análoga a essa liberdade da pintura.(...)

Mantendo as devidas proporções, os volumes sólidos das casas puristas de Le Corbusier correspondem aos objetos de suas pinturas tanto em sua flexibilidade de disposição quanto em suas funções e conotações (COLQUHOUN 2004:166, grifo nosso).

A partir da colocação de Colquhoun, podemos traçar um percurso que indique um sentido para a reflexão sobre a construção do raciocínio gráfico-espacial presente em diversos projetos de Le Corbusier. Dois parâmetros de concepção de projeto devem ser considerados para a análise: organização e composição.

Se a presença das formas livres contidas no interior dos volumes puros nos projetos de Le Corbusier é conseqüência de suas experiências pictóricas, podemos intuir que a forma livre, para Le Corbusier, é um instrumento primeiramente gráfico que cumprirá o papel de enfatizar a própria estanqueidade pura da moldura reguladora.

Le Corbusier elege formas encurvadas, elípticas e circulares que são agenciadas a partir de um senso compositivo próximo da pintura, onde essas peças curvas são representadas no interior de perímetros retangulares que são adotados como parâmetros para organização das superfícies curvas e o reticulado de pilares.

Em Le Corbusier, os fechamentos externos da planta têm a mesma função de limite presente na moldura da pintura. Cabe ao artista dispor os elementos internos ao plano regular, seja ele o quadro ou as paredes externas representadas em planta. Em ambos os casos, o suporte é um plano bidimensional, seja a tela ou o papel.

163 o encontro de 1936: formação 




[173] guitarra vertical, 1920

(JENCKS, 200:115) 
O raciocínio purista presente tanto na pintura como na arquitetura configura-se como uma reação à visualidade fragmentada do Cubismo. Le Corbusier, em suas experiências pictóricas, propõe um retorno à figuração integral, direta, cujo tema deve ser compreendido sem a necessidade de uma reconstrução da forma pela memória, como ocorre com o Cubismo.

No livro Depois do Cubismo, Le Corbusier e Amedée Ozenfant questionam a vigência do cubismo como a "arte de amanhã".

Poderia o cubismo ser a arte de amanhã? Mostraremos adiante por que isso não é provável.(...) As idéias de uma escola são feitas principalmente das idéias de seus líderes, mas não deve se esquecer as dos alunos; se, de modo geral, elas alteram as dos mestres, às vezes também as tornam mais precisas; em todo caso, são as idéias dos mestres unidas às idéias dos alunos que constituem o que chamamos de uma Escola. A utilidade dos alunos é também esgotar as fórmulas dos mestres, aumentar seus excessos e tornálos rapidamente insuportáveis, desatando assim a liberdade que os mestres acorrentaram. É preciso então levar isso em conta (LE CORBUSIER \& OZENFANT, 1918-2005:26-28, grifo nosso).

$\mathrm{Na}$ intenção de relativizar a perenidade do raciocínio cubista, Le Corbusier e Ozenfant apontam para o papel fundamental que os discípulos exercem sobre os códigos propostos pelos mestres. Ao destacar o ímpeto de liberdade presente nos discípulos atentos como um fator primordial para o desenvolvimento da linguagem, os autores, inconscientemente, encontram uma definição precisa para a compreensão da autonomia da obra de Oscar Niemeyer (aluno) sobre a arquitetura de Le Corbusier (mestre). Afinal, no projeto do Cassino da Pampulha, Niemeyer justamente não "desata a liberdade acorrentada" nos modelos puristas de Le Corbusier?

Em outro momento do livro, Le Corbusier e Ozenfant apontam a diferença entre a "arte ornamental" e a "arte superior". Para os autores, a idéia de pureza deve ser transposta do campo das sensações para o campo das cores e das formas organizadas a partir de um senso compositivo simplificado, essencial.

\footnotetext{
Resumamos: das artes:

Sensação pura: arte ornamental.

Organização das sensações brutas - cores e formas puras: arte superior (Ibid.:35).
}

Tendo demonstrado que a sensação pura, bruta é apenas o meio da grande arte, admitimos uma hierarquia

Apesar do afastamento entre o Purismo e o Cubismo - do ponto de vista da legibilidade do tema - as composições puristas de Le Corbusier serão tributárias ao esquema cubista da estruturação de objetos tridimensionais representados a partir de planos em "verdadeira grandeza" (ora em elevação, ora em planta). Tomemos como exemplo a pintura intitulada Guitarra Vertical (1920) de Le Corbusier, onde a garrafa presente na composição está representada em elevação, mas seu gargalo é desenhado em "vista de topo", como um círculo, ao passo que a rolha que fecha a garrafa é vista em elevação. [173]

Segue trecho em que Sophia Telles discorre sobre a suposta rejeição da representação cubista por parte de Le Corbusier:

$$
165 \text { o encontro de 1936: formação }
$$



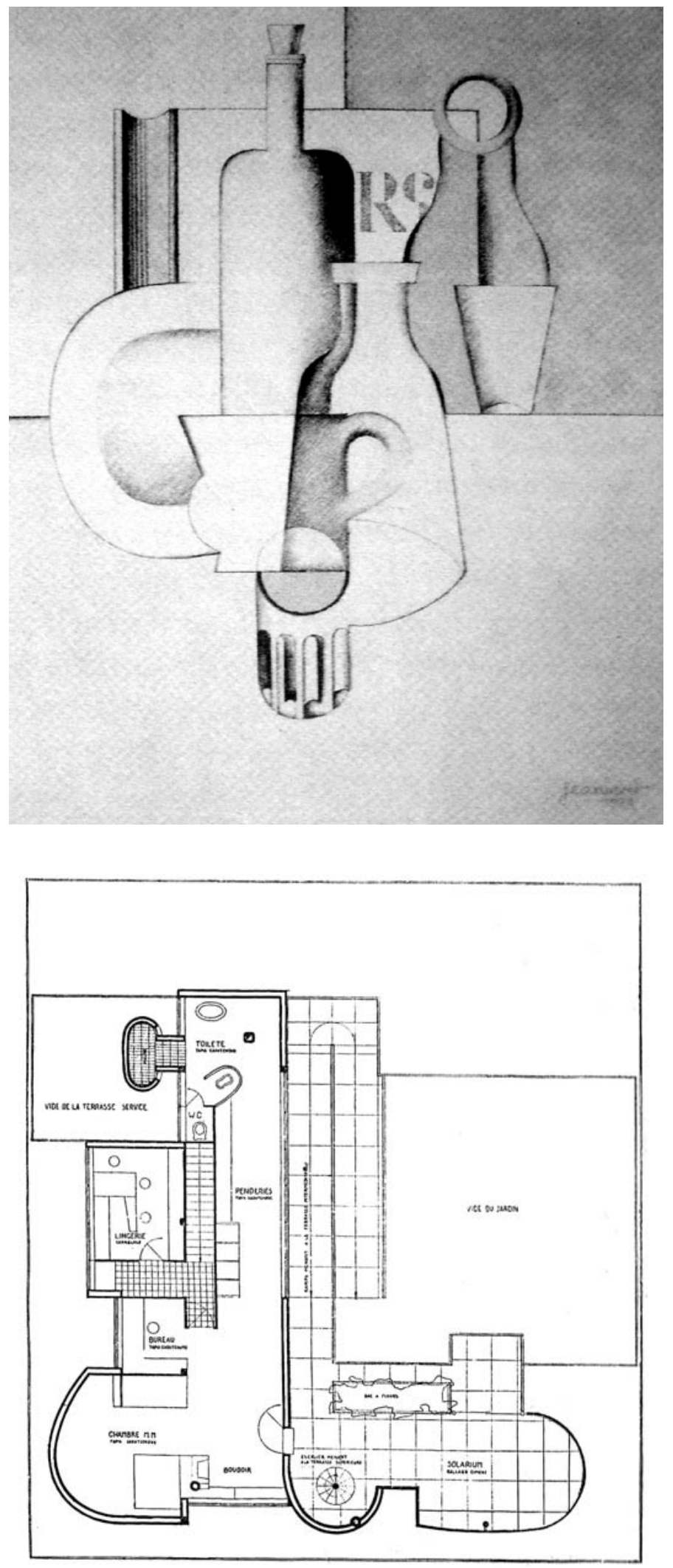

[174] Nature mort avec boiteilles, verres e livre - 1921 - Charles Edouard Jeanneret - LC

(LE CORBUSIER \& OZENFANT, 1918-2005: 22)

[175] Casa Savoye - planta de cobertura - estudo - 1929 - LC

(SBRIGLIO, 2005:115) 
Ozenfant e Corbusier reclamam da fase analítica de Braque e Picasso por terem quase completamente dissolvido a figura, ou seja, os contornos, e destruído assim a possibilidade de colocar em relação as formas pictóricas. (TELLES 1988:23).

Os objetos representados nas pinturas puristas de Le Corbusier, conhecidos como objetos-tipo $^{57}$, estabelecem a fusão de dois fundamentos do pensamento moderno: funcionalidade e beleza. Ao representar violões, pratos e garrafas a partir de uma formalização purista, Le Corbusier condiciona os objetos do cotidiano a um "design regulador" que tem como objetivo representar a figura em sua essência de linguagem sem subtrair do tema o seu significado.

Quando o diálogo entre a pintura e a arquitetura transcende a relação quadro/planta e o código gráfico-geométrico da arquitetura é transportado para uma especulação construtiva, o paralelo entre essas duas manifestações assume um outro patamar de complexidade. Os traços curvos, os círculos e os aros presentes na pintura transformam-se em cilindros regulares, oblongos ou ovóides, ora opacos, ora transparentes.

$\mathrm{Na}$ casa Savoye, esses atributos pictóricos podem ser notados em três momentos: no caixilho semi-circular transparente que abriga o hall de distribuição no pavimento térreo; na organização dos ambientes no pavimento intermediário; e nos "pára-ventos" localizados na cobertura que emergem para o meio externo, que representam a transposição dos objetos-tipo da pintura para a arquitetura, assumindo a condição de objeto de reação poética ${ }^{58}$.

$\mathrm{Na}$ pintura de Le Corbusier, os objetos-tipo são representações figurativas de temas do cotidiano. Porém, a formalização desses temas no suporte ocorre a partir de um senso de organização do campo bidimensional onde as formas encurvadas dos perfis de objetos, como um violão e uma garrafa, resultam em uma composição gráfica balizada pela própria ortogonalidade do suporte.

A transposição do tema da pintura purista para a arquitetura não ocorre apenas na dimensão gráfica da planta ou volumétrica da construção. Segundo Kenneth Frampton, os objetos-tipo representados na pintura estão presentes de forma literal nos experimentos arquitetônicos puristas de Le Corbusier, como no Pavilhão l'Esprit Nouveau (1925) que

\footnotetext{
57. Le Corbusier (...) desejava ver o Dom-Ino como uma peça de equipamento, análoga em sua forma e modo de montagem a uma peça típica do design de produtos. Esses elementos eram vistos por Le Corbusier como objets-types, cujas formas já haviam refinado em resposta a necessidades típicas. Em Vers une architecture, ele escreveu:

'Se eliminarmos de nossos corações e mentes todos os conceitos mortos a propósito das casas e examinarmos a questão a partir de um ponto de vista crítico e objetivo, chegaremos à 'Máquina de Morar', a casa de produção em série, saudável (também moralmente) e bela como são as ferramentas e os instrumentos de trabalho que acompanham nossa existência (FRAMPTON, 1997:183, grifo nosso).

58. “Arma assim uma dualidade que é reconhecida em seus projetos, entre a lógica do raciocínio e o que chama de liberdade poética, que deve operar por contraponto à emoção intelectual produzida pela abstrata proporção arquitetônica. Daí a série de "objets à réacton poétique", quase surrealistas, que desenha para elementos do cotidiano como a chaminé ou playground, alocados em geral nos tetos jardim, mas presentes também nas curvas inusitadas de um prosaico banheiro" (TELLES, 1988:22, grifo nosso).
}

167 | o encontro de 1936: formação 




[176] Pintura Purista - LC

(BOESIGER, 1971:300)

[177] Casa Savoye

- planta da cobertura estudo - 1929 - LC

(SBRIGLIO, 2005:115)




(...) era mobiliado segundo o cânone purista dos objets-types, isto é, com poltronas inglesas do estilo 'club', móveis Thonet de madeira curvada e peças parisienses padronizadas em ferro fundido, com objets-tableaux de origem purista, (...) (FRAMPTON 1997:188, grifo nosso).

Os pára-ventos encurvados presentes na cobertura da casa Savoye assumem a condição de uma forma exterior, apesar de estarem internos ao limite dado pelos fechamentos externos da residência. Por absoluto contraste, a liberdade presente nos pára-ventos da cobertura da casa Savoye explicita a pureza do volume que lhe serve de base. Porém, esses mesmos pára-ventos, quando vistos em planta, preservam a idéia da forma regular que retém a forma curva. [174], [175]

A pesquisa gráfico-volumétrica presente no projeto da casa Savoye é ilustrada pelos estudos antecedentes ao projeto definitivo. As curvas presentes nas diferentes alternativas para as plantas de cobertura são conseqüência da manipulação de arcos parabólicos e de formas circulares associadas a segmentos de reta tangentes ou secantes a semi-círculos ou a quartos-decírculo. [176], [177]

No projeto do Cassino, Niemeyer também lança mão da solução dos paramentos encurvados sobrepostos a volumes maiores. A caixa cênica, situada acima do palco do salão de dança, figura como um volume oblongo pousado sobre o volume oval e transparente do salão de baile.

No salão de baile do Cassino, Niemeyer insere uma peça de traçado curvo sobre o volume de proporção horizontal, aos moldes da casa Savoye. Porém, a natureza geométrica dessa peça se remete diretamente às formas curvas implantadas sobre a cobertura do MES. [178], [179]

Nos projetos do MES e do Cassino, o volume oblongo da cobertura é conseqüência da concordância de segmentos encurvados que se alternam, ao passo que, na casa Savoye, essas peças na cobertura são superfícies abertas, cujo traçado não possui a mesma ondulatória dos volumes presentes nas coberturas do MES e do Cassino.

A contensão da construção geométrica da curva nas "casas brancas" de Le Corbusier ilustra com precisão a distância entre os desenhos da curva em Le Corbusier e em Oscar Niemeyer. A curva, para Niemeyer, é resultado da continuidade do gesto que concorda segmentos de reta e arcos que oscilam, seja em planta, nas marquises e nos volumes, ou em corte, nas abóbadas.

Quando no Cassino, Niemeyer "expele" o volume ovóide do salão de baile para além dos domínios da forma pura do salão de jogos, o arquiteto exterioriza o objeto de reação poética típico das composições interiores às residências de Le Corbusier da década de 1920.[180], [181], [182]

O volume ovóide que abriga o salão de baile do Cassino representa a forma livre que transpõe o limite físico do prisma corbusiano. Aquilo que em Le Corbusier era um paramento curvo, aprisionado em um volume oco, em Niemeyer assume o papel de um objeto com marcante presença na paisagem. [183], [184]

Le Corbusier acredita que os objetos de reação poética, contidos no interior da forma, preenchem o espírito no instante em que o indivíduo perde sua relação de identidade com a arquitetura massificada devido à estandartização da linguagem. Por outro lado, no projeto do Cassino, Niemeyer sinaliza que o tour de force do inesperado, representado pelos objetos de reação poética não necessita duelar com a razão e nem deve estar contido dentro dela, mas pode ser compreendido

169 | o encontro de 1936: formação 

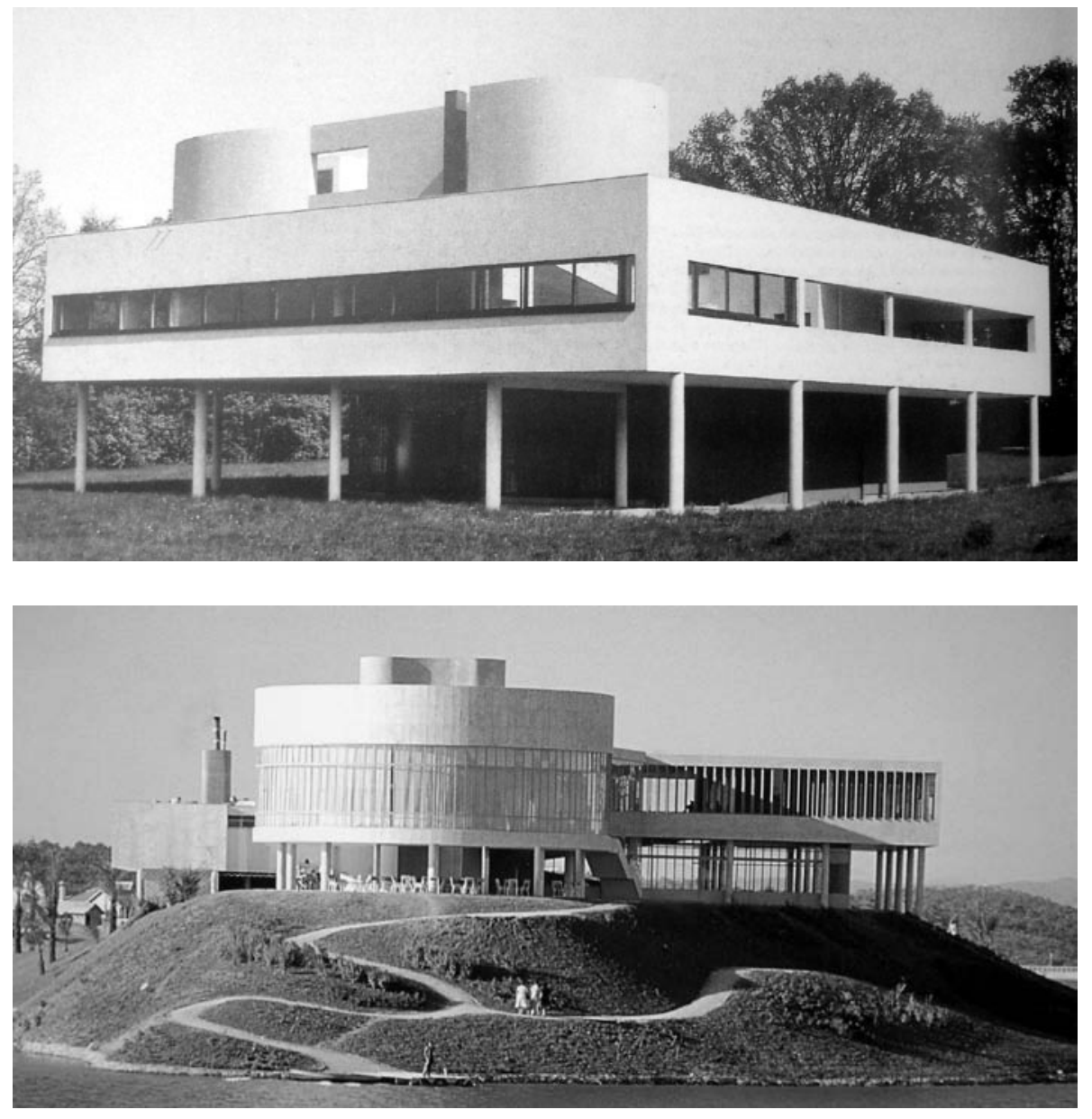

[178] Casa Savoye - volumes encurvados na cobertura - 1929 - LC

(CURTIS, 1997:95)

[179] Cassino da Pampulha - volume oblongo e fechado na cobertura do salão de baile - 1940 - ON (ANDREOLI, 2004:118) 
como a própria arquitetura, produto da sensibilidade, e - como o próprio "mestre" diz da intuição.

A experiência emancipadora de Niemeyer no Cassino resulta em um edifício composto por um volume retangular que se conecta a um volume ovóide em sua face leste e a uma lâmina mais baixa na face norte.

Enquanto na casa Savoye Le Corbusier subordina a forma arquitetônica à uniforme retícula de pilares, no Cassino Niemeyer age de maneira oposta: subordina a retícula de pilares à forma arquitetônica.

A inversão de Niemeyer indica que seu comprometimento com os cânones corbusianos é muito mais estético do que conceitual. No Cassino a noção da planta livre está intacta, porém a idéia da retícula reguladora, presente em Le Corbusier, é substituída por um partido estrutural condicionado à forma.

Enquanto Le Corbusier, na casa Savoye, estabelece uma trama regular que condiciona o comportamento dos fechamentos internos, Niemeyer, no Cassino, desenvolve três retículas distintas, uma para cada bloco do edifício: retangular para o salão de jogos; retangular distendida para o bloco de serviços e radial para o salão de dança e restaurante.

Julio Katinsky, em seu texto Técnica e Arte na obra de Oscar Niemeyer discorre sobre essa relação entre forma e estrutura presente nos exemplares puristas de Le Corbusier e no Cassino de Niemeyer:

Retomemos então aquelas considerações sobre a norma tal como se apresenta em Le Corbusier e comparemos com o primeiro edifício de Pampulha a ser projetado: o cassino. Se examinarmos a sua planta, com as áreas definidas em sua configuração individual e agregadas aos volumes justapostos: o restaurante e pista de dança, o prisma dos serviços e o grande salão com seus mezaninos destinados a modalidades de jogos específicos, notaremos que cada uma dessas áreas obedece a uma norma própria, com um espaçamento de colunas antes de tudo estabelecido em função do uso do espaço. Ou, em outras palavras, enquanto o mestre francês aceita uma norma previa (fornecida impositivamente pela indústria comtemporânea) e sobre ela constrói sua impressionante e criativa inventividade, para o arquiteto brasileiro sucede exatamente o contrário: ele submete sempre a norma ao programa previamente proposto e cuja forma também foi estabelecida por razões expressivas. Estas exigem sempre uma adaptação a posteriori da própria norma (KATINSKY 1996:09, grifo nosso).

Conectado ao salão de jogos do Cassino, à direita do acesso principal, encontra-se um pequeno pavilhão de serviços que ilustra mais um interessante diálogo com o projeto do MES. No pavimento térreo desse pavilhão, Niemeyer soluciona o recinto do vestiário dos funcionários como um volume oval revestido de azulejo e autônomo com relação à trama de pilares, solução que se aproxima daquela presente no MES, na qual o volume de planta oval que abriga a escada helicoidal que acessa o bloco de exposições possui as mesmas características, na forma e na superfície. Ambos os casos são variações sobre o tema da forma curva contida sob a projeção da forma pura presente nos projetos de Le Corbusier da década de 1920.

No bloco superior do pavilhão de serviços, Niemeyer opta por um acabamento distinto do restante do edifício (granito apicoado, azulejo pintado e vidro). O volume retangular suspenso

171 o encontro de 1936: formação 

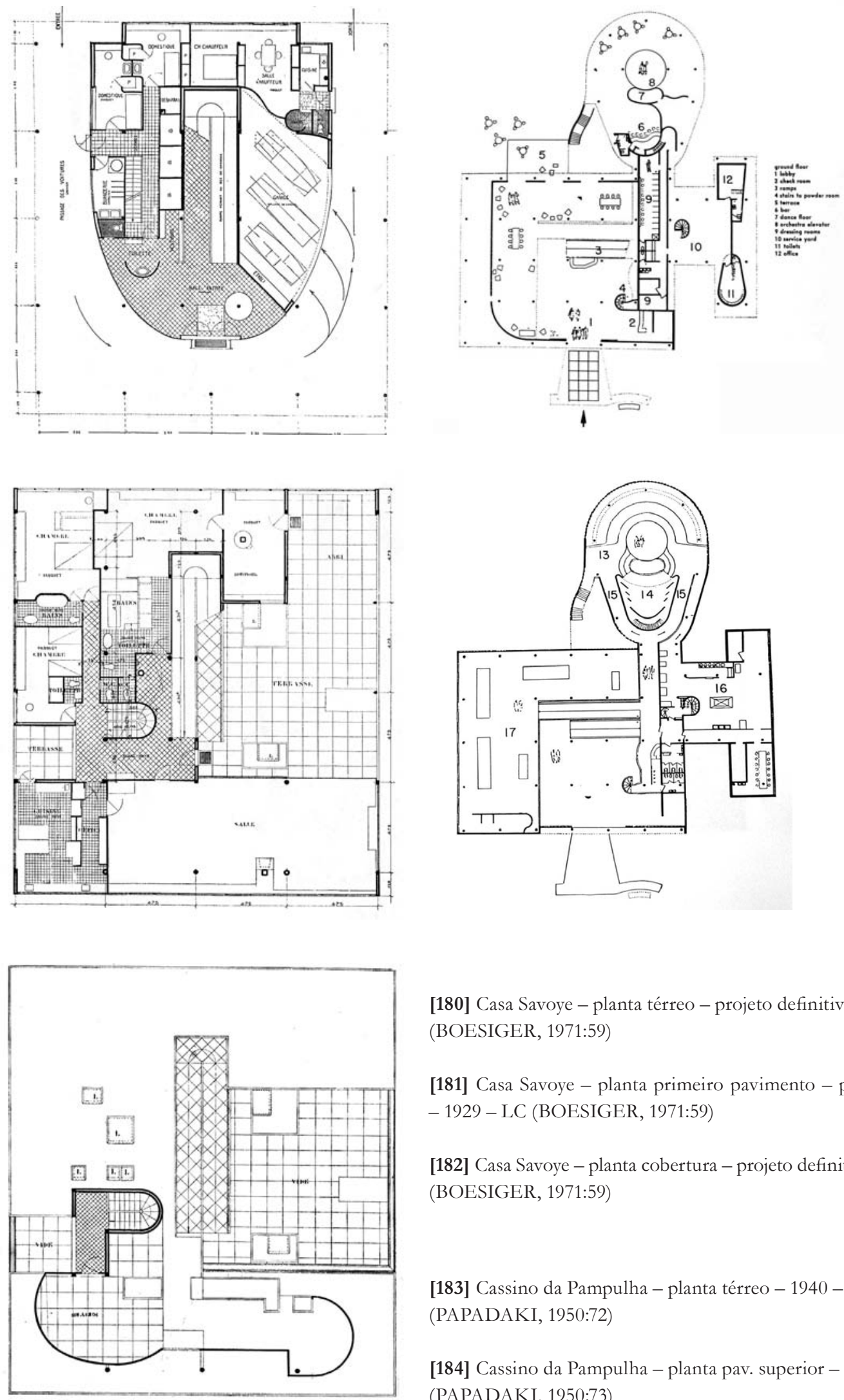

[180] Casa Savoye - planta térreo - projeto definitivo - 1929 - LC (BOESIGER, 1971:59)

[181] Casa Savoye - planta primeiro pavimento - projeto definitivo - 1929 - LC (BOESIGER, 1971:59)

[182] Casa Savoye - planta cobertura - projeto definitivo - 1929 - LC (BOESIGER, 1971:59)

[183] Cassino da Pampulha - planta térreo - 1940 - ON (PAPADAKI, 1950:72)

[184] Cassino da Pampulha - planta pav. superior - 1940 - ON (PAPADAKI, 1950:73) 
é revestido com uma massa rústica pintada de branco. Nesse instante, o Cassino dialoga com a casa Savoye nas dimensões da forma e da superfície. As aberturas do prisma alvo do bloco de serviços, assim como na casa Savoye, caracterizam-se por janelas em fita. [185], [186]

O projeto do Cassino, juntamente com os demais projetos do conjunto da Pampulha, pode ser compreendido como um desdobramento dinâmico dos objetos de reação poética de Le Corbusier que extrapolar a condição meramente compositiva e assumem a dimensão do edifício.

A relação exterior entre os volumes do salão de jogos e do salão de baile representam um rompimento com a condição hermética das formas curvilíneas presentes nas "casas brancas" de Le Corbusier. Por outro lado, no interior do salão de jogos, Niemeyer ainda preserva soluções que se aproximam dos mesmos objetos de reação poética de Le Corbusier: escada em semi-círculo e o peitoril em arco do primeiro mezanino. [187], [188]

Sobre a relação entre o Cassino e a casa Savoye, Kenneth Frampton escreve:

(...) Em diversos aspectos, o Cassino da Pampulha, realizado em 1942 nos arredores de Belo Horizonte é o melhor exemplar neo-corbusiano da fase inicial de Oscar Niemeyer.(...) Cassino é novamente uma transposicão da Maison Savoye de 1929. (...) Enquanto a Maison Savoye estende-se em destaque na paisagem, o Cassino de Niemeyer emerge orgânico e é extremamente receptivo ao cenário que se situa junto ao lago. (...) Nós somos testemunhas de um momento em que a planta livre corbusiana estende-se à topografia da paisagem brasileira. Ao mesmo tempo, Niemeyer usa um pano de vidro em ritmo vertical remanescente da Maison Savoye mantendo uma severidade cristalina contra a plasticidade do concreto (FRAMPTON apud BRILLEMBOURG, 2004:43, grifo nosso).

Frampton situa o Cassino como uma "transposição da Maison Savoye" para um contexto diverso de Poissy. Quando diz que o projeto de Niemeyer "emerge orgânico", entende que a fragmentação em três núcleos (salão de jogos, salão de baile e serviços) o difere, por oposição, da configuração adotada por Le Corbusier na casa Savoye: que não "emerge orgânica", mas "pousa pura". [189], [190], [191]

Para Alan Colquhoun, os projetos dos edifícios públicos de Le Corbusier possuem a mesma preocupação compositiva presente nas "casas brancas" da década de 1920, oriunda da pintura purista. As lâminas perpendiculares que abrigam o programa administrativo desempenham o mesmo papel do limite regulador do volume puro que contém as formas curvas (escadas, lavabos, e pára-ventos na cobertura) nos projetos das vilas puristas.

Nos projetos dos edifícios públicos, os salões que abrigam as grandes assembléias invariavelmente em formato trapezoidal - assumem a condição de protagonistas do conjunto. Segundo Colquhoun: "Nas casas a base do jogo é o volume circundante, perfurado e escavado, nos edifícios públicos a base é formada pelas lâminas." (COLQUHOUN 2004:166, grifo nosso).

Assim como nos projetos dos edifícios públicos de Le Corbusier, no Cassino Niemeyer articula volumes que contém a qualidade espacial e arquitetônica dos programas que abriga. Niemeyer extravasa a aparente estanqueidade da casa Savoye, ao mesmo tempo em que desmembra o programa em três núcleos separados, porém interligados, que assumem intensidades formais diversas: o salão de jogos; o salão de baile e o bloco de serviços. [192], [193], [194]

\footnotetext{
173 o encontro de 1936: formação
} 

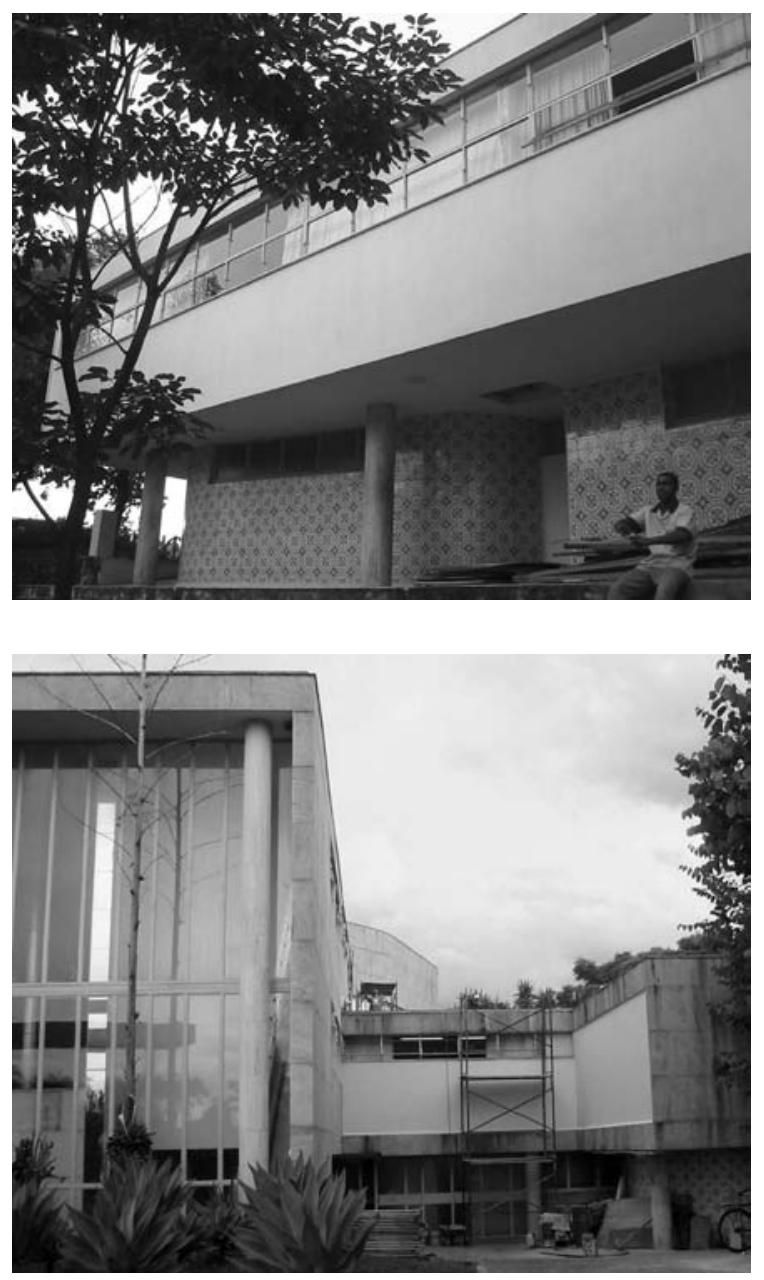

[185] Cassino da Pampulha - bloco de serviços - 1940 - ON(Foto: Rodrigo Queiroz)

[186] Cassino da Pampulha - junção entre o salão de jogos e o bloco de serviços - 1940 - ON (Foto: Rodrigo Queiroz)
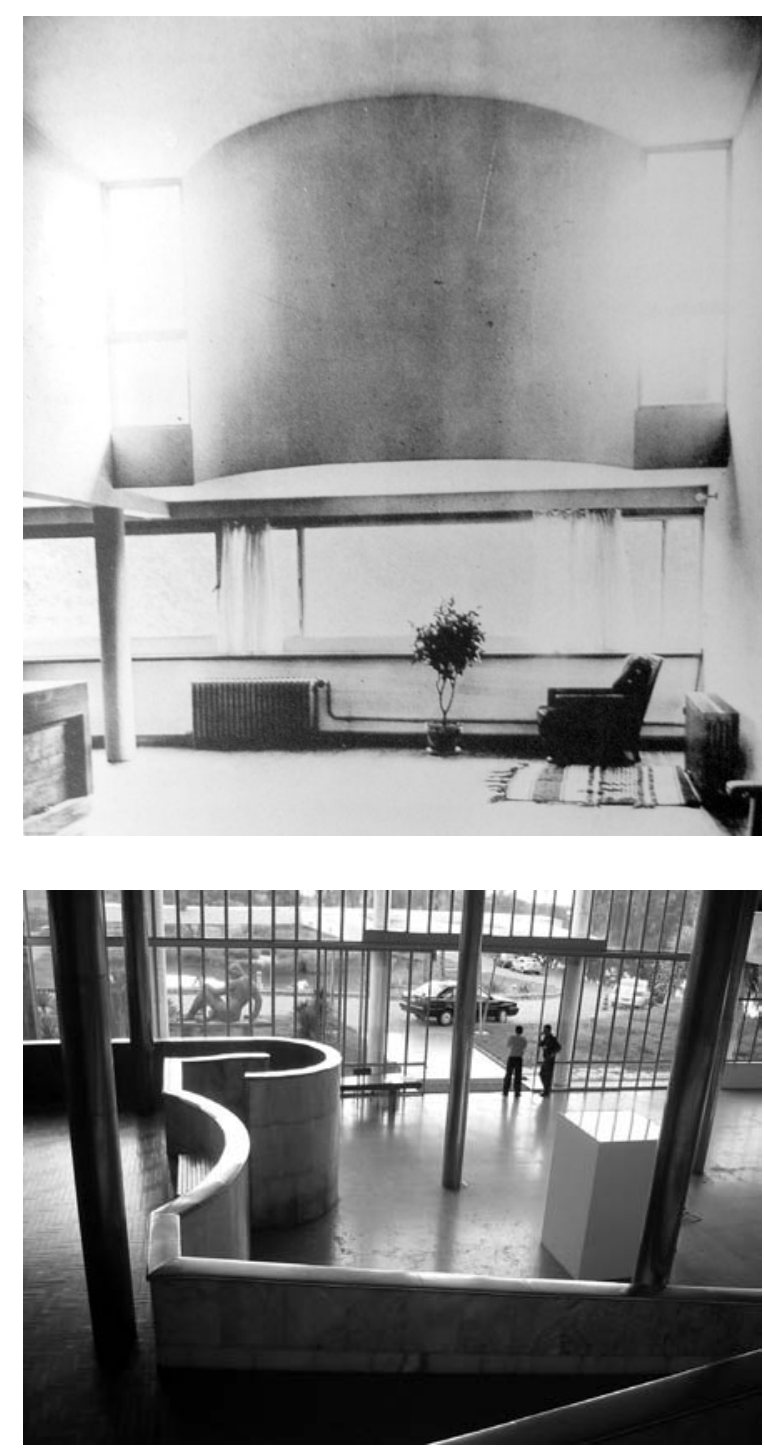

[187] Casa Cook - 1926 - estar - LC (FRAMPTON, 2001:75)

[188] Cassino da Pampulha - 1940 - vista da rampa para o salão principal - ON

(Foto: Rodrigo Queiroz) 
O raciocínio compositivo de Le Corbusier, expresso por um diálogo entre a forma livre e a forma regular, é regido por uma equação que agencia programa e forma. A hierarquização da expressão da forma dos recintos que compõem o projeto, além de tributária às suas experiências pictóricas, baseia-se em um senso de organização cujo campo é o próprio limite exterior do projeto, seja o perímetro regular das casas ou a disposição ortogonal das lâminas de alguns projetos de edifícios públicos.

Em projetos de escala urbana como a Liga das Nações em Genebra (1927) e o Centrosoyus em Moscou (1929), Le Corbusier estrutura uma regra, na qual o arranjo físico-espacial é conseqüência de uma clara organização do programa, onde elementos relacionados às atividades cotidianas, caracterizados pela compartimentação excessiva e pela repetição, assumem a forma de prismas regulares, delgados e de proporção horizontal, e os elementos do programa cuja finalidade está vinculada às atividades coletivas devem assumir uma expressão arquitetônica pronunciada e centralizadora, que estabelece uma relação de contraste com os objetos de forma simplificada. Trata-se de um conjunto harmônico, onde a discrição e a simplicidade do todo valoriza a invenção do singular que, por sua vez, assumirá o papel de componente protagonista do conjunto.

No projeto para o Centrosoyus, Le Corbusier arma um diálogo contrastante e ao mesmo tempo complementar entre a forma trapezoidal do auditório e a forma regular das lâminas que abrigam os escritórios. Os volumes são unidos por conexões discretas que, por serem estreitas, preservam a característica formal de cada volume que compõe o conjunto. No Cassino, Niemeyer lança mão da mesma solução de conexão estreita entre os volumes. Nesse projeto estão condensadas duas características tipológicas presentes em projetos de Le Corbusier de escalas distintas: a forma regular que contém a forma livre (casa Savoye), e a interação hierárquica entre elementos de um conjunto que abrigam programas diferentes (Centrosoyus). Niemeyer, em um mesmo projeto, funde duas operações corbusianas distintas: a do objeto e a do conjunto.

Edson Mahfuz, no texto O clássico, o poético e o erótico: método, contexto e programa na obra de Oscar Niemeyer, aponta em Niemeyer a mesma estratégia presente nos projetos de Le Corbusier, caracterizada pela relação de oposição entre os diferentes recintos que compõem o programa: a forma racional como elemento coadjuvante que emoldura a expressão liberta do objeto que redentor do programa centralizador do conjunto. Segundo Mahfuz:

(...) É também significativa nessa estratégia a tendência a contrastar espaços secundários e repetitivos - usualmente estruturais e seguindo as direções da malha estrutural - com os espaços hierarquicamente mais importantes. Esses são tratados como objetos especiais e recebem formas únicas, não ortogonais (MAHFUZ, 2002:122-123).

Ao liberar o volume expressivo para o exterior do cubo já desfigurado, Niemeyer indica sua posição perante o projeto purista de Le Corbusier que, apesar de desejar-se essencial e geométrico, mantém na manipulação dos fechamentos encurvados contidos no interior da forma pura a dimensão emotiva que preserva, na escala doméstica, um diálogo com o indivíduo.

175 | o encontro de 1936: formação 



[189] Casa Savoye - 1929 - perspectiva - LC

(BOESIGER, 1971:59)

[190] Cassino da Pampulha - 1940 - ON

(CORONA, 2001:31)

[191] Cassino da Pampulha - 1940 - ON

(GOODWIN, 1944:sn) 
No Cassino, Niemeyer transporta para o exterior do volume corbusiano as formas encurvadas contidas dentro dele. A partir dessa operação, o arquiteto liberta a "forma livre", antes encapsulada no interior do volume puro, e atribui a essa forma livre a condição de elemento integrante de uma composição maior, de um conjunto.

Nas vilas puristas de Le Corbusier inexiste a idéia de apêndice, de anexo. Os valores técnico e estético do objeto estão associados à capacidade de organizar um programa a um volume de contorno simples que sofre ocasionais subtrações preenchidas ora por vidro, ora pelo mero vazio.

A busca por um sentido abstrato geométrico em projetos de Le Corbusier como a casa Meyer, a casa Cook e a casa Savoye faz com que o arquiteto, na intenção de conseguir a superfície pura, execute uma operação ornamental de regularizar as imperfeições de uma "verdade construtiva" que, desprovida desse diáfano regulador, estaria muito próxima - pelo menos do ponto de vista da superfície - de suas experiências vernáculas.

A superfície imaculadamente uniforme e alva do volume suspenso da casa Savoye não é produto da técnica moderna, mas de um tratamento a posteriori que faz com que o objeto tenha a superfície tão "pura" quanto sua forma. [195], [196], [197]

A partir de 1929, Le Corbusier são se furtará em usar materiais tradicionais como pedra e madeira em seus projetos residenciais, como nas casas Errazuris (1930), Mandrot (1931) e Mathes (1935). Porém, Le Corbusier não utilizará esses materiais como superfícies para os prismas suspensos e puros. Os perfis exteriores desses projetos evocarão uma temática local vinculada ao lugar ${ }^{59}$.

Niemeyer, no Cassino, plasma a volumetria pura dos projetos corbusianos de 1925 a 1929 à superfície vernácula das casas de 1930 a 1935. Devemos salientar que, em Niemeyer, a adoção de superfícies que dialogam com uma tradição construtiva é oriunda de um aprendizado de mão dupla: as experiências de Le Corbusier com o vernáculo (casas Errazuris, Mathes e Mandrot) e os ensinamentos de Lucio Costa que versam sobre a legitimidade da arquitetura moderna brasileira a partir de sua estreita ligação com a arquitetura do período colonial, considerando não a forma e a linguagem do artefato colonial em si, mas o seu sentido de correção, austeridade, simplicidade e singeleza.

Os acabamentos exteriores do Cassino, em pedra apicoada, cerâmica estampada, vidro e massa rústica pintada de branco, transportam o prisma corbusiano para uma realidade que estabelece uma relação de identidade com aspectos nacionais, a partir da manipulação das superfícies que remetem a uma tradição popular, já presente no projeto do MES: cerâmica pintada aplicada sobre os volumes curvos; e a pedra apicoada que reveste tanto os pilotis cilíndricos, como as empenas laterais do bloco de escritórios.

No diagrama "Quatro Composições", feito por Le Corbusier para ilustrar a evolução presente

59. Tanto na casa Errazuris, como a casa em Mathes, Le Corbusier lança mão da cobertura em telhado invertido, contrariando o monolito puro das casas brancas de 1925 a 1929 e indicando, no desenho da cobertura, um perfil em corte que flertará com uma certa tradição vernacular.

177 | o encontro de 1936: formação 


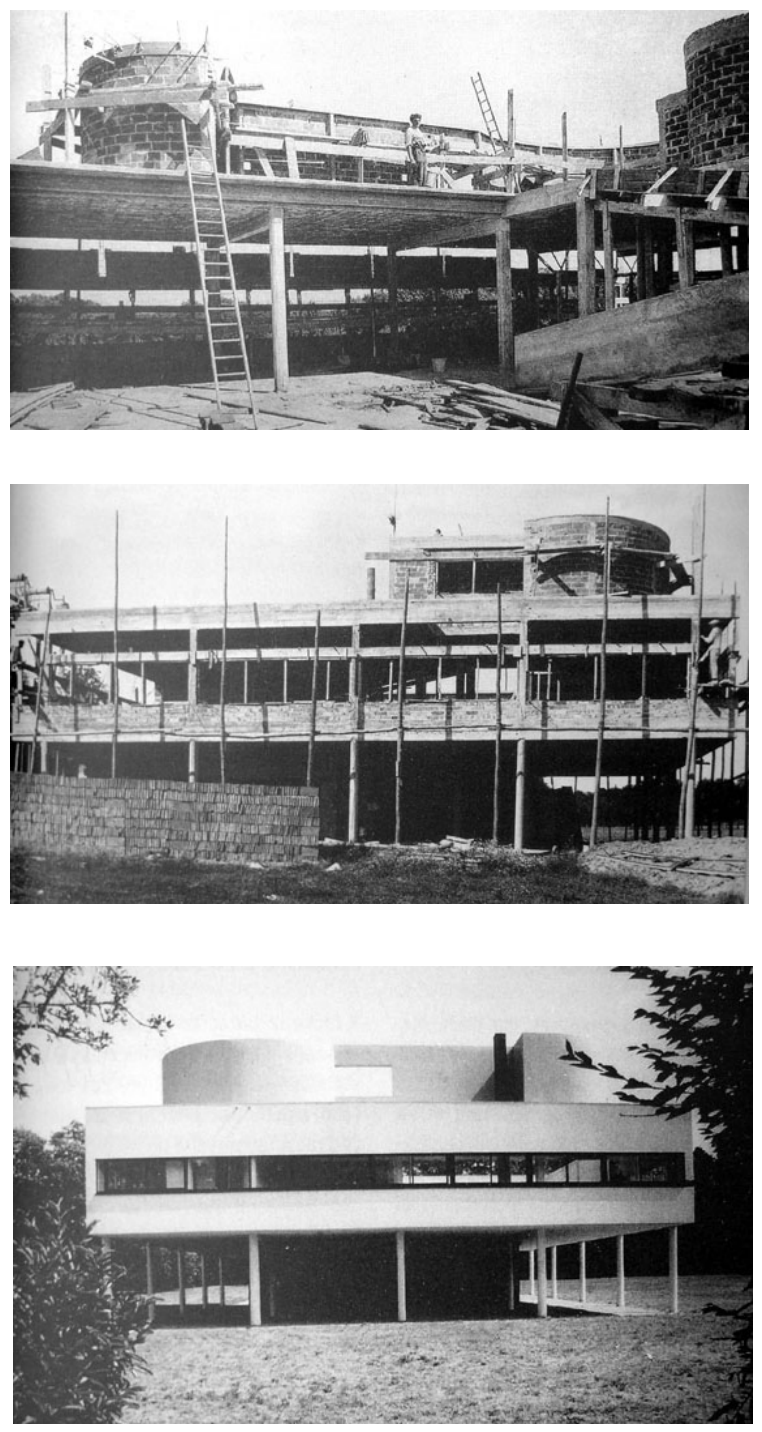

[192] Palácio Centrosoyus em Moscou - planta - 1929 - LC (BOESIGER, 1971:103)

[193] Casa Savoye - 1929 - planta cobertura - estudo - LC (BOESIGER, 1946:187)

[194] Cassino da Pampulha - 1940 - planta pav. Superior - ON (PAPADAKI, 1950:73)

[195] Casa Savoye - 1929 - construção - LC

(SBRIGLIO, 2005:135-133)

[196] Casa Savoye - 1929 - construção - LC

(SBRIGLIO, 2005:135-133)

[197] Casa Savoye - 1929 - LC

(SBRIGLIO, 2005:47) 
em quatro projetos de residências, podemos observar os avanços e conflitos de um raciocínio que lida com a dúvida entre o todo retentor e o componente expansor.

A seqüência de croquis ilustra, respectivamente, os seguintes projetos: casa La Roche-Jeanneret (1923); casa Stein (1927); casa na Tunísia (1928) e casa Savoye (1929). [198]

No primeiro croqui, vemos um esquema diferente daqueles que versam sobre o prisma puro. Tal modelo é classificado por Le Corbusier como "fácil, pitoresco, movimentado, podendo se instaurar a ordem através da classificação e a hierarquia” (LE CORBUSIER apud BOESIGER, 1971:45).

$\mathrm{Na}$ casa La Roche-Jeanneret, a organização do programa é fragmentada em volumes simples conectados por estreitas passagens recuadas com relação às faces principais desses volumes, permitindo uma clara leitura de cada um dos objetos. Le Corbusier indica nesse projeto, que o sentido de ordem é dado por um senso de organização que deve compreender o "todo" como uma ação compositiva entre as partes. [199], [200]

Se, em projetos como a casa Stein e a casa Savoye, Le Corbusier privilegia a forma pura, em seus grands travaux, como o Centrosoyus em Moscou (1929) e a Liga das Nações em Genebra (1927), o arquiteto estabelece uma composição exterior a partir de uma hierarquia organiz̧ada que já transparece na casa La Roche-Jeanneret (1923). Esse sistema de organização será fundamental para a distribuição do programa entre as atividades triviais, associadas às formas simplificadas e horizontais, e as atividades solenes, coletivas, vinculadas às formas expressivas.

No caso do Cassino a hierarquização exterior parte da expressividade do prisma de origem racional (salão de jogos), diversamente de Le Corbusier que, em seus grandes edifícios públicos, elege como protagonista um volume trapezoidal que assume as mais diferentes formas: trapézio com a base menor em curva convexa no Centrosoyus, ou em curva côncava na Liga das Nações.

Nas "vilas puristas", Le Corbusier reduz o projeto a um único objeto que possui princípios como "organização, hierarquização e composição" interiores a um perímetro ortogonal, como vemos no segundo esboço que representa a casa Stein (1927) como um paralelepípedo regular que, segundo Le Corbusier, "é muito difícil, mas satisfaz ao espírito" (idem). [201]

O terceiro croqui pode ser considerado como a antítese do anterior. Apesar de manter um claro sentido de regularidade volumétrica, não serão as faces uniformes, brancas e rasgadas com as janelas "em fita", como nas casas Stein e Savoye, as responsáveis pela noção reguladora que envolve o projeto. [202]

A manutenção das lajes regulares de formato retangular indica um desejo de ordem exterior expresso pelos planos horizontais que ilustram uma recorrência ao esquema Dom-ino de 1914. Esse terceiro esboço representa o projeto da casa Baizeau na Tunísia (1928), onde as formas curvas - pelo menos do ponto de vista visual - assumem certa exterioridade.

Nesse projeto, Le Corbusier elabora um arranjo interior à projeção de um volume subtraído de suas faces, na intenção de conceber um ambiente sombreado que afaste os recintos da incidência da luz solar.

A arquitetura, enquanto configuração dos recintos, é reduzida a um desenho fragmentado

179 | o encontro de 1936: formação 

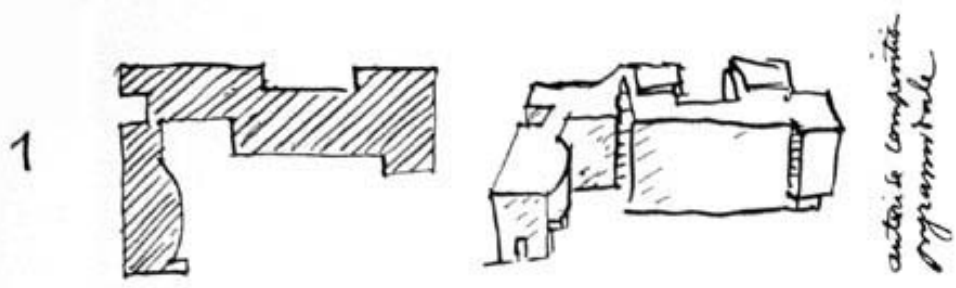

gence plutit facile,

mouvennate' esicfilinen pon clasumar

2


tus gacile,
patym
continabe

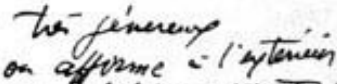

me Colnti anchite temen, a bariftar a' I'miencin - tos lo beveris fraromes cindolation, coatigutes, cinulater.

[198] Quatro Composições - LC

(BOESIGER, 1971:45) 
independente da retícula, mas que obedece o limite dos planos horizontais e não o extravasa. Como não há fechamento exterior, perde-se a idéia de volume. Trata-se de um exemplo que, apesar de flertar com o esquema Dom-ino, subverte os princípios de um purismo que se deseja materializar por uma síntese exterior.

No projeto da casa Shodam na Índia (1952) veremos um exemplo próximo da experiência na casa na Tunísia, no qual Le Corbusier desmembra os fechamentos externos em planos autônomos e confere um outro caráter à abertura, substituindo a mera obstrução, o rasgo, por intervenções subtrativas que rompem com a aparente estanqueidade do volume. [203]

O quarto croqui, que representa a casa Savoye, pode ser compreendido como a síntese entre os três croquis anteriores, pois preserva a volumetria vinculada a uma identidade purista próxima da casa Stein, ao mesmo tempo em que tem a capacidade de reter em seu interior a organização compositiva da casa La Roche-Jeanneret e a liberdade ensolarada da casa na Tunísia.

Poderia um quinto e fictício croqui, ilustrar um novo enfrentamento entre a forma compositiva (La Roche-Jeanneret e Tunísia) e a forma pura (Stein e Savoye)? Como seriam essas possíveis configurações?

Onze anos separam a derradeira experiência de Le Corbusier que vincula os pressupostos puristas ao projeto de uma residência unifamiliar (Savoye-1929), e o projeto de Oscar Niemeyer para o Cassino da Pampulha (1940). No Cassino, Niemeyer equaciona diferentes vertentes do raciocínio de Le Corbusier: aquela compreendida por um volume purista que abriga uma espacialidade dinâmica (casa Savoye) e aquela que se constitui pela organização hierárquica de volumes exteriores conectados entre si (La Roche-Jeanneret e Centrosoyus).

Ao fundir as duas alternativas, Niemeyer concebe um objeto cujo volume principal possui uma matriz purista (salão de jogos), mas que não está só, e se permite interligar com um objeto de perfil dinâmico (salão de baile) e com um paralelepípedo suspenso (bloco de serviços).

Niemeyer incorpora duas referências paradigmáticas de Le Corbusier: manipula a aparência geométrica das "vilas puristas" e a coloca como elemento articulador de um conjunto hierarquizado que remete aos grands travaux de Le Corbusier.

Quando exterioriza a forma livre, o projeto do Cassino materializa uma alternativa para a suposta continuação das "Quatro Composições” elaboradas por Le Corbusier e abre uma perspectiva para a própria obra do "mestre" que, a partir da década de $1950^{60}$, encontrará, justamente, na exteriorização dos componentes encurvados, reclusos ao interior dos exemplares puristas, uma direção e um novo fôlego para sua obra que, caso contrário, estaria reduzida a redesenhos sucessivos sobre seu próprio raciocínio pictórico.

$\mathrm{Na}$ experiência da casa Savoye, Le Corbusier funde o desejo pela abstração geométrica pura com a necessidade de uma composição liberta interna ao volume. No Cassino, Niemeyer extravasa a liberdade para além dos limites da contenção do volume puro e, aquilo que para Le Corbusier cumpria o papel de um elemento compositivo interior, para Niemeyer assume a con-



181 o encontro de 1936: formação 
$<$ andithyins sisons.
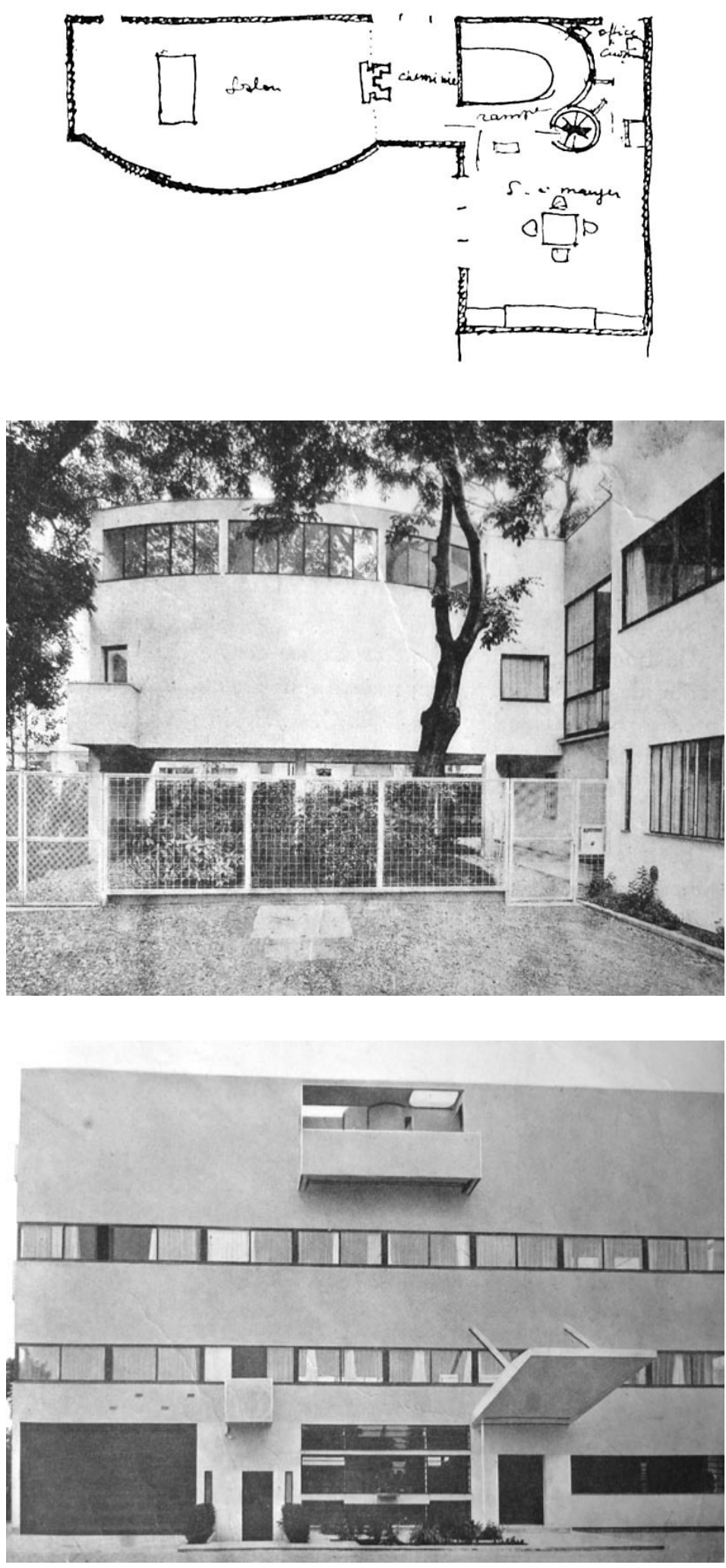

[199] Casa La Roche - Jeanneret - 1923 estudo - planta segundo pavimento - LC (BOESIGER, 1946:61)

[200] Casa La Roche - Jeanneret - 1923

- LC

(BOESIGER, 1946:67)

[201] Casa Stein - 1927 - LC

(BOESIGER, 1946:147) 
dição de edifício.

Como podemos observar, o projeto de Niemeyer para o Cassino da Pampulha está longe de ser considerado uma mera interpretação dos estilemas modernos de Le Corbusier desenvolvidos durante a década de 1920. Ao manipular o vocabulário corbusiano, Niemeyer elabora um conjunto de soluções que constituirá a linguagem formal de sua própria obra. Será, justamente, essa capacidade de assimilar os índices arquitetônicos presentes nos "cinco pontos" de Le Corbuiser, a partir de uma perspectiva ao mesmo tempo respeitadora e transgressora, que fará com que Niemeyer cultive uma liberdade que, por mais expressiva e autoral que seja, ainda preserva o nexo com seu referencial corbusiano.

O projeto do Cassino da Pampulha representa um momento de tensão máxima na obra de Niemeyer. Ao mesmo tempo em que mantém, de maneira esquemática, os modelos corbusianos, extrapola a curva para o meio externo, executando uma operação crucial para autonomia de sua arquitetura.

Paulatinamente, a obra de Niemeyer assimila a liberdade da forma em intensidade crescente, mas nunca se desgarra de sua raiz moderna. Talvez esse seja o motivo que fará com que a obra do "discípulo", a partir do projeto do Cassino, tenha a capacidade de indicar uma possível direção para a própria obra do "mestre". 



[202] Casa na Tunísia - planta segundo pavimento - 1928 - LC

(BOESIGER, 1946:178)

[203] Casa na Tunísia - 1928 - LC (BOESIGER, 1946:177)

[204] Casa Shodam - Índia - 1952 - LC (BOESIGER, 1957:134) 


\section{Casa de Baile e Hotel Resort}

Os projetos da Casa de Baile e do Hotel Resort da Pampulha ilustram o gradativo processo de emancipação da forma livre na obra de Oscar Niemeyer, já diagnosticado em intensidade crescente nos projetos do Ministério da Educação e Saúde (1936), do Pavilhão do Brasil (1938) e do Cassino da Pampulha (1940).

Tanto o Cassino (fusão entre o volume puro e o cilindro irregular), como o Iate Clube (telhado invertido) e o Golfe Clube (sobreposição da abóbada à junção das águas invertidas da cobertura) possuem em seus contornos um traçado geométrico que os distancia da liberdade presente nas marquises curvas da Casa de Baile e do Hotel Resort da Pampulha.

No projeto para a Casa de Baile, Niemeyer combina um cilindro raso, parcialmente transparente, a uma marquise curva que é a continuidade sinuosa da laje de cobertura da forma cilíndrica. O percurso da marquise culmina em outra forma curva, um vestiário de contorno oblongo revestido de cerâmica pintada, aos moldes do vestiário presente no pavimento térreo do Ministério da Educação. [205]

$\mathrm{Na}$ Casa de Baile, assim como nos demais edifícios da Pampulha, Niemeyer sublima em um mesmo objeto a forma livre - produto da técnica moderna - e a superfície vernácula, que sintetiza as referências de um ideário nacional inspirado na arquitetura colonial: a pedra apicoada e a azulejaria pintada.

O movimento ondulante da marquise da Casa de Baile é paralelo a uma mureta baixa que isola a construção da margem do lago artificial. Em uma mesma visada pode-se apreender dois itinerários curvilíneos e paralelos: a marquise com a borda revestida de pedra apicoada e a mureta revestida de azulejo pintado. [206]

A forma livre de Niemeyer em Pampulha é o suporte ideal para a apropriação moderna da matéria vernácula: as formas sutis e levemente ondulantes evidenciam, com delicada precisão, a rusticidade da pedra e a docilidade do azulejo que recebe a pintura que o esmalta.

A aspereza da pedra e a difusa reflexão da cerâmica materializam um desejo de contraste onde a pedra, impregnada no piloti e nos planos esbeltos dos contornos dos objetos, é o contraponto ideal ao azulejo, aplicado sempre nos paramentos curvos que não possuem função estrutural.

185 | o encontro de 1936: formação 

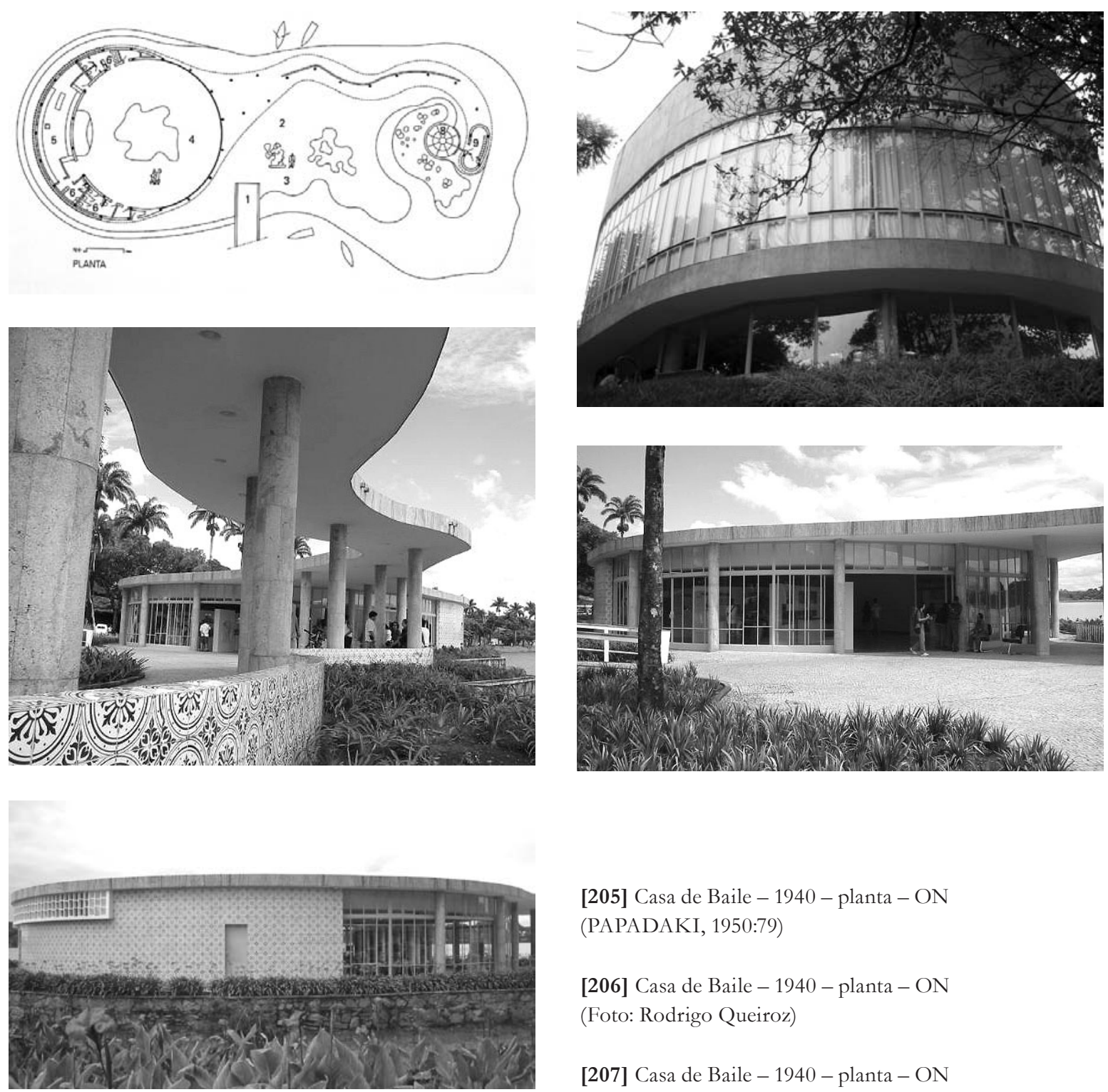

[205] Casa de Baile - 1940 - planta - ON (PAPADAKI, 1950:79)

[206] Casa de Baile - 1940 - planta - ON (Foto: Rodrigo Queiroz)

[207] Casa de Baile - 1940 - planta - ON (Foto: Rodrigo Queiroz)

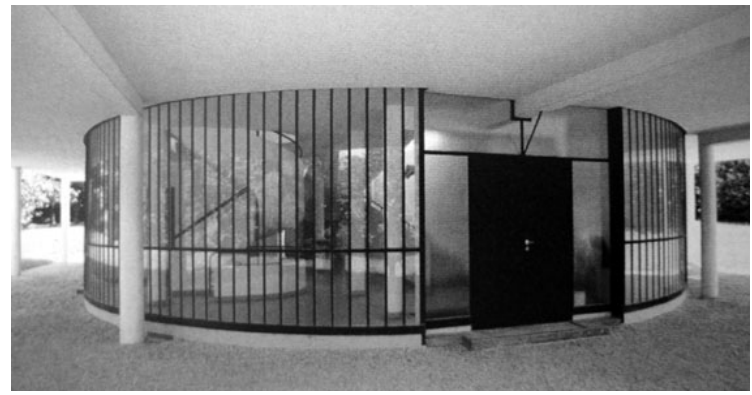

[208] Casa Savoye - 1929 - caixilho semi-circular - LC (SBRIGLIO, 2005:17)

[209] Cassino - 1940 - salão de baile/restaurante - ON (Foto: Rodrigo Queiroz)

[210] Casa de Baile - 1940 - salão de baile/restaurante $-\mathrm{ON}$

(Foto: Rodrigo Queiroz) 
Com essa hierarquização, onde a estrutura se diferencia dos fechamentos livres a partir do tratamento de suas faces, Niemeyer intensifica as naturezas da matéria e da superfície.

O cilindro transparente marcado por montantes na posição vertical encontra paralelo no próprio conjunto da Pampulha, no edifício do Cassino: tanto no caixilho em quarto-decírculo que arremata um dos vértices do salão de jogos, como no próprio salão de baile de planta ovalada.

O projeto da Casa de Baile não é apenas um desdobramento sinuoso das tentativas curvas presentes no Cassino. A solução do cilindro raso conectado a marquise curva já se fazia presente na obra de Niemeyer em uma experiência anterior a Pampulha.

Em 1938, no projeto do Pavilhão do Brasil para a Feira Internacional de Nova York de 1939, Niemeyer já havia lançado mão do cilindro raso conectado a marquise curva. No interior do pátio contido pela implantação em "L" do Pavilhão, o cilindro do aquário está ligado ao orquidário por marquise, cujo desenho não se configura como um desdobramento do traçado circular da planta, como vemos na Casa de Baile, mas como um mero elemento conector entre os volumes.

Toda a compartimentação do programa de serviços da Casa de Baile (cozinha, refeitório e sanitários) está organizada em forma de meia-lua. A face externa da porção do cilindro que contém o serviço não é encaixilhada, mas revestida de azulejo pintado. No trecho fechado, Niemeyer mantém uma fresta (ventilação das dependências de serviço e sanitários) entre o limite vertical do fechamento e a laje de cobertura circular e utiliza elementos vazados com amarração alternada, aos moldes daqueles presentes na fachada principal do Pavilhão do Brasil em Nova York. [207]

A planta do restaurante/pista de dança da Casa de Baile não se configura como um cilindro regular. O desenho é resultante da interseção de dois círculos de tamanhos diferentes. O trecho do círculo maior, que não está contido no círculo menor, assume uma forma de meia-lua que abriga os serviços e sanitários. Com esse artifício, Niemeyer preserva o contorno do salão do restaurante como um círculo perfeito.

A pele de vidro semi-circular da casa Savoye de Le Corbusier (1929), apesar de assumir um traçado diverso daqueles adotados por Niemeyer no Cassino e na Casa de Baile, pode ser compreendida como referência para ambos os projetos. Na casa Savoye, assim como nos exemplares de Niemeyer, o fechamento curvo transparente decorre da justaposição de montantes em forma de réguas verticais sob a projeção da matéria opaca, evidenciando a antítese entre a massa suspensa e o gesto curvo transparente, seja o volume de matriz purista de Le Corbusier, o sólido recortado do salão de jogos do Cassino ou a marquise da Casa de Baile. Será justamente a esbeltez das réguas transparentes nos caixilhos encurvados que permitirá a plena leitura da curva. [208], [209], [210]

A relação entre as formas cilíndricas envidraçadas de Niemeyer e o caixilho curvo da casa Savoye possui no projeto para o reservatório de água em Ribeirão das Lajes no Rio de Janeiro (1941) sua representação mais evidente, onde o arquiteto, ao contrário das experiências da Casa de Baile e do Cassino, elabora uma planta circular completamente envidraçada contida no interior da projeção de uma plataforma quadrada estruturada por retícula de pilares, aos moldes do projeto de Le Corbusier.[211]

\footnotetext{
187 | o encontro de 1936: formação
} 

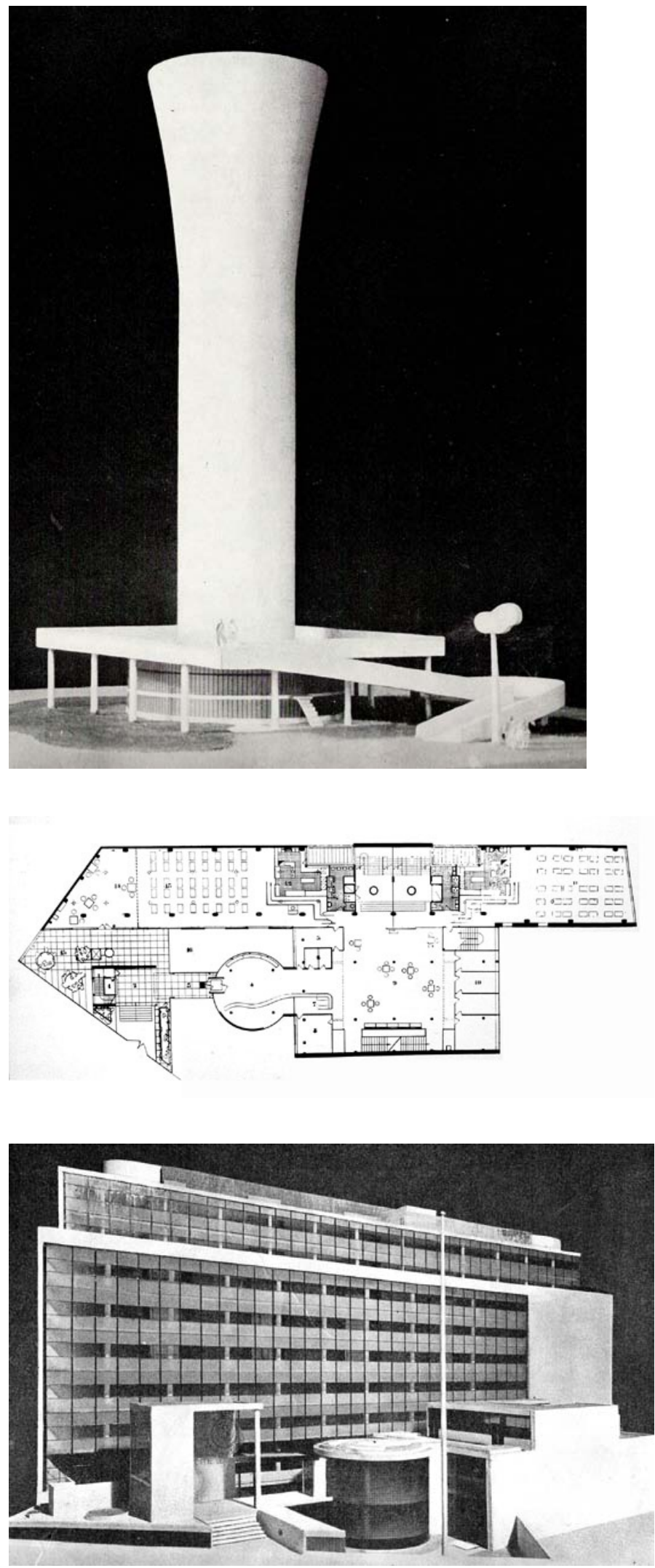

[211] Reservatório de água em Ribeirão das Lajes - 1940 - ON

(PAPADAKI, 1950:17)

[212] Cité Refuge - Paris - planta - Le Corbusier - 1929 (BOESIGER, 1947: 101)

[213] Cité Refuge - Paris - maquete - Le Corbusier - 1929

(BOESIGER, 1947: 97) 
Kenneth Frampton, em sua leitura sobre o reservatório de água em Ribeirão das Lajes, também ressalta a referência a casa Savoye, além de estabelecer uma ligação com a rampa do Pavilhão do Brasil em Nova York:

A plataforma quadrada que é a cobertura da casa de máquinas foi influenciada pelo pavimento térreo da casa Savoye, enquanto a rampa sinuosa e monumental que acessa sua cobertura lembra a rampa do Pavilhão Brasileiro na Feira Internacional de Nova York de 1939. (FRAMPTON apud BRILLEMBOURG, 2004:45).

A solução do cilindro conectado a marquise, comum à Casa de Baile e ao Pavilhão do Brasil em Nova York, já integrava o rol de soluções de Le Corbusier e está presente no acesso principal do edifício do Exército da Salvação em Paris (Cité Refuge ${ }^{61}$ ) (1929). [212], [213]

Apesar das semelhanças tipológicas, as soluções de Niemeyer diferem da elementarização purista de Le Corbusier. Em Niemeyer a proporção horizontal dos volumes se alastra, os objetos esparramam-se em um jogo multidirecional, e a curva, ao mesmo tempo em que conecta, envolve os volumes com superfícies ora transparentes (vidro), ora reflexivas (azulejo), ora opacas (granito apicoado). [214]

No projeto de Le Corbusier para a sede do Exército da Salvação, o cilindro transparente e a marquise são elementos autônomos, porém justapostos. Na Casa de Baile, Niemeyer integra os dois elementos sob um traço fluido e contínuo, conferindo unidade plástica a partir de um gesto único que transfigura a feição estanque da forma de filiação purista presente no exemplar de Le Corbusier. Niemeyer desmembra a lógica da associação de volumes a elementos arquitetônicos menores no instante em que arregimenta forma e programa em um contorno contínuo, gestual e inesperado. [215]

O latente desejo de separação dos volumes, presente no projeto do Cassino, efetiva-se na Casa de Baile. No Cassino, Niemeyer preserva uma conexão física entre o volume retangular do salão de jogos e o volume de planta oval do restaurante/pista de dança. $\mathrm{Na}$ Casa de Baile, o volume circular assume uma maior autonomia, possui contorno exterior pleno, mas o elemento de conexão entre os volumes ainda é preservado, representado, nesse caso, pela própria marquise, que interliga os dois volumes (salão de baile e vestiário). [216]

Para Luiz Recamán:

$\mathrm{Na}$ Casa de Baile (...) pode-se perceber claramente que um dos elementos do Cassino vai ser isolado e depurado: o volume curvo do restaurante.(...) Essa reconciliação volumétrica dá mais um passo no Cassino, quando o volume do restaurante cresce e tende a se independentizar. (...) $\mathrm{Na}$ Casa de Baile a independência


composição) reaparece, potencializado, individualizado e suficiente (RECAMÁN, 2002:156, grifo nosso).

Segundo Recamán, o desejo de uma articulação planar entre os objetos autônomos, pre$\overline{\text { 61. (Cf. BOESIGER,1971.p.115). }}$

189 | o encontro de 1936: formação 

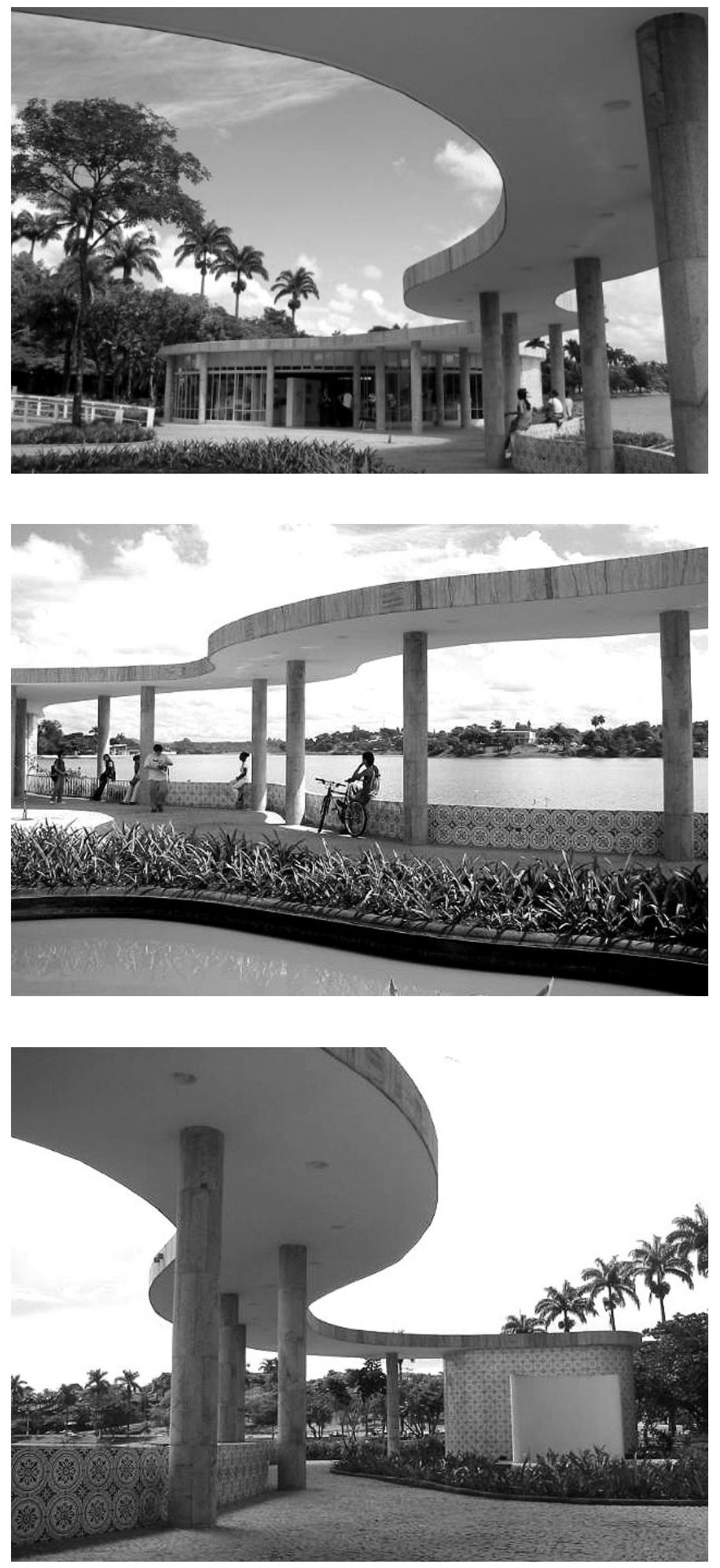

[214] Casa de Baile - 1940 - ON (Foto: Rodrigo Queiroz)

[215] Casa de Baile - 1940 - ON (Foto: Rodrigo Queiroz)

[216] Casa de Baile - 1940 - ON

(Foto: Rodrigo Queiroz) 
sente na Casa de Baile, já estava presente no bloco-terraço do Pavilhão do Brasil, onde a laje recortada em curva conecta o bloco expositivo ao volume trapezoidal do auditório. "Uma laje - cujo embrião é um mero elemento de ligação dos volumes do Pavilhão, (...)” (Idem:158).

No Pavilhão do Brasil, Niemeyer elabora o elemento de conexão, não como mera marquise, mas como moldura delgada que, ao mesmo tempo, enquadra a vista e abriga o homem.

$\mathrm{Na}$ Casa de Baile, a relação entre planos esbeltos e volumes de contornos e superfícies variadas assume uma configuração diversa daquela presente do Pavilhão do Brasil e no Cassino. A marquise da Casa de Baile é o elemento protagonista do conjunto. Tanto o volume de planta oval do restaurante/pista de dança, como o volume oblongo do vestiário estão recolhidos sob a projeção do contorno da marquise que assume um traçado ondulatório e fechado, que é ao mesmo tempo teto do restaurante e abrigo da vista para a lagoa e de onde se enquadra uma bela visual do próprio Cassino. Trata-se de uma precisa orquestração de efeitos: um belvedere abrigado por marquise ondulante implanta-se sobre ilhota artificial que, por sua vez, emerge de um lago tão artificial quanto.

As experiências sucessivas do MES, do Pavilhão do Brasil, do Cassino e da Casa de Baile ilustram uma crescente busca pela liberdade, diagnosticada na evolução dos procedimentos de organização hierárquica da forma livre.

A crescente emancipação plástica da forma arquitetônica em Niemeyer rebate-se no desenho da estrutura que, apesar de referenciar-se aos "cinco-pontos", lança mão de instrumentos que subvertem a modulação presente nos projetos de Le Corbusier realizados durante a década de 1920.

No projeto do MES já podemos observar a primeira ocorrência de uma "desobediência" à rigidez da trama constante de pilares presente nos exemplares corbusianos. No instante em que o bloco de exposições funde-se ao auditório, o renque de pilares desalinha-se e abre-se em leque para abrigar o volume trapezoidal do auditório. [217]

No Pavilhão do Brasil, o desdobramento assume um grau de liberdade ainda maior. O bloco de exposições - que adota a mesma solução do volume horizontal transparente sobre pilotis que caracteriza o bloco de exposições do MES - possui planta encurvada em sutil "S" e toda a trama de pilares acompanha a curvatura do bloco. Inexiste a idéia de modulação retangular. O volume de feição circular que abriga o salão de baile já está presente, porém ainda recluso ao interior do bloco de exposições. [218]

No Cassino, Niemeyer adota uma modulação diferente para cada bloco do edifício: retangular no salão de jogos, retangular distendida no pavilhão de serviços e radial no salão de dança/ restaurante que, nesse caso, migra para o meio externo. [219]

$\mathrm{Na}$ Casa de Baile não há o conceito de modulação, de trama. A disposição aparentemente aleatória dos pilotis é suporte para um plano horizontal suspenso, cujo recorte ondulatório elimina toda e qualquer possibilidade de inserção de um reticulado de apoios. O itinerário de exteriorização da forma circular que abriga o salão de dança é completado na Casa de Baile. [220]

Como podemos observar, a solução estrutural (apesar de ainda ser balizada pela organização de pilotis) evolui conforme a forma arquitetônica assume uma condição de liberdade e autonomia

191 | o encontro de 1936: formação 



[217], [218], [219], [220] plantas: MES (retícula que abre em leque) (UNDERWOOD,2002:39); Pavilhão do Brasil (retícula em "S") (Idem, 2002:53); Cassino (retículas quadrada, retangular e radial) (PAPADAKI, 1950:73); Casa de Baile (disposição dos apoios ao sabor da curva livre da marquise) (CASTRO, 2006:115) 
plástica cada vez maior.

Da sutil inflexão da retícula do MES à proposital aleatoriedade da Casa de Baile, Niemeyer desenha um percurso que deseja romper com a racionalidade hermética presente nos exemplares puristas de Le Corbusier, porém sem abrir mão de seus elementos constituidores: os planos e volumes suspensos, apoiados sobre pilotis.

Somente no projeto para a Igreja de São Francisco de Assis que Niemeyer superará o paradigma do esquema Dom-Ino, ao sublimar forma e estrutura em um mesmo traço.

A solução da marquise sinuosa sobreposta a um volume cilíndrico que caracteriza a Casa de Baile será incorporada por Niemeyer em projetos que sucedem a experiência em Pampulha.

O projeto para o Restaurante e garagem de barcos da Lagoa Rodrigo de Freitas (1944 - não construído) pode ser considerado como uma versão aérea e distendida do partido formal proposto na Casa de Baile.

No Restaurante da Lagoa, Niemeyer suspende o corpo cilíndrico da Casa de Baile. Ao elevar o cilindro raso, a marquise, que na Casa de Baile cumpre apenas função de cobertura, assume o papel de belvedere/passarela que conecta o salão circular do restaurante ao terraço coberto por abóbadas sucessivas em leque. $\mathrm{O}$ acesso ao cilindro suspenso é feito por rampa com curvatura em "U”, é o mesmo promenade presente no projeto para o Hotel Resort da Pampulha, cujo belvedere também se caracteriza como uma continuidade da rampa em "U”. [221]

Ao elevar o volume cilíndrico, Niemeyer suspende aquilo que Le Corbusier, na casa Savoye (1929), mantinha implantado diretamente no solo e abrigado sob a projeção do volume de perímetro quadrado.

Em suas vilas puristas, Le Corbusier condena a forma curva à condição de elemento dinâmico e expressivo subordinado à contensão da forma pura. Na casa Savoye, os elementos encurvados estão presentes em três situações distintas: no interior do volume prismático suspenso; nos páraventos da cobertura; e no fechamento transparente em semi-círculo no térreo. Nas três configurações a expressão da curva não despotencializa a virtude essencial da forma pura. Ao contrário, a curva como informação gráfica e visual enfatiza a ortogonalidade do corpo principal.

No Restaurante da Lagoa, Niemeyer promove à condição de protagonista aquilo que Le Corbusier preserva como elemento compositivo e coadjuvante. O volume circular do salão do restaurante não se encontra abrigado sob a projeção de uma laje, como na Casa de Baile. Ao contrário, emerge sobre a marquise sinuosa que agora também é piso. Trata-se de uma inversão literal da Casa de Baile. É quase como se o conjunto da marquise e do cilindro da Casa de Baile fosse virado ao contrário e depois suspenso.

A “inversão" presente no projeto do Restaurante da Lagoa indica mais uma evolução nas experiências diagnosticadas no Pavilhão do Brasil, no Cassino e na Casa de Baile.

O ballroom/restaurante de forma "circular" presente nos projetos de Niemeyer se torna cada vez mais pleno. Inicialmente, apresentava-se interno ao bloco em " $\mathrm{S}$ " do Pavilhão; no Cassino, migra para o exterior, mas ainda está conectado a um volume retangular; na Casa de Baile, apesar de estar sob a projeção da laje ondulante, já possui o contorno circular pleno; e finalmente,

193 | o encontro de 1936: formação 

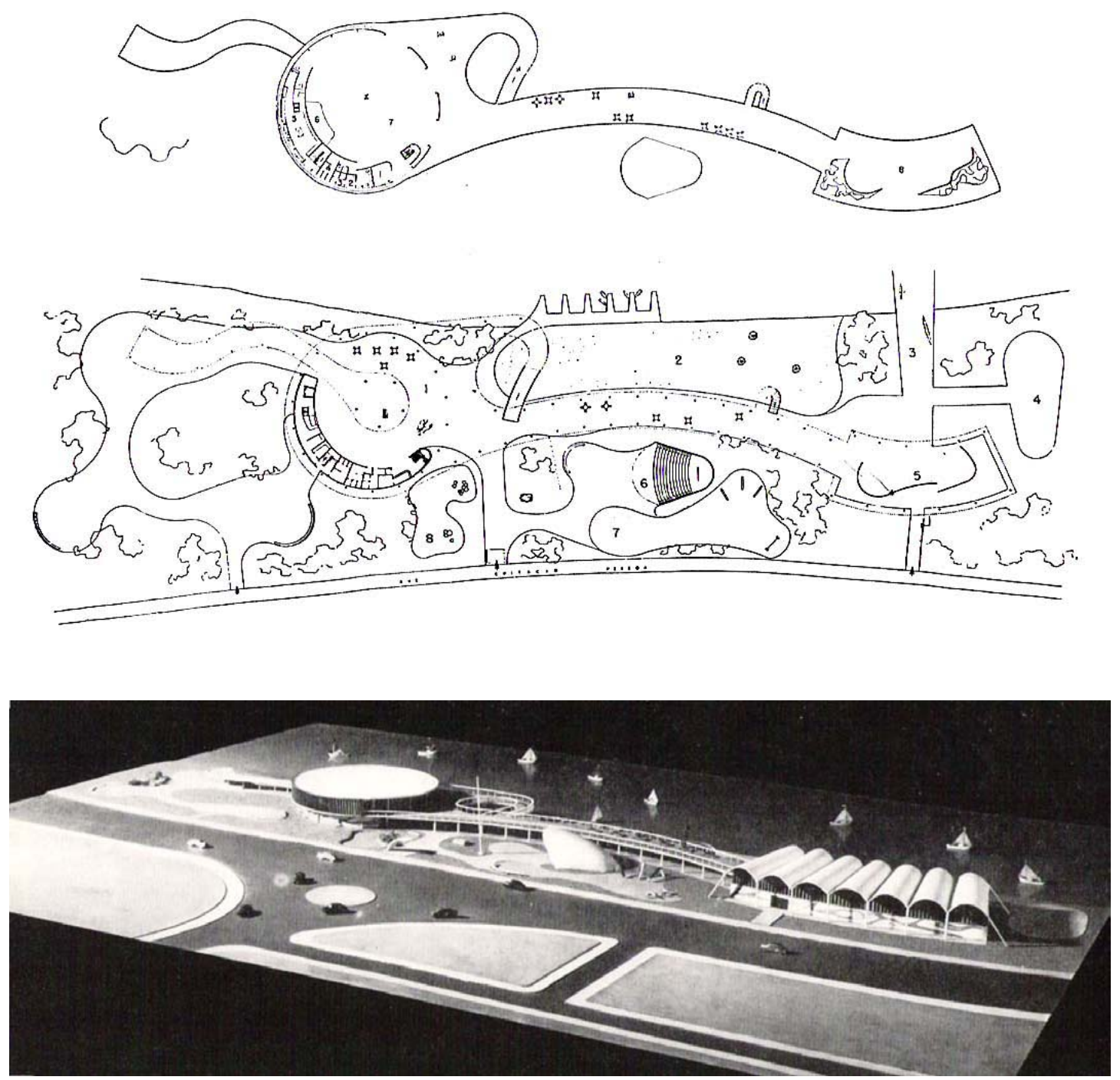

[221] Restaurante e garagem de barcos da Lagoa Rodrigo de Freitas - 1945 - plantas térreo e superior - ON (PAPADAKI, 1950:130)

[222] Restaurante e garagem de barcos da Lagoa Rodrigo de Freitas - 1945 - maquete - ON

(PAPADAKI, 1950:131) 
no Restaurante da Lagoa, a forma circular emancipa-se completamente, tornando integral todo o seu contorno.

O Restaurante da Lagoa figura como um projeto que incorpora diversas das soluções que integram os edifícios do Conjunto da Pampulha: a forma cilíndrica, a marquise sinuosa, a rampa curva e as abóbadas sucessivas que, nesse caso, descarregam sua carga no solo através de apoios inclinados. [222]

A planta circular, para Niemeyer, possui um sentido versátil. É o perfil envoltório que abriga os mais distintos programas, como podemos perceber nas formas cilíndricas presentes no Memorial da América Latina (1986). O restaurante (atual Galeria de Arte Marta Traba) configura-se como um cilindro raso envolvido por caixilho preto, e a estrutura se reduz a um único apoio central que sustenta a cobertura. No Parlamento Latino-americano, Niemeyer concebe uma planta em forma de anel e distribui os recintos administrativos na periferia do círculo, cujo interior fica reservado ao salão da assembléia. No Museu do Índio em Brasília, um percurso em espiral ascendente acompanha o desenho circular da planta e mantém o interior do círculo isolado do anel periférico. [223], [224], [225]

Em projetos como a sede da Cartiere Burgo em Turim (1979), o Centro Administrativo do Recife (1982), e a Estação das Barcas de Charitas em Niterói (1997/2004), Niemeyer usa a forma cilíndrica como uma plataforma circular que recebe um volume de menor dimensão, também caracterizado pela planta circular, seja o tronco de cone da Cartiere-Burgo e da Estação das Barcas ou a cúpula secionada do projeto em Recife. [226], [227], [228]

$\mathrm{O}$ advento da planta circular não terá como conseqüência formal apenas as formas cilíndricas. Basta lembrarmos que projetos como a Catedral Metropolitana de Brasília (1957), o Palácio das Artes do Parque Ibirapuera (Oca-1951/1954), o Museu de Arte Contemporânea de Niterói (1991) possuem plantas circulares e assumem volumetrias as mais diversas, que são conseqüência da extrusão radial do perfil exterior do corte. [229], [230], [231]

Como podemos observar, Niemeyer condiciona o programa à forma. A planta circular, além propiciar volumetrias diversas do cilindro, abriga os mais distintos usos: templos, auditórios, teatros, museus, restaurantes, hotéis, edifícios de apartamentos, entre outros.

Em Niemeyer, a liberdade é exaustivamente calculada. Não há aproximações, o traço é preciso. O rigor geométrico de seus desenhos confere unidade e equilíbrio a um gesto que, a primeira vista, parece surgir ao acaso.

A curva de Niemeyer é construída pela concordância entre arcos e retas. Não é, como o próprio arquiteto diz, "desfibrada":

"A própria curva, que tanto os perturbava, era por eles desenhada de forma frouxa e desfibrada, não a sentindo, como nós, estruturada, feita com curvas e retas." (NIEMEYER, 1978: 32, grifo nosso).

Para Niemeyer, a solução final é conseqüência de um exercício exaustivo que busca a resposta a partir da realização de inúmeros estudos que ilustram o processo de amadurecimento da idéia. Na maioria de seus projetos posteriores a 1953, tanto as curvas em corte (abóbadas, cúpulas,

195 | o encontro de 1936: formação 



[223] Restaurante do Memorial da América Latina (atual Galeria Marta Traba) - corte -1987 - ON

(BOTEY, 1996:224)

[224] Parlamento Latino-americano - Memorial da América Latina - corte - 1991 - ON (BOTEY, 1996:229)

[225] Museu do Índio - Brasília - corte - $1981-\mathrm{ON}$

(BOTEY, 1996:229)
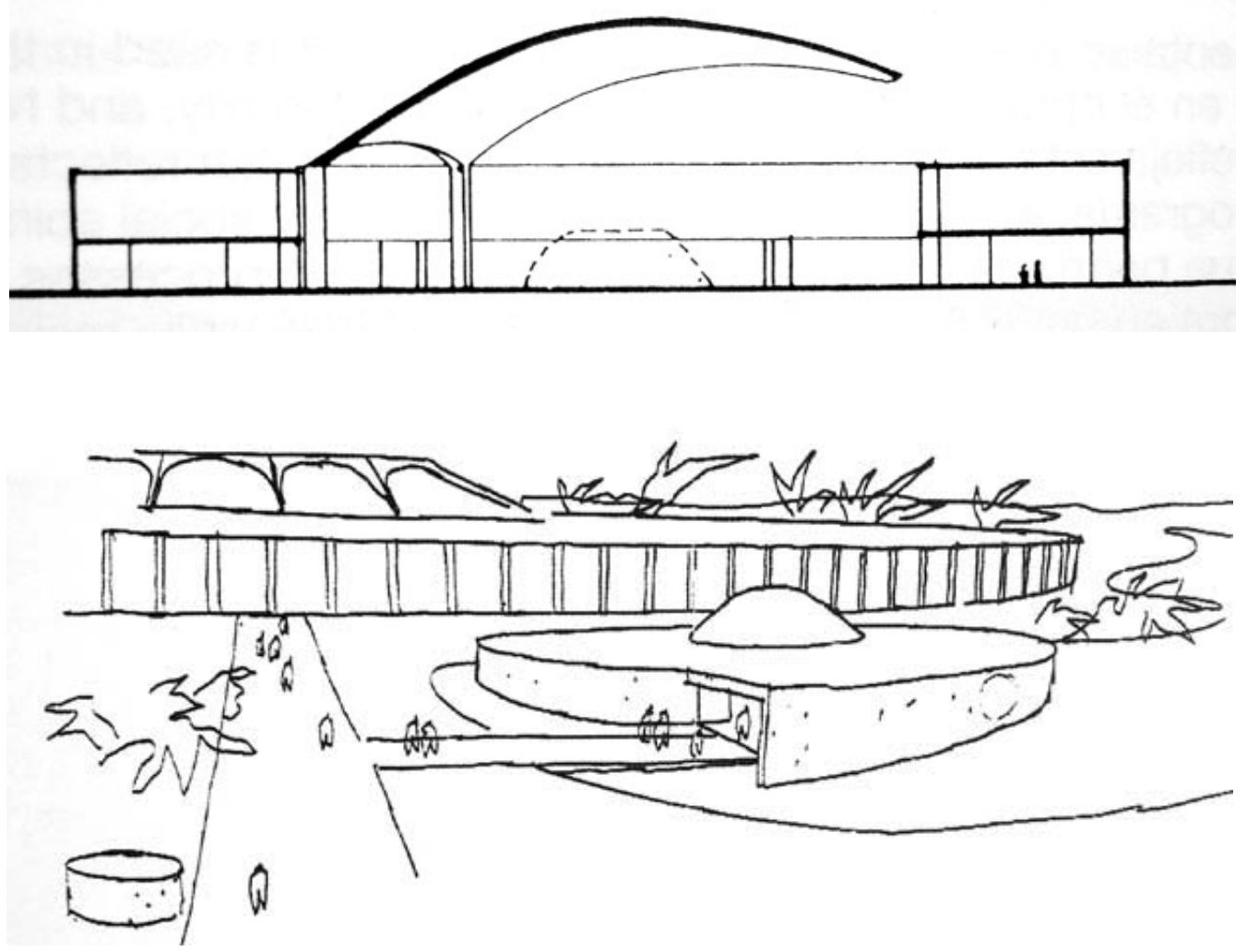

[226] Cartiere-Burgo - Turim - 1978 - ON (PUPPI, 1988:130) 
coberturas côncavas e ondulantes) como as curvas em planta (marquises, rampas, plantas circulares, lâminas arqueadas e fechamentos verticais curvos), são oriundas de uma construção geométrica que concorda segmentos de reta com segmentos de arco.

Nos desenhos das marquises da Casa de Baile e do Hotel Resort da Pampulha, quase não se nota a presença de segmentos de reta, apenas de segmentos de arco. Com a concordância entre segmentos de arco, a intensidade sinuosa do desenho das marquises é aumentada. Nesses projetos, o gesto ainda ondula, oscila entre a curva e a contra-curva.

A marquise do Hotel da Pampulha, diferentemente da marquise da Casa de Baile, não cumpre o papel de abrigo de um percurso entre dois elementos, é uma grande laje orgânica que cobre os recintos sociais e de lazer delimitados por caixilharia curva configurada pelas réguas verticais. A marquise do Hotel Resort, além de abrigo, também é belvedere, que é acessado por rampa encurvada. [232], [233], [234]

No Hotel Resort da Pampulha, assim como no Cassino, Niemeyer também lança mão do fechamento transparente e encurvado em elipse aberta que difere do oval fechado da Casa de Baile. [235]

A idéia do caixilho de "percurso livre" sob laje estruturada por retícula de pilares, preconizada por Le Corbusier na casa Savoye, será recorrente em Niemeyer. Enquanto na casa Savoye Le Corbusier contrapõe a liberdade do caixilho curvo à estanqueidade do volume prismático que o sobrepõe, em projetos de Niemeyer como a Casa de Baile e o Hotel Resort o caixilho curvo estabelece um arranjo combinatório com a sinuosidade da laje acima dele, resultando em uma sobreposição de curvas: a curva da matéria opaca sobreposta à curva da matéria transparente.

A sinuosidade ondulante, conseqüência da concordância entre segmentos de arco, presente nas marquises da Casa de Baile e do Hotel Resort, será revisitada por Niemeyer em projetos como o Hotel Quitandinha em Petrópolis (1950) e a Fábrica Duchen em São Paulo (1950).

No projeto do Hotel Quitandinha, Niemeyer lança mão da sinuosidade das marquises da Pampulha a serviço de um objeto de dimensões titânicas. Quando a proporção das marquises aumenta de tamanho, o contorno sinuoso perde parte de sua elementaridade, e torna arbitrário aquilo que em Pampulha era preciso.

No Hotel Quitandinha, na Fábrica Duchen e, até mesmo, na primeira versão para o conjunto arquitetônico do Parque Ibirapuera (1951/1953) o arranjo ondulatório da concordância entre os segmentos de arco não possui a mesma singeleza da Casa de Baile, pois a escala do edifício é aumentada, porém a escala da curva é preservada. [236], [237], [238] [239]

Quando as proporções dos projetos se agigantam, a composição sinuosa necessita adequarse a dimensões monumentais. Nesse instante, Niemeyer abandonará as composições oriundas da concordância apenas de segmentos de arco (curva e contra-curva) e intercalará segmentos de reta entre os segmentos de arco. A gestualidade ondulante presente na Casa de Baile, no Hotel da Pampulha e na Fábrica Duchen é substituída por movimentos que distendem a curva a partir da adição de segmentos de reta concordantes. Trata-se de um procedimento que se contrapõe à curva "desfibrada".

197 | o encontro de 1936: formação 

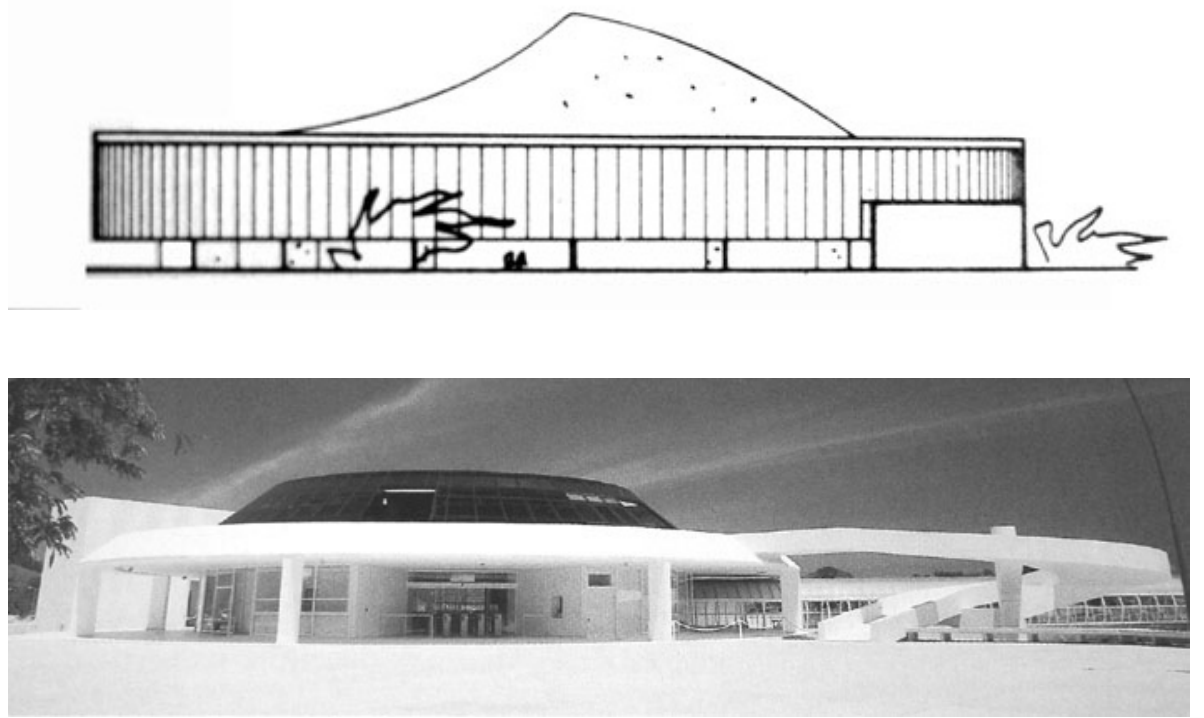

[227] Centro Administrativo em Recife - 1980 $-\mathrm{ON}$

(Revista Módulo n.58, abril/maio 1980:73)

[228] Estação das barcas em Charitas - Niterói $-2001-\mathrm{ON}$

(Revista Arquitetura e Urbanismo n.129, dezembro/2004:49)
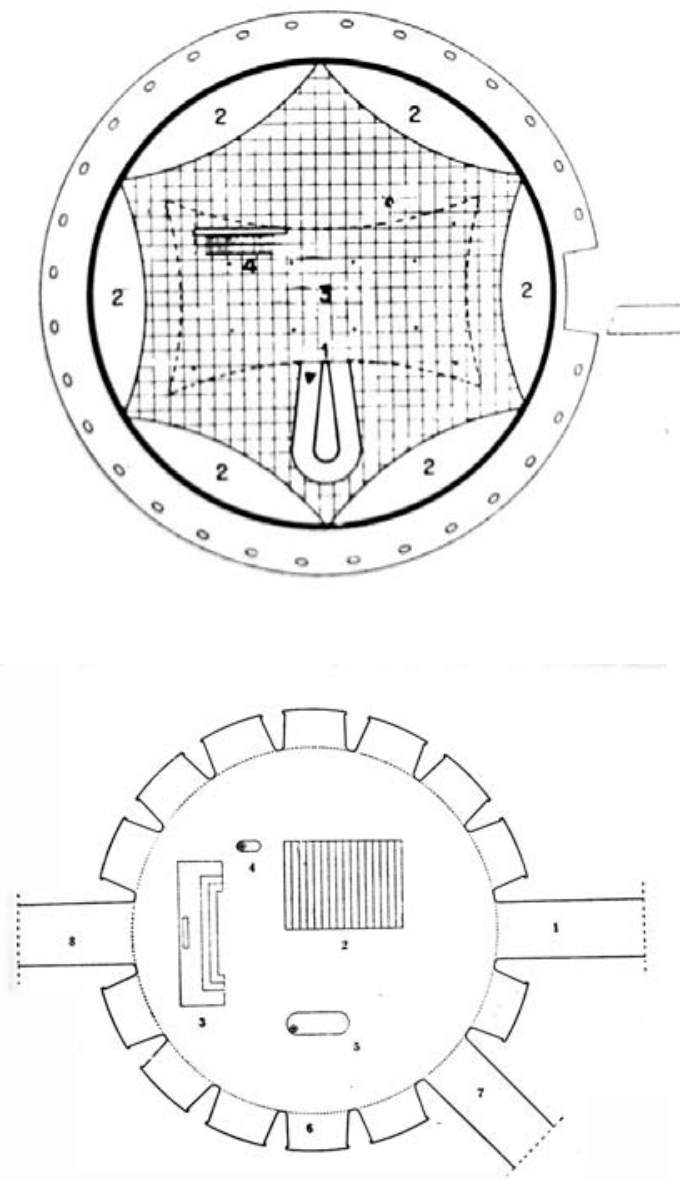

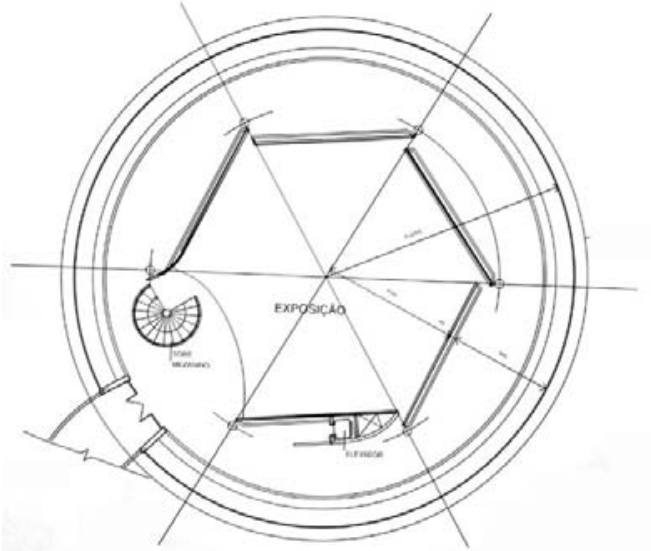

[229] Palácio das Artes - Conjunto do Parque Ibirapuera - São Paulo - planta primeiro pavimento - 1951/1954 - ON. (Revista Módulo n.1, março/1955:25)

[230] Catedral Metropolitana de Brasília - planta - 1958 - ON (Revista Módulo n.11, dezembro/1958:13)

[231] Museu de Arte Contemporânea de Niterói - planta salão de exposições - 1991 - ON

(NIEMEYER, 1997:44) 
No projeto definitivo para o conjunto arquitetônico do Parque Ibirapuera, podemos observar no desenho da marquise a continuidade de um traço que não se faz meramente sinuoso como na Casa de Baile, mas distende-se para encontrar o sentido de unidade em um gesto que assume uma escala monumental.

Para Luis Eduardo Borda, o projeto definitivo do conjunto arquitetônico do Ibirapuera (1953/1954) já prenunciava a fase caracterizada pela concisão e simplicidade, representada de maneira emblemática pelo projeto do Museu de Arte de Caracas (1955). Segue trecho do autor:

Ponto de inflexão da obra de Oscar Niemeyer, o projeto para o Museu de Caracas assinala um claro direcionamento do arquiteto rumo às formas compactas, de forte sentido escultórico. A meu ver, alias, esse direcionamento já estava anunciado no projeto para o Ibirapuera, marcado pela austeridade geométrica dos edifícios destinados às exposições (prismas retangulares), bem como pelo caráter compacto do Pavilhão das Artes e do Auditório (BORDA 2003:137, grifo nosso)

O projeto para a residência particular do arquiteto $^{62}$ na estrada de Canoas no Rio de Janeiro (1953), expressa com precisão o instante em que a mera sinuosidade ganha um senso de unidade através da associação entre curvas e retas.

Diferentemente da Pampulha, em Canoas Niemeyer não demonstra um compromisso atento as superfícies tradicionais dos azulejos e da pedra apicoada. O pilar é um tubo de aço pintado de preto, e a aspereza da pedra que reveste as espessuras das marquises de Pampulha já não se faz presente em Canoas. Nesse projeto, Niemeyer muda o foco do sentido criativo, que parece migrar da diversidade compositiva forma/superficie de Pampulha para uma essencialidade que, para se emancipar enquanto produto singular, não necessita mais do apoio da pictorialidade nativista das superfícies enriquecidas por revestimentos tradicionais. [240]

A laje de contorno sinuoso que caracteriza o projeto da casa de Canoas é o abrigo dos espaços de estar, refeição e cozinha. Todas as dependências íntimas da casa estão implantadas abaixo do ambiente protegido pela laje curva, acomodadas em um recorte no declive presente no fundo do terreno. [241], [242]

Em Canoas, Niemeyer afasta-se tanto do diálogo com as estratégias corbusianas como das referências vernaculares presentes em seus projetos de residências realizados durante as décadas de 1930 e 1940.

Apesar da evidente liberdade formal presente em Canoas, podemos traçar uma aproximação com as experiências de Mies van der Rohe em projetos como o Pavilhão da Alemanha em Barcelona (1929) e na casa Tungendhat (1928).

Assim como Mies no Pavilhão de Barcelona, Niemeyer em Canoas preocupa-se em

62. Aos moldes dos grandes nomes da arquitetura moderna, Niemeyer também sintetizará no projeto de uma simples residência toda a intensidade de uma pesquisa pessoal.

Alguns expoentes da arquitetura moderna como Mies van der Rohe e a casa Farswoth (1929), Le Corbusier e a casa Savoye (1929), Frank Lloyd Wrigth e a casa Kauffman (1939 - Fallingwater House) e Alvar Aalto e a casa Mairea (1938), Niemeyer com a casa de Canoas realiza um projeto rigoroso que ilustra a reflexão pessoal sobre temas como: técnica, forma, a escala do homem e a relação entre o objeto construído e a paisagem.

199 | o encontro de 1936: formação 

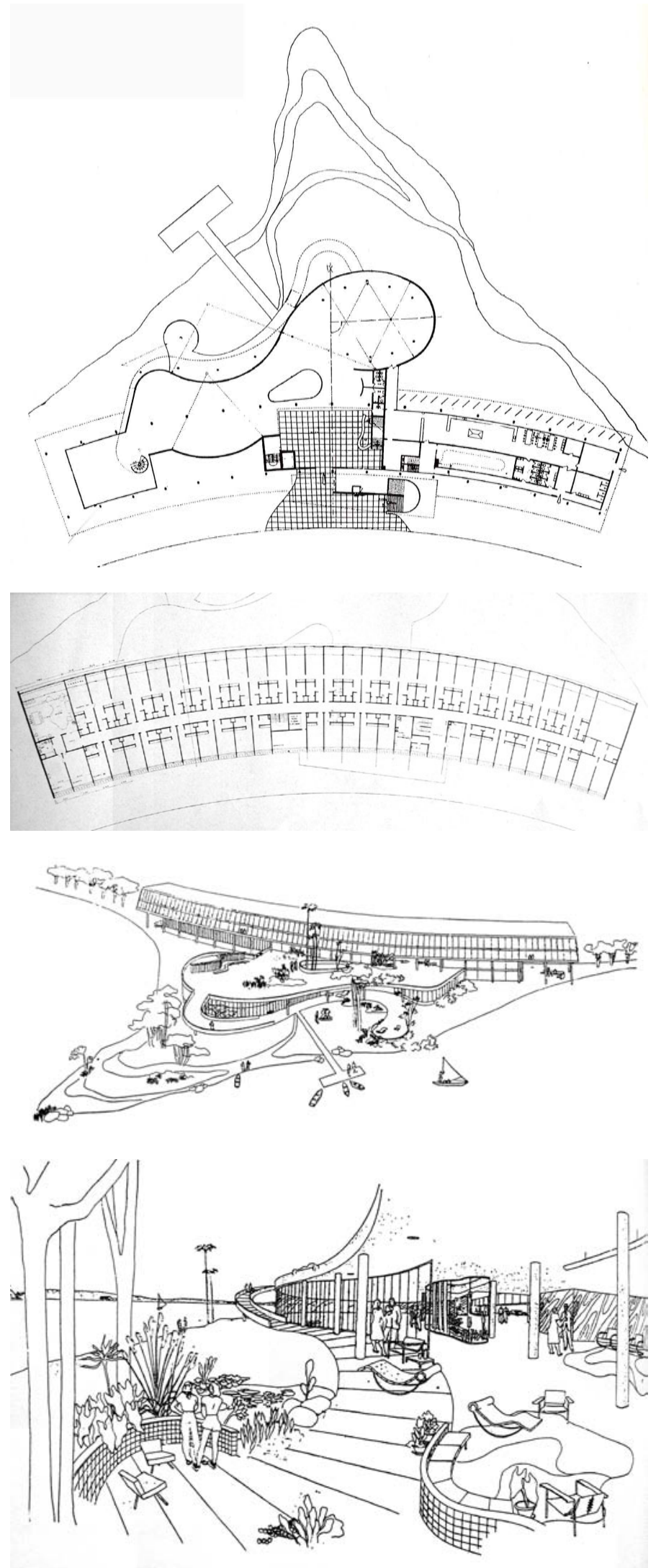

[232], [233] Hotel Resort da Pampulha plantas dos níveis térreo e dormitórios - 1943 - ON(GOODWIN, 1944:s.n.)

[234], [235] Hotel Resort da Pampulha perspectiva de todo o projeto e perspectiva dos espaços comuns - 1943 - ON (PAPADAKI, 1950: 104, 105) 
conferir uma autonomia física e espacial aos elementos planares e lineares que constituem o projeto. A esbeltez do caixilho que separa a área de estar da área externa permite que, em uma mesma visada exterior, se percorra quase toda a face inferior da laje sinuosa que adentra o recinto de estar. Não há ruído, nem obstáculos na construção das miradas. As perspectivas são vigorosas, a concavidade no recorte ondulante da laje é o contraponto à pedra que aflora de dentro da piscina e invade o interior do salão envidraçado. [243], [244], [245]

O piso preto que acompanha a projeção da laje de cobertura - dramatização da penumbra presente no estar abrigado em sombra - enfatiza a leveza da laje alva, suspensa por finíssimas colunas metálicas. Nesse efeito em chiaro/ oscuro, Niemeyer resolve com precisão a equação entre forma, paisagem e técnica.

Os fechamentos encurvados das salas de estar e jantar encontram no revestimento em ripas verticais de madeira o meio-termo apropriado entre o piso preto e a laje branca. Tal artifício lembra o espaço curvo que Mies van der Rohe elabora para abrigar o ambiente de refeições da casa Tungendhat $^{63}$ (o gesto de Mies não é aberto como o de Niemeyer em Canoas, é um semi-círculo).

O diálogo entre Niemeyer e Mies van der Rohe presente em Canoas não deve ser compreendido como uma referência direta. A essência da linguagem gráfica de Niemeyer é oposta à de Mies, mas o sentido que as aproxima reside no desejo de uma síntese espacial, só possível a partir da emancipação dos cinco componentes do projeto: coluna, cobertura, piso, fechamentos opacos e transparentes. [246], [247], [248], [249], [250]

No projeto da casa de Canoas, Niemeyer torna "habitável" o contorno sinuoso da marquise sinuosa preconizada na Casa de Baile, mas esse tipo de solução já estava presente na marquise do próprio Hotel da Pampulha que assume dupla função: abrigo e terraço.

As plantas dos ambientes abrigados por marquise sinuosa em projetos como a casa BurtonTremaine (1947) e o Hotel Quitandinha em Petrópolis (1950), exibem um jogo gráfico entre o desenho da caixilharia curva e a projeção da laje sinuosa de cobertura. Os percursos das diferentes curvaturas são autônomos, independentes, porém há uma clara intenção compositiva entre as curvas da laje de cobertura e do caixilho. [251], [252]

$\mathrm{Na}$ Casa de Baile, em que pese a liberdade do traçado da marquise, o fato de seu desenho alinhar-se a caixilharia - o que, inclusive confere seu formato cilíndrico - demonstra uma interdependência entre cobertura e caixilho transparente. Essa correspondência entre os traçados dos fechamentos e das marquises irá se diluir conforme a dimensão dos projetos aumenta.

No projeto do Hotel Resort, a experiência da Casa de Baile é transposta para um outro patamar de complexidade. A maior escala do edifício e a especificidade do programa exigem do arquiteto uma solução que transcenda a mera marquise sinuosa que conecta volumes de dimensões modestas e de traçados também sinuosos. A marquise de traçado ondulante, que na Casa de Baile cumpria o papel de abrigo, no Hotel Resort é utilizada tanto como cobertura e como piso suspenso, reconhecido como um generoso belvedere que serve de embasamento para a barra encurvada

63. (Cf. BLASER, ).

201 | o encontro de 1936: formação 

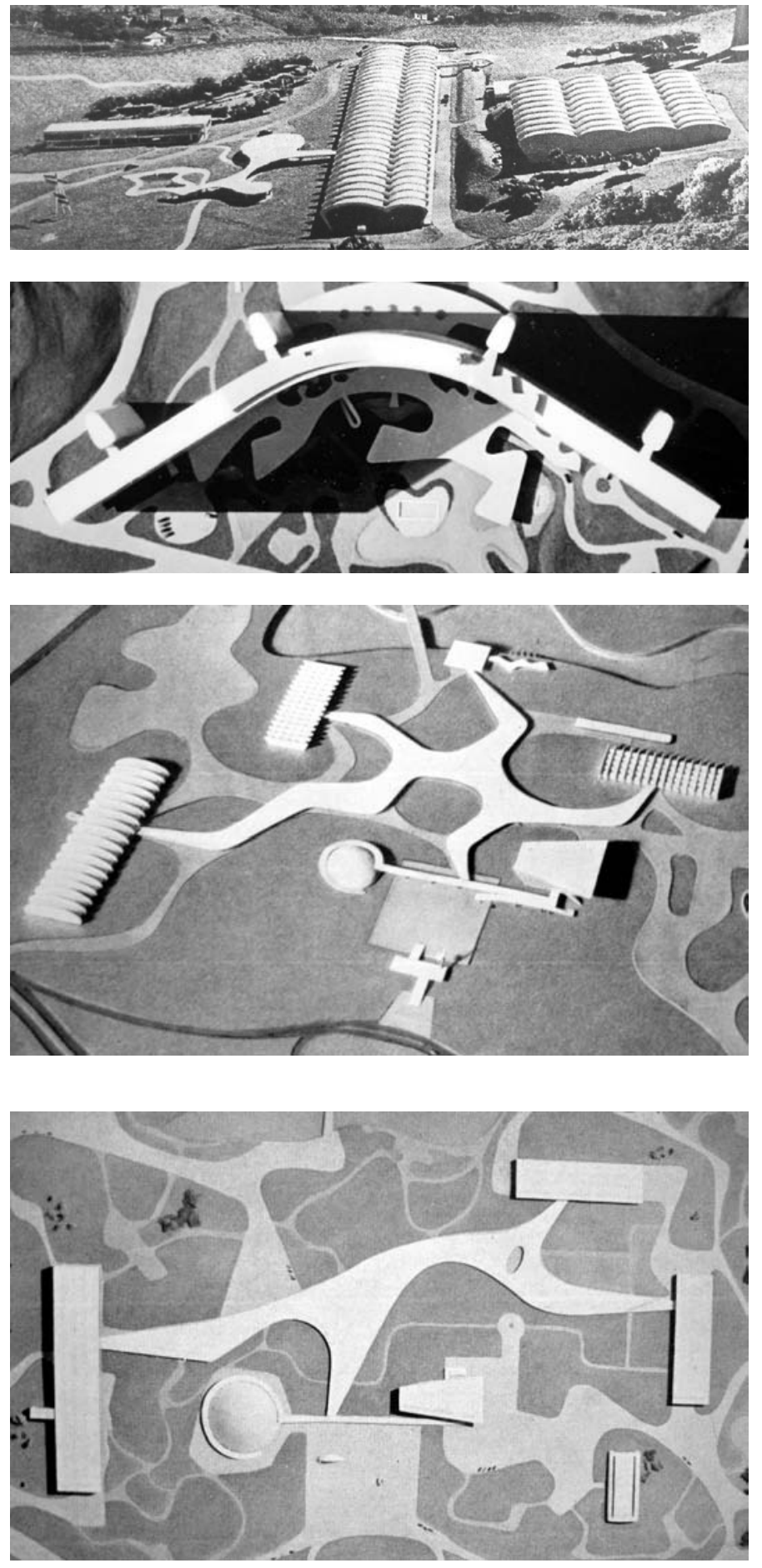

[236] Fábrica Duchen - São Paulo - 1950 - ON (CAVALCANTI, 2001:281)

[237] Hotel Quitandinha - Petrópolis - 1951 - ON

(PAPADAKI, 1956:20)

[238] Conjunto arquitetônico do Parque

Ibirapuera - São Paulo - versão preliminar 1951/1953 - ON

(Revista Módulo nº1, março/1955:19)

[239] Conjunto arquitetônico do Parque Ibirapuera - São Paulo - versão definitiva 1951/1953 - ON

(Revista Módulo nº1, março/1955:21) 
que contém os apartamentos. Trata-se de uma plataforma suspensa, instância planar intermediária entre o volume dos apartamentos e o chão.

A seguir abordaremos projeto do Hotel Resort da Pampulha, a partir da análise de sua solução formal, cujo partido, dado pela relação entre plataforma sinuosa e lâmina encurvada, fundamentou diversos projetos de Niemeyer realizados durante as décadas seguintes, como o Hotel Quitandinha em Petrópolis (1950), o edifício Copan em São Paulo (1951), e Biblioteca Municipal de Belo Horizonte. 

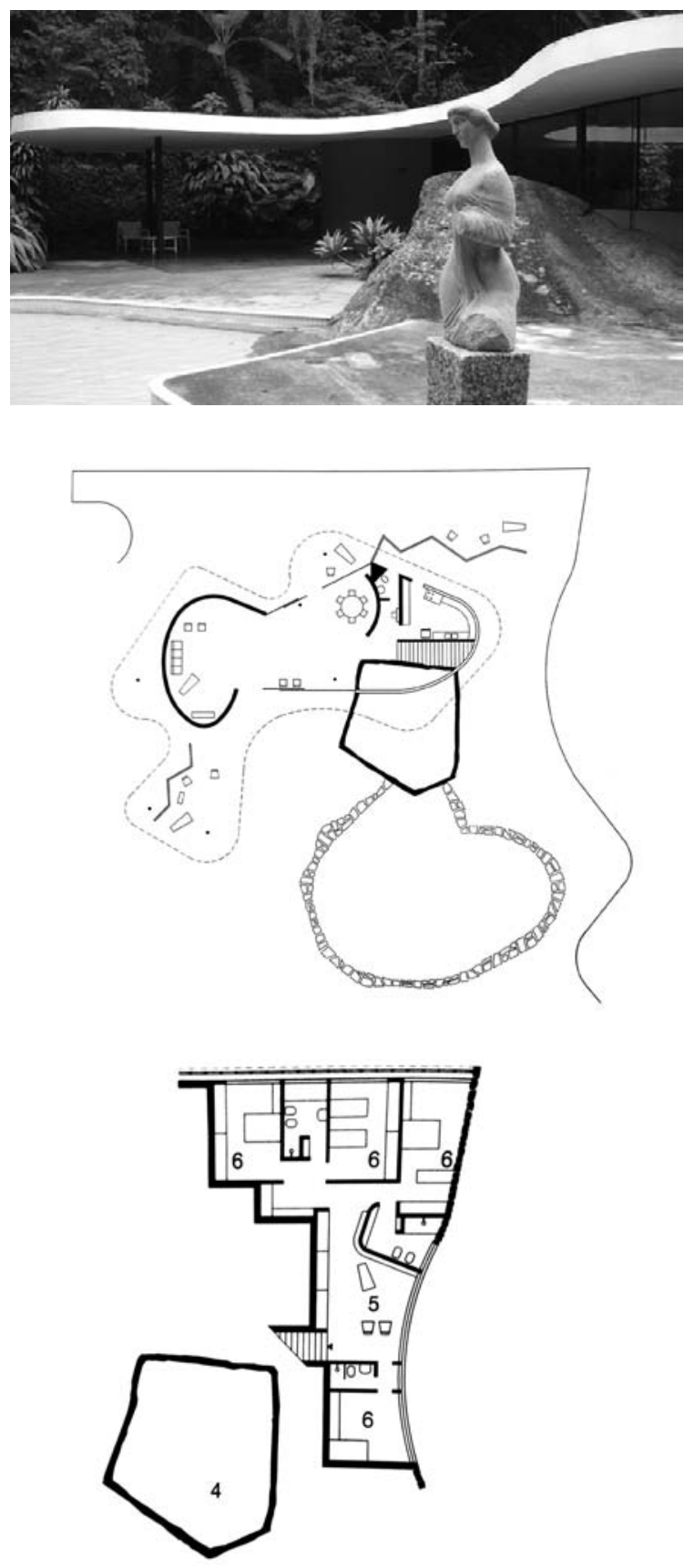

[240] Residência do arquiteto em Canoas - Rio de Janeiro - 1953 - ON(Foto: Rodrigo Queiroz)

[241] Residência do arquiteto em Canoas - Rio de Janeiro - 1953 - planta térreo - ON

(UNDERWOOD, 2002:76)

[242] Residência do arquiteto em Canoas - Rio de Janeiro - 1953 - planta nível inferior - ON (UNDERWOOD, 2002:76) 



[243] Pavilhão da Alemanha na Feira Internacional de Barcelona - 1929 - Mies van der Rohe

(VÁZQUEZ: 1999, s.n.)

[244], [245] Residência do arquiteto em Canoas - Rio de Janeiro - 1953 - ON

(Foto: Rodrigo Queiroz) 

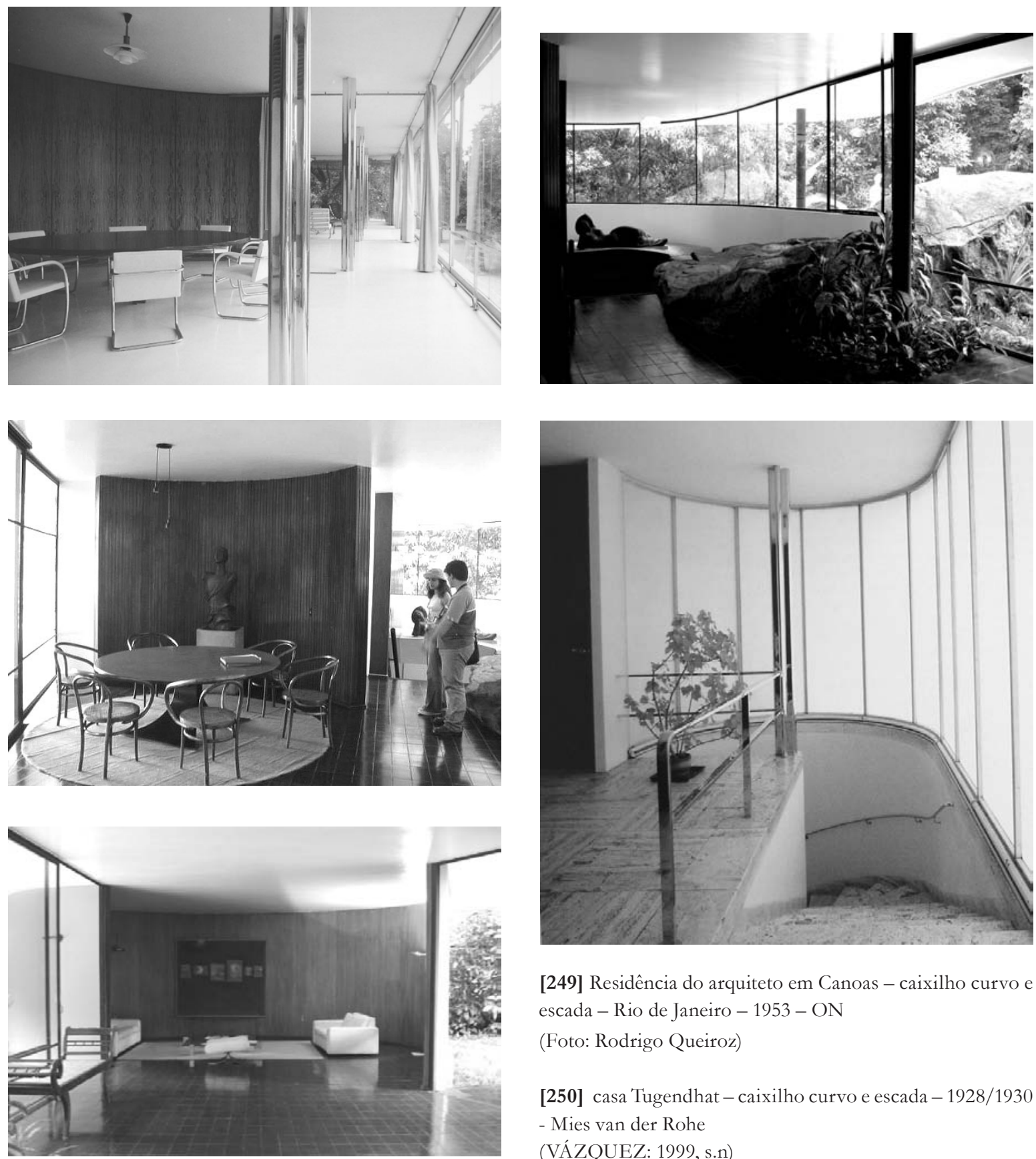

[249] Residência do arquiteto em Canoas - caixilho curvo e escada - Rio de Janeiro - 1953 - ON

(Foto: Rodrigo Queiroz)

[250] casa Tugendhat - caixilho curvo e escada - 1928/1930 - Mies van der Rohe (VÁZQUEZ: 1999, s.n)

[246] casa Tugendhat - sala de jantar - 1928/1930 -

Mies van der Rohe

(VÁZQUEZ: 1999, s.n)

[247], [248] Residência do arquiteto em Canoas - estar e jantar - Rio de Janeiro - 1953 - ON

(Foto: Rodrigo Queiroz) 

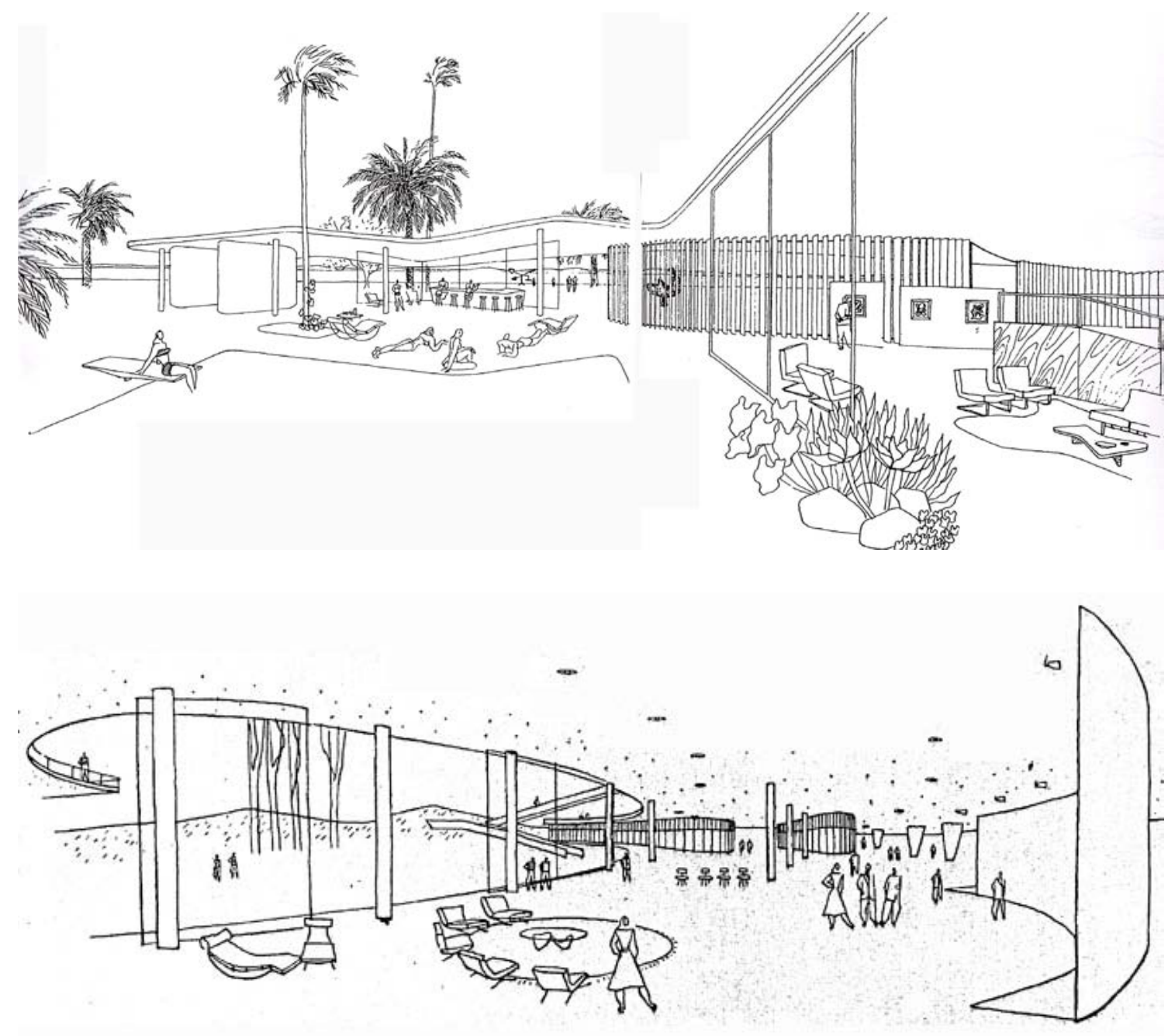

[251] Residência Burton Tremaine - Santa Bárbara - Califórnia - perspectiva - 1947 - projeto - ON (PAPADAKI, 1950:188, 189)

[252] Hotel Quitandinha - Petrópolis - perspectiva -1950 - projeto - ON

(PAPADAKI, 1956:33) 


\section{Curva sobre curva e a relação entre lâmina e plataforma}

Além da marquise sinuosa, no Hotel Resort da Pampulha Niemeyer fará uso de outras três soluções que serão recorrentes em seus projetos futuros: o bloco curvo, a fachada inclinada e o telhado invertido.

O Hotel da Pampulha representa a primeira ocorrência da utilização da lâmina encurvada na obra de Oscar Niemeyer. Essa solução figurará em inúmeros projetos do arquiteto: a Biblioteca Municipal de Belo Horizonte (1955), o Plano Urbanístico de Grasse na França (1967), o Pavilhão da Criatividade do Memorial da América Latina (1986), o Museu do Cinema em Niterói (1997), entre outros.

O princípio do bloco encurvado que caracteriza o Hotel da Pampulha já havia sido experimentado por Le Corbusier no projeto urbanístico para a cidade do Rio de Janeiro ${ }^{64}$, realizado em 1929, por ocasião de sua primeira visita ao Brasil. O arquiteto elabora gigantescas serpentinas que se acomodam no estreito escarpado entre as montanhas e o oceano.

A lâmina encurvada que abriga os apartamentos do Hotel da Pampulha está longe de materializar uma referência ao projeto urbanístico de Le Corbusier para o Rio de Janeiro. O projeto de Niemeyer é um fragmento diminuto da proposta de Le Corbusier, mas que guarda em sua natureza formal o mesmo princípio aplicado no projeto carioca do mestre franco-suíço.

Essa não era a primeira experiência de Niemeyer com o programa de hotel. O arquiteto já havia projetado o Grande Hotel de Ouro Preto ${ }^{65}(1938)$ que, apesar de sua feição vincular-se a tradição colonial, seu partido assemelha-se ao do Hotel da Pampulha (1943): bloco linear horizontal sobre pilotis, elevado sobre plataforma suspensa que abriga o restaurante e os recintos sociais e de lazer. [253], [254], [255]

Segundo Carlos Eduardo Comas:

Niemeyer volta à estrutura independente e à curva no Hotel, quase tão absoluta quanto na Casa do Baile mas implicando agora a deformação regrada de figura ortogonal ou a forma composta, normal e equivocadamente dita livre. (...) Como no Hotel de Ouro Preto, o partido superpõe o setor de apartamentos priva-

64. A análise do plano urbanístico de Le Corbusier para a cidade do Rio de Janeiro está presente no capítulo XX.

65. (Cf. VALLE, 2000:107-120). 
tivos ao setor de espaços públicos e serviços, cada um com dois andares. Aqui, porém, a barra se arqueia e o térreo se expande, gerando uma cruz (COMAS apud CASTRO, 2006:141)

No projeto para o Hotel Regente no Rio de Janeiro (1949), Niemeyer estabelece um paralelo mais estreito com o projeto de Belo Horizonte: mantém a tipologia da barra horizontal com fachada inclinada sobreposta à plataforma sinuosa.

O projeto para o Hotel Quitandinha em Petrópolis pode ser considerado como o desdobramento mais eloqüente e monumental do Hotel da Pampulha. Trata-se de uma única lâmina curva que abrigaria 5.700 apartamentos, divididos em cinco tipologias diferentes distribuídas pelos 32 pavimentos $^{66}$. Niemeyer coloca as circulações horizontais em andares alternados, com a distribuição em meio nível para as unidades duplex. Esse tipo de solução lembra a distribuição proposta por Le Corbusier para a Unité d'Habitacion (1946). Essa não será a única semelhança entre os projetos.

Para ilustrar a relação entre a projeção da área construída e a área de intervenção, Niemeyer sobrepõe o desenho da lâmina a uma quadrícula, onde cada célula do quadriculado representa um apartamento. Com esse desenho, o arquiteto compara seu projeto em delgada lâmina curva a uma suposta ocupação rarefeita que certamente seria desastrosa. Esse mesmo tipo de ilustração (com exatamente o mesmo significado e intenção) é realizado por Le Corbusier para ilustrar a mesma idéia no projeto da Unité d'Habitation. [256], [257], [258], [259], [260]

Em um outro estudo realizado para o Hotel Quitandinha, Niemeyer divide os apartamentos em duas lâminas separadas, ambas curvas, uma delas oriunda de um único arco e a outra com traçado ondulante, resultado da concordância de três arcos alternados. Ambas as torres, assim como no primeiro projeto, estão sobrepostas à marquise sinuosa e possuem pilar em "V". Em um dos estudos realizados por Niemeyer para o edifício Copan ${ }^{67}$ (1951) em São Paulo, notamos a presença da mesma ondulação na lâmina presente na proposta que divide o Hotel Quitandinha em duas lâminas separadas, além da adoção do pilar em "V" e das abóbadas suspensas por apoios inclinados na cobertura. Tanto a ondulação excessiva da lâmina como o pilar em "V" e as formas livres da cobertura serão abandonados na solução final do edifício, cuja dimensão monumental seria incompatível com a adoção de elementos formais de viés compositivo. [261], [262], [263], [264]

No projeto definitivo do edifício Copan, a lâmina encurva-se em dois arcos alternados, resultando em uma planta em "S", a marquise sinuosa tem suas dimensões reduzidas, se comparada com a marquise do Hotel Quitandinha, devido às dimensões menores do lote inserido no centro da cidade de São Paulo.

A adoção dos grandes brises horizontais de concreto no Copan enfatizam o movimento horizontal da fachada principal. A eliminação estratégica de poucos brises confere um aspecto dinâmico à ondulatória.

Com o advento dos brises, a materialidade do edifício dissolve-se em uma seqüência de planos horizontais sobrepostos que mantém os caixilhos incógnitos, preenchidos pela sombra provocada pelos próprios brises. Com esse artifício, Niemeyer atribui uma leitura horizontal e aérea a

66. Mesmo número de pavimentos do edifício Copan (Cf. PAPADAKI, 1956;41).

67. (Cf. BARBARA, 2004).

209 | o encontro de 1936: formação 

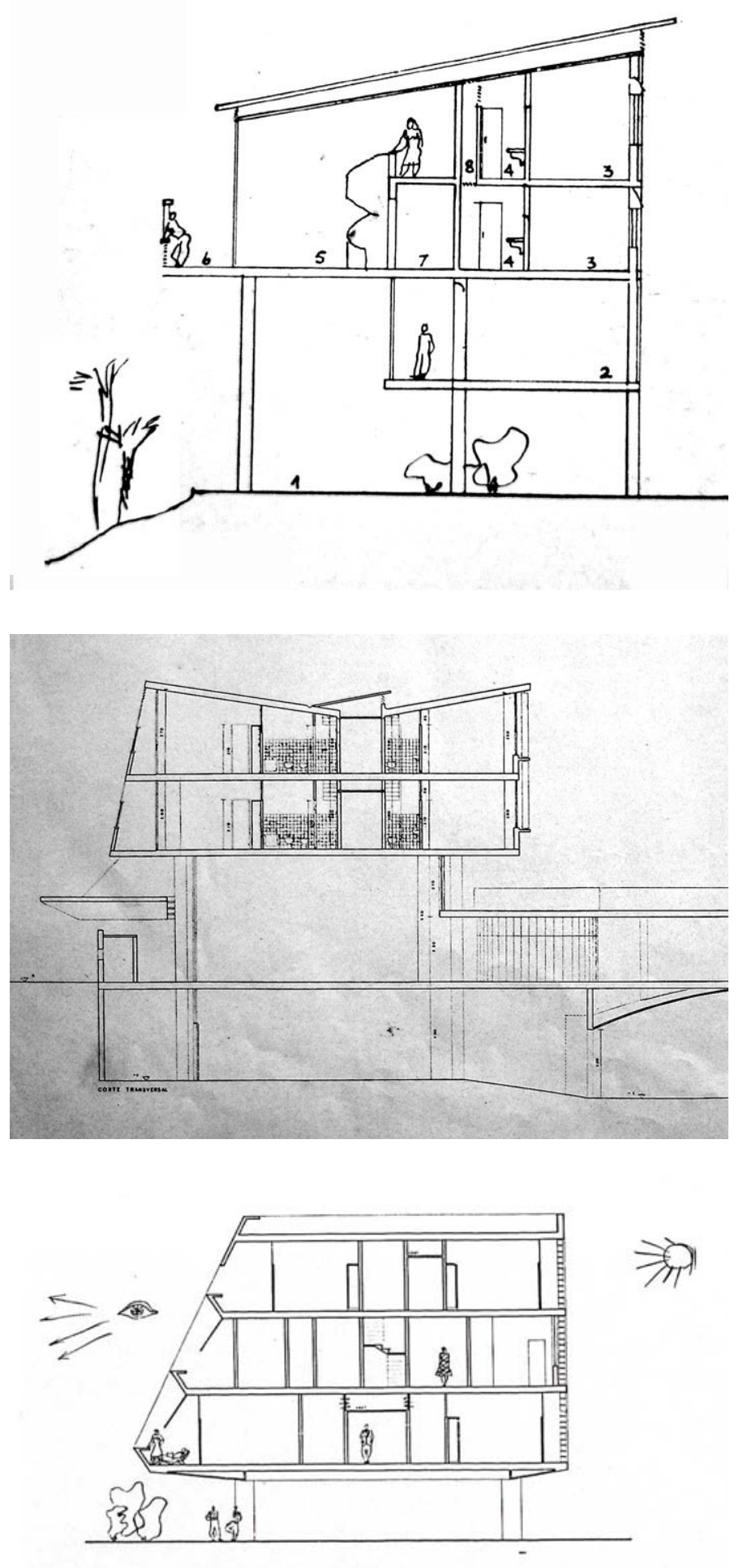

[253] Grande Hotel de Ouro Preto - corte - $1938-\mathrm{ON}$ (GOODWIN, 1943:132)

[254] Hotel Resort da Pampulha - 1943 - corte - ON (GOODWIN, 1944:s.n.)

[255] Hotel Regente - Rio de Janeiro - 1949 - corte - ON

(PAPADAKI, 1950:217) 
um volume de proporções gigantescas.

Em projetos como o Hotel Quitandinha e o Copan, a plataforma intermediária entre o volume encurvado e o chão assume uma sinuosidade dinâmica e alternante, contrastando com a serenidade da curva monumental e distendida do bloco do edifício. Nessas circunstâncias, o recorte sinuoso das plataformas representa o desenho expressivo que se contrapõe à simplicidade da curvatura das lâminas.

As curvaturas em arcos concordantes a segmentos de reta - que caracteriza tanto o bloco em "U” do Hotel Quitandinha como o bloco em "S" do Copan - assumem uma condição plástica que se aproxima muito mais de uma distensão dinâmica da reta do que a de uma sinuosidade gratuita que visa a mera contraposição a reta. [265], [266], [267]

Entre as versões preliminares e as propostas definitivas para os projetos do Hotel Quitandinha e do Edifício Copan, podemos observar uma evidente depuração da intensidade plástica, onde a profusão de "curvas e contracurvas" os pilares em "V" no térreo como as abóbadas na cobertura - presentes na versão preliminar do projeto do Copan - desaparecem no projeto definitivo.

As supressões de elementos arquitetônicos de caráter compositivo com uma densidade de expressão própria são um indício de que Niemeyer assimila a necessidade de abrir mão de um vocabulário formal de escala doméstica para que os projetos de dimensões monumentais, como o Hotel Quitandinha e o Copan, possam ser compreendidos a partir de uma unidade formal que contemple o todo. [268], [269], [270]

A percepção do pormenor (pequenas curvaturas de marquise, pilar em " $V$ " e abóbadas sucessivas na cobertura) exige uma aproximação física que inviabiliza a compreensão do conjunto. Nesse sentido, em diversos projetos de escala monumental, Niemeyer substituirá o "compositivo" de pequena escala (presente nos edifícios do Conjunto da Pampulha) por grandes gestos curvos estruturados por retas, seja o empilhamento de brises no Copan ou a concordância entre arcos abertos e retas da marquise do conjunto do Parque Ibirapuera.

Seu projeto para um edifício de apartamentos em Belo Horizonte (hoje Edifício Niemeyer), assim como no Copan, apresenta os brises horizontais de concreto que acompanham o contorno do edifício. Nesse projeto o arquiteto não utilizará a lâmina encurvada presente em projetos como o Hotel Quitandinha e o Copan. No Edifício Niemeyer ${ }^{69}$, o contorno exterior da planta é resultante de um gesto contínuo, sinuoso e cíclico que se sobrepõe ao desenho triangular do terreno. Enquanto no Copan, Niemeyer implanta uma lâmina encurvada sobre uma plataforma sinuosa e suspensa (assim como no Hotel da Pampulha e no Hotel Quitandinha), no Edifício Niemeyer, o arquiteto empilhará na vertical a própria marquise sinuosa. Nesse projeto não há a separação entre o embasamento e o corpo principal, como acontece nos outros projetos citados. Há apenas a seqüência de brises ondulantes que envolvem todo o perímetro da construção. A idéia de se sobrepor sucessivos planos horizontais de contornos livres, resultando em um elemento vertical, terá no projeto do

68. Basta observarmos o contorno caótico da marquise/plataforma presente na versão preliminar do Hotel Quitandinha.

69. (Cf. BARNABÉ, 2000).

211 o encontro de 1936: formação 



[259] Unité d'habitation de Marselha - corte da habitação - 1947/1952 - LC

BOESIGER, 1971:145

[260] Hotel Quitandinha - Petrópolis - esboço cortes $1950-\mathrm{ON}$

PAPADAKI, 1956:25

[256] Unité d'habitation de Marselha - esboço da implantação - 1947/1952 - LC

BOESIGER, 1971:138

[257] Hotel Quitandinha - Petrópolis - esboço da implantação - 1950 - ON

PAPADAKI, 1956:21

[258] Unité d'habitation de Marselha - corte - 1947/1952 - LC

BOESIGER, 1971:144 
Edifício Niemeyer seu único exemplo na obra do arquiteto. [271], [272], [273]

O projeto para a sede do Partido Comunista Francês ${ }^{70}(1965 / 1967)$ ilustra a continuidade das pesquisas de Niemeyer sobre as lâminas encurvadas. A experiência do PCF ilustra a busca de uma essencialidade tanto da forma como da superfície.

Em projetos como o Hotel Quitandinha e o edifício Copan, Niemeyer estabelece uma relação de dualidade entre a profusão sinuosa do embasamento e a simplicidade da curvatura do bloco sobreposto a ele. Esse diálogo entre a curva ondulante dos planos horizontais - dispostos como plataformas suspensas - e a curva sintética da lâmina que o sobrepõe, já está presente no projeto do Hotel da Pampulha. Muito mais que uma estratégia estética, trata-se de um procedimento de projeto.

Para Luis Eduardo Borda:

No Hotel da Pampulha, a curva define uma curva livre: a cobertura do foyer. Trata-se de contrastar o plano sinuoso com a forma retangular do edifício, situação idêntica a do Cassino e à da Casa de Baile. (Nesse último caso o contraste é entre forma cilíndrica e o plano da marquise) (BORDA, 2003:97)

No projeto do PCF essa relação barra encurvada/embasamento inexiste. O sentido de composição entre elementos assume um poder de síntese que resume o edifício a uma pele de vidro escuro sutilmente encurvada que se configura como pano de fundo para a cúpula branca que emerge em meio à praça de piso inclinado. Nesse projeto, Niemeyer abre mão dos brises e propõe o fechamento em réguas verticais que, por serem estreitas, mantém íntegra a leitura da curva da lâmina escura.

A lâmina curva do PCF está apoiada em cinco pilares dispostos em seu eixo de simetria longitudinal. O plano inclinado da face inferior da laje de piso do primeiro pavimento do edifício rebate a inclinação do próprio piso da praça que se eleva em direção ao edifício. Resta apenas um estreito rasgo em penumbra entre o piso da praça que se inclina sutilmente e a própria lâmina curva, cuja pele escura representa a plena antítese a alvura da praça. Com essa solução, Niemeyer faz com que o chão assuma o papel das plataformas sinuosas suspensas. Aquilo que no Hotel Quitandinha era compositivo e ornamental, no PCF torna-se uma mera fresta sombreada. [274], [275], [276]

No projeto do Brasília Palace Hotel (1957), Niemeyer incorpora a tipologia do Hotel da Pampulha, mas substitui a profusão das curvas - seja da plataforma ou do bloco dos apartamentos - por soluções de plano e volume ortogonais.

No Hotel da Pampulha, o bloco dos apartamentos se sobrepõe à marquise. É uma barra encurvada sobre uma plataforma sinuosa suspensa. Já no projeto do Brasília Palace Hotel, o bloco dos apartamentos, além de ser uma barra de planta retangular, não está sobreposto ao embasamento/ plataforma: está deslocado. A marquise do Hotel de Brasília caracteriza-se como um prolongamento em " $\mathrm{T}$ " da laje de piso do volume suspenso. O único instante sinuoso restringe-se aos fechamentos transparentes abrigados sob a marquise de traçado ortogonal.

70. (Cf. LUIGI, 1987).

213 o encontro de 1936: formação 

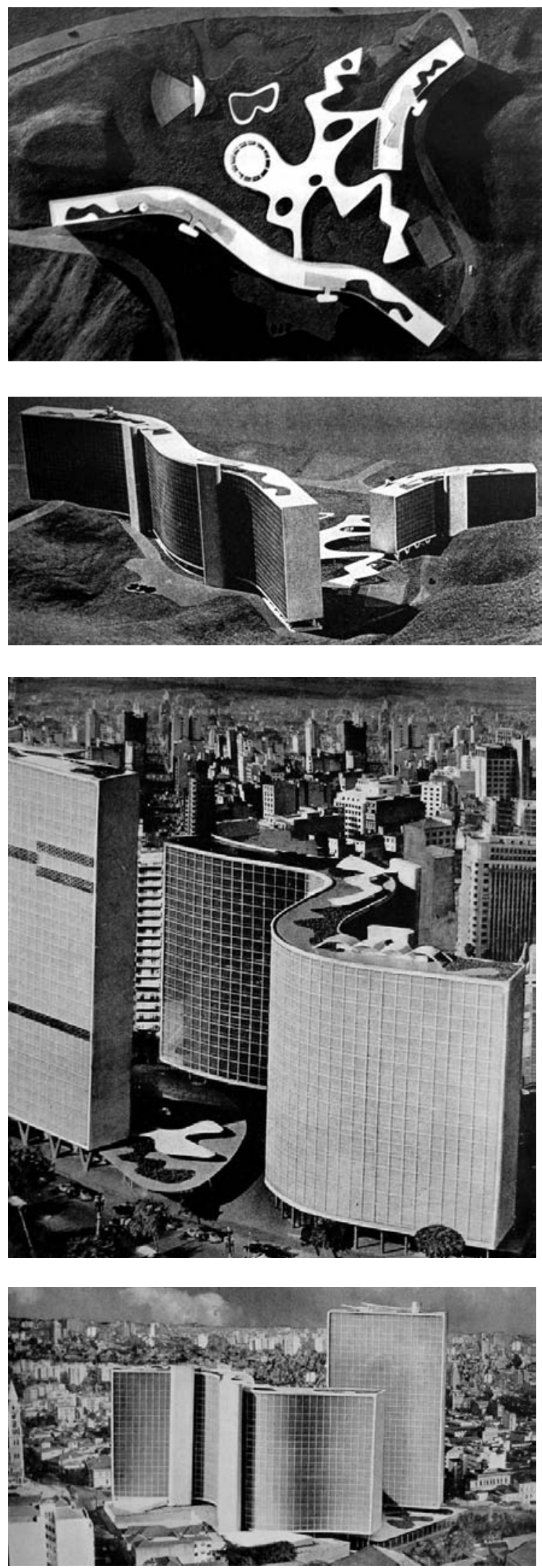


[261], [262] Hotel Quitandinha - Petrópolis - esboço da implantação - 1950 - ON

PAPADAKI, 1960:64/65

[263], [264] Edifício Copan - São Paulo - primeira versão $-1951-\mathrm{ON}$

l'architecture d'aujourd'hui, 1952, n.42/43, p.120, 121

[265], [266] Hotel Quitandinha - Petrópolis - maquete projeto definitivo - 1950 - ON

l'architecture d'aujourd'hui, 1952, n.42/43, p.118, 119 
Os sucessivos arcos concordantes presentes na planta do embasamento de cobertura retangular do Brasília Palace Hotel guardam uma sutil semelhança com os fechamentos sinuosos do Hotel Resort da Pampulha.

As diferenças e semelhanças entre os hotéis de Pampulha e de Brasília ilustram com clareza a direção de uma linguagem que migra da profusão compositiva da forma e da superfície para a concisão e simplicidade de objetos que, por adquirirem uma escala monumental, reclamam uma revisão do sentido da curva na arquitetura. [277], [278], [279], [280]

Projetos como o Brasília Palace Hotel (1957), a sede da Fundação Getúlio Vargas (1955) e a própria versão definitiva para o conjunto arquitetônico do Parque Ibirapuera (1953), são exemplares que ilustram o início de um período da obra de Niemeyer caracterizado pela revisão dos procedimentos estéticos presentes no conjunto da Pampulha e nos projetos que o sucedem. ${ }^{71}$

A fachada inclinada presente na lâmina curva do Hotel da Pampulha é uma solução que será explorada por Niemeyer em diversos projetos posteriores à experiência mineira.

Com a inclinação da fachada, Niemeyer incorpora o espaço vazado dos terraços à volumetria chanfrada dos prismas horizontais. Aquilo que poderia se configurar como um elemento adicionado à fachada integra-se a ela.

A fachada inclinada em Niemeyer é, na verdade, conseqüência da adoção de um anteparo chanfrado que protege um simples terraço. Tal anteparo pode configurar-se como caixilho, peitoril ou brise.

Nos projetos das residências Prudente de Moraes Neto ${ }^{72}(1943)$ e Leonel Miranda (1952), Niemeyer concebe um volume suspenso com sua fachada principal chanfrada, quase como um fragmento do projeto do Hotel da Pampulha.

Os terraços configurados como planos virtuais inclinados dissolvem a materialidade volumétrica do objeto. A adoção da superfície, ora ripada por brises horizontais, ora perfurada por orifícios circulares, confere à face do objeto uma condição vazada ${ }^{73}$. Essa característica não é inerente apenas às fachadas inclinadas de Niemeyer, mas constitui um raciocínio projetual que transgride a matriz corbusiana cubista, no instante em que transforma o objeto puro em um

\footnotetext{
71. Projetos realizados entre 1943 e 1954, caracterizados como uma manipulação do repertório formal presente em Pampulha. Niemeyer incorpora as soluções dos projetos da Pampulha e as transforma em índices compositivos e ornamentais. $O$ capítulo Do Museu de Arte de Caracas à Brasília abordará a revisão crítica de Oscar Niemeyer.

72. No projeto da residência Prudente de Moraes Neto, Niemeyer reutiliza a solução que havia especulado para a primeira versão da casa de fim-de-semana de Juscelino Kubitschek à margem da Lagoa da Pampulha. No projeto definitivo para a residência de Juscelino, Niemeyer não utiliza a solução da fachada inclinada, inclina a cobertura em duas águas invertidas. 73. A adoção das superfícies vazadas nos projetos de Niemeyer - seja o ripado de venezianas, a treliça de madeira ou as superfícies com perfurações circulares - deve ser compreendida como uma característica que estabelece um nexo cultural com a tradição da arquitetura colonial brasileira. Essa necessidade de uma autenticidade brasileira como instrumento de legitimação de uma arquitetura moderna corresponde às postulações de Lucio Costa que versam sobre a justeza, a retidão e a simplicidade dos exemplares de uma arquitetura nativa.

Dentro do capítulo Iate Clube e Golfe Clube da Pampulha, os textos Entre as modernidades e Le Corbusier e Lucio Costa e A superfície da memória contida no traço moderno abordarão a questão da síntese entre as linguagens moderna e vernacular na obra de Oscar Niemeyer, e o tema das superfícies vazadas será retomado em profundidade.
}

215 o encontro de 1936: formação 


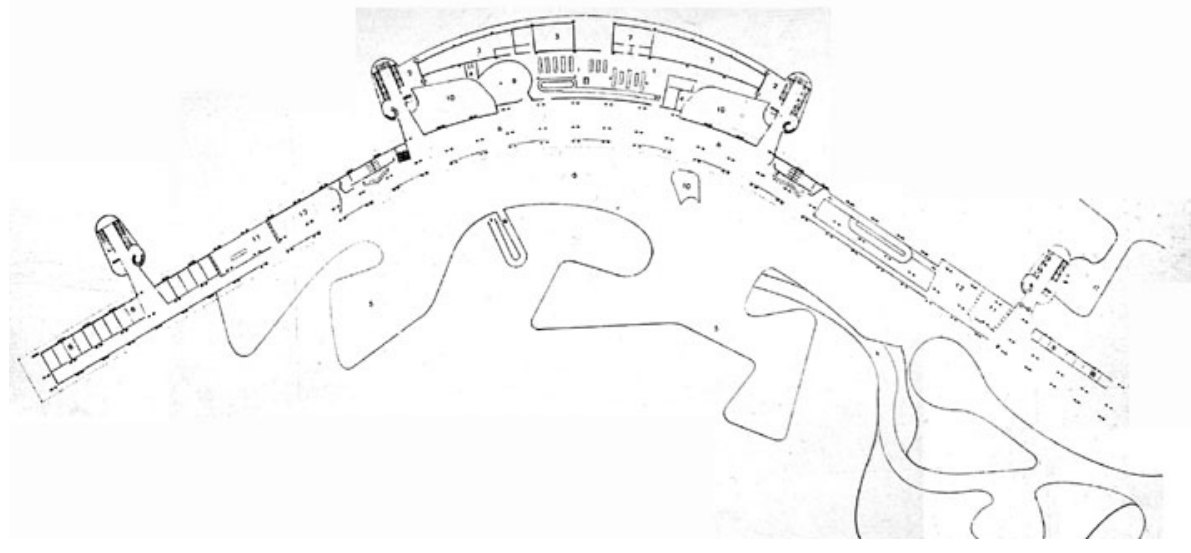

[267] Hotel Quitandinha - Petrópolis - maquete projeto definitivo - 1950 - ON

l'architectured'aujourd'h ui, 1952, n.42/43, p.117


[268], [269] Edifício Copan - São Paulo - 1951 - bloco de apartamentos e embasamento - ON foto: Rodrigo Queiroz

[270] Edifício Copan São Paulo - 1951 - planta pavimento tipo - ON PAPADAKI, 1956:43 
arranjo aéreo revestido por uma superfície rarefeita ${ }^{74}$.[281], [282], [283], [284]

No Centro Tecnológico da Aeronáutica em São José dos Campos (1947), Niemeyer elabora diversas tipologias para as habitações e adota às superfícies inclinadas nas fachadas. Uma delas é caracterizada por um agrupamento enfileirado de habitações de dois pavimentos. Esse conjunto de distendida proporção horizontal não está suspenso como o Hotel da Pampulha e as residências Prudente de Moraes Neto e Leonel Miranda, mas está implantado diretamente sobre o solo.

Nas casas do CTA, Niemeyer insinua o plano inclinado tanto nos brises horizontais como nos planos trapezoidais com perfurações circulares que dividem as diversas unidades. Em um dos agrupamentos de habitações, o plano inclinado da fachada consiste de um painel formado por brises horizontais que cobrem todo o plano inclinado, do piso à laje de cobertura. $\mathrm{O}$ brise horizontal como fechamento do plano inclinado já estava presente na residência Prudente de Moraes Neto, porém, restringia-se ao peitoril e a porção superior do terraço. [285], [286]

A solução do painel com obstruções circulares que divide as habitações em uma das tipologias do CTA seria reeditada no projeto da residência Leonel Miranda, cujo peitoril do terraço consiste de um plano inclinado com pequenas perfurações circulares.

Em um projeto para sua residência de fim de semana em Mendes ${ }^{75}$ (1949), no interior do estado do Rio de Janeiro, Niemeyer encontrará uma solução próxima daquela utilizada nas habitações do CTA. A casa em Mendes é um pequeno volume de um pavimento com fachada inclinada. Ao invés da adoção dos brises e das perfurações circulares, Niemeyer cobre a fachada com uma treliça de madeira em diagonal, um muxarabi que, no trecho próximo à laje de cobertura, muda de tessitura, e se afrouxa em losangos maiores. [287]

Em todos os exemplos citados, inexiste o plano inclinado como fechamento integral, cego. A inclinação da fachada é resultado de um desalinhamento entre o piso e a cobertura do terraço. O fechamento inclinado consiste de uma superfície vazada alinhada à diagonal resultante das diferentes profundidades do terraço: da cobertura mais estreita e do piso mais largo.

Em virtude da inclinação, a laje de cobertura dos terraços é menor que a laje de piso e inexiste o beiral como aba de proteção da luz solar. Se não fossem os muxarabis e os brises, os terraços estariam praticamente desguarnecidos.

Em diversos projetos, Niemeyer inverte o sentido da inclinação da fachada: ao invés de afunilar o volume conforme se eleva, irá operar o objeto ao contrário, diminuindo sua secção à medida em que se aproxima do solo. Nesses casos não há a necessidade do uso das treliças, pois a laje de cobertura dos terraços se estenderá para além dos limites da laje de piso, mantenho o terraço protegido e sombreado.

No projeto para as habitações dos estudantes do Centro Tecnológico da Aeronáutica, Niemeyer desenvolve uma solução diversa das demais habitações do conjunto. Nas habitações

\footnotetext{
74. Projetos como o conjunto do Parque Guinle (1947) de Lucio Costa e os conjuntos de Pedregulho (1946) e Marquês de São Vicente de Affonso Eduardo Reidy, também são exemplares que utilizam as superfícies vazadas como fechamento exterior. 75. (Cf. HESS, 2006:60).
}

217 | o encontro de 1936: formação 

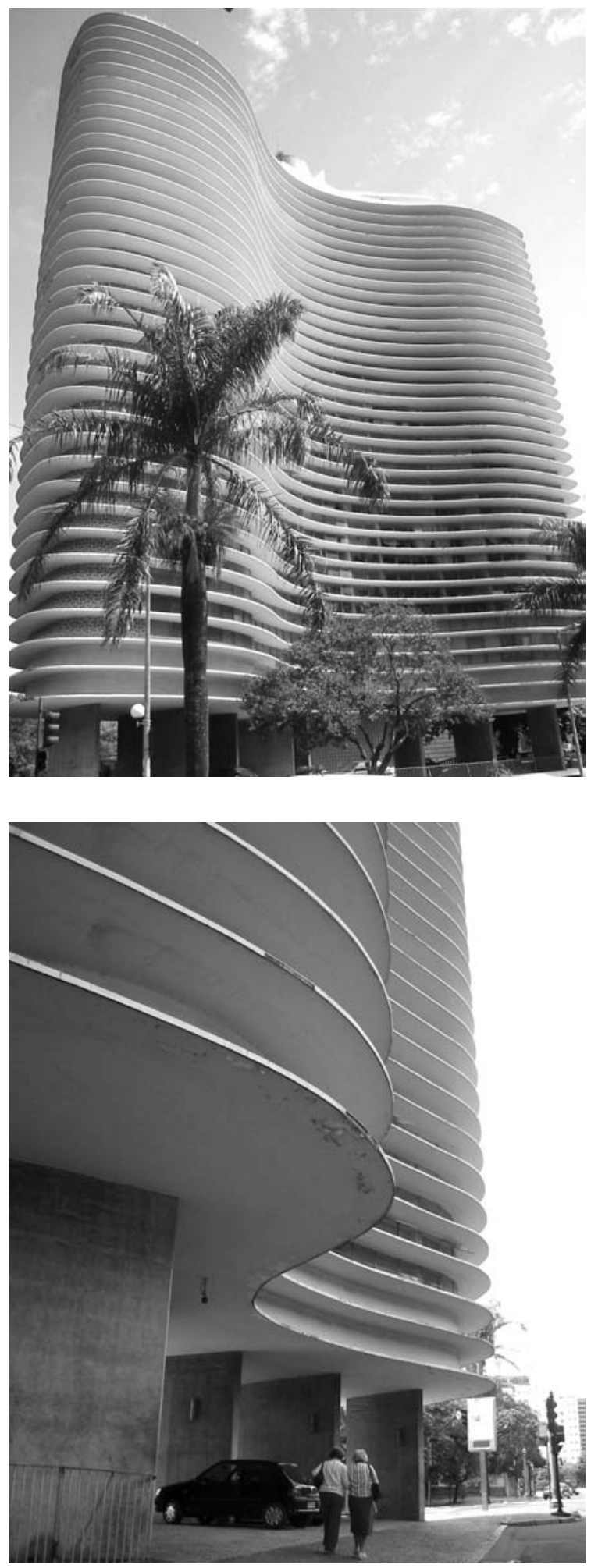

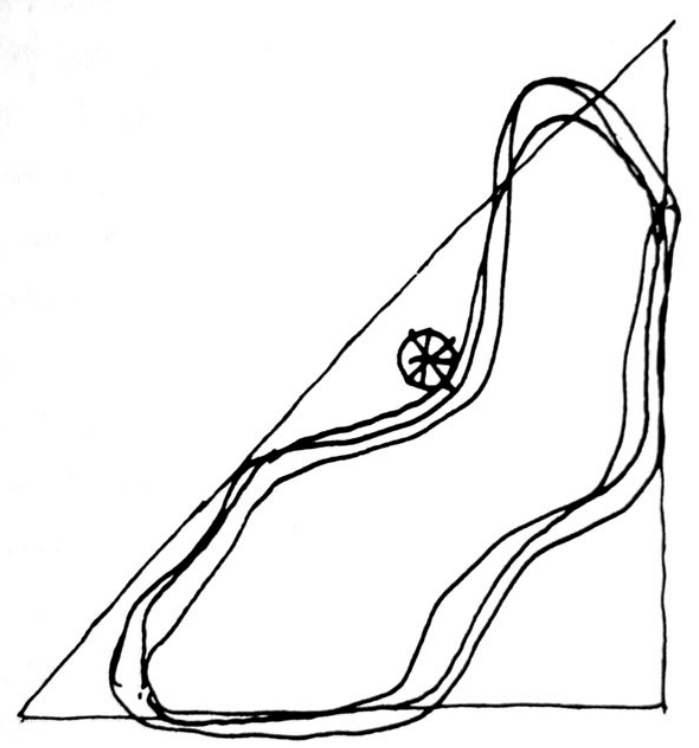

[271], [272] Edifício Niemeyer - Belo Horizonte - 1954 - bloco de apartamentos e térreo - ON foto: Rodrigo Queiroz

[273] Edifício Niemeyer - Belo Horizonte - 1954 - esboço implantação - ON LUIGI, 1987:131 
estudantis a laje de cobertura extravasa o alinhamento dos fechamentos verticais externos. $\mathrm{O}$ balanço da cobertura é apoiado em pilares inclinados em " $\mathrm{V}$ ", posicionados perpendicularmente às unidades habitacionais sucessivas. A seqüência contínua e extensa dos apoios inclinados confere ao conjunto o aspecto de um longilíneo objeto que diminui de seção conforme se aproxima do solo. As habitações estudantis enfileiradas do CTA representam a primeira experiência em que Niemeyer utiliza os apoios inclinados como elementos compositivos e seriais em projetos de proporção horizontal. Essa solução caracterizará projetos como o Hotel Tijuco (1951) e a Escola Julia Kubitschek (1951), ambos em Diamantina. [288], [289], [290]

A treliça, que na casa de fim de semana de Niemeyer em Mendes era anteparo, no Hotel Tijuco de Diamantina (1951) é o peitoril do terraço dos apartamentos localizados na fachada principal.

A ordenação e o desenho dos apoios, tanto do Hotel Tijuco como da Escola Julia Kubitschek, conferem a tônica de linguagem de ambos os projetos. O sentido do plano inclinado virtual das fachadas é conseqüência direta da adoção dos pilares inclinados que, em conjunto, configuram um ritmo serial e homogêneo ao volume horizontal.

No projeto para o Hotel Tijuco, Niemeyer funde o tratamento tradicional das superfícies em pedra apicoada, madeira e pastilha, à dinâmica expansiva de um objeto de proporção horizontal marcado pelo ritmo vertical dos pilares em "V".

Os pilares em "V" do Hotel Tijuco são assimétricos e diferem daqueles presentes nos "térreos livres" de projetos como a Fundação Getúlio Vargas ${ }^{76}$ (1955) ou o Hospital Sulamérica (1953). No Hotel Tijuco, uma das hastes do " $V$ " arranca do solo e encontra a laje de cobertura dos apartamentos do pavimento superior, enquanto a haste menor apóia a laje de piso dos mesmos apartamentos. Niemeyer recua sutilmente a laje do terraço dos apartamentos com relação à haste maior do "V". Com esse detalhe o perfil inclinado da haste maior do pilar mantém-se proeminente com relação ao fechamento do peitoril dos apartamentos.

O princípio do pilar em " $V$ " assimétrico, presente no Hotel Tijuco, ao mesmo tempo em que sustenta a laje do primeiro andar recebe a carga da cobertura. Esse tipo de solução encontrará seu redesenho mais ilustre nos pórticos do projeto de Affonso Eduardo Reidy para o Museu de Arte Moderna do Rio de Janeiro ${ }^{77}$ (1953). [291]

Para Guilherme Wisnik,

O pórtico é um elemento estrutural que condensa o caráter plástico e construtivo do edifício em uma peça: estanque solidária e sem articulação. E, nesse sentido, torna formais as qualidades intrínsecas do próprio material, o concreto: um composto agregado que se transforma em massa maleável e contínua. Essa condensação simbólica, que faz da reflexividade estrutural da obra construída a expressão de uma unidade plástica poderosa, é uma conquista marcante dos projetos mais rigorosos de Niemeyer e de Reidy, culminando no edifício do Museu de Arte Moderna do Rio de Janeiro (1953) (WISNIK, 2003:103).

Na escola Julia Kubitschek, o apoio inclinado não toca o solo, está suspenso, recebe a car-

76. (Cf. PAPADAKI, 1956:168).

77. (Cf. BONDUKI,2000).

219 | o encontro de 1936: formação 

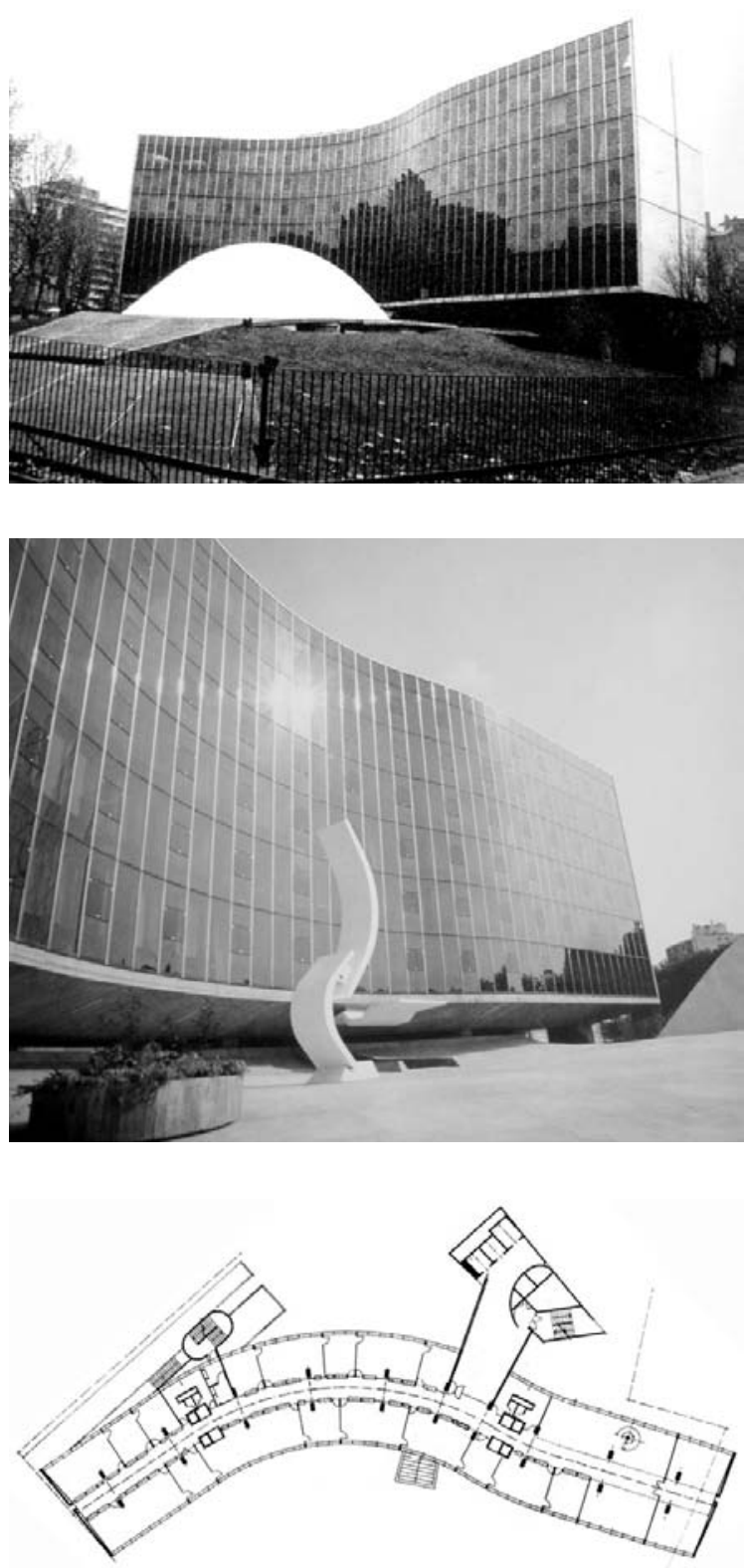

[274] Sede do Partido Comunista Francês - Paris - 1965/1967 $-\mathrm{ON}$

UNDERWOOD, 2002:112

[275] Sede do Partido Comunista Francês - Paris - 1965/1967 $-\mathrm{ON}$

PENTEADO, 1985:103

[276] Sede do Partido Comunista Francês - Paris - 1965/1967 - planta - ON

FROLICH, 1982:155
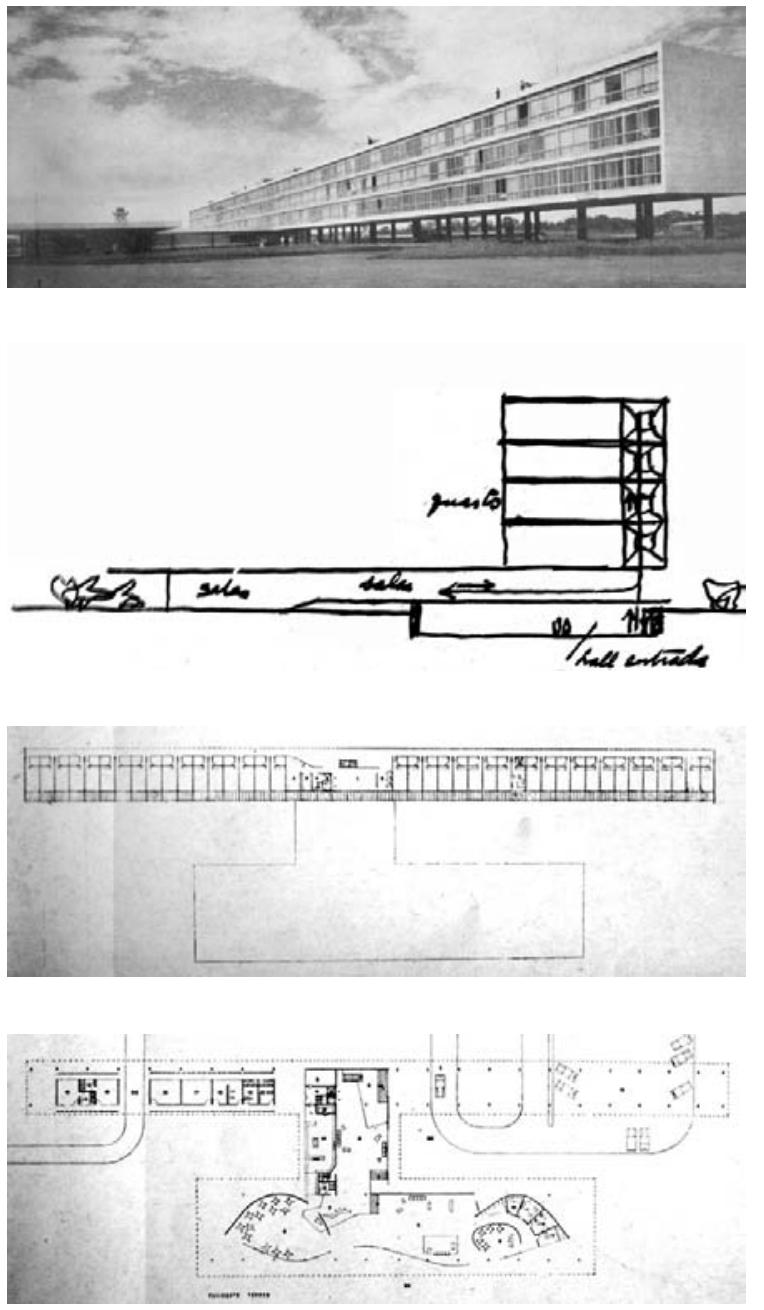

[277] Brasília Palace Hotel - 1958 - ON

Módulo n.12, fevereiro/1959, p.29

[278] Brasília Palace Hotel - 1958 - croqui corte - ON Módulo n.12, fevereiro/1959, p.28

[279] Brasília Palace Hotel - 1958 - planta nível dos apartamentos - ON

Módulo n.12, fevereiro/1959, p.29

[280] Brasília Palace Hotel - 1958 - planta térreo - ON Módulo n.12, fevereiro/1959, p.29 
ga da cobertura e conecta-se a uma pequena transição que descarrega todo o peso da peça em pilares de seção circular localizados sob a projeção do volume principal. Niemeyer coloca em evidência todo o volume das salas de aula que se debruça vazado sobre a paisagem.[292]

Enquanto o Hotel Tijuco ${ }^{78}$ ainda mantém uma relação com as experiências de Niemeyer com os pilares em "V", a Escola Julia Kubitschek eleva o desenho dos apoios inclinados a um nível de raciocínio que subverte o sentido lógico do pilar como apoio que descarrega a carga da construção no solo. Nesse projeto, Niemeyer suspende o volume das salas sobre um prisma transparente recuado que assume o papel de hiato entre o volume das salas que se projeta para fora e o perfil natural do terreno, que é o espelhamento da própria inclinação do volume das salas de aula. $\mathrm{O}$ apoio inclinado restringe-se ao suporte do generoso beiral em balanço.

Ao inverter a inclinação da fachada, Niemeyer abre uma nova perspectiva para sua pesquisa formal. O apoio inclinado e em "V" torna-se um índice formal que caracteriza formalmente o objeto.

Em projetos como o auditório do conjunto arquitetônico do Parque Ibirapuera (1951/1954), Niemeyer irá sublimar o desenho do apoio inclinado - presente nos projetos de Diamantina à superfície da fachada inclinada. Nesse caso não há mais diferença entre o fechamento e a estrutura, que agora estão incorporados em um só volume de faces planificadas. [293]

No projeto para o Museu de Arte de Caracas $^{79}$ (1955) Niemeyer dá continuidade ao raciocínio que concebeu o auditório do Ibirapuera. A pirâmide invertida do Museu de Caracas representa um desdobramento crítico das experiências de Niemeyer com planos inclinados que tiveram início no Hotel da Pampulha e que se desdobraram em diversos projetos de residência ${ }^{80}$ durante a década de 1940. [294]

O projeto do edifício do Congresso Nacional de Brasília (1958) também pode ser considerado como um desdobramento dessas soluções caracterizadas pelas formas que se alargam conforme ascendem verticalmente. Tanto no Ibirapuera como no Congresso, Niemeyer contrapõe a forma dinâmica (o auditório como um triângulo raso apontado para o solo, ou a Câmara dos Deputados como uma seção de esfera que tangencia a plataforma) com um outro volume separado, porém que se conecta visualmente à forma dinâmica (as cúpulas do Palácio das Artes e da Câmara do Senado). [295]

Como vimos, as soluções presentes na Casa de Baile e no Hotel Resort da Pampulha serão incorporadas e reinterpretadas por Niemeyer em inúmeros projetos. A cada redesenho que se sobrepõe às soluções presentes em Pampulha, o arquiteto exercita e depura uma linguagem estruturada por procedimentos que organizam um restrito repertório formal a partir de estratégias compositivas versáteis.

Niemeyer elabora um ritual consciente, orientado por um raciocínio que condiciona tanto

78. (Cf. CAVALCANTI, 2001).

79. O projeto do Museu de Arte de Caracas será abordado no capítulo Do Museu de Arte de Caracas à Brasília.

80. Residências: Prudente de Moraes Neto (1943); Gustavo Capanema (1947); Burton Tremaine (1947); do Centro Tecnológico da Aeronáutica (1947); Oscar Niemeyer (Mendes, 1949) e Leonel Miranda (1952).

221 o encontro de 1936: formação 



[281] Res. Prudente de Moraes Neto - ON - 1943 (HESS, 2006:62)

[282] Res. Prudente de Moraes Neto - terraço - ON - 1943 (HESS, 2006:63)

[283] Res. Leonel Miranda - ON - 1952 (HESS, 2006:76-77)

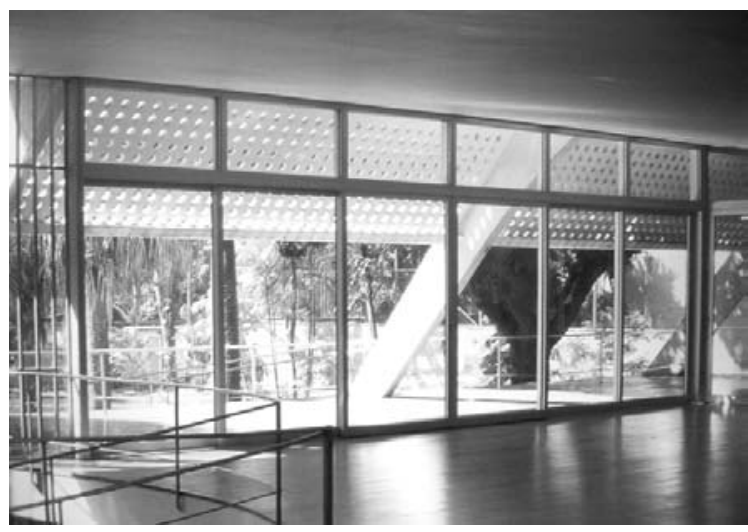

[284] Res. Leonel Miranda - terraço - ON - 1952 (HESS, 2006:81)

[285] Centro Tecnológico da Aeronáutica - São José dos Campos - fachada inclinada (brises horizontais) - ON - 1947 (foto: Rodrigo Queiroz)

[286] Centro Tecnológico da Aeronáutica - São José dos Campos - fachada inclinada (perfurações circulares) - ON - 1947 (foto: Rodrigo Queiroz) 
o programa à forma, como a forma ao programa. O arquiteto opera adaptações dos mais distintos programas aos mais diversos contornos justamente pelo fato de suas formas possuírem contornos simplificados e elementares, permitindo abrigar os mais diversos usos. 

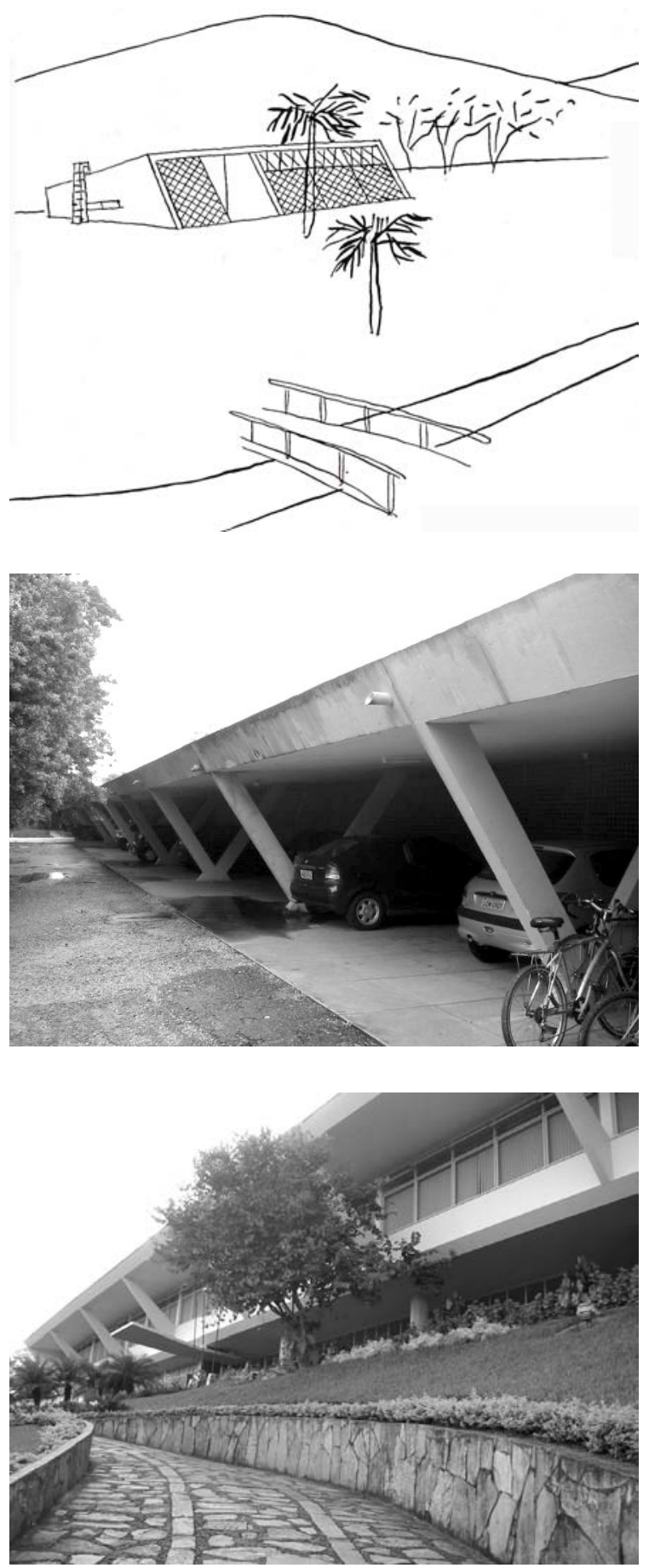

[287] Casa do arquiteto em Mendes - RJ - ON - 1949 (PAPADAKI, 1950:197)

[288] CTA - habitação estudantil - 1947 - ON foto: Rodrigo Queiroz

[289] Escola Júlia Kubitschek - 1951 - Diamantina - ON foto: Rodrigo Queiroz 

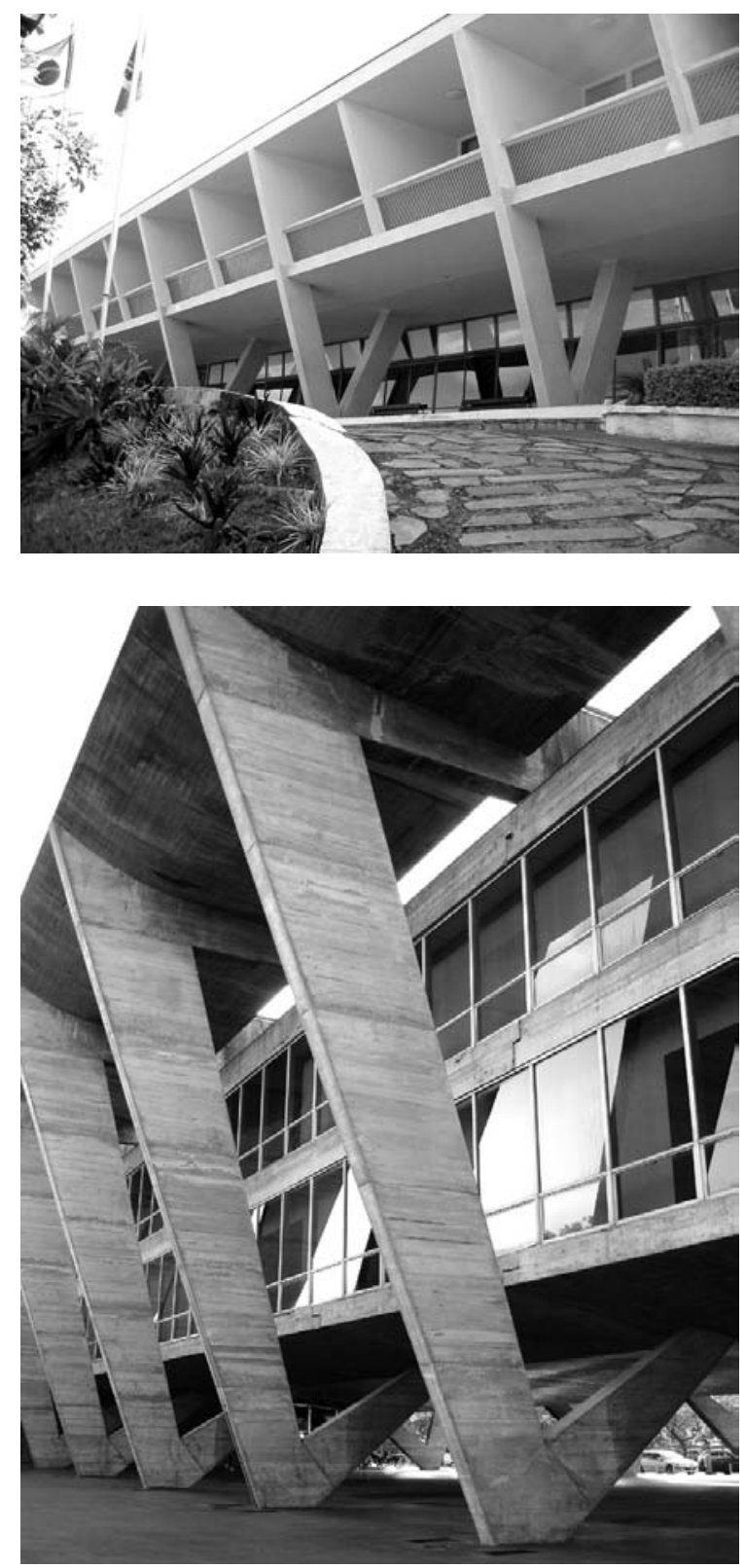

[290] Hotel Tijuco - 1951 - Diamantina - ON foto: Rodrigo Queiroz

[291] Museu de Ate Moderna do Rio de Janeiro - 1953 Affonso Eduardo Reidy foto: Rodrigo Queiroz 




[292] Escola Júlia Kubitschek - 1951 - Diamantina - ON foto: Rodrigo Queiroz
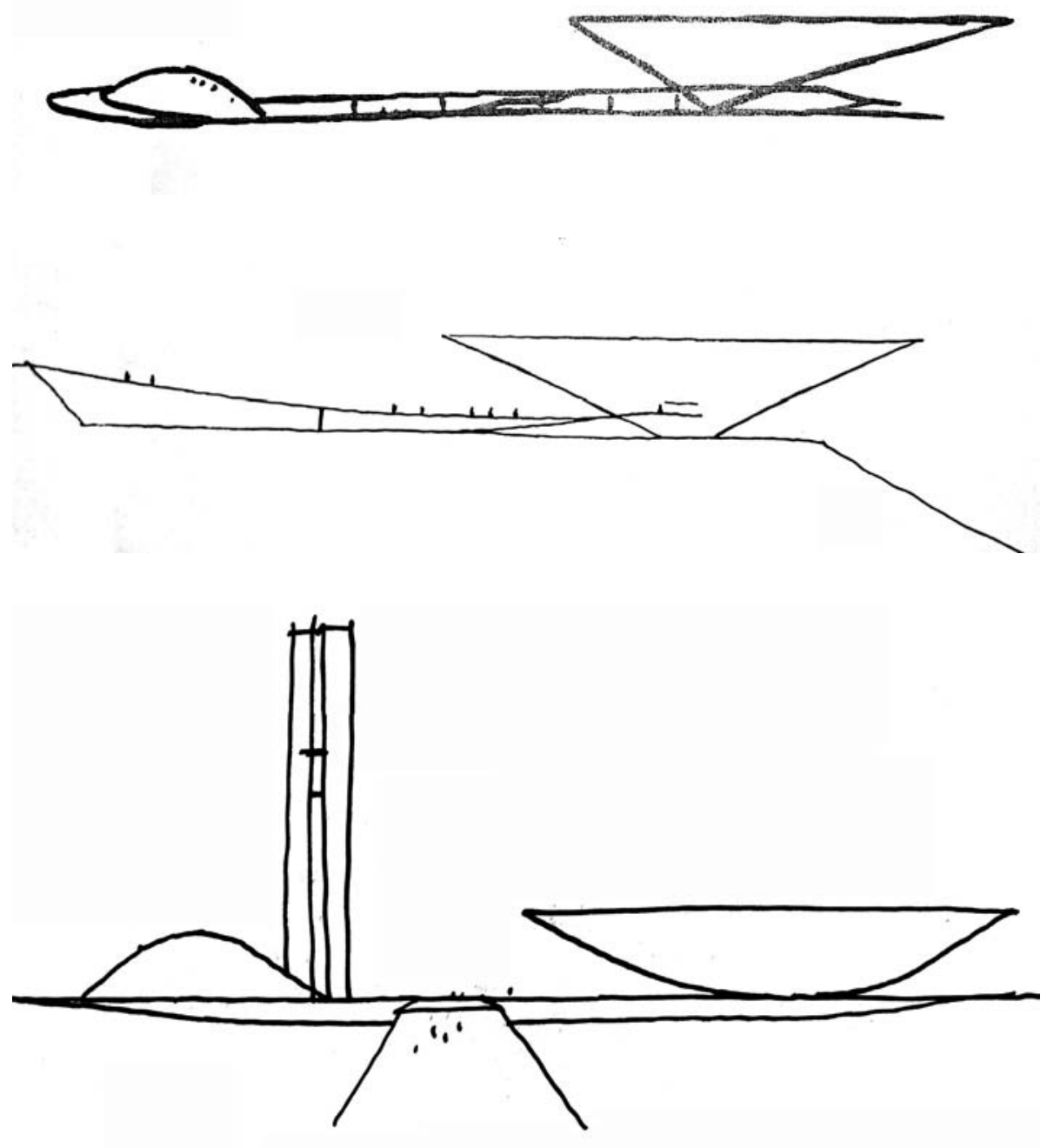

[293] Conjunto Arquitetônico do Parque Ibirapuera - Palácio das Artes e Auditório - ON - 1951-1954 (PAPADAKI, 1960:129)

[294] Museu de Arte de Caracas - ON - 1955 (Revista Módulo n.4, março/1956 p.38)

[295] Congresso $\mathrm{Na}$ cional de Brasília - ON - 1958 (CORONA, 2001:75) 


\section{Iate Clube e Golfe Clube}

Diferentemente dos demais projetos do conjunto da Pampulha, no Iate Clube a curva não é um condicionante plástico que caracteriza sua concepção formal. Nos outros edifícios do conjunto, a curva se expressa em diferentes níveis de intensidade: no volume ovóide transparente que se conecta ao prisma recortado do Cassino; no bloco dos apartamentos e na plataforma ondulante do Hotel Resort; no cilindro raso transparente e na marquise sinuosa da Casa de Baile; na abóbada presente na cobertura do Golfe Clube e na seqüência de abóbadas que caracteriza a igreja de São Francisco de Assis.

No projeto do Iate Clube, Niemeyer confere à linguagem da arquitetura o sentido dinâmico dos esportes e das atividades náuticas inerentes a um programa vinculado ao lazer. Assim como nos demais edifícios do Conjunto da Pampulha, no Iate Clube o sentido de fluidez não reside apenas na forma, mas no tratamento das superfícies.

O percurso linear da rampa que ascende à plataforma como um gesto que sai do solo e desenha o perfil exterior do volume vazado e suspenso se assemelha às experiências do Pavilhão do Brasil na Feira Internacional de Nova York (1938) e do Clube dos Estudantes da Universidade do Brasil (1937). A face oeste do Iate Clube, totalmente envidraçada, enfatiza o caráter gráfico do perfil exterior do projeto. Em um único contorno, as lajes inclinadas da cobertura transformam-se em fechamentos verticais. É quase uma dobradura, um invólucro regular composto praticamente de vidro e brise em suas faces maiores. Não há interrupção, a esbeltez da laje transfere-se para as paredes. [296], [297]

Ao alastrar a dimensão da abertura ao limite da própria espessura das lajes inclinadas e dos fechamentos laterais, Niemeyer rompe com a rigidez purista caracterizada por uma relação de contraste entre o interior e o exterior presente nos projetos de Le Corbusier da década de 1920.

No Iate Clube, como a obstrução da fachada atinge sua dimensão máxima, a espacialidade interior é também percebida por quem está fora do objeto. Com o advento das aberturas integrais, podemos observar - em uma mesma mirada exterior - tanto a face externa dos fechamentos verticais, como a face interna das coberturas inclinadas. O volume transforma-se em um delgado contorno planar suspenso.

227 | o encontro de 1936: formação 

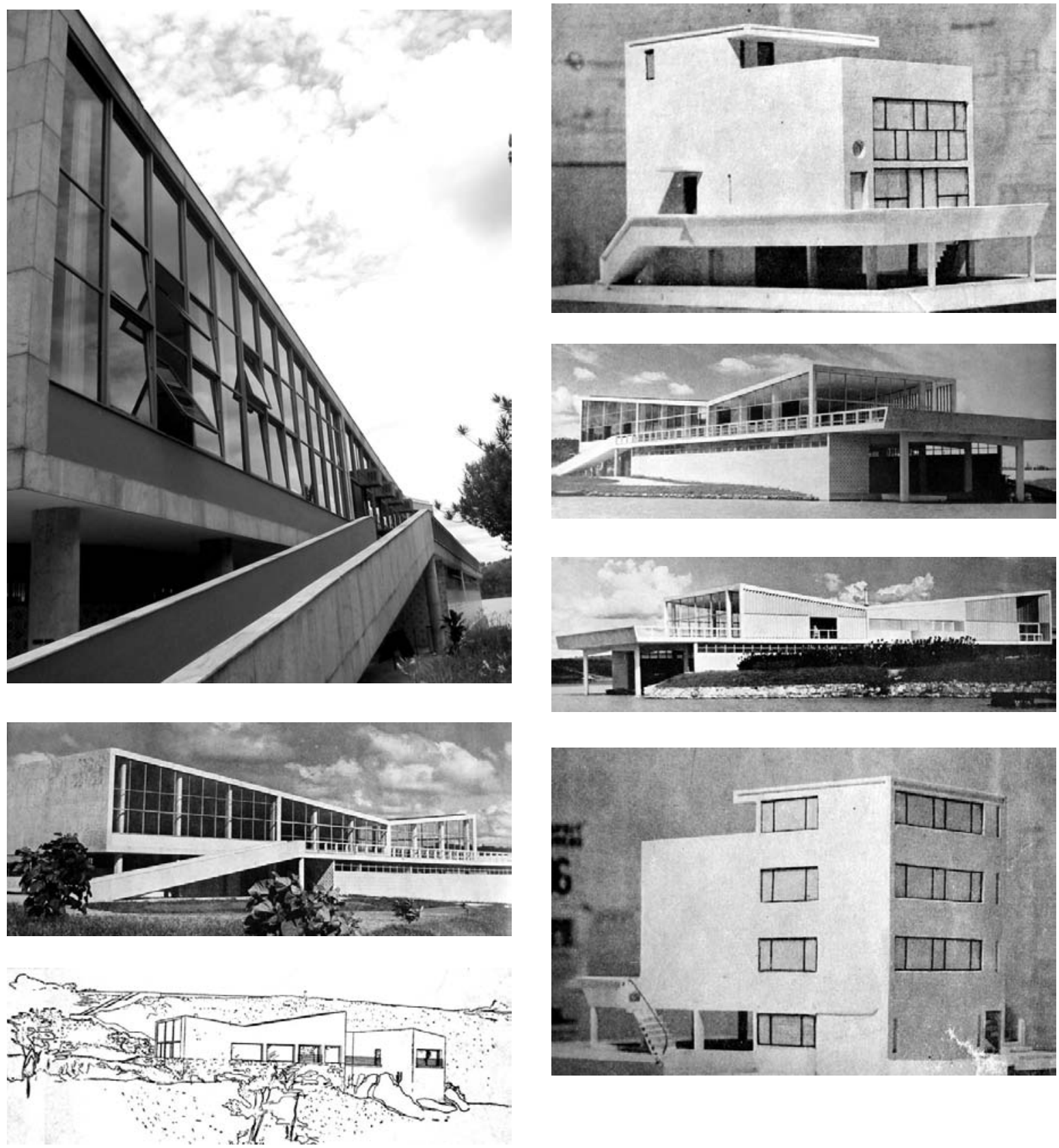

[296] Iate Clube da Pampulha - ON - 1943

foto: Rodrigo Queiroz

[297] Iate Clube da Pampulha - ON - 1943

(GOODWIN, 1944:sn)

[298] Casa Errazuris - perspectiva - Le Corbusier - 1930 (BOESIGER, 1947:52)

299] Casa Citrohan - maquete - Le Corbusier - 1922 (BOESIGER, 1946:45)

[300] Iate Clube da Pampulha - Oscar Niemeyer - 1943 (GOODWIN, 1943:sn)

[301] Iate Clube da Pampulha - Oscar Niemeyer - 1943 (GOODWIN, 1943:sn)

[302] Casa Citrohan - maquete - Le Corbusier - 1922 (BOESIGER, 1946:45) 
Assim como nos demais edifícios do Conjunto da Pampulha, no Iate Clube, Niemeyer utiliza a pedra como borda, o vidro como dimensão imaterial abrigada sob a projeção dessa mesma "borda" e a cerâmica esmaltada como revestimento exterior das alvenarias. Os brises verticais presentes na face leste do Iate Clube são retomados apenas no projeto da Igreja de São Francisco de Assis, como anteparo que protege o coro.

O volume do Iate Clube tem seu sentido ascensional e aéreo dado por três características marcantes: a transparência, a suspensão e a inclinação em " $V$ " assimétrica da cobertura.

Ao conceber um projeto composto por um volume com cobertura em " $\mathrm{V}$ " sobreposto a uma retícula de pilotis cilíndricos, Niemeyer incorpora soluções de projetos distintos de Le Corbusier: o volume com cobertura invertida da casa Errazuris (1930) e a idéia de suspensão presente em projetos como a segunda versão da casa Citrohan (1920) e a casa Savoye (1929). [298]

O terraço do Iate Clube, caracterizado como um plano horizontal e suspenso, é a continuidade tanto da laje de piso do volume elevado como da rampa de acesso ao pavimento superior, exatamente como o terraço presente na segunda versão de Le Corbusier para a casa Citrohan (1920). No estudo de Le Corbusier, o terraço também é um avanço exterior do plano horizontal da base do volume suspenso. Enquanto que, no Iate Clube, o peitoril do terraço/plataforma é a continuidade da linha diagonal desenhada pelo guarda-corpo da rampa, na casa Citrohan, o peitoril do terraço é a continuidade do guarda-corpo de uma escada externa ao volume. Um olhar mais atento perceberá inclusive que Niemeyer adota o peitoril inclinado do trecho em balanço do terraço/plataforma, do mesmo modo que Le Corbusier na casa Citrohan. [299], [300], [301], [302], [303], [304]

Ao mesmo tempo em que as concepções formais do Iate Clube e da casa Citrohan são divergentes, as estratégias de arranjo entre volumes e planos coincidem. Em ambos os projetos a dimensão da plataforma suspensa é maior que a dimensão do volume sobreposto a ela, seja o volume de matriz cúbica de Le Corbusier, ou o volume de matriz trapezoidal de Niemeyer.

Podemos compreender o projeto do Iate Clube não como um mero redesenho de um exemplar corbusiano, mas como a interpretação de um esquema de raciocínio presente no projeto de Le Corbusier. Trata-se de um arranjo versátil, que se presta como parâmetro compositivo tanto para uma morada purista, como para um clube horizontal, transparente e suspenso, "atracado" na margem da Lagoa da Pampulha.

Niemeyer transita com liberdade nesse exercício de apropriação e redesenho das soluções corbusianas pertencentes a projetos tão diferentes como a casa Errazuris (1930) e a casa Citrohan (1922). Em um mesmo projeto, o arquiteto brasileiro amalgama referências distintas entre si: a cobertura em "V" da pioneira experiência vernácula de Le Corbusier na casa Errazuris (1930) e o jogo entre planos e volumes que caracteriza o exemplar purista da casa Citrohan. Esse exercício de livre interpretação e redesenho das soluções corbusianas permite que Niemeyer desenvolva um raciocínio que desmembra a relação forma/programa.

Segundo Marco do Valle: “(...) Niemeyer se baseia no repertório de formas e procedimentos de Le Corbusier e realiza uma recriação ou redesenho deles, chegando a um repertório particular, que forma seu próprio vocabulário formal.” (VALLE, 2000:133).

229 | o encontro de 1936: formação 

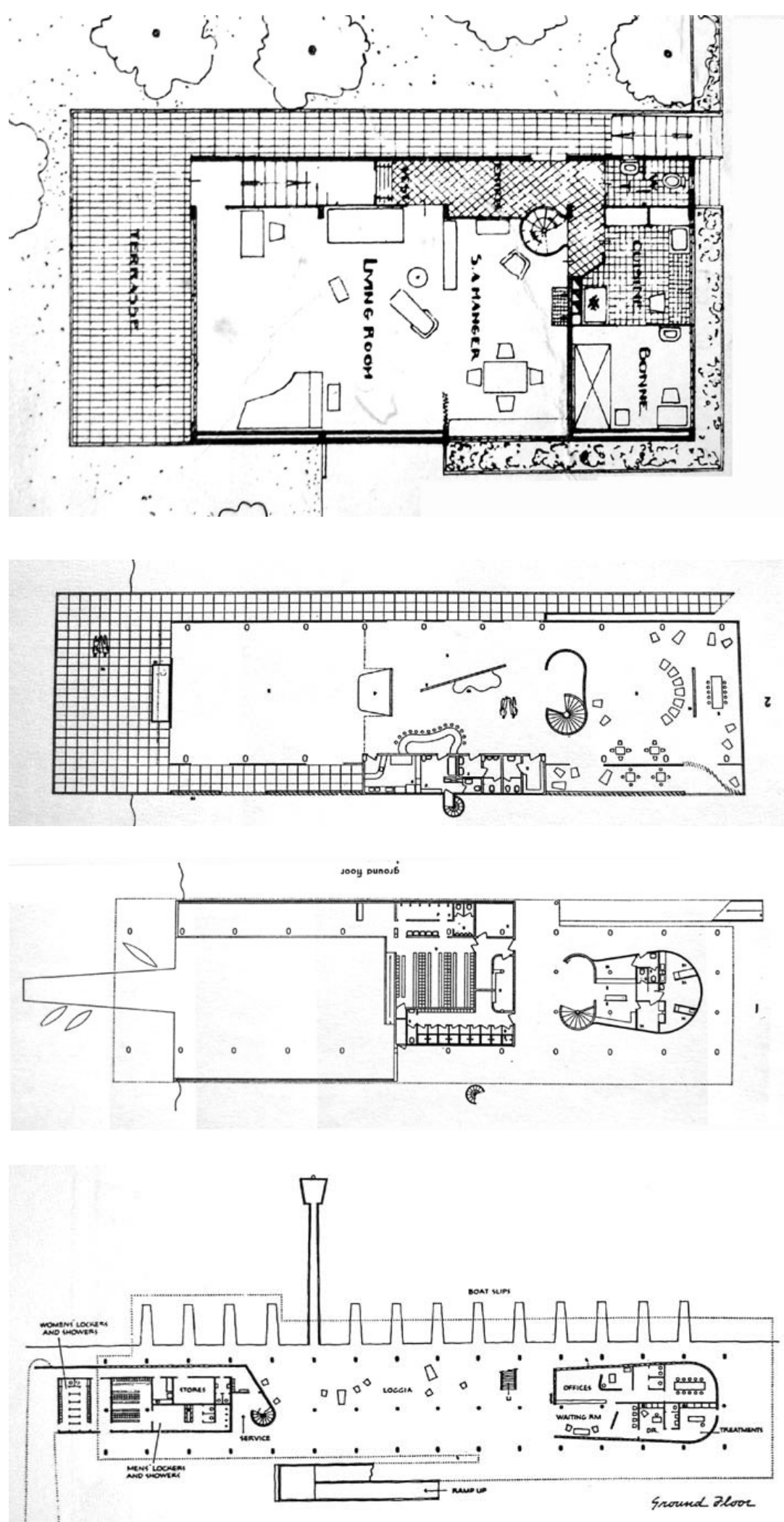

[303] Casa Cithohan - planta terraço - Le Corbusier - 1922 (BOESIGER, 1946:44)

[304] Iate Clube - planta terraço - Oscar Niemeyer - 1943

(PAPADAKI, 1950:84)

[305] Iate Clube - planta térreo

- Oscar Niemeyer - 1943

(PAPADAKI, 1950:84)

[306] Fluminense Iate Clube - planta térreo - Oscar Niemeyer $-1945$

(PAPADAKI, 1945:134) 
A partir da afirmação de Valle, poderíamos considerar que Niemeyer não apenas estrutura seu vocabulário formal a partir de um redesenho das soluções de Le Corbusier, como concebe seus projetos posteriores à Pampulha a partir de um redesenho das formas do conjunto mineiro.

Em alguns casos, como no Restaurante da Lagoa Rodrigo de Freitas ${ }^{81}$, Niemeyer não redesenha apenas a dimensão formal da Casa de Baile (volumes de planta circular interligados por marquise sinuosa), como também incorpora soluções relativas à articulação do programa em planta (setor de serviços e cozinha abrigados dentro da planta circular em fechamentos em forma de "meia-lua").

No projeto de Niemeyer para o Fluminense Iate Clube no Rio de Janeiro (1945), percebemos que o arquiteto utiliza soluções em planta muito próximas do projeto do Iate Clube da Pampulha, tais como: o volume encurvado contido sob a projeção do corpo principal; acesso ao pavimento superior por rampa externa disposta no sentido do comprimento da planta; terraço em plataforma descoberta como uma continuidade da laje de piso do pavimento superior. [305], [306]

No Fluminense Iate Clube, o terraço/plataforma não está apoiado sobre pilares como no Iate Clube da Pampulha. Está pendurado com tirantes fixados na laje de cobertura do volume principal.

O telhado invertido do exemplar da Pampulha dá lugar a uma cobertura côncava no projeto do Fluminense Iate Clube, nas quais o vértice é substituído pelo arco. Os próprios estudos do arquiteto para o projeto ilustram esse processo de transformação da forma. [307], [308]

Quando Niemeyer, no Fluminense Iate Clube, adiciona o arco à cobertura ascendente do Iate Clube da Pampulha, concebe sua primeira cobertura côncava que se desdobrará em projetos como a residência Cavanelas no Rio de Janeiro (1952), a Igreja de Nossa Senhora de Fátima em Brasília (1957), o auditório do Ministério do Exército em Brasília (1967), o Pavilhão Serpentine em Londres (2003) e o Templo Batista do Caminho Niemeyer (2000). [309], [310], [311], [312], [313]

Em todos os projetos citados acima, Niemeyer arremata as extremidades longitudinais das coberturas em arco com peças de perfil inclinado. $\mathrm{O}$ arquiteto dispõe os fechamentos inclinados quase como um segmento de reta secante à curvatura da cobertura. São peças que se agigantam conforme se aproximam do chão, com esse efeito estabelece-se o contraste ideal com a cobertura que ascende verticalmente, como podemos perceber na relação entre coluna e a cobertura na residência Cavanelas e na Igreja de Nossa Senhora de Fátima em Brasília.

Enquanto as espessuras das abóbadas de Niemeyer se estreitam conforme se elevam, a ponto de manter a menor espessura em seu ponto mais alto (Igreja de São Francisco de Assis ou Clube de Diamantina), em determinadas coberturas côncavas o arquiteto procederá de maneira oposta, alargando a espessura da cobertura gradativamente até o ponto mais baixo do perfil côncavo, como na Igreja de Nossa Senhora de Fátima (1958), no Auditório do Ministério do Exército (1962) e no Pavilhão Serpentine (2003). Em ambas as situações, Niemeyer lida com a intensidade gráfica e formal de um movimento visual dinâmico: as formas em arco perdem matéria conforme se elevam,



231 o encontro de 1936: formação 



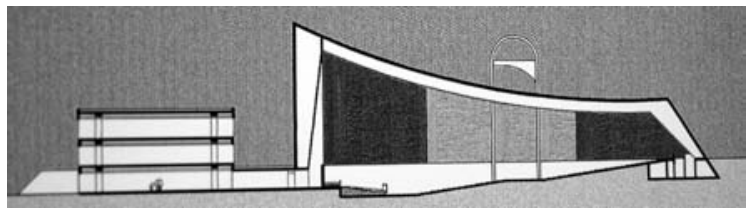

[307] Fluminense Iate Clube - estudos - Oscar Niemeyer $-1945$

(PAPADAKI, 1945:133)

[308] Fluminense Iate Clube - maquete - Oscar Niemeyer $-1945$

(PAPADAKI, 1945:132)

[309] Residência Cavanelas - 1954 - Oscar Niemeyer (HESS, 2006:114)

[310] Igreja de Nossa Senhora de Fátima - Brasília - 1962 $-\mathrm{ON}$

foto: Rodrigo Queiroz

[311] Auditório do Ministério do Exército - Brasília - 1962 $-\mathrm{ON}$

foto: Rodrigo Queiroz

[312] Pavilhão Serpentine - Londres - 2003 - ON

(NIEMEYER, 2003:sn)

[313] Templo Batista - Caminho Niemeyer - Niterói - ON $-2000$

(NIEMEYER, 2004: 257) 
enquanto os perfis côncavos aumentam de secção conforme se aproximam do ponto mais baixo da catenária. Trata-se de um desenho que ilustra uma lógica gravitacional que enfatiza próprio peso da porção central da cobertura arqueada.

No projeto para o Golfe Clube da Pampulha (1943) - de maneira oposta ao exemplo das coberturas côncavas - Niemeyer sobrepõe uma abóbada ao vértice do telhado invertido, resultando em um arco interligado a dois planos inclinados, um em cada extremidade.

A imensa maioria da bibliografia especializada descreve o Golfe Clube como um projeto não construído, citando apenas o Cassino, a Casa de Baile, o Iate Clube e a Igreja como obras finalizadas do Conjunto da Pampulha. Devemos salientar que tal projeto foi construído, porém hoje abriga outro uso. Trata-se da sede da administração do Zoológico Municipal de Belo Horizonte, localizado, assim como os demais edifícios, no bairro da Pampulha. Com essa informação, deve-se concluir que o único edifício da Pampulha não construído foi o Hotel Resort. Somente em publicação referente ao restauro da Igreja de São Francisco de Assis, datada de $2006^{82}$, o Golfe Clube da Pampulha foi analisado por Danilo Matoso Macedo ${ }^{83}$ como edifício construído e integrante do conjunto. Macedo discorre que "Neste exuberante contexto, comumente considerado como o Conjunto da Pampulha, a pequena sede do Golfe Clube - hoje dentro do jardim zoológico -, apartada das margens da represa, passa despercebida." (MACEDO apud CASTRO, 2006:116).

A solução apresentada por Niemeyer para o Golfe Clube da Pampulha já havia sido utilizada anteriormente pelo arquiteto no projeto da residência Oswald e Tarsila (1938). Nesse projeto, a disposição dos ambientes seguirá a regra dos projetos de residência com telhado invertido: dormitórios no pavimento superior com hall de distribuição como um balcão que se volta para o estar contido no vazio intermediário entre as diferentes alturas do volume.

O Golfe Clube da Pampulha acompanha a solução formal presente na residência Oswald e Tarsila, porém seu arranjo interno não demonstra a utilização de dois pavimentos no extremo mais alto da construção. Trata-se de um projeto de um único pavimento.

Mais uma vez, podemos observar que Niemeyer não se prende aos condicionantes funcionalistas associados a forma arquitetônica (relação forma/função). $\mathrm{O}$ arquiteto não relaciona a solução formal a um determinado programa fechado. Essas soluções se modificam na medida em que se adaptam aos novos usos.

O princípio do telhado invertido com abóbada - presente na obra de Niemeyer, inicialmente na residência Oswald de Andrade e no Golfe Clube da Pampulha, também pode ser compreendido como uma interpretação do vocabulário corbusiano. Nesse caso, Niemeyer elabora o projeto a partir da fusão de características de dois projetos de Le Corbusier: a residência Monol (1919) e a residência Errazuris (1930).

No projeto da residência Monol, Le Corbusier concebe a cobertura como uma seqüência de abóbadas suspensas, apoiadas em colunas de secção quadrada. Para enfatizar a esbeltez das abó-

82. (CASTRO, Mariângela, FINGUERUT, Silvia (org). Igreja da Pampulha: restauro e reflexões. Rio de Janeiro: Fundação Roberto Marinho, 2006).

83. (Análise de Danilo Matoso Macedo - p.116-117).

233 o encontro de 1936: formação 



[314] Casa Monol - 1919 - LC

(BOESIGER, 1971:25)

[315] Casa Oswald de Andrade e Tarsila do Amaral -

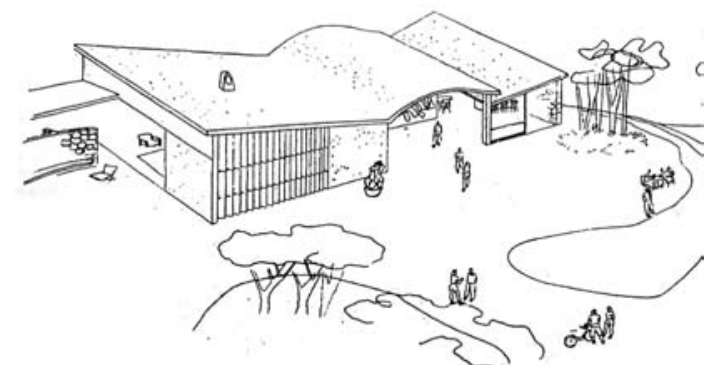

eleveção - 1938 - ON

(PAPADAKI, 1950:18)

[316] Casa Oswald de Andrade e Tarsila do Amaral perspectiva - $1938-$ ON

(PAPADAKI, 1950:19)

[317] Golfe Clube da Pampulha - 1943 - ON

(CASTRO, 2006:140)


[318] Golfe Clube da Pampulha (atual administração do Zoológico Municipal de Belo Horizonte) -1943 - ON foto: Rodrigo Queiroz

[319] Golfe Clube da Pampulha (atual administração do Zoológico Municipal de Belo Horizonte) -1943 - ON foto: Rodrigo Queiroz 
badas, o arquiteto mantém recuados no interior da projeção das abóbadas tanto os fechamentos externos como os apoios situados no ponto de encontro das abóbadas, tornando evidente a espessura da cobertura, caracterizando-a como uma delgada casca.

O tratamento dado por Le Corbusier às abóbadas da residência Monol aproxima-se daquele presente nas abóbadas da residência Oswald e Tarsila e do Golfe Clube da Pampulha. O encontro entre as abóbadas da casa Monol é configurado como um sutil intervalo horizontal, quase como um instante de acomodação visual da curvatura das abóbadas, intervalo também presente na extremidade da última abóbada. As curvaturas das abóbadas não se tocam, e os apoios se dão nesse sutil intervalo horizontal. [314], [315], [316], [317], [318], [319]

O mesmo arremate horizontal adotado por Le Corbusier nas abóbadas da casa Monol é diagnosticado nas extremidades das abóbadas da residência Oswald e Tarsila e no Golfe Clube. Em ambos os projetos Niemeyer adota o mesmo pilar de secção quadrada disposto sob a calha horizontal presente na extremidade da abóbada da casa Monol.

A fusão das referências formais presentes na residência Errazuris (telhado invertido) e na residência Monol (abóbada), terão nos projetos da Residência Oswald e Tarsila e do Golfe Clube da Pampulha seus exemplares mais literais.

As experiências oriundas da junção da abóbada ao telhado invertido, posteriores ao Golfe Clube da Pampulha, apresentam um sentido dinâmico que distende horizontalmente a proporção dessas formas. A abóbada, ao invés de apoiar-se em pilares, descarregará seu peso em apoios inclinados concordantes à curvatura das abóbadas.

No projeto para a biblioteca e auditório do Centro Tecnológico da Aeronáutica em São José dos Campos, realizado em 1947, Niemeyer concebe uma peça constituída por uma seqüência de abóbadas que se conectam a um volume trapezoidal. A abóbada toca o solo apenas em dois pontos extremos, permitindo que o volume do auditório, na medida em que se afunila, atinja uma largura suficiente para penetrar na porção vazada da abóbada. Para alcançar esse efeito compositivo que mantém a integridade formal tanto da abóbada quanto do prisma trapezoidal - mesmo que ambos estejam fundidos entre si - Niemeyer projeta a abóbada mais larga que o volume que se conecta a ela. Com esse artifício, o desenho da abóbada que toca o chão será preservado e dramatizado, pois o arquiteto deixará evidente o ponto de apoio que sustenta a abóbada. [320]

Devemos lembrar que o projeto para Centro Tecnológico da Aeronáutica foi objeto de concurso fechado entre cinco arquitetos, sendo Oscar Niemeyer laureado com a primeira colocação e Affonso Eduardo Reidy com o terceiro lugar.

A solução das abóbadas sucessivas associadas à cobertura inclinada presente no bloco do auditório e biblioteca na versão de Niemeyer também caracteriza um dos edifícios da proposta de Reidy. No caso, o bloco do restaurante e do centro comercial. Enquanto Niemeyer une uma das extremidades da seqüência de abóbadas a um volume trapezoidal de cobertura côncava, Reidy concebe dois volumes trapezoidais, um em cada extremidade da seqüência de abóbadas. Trata-se de um desenho distendido da fusão entre telhado invertido e abóbada presente nos

235 | o encontro de 1936: formação 


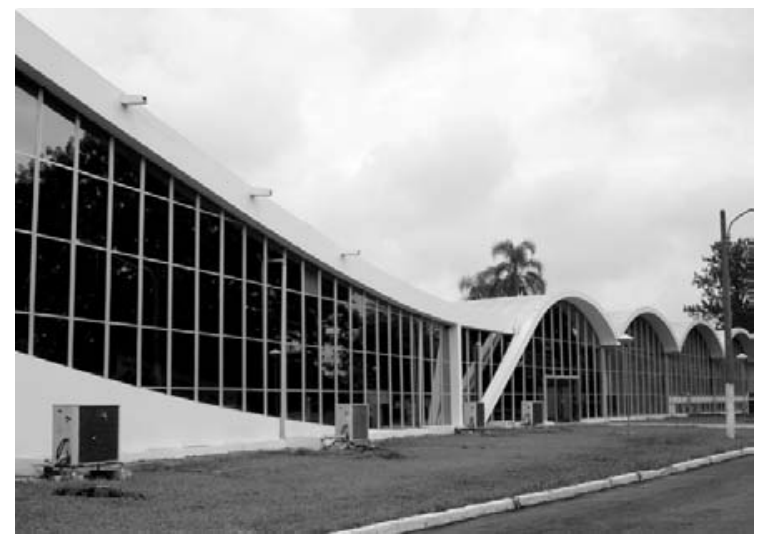

[320] Biblioteca e auditório do CTA - São José dos Campos $-1947-\mathrm{ON}$

foto: Rodrigo Queiroz

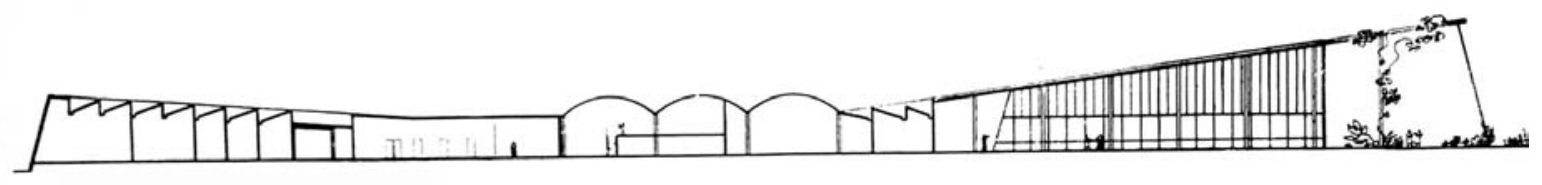



[323] Hospital Sul América - salão social - Rio de Janeiro - 1953 - ON foto: Rodrigo Queiroz

[324] Hospital Sul América - salão social - Rio de Janeiro - 1953 - ON foto: Rodrigo Queiroz

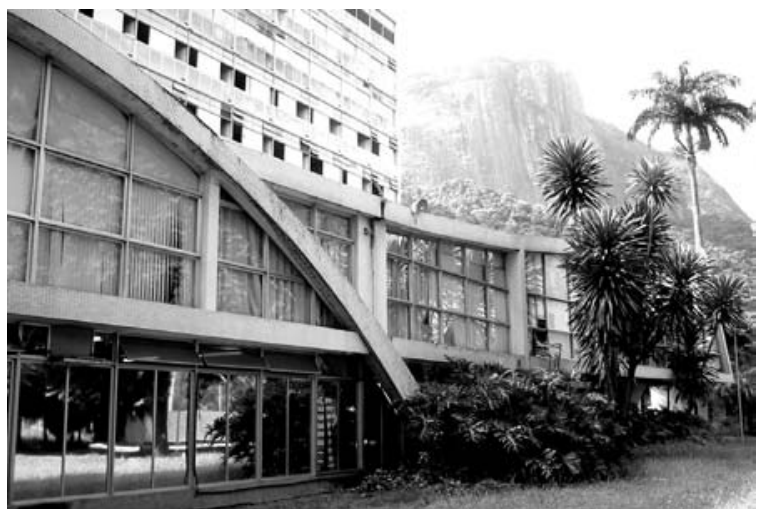


projetos de Niemeyer para a casa Oswald e Tarsila e para o Golf Clube da Pampulha. [321]

No projeto para o edifício-sede da Administração Central da Viação Férrea do Rio Grande do Sul - datado de 1944 - Reidy já havia utilizado, na cobertura do edifício, um pavilhão caracterizado pela seqüência de abóbadas apoiadas em pilares inclinados, conectada a um volume trapezoidal. Provavelmente, esse arranjo formal na cobertura do edifício gaúcho tenha influenciado tanto a solução do próprio Reidy como a de Niemeyer para os pavilhões no CTA em São José dos Campos, realizados em (1947). Nesse mesmo ano, Reidy lança essa mesma solução formal no ginásio de esportes (abóbada) e escola (cobertura inclinada) integrantes do conjunto residencial Pedregulho. [322]

A fusão entre abóbadas e coberturas inclinadas - que possui sua primeira ocorrência na arquitetura moderna brasileira no projeto da casa de Oswald de Andrade - caracterizará as soluções de projeto de diversos arquitetos, como a escola do conjunto habitacional de Pedregulho de Affonso E. Reidy e a Rodoviária de Londrina de João B. Vilanova Artigas (1950).

Para Hugo Segawa, Vilanova Artigas

(...) fez franca oposição ideológica ao trabalho de Le Corbusier, (...), abraçou a linguagem da arquitetura carioca em obras como o Edifício Louveira, em São Paulo, ou seus projetos para a cidade de Londrina, interior do estado do Paraná, como o edifício Autolon e a estação rodoviária, do final da década de 1940 (SEGAWA, 1998:143).

Quando Niemeyer funde a cobertura inclinada de perfil suavemente convexo com a abóbada, cria uma composição cujas formas assumirão um caráter fortemente antagônico e contrastante. O dinamismo da cobertura convexa prolonga-se em diagonal, induzindo o olhar a ascender num movimento que acompanha a direção da linha da cobertura, enquanto a abóbada, por mais distendida e esbelta que seja, irá assentar-se no solo em um movimento de acomodação.

Nos projetos que sucedem a biblioteca/auditório do CTA, Niemeyer irá substituir a seqüência de abóbadas por um único arco abatido, como podemos observar no projeto do pavilhão administrativo do Hospital Sul América no Rio de Janeiro (1953).

No pavilhão anexo ao Hospital Sul América, Niemeyer eleva o volume trapezoidal que, nesse caso, não abriga um auditório como no CTA, mas um salão de recepção. O volume trapezoidal de cobertura côncava encontra-se suspenso. A linha horizontal da laje de piso do volume do salão social prolonga-se até a outra extremidade da abóbada. Como apoio para o volume trapezoidal suspenso, Niemeyer prevê outra abóbada de altura reduzida que nasce do mesmo ponto em que a abóbada maior toca o solo. São abóbadas sucessivas, que nesse caso, não se encontram no ar, mas no chão. [323], [324]

Assim como no CTA e no Hospital Sulamérica, nos projetos para o Clube de Diamantina (1950) e para o Clube Libanês de Belo Horizonte (1955), Niemeyer exercita essa relação dual entre a abóbada abatida e uma outra peça de menor largura que se encaixa no vão compreendido pelo espaço entre os apoios inclinados da abóbada. Porém, nos dois projetos para os clubes mineiros, Niemeyer substitui o volume trapezoidal (assentado diretamente no solo no CTA e

237 | o encontro de 1936: formação 



[325] Clube de Diamantina - 1950 - ON

foto: Rodrigo Queiroz

[326] Clube de Diamantina - 1950 - ON

foto: Rodrigo Queiroz

[327] Clube Libanês - corte - Belo Horizonte - 1955 - ON

(PAPADAKI, 1956:122)

[328] Escola de Ensino Secundário - Corumbá - 1953 - ON

(PAPADAKI, 1953:178) 
suspenso no Hospital Sulamérica) por plataformas em balanço que se projetam para fora do conjunto, apoiadas sobre peças inclinadas e encurvadas.

No projeto de Niemeyer para o Clube de Diamantina (1950), a laje suspensa está apoiada no exato ponto de tangência da abóbada abatida que a suporta, enquanto a abóbada maior abriga o restaurante e o salão de jogos implantados sobre a laje suspensa.

No Clube Libanês de Belo Horizonte (1955), Niemeyer segue o mesmo sentido de articulação entre as peças presente no Clube de Diamantina. Porém, no caso de Belo Horizonte, o arquiteto concebe a cobertura não com uma, mas com duas abóbadas de amplitudes diferentes que nascem no solo e encontram em uma cota suficientemente alta para que ambos os espaços compreendidos pelas abóbadas se relacionem. A plataforma em balanço - continuidade da laje suspensa - não se apóia no ponto de tangência de uma abóbada abatida, como no caso do Clube de Diamantina, mas é sustentada por um apoio encurvado em forma de "meia-abóbada". [325], [326], [327]

O sentido ascensional das coberturas invertidas e côncavas possui um forte apelo cinético que nos faz apreender esses projetos a partir de uma visada em movimento horizontal e, às vezes, parece que nossa percepção visual prolonga as linhas estruturadoras da composição para além dos limites do próprio objeto.

Quando funde a abóbada e a cobertura inclinada em um mesmo objeto, Niemeyer anima esse percurso cinético com um arranjo caracterizado pela dualidade entre o dinamismo da cobertura côncava e o suave repouso da abóbada. Na escola de ensino secundário em Corumbá (1953) encontramos um típico exemplar da combinação entre o dinamismo ascendente do perfil trapezoidal que abriga o auditório e a serenidade da abóbada abatida e apoiada no solo por dois pilares inclinados. [328]

Essa composição dada pela fusão entre volumes trapezoidais e abóbadas - na obra de Niemeyer - nasce do encontro entre a abóbada e o telhado invertido no projeto para a casa de Oswald de Andrade e Tarsila do Amaral (1938) e sofre sucessivas modificações. A cobertura em "V" é substituída por um único volume de secção trapezoidal, cuja cobertura inclinada encurvase, em sutil concavidade, para encontrar a abóbada em um plano horizontal.

Apesar da casa Oswald e Tarsila representar um aparente pioneirismo na utilização da cobertura inclinada e da abóbada, devemos lembrar do projeto de Luis Nunes para a Escola rural Alberto Torres em Recife, datado de 1935, no qual o arquiteto desenvolve um esquema de rampas atirantadas por cabos fixados em uma parábola cujo contorno se mistura às diagonais da rampa. Tal solução só foi possível graças ao cálculo estrutural do então engenheiro local Joaquim Cardozo, que posteriormente acompanharia Oscar Niemeyer em Pampulha (1940/1943) e em Brasilia (1957/1962).

Para Yves Bruand:

(...) o jogo de rampas suspensas por dois arcos parabólicos foi sem dúvida inspirado nos projeto de Le Corbusier para o Palácio dos Sovietes em Moscou (1931), embora a interpretação seja diferente (...) Le Corbusier havia previsto um grande arco parabólico que suportaria uma das extremidades da laje de cobertura

239 | o encontro de 1936: formação 
da grande sala de reuniões (BRUAND 1981:79).

A posição de Bruand reforça nossa colocação que entende a obra de Le Corbusier como um tema plástico que será assimilado pela arquitetura moderna brasileira - seja Niemeyer em Pampulha, Luis Nunes em Recife, ou Affonso E. Reidy em Pedregulho - como um rol de soluções formais adaptáveis aos mais diversos programas.

Mesmo em projetos que não são caracterizados pelo uso conjunto de abóbada e cobertura inclinada, Niemeyer preservará a tensão por oposição de natureza geométrica, como no projeto para o Congresso Nacional de Brasília (1958), com a cúpula do Senado que repousa e a cúpula invertida da Câmara dos Deputados que tangencia o embasamento, e no conjunto arquitetônico do Parque Ibirapuera (1951/1954), onde a expansão vertical do auditório de secção triangular que toca o chão em um único ponto é a plena inversão da cúpula achatada do Palácio das Artes (hoje Oca). A marquise de conexão entre o auditório e o Palácio das Artes é o elemento estruturador do conjunto. É uma linha horizontal que interliga os dois volumes em suas dimensões física e visual. $^{84}$

Em edifícios como o bloco auditório/biblioteca do CTA e o salão social do Hospital Sulamérica, a relação de antagonismo entre as formas estáticas e as formas dinâmicas constituem um conjunto "truncado", onde as formas se interseccionam, não possuindo o mesmo grau de independência presente nos conjuntos formados pelo Palácio das Artes e o Auditório do Ibirapuera e pelas cúpulas inversas das câmaras dos senadores e dos deputados no Congresso Nacional, nos quais os volumes contrastantes assumem uma autonomia própria.

Projetos como as residências Passos e Oswald de Andrade ou o Iate Clube e o Golfe Clube da Pampulha representam uma interpretação pessoal do vocabulário corbusiano presentes nas residências Errazuris e Monol. Porém, a medida em que Niemeyer experimenta outras associações compositivas aos mesmos elementos formais, se afasta de suas referências iniciais e legitima uma obra que se constitui como um redesenho dela mesma.

84. Tanto o auditório de secção triangular que toca o solo em um vértice e a marquise que o conecta ao Palácio das Artes não foram construídos. Durante mais de cinqüenta anos Niemeyer realizou diversos estudos para o auditório do Parque Ibirapuera e em 2003 o auditório foi construído. Trata-se de uma inversão do primeiro projeto. No projeto definitivo, o perfil triangular do auditório toca o solo em uma de suas arestas e não em um dos vértices como nas versões realizadas entre 1951 e 1954. 


\section{Entre as modernidades de Le Corbusier e Lucio Costa}

No projeto do Iate Clube da Pampulha, Niemeyer transporta o raciocínio volumétrico presente nos exemplares puristas de Le Corbusier para um novo patamar de transparência, leveza e liberdade. Todas as aberturas dos recintos contidos no pavimento térreo do Iate Clube (hangar, vestiários e primeiros-socorros) configuram-se como frestas entre os volumes do térreo e a laje de piso do volume trapezoidal suspenso. Esse artifício enfatiza a separação entre o volume regular elevado e o volume oblongo abrigado sob sua projeção. O recuo do volume oblongo do térreo torna ainda mais intensa essa relação de contraste entre o que está elevado e o que está no chão. [329]

A utilização da cerâmica pintada na totalidade das superfícies externas dos ambientes do pavimento térreo contrapõe-se as espessuras delgadas e opacas, aos brises verticais e aos extensos planos transparentes presentes nas faces "em borboleta" do Iate Clube. O motivo pintado na cerâmica, tema presente na arquitetura luso-brasileira, é exatamente o mesmo que reveste tanto a mureta que acompanha a marquise na Casa de Baile como a base que apóia o caixilho do térreo do Cassino. [330]

No conjunto da Pampulha, cada edifício possui uma autonomia formal independente e o sentido de unidade entre eles é dado pelo material, pelo tratamento hierárquico das superfícies (cerâmica, vidro e pedra) e pelos perfis exteriores resultantes das espessuras das lajes e das abóbadas revestidas de pedra apicoada.

A unidade entre o Cassino, o Iate Clube e a Casa de Baile - dada pela escolha dos mesmos materiais e pela adoção de um partido formal que prevê a utilização de lajes estruturadas por trama de pilares - faz com que o projeto da Igreja de São Francisco de Assis assuma um papel de destaque no conjunto, apesar de manter as características de tratamento da superfície próximas dos demais projetos, como a borda em pedra que desenha o perfil exterior da forma, o caixilho sutilmente recuado com relação à projeção do contorno exterior e a cerâmica pintada que, na igrejinha, é suporte para uma temática figurativa.

Para Luiz Recamán:

241 o encontro de 1936: formação 

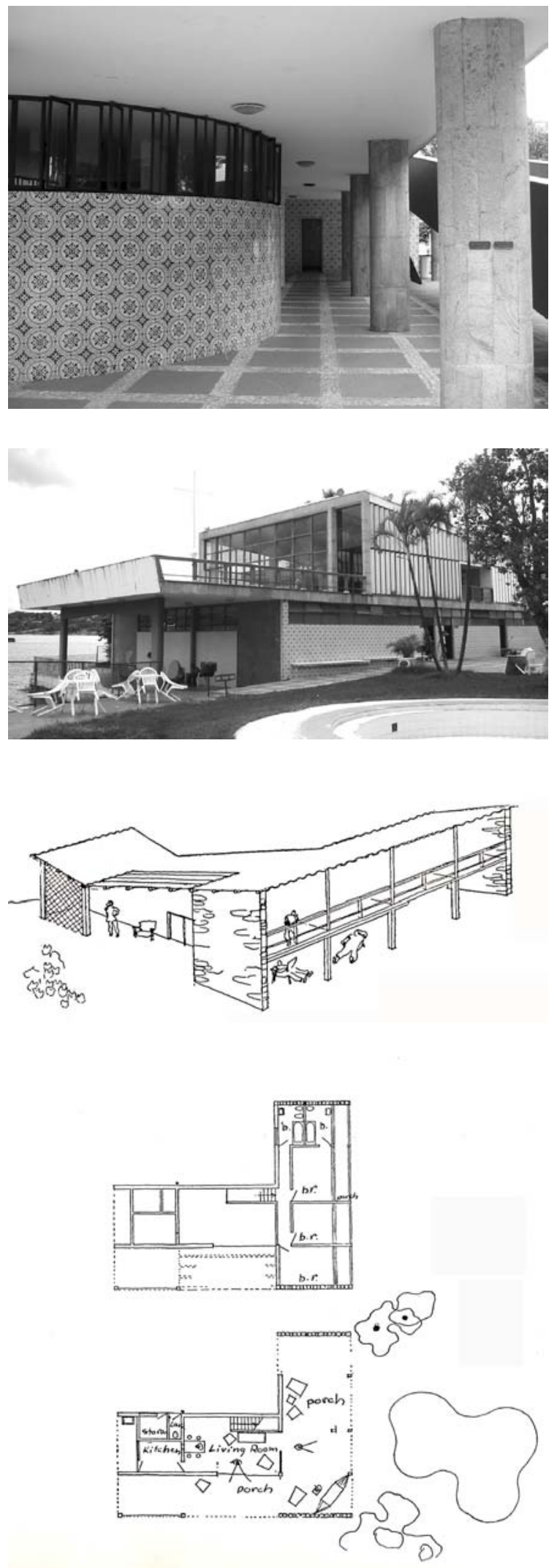
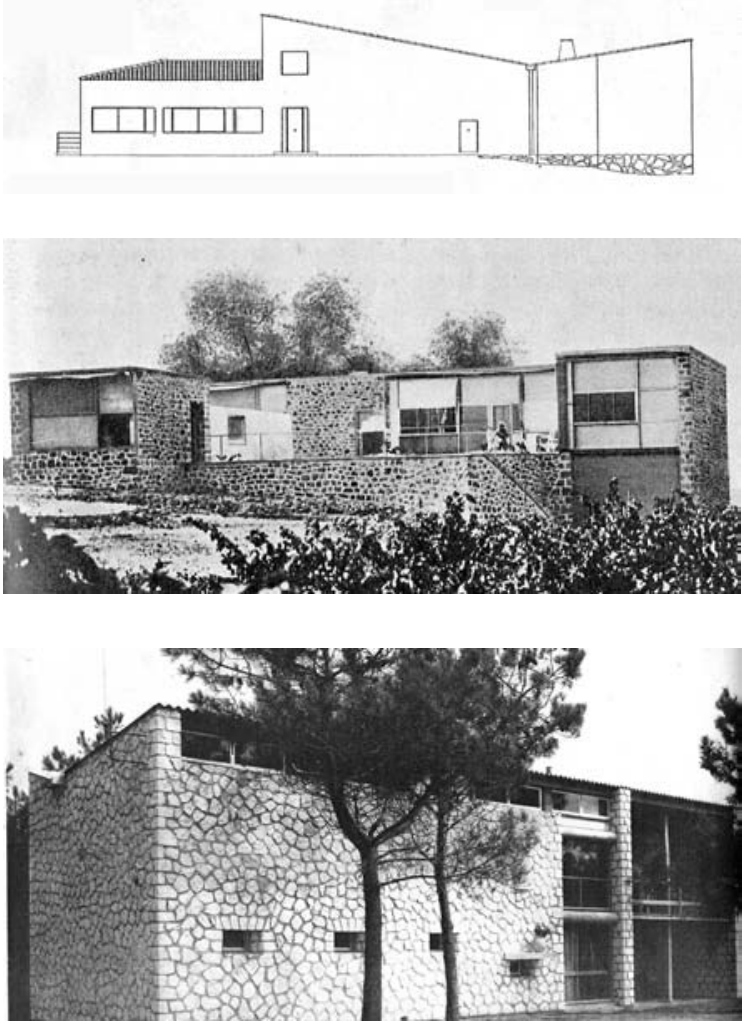

[329] Iate Clube da Pampulha - vestiários - 1943 - ON foto: Rodrigo Queiroz

[330] Iate Clube da Pampulha - terraço - 1943 - ON foto: Rodrigo Queiroz

[331] Casa Passos - perspectiva - 1939 - ON

(PAPADAKI, 1950:20)

[332] Casa Passos - planta - 1939-ON

(PAPADAKI, 1950:21)

[333] Casa Errazuris - fachada leste - 1930 - LC

(BOESIGER, 1947:50)

[334] Casa da Mme. Mandrot - 1931 - LC

(BOESIGER, 1947:61)

[335] Casa em Mathes - 1935 - LC

(BOESIGER, 1971:70) 
A conjugação de dois prismas trapezoidais unidos pela base menor vai formar um volume que é irregular, não em planta, mas em elevação. Essa laje tipo "borboleta", que forma uma calha interna, vai ser repetida com freqüência a partir de então. (...) O Iate Clube nos mostra um importante estágio desse volume em busca de concentração máxima, o que não fora alcançado nem no Cassino (ainda volumes em tensão), nem na Casa de Baile (que não constitui propriamente um volume, mas como que uma extrusão da planta curva) (RECAMÁN, 2002:161-162).

Certamente, a cobertura em "V" do Iate Clube é a peculiaridade que caracteriza o edifício dentro do rol de soluções formais concebidas por Niemeyer em Pampulha.

Apesar do conjunto da Pampulha representar o marco inicial da longeva trajetória de Niemeyer, diversas soluções aplicadas em Pampulha já haviam sido especuladas pelo arquiteto em projetos anteriores. O Iate Clube não será o primeiro exemplar na arquitetura de Niemeyer que utiliza o telhado invertido.

O perfil exterior do projeto do Iate não é um redesenho direto da cobertura da residência Errazuris de Le Corbusier, mas um desdobramento das pesquisas formais de Niemeyer sobre as coberturas invertidas presentes em projetos como a residência de Oswald e Tarsila (1938) e a residência Passos (1938).

Para a compreensão dos percursos e das origens dessas soluções que incorporam a forma moderna às superfícies “embrutecidas” nos projetos de Niemeyer, faze-se necessária uma análise de alguns referenciais que antecedem à produção do arquiteto, são eles: as autenticidades modernas de caráter regionalista presentes em Le Corbusier e Lucio Costa.

O percurso que leva Oscar Niemeyer a adotar a solução do volume trapezoidal em "V" que caracteriza o Iate Clube passa pelos projetos realizados no período que antecede a experiência em Pampulha. Em diversos projetos de residências ${ }^{85}$, Niemeyer utiliza as coberturas em caimento invertido.

Em projetos como a residência Passos (1938), Niemeyer já utiliza a cobertura de duas águas com inclinação contrária, também com a divisão assimétrica dos caimentos, porém em uma planta em “L”, diferentemente do retângulo do Iate Clube. [331], [332]

Para Danilo Matoso Macedo:

(...), Niemeyer vinha desenvolvendo em seus projetos de 1936 a 1943 um pensamento de cunho nativista que o leva a articular telhados cerâmicos, muxarabis e generosos avarandados, devidamente codificados pelas interpretações modernas que Lúcio Costa vinha dando a estes elementos, não apenas em projetos com a Vila Operária de Monlevade (1934), como também em seus textos - Rãões da nova arquitetura (1934) e Documentação Necessária (1938). A estas leituras some-se o contato direto com Le Corbusier e a condução das obras do Ministério da Educação e Saúde Pública - Mesp - pelo próprio Niemeyer, concluídas apenas em 1945 e simultâneas à construção da Pampulha (MACEDO apud CASTRO, 2006:106-107,grifo nosso).

O autor coloca a produção de Niemeyer compreendida entre 1936 e 1943 como uma

85. Os primeiros projetos de Niemeyer que acusam a adoção da cobertura em "V" são a casa Passos (1938) e a casa Ofair (1943).

243 | o encontro de 1936: formação 
síntese entre a proposta de Lúcio Costa que vincula modernidade à tradição e a experiência com Le Corbusier por ocasião do encontro ocorrido em 1936 para a realização do projeto do MES.

É certo que a estruturação da linguagem da arquitetura de Niemeyer é conseqüência dessa formação de mão-dupla. Porém, gostaríamos de adicionar à afirmação de Danilo Matoso um outro fator fundamental para a compreensão da produção "nativista" de Niemeyer, que segundo Matoso, é realizada entre 1936 e 1943: o papel do caráter primitivista de viés vernacular presente nos projetos de residências de Le Corbusier realizados entre 1929 e 1935.

As residências de Niemeyer projetadas entre 1936 e 1952 não sintetizam apenas uma interpretação dos ensinamentos de Lucio Costa associada à assimilação dos pressupostos corbusianos ocorridos durante o encontro de 1936. Devemos somar a esse conjunto de influências os projetos de residências ${ }^{86}$ de Le Corbusier realizados durante a década de 1930. Nesses projetos, o purismo estilizado das casas brancas da década de $1920^{87}$ é substituído pela "temática do lugar", nos quais o arquiteto lança mão das telhas cerâmicas em coberturas inclinadas ede materiais como pedra bruta e madeira, tanto na estrutura como nos próprios revestimentos interiores e exteriores.

Podemos dizer que as "casas vernáculas" de Niemeyer realizadas entre 1936 e 1952, não são apenas um produto da confluência da "tradição" de Costa e da "modernidade" de Le Corbusier. Na verdade, Niemeyer funde duas "tradições": a de Costa e de Le Corbusier.

Segundo Abílio Guerra:

(...) a articulação entre modernidade e tradição visando uma arte moderna com estreitos vínculos com as raízes da modernidade defendida pelo intelectual paulista ${ }^{88}$ vai ser ponto de partida para que o arquiteto carioca $^{89}$ desenvolvesse sua visão de uma arquitetura ao mesmo tempo atualizada em relação aos princípios modernos europeus - em especial, os de Le Corbusier - e que mantivesse profundos vínculos com a arquitetura tradicional realizada por mestres anônimos durante o período colonial (GUERRA, 2002:07, grifo nosso).

Podemos acrescentar à colocação de Abílio Guerra o fato de que os "os princípios modernos" não foram os únicos elementos do mestre franco-suíço assimilados por Costa como instrumental de referência para sua postulação que define a autenticidade a partir da síntese entre tradição e modernidade.

Lucio Costa assimila tanto o referencial moderno de Le Corbusier - representado pelo esquema Dom-ino e pelas vilas puristas - como referencial vernacular - representado pelas moradas da década de 1930 .

Ao "postular" a necessidade de um nexo entre a arquitetura moderna e a tradição colonial, Lucio Costa não amalgama apenas dois conhecimentos separados por mais de dois séculos. $\mathrm{Na}$ verdade, Costa interpreta - a partir de uma perspectiva brasileira - uma equação que já havia

86. Residências Loucheur (1929), Errazuris (1930), Mathes (1935) e Mandrot (1931), entre outras.

87. Vide o capítulo Cassino.

88. Leia-se: Mário de Andrade.

89. Leia-se: Lucio Costa. 
sido formulada pelo próprio Le Corbusier.

Com o abandono das soluções puristas e a afeição pela temática vernácula, Le Corbusier estabelece uma conexão entre o homem, a arquitetura e o lugar. A partir desse raciocínio, o arquiteto encontra uma perspectiva, não só para sua própria obra, mas para a arquitetura moderna, libertando-a dos códigos de uma abstração geométrica e abrindo a possibilidade para a construção de uma nova cultura arquitetônica, balizada não mais pela abstração pictórico-tecnicista, mas pela adoção da matéria que possui memória.

Para Sophia Silva Telles, os materiais as superfícies primitivas presentes nos projetos de Le Corbusier

(...) São tratados como referências do mundo que devem ser respeitadas na sua materialidade de coisas cotidianas e vernaculares; são correlatos à escala e à presença do corpo humano e se tornam modernos pelo ato do arquiteto de unificá-los por meio da construção de um espaço sem hierarquias e sem sentimentalismos (TELLES, 1988:25).

O rompimento de Le Corbusier com o dogmatismo purista é conseqüência de diversos fatores, desde a escassez de aço na Europa até uma suposta desilusão com a "civilização maquinista" cuja sedução dos predicados não exerceu um convencimento pleno do poder público, tanto na Europa como no continente americano.

O argumento que afirma que Le Corbusier migra da abstração purista para a temática vernácula por causa da escassez de aço no pós-guerra poderia ser acrescido de outros fatores. Devemos lembrar que desde 1929 - mesmo ano em que realiza a casa Savoye - o arquiteto desenvolve experiências que utilizam materiais regionais. A inclinação de Le Corbusier sobre o vernáculo e o primitivo já está presente em sua obra há, pelo menos, quinze anos antes do "pós-guerra".

Kenneth Frampton reconhece uma certa nebulosidade nos motivos que fizeram Le Corbusier migrar da "estética da máquina" para a "estética do lugar":

Pouco depois de 1933, começou a reagir contra a produção racionalizada da machine d'habiter, embora não se saiba ao certo se o terá feito por desilusão com a técnica moderna, ou por desespero diante de um mundo arrebentado pela depressão econômica e pela reação política.(...)

Por alguma razão cujos fundamentos últimos desconhecemos, o fato é que elementos técnicos primitivos começam a aparecer em sua obra com uma freqüência e uma liberdade de expressão cada vez maiores a partir da década de 1930. Primeiro na casa Errazuris, um projeto de 1930 para o Chile, obra em madeira, pedra e com o telhado em vertente, depois na villa de paredes de cascalho construída para Madame Mandrot perto de Toulon, em 1931, e por último em duas extraordinárias obras de 1935 e 1937, respectivamente: uma casa para fins de semana construída nos subúrbios de Paris de concreto e abobadada, e seu leve Pavillon des Temps Nouveaux, feito em lona para a Exposição Internacional de Paris de 1937 (FRAMPTON 1997:221-222, grifo nosso).

Para Frampton, a casa Errazuris representa a primeira incursão de Le Corbusier com a temática primitiva. Gostaríamos de acrescentar à afirmação do autor o projeto das casas Loucheur realizado por Le Corbusier em 1929.

245 | o encontro de 1936: formação 
No mesmo ano, o arquiteto elabora a versão definitiva da casa Savoye - reconhecida como o exemplar mais depurado ${ }^{90}$ das casas brancas da década de 1920 - e realiza a experiência das casas Loucheur, que já expressa um diálogo com o vernacular antes mesmo dos exemplares que, pelo menos do ponto de vista historiográfico, serão os representantes dessa nova fase: casa Errazuris no Chile (1930), casa da Mme. Mandrot em Toulon (1931) e a casa em Mathes (1935). [333], [334], [335]

O projeto para as casas Loucheur ilustra o exato instante em que Le Corbusier revê os pressupostos de um purismo estilizado e assimila a matéria bruta - plena antítese às superfícies imaculadas das casas da década de 1920 - como elemento de uma experiência que especulava a pré-fabricação.

Ao apontar a necessidade do "muro primitivo" e do uso da mão do homem local, Le Corbusier estabelece um nexo entre a cultura do lugar e a técnica moderna.

Provavelmente, as casas Loucheur - devido ao pronunciado teor tecnológico da proposta - pudessem existir, enquanto artefato construído, sem a necessidade da construção de um artesanal muro de pedra. Nesse projeto, parece que Le Corbusier especifica o muro rudimentar muito mais como uma dimensão simbólica e memorial do que como uma solução que provém de um raciocínio eminentemente técnico.

A adoção da matéria do lugar como componente da construção é uma decisão que representa o momento em que o arquiteto elege a substância da terra, em sua linguagem mais crua, como índice estruturador da expressão do objeto arquitetônico. O engenho "Dom-ino" revestido por um diáfano purificador (Stein e Savoye) nas casas Lourcheur é substituído pelo experimento fabril que, para encontrar um nexo com o homem, se apóia no muro erigido pelo lugar (a matéria e o homem).

Segundo Frampton:

Em resumo, como nos casos de Toulon e Mathes, o arquiteto recorrera a uma expressiva bricolage. A partir daí, a justaposição de materiais contrastantes tornou-se um aspecto fundamental do estilo de Le Corbusier, não só como "pallete" expressiva, mas também como meio de construção.

Essa adesão a materiais naturais e métodos primitivos teve conseqüências que extrapolaram a mera mudança de técnica ou de estilo da superfície. Acima de tudo, significou o abandono do envoltório clássico que tinha sido usado nas villas de fins da década de 1920 (FRAMPTON 1997:227, grifo nosso).

Nas casas Loucheur, a parede de pedra divide as habitações que possuem plantas espelhadas. Cada unidade consiste de um volume de um único pavimento, suspenso por pilotis metálicos e escorado na própria parede de pedra. Um recinto quadrado, localizado no centro da planta, além de abrigar o banheiro, tem a função de organizar os espaços internos divididos ora por painéis de correr, ora pelos armários. No térreo, um volume com as mesmas características do banheiro, porém com dimensões um pouco maiores, abriga um pequeno depósito e área de

90. (Cf.: SBRIGLIO, 2005:06) 
serviço. [336], [337]

Le Corbusier explica que o projeto das casas Loucheur:

(...) nasceu de uma encomenda de pequenos proprietários de uma terra localizada em uma região afastada, desprovida de meios para uma construção que atendesse tanto os requisitos técnicos como econômicos.(...) A concepção da casa seca vem propor uma solução: deve ser construída em fábricas de componentes metálicos para a construção civil. A casa seca é feita de elementos combináveis, montáveis, transportado facilmente por vagões. (...) A casa sai da fábrica num vagão, com todos os seus elementos, incluindo o equipamento interior, acompanhada por sua equipe de montagem. $\mathrm{O}$ montador ergue a casa no próprio local em questão de dias. (...), está prevista a construção de um muro de apoio para a casa ou de um muro de divisão entre as duas casas, em pedras de alvenaria, tijolos ou aglomerados, materiais da região, construído pelo pedreiro local. E assim, os obscuros arranjos que envolvem os procedimentos das relações comerciais locais será suplantado e uma útil aliança se selará.

A ossatura da casa Loucheur permite combinações múltiplas: pequenas casas de $45 \mathrm{~m}^{2}$, conveniente aos pequenos programas; unidades de $90 \mathrm{~m}^{2}$ dois módulos; unidades de $135 \mathrm{~m}^{2}$ de três módulos e unidades de $180 \mathrm{~m}^{2}$ de quatro módulos.

Eis portanto, só em 1929 a realização da casa Dom-ino imaginada em 1914 (LE CORBUSIER apud BOESIGER, 1946:199, tradução do autor - grifo nosso).

Ao referir-se a casa Loucheur como "casa seca", Le Corbusier usa um termo cujo significado se opõe a natureza "fluída e úmida" da matéria-prima das construções em concreto como as casas puristas da década de 1920. A palavra "seca" é carregada de uma afeição ao fabril, ao tecnológico.

Em nenhum instante de sua explicação Le Corbusier justifica a adoção da matéria vernácula a partir de uma perspectiva plástica. Ao contrário, pelo menos nessa explicação, a dimensão estética é substituída pela dimensão ética. O arquiteto encontra na predileção pela matéria e pelo homem do "lugar" uma maneira de conferir dignidade a partir do trabalho de quem constrói.

Para Luis Espallargas Gimenez, as casas Loucheurs (1929) de Le Corbusier exerceram um papel fundamental na concepção do projeto de Lucio Costa para as habitações da Vila Monlevade (1934). Segue trecho do autor:

Nem a função, nem a técnica, nem a sociedade, tripé do movimento moderno, visitam espontaneamente a cultura. Lúcio Costa deve sentir este drama com as operações de adaptação que foi obrigado a fazer em Monlevade, para conciliar seu fascínio pelo novo com seu respeito pelo tradicional. As Maisons Loucheurs sofrem todas as transgressões necessárias e dolorosas para ajustar o sistema Dom-ino à nossa realidade e o resultado é a modernidade possível e o testemunho da confusão entre cultura nacional e cultura arquitetônica: o barro e a taquara sobre pilotis de concreto (ESPALLARGAS apud GUERRA, 2002:84).

A colocação de Espallargas abre uma interessante perspectiva para a análise desse "trânsito de influências" que conformará as linguagens de Niemeyer e de Lucio Costa.

Como já foi dito no início do capítulo, devemos compreender que grande parte dos projetos de residências realizada por Niemeyer entre 1936 e 1952 não é mera conseqüência da interpretação da "tradição" de Costa e da "modernidade" de Le Corbusier, mas também devem

247 | o encontro de 1936: formação 

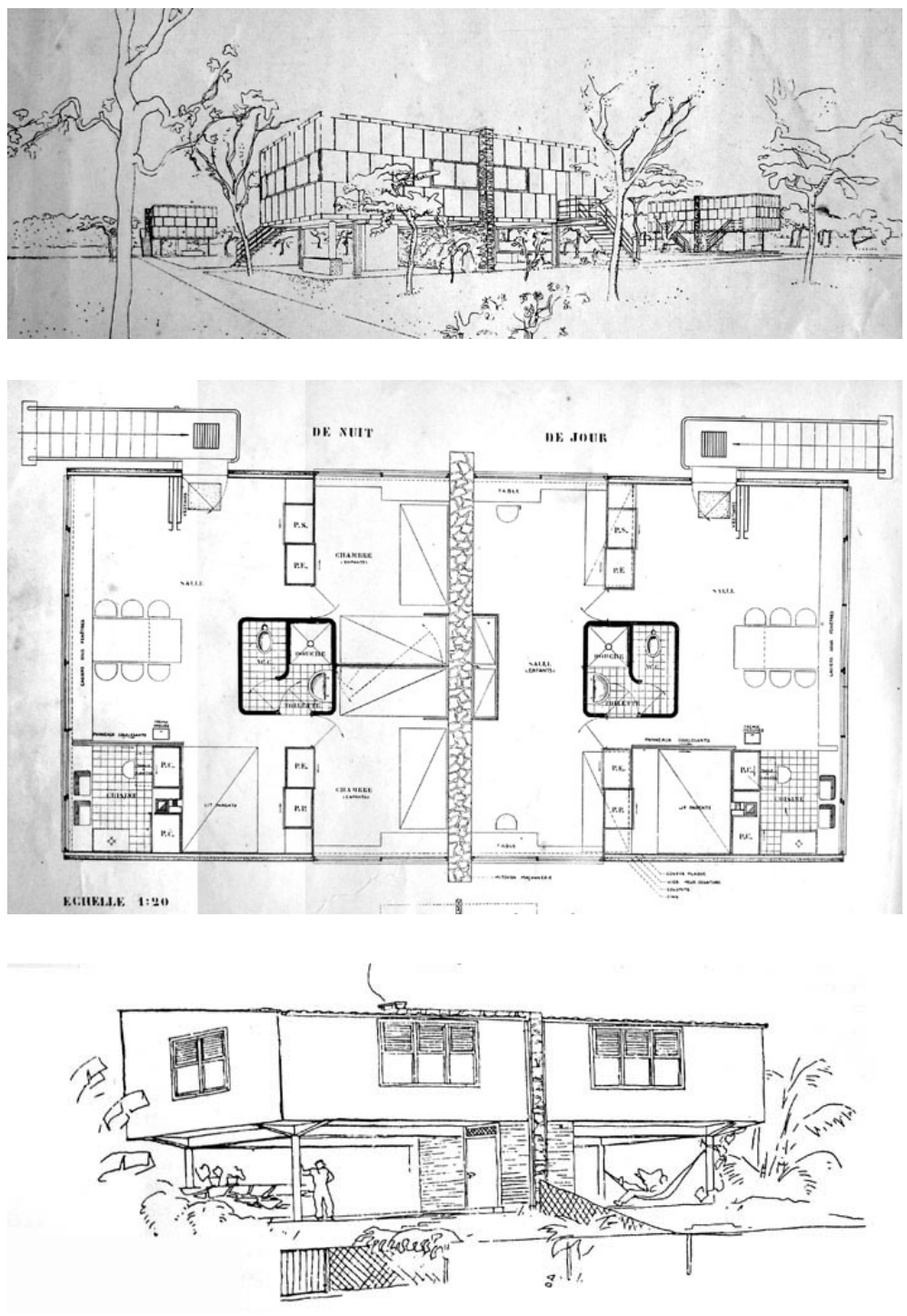



TYPO A.



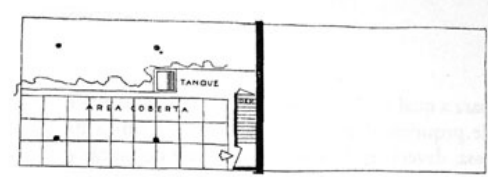

TYPOB.

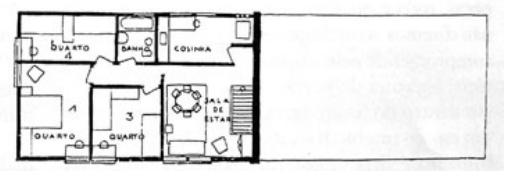

[336] Casas Loucheur - perspectiva - 1929 - LC

(BOESIGER, 1946:199)

[337] Casas Loucheur - planta pavimento superior - 1929 - LC

(BOESIGER, 1946:198)

[338] Casas na Vila de Monlevade - perspectiva - 1934 - Lucio Costa (COSTA, 1995:93)

[339] Casas da Vila Monlevade - plantas - 1934 - Lucio Costa (COSTA, 1995:93) 
ser considerados como um desdobramento de uma tradição de linhagem corbusiana (Loucheur, Errazuris, Mandrot e Mathes).

Se adicionarmos à nossa afirmação, a colocação de Espallargas que postula sobre o papel do vernáculo corbusiano na estruturação do "ideário nacional” de Costa, poderemos concluir que o diálogo entre modernidade e tradição presente nos projetos das casas de Le Corbusier concebidas na primeira metade da década de 1930 será um instrumento fundamental para a formulação de uma estética nacional tanto em Lucio Costa como em Oscar Niemeyer.

Em um dos desenhos de Costa para a Vila Monlevade, podemos observar a utilização, não apenas da mesma tipologia dos volumes suspensos e rebatidos presentes na proposta de Le Corbusier em Loucheur, como da mesma parede de pedra bruta que divide as unidades espelhadas. [338]

Se a solução tipológica apoiada no muro de pedra aproxima as duas propostas, o mesmo não pode ser dito dos tratamentos das superfícies do corpo edificado.

Le Corbusier desenvolve os fechamentos das casas Loucher com uma delgada placa de solomita revestida com chapa de zinco, cuja dimensão se aproxima do tamanho das próprias janelas. Trata-se de três fileiras de chapas sobrepostas. Na fileira do meio, o arquiteto enquadra as aberturas. Como em uma parede de tijolos, as chapas estão dispostas desalinhadas. Com esse artifício, Le Corbusier afasta a idéia do rasgo que perfura a face pura, presente nas vilas puristas. À distância, salta aos olhos uma trama irregular que incorpora as aberturas ao seu desenho.

$\mathrm{Na}$ habitações da Vila Monlevade, Lucio Costa assumirá uma posição diametralmente oposta daquela presente nas casas Loucheur. Enquanto Le Corbusier assimila a técnica moderna tanto na estrutura como nos fechamentos, Lucio Costa sobrepõe aos pilotis cilíndricos de concreto um volume cujos fechamentos são de pau-a-pique, preenchidos com barro e pintados com cal. As aberturas são constituídas de singelas janelas retangulares de madeira, cujas venezianas, em sistema de guilhotina, deslizam pela face externa do fechamento. [339], [340]

Segue trecho em que Lucio Costa, ao descrever uma arquitetura popular carregada de justeza e retidão, a compara com as novas tecnologias da arquitetura moderna:

(...) é sair da cidade e ver à beira da estrada, feitas de pau-a-pique, pau do mato próximo, próxima da terra do chão, como casas de bicho (...) e ninguém liga, tão habituado que está, pois aquilo faz parte da terra como formigueiro, figueira brava e pé de milho (...) é o chão que continua. (...) o engenhoso processo como são feitas - barro armado com madeira - tem qualquer coisa do nosso concreto armado (COSTA apud TELLES, 1988:37).

Se nas casas Loucheur, Le Corbusier reduz a dimensão nativa à parede divisória de pedra, na Vila Monlevade, Lucio Costa expande a autenticidade do passado à praticamente todo o projeto, excetuando-se os pilotis em concreto. [341], [342], [343]

Tanto nas perspectivas desenhadas por Costa como naquelas que ilustram o projeto de Le Corbusier há uma atmosfera preguiçosa que transparece uma mistura de ócio e liberdade. Ambos os arquitetos ambientam em suas arquiteturas um homem que descansa em um cenário quase "franciscano", mas que se permite uma certa frugalidade vagarosa. É o homem que, sere-

249 | o encontro de 1936: formação 

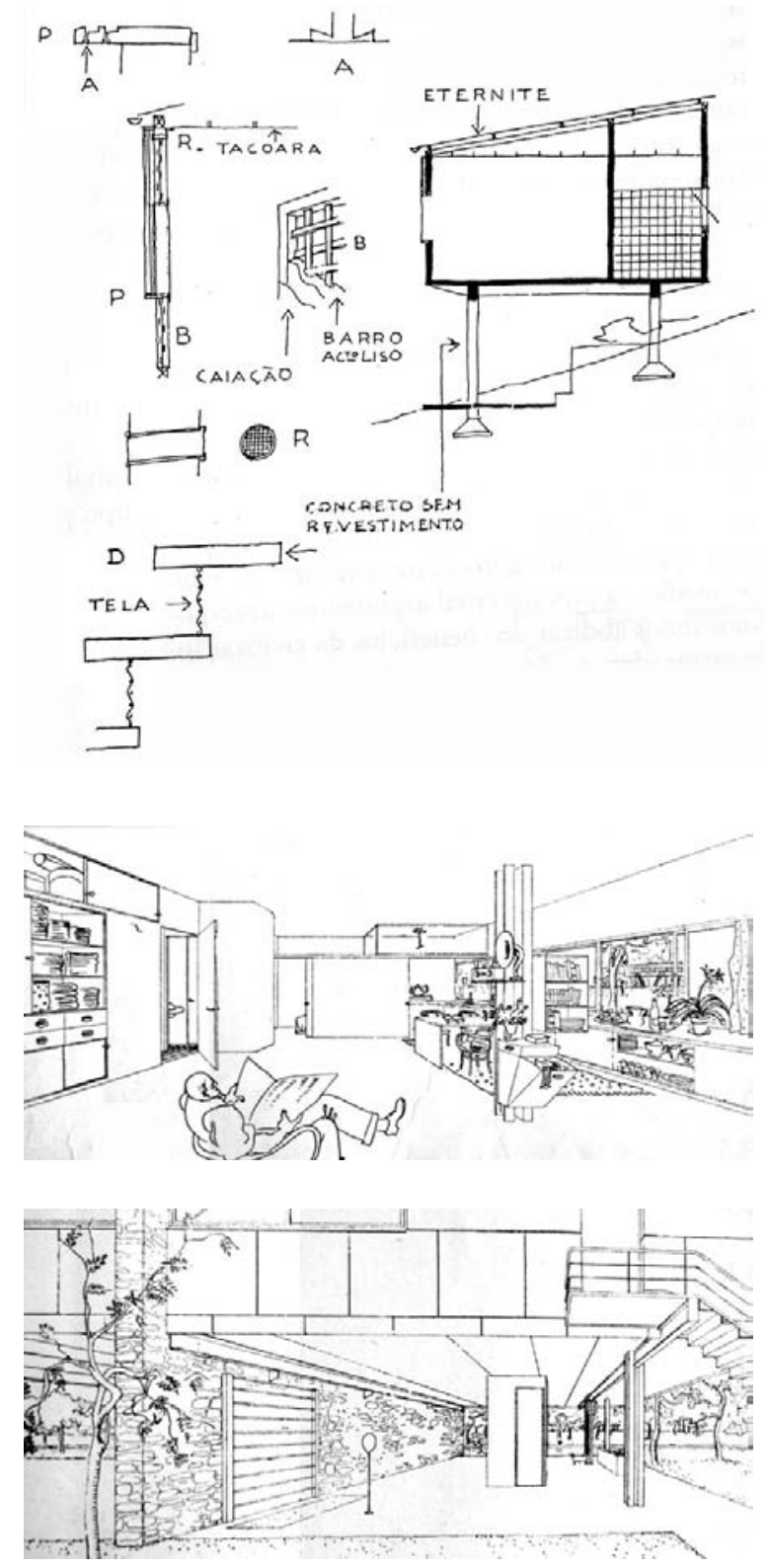

[340] Casas da Vila Monlevade - corte - 1934 - Lucio Costa (COSTA, 1995:93)

[341] casas Loucheur - perspectiva interna - 1929 - LC (BOESIGER, 1946:199)

[342] casas Loucheur - perspectiva térreo - 1929 - LC (BOESIGER, 1946:199)

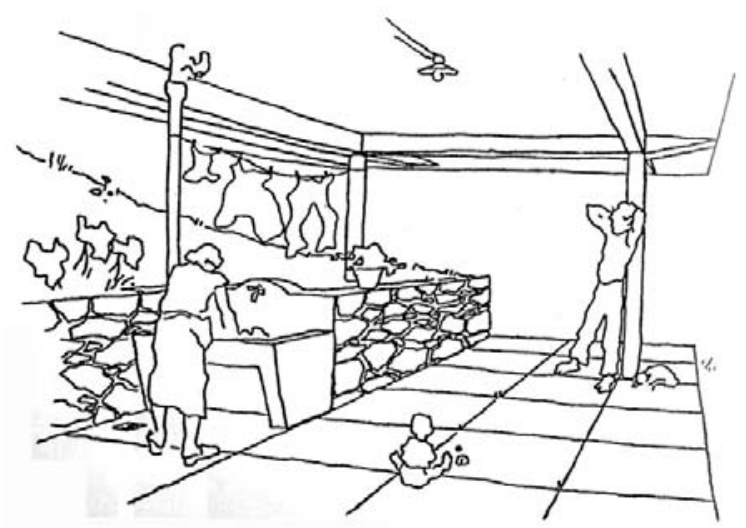

[343] Casas da Vila Monlevade - perspectiva pilotis - 1934 - Lucio Costa

(COSTA, 1995:90) 
namente, assimila uma conduta moderna a partir de sua condição social: indivíduo integrante de uma comuna de trabalhadores.

Ao adicionar a matéria primitiva a um raciocínio moderno, Le Corbusier abre uma nova perspectiva para a construção de uma autenticidade moderna a partir da adoção das características do lugar.

Allan Colquhoun no texto Arquitetura e engenharia: Le Corbusier e o paradoxo da razão cita um trecho em que Le Corbusier discorre sobre a memória:

(...) 'Quando o homem faz uso da memória, do exame do raciocínio da criação (...) surgem certas relações que agitam nossa consciência e nos deixam em um estado de regozijo'. Com essa declaração, Le Corbusier abre a arquitetura a uma incalculável e infinita cultura (COLQUHOUN 2004:106, grifo nosso).

Em Le Corbusier, a fuga de um abstracionismo cúbico-purista e a aproximação a uma manifestação de linguagem oposta, vinculada a uma matéria que contém um carregado teor de memória, serão a chave para o estabelecimento de uma relação de identidade entre o território e a edificação moderna.

A configuração do lugar está presente tanto na própria matéria da construção, como nos procedimentos construtivos: estruturas de madeira, paredes de pedras e coberturas em telha cerâmica.

A idéia de modernidade só atinge um alto patamar de identificação com a cultura do lugar quando adota os elementos materiais dessa mesma cultura para a construção, não apenas do edifício em si, mas de um "tema” que vincule, a partir da figuração de uma tradição, os anseios da modernidade ao desejo por uma produção genuína, autêntica.

Esse traço que utiliza a memória como instrumento para a configuração de uma estética ao mesmo tempo moderna e nacional não está presente apenas nos projetos de Le Corbusier e de Lucio Costa realizados durante a década de 1930.

No Brasil, a pintura moderna figurativa, durante as quatro primeiras décadas do século XX, só legitima sua produção quando vincula uma temática nacional a uma técnica de representação importada das vanguardas européias. Segundo esse raciocínio, pode-se intuir que o que confere um sabor nacional à pintura moderna não é ela em si, mas o tema retratado, carregado de significado, simbolismo e afinidades afetivas com o imaginário popular, por vezes distante da realidade do próprio artista.

Se a pintura, quando ainda figurativa, cumpre a sentença da representação, a arquitetura moderna brasileira enfrentará o problema por outro vetor. O tema na arquitetura, diferentemente da pintura, não é a representação da figura. Trata-se da operação que sintetiza uma intenção através da manipulação da superfície, da forma e do espaço.

Poderíamos traçar aproximações entre as "modernidades nacionais" presentes na pintura de artistas como Tarsila do Amaral e a arquitetura de Lucio Costa.

Assim como Tarsila formaliza uma relação tema-linguagem a partir da síntese entre o cubismo de Fernand Léger e a realidade brasileira (homem e paisagem), Lucio Costa encontra

251 o encontro de 1936: formação 
um nexo entre o esquema corbusiano - estruturado pelo esquema Dom-ino e praticado nas vilas puristas - e a austeridade e retidão presentes em nossa arquitetura vernacular. Em ambos os casos, o sentido de brasilidade está presente no "tema" e não no esquema formal.

Lucio Costa assume que a construção de um ideário nacional - a partir do reconhecimento dos predicados da arquitetura "de nosso passado autêntico" - ocorre tanto em 1922 com os paulistas como em 1936 com os cariocas.

Segue declaração de Lucio Costa:

No Brasil, tanto em 22 como em 36, os empenhados na renovação foram os mesmos empenhados na 'preservação', quando alhures, na época, eram pessoas de formação antagônica e se contrapunham.

Em 22, Mário, Tarsila, Oswald \& Cia., enquanto atualizavam internacionalmente a nossa defasada cultura, também percorriam as cidades antigas de Minas e do norte na busca "antropofágica" das nossas raízes; em 1936, os arquitetos que lutaram pela adequação arquitetônica às novas tecnologias construtivas foram os mesmos que se empenharam com Rodrigo M. F. de Andrade no estudo e salvaguarda do permanente testemunho de nosso passado autêntico (COSTA, 2001:70).

Ao reclamar a síntese entre tradição e modernidade, Lúcio Costa reivindica a formulação de uma autenticidade nacional a partir de um esquema que plasma o perfil moderno às superfícies rústicas da mesma maneira que Le Corbusier em seus projetos das casas de teor "nativista" realizados da primeira metade da década de 1930.

Para Sophia Silva Telles, as experiências primitivistas de Le Corbusier terão um papel fundamental no direcionamento do raciocínio de Lucio Costa rumo a elaboração de uma modernidade alicerçada na autenticidade e no rigor da arquitetura do passado. Segue trecho da autora:

(...) na senda aberta por Le Corbusier, Lúcio procura um vínculo entre o procedimento construtivo do passado e as novas técnicas do concreto armado. Como o fará Corbusier, toma como base a casa e não o palácio e igrejas, mas justamente as construções rurais, rudes e acolhedoras, qualidades das casas populares portuguesas, com seu aspecto viril, com justeza de proporções e "ausência de make-up, uma saúde plástica perfeita." (TELLES 1988:36, grifo: COSTA).

Se o tema para Le Corbusier é a matéria e o homem de regiões remotas da França (Mandrot e Mathes), para Lucio Costa, o tema é a "arquitetura regional autêntica" que "(...) tem as suas raízes na terra; é produto espontâneo das necessidades e conveniências da economia a um tempo incipiente e apurada, à feição da índole e do engenho de cada povo (...)"(COSTA, 2002:33, grifo nosso).

Lucio Costa justifica a "escolha” por Le Corbusier:

E estudei a fundo a obra dos criadores, Gropius, Mies van der Rohe, Le Corbusier - sobretudo esse, porque abordava a questão no seu tríplice aspecto: o social, o tecnológico e o artístico, ou seja, o plástico, na sua ampla abrangência (COSTA, 2001:49, grifo nosso).

Poderíamos considerar que Lucio Costa “elege" Le Corbusier justamente pelo fato do arquiteto franco-suíço considerar os aspectos social e tecnológico a partir de uma perspectiva 
artística que aborde a questão plástica em "sua ampla abrangência".

Qual seria essa "abrangência” presente na plástica corbusiana e apontada por Costa como fator preponderante de sua escolha?

A dimensão plástica presente em Le Corbusier, mesmo nos exemplares puristas, transcenderá tanto o pragmatismo de Walter Gropius, com a essencialidade de Mies van der Rohe. Em projetos como as casas Stein (1927) e Savoye (1929), apesar de um desejo de simplificação e pureza, a relação entre cheiros e vazios, entre o dentro e o fora, é dotada de uma rigorosa organização que compactua com as experiências pictóricas de Le Corbusier, principalmente com as pinturas puristas realizadas na década de 1920.

Apesar da rigidez dada pelo perímetro do campo - seja ele a moldura da pintura ou a planta da residência - a organização dos elementos e das aberturas é dada por um senso de composição que permite uma liberdade cujo limite é a preservação da forma pura. Portanto, o raciocínio pictórico-abstrato não restringe a liberdade de criação do artista. Ao contrário, estabelece um vínculo entre as artes visuais e a arquitetura a partir de um código gráfico que entende tanto a arquitetura como a pintura como configurações pictóricas, seja no plano ou no espaço. ${ }^{91}$

A “abrangência” da questão plástica em Le Corbusier transcende as experiências puristas das casas da década de 1920 e abarca a dimensão tectônica nas casas da década de 1930 que, enquanto plástica, extrapolam a composição abstrata das superfícies uniformes das casas brancas e assimilam a memória da matéria e do lugar como elemento estético.

Será esse potencial de liberdade criativa, mesmo que estancado pelas postulações puristas, sucedido pela adoção da temática vernacular, que fará com que Lucio Costa eleja Le Corbusier como referência de uma modernidade consciente.

91. A análise da relação entre a pintura e a arquitetura de Le Corbusier encontra-se no capítulo Cassino. 


\section{O desenho moderno e a superfície da memória}

Oscar Niemeyer interpretará os ideais de modernidade e tradição presentes nos discursos e nos projetos de Le Corbusier e Lucio Costa a partir de uma equação singular.

Niemeyer compreende, tanto os materiais naturais (pedra e madeira) como as manufaturas coloniais (telha cerâmica e azulejaria pintada) como referências de memória a serviço de um desenho moderno.

Em Le Corbusier e Lucio Costa, a matéria oriunda da terra - seja em seu estado bruto, ou manipulada segundo a tradição do lugar - se traduz tanto na forma como na superfície. Em alguns projetos de Niemeyer, essa mesma matéria nativa é apenas uma superfície que é incorporada a uma estrutura formal eminentemente moderna.

Para Niemeyer, o vocabulário purista de raiz pictórica de Le Corbusier presta-se como base para a aplicação das superfícies rústicas, ao passo que, para Le Corbusier essas mesmas superfícies estão incorporadas a projetos cuja solução formal, por sua vez, se remete a um imaginário antiurbano como por exemplo, a adoção das coberturas inclinadas das casas Errazuris (1930) e Mathes (1935) e a cobertura em abóbada da casa de fim de semana em La Celle Saint-Cloud (1935).

Tomemos como exemplo o projeto para o Cassino (1940) da Pampulha, onde Niemeyer influencia-se por soluções formais presentes na casa Savoye (1929), mas se vê livre para substituir as superfícies lisas e brancas pela pedra apicoada e pela cerâmica esmaltada.

Poderíamos supor que Niemeyer incorpora o raciocínio purista de Le Corbusier não como uma doutrina, mas como um esquema formal, como um repertório plástico passível de sofrer intervenções tanto na superfície como na forma.

Se, para Le Corbusier, os "cinco pontos" postulados nas casas brancas são balizadores de um esquema refreado pelos dogmas do purismo, para Niemeyer esses mesmos "cinco pontos", associados ao repertório de formas do próprio Le Corbusier, são parâmetros para uma criação autônoma e sensível.

$\mathrm{Na}$ maioria dos projetos de residências realizados por Niemeyer entre 1936 e 1952, podemos identificar com facilidade os estilemas vernaculares presentes nos projetos de Le Corbusier: 
o telhado invertido, a estrutura de madeira, a parede de pedra e a telha cerâmica.

O que confere uma autonomia ao raciocínio de Niemeyer com relação aos legados de Le Corbusier (seja o purista ou o regionalista) é a maneira como o arquiteto brasileiro rompe com uma certa lógica de manipulação da forma.

Le Corbusier intervém no volume a partir de perfurações e recortes que preservam as suas características formais, enquanto Niemeyer transforma o volume em uma esbelta moldura. A abertura, para Le Corbusier, é uma obstrução que assume a face do volume como um suporte para uma ação compositiva de matriz pictórica. Tanto na casa Savoye como na casa Errazuris as aberturas comportam-se como subtrações que estão contidas no interior de um campo material maior.

A matéria do lugar, que tanto em Le Corbusier como em Lucio Costa éincorporada como forma e superfície, éutilizada por Niemeyer para revestir as espessuras dos perfis exteriores dos objetos. No projeto de Niemeyer para a casa Passos (1938) podemos observar essa emancipação sobre a estética corbusiana. Trata-se da primeira ocorrência da adoção do telhado invertido na obra do arquiteto brasileiro.

Tanto o suporte formal de Le Corbusier como a superfície da memória reclamada por Costa prestam-se como instrumentos de uma equação singular no projeto da casa Passos. Para Niemeyer, o raciocínio formal de Le Corbusier presente nas casas Errazuris e Mathes é quase como um parâmetro gráfico que define o perfil exterior do volume. A cobertura invertida das casas de Le Corbusier será o referencial para a adoção do telhado em "V" da casa Passos.

Nesse projeto de residência, Niemeyer incorpora o regionalismo corbusiano - diagnosticado principalmente nas casas Errazuris (1930) e Mathes (1935) - ao desejo de autenticidade nativa presente nas postulações de Lucio Costa. Porém, devemos salientar que o projeto da casa Passos não se restringe a uma mera síntese entre as "tradições" de Le Corbusier e Lucio Costa. Nesse projeto, Niemeyer incorpora essas influências a partir de uma estética pessoal que se encontrava ainda em um período de experimentação.

Na casa em Mathes (1935), Le Corbusier concebe o telhado invertido no sentido da largura do volume de planta retangular, e escava parte de uma das faces do comprimento para abrigar um terraço. Na casa Passos (1938), Niemeyer opera à semelhança de Le Corbusier. Porém, ao invés de recortar em "V" a cobertura no sentido da largura do volume, desenha a cobertura invertida no sentido de seu comprimento, exatamente como Le Corbusier na Casa Errazuris (1930). Por outro lado, o terraço desenhado em uma das faces da largura da casa Passos indica uma referência ao terraço da casa em Mathes.

Devemos observar que na casa Passos o arranjo dado pelo conjunto compreendido pelo terraço e o "térreo-livre" assume uma liberdade espacial que não está presente nem na casa em Mathes, nem na casa Errazuris. Enquanto em Mathes Le Corbusier escava um trecho linear na fachada do objeto, na casa Passos Niemeyer suspende o terraço sobre pilotis e esvazia o pavimento térreo, pelo menos no trecho sob a projeção dos dormitórios.

Niemeyer utiliza uma espacialidade moderna a serviço de um tema primitivista. Poderíamos supor que Niemeyer, para sublimar a corporialidade enbrutecida presente nas casas

255 | o encontro de 1936: formação 

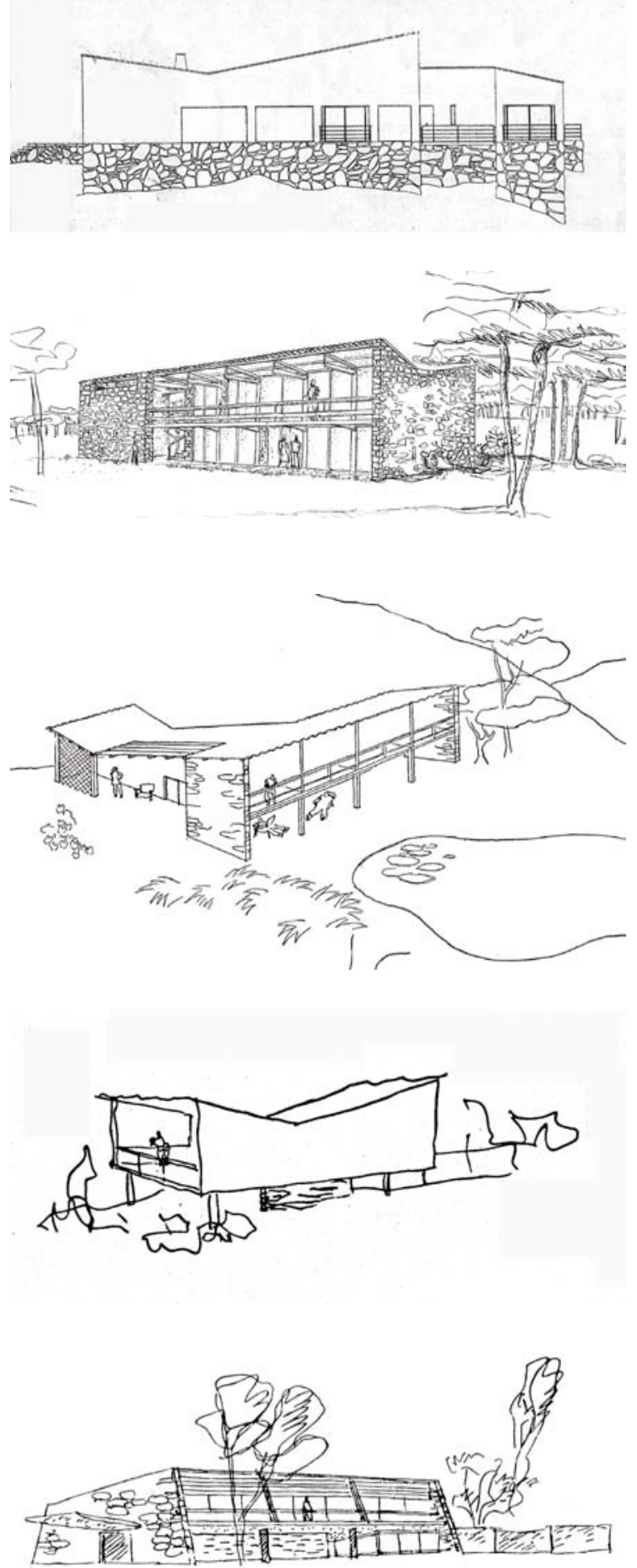



[344] Casa Errazuris - fachada oeste - 1930 - LC (BOESIGER, 1947:50)

[345] Casa em Mathes - 1935 - LC (BOESIGER, 1971:71)

[346] Casa Passos - 1939 - ON (PAPADAKI, 1950:18)

[347] Casa Charles Ofair - 1943 - ON (PAPADAKI, 1950:116)

[348] Casa Capanema - 1947 - ON

(PAPADAKI, 1950:172)

[349] Casa no Rio de Janeiro - 1949 - ON (PAPADAKI, 1950:206) 
Errazuris e Mathes, lança mão de artifícios do próprio Le Corbusier presentes no esquema Dom-Ino. [344], [345], [346]

Nas casas vernaculares de Niemeyer, a relação entre a forma exterior e suas aberturas assume uma condição que a distingue da operação pictórica de Le Corbusier. Em Niemeyer, as aberturas não são perfurações como em Le Corbusier, mas são resultantes do arranjo entre os planos (fechamentos verticais, piso e cobertura).

Nas casas Passos (1938), Ofair (1943), Capanema (1947) e da Gávea (1948), Niemeyer concebe uma volumetria a partir da articulação entre planos. As aberturas configuram-se como vazios abrigados no interior do arranjo desses planos autônomos. Nesses projetos de Niemeyer, diferentemente de Le Corbusier, não há a pré-existência de um volume que sofre subtrações a posteriori. As dimensões das subtrações se alastram ao limite físico do próprio volume.

Nos desenhos dos terraços das casas Passos, Ofair, Capanema e da Gávea, Niemeyer preserva apenas as espessuras dos planos que desenham o próprio volume. $\mathrm{O}$ peitoril não se configura como um plano vertical, é uma mera barra delgada, autônoma à face escavada do recinto guarnecido pelo terraço. Com esse tipo de operação, Niemeyer substitui a estanqueidade da forma purista corbusiana por volumes vazados por generosas aberturas abrigadas apenas pelo contorno da forma, enfatizado pelas delgadas espessuras que emolduram o vazio em difusa penumbra. [347], [348], [349]

Niemeyer submete o esquema purista de Le Corbusier a uma operação que desmembra a regularidade do volume em componentes autônomos articulados a partir de um senso compositivo que dissolve a rigidez do bólido corbusiano, ao conceber objetos suspensos, vazados, ao mesmo tempo abertos e sombreados.

Ao subverter a estanqueidade da forma arquitetônica de Le Corbusier (seja ela a purista ou a primitiva), Niemeyer formula um raciocínio estético que não apenas caracterizará sua obra, mas que lhe conferirá uma autonomia plástica logo nos primeiros anos de sua carreira profissional.

A presença dos volumes sobre pilotis - mesmo que a serviço de uma temática vernácula (casa Ofair) - nos dá pistas de que Niemeyer assimila o tanto o raciocínio do Esquema Dom-ino e das casas brancas de Le Corbusier, como as experiências que flertam com uma ambiência nativista. Nesses projetos de residências, Niemeyer plasma a superfície primitiva a procedimentos formais puristas.

As superfícies vazadas, as aberturas generosas, a proporção horizontal e o desejo de suspensão configuram uma "ambiência brasileira" aos projetos de Niemeyer. A manipulação sensível desses elementos estabelece um diálogo sutil entre a forma e paisagem.

Essa "generosidade" da forma arquitetônica não reside na escala, mas na maneira como incorpora o vazio que, ao mesmo tempo em que enquadra a paisagem, funde-se a ela. Será essa emancipação calculada e sensível que fará Niemeyer se afastar dos postulados corbusianos e estruturar sua própria linguagem.

Ao preencher as faces dos volumes com superfícies vazadas uniformes (elementos vazados, treliças e brises e cobogós), Niemeyer confere aos componentes típicos da tradição colonial

257 | o encontro de 1936: formação 

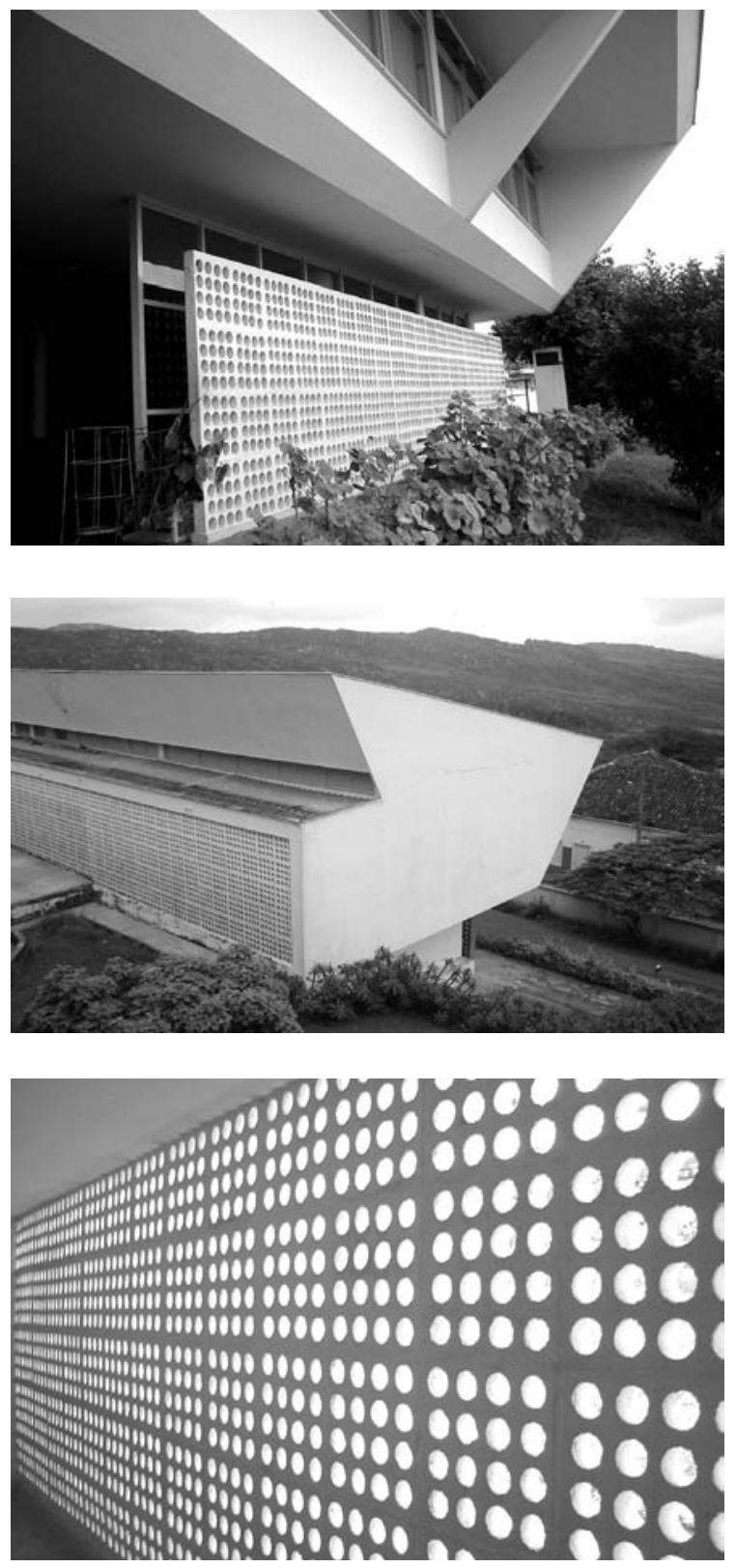

[350] Escola Julia Kubitschek - Diamantina - painel vazado - frente-1951 - ON

(foto: Rodrigo Queiroz)

[351] Escola Julia Kubitschek - Diamantina - painel vazado - fundos - 1951 - ON

(foto: Rodrigo Queiroz)

[352] Escola Julia Kubitschek - Diamantina - painel vazado - fundos - vista interna - 1951 - ON

(foto: Rodrigo Queiroz)
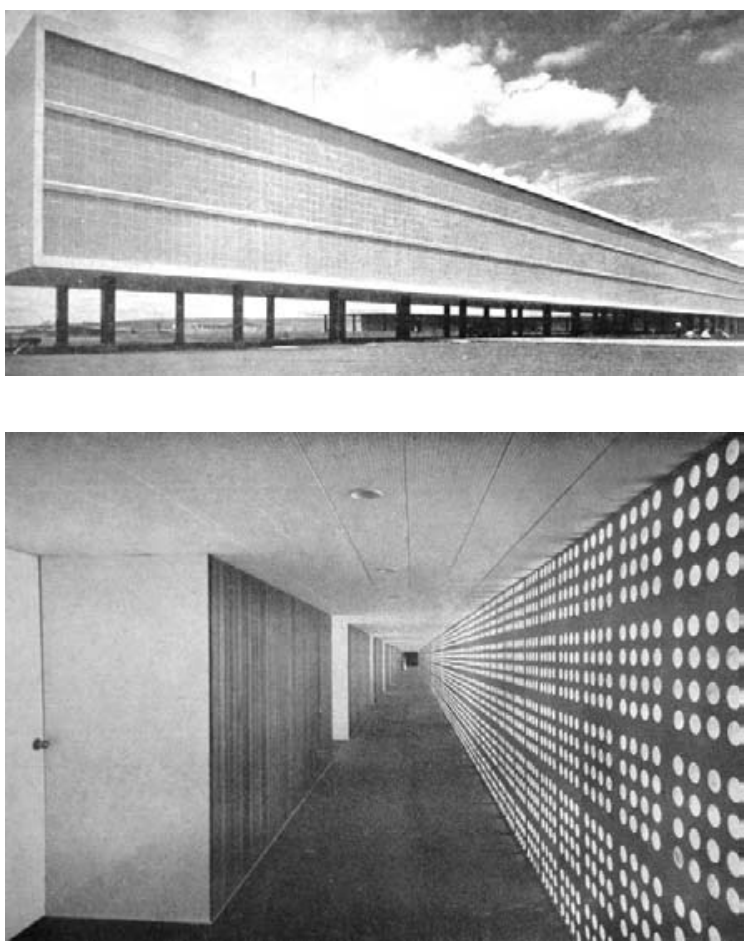

[353] Brasília Palace Hotel - painel vazado - fundos - 1958 $-\mathrm{ON}$

(Revista Módulo n.12 - fevereiro/1959:28)

[354] Brasília Palace Hotel - painel vazado - fundos - vista interna - 1958 - ON

(Revista Módulo n.12 - fevereiro/1959:31) 
luso-brasileira uma feição moderna, abstrata.

Niemeyer distende a proporção das superfícies perfuradas, mas preserva o tramo do elemento vazado. Com essa operação, o significado vernacular das superfícies reticuladas que revisitam uma tradição colonial se dilui na medida em que suas dimensões se agigantam.

Le Corbusier manipula a face do volume como um suporte para uma composição balizada pela contraposição entre a superfície opaca (seja a branca ou a bruta) e as obstruções contidas na mesma face (seja a janela "em fita" das casas brancas ou os orifícios retangulares das casas vernaculares). Diferentemente de Le Corbusier, Oscar Niemeyer entende a superfície do volume como suporte para um único plano vazado integral que atende as exigências de isolamento, sombreamento, ventilação e iluminação da mesma maneira que as obstruções corbusianas. Niemeyer eleva a condição de superfície homogênea, os componentes anteriormente utilizados como proteção de pequenas aberturas.

Segundo Sophia Telles:

o uso cerrado do cobogó será entendido na qualidade de fechamento do volume, sem ambigüidade, no projeto da Escola Julia Kubitschek por exemplo, onde desaparece seu caráter artesanal pela repetição extensa que constrói um pano único necessário à construção do volume (TELLES 1988:46, grifo nosso)

Na Escola Julia Kubitschek (1951), em Diamantina, Niemeyer utiliza painéis com perfuração circular nas duas faces de seu comprimento. $\mathrm{Na}$ face principal, como anteparo ao corpo transparente do salão da recepção no pavimento térreo, o painel vazado configura-se como um plano solto que não chega a tocar o volume em balanço das salas de aula no pavimento superior. Ao preservar uma fresta entre o painel perfurado no térreo e o volume em balanço das salas de aula no pavimento superior, Niemeyer torna ainda mais dramática a relação de contraste entre o corpo transparente no térreo - ocultado em sombra - e o volume elevado, caracterizado pelos apoios inclinados que sustentam o balanço da laje de cobertura das salas de aula.

O volume das salas de aula da Escola de Diamantina possui seção trapezoidal com cobertura inclinada e com caimento dirigido para a frente do terreno. O corredor de circulação para as salas de aula, localizado das costas do edifício, tem seção retangular e altura inferior ao volume trapezoidal das salas de aula. Com esse artifício, é garantida a ventilação cruzada nas salas de aula que possuem uma janela corrida alta, na parede oposta as janelas da face principal. São dois volumes conectados, um retangular de pequena altura e um trapezoidal que caracteriza formalmente o projeto. A extensa face horizontal do volume retangular que abriga a circulação para as salas é preenchida por um grande painel perfurado com orifícios circulares que ocupa toda a face posterior do projeto. [350], [351], [352]

Da mesma maneira que na Escola Julia Kubitschek, no projeto para o Brasília Palace Hotel (1957), Niemeyer preenche todo o fechamento do corredor de distribuição para os apartamentos com a mesma superfície com perfurações circulares.

Esses grandes planos uniformes e vazados conferem unidade as superfícies que, ao assumirem extensões cada vez maiores, exigem soluções compatíveis com a dimensão do edifício.

259 | o encontro de 1936: formação 

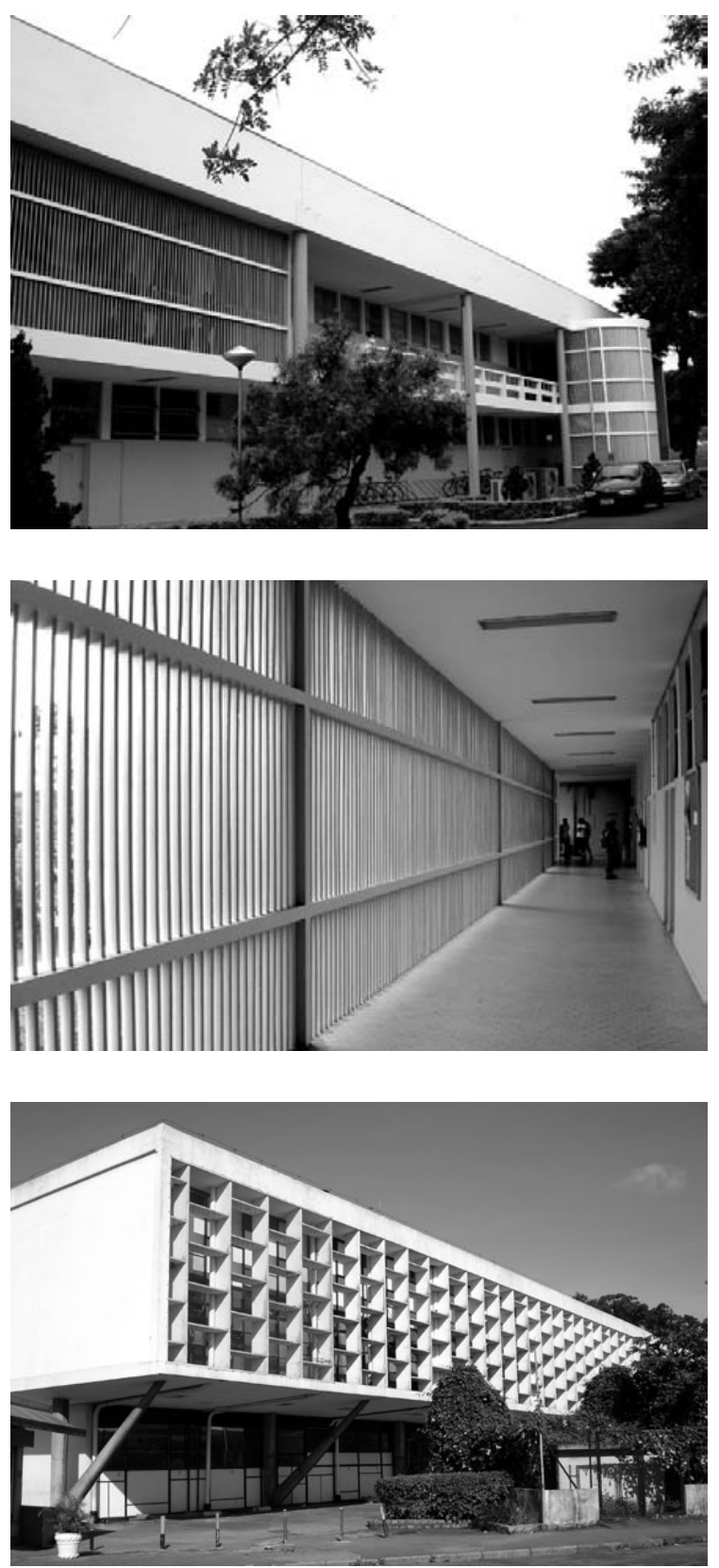

[355] Centro Tecnológico da Aeronáutica - São José dos Campos - painel ripado - 1947 - ON

(foto: Rodrigo Queiroz)

[356] Centro Tecnológico da Aeronáutica - São José dos Campos - painel ripado - vista interna - 1947 - ON

(foto: Rodrigo Queiroz)

[357] Pavilhão dos Estados - Parque Ibirapuera - superfície reticulada - 1951/1953-ON

(foto: Rodrigo Queiroz)
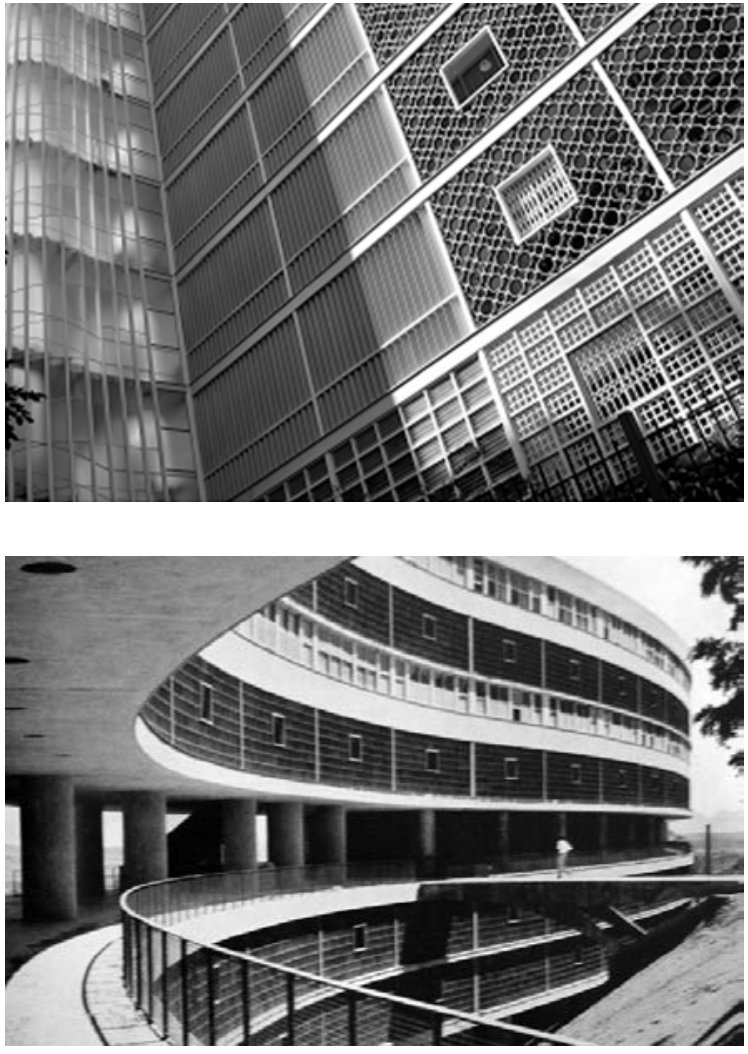

[358] Parque Guinle - edifício Nova Cintra - 1948 - Lucio Costa

(foto: Rodrigo Queiroz)

[359] Conjunto Residencial Pedregulho - bloco A - 1946 - Affonso Eduardo Reidy

(BONDUKI, 2000:91) 
O enquadramento das visuais desses objetos, de extrema distensão horizontal, exige um afastamento que inviabiliza a utilização e a conseqüente apreciação de pormenores de escala doméstica: diferentes aberturas e utilização de materiais com texturas diversas.

A extensa superfície vazada observada a uma distância compatível com a dimensão do edifício perde seu aspecto artesanal e assume a aparência de uma estampa. No Brasília Palace Hotel, a superfície perfurada se estende por um retângulo suspenso de dez metros de altura por cento e noventa metros de comprimento. Todo e qualquer vínculo literal com a tradição perde-se nas dimensões da superfície vazada e do edifício. [353], [354]

No projeto para o edifício de salas de aula do Centro Tecnológico da Aeronáutica em São José dos Campos (1947), Niemeyer também arremata a face que abriga o corredor de distribuição das salas com uma superfície vazada. Não se trata do painel com perfurações circulares presente na Escola Julia Kubitschek e no Brasília Palace Hotel. No bloco de aulas do CTA, Niemeyer utiliza brises verticais fixos de madeira em suave inclinação e enfileirados em justaposição uns aos outros. A aparência é a de um contínuo ripado que, sob alguns ângulos, isola visualmente o corredor de distribuição das salas.

Diferentemente da Escola de Diamantina e do Hotel de Brasília, no bloco de aulas do CTA, a face preenchida pela superfície vazada sofre algumas intervenções e interrupções, mas que não prejudicam a solução do edifício: o terraço que se abre para o jardim; a caixa de escada externa de planta circular e circunscrita a uma superfície ripada que acompanha o desenho dos brises; e a seqüência de pilares cilíndricos localizados externamente a plano dos brises. [355], [356]

Os Palácios das Nações e dos Estados que integram o conjunto do Parque Ibirapuera $(1951 / 1954)$ possuem uma de suas faces totalmente recoberta por profundos elementos vazados que cumprem a função de brise. É como uma volumetria oca que se sobrepõe a superfície transparente da fachada. O reticulado que protege a face do edifício possui um desenho irregular, alternado, próximo daquele presente na superfície vazada do Pavilhão do Brasil na Feira Internacional de Nova York. Será justamente essa trama "desalinhada" que vinculará o desenho dos brises a uma lembrança dos cobogós cerâmicos presentes na arquitetura luso-brasileira. Mais uma vez, Niemeyer alastra a superfície e coloca o tramado vazado como um módulo que, ao multiplicar-se, assume a condição de um estampado que "filtra" essa ambígua relação entre interior e exterior. [357]

Assim como Niemeyer em Diamantina, Brasília e São José dos Campos, Lucio Costa, nos edifícios do Parque Guinle (1947) e Affonso Eduardo Reidy, no Conjunto de Pedregulho (1947) também utilizam os planos vazados como preenchimentos das superfícies externas dos edifícios. Tanto Costa como Reidy especulam o arranjo desses planos perfurados a partir de um raciocínio que compreende a face do objeto como suporte para uma composição tramada em um patchwork de diversos rendilhados.

No Conjunto do Parque Guinle, as faces principais dos edifícios sofrem subdivisões reticuladas, desenhadas pelas espessuras das paredes e das lajes que afloram na fachada e abrigam, em cada célula, superfícies vazadas diversas: os brises verticais justapostos em forma de um justo

\footnotetext{
261 o encontro de 1936: formação
} 

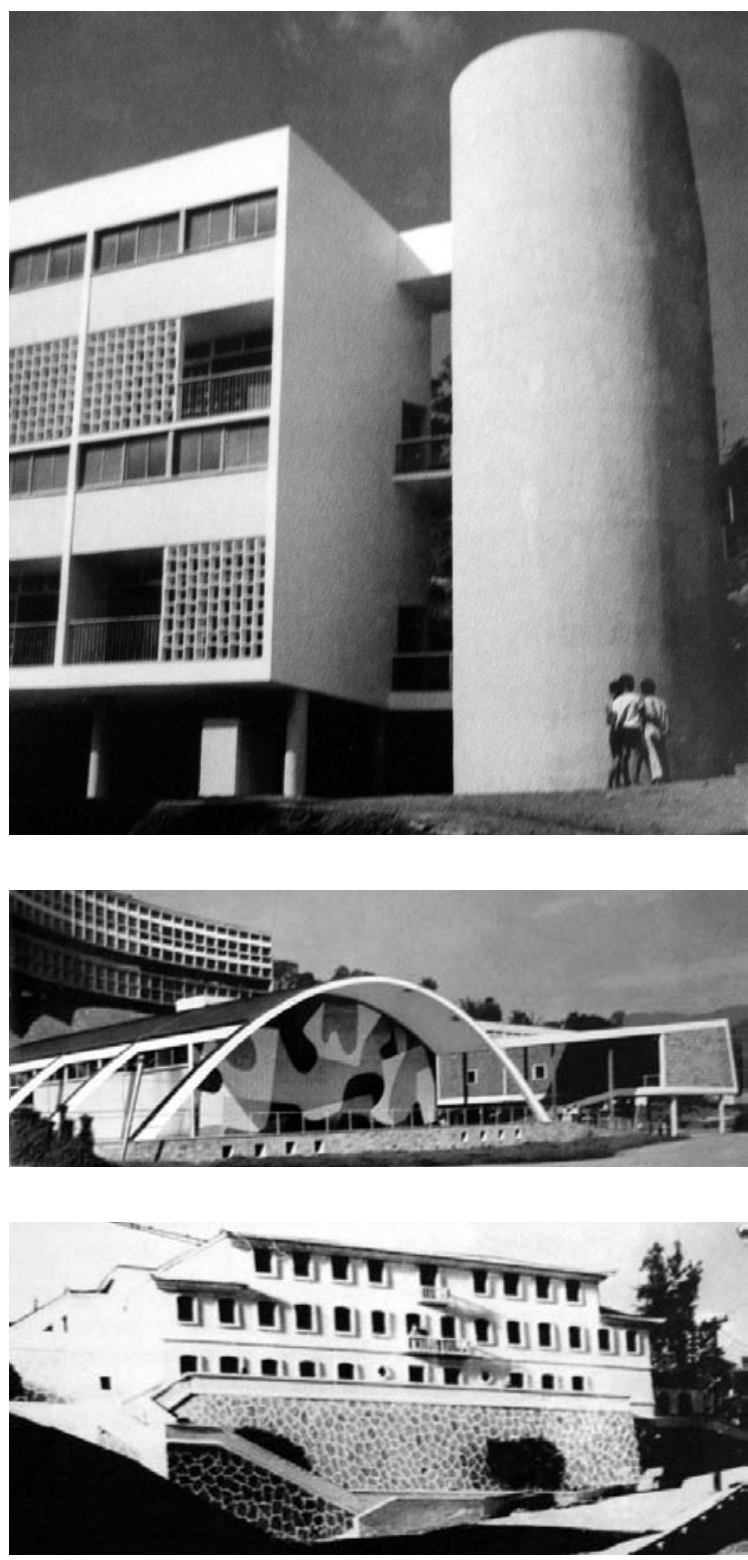

[360] Conjunto Residencial Pedregulho - bloco B - 1946 - Affonso Eduardo Reidy

(BONDUKI, 2000:94)

[361] Conjunto Residencial Pedregulho - escola - 1946 - Affonso Eduardo Reidy

(BONDUKI, 2000:99)

[362] Grande Hotel de Ouro Preto - maquete - 1938 Carlos Leão
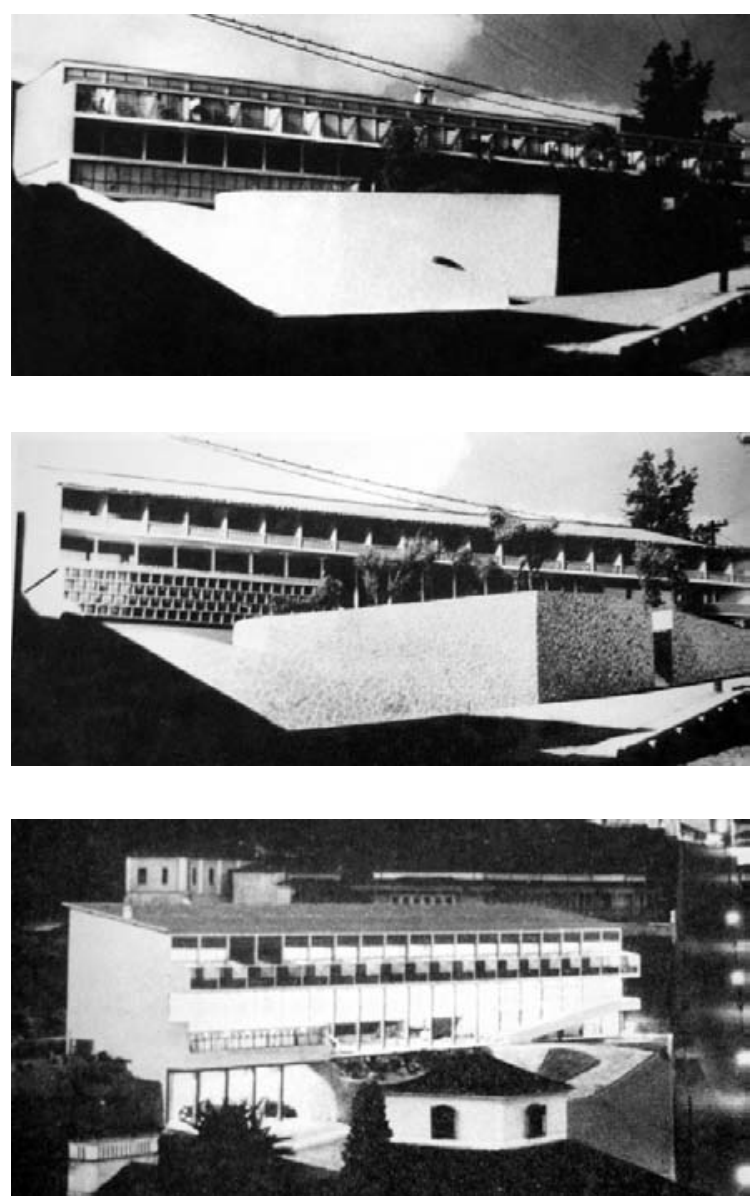

[363] Grande Hotel de Ouro Preto - 1938-1939 - ON - primeiro estudo

(CAVALCANTI, 2006:117)

[364] Grande Hotel de Ouro Preto - 1938-1939 - ON - segundo estudo

(CAVALCANTI, 2006:118)

[365] Grande Hotel de Ouro Preto - 1938-1939 - ON - projeto definitivo

(MINDLIN, 2000:127) 
ripado de madeira; os cobogós cerâmicos que formam uma superfície preenchida por círculos de dois tamanhos diferentes e tangentes entre si; o muxarabi em tessitura diagonal e os elementos vazados de simples tramado quadrado.

Os extensos planos vazados e uniformes de Niemeyer em São José dos Campos, Diamantina e Brasília só são possíveis graças à ausência de divisões internas nesses longos corredores de distribuição, ao passo que no Parque Guinle, as divisões internas dos apartamentos desenham uma retícula uniforme que, emoldura as diferentes superfícies vazadas. Trata-se de uma operação compositiva que adota como suporte o esquema corbusiano das lajes sucessivas suspensas por pilotis, cujo traçado é preservado justamente pela ausência de superfícies uniformes e opacas nas fachadas. Lucio Costa coloca o desenho moderno como suporte para uma materialidade de raiz tradicional.

Ao abrir janelas quadradas nas superfícies vazadas, Lucio Costa assume uma suposta ambigüidade na adoção dessas superfícies que, de certa maneira, também podem ser entendidas como "parede". É como se a intimidade fosse resguardada pelos próprios planos vazados que externamente assumem o papel de vedação visual: permitem "ver" e não "ser visto". [358]

Para Sophia Telles:

\begin{abstract}
A solução utilizada por Lúcio, combinando brise, treliças ou cobogós será muito comum em arquitetos seus contemporâneos. A defesa de uma arquitetura moderna brasileira parecia se instaurar pela integração a uma estrutura moderna dos elementos da colônia (...)

Em muitos projetos brasileiros, o elemento vazado, pouco a pouco, se transforma em uma retícula mais aberta que adquire um valor sempre mais gráfico pela incidência de luz e sombra. Parece assim assumir a relação com o exterior que o brise sugere, perdendo de certa forma a referência colonial para se transformar em um equipamento moderno (TELLES 1988:44, grifo nosso).
\end{abstract}

No projeto para o Conjunto Residencial Pedregulho (1946), Affonso Eduardo Reidy também lança mão dessas superfícies vazadas de rendilhados variados: cobogós cerâmicos retangulares, elementos vazados de concreto em tramo diagonal e brises verticais de madeira.

Nos projetos citados, o pressuposto corbusiano da fachada-livre é levado a um nível de abstração extremo. Praticamente, inexistem fechamentos opacos em alvenaria. Todas as superfícies exteriores possuem um tratamento que intenta subverter a lógica cubista da forma fechada obstruída por “janelas em fita”. Quando a vedação cega é inevitável, entram em cena os painéis em azulejo pintado e as paredes revestidas com pedra apicoada ou cerâmica bruta.

A escola do Conjunto de Pedregulho é um típico exemplo dessa relação entre planos de tratamentos variados abrigados sob o contorno da forma exterior. É como se um "gesto" moderno e branco emoldurasse os fechamentos carregados de significado e memória.

A abóbada do ginásio de esportes se projeta para além dos limites do ginásio em si. Em um dos fechamentos laterais, o painel azulejado recebe um painel de Cândido Portinari na forma de uma composição abstrata sobreposta a pequeninos desenhos que representam jovens esportistas, um dentro de cada azulejo.

263 o encontro de 1936: formação 
Ao recuar os fechamentos azulejados sob a projeção da abóbada que cobre o ginásio, Reidy transforma esse volume em uma grande cobertura em arco que se apóia no chão em pilares inclinados e que abriga o painel cego de fechamento que, por ser o suporte para um desenho orgânico e livre, perde parte de sua estanqueidade visual. [359], [360], [361]

Esse jogo compositivo de modulações de espessuras delgadas que abrigam superfícies vazadas presente no Parque Guinle (1947) e em Pedregulho (1947) já era um condicionante plástico no projeto de Oscar Niemeyer para o Grande Hotel de Ouro Preto ${ }^{92}$ (1938).

O primeiro projeto para o Grande Hotel de Ouro Preto é de autoria do arquiteto Carlos Leão. O projeto de Leão seguia as linhas da arquitetura colonial da velha cidade mineira: janelas e portas em arco; cobertura inclinada em telha cerâmica; pátio interno; arrimos recobertos de pedra bruta e paredes externas caiadas. [362]

Em carta ${ }^{93}$ datada de 05 de dezembro de 1938, Washington de Araújo Dias, prefeito de Ouro Preto, solicita a Rodrigo Melo Franco de Andrade, Diretor do SPHAN", o "envio de um técnico capaz de dar uma solução decente para a pequena praça fronteira ao hotel.” Oscar Niemeyer é o "técnico" indicado pelo SPHAN para resolver o desenho da praça.

Durante o período em que o projeto do Grande Hotel de Ouro Preto foi desenvolvido por Carlos Leão, Oscar Niemeyer encontrava-se em Nova York realizando o projeto para o Pavilhão do Brasil juntamente com Lucio Costa.

Lucio Costa via na proposta de Leão um retrocesso na evolução e no amadurecimento de uma arquitetura brasileira que, para ser autêntica, não precisava configurar-se como um arremedo literal da arquitetura colonial, mas deveria interpretar as virtudes da tradição a partir de um desenho moderno. Prevendo um desfecho catastrófico, Lucio Costa indica a Rodrigo Melo Franco de Andrade a intervenção de Niemeyer, que retorna ao Brasil especialmente para desenvolver o projeto para o Hotel em Ouro Preto.

Após a apreciação negativa de Costa com relação a proposta de Leão, a intervenção de Niemeyer não se restringirá ao desenho da praça fronteiriça. O arquiteto desenvolverá uma nova proposta de projeto para o Hotel.

Niemeyer desenvolve um primeiro projeto caracterizado por um grande bloco horizontal sobre pilotis coberto por um teto-jardim de grama que, quando visto de cima, se confundiria com a vegetação envoltória. A proposta de Niemeyer ia no sentido oposto do projeto de Leão. Niemeyer incorpora o edifício na paisagem como uma forma que se auto-anula, por ser transparente e coberta de vegetação. Tratava-se de um bloco horizontal escalonado sobre pilotis. O volume mais alto abrigava os apartamentos, o volume mais baixo e mais proeminente abrigava o terraço descoberto dos apartamentos duplex. O fechamento dos terraços é constituído por grandes painéis de correr preenchidos por um ripado horizontal e enquadrados em uma moldura branca e delgada que confere um sentido de unidade, leveza e imaterialidade ao conjunto. [363]

92. (Cf.: CAVALCANTI, 2006:109-120).

93. Arquivo IPHAN.

94. Serviço de Patrimônio Histórico e Artístico Nacional. 
Lucio Costa, mesmo em Nova York, desautoriza o primeiro estudo de Niemeyer para o Hotel. Se Leão apenas mimetizou uma temática colonial, Niemeyer não faz uma menção sequer da arquitetura do lugar.

Em depoimento, José de Souza Reis ${ }^{95}$ relata que Lucio Costa

(...) escrevera uma carta a Rodrigo, na qual declarava que, apesar de não desejar interferir no assunto, por razões particulares, reprovava, entretanto, a solução do terraço-jardim e recomendava, expressamente, a adoção de cobertura de telhas que deveria, a seu ver, atingir a área de pequenos terraços dos apartamentos, com treliças de madeira na fachada. (...) (REIS apud CAVALCANTI, 2006:112, grifo nosso).

Ao recomendar a adoção do telhado e da treliça na primeira versão de Niemeyer para o Hotel, Lucio Costa não desaprova nem a condição de prisma horizontal, nem a presença dos pilotis que suspendem o volume. Costa preocupa-se em conferir a feição do lugar ao objeto moderno. As intervenções de Costa modificam o projeto de Niemeyer tanto na forma como na superfície: a cobertura inclinada que rompe com a pureza da forma e a treliça de madeira que confere um aspecto pitoresco aos terraços, originalmente protegidos por painéis corrediços.

Para Marco do Valle:

Na polêmica construção do Hotel de Ouro Preto (1938-1939), podemos ver claramente que o projeto de Lúcio Costa, de uma arquitetura moderna que incorpora o passado de nossa tradição brasileira, caracterizado por uma concepção estática, foi imposto ao projeto moderno de Oscar Niemeyer (VALLE 2000:114).

Em um segundo estudo, Niemeyer atende de maneira literal as solicitações de Costa: cobre o bloco dos apartamentos e os terraços salientes com uma cobertura cerâmica inclinada em duas águas e substitui os painéis de correr dos terraços por um guarda-corpo preenchido por treliça ${ }^{96}$. [364]

Porém, o projeto definitivo trata-se de uma terceira versão o Hotel de Ouro Preto. Niemeyer não deixa de atender as exigências de Costa. Tanto a cobertura cerâmica inclinada como a treliça que protege os terraços são partes integrantes do projeto final. Mas esses componentes assumem uma configuração diversa daquela presente no segundo estudo de Niemeyer.

Devemos atentar para o fato de que Niemeyer retrocede e não segue o conselho de Costa de prolongar a cobertura inclinada até o alinhamento dos terraços. Na verdade, Niemeyer simplesmente insere a cobertura inclinada e as treliças reclamadas por Lucio Costa à sua primeira versão para o projeto do Hotel de Ouro Preto, que havia sido desautorizada por Costa. O projeto definitivo trata-se de uma retomada da versão moderna, que incorpora "a sua maneira" os conselhos de Costa. [365], [366], [367]

Tanto as considerações de Costa como a revisão de Niemeyer apontam para uma disputa entre o contorno moderno e os elementos arquitetônicos vinculados a tradição.

Assim como a primeira versão de Niemeyer, a versão definitiva também possui corte

95. Arquiteto pertencente aos quadros do SPHAN (depoimento de José de Souza Reis; Arquivo Iphan, s/d).

96. Que posteriormente seria revisitado no projeto do Hotel Tijuco em Diamantina (1951).

265 o encontro de 1936: formação 



[366] Grande Hotel de Ouro Preto - croquis - 1938/1939 - ON (PAPADAKI, 1950:21)

[367] Grande Hotel de Ouro Preto - rampa de acesso e terraços com fechamento em treliça de madeira - 1938/1939 - ON (PAPADAKI, 1950:21)
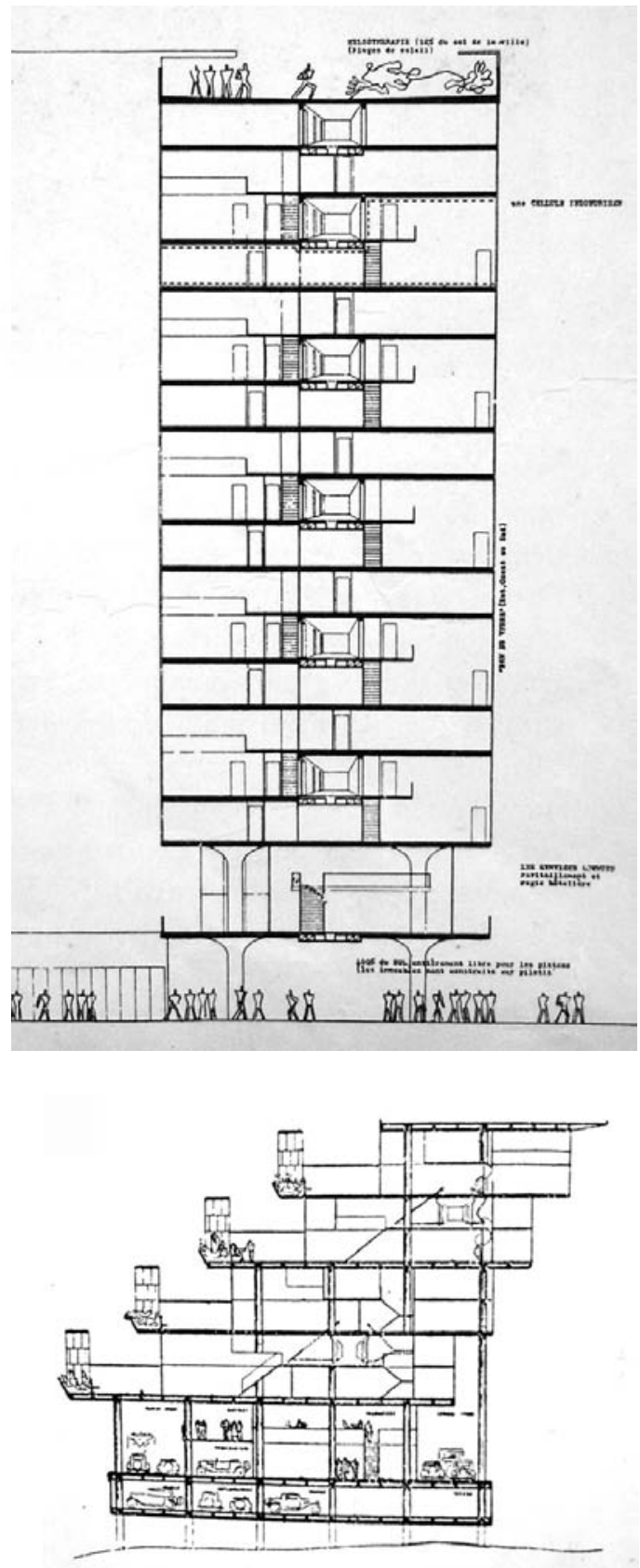

[368] Ville Radieuse - bloco de habitação - corte 1935 - LC

(BILL, 1947:32)

[369] Edifício de habitação e serviços em Argel - corte -1933 - LC

(BOESIGER, 1947:163) 
transversal escalonado. É um volume de dois pavimentos sobre pilotis que abriga apartamentos simples nos fundos e apartamentos duplex voltados para a face principal. No pavimento inferior do duplex encontra-se um estar contíguo a um terraço isolado do exterior por uma treliça alta obstruída por uma abertura quadrada que garante a vista para a cidade. $\mathrm{O}$ andar de cima do duplex é um mezanino de recorte sinuoso que abriga banheiro e dormitório com abertura na face posterior do edifício. Os terraços dos apartamentos duplex avançam para além da projeção da cobertura inclinada. A idéia do beiral colonial sombreado presente na reivindicação de Costa inexiste na proposta final de Niemeyer.

A distribuição interna do Hotel de Ouro Preto, em planta e em corte, guarda grandes semelhanças com as unidades de habitação projetadas por Le Corbusier para os blocos a réndent na Ville Radieuse (1930).

Le Corbusier concebe modulações em corte de três pavimentos, com um corredor de distribuição central localizado em pavimento intermediário, por onde se acessam as unidades duplex. De um dos lados desse corredor central dá acesso ao pavimento speriordas unidades, e do outro lado do corredor acessa-se as unidades em seu piso inferior. A distribuição das unidades no corte dos blocos a réndent será revisitada por Le Corbusier no projeto das Unités d'Habitation (1947).

Como o bloco de apartamentos do Hotel de Ouro Preto possui apenas dois pavimentos, Niemeyer adota, em parte, a tipologia presente no corte dos blocos a réndent de Le Corbusier. O corredor de distribuição do projeto de Niemeyer de um lado dá acesso ao pavimento inferior dos apartamentos duplex e do outro volta-se para apartamentos de um único pavimento. O dormitório do apartamento duplex localiza-se acima do apartamento simples.

O princípio do volume escalonado de proporção horizontal, observado com mais clareza no primeiro estudo de Niemeyer para o Hotel de Ouro Preto, já havia sido experimentado por Le Corbusier no projeto para a o loteamento Durand na Argélia (1933), no qual o arquiteto propõe um bloco escalonado, cujos terraços proeminentes são descobertos e protegidos em sua face principal por uma retícula horizontal delgada em forma de molduras sucessivas que enquadram cada um dos terraços, exatamente como a primeira versão de Niemeyer para o Hotel de Ouro Preto. Enquanto Niemeyer preenche essa imensa retícula horizontal, branca e regular com os painéis de correr no primeiro estudo, e com treliça nos segundo e terceiro estudos, Le Corbusier elimina qualquer tipo de fechamento inscrito nessa moldura. Implanta apenas um jardim-peitoril linear que se estende por todo o comprimento dos terraços alinhados. [368], [369], [370], [371]

Ao restringir a cobertura inclinada ao corpo dos apartamentos, Niemeyer coloca em primeiro plano o volume retangular dos terraços em balanço conferindo forte expressão geométrica, caracterizado por uma extensa faixa horizontal subdividida em requadros retangulares preenchidos parcialmente por treliça de madeira. As "janelas" retangulares inseridas nesses requadros de madeira pintada de branco conferem um sentido mais vazado e aberto à superfície de fechamentos dos terraços, que, por projetar-se para além dos limites da projeção da cobertura, assume papel de destaque no edifício.

267 | o encontro de 1936: formação 


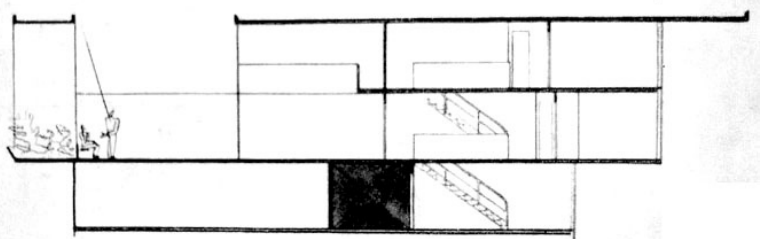

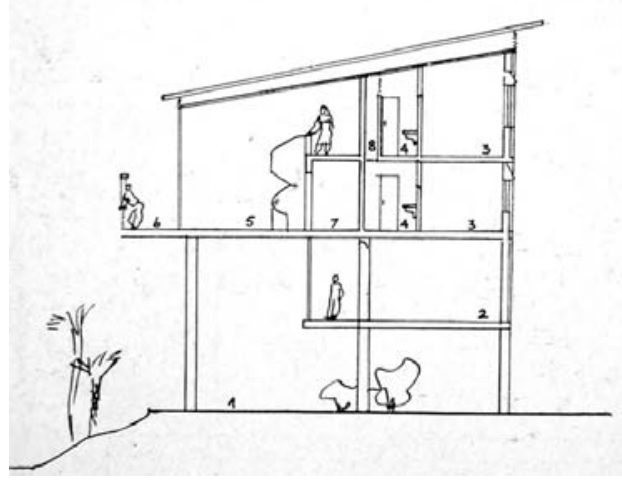
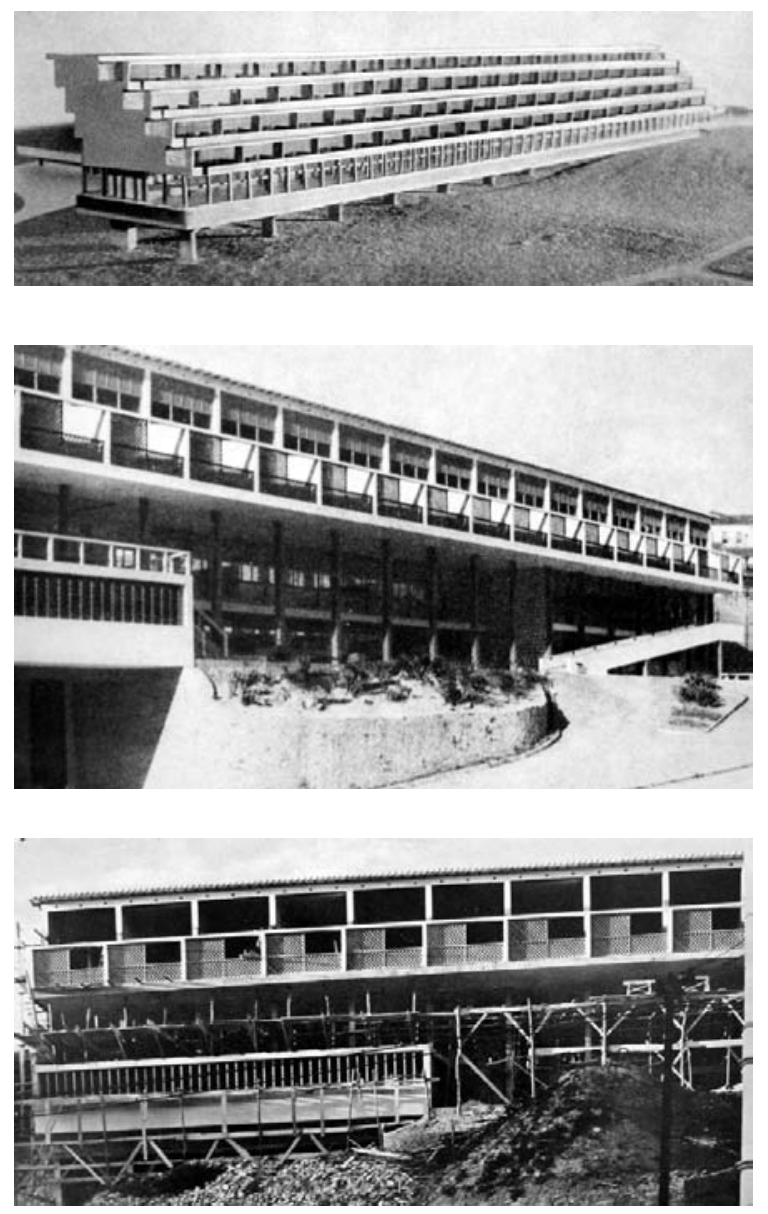

[370] Edifício de habitação e serviços em Argel - corte da unidade - 1933 - LC

(BOESIGER, 1947:164)

[371] Grande Hotel de Ouro Preto - corte - 1938/1939 - ON (GOODWIN, 1943:133)

[372] Edifício de habitação e serviços em Argel - maquete - 1933 - LC

(BOESIGER, 1947:166)

[373]Grande Hotel de Ouro Preto - 1938/1939 - ON (MINDLIN, 2000:126)

[374] Grande Hotel de Ouro Preto - 1938/1939 - ON (GOODWIN, 1943:133) 
Niemeyer não limita a treliça à mera função de peitoril, mas eleva essa superfície vazada à condição de um extenso plano translúcido de fechamento, emoldurado e dividido por perfis brancos e esbeltos. [372], [373], [374]

Entre o projeto de Carlos Leão, a intervenção de Lucio Costa e as três versões realizadas por Niemeyer para o Grande Hotel de Ouro Preto, observamos a presença de um jogo entre as correntes neocolonial e moderna, orquestrado pelos pareceres e pelas sugestões de Lucio Costa, mesmo que feitos à distância.

Ao opinar "de longe", Lucio Costa tece a complexa trama que amalgama tradição e modernidade, seja descartando a proposta neocolonial de Leão, ou aprimorando - a partir da adoção de elementos tradicionais - a proposta moderna de Niemeyer.

As diferentes versões para o Hotel de Ouro Preto ilustram a evolução de uma idéia que transita entre compromissos à primeira vista antagônicos: a autenticidade da tradição e a liberdade da modernidade.

O projeto de Lucio Costa para o Parque Hotel São Clemente, em Nova Friburgo (1944) apresenta uma semelhança contundente com o projeto de Niemeyer para Ouro Preto: bloco horizontal com cobertura inclinada, suspenso sobre pilotis, e a proteção dos terraços com treliça. Por outro lado, os procedimentos apontam posturas divergentes.

O projeto de Costa permite um alto teor de exteriorização do vernáculo, postura inversa daquelada por Niemeyer em Ouro Preto. Niemeyer sublima a tradição nas superfícies vazadas e na cobertura inclinada, ambas contidas em uma modenatura moderna que serve de parâmetro físico e visual para a unidade arquitetônica. Já no projeto de Lúcio Costa, de maneira oposta ao projeto de Niemeyer, a rusticidade da madeira assume a tanto a condição de componente construtivo e estrutural como a da superfície da própria modenatura, aproximando-se dos procedimentos presentes na casa de Le Corbusier em Mathes (1935).

Atentemos para o fato de que o projeto para Hotel São Clemente se assemelha muito mais com a segunda versão de Niemeyer para o Grande Hotel de Ouro Preto do que com o edifício construído. Costa incorpora em seu projeto as mesmas sugestões feitas por ele mesmo ao primeiro projeto de Niemeyer para o Hotel de Ouro Preto: a necessidade da adoção da cobertura inclinada prolongada até o alinhamento dos terraços e a utilização das treliças de madeira como peitoril.

Lembrem-se que Niemeyer, após a rejeição de sua primeira versão para o Hotel de Ouro Preto, atende aos apelos de Costa e realiza um modelo que incorpora suas sugestões de maneira literal, consegue o aval de Costa para, em seguida, retroceder ao primeiro projeto (de feição moderna), eliminando o beiral sobre os terraços e aumentando consideravelmente a altura dos peitoris vazados, a ponto de se configurarem como fechamentos. Em síntese, no projeto do Parque Hotel São Clemente, Lucio Costa assimila características das diferentes versões de Niemeyer para o Grande Hotel de Ouro Preto: o partido arquitetônico, preservado nas três versões, e a solução formal presente no segundo estudo de Niemeyer que, na verdade, traduz os conselhos do próprio Lúcio Costa. [375], [376], [377]

269 | o encontro de 1936: formação 

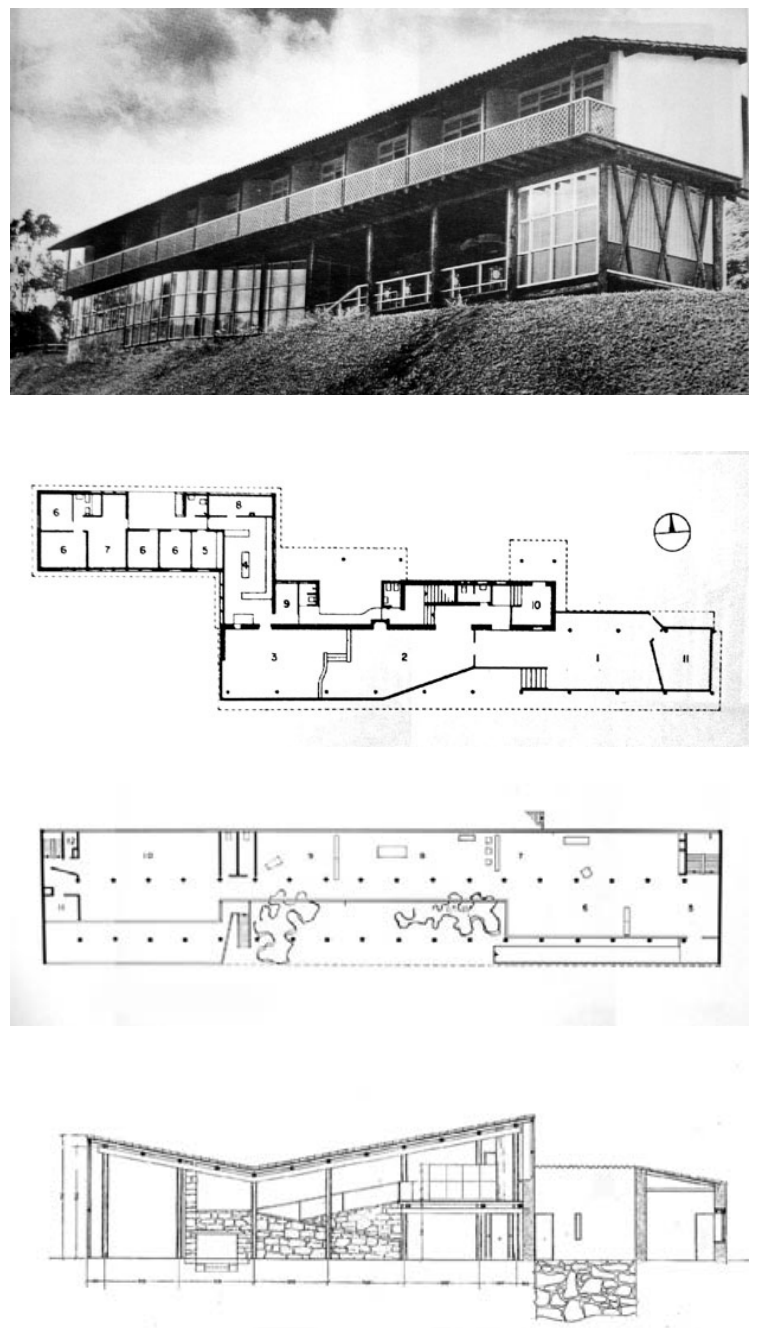

[375] Park Hotel São Clemente - Nova Friburgo - 1944 - Lucio Costa (WISNIK, 2001:81)

[376] Park Hotel São Clemente - Nova Friburgo - planta térreo - 1944 - Lucio Costa

(MINDLIN, 2000:129)

[377] Grande Hotel de Ouro Preto - planta salão social e restaurante $-1938 / 1939-\mathrm{ON}$

(MINDLIN, 2000:127)

[378] Casa Errazuris - corte longitudinal - 1930 - Le Corbusier

(BOESIGER, 1947:48)



[379] Residência Oscar Niemeyer - corte longitudinal 1942 - ON(PAPADAKI, 1950:64)

[380] Residência Oscar Niemeyer - plantas - 1942 - ON (PAPADAKI, 1950:64) 
Segundo Marco do Valle:

Não passa desapercebida a semelhança entre o hotel de Ouro Preto, de Oscar Niemeyer, e o hotel do Parque São Clemente, em Nova Friburgo, realizado por Lúcio Costa. Embora as técnicas construtivas sejam distintas, os dois hotéis juntos são, na verdade, complementares de uma demonstração das teorias de Lúcio Costa das semelhanças estruturais entre madeira e concreto armado, entre arquitetura tradicional e arquitetura moderna (VALLE 2000:118).

Retomemos a discussão sobre os projetos de residências. Na casa Errazuris, Le Corbusier elabora um telhado invertido assimétrico, em diagonais com a mesma inclinação rebatida. O objeto resulta do encontro de dois volumes trapezoidais de tamanhos diferentes, porém com suas alturas menores idênticas. No trecho de maior altura, um mezanino se debruça sobre o estar que ocupa toda a extensão do pavimento térreo do volume principal.

A solução do dormitório em mezanino sobre o estar da casa Errazuris já estava presente no projeto de Le Corbusier para o Pavilhão L'Esprit Nouveau ${ }^{97}$ (1925). Nesse caso, o mezanino estava contido em um volume de matriz cúbica. Na casa Errazuris, Le Corbusier funde a espacialidade em pé-direito duplo e mezanino do Pavilhão L'Esprit Nouveau ao deslocamento vertical em rampa de dois lances presente na casa Savoye. [378]

Essa distribuição em corte, que tira proveito das coberturas inclinadas e da assimetria das diferentes alturas presente nas casas primitivistas de Le Corbusier, será adotada por Niemeyer como parâmetro para a distribuição do programa nas casas Passos (1938), Oswald e Tarsila (1938), Oscar Niemeyer (1942), Herbert Johnson (1942), Francisco Ignácio Peixoto (1942), Charles Ofair (1943) e Juscelino Kubitschek (1943).

Em sua residência particular (1942), nas proximidades da Lagoa Rodrigo de Freitas, Niemeyer eleva sobre pilotis cilíndricos de concreto um único volume trapezoidal de feição elementar. Trata-se de uma "colagem". Esse volume suspenso desdobra-se em um generoso terraço que se projeta para além da projeção do pavimento dos dormitórios. A lateral de contorno trapezoidal é rasgada por uma janela em fita, solução recorrente nas vilas puristas de Le Corbusier.

A aparência moderna do volume, associada ao telhado cerâmico - referência à arquitetura colonial - exprime esse limiar entre o compromisso com a liberdade moderna e o respeito pela tradição.

A rampa que se desenvolve no sentido do comprimento da planta distribui os recintos em meios-níveis. Num primeiro lance ascende-se do estar para um pequeno escritório, separado apenas por um peitoril que é a continuidade da parede lateral do próprio estar. O segundo lance de rampa leva aos dois dormitórios. A cozinha e os banheiros alinham-se ao comprimento das rampas, ocultando-se atrás da parede contígua às mesmas. Trata-se do "núcleo hidráulico" que serve toda a residência. [379], [380], [381], [382]

Ao organizar os pequenos ambientes (escritório e dormitórios) nas extremidades do

97. Vide o capítulo Pavilhão do Brasil na Feira de Nova York.

271 o encontro de 1936: formação 

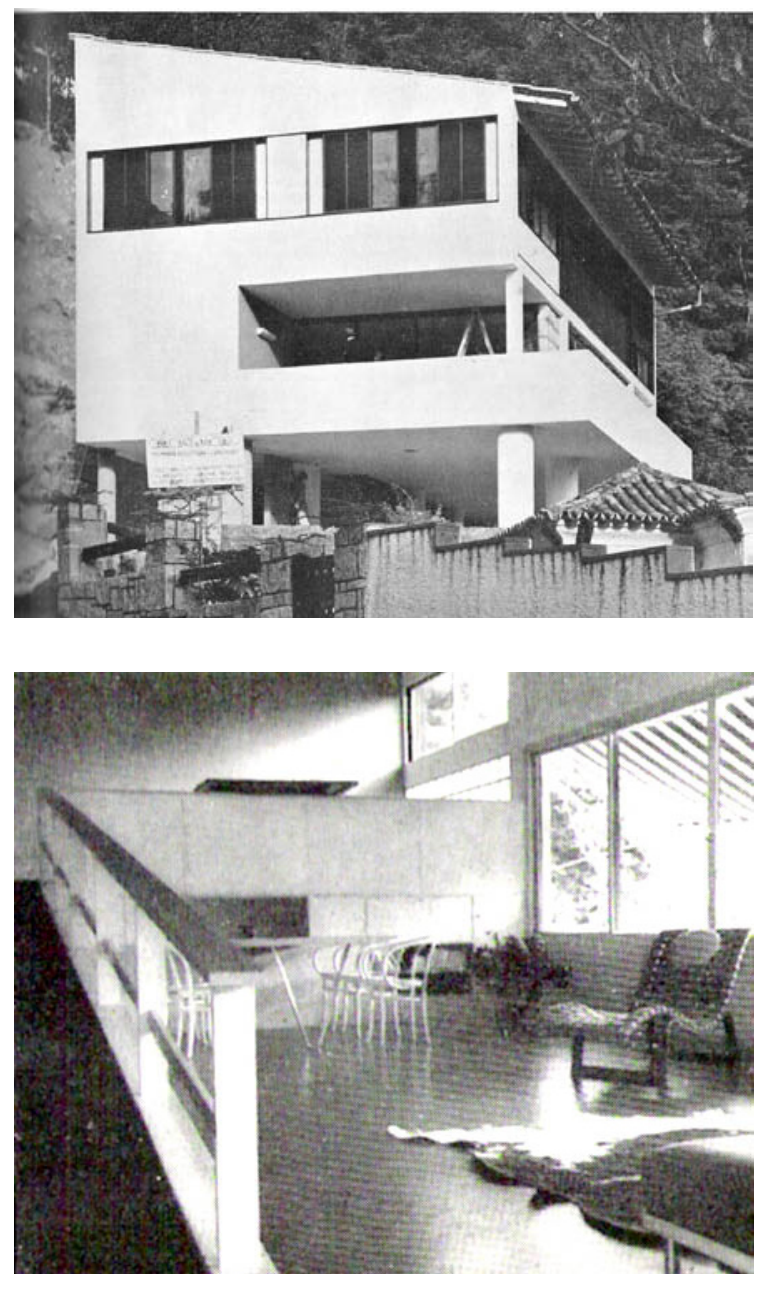

[381] Residência Oscar Niemeyer - 1942 - ON (PAPADAKI, 1950:67)

[382] Residência Oscar Niemeyer - interior - 1942 - ON (Revista l'Architecture d'Aujourd'hui n.13/14 setembro/1947:49)
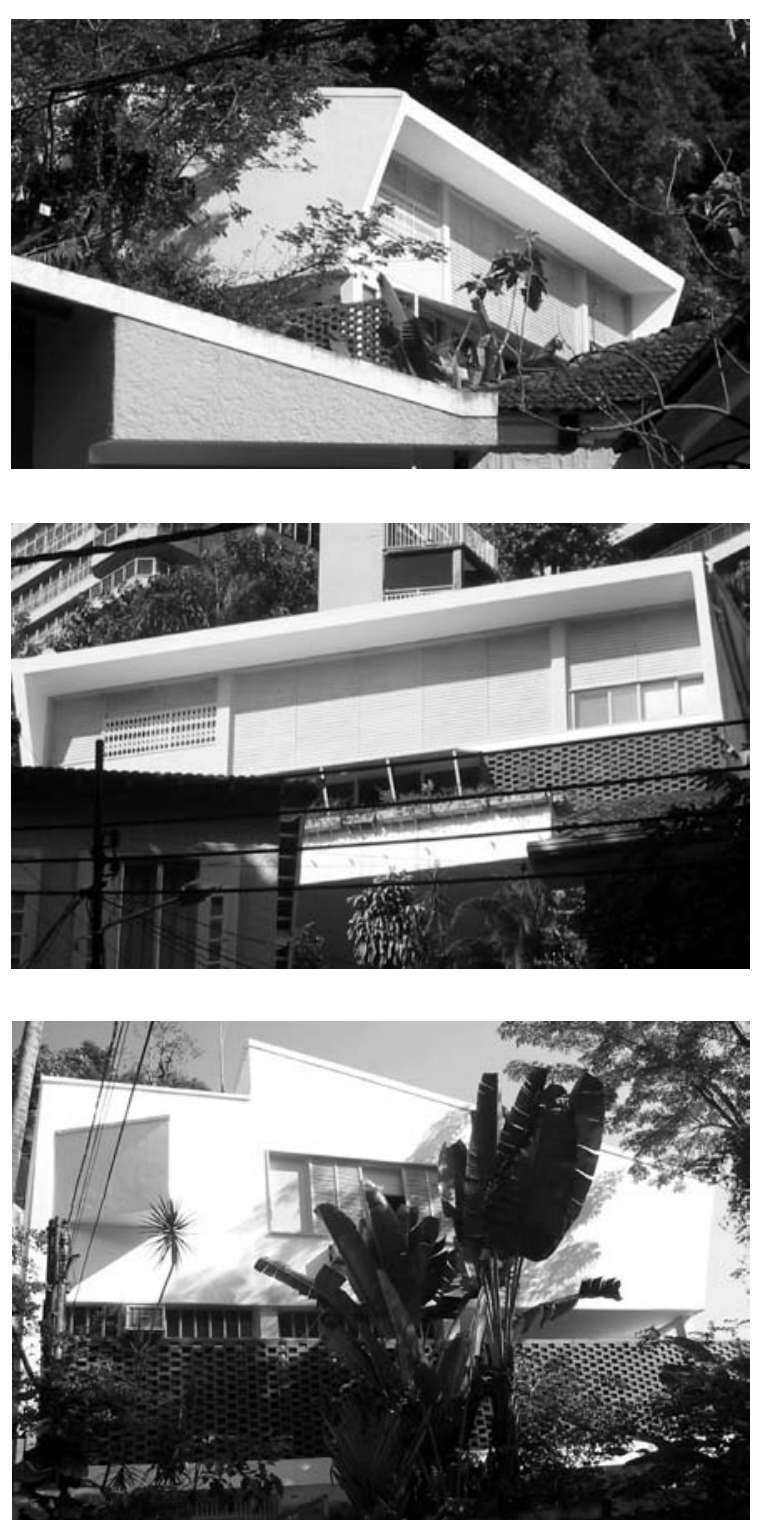

[383] Residência Oscar Niemeyer - 1942 - situação atual foto: Rodrigo Queiroz

[384] Residência Oscar Niemeyer - 1942 - situação atual foto: Rodrigo Queiroz

[385] Residência Oscar Niemeyer - 1942 - situação atual foto: Rodrigo Queiroz 
comprimento da planta, e o setor de serviços no estreito trecho compreendido entre as rampas e o fechamento exterior, Niemeyer libera toda a porção central da construção para um confortável estar com pé-direito duplo.

Segue trecho em que Niemeyer discorre sobre o projeto de sua residência:

O terreno era pequeno e a vista tão bonita que, na verdade, comandou o projeto.

As salas, a cozinha e o quarto da Milota ${ }^{98}$ foram localizados no primeiro andar, acima dos pilotis, e o nosso quarto e o de Anna Maria ${ }^{99}$, já casada, no andar superior, servidos por uma rampa.

O pé direito da sala tinha altura dupla. O primeiro lance da rampa levava à sobreloja onde eu trabalhava, e o outro aos quartos e banheiros.

Foi a primeira vez que desenhei uma sala como aquela. Como gostava daquele espaço maior que nos dava a sensação de estarmos do lado de fora! E ficávamos a olhar a lagoa, o mar distante a se perder de vista (NIEMEYER 2006:18).

O estado atual dessa construção mostra algumas alterações com relação ao projeto original. Um corpo retangular foi adicionado à face posterior da construção. Para que esse novo volume, assim como o terraço do estar, também tivesse vista para a Lagoa Rodrigo de Freitas, sua janela configura-se como uma protuberância que nasce da fachada lateral e, em diagonal, busca a amplitude suficiente para que a vista se descortine.

O beiral do telhado foi recoberto por um forro pintado de branco. Foram construídos dois fechamentos triangulares que arrematam ambas as laterais da residência. Com esse artifício o pequeno trecho em balanço do telhado fica incorporado a as paredes laterais. O terraço do estar, originalmente descoberto, recebeu uma cobertura inclinada de feição provisória que destoa da concepção geral do projeto. As venezianas altas que protegem o estar da incidência solar foram pintadas em um tom amarelo intenso. Tal reforma elimina grande parte dos "vestígios" da feição vinculada à tradição presente em seu projeto original. [383], [384], [385]

O projeto da residência Johnson em Fortaleza (1942), assim com a residência particular do arquiteto, ainda expressa o desejo por uma síntese entre modernidade e tradição dado pela adoção de elementos literais de ambas as linguagens: o volume "puro" sobre pilotis e o telhado inclinado.

O terraço, que na casa do arquiteto projeta-se para fora, na casa Johnson abriga-se sob a projeção do volume sobreposto aos pilotis que assumem uma pronunciada proporção vertical, incompatível com a horizontalidade do volume ortogonal suspenso, o que, à primeira vista, causa um certo estranhamento. O terraço configura-se como uma plataforma intermediária entre o térreo e o corpo que abriga os dormitórios.

Devemos observar que, no desenho de Niemeyer para a casa Johnson, a proporção horizontal, tanto dos pilotis como do volume suspenso, está preservada mesmo com a adoção dos três pavimentos, ao passo que a obra construída revela um claro desajuste com relação ao

98. tia de Oscar Niemeyer.

99. filha de Oscar Niemeyer.

273 | o encontro de 1936: formação 

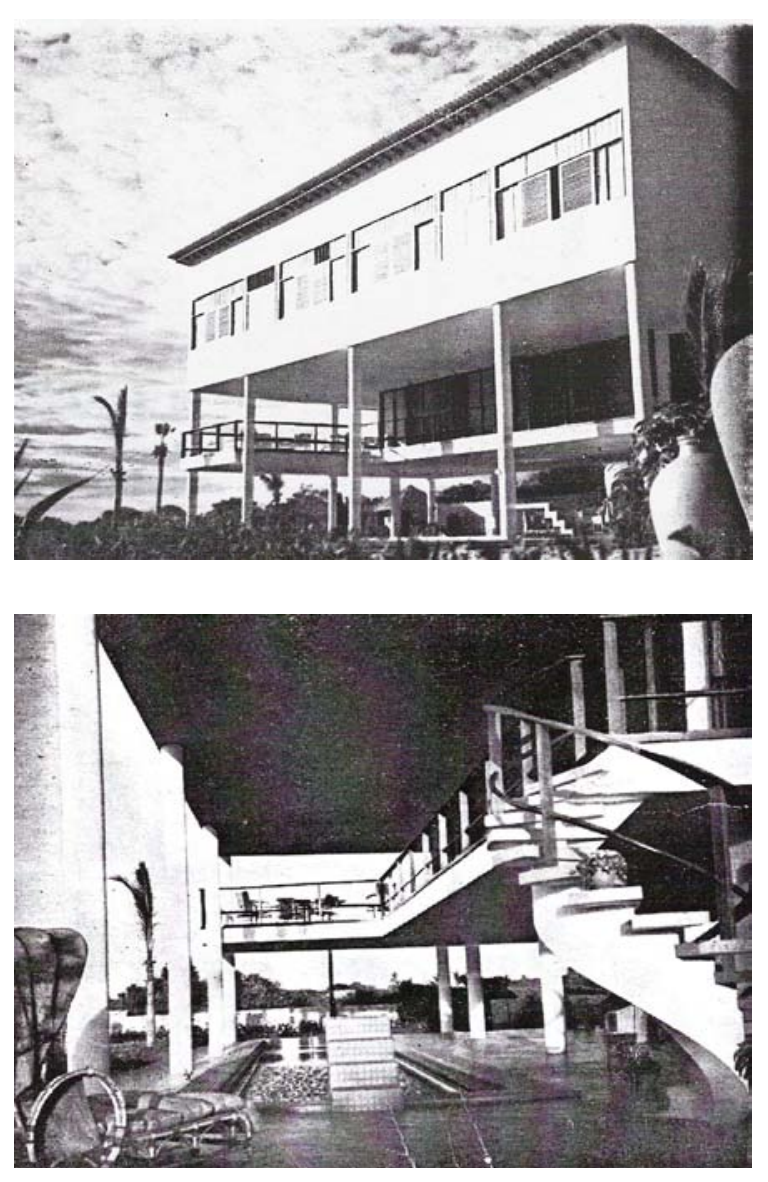

[386] Casa Johnson - Fortaleza - 1942 - ON (Revista Acrópole n.362 maio/1951:24)

[387] Casa Johnson - Fortaleza - 1942 - ON

(Revista Acrópole n.362 maio/1951:24)

[388] Casa Johnson - Fortaleza - perspectiva - 1942 - ON (HESS, 2006:22)

[389] Casa Johnson - Fortaleza - perspectiva terraço - 1942 $-\mathrm{ON}$

(GOODWIN, 1943:169)

[390] Residência Francisco Inácio Peixoto - Cataguases - corte - 1943 - ON

(PAPADAKI, 1950:118)
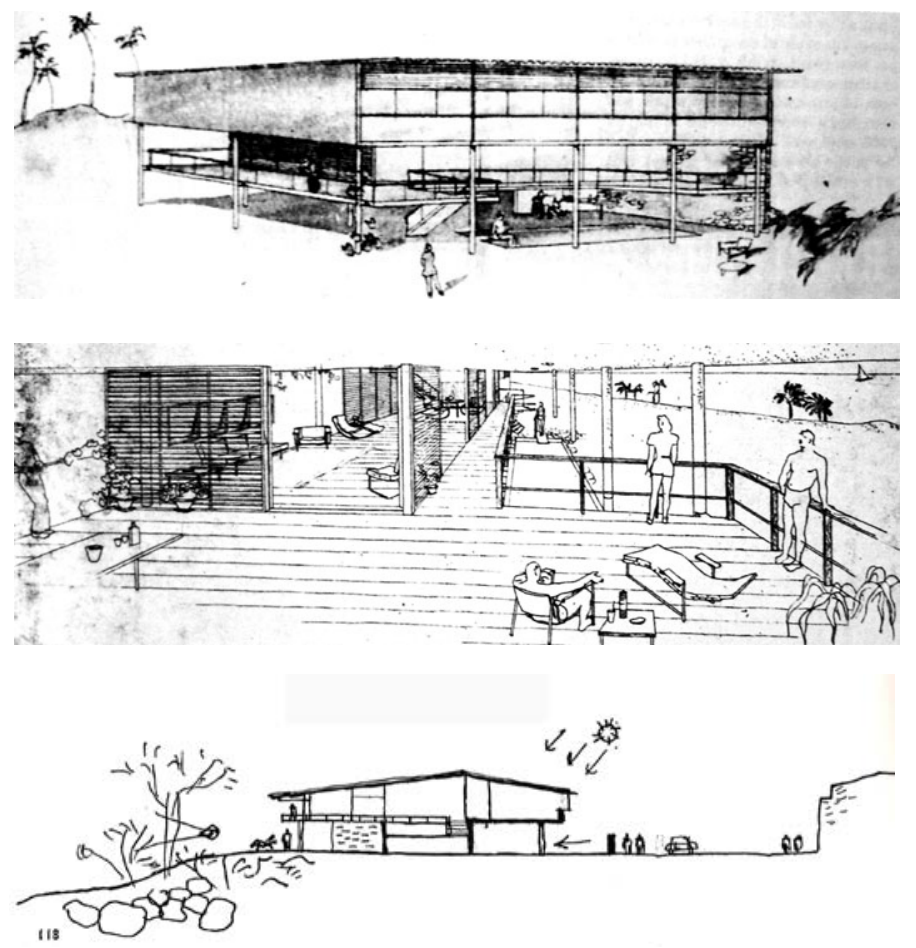
desenho. A proporção horizontal e a agradável relação entre o vazio do embasamento e a materialidade sintética do volume suspenso presente no desenho não se transpõe para a construção. [385], [386], [387], [389]

A idéia do terraço como uma delgada plataforma representa o desejo por um elemento intermediário entre o chão e o objeto sobreposto à retícula de pilotis. Em projetos com a Maternidade (1937) e o Grande Hotel de Ouro Preto (1938/1939) já é possível observar esse tipo de solução. Ao conceber esses planos horizontais de traçado recortado, Niemeyer torna mais sutil e delicada a relação entre o "térreo livre" e o objeto suspenso que, nos exemplares de Le Corbusier apresenta-se de maneira enfática devido a inexistência dessas plataformas suspensas. Trata-se de mais uma intervenção de Niemeyer nos paradigmas corbusianos, com o objetivo de diluir a rigidez na composição entre os vazios e as massas construídas. Nessas plataformas, Niemeyer incorpora um plano horizontal paralelo à linha do chão a um arranjo que, sem esse tipo de intervenção, seria reduzido a um mero volume regular suspenso por pilotis.

A casa Francisco Inácio Peixoto (1942), na cidade mineira de Cataguases, segue a mesma configuração espacial presente na residência particular de Niemeyer e na casa Johnson: mezanino que se debruça sobre o estar com pé-direito duplo e os dormitórios em um volume horizontal sobreposto aos pilotis do pavimento térreo. Por outro lado, na casa de Cataguases, Niemeyer opta por um telhado em duas águas de inclinação branda, diferentemente das outras duas residências, caracterizadas por uma cobertura inclinada com um único caimento.

As vigas que sustentam o balanço do volume dos dormitórios possuem um desbaste diagonal que encontra o vértice compreendido entre o final do trecho em balanço e o plano vertical do fechamento exterior que abriga as aberturas dos dormitórios. As vigas desbastadas, presente na casa de Cataguases, já estavam presentes em projetos de Lucio Costa, como nas habitações, na escola e no clube de Monlevade (1934) e nas "casas sem dono" (1932-1936).

O desbaste nas vigas que sustentam o balanço evita que suas alturas apareçam nas elevações dos projetos, o que, certamente, caracterizaria um ruído no desenho do contorno elementar dos volumes suspensos e em balanço. Trata-se de um simples artifício para se aumentar a proporção horizontal do volume suspenso.

No projeto da casa de Cataguases, tanto as vigas desbastadas como os pilotis de secção quadrada são pintados de marrom escuro. Através da diferença de cor, a estrutura e o volume suspenso ganham autonomia própria. As janelas dos dormitórios, assim como em sua residência pessoal e na casa Johnson, são venezianas retangulares de madeira que se estendem pelo rasgo horizontal que ocupa todo o comprimento do volume suspenso. $\mathrm{Na}$ casa de Cataguases as janelas são pintadas em um azul profundo, aos moldes das residências do período colonial brasileiro. [390], [391], [392]

O projeto de Niemeyer para a residência Cavalcanti (1940) já apresentava as soluções

275 | o encontro de 1936: formação 



[391] Residência Francisco Inácio Peixoto - Cataguases - $1943-\mathrm{ON}$

(HESS, 2006:57)

[392] Residência Francisco Inácio Peixoto - Cataguases -interior - 1943 - ON

(HESS, 2006:58)

[393] Residência Cavalcanti - Rio de Janeiro - 1940 - ON (foto: Rodrigo Queiroz)

[394] Residência Cavalcanti - Rio de Janeiro - 1940 - ON (foto: Rodrigo Queiroz) 
que seriam adotadas tanto em sua residência particular, como nas casas Johnson e Peixoto. $\mathrm{Na}$ residência Cavalcanti nota-se com clareza essa fusão entre o paradigma purista de Le Corbusier e o compromisso com uma tradição de matriz colonial apregoado por Lucio Costa. O volume branco - escavado por aberturas retangulares ${ }^{100}$, acrescido de um generoso terraço e coberto com telhado inclinado em um único caimento, suspenso sobre pilotis cilíndricos, está recolhido atrás de um muro de pedra que isola a residência do espaço público, da mesma maneira que na casa Peixoto.

No pavimento térreo da residência Cavalcanti, Niemeyer concebe um fechamento sinuoso em tom azul-acinzentado para separar a varanda do jardim externo. Esse fechamento encurvado não chega a tocar a laje do pavimento superior.Trata-se de um interessante diálogo com a curva que se serpenteia por trás do alinhamento de pilares do térreo. O contraste cromático entre a parede encurvada e a retícula de pilotis torna ainda mais vigorosa essa relação entre a forma austera e racional, do conjunto formado pelos pilotis e o volume do pavimento superior, e a forma livre. [393], [394]

Phillip Goodwin exaltará os predicados que vinculam a residência Cavalcanti a uma ambiência brasileira:

Excelentes proporções e material bem escolhido dão a essa casa um encanto particular. O pátio de serviço está oculto por um lindo muro de pequenas pedras cor de cinza, pormenor incomum e fresco na arquitetura brasileira.

Parte da casa repousa sobre colunas de concreto. Embaixo, paredes delgadas e livremente curvas dão relevo à entrada e ocultam a garagem e a varanda (GOODWIN 1943:162-164, grifo nosso).

Nesses quatro ${ }^{101}$ projetos de residências, Niemeyer estabelece uma curiosa síntese entre as arquiteturas moderna e colonial. Como podemos observar, essa síntese não é conseqüência do mero arranjo de elementos de períodos distintos. Em Niemeyer, o limiar entre a tradição e a modernidade está indefinido.

Nessas casas de Niemeyer, os pilotis soltos que apóiam os terraços ou os volumes dos dormitórios, ao mesmo tempo em que expressam um estreito diálogo com o "térreo livre" de Le Corbusier, possuem uma feição que lembra as sombreadas varandas coloniais. O volume regular, branco e rasgado pelas janelas "em fita" tanto remete à "fachada livre", presente nas vilas puristas de Le Corbusier, como faz uma alusão à simplicidade austera das superfícies caiadas do casario colonial, apenas interrompida pelas janelas retangulares em veneziana de madeira pintada de azul.

Trata-se de um nó difícil de ser desatado. A extrema sensibilidade de Niemeyer contribui para que continuemos com algumas dúvidas intrigantes. $\mathrm{O}$ valor da modernidade presente nessas casas reside, justamente, nesse nexo estético e ético com a tradição. Características como

100. Além das janelas com venezianas de madeira, Niemeyer recorta uma abertura retangular e a preenche de blocos de vidro. Essa solução foi retomada na casa do arquiteto na Lagoa (1942) e na casa Peixoto em Cataguases (1942).

101. Residências Cavalcanti (1940), Niemeyer (1942), Johnson (1942) e Peixoto (1942).

277 | o encontro de 1936: formação 

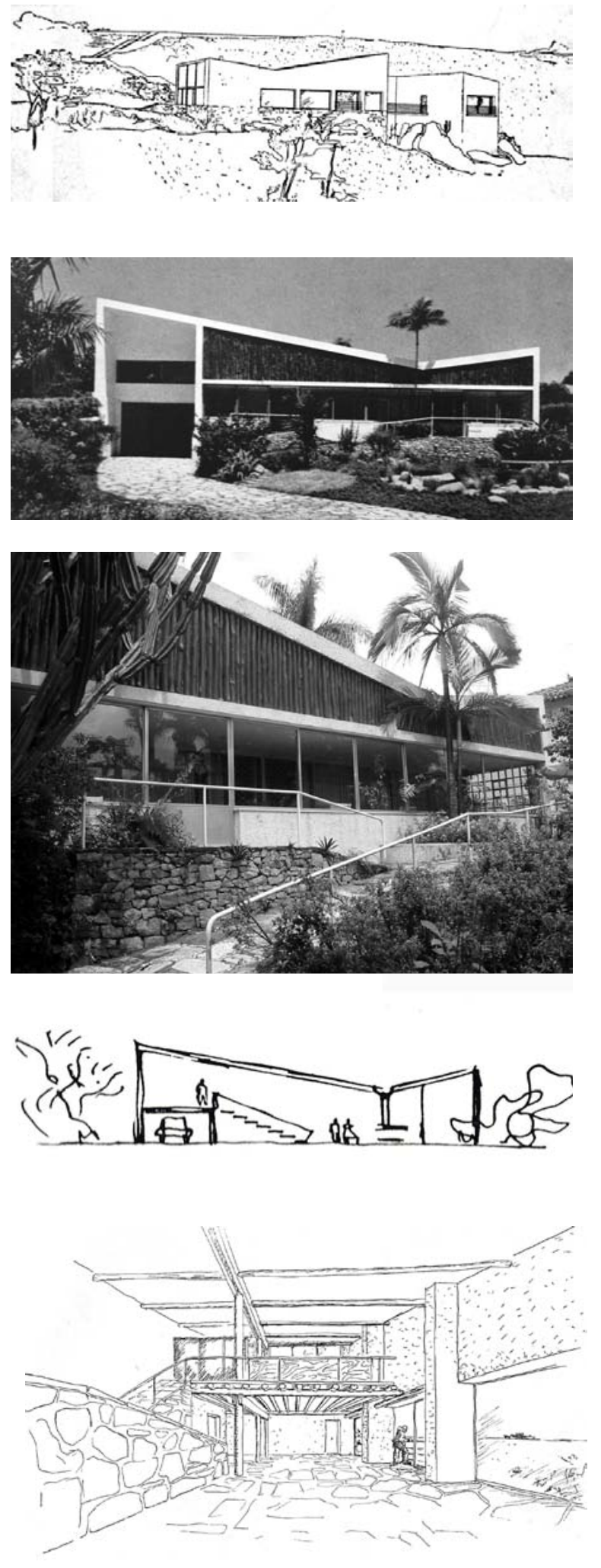

[395] Casa Errazuris - perspectiva - 1930 - LC

(BOESIGER, 1947:52)

[396] Residência Juscelino Kubitschek - Pampulha - 1943 - ON

(PAPADAKI, 1950:108)

[397] Residência Juscelino Kubitschek - Pampulha - 1943 - ON

(foto: Rodrigo Queiroz)

[398] Residência Juscelino Kubitschek - Pampulha - corte - 1943 - ON

(PAPADAKI, 1950:109)

[399] Casa Errazuris - perspectiva interna - 1930 - LC (BOESIGER, 1947:49) 
simplicidade, singeleza, austeridade e verdade construtiva são inerentes tanto ao modelo moderno de matriz corbusiana como aos exemplares de nossa arquitetura colonial e aos exercícios primitivistas de Le Corbusier e de Lucio Costa.

No projeto da residência Kubitschek (1943), assim como no Iate Clube, Niemeyer confere um sentido gráfico à solução do telhado invertido. A espessura da laje em "V" da cobertura se projeta para além dos fechamentos da fachada. Com esse artifício, Niemeyer abranda o sentido volumétrico da construção. O contorno externo do volume emancipa-se ao tratamento das superfícies da fachada, não apenas pelo destaque dado pelas diferentes profundidades das superfícies verticais da fachada, mas principalmente pela solução cromática.

O produto resultante dos traçados efetuados pelas espessuras alvas na fachada aproxima-se de uma composição geométrica. Ao prever uma linha horizontal sob o "V", Niemeyer tensiona a dinâmica dos planos inclinados convergentes da cobertura, conferindo uma proporção horizontal e uma sensação de suspensão ao conjunto.

Assim como Le Corbusier na casa Errazuris, Niemeyer na casa Kubitschek concebe uma abertura horizontal que se estende por quase toda a extensão da fachada, logo abaixo do trecho em "V" da cobertura.

$\mathrm{Na}$ porção lateral esquerda da fachada, reservada ao abrigo de veículos, Niemeyer interrompe a continuidade do fechamento, mas preserva o perfil exterior em "V". Os planos de cobertura e de fechamento lateral emolduram o vazio, a penumbra. Com esse artifício, o arquiteto dilui o sentido hermético do volume. O resultado é apenas um contorno exterior que se desdobra, o fechamento lateral é continuidade da cobertura.

As extremidades ocas enfatizam um desejo de tornar a composição mais livre e arejada. A escavação atinge seu limite, preserva apenas as espessuras das paredes externas. Esse artifício presente na Residência Kubitschek, pode ser diagnosticado no Pavilhão de Nova York (1938), no Clube dos Estudantes da Universidade do Brasil (1937) e também no próprio Iate Clube (1943), na face oeste, onde o plano de brises verticais desalinha-se em sutil curvatura da cobertura inclinada. [395], [396], [397]

As pastilhas em dois tons pastéis, assentadas em uma disposição aleatória, revestem todas as espessuras que contornam a fachada da residência Kubitschek. Como contraponto à precisão da forma e da superfície que envolve o projeto, Niemeyer utiliza um revestimento no mínimo inusitado na porção cega da fachada: delgados troncos de árvore justapostos e assentados verticalmente. Os troncos de árvore, ainda em seu estado bruto, já haviam sido utilizados por Le Corbusier como estrutura para os pisos suspensos formados por tábuas de madeira na casa Errazuris e na casa em Mathes.

O projeto da residência Errazuris, além de utilizar o telhado invertido, possui uma distribuição dos ambientes semelhante a aquela presente no projeto da residência Kubitschek. O corte da residência Errazuris já indica a solução que Niemeyer utilizará na residência Kubitschek: o telhado invertido assimétrico; a diferença de pé-direito que permite o uso de dois pavimentos

279 | o encontro de 1936: formação 

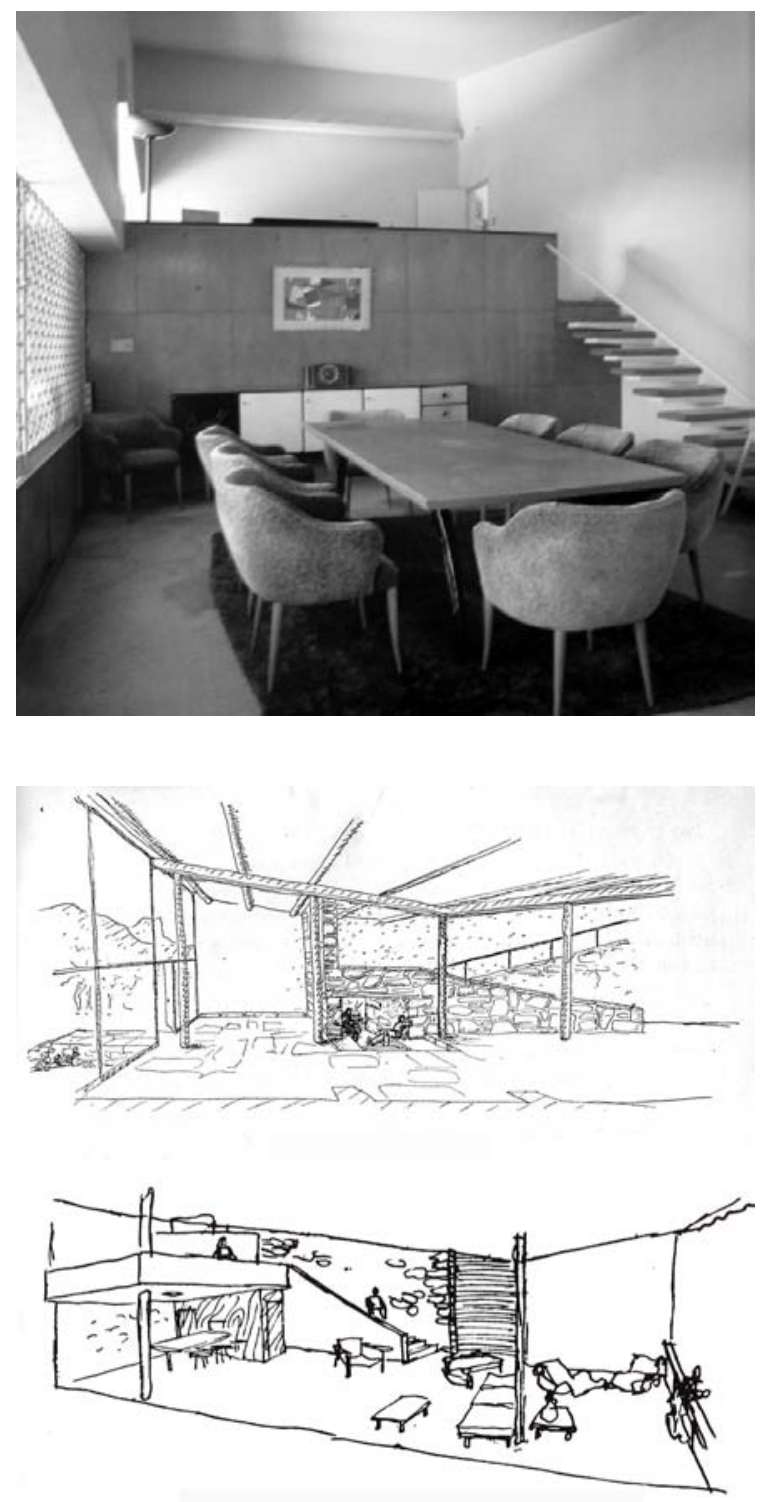

[400] Residência Juscelino Kubitschek - Pampulha - interior - 1943 - ON (HESS, 2006:70)

[401] Casa Errazuris - perspectiva interna - 1930 - LC

(BOESIGER, 1947:51)

[402] Casa Charles Ofair - perspectiva interna - 1943 - ON (PAPADAKI, 1950:116) 
em uma das extremidades; a circulação íntima como um mezanino que se volta para o estar, configurado como um espaço intermediário de volumetria trapezoidal, situado entre a extremidade mais alta, que abriga os dormitórios, e o ponto mais baixo da cobertura (vértice do telhado). [398], [399], [400]

A interpretação da casa Errazuris contida na casa Kubitschek, nos permite compreender com exatidão a maneira como Niemeyer processa os referenciais de Le Corbusier.

$\mathrm{Na}$ casa Errazuris, Le Corbusier concebe um volume de planta retangular conectado pela cozinha a um pequeno anexo que contém dois dormitórios e um banheiro. O volume principal possui sua cobertura com caimento duplo, assimétrico e invertido - da mesma forma que o Iate Clube e a casa Kubitschek. As aberturas da elevação principal consistem de obstruções retangulares no trecho próximo ao embasamento de pedra.

Niemeyer, na casa Kubitschek, preserva a configuração trapezoidal do volume presente na casa Errazuris. Por outro lado, utiliza a elevação principal como suporte para uma composição gráfica quase "mondrianesca". As aberturas na face principal da casa Kubitschek - que na casa Errazuris são meros recortes isolados dentro de um campo sem referencial - caracterizam-se por um único rasgo horizontal emoldurado por uma esbelta laje de concreto e pelos próprios limites das faces paralelas dos trapézios.

Niemeyer transforma a casa vernácula de Le Corbuiser em objeto cuja fachada possui um apelo geométrico que fragmenta a superfície em diferentes campos autônomos e puros: o retângulo horizontal e transparente da caixilharia da sala; o trecho em forma de dois trapézios, revestido de troncos de madeira; e a porção escavada reservada ao estacionamento. Tratam-se de campos de superfície limitados por linhas reguladoras que desenham, além do arranjo interno, o contorno do próprio volume.

Na casa Kubitschek, Niemeyer compreende a casa Errazuris como um simples suporte para uma intervenção que transforma o volume em um arranjo gráfico-pictórico compreendido pelo diálogo entre uma moldura delgada e as superfícies contidas dentro dela. Assim como o Iate Clube, a casa Kubitschek rompe com a estanqueidade dos volumes concebidos por Le Corbusier, presente tanto nos exemplares puristas, como nos projetos de teor regionalista (casas Errazuris e Mathes). A forma de contorno geométrico se sobrepõe as características vernáculas, mas ainda guarda reminiscências de uma tradição construtiva, mesmo que seja na dimensão do mero ornamento, como vemos nos pequenos troncos de madeira aplicados na fachada principal.

No projeto de Niemeyer para a residência Charles Ofair (1943), observamos uma outra versão da tipologia presente na residência Errazuris (telhado invertido assimétrico e mezanino). Ali, Niemeyer funde duas características de experiências corbusianas distintas: a volumetria e a materialidade construtiva artesanal, presente na casa Errazuris e a idéia de suspensão do volume e do térreo-livre presente nos exemplares puristas com a casa Savoye. [401], [402]

Na perspectiva interna da residência Ofair, Niemeyer evidencia sua inclinação para a utilização dos materiais brutos, como podemos observar na parede de pedra que recebe a escada, no fechamento em madeira que divide a cozinha da sala de jantar e na telha aparente. Nesse desenho

281 o encontro de 1936: formação 
Niemeyer preserva a mesma espacialidade interna da casa Errazuris: estar com pé-direito duplo e mezanino.

Nesses projetos de residências, Niemeyer equaliza suas referências e concebe arquiteturas que sintetizam o desejo por uma modernidade autêntica que transpõem o mero mimetismo dos elementos modernos e tradicionais e que assume, gradativamente, uma condição de liberdade e autonomia a ponto de se transformar em uma linguagem, ao mesmo tempo singela e revolucionária. 


\section{Igreja de São Francisco de Assis}

O projeto de Niemeyer para a Igreja de São Francisco de Assis (1942) assume nítido papel de destaque no Conjunto Arquitetônico da Pampulha. Os demais edifícios do conjunto, quando comparados com a Igreja de São Francisco, reduzem-se a um redesenho libertário da regra corbusiana do Esquema Dom-ino: lajes sucessivas estruturadas por retícula de pilares contida no interior da projeção da construção, seja na complexidade perturbadora do Cassino, nos curvilíneos contornos exteriores da Casa de Baile ou na transparência dinâmica do Iate Clube.

Na Igreja da Pampulha, a plena autonomia da matéria não carece mais do suporte da razão presente nos apoios verticais e das transições horizontais. A retícula espacial de pilares e vigas é substituída por um contorno pleno. A volumetria do edifício é definida pelo movimento aéreo das abóbadas sucessivas.

Em que pese as evidentes diferenças entre a Igreja de São Francisco de Assis e os demais edifícios do Conjunto da Pampulha, devemos lembrar que Niemeyer mantém a unidade entre todos os edifícios ao preservar a utilização de três materiais básicos: vidro, azulejo pintado e pedra apicoada.

Na Igreja de São Francisco, Niemeyer reveste as espessuras das abóbadas com granito apicoado, a mesma pedra que cobre as espessuras expostas das lajes do Cassino, da Casa de Baile e do Iate Clube. O azulejo pintado da Igreja de São Francisco substitui o motivo lusitano, circular e floreado presente nos outros três edifícios, pela representação das cenas da vida de São Francisco de Assis. ${ }^{102}$

A abóbada, elemento que caracteriza a Igreja de São Francisco, já havia sido utilizada por Niemeyer em 1938 no projeto da residência Oswald de Andrade como uma cobertura em arco apoiada sobre pilares de secção quadrada e implantada entre duas coberturas com inclinações invertidas. Trata-se de uma fusão das experiências de Le Corbusier nas residências Monol (1919 - abóbada) e Errazuris (1930 - telhado invertido). Na residência de Oswald de Andrade, a abóbada se restringe a condição de mera cobertura. É um abrigo encurvado sobreposto a um volume

102. (Cf.: FABRIS, 2000:203).

283 | o encontro de 1936: formação 

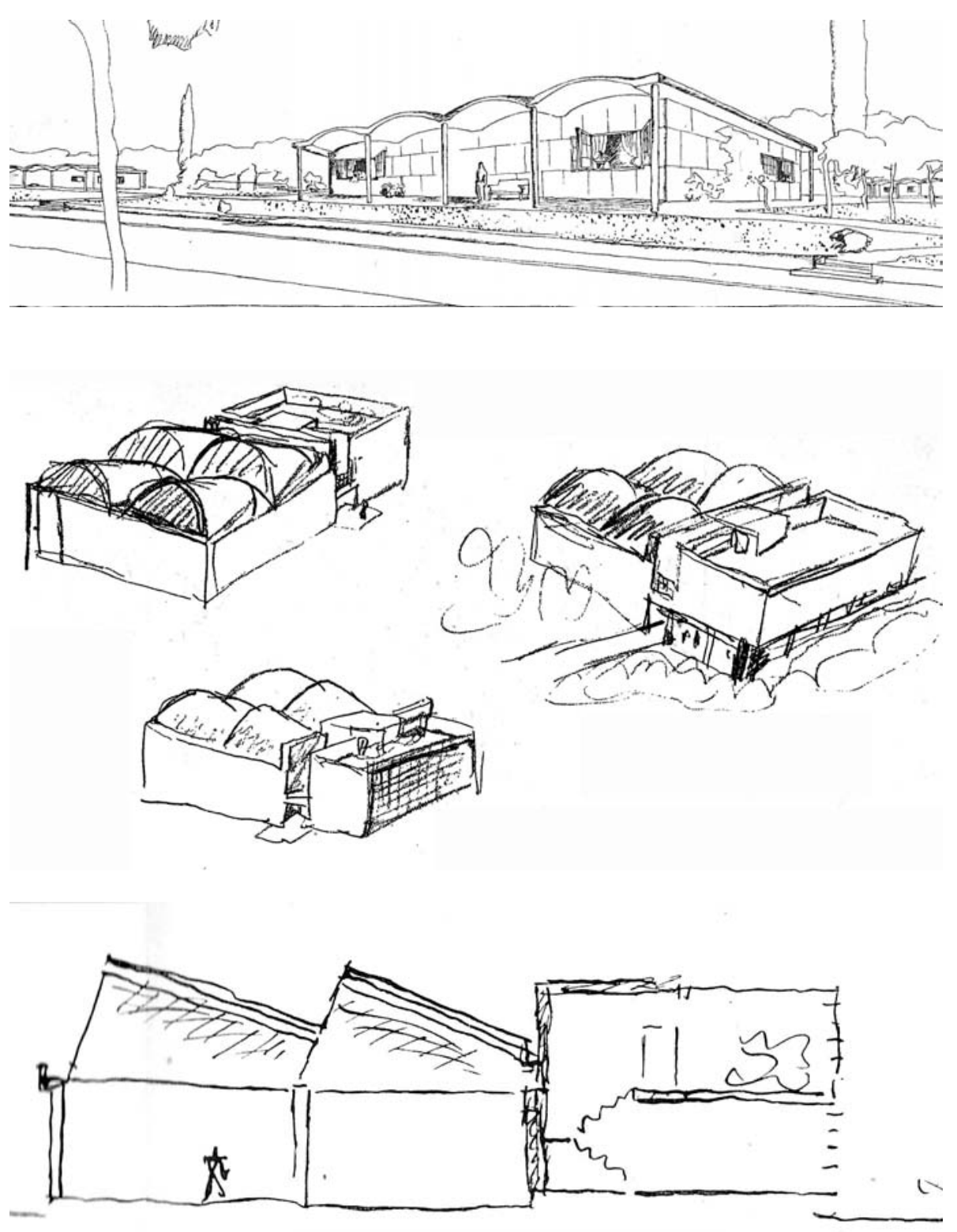

[403] Casa Monol - 1919 - LC

(BOESIGER, 1946:30)

[404] Atelier do arquiteto - estudos - 1929 - LC

(BILL, 1947:131)

[405] Atelier do arquiteto - corte - 1929 - LC

(BILL, 1947:131) 
vazado de geometria regular.

Na Igreja de São Francisco, Niemeyer expõe as espessuras das abóbadas que se projetam para fora dos limites verticais leste/oeste. Com esse artifício, o arquiteto evidencia as membranas parabólicas que envolvem o templo.

No projeto da casa Monol, Le Corbusier já havia lançado mão da mesma estratégia de recuar o fechamento em relação à cobertura com o intuito de enfatizar o desenho das cascas sucessivas, configuradas como um conjunto de delgados planos encurvados interligados entre si por calha horizontal. [403]

Da mesma maneira que Le Corbusier na casa Monol, Niemeyer elabora - na elevação posterior da Igreja de São Francisco - um conjunto de quatro abóbadas que se projetam à frente do fechamento que, no caso, recebe o painel azulejado de Candido Portinari.

A diferença crucial entre as abóbadas sucessivas de Le Corbusier e Oscar Niemeyer reside justamente no fato de que Le Corbusier condena as cascas à condição de simples cobertura, ao passo que Niemeyer faz do desenho da abóbada o desenho do próprio edifício.

Na Igreja da Pampulha, Niemeyer, além de preservar as espessuras das abóbadas, encaixará as duas parábolas maiores (altar e nave) uma sobre a outra, mantendo um vão entre elas, aos moldes da experiência de Le Corbusier no projeto de 1929 para seu atelier particular em Paris, que consiste de uma planta quadrada encimada por quatro abóbadas com dimensões oriundas da divisão da planta em quatro "quadrantes" iguais. [404], [405], [406], [407]

No projeto do atelier de Le Corbusier, as abóbadas restringem-se a cobertura e estão apoiadas sobre a base quadrada. Assim como no exemplar da Pampulha, as abóbadas de Le Corbusier possuem secções variáveis, porém não se encaixam em seus pontos de amplitude de curvatura menor como na Igrejinha. Ao contrário, agrupam-se em dois pares, sendo que a borda de curvatura mais abatida abriga-se sob a projeção da borda com maior amplitude de curva, como um "shed abobadado".

Com essa comparação, atestamos no projeto do atelier de Le Corbusier a existência das mesmas características que são peculiares ao templo de Niemeyer: o arranjo entre as abóbadas sucessivas de secção variável que se interceptam, mas que não se tocam, resultando em uma fresta de luz que desenha o encontro das diferentes curvaturas.

No projeto para a sede da empresa de seguros Rentenanstalt em Zurique (1933), Le Corbusier elabora uma lâmina de escritórios cuja planta é resultante da junção de dois trapézios idênticos unidos pelas suas bases maiores. Na cobertura do volume, estão dispostos os espaços de estar, o terraço e o auditório, abrigados sob um conjunto formado por duas abóbadas de planta trapezoidal unidas por marquise. Uma laje plana, de recorte irregular, conecta a abóbada maior que abriga o auditório à abóbada menor que protege o terraço. As duas abóbadas extravasam verticalmente a laje de conexão. É quase como uma "acomodação arqueada" do plano horizontal da laje. Com essa operação, delgadas frestas zenitais em forma de "meia-lua" afloram sobre a laje de cobertura.

O conjunto proposto por Le Corbusier para a cobertura do edifício da seguradora Rentenanstalt possui um comportamento plástico que o aproxima da experiência de Niemeyer na Igreja

285 | o encontro de 1936: formação 

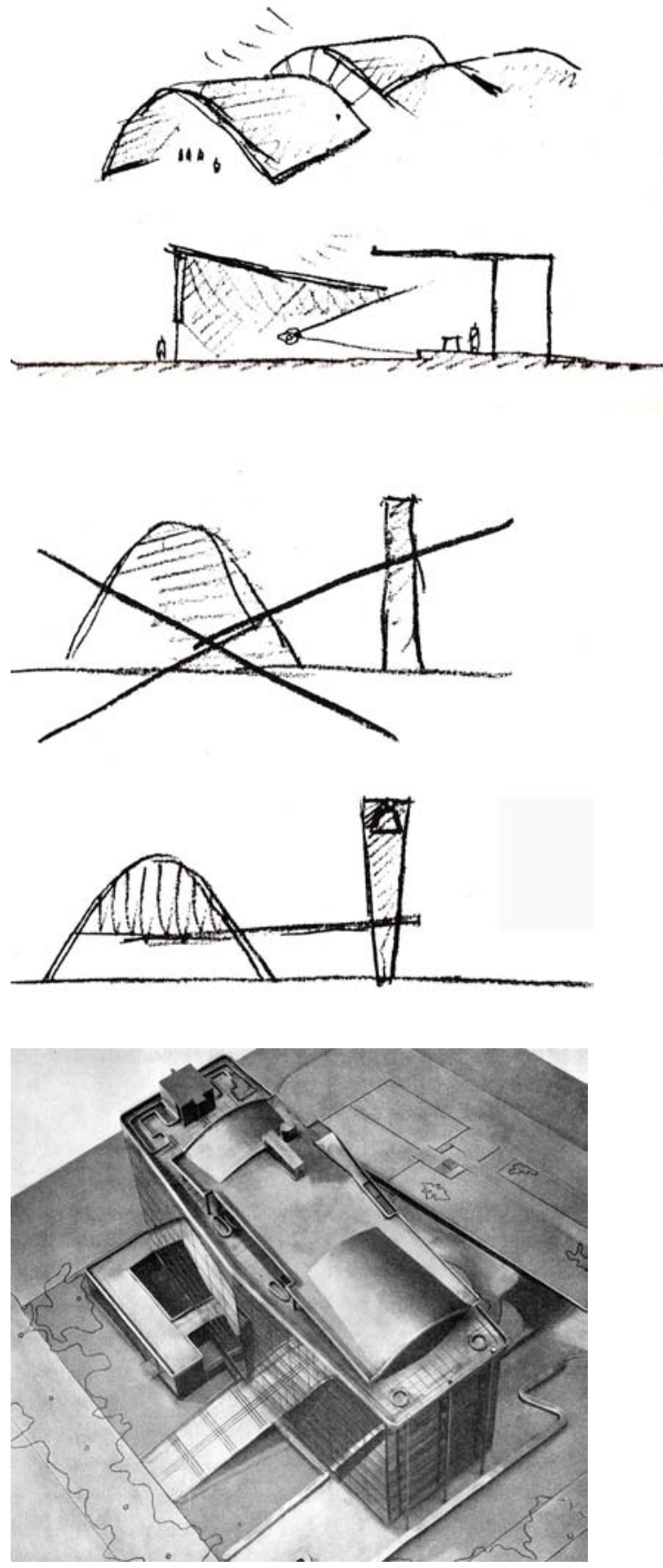

[406] Igreja de São Francisco de Assis - estudos perspectiva e corte - 1943 - ON

(PAPADAKI, 1950:93)

[407] Igreja de São Francisco de Assis - estudos - elevação $-1943-\mathrm{ON}$

(PAPADAKI, 1950:93)

[408] Edifício Rentenanstalt - maquete - 1933 - LC

(BOESIGER, 1971:118)
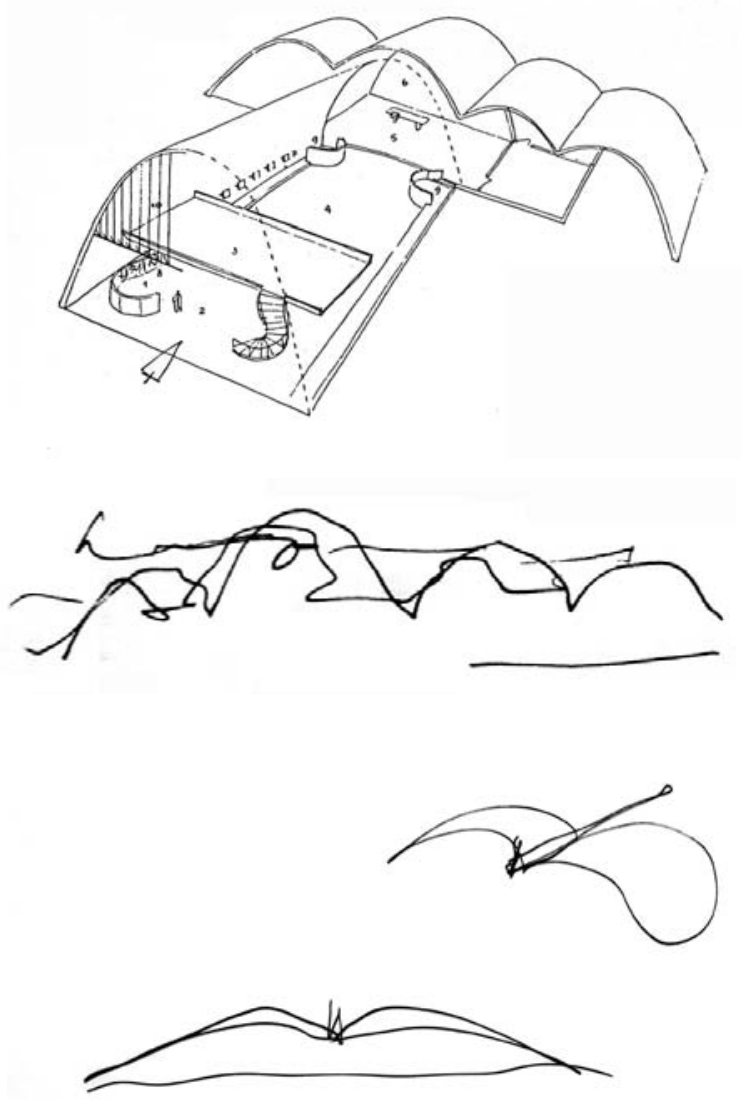

[409] Igreja de São Francisco de Assis - estudos perspectiva e corte - 1943 - ON

(PAPADAKI, 1950:94)

[410] Igreja de São Francisco de Assis - 1943 - croqui - ON (acervo Rodrigo Queiroz)

[411] Auditório da Universidade de Constantine - Argélia $-1969-\mathrm{ON}$

(acervo Biblioteca da FAU-USP) 
de São Francisco. Em ambos os casos, as abóbadas de planta trapezoidal (o terraço e o auditório em Le Corbusier e a nave em Niemeyer) diminuem de altura na medida em que diminuem de seção, resultando em uma cobertura inclinada. Tanto Le Corbusier como Niemeyer desenham as aberturas zenitais como frestas delgadas e curvas, seja o shed que ilumina o auditório no projeto de Le Corbusier, ou o arco-cruzeiro de Niemeyer que banha de luz o retábulo e o altar. [408], [409]

Do ponto de vista da apropriação utilitária da cobertura em abóbada, os projetos de Le Corbusier e Oscar Niemeyer se aproximam. Por outro lado, as configurações plásticas dos projetos caminham em sentidos opostos. A abóbada, que para Le Corbusier cumpre a função de cobertura de um outro elemento, para Niemeyer assume a feição do próprio edifício, justamente no instante em que a cobertura em arco aterriza diretamente no chão em superfícies inclinadas.

As abóbadas presentes nos projetos de Le Corbusier para a Casa Monol (1919), para seu atelier particular em Paris (1929) e para o edifício Rentenanstalt em Zurique (1933) compreendem a cobertura convexa como algo autônomo em relação ao todo, sejam elas sucessivas como as da casa Monol, embutidas no interior da planta quadrada como as que cobrem seu atelier particular, ou como as duas abóbadas trapezoidais dispostas sobre pilotis na cobertura do edifício em Zurique.

No projeto da Igreja de São Francisco, apesar de Niemeyer romper com a idéia da abóbada como simples cobertura, podemos diagnosticar o redesenho das características principais das abóbadas presentes no três projetos de Le Corbusier citados acima. Assim como a casa Monol, a Igreja de Niemeyer desenvolve-se em quatro abóbadas sucessivas. Aos moldes do projeto do atelier de Le Corbusier, Niemeyer encaixa as bordas das abóbadas, uma de seção variável e outra de seção regular, propiciando o aparecimento de frestas de luz. Da mesma maneira que a abóbada que abriga o auditório no edifício Rentenanstalt, na Igreja da Pampulha Niemeyer inscreve a abóbada principal (nave) em uma planta trapezoidal.

O projeto da Igreja de São Francisco representa um desses momentos em que Niemeyer opera um redesenho que transpõe para a escala do próprio edifício aquilo que Le Corbusier condena à instância meramente compositiva.

As abóbadas presentes nesses três projetos de Le Corbusier prestam-se como componentes encurvados que se sobrepõem a objetos tributários ao esquema Dom-Ino. Na Igreja de São Francisco, Niemeyer abandona a relação espacial laje/pilar/viga - presente nos exemplares de Le Corbusier e nos demais edifícios do Conjunto Pampulha - e realiza sua primeira experiência efetiva com a "forma livre".

Em Niemeyer, a adição de segmentos de reta concordantes aos segmentos de arcos, em planta e em corte, conferirá à curva a precisão de um gesto estruturado que percorre tanto o papel (na ação motora da mão) como o espaço (na visada contínua e linear). O objeto se faz perceber como um movimento material da linha do horizonte. Para Niemeyer as relações dessas formas com a paisagem e com o solo serão caracterizadas pelo comportamento contundente de um objeto que se configura como uma continuidade do solo, ou como um bólido que - em tensão extrema - apenas tangencia, esbarra com o chão. [410]

As abóbadas da Igreja de São Francisco de Assis ilustram a síntese entre a memória e a

287 | o encontro de 1936: formação 



[412] Biblioteca - Memorial da América Latina - São Paulo - corte - 1986 - ON

(UNDERWOOD, 2002:126)

[413] Auditório em Ravello - Itália - perspectiva - 2003 $-\mathrm{ON}$

(NIEMEYER, 2004:299)

[414] Monumento a Rui Barbosa - Rio de Janeiro - 1949 - ON

(PAPADAKI, 1950:209)

[415] Ministério do Exército - Brasília - 1969 - ON (foto: Rodrigo Queiroz) 
tecnologia moderna. O arco parabólico caracteriza tanto os interiores das antigas catedrais góticas com seus arcos cruzados, como as estruturas metálicas que vencem os vãos das grandes estações de trem e dos hangares.

Niemeyer transporta o perfil parabólico dos grandes arcos modernos, como os hangares de Freyssenet em Orly, para um objeto no qual a escala, a forma e a superfície corporificam um singelo templo construído à beira da Lagoa da Pampulha.

Na Igreja de São Francisco, Niemeyer manipula uma solução formal que encontra na curva uma tripla razão: técnica, estética e simbólica.

Assim como as demais soluções formais presentes no Conjunto da Pampulha, a abóbada que caracteriza a Igreja de São Francisco integrará o rol das estratégias projetuais do arquiteto aplicadas nos projetos realizados posteriormente à experiência da Pampulha. Inicialmente, desdobram-se em algumas variações onde a abóbada descarrega seu peso, não em planos, mas em apoios inclinados, presentes em projetos como o Teatro Municipal de Belo Horizonte (1943) e o Restaurante da Lagoa Rodrigo de Freitas (1944).

Em projetos como o auditório da Universidade de Constantine na Argélia (1969) e a biblioteca do Memorial da América Latina em São Paulo (1986), Niemeyer conjuga a abóbada ao pórtico retangular de proporção horizontal. Ambos os projetos são constituídos de duas abóbadas simétricas que nascem do chão em um plano regular inclinado, encurvam-se e repousam na peça horizontal do pórtico. Como as abóbadas apóiam na trave em uma de suas extremidades, o arquiteto preserva a espacialidade integral dos espaços internos. Em ambos os casos, os apoios encontram-se fora do edifício.

No auditório de Constantine, Niemeyer mantém o caixilho com vidro escuro na penumbra, recuado no interior da projeção das cascas que em planta assumem um traçado trapezoidal, afunilando-se em direção ao chão. Nesse projeto, a abóbada se destaca como uma delgada membrana encurvada que sai do pórtico e toca o piso em angulação rasa. [411]

No caso da Biblioteca do Memorial da América Latina, Niemeyer procederá de maneira oposta. Trata-se de um volume de planta retangular de proporção horizontal. O caixilho preto alinha-se à borda das abóbadas. A idéia de superfície encurvada bidimensional dá lugar a um volume. A presença de uma estreita junta entre o caixilho e a face inferior da abóbada indica o desejo do arquiteto em manter aparente as espessuras que mostram o desenho da membrana que envolve o edifício. [412]

Em alguns casos, Niemeyer substitui as abóbadas sucessivas por um único arco que envolve todo o programa. No projeto para o auditório em Ravello na Itália (2003), o arquiteto concebe uma casca que se projeta sobre um declive acentuado. A casca assume uma volumetria escultórica, onde a própria espessura da abóbada, do lado oposto ao balanço, alarga-se em curva convexa até tangenciar o chão. [413]

Ao manipular o perfil das abóbadas, Niemeyer potencializa ao extremo a experiência gestada na Igreja da Pampulha. Lança mão dos apoios inclinados; distorce a superfície encurvada, afunilando-a conforme se aproxima do solo; transita entre as abóbadas sucessivas e as abóbadas simples,

289 | o encontro de 1936: formação 
fechadas ou abertas; encurva o trecho que toca o solo, a abóbada simples se torna um caracol aberto.

Em seu projeto para o Monumento a Rui Barbosa no Rio de Janeiro (1949), a abóbada parte em ângulo obtuso e aterriza em curvatura convexa e tangente ao solo na extremidade oposta. Nesse projeto, a abóbada encurva-se tanto no sentido de seu comprimento como no sentido de sua largura, configurando um conchóide oco. [414]

Passados vinte anos, em 1969, Niemeyer retoma a solução do Monumento a Rui Barbosa e concebe a grande casca que abriga a tribuna de honra do Ministério do Exército em Brasília, sem esquecer nem mesmo do obelisco em forma de pirâmide vertical. Mas a tensão visual dada pelo contraste entre a casca que aterriza e o obelisco que emerge do solo já estava presente na própria concepção da Igrejinha da Pampulha. Basta lembrarmos da composição antagônica formada pela estabilidade da abóbada da nave e o dinamismo instável do campanário. [415]

Em suas abóbadas, Niemeyer incorpora a idéia de abrigo como um único gesto, sutil inflexão da linha horizontal do chão que, em diagonal, ascende e encurva-se convexa para, na outra extremidade, encontrar novamente o chão.

Esses perfis arqueados em corte configuram-se como o registro gráfico de um movimento que desenha elegantes espessuras distendidas, seja a linha sobre o papel, sejam as abóbadas dispostas no espaço. 


\section{Modernidade e religiosidade}

Na Igreja da Pampulha, as abóbadas rompem o limite físico da simples cobertura ${ }^{103}$ e prolongam-se inclinadas em direção ao chão. A reminiscência de um purismo estilizado presente nos demais edifícios do conjunto desaparece.

Apesar das características peculiares de cada edifício da Pampulha, cinco dos seis edifícios expressam-se a partir da manipulação de um esqueleto racional (trama de pilares e lajes). Somente a Igreja distancia-se dessa lógica construtivo-formal comum a todos os outros edifícios.

A concepção do projeto da Igreja de São Francisco de Assis ultrapassa a simples utilização das abóbadas sucessivas. Em uma planta em "T", Niemeyer funde uma seqüência de quatro abóbadas menores a um arco parabólico maior. [416]

As abóbadas que cobrem a sacristia, o altar e a sala do padre possuem desenvolvimento regular, isto é, em qualquer secção transversal da abóbada iremos obter a mesma parábola. Já a abóbada que cobre a nave expande-se para fora. A secção da parábola aumenta de tamanho conforme se afasta em direção a elevação principal do edifício.

$\mathrm{Na}$ vista posterior da Igreja, observamos apenas a seqüência de quatro abóbadas, sendo que somente as extremas tocam, em plano inclinado, o solo. A abóbada que abriga o altar, sobressai-se às cascas da sacristia e da sala do padre.

A cerâmica que reveste o fechamento posterior da Igreja recebe um imenso painel de Cândido Portinari que retrata cenas da vida de São Francisco, que ocupa toda a fachada. Assim como Le Corbusier na casa Monol, Niemeyer mantém o plano vertical que recebe o mural sutilmente recuado da projeção das abóbadas. Com esse sutil deslocamento, o arquiteto exterioriza apenas a espessura das abóbadas revestidas em pedra apicoada, imprindo o contraste necessário com a extensa parede vitrificada em plano recuado.

Com a exímia precisão na disposição do plano vertical e do perfil envoltório em arco, Niemeyer faz com que a construção assuma a qualidade gráfica do desenho. Apreendemos um sutil contorno que se destaca do fechamento como um traço que sai do chão, suspende-se em

103. Presente nos projetos de Le Corbusier para a casa Monol e para o seu escritório particular e para o Edifício Rentenanstalt e no projeto de Niemeyer para a residência de Oswald de Andrade (1938).

291 o encontro de 1936: formação 

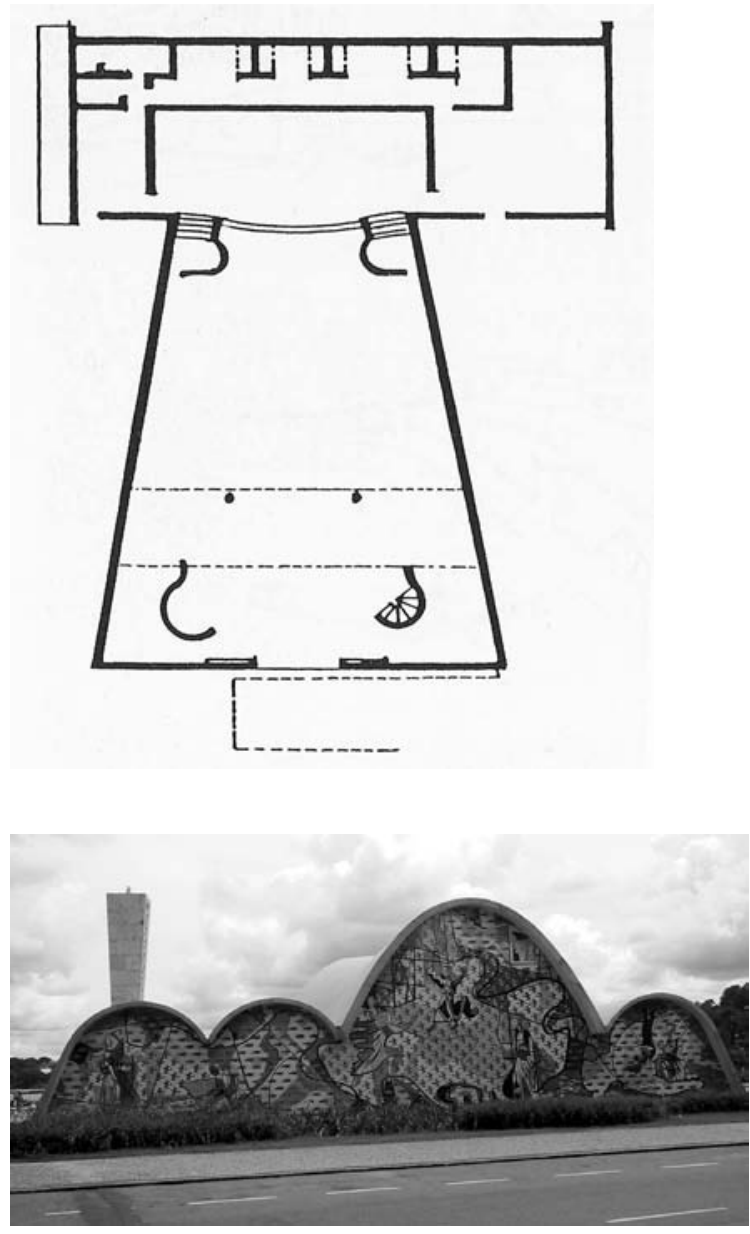

[416] Igreja de São Francisco de Assis - Pampulha - planta - 1943 - ON (BOTEY, 1996:158)

[417] Igreja de São Francisco de Assis - Pampulha - 1943 - ON (painel de azulejos com cenas da vida de São Francisco de Assis - Cândido Portinari)

(foto: Rodrigo Queiroz)
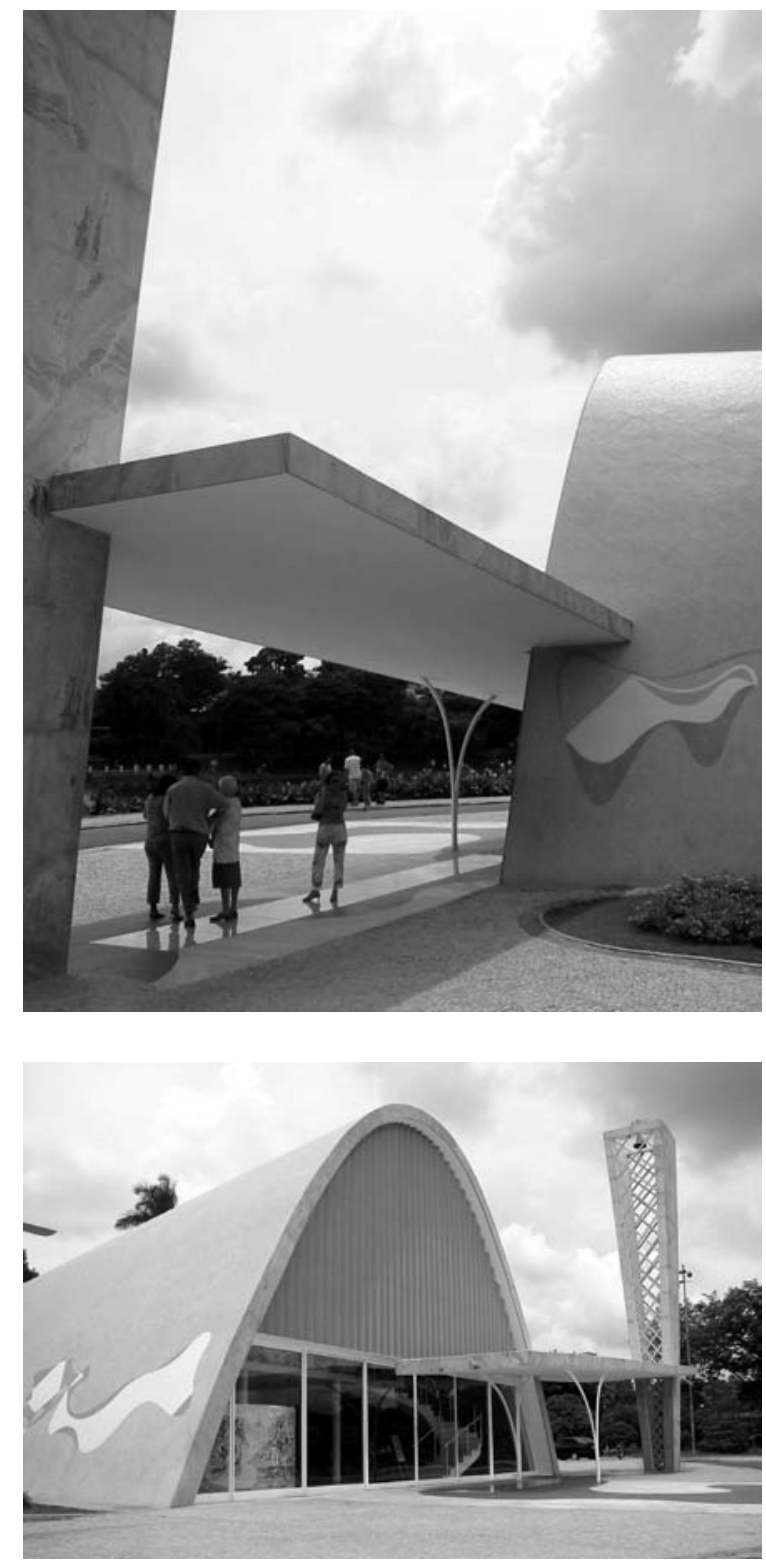

[418] Igreja de São Francisco de Assis - Pampulha percurso até o adro - 1943 - ON

(foto: Rodrigo Queiroz)

[419] Igreja de São Francisco de Assis - Pampulha - acesso - 1943 - ON

(foto: Rodrigo Queiroz) 
seqüência aérea e retorna ao chão, em plano concordante aos arcos das abóbadas extremas. [417]

Curiosamente, chega-se a Igreja por sua face posterior que está voltada para a rua. $\mathrm{O}$ arquiteto induz um percurso onde o pedestre descobre aos poucos a elevação principal que se descortina em diagonal em adro que se abre para a Lagoa da Pampulha. [418]

A maior abóbada do conjunto, que abriga a nave, o nártex, o coro e o batistério possui seu fechamento em vidro transparente e recebe uma superfície de brises verticais que parte do alinhamento com o piso do coro e preenche toda a porção encurvada da abóbada. $\mathrm{O}$ acesso principal é protegido por marquise inclinada, sustentada por pilar em "V" encurvado. Trata-se de um redesenho do mesmo conjunto de marquise inclinada e pilar em " $\mathrm{V}$ " presente na entrada o projeto de Le Corbusier para o Exército da Salvação (1929). [419]

A extremidade mais alta da marquise inclinada intercepta o campanário em forma de tronco de pirâmide invertido de proporção vertical que aumenta de secção conforme se eleva. A treliça de madeira do campanário possui tessitura irregular que se afrouxa na medida em que ascende verticalmente. Com esse artifício quase gráfico, Niemeyer enfatiza o sentido de expansão vertical do campanário.

A solução do campanário da Igreja de São Francisco, dada por um volume vertical de planta quadrada revestido por treliça de madeira, já estava presente na Igreja projetada por Lucio Costa para o projeto da Vila Monlevade (1934). No projeto de Costa, o campanário está incorporado a volumetria do templo e alinha-se ao eixo de simetria vertical de sua elevação principal. Na Igreja de São Francisco, Niemeyer separa o campanário do volume da construção. O volume vertical assume a autonomia de um componente dinâmico e ascendente, plena antítese à estabilidade das abóbadas sucessivas que se acomodam no chão em suas extremidades. [420], [421]

A abóbada que protege a nave da Igreja de São Francisco diminui de secção conforme se aproxima do retábulo. A extremidade menor da abóbada da nave abriga-se sob o pequeno trecho da abóbada do altar. Do encontro das extremidades internas de ambas as abóbadas (nave e altar) que se sobrepõem, mas não se tocam, resta uma fresta que banha de luz o retábulo de São Francisco de Assis. [422]

Assim como na Igreja da Ordem Terceira de São Francisco de Assis, projetada por Antônio Francisco Lisboa, o Aleijadinho, em 1766, no exemplar de Oscar Niemeyer a nave é coberta por um forro de madeira em ripa de sentido longitudinal. O revestimento de madeira não avança na abóbada do altar, restringindo-se apenas à cobertura da nave.

O púlpito lateral ao altar, revestido de cerâmica, recebe a pintura em motivo sacro de Portinari e assume destaque na perspectiva do altar que abriga apenas as volumetrias do púlpito e do ambão caracterizado por uma simples bancada sustentada por dois apoios.

Da mesma maneira que no exemplar da Pampulha, os púlpitos em pedra-sabão esculpidos por Aleijadinho também se destacam nas composições barrocas. São saliências em pedra que saltam da parede caiada. Os púlpitos de Aleijadinho registram sua exímia habilidade sobre a técnica da talha em pedra-sabão. As inscrições litúrgicas em alto relevo sobre a superfície irregular

293 | o encontro de 1936: formação 

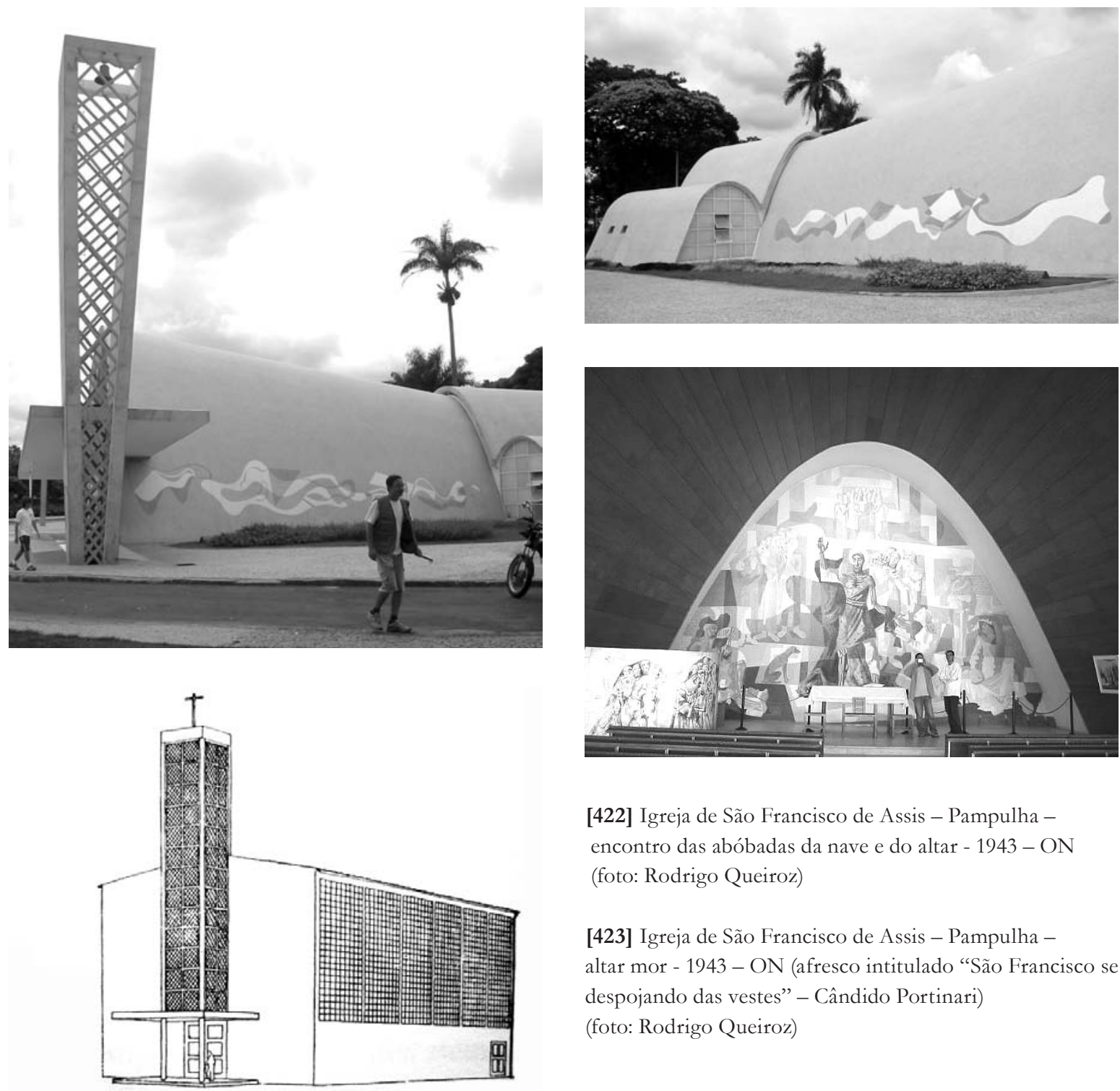

[422] Igreja de São Francisco de Assis - Pampulha encontro das abóbadas da nave e do altar - 1943 - ON (foto: Rodrigo Queiroz)

[423] Igreja de São Francisco de Assis - Pampulha altar mor - 1943 - ON (afresco intitulado "São Francisco se despojando das vestes" - Cândido Portinari) (foto: Rodrigo Queiroz)

[420] Igreja de São Francisco de Assis - Pampulha - campanário - 1943 - ON

(foto: Maria Isabel Imbronito)

[421] Igreja da Vila Monlevade - 1934 - Lucio Costa (COSTA, 1995:96) 
e arqueada do púlpito ${ }^{104}$ demonstram o domínio da técnica da talha.

Ao fundo do altar-mor, Portinari executa mural em têmpera que ocupa toda a parede, intitulado "São Francisco se despojando das vestes". Trata-se de uma versão moderna de um retábulo que perde a efusiva materialidade barroca e se restringe a simples pintura. [423]

Os pequenos altares laterais, presentes nas igrejas barrocas, inexistem no exemplar de Niemeyer. A própria concepção elementar da abóbada que toca o chão, que caracteriza a nave, impossibilitaria o arranjo dos altares laterais. A solução encontrada foi a introdução de dois supedâneos laterais, um de cada lado, que percorrem toda a extensão da nave. Sobre os mesmos, encontram-se dezesseis gravuras de Guignard ${ }^{105}$, fixadas no plano inclinado da abóbada, oito de cada lado da nave, que ilustram a Via Sacra, mesmo tema pintado por Manuel Gonçalves Neves em suas pinturas parietais presentes na Igreja da Ordem Terceira de São Francisco de Assis em Ouro Preto.

Os atributos barrocos, em Niemeyer e Portinari, perdem sua presença material. Não há uma reminiscência sequer das "folhas de acanto" ou das "colunas salomônicas". O diálogo com a arquitetura religiosa do Brasil-Colônia reside na interpretação de seus atributos simbólicos e não de seus elementos ornamentais. [424]

A Igreja da Pampulha, por sua esbeltez gráfico-pictórica, esvazia a alegoria barroca, reduzindo-a a uma peça em casca que abriga composições figurativas e abstratas em suas superfícies exteriores e interiores.

A luz natural que invade a nave é difusa, não atinge com intensidade o forro em madeira. Tanto o brise como a laje do coro impedem que a luz natural invada deliberadamente a nave. Mesmo a luz que chega a nave é delicadamente absorvida pela opacidade da madeira natural que reveste a face inferior da casca. [425]

Por pleno contraste e oposição à retidão da oração do ambiente na nave, o altar é iluminado por uma luz que vem de cima, da fresta entre as abóbadas. A luz indireta que banha o altar é refletida na alvura da face inferior da abóbada. Quem está na nave, olhando em direção ao altar, contempla uma suave coroa de luz que nasce no exato instante em que a nave termina e começa o altar. Trata-se de um arco-cruzeiro imaterial. É apenas luz misteriosa e arrebatadora presente nas igrejas barrocas: se sabe que ela existe, mas não se sabe de onde ela vem. [426]

As autoridades clericais mineiras não veriam com bons olhos a arte moderna como suporte para a fé. Em agosto de 1946, o arcebispo de Belo Horizonte, dom Antônio Santos Cabral recusa-se a consagrar o templo: "armada em sentido inverso, nada representando além de um bom cálculo de engenharia. (...) parece querer perfurar o solo, em busca das trevas...” e quanto às pinturas de Portinari, dom Antônio é mais incisivo:

104. Na planta da Igreja de São Francisco de Assis, observamos dois púlpitos, um de cada lado do altar, porém, apenas o púlpito do lado esquerdo foi executado.

105. (Cf.: COMAS apud CASTRO, 2006:144).

295 o encontro de 1936: formação 

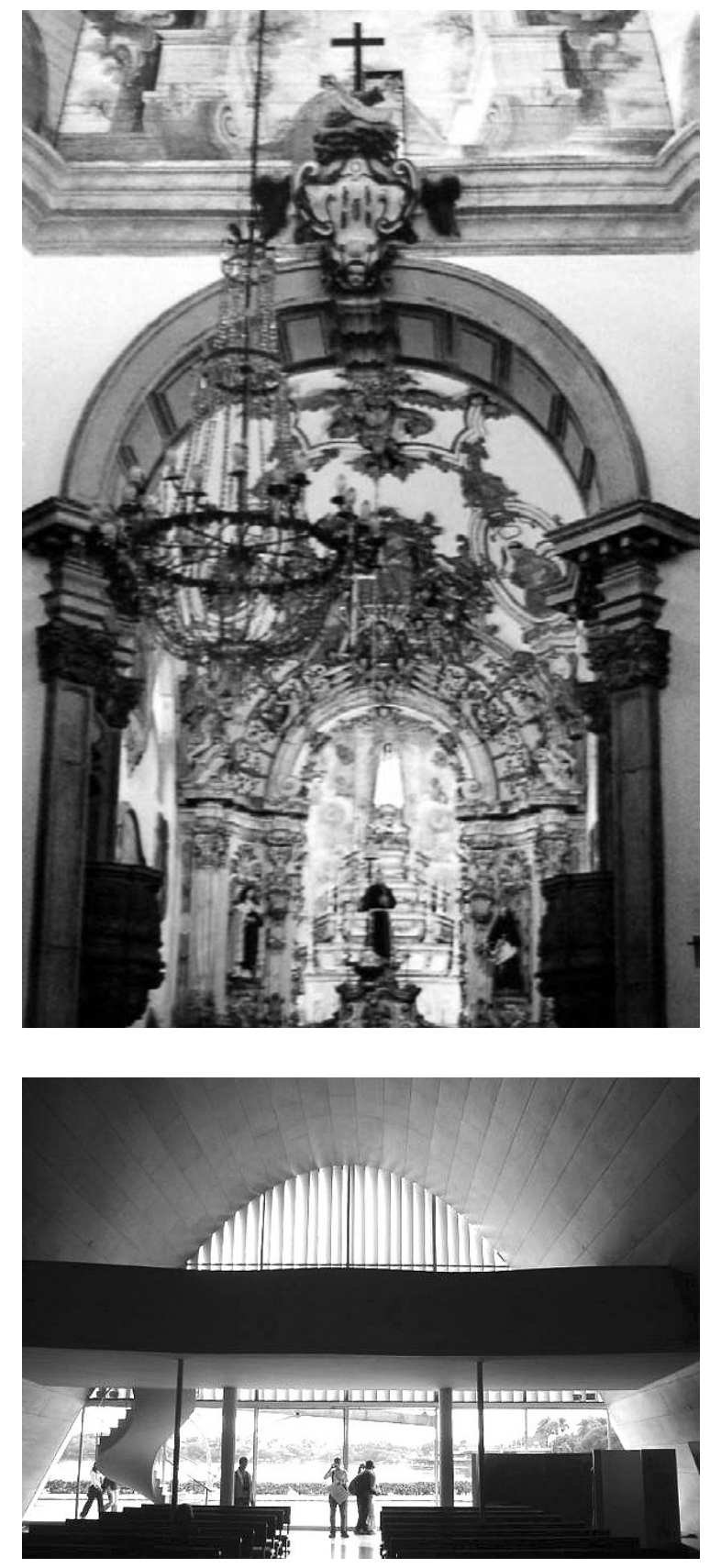

[424] Igreja da Ordem Terceira de São Francisco de Assis - Ouro Preto - vista para o altar-mor - 1766 - Antônio Francisco Lisboa (Aleijadinho)

(foto: Rodrigo Queiroz)

[425] Igreja de São Francisco de Assis - Pampulha - nave - 1943 - ON

(foto: Rodrigo Queiroz)

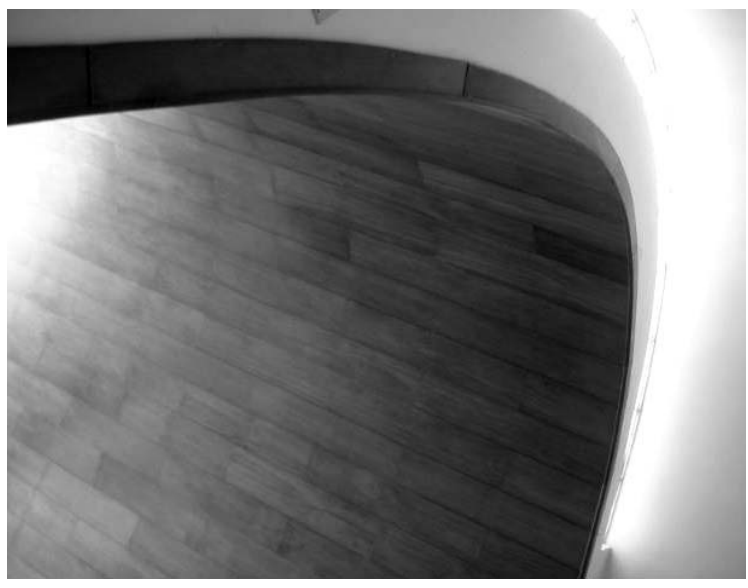

[426] Igreja de São Francisco de Assis - Pampulha - fresta de luz entre as abóbadas da nave e do altar - 1943 - ON (foto: Rodrigo Queiroz) 
Fantasias de artistas. Extravagâncias que podem ficar muito bem nos salões de arte; motivo para estudos, polêmicas e discussões entre artistas, jornalistas e escritores. (...) Mas, para um templo, aquilo não fica bem; não podemos desvirtuar a obra do Senhor nem a igreja é lugar para experiências materialistas, embora artísticas $^{106}$ (DOM ANTONIO apud FABRIS, 2001:187).

Dado o futuro incerto da Igreja de São Francisco de Assis, devido à resistência em consagrá-la, em dezembro de 1947 foi aprovada a proposta de tombamento preventivo do templo, baseada em quatro justificativas:

1. Estado de ruína precoce (...) devido a certos defeitos de construção e ao abandono ao que foi relegado esse edifício pelas as autoridades municipais e eclesiásticas;

2. abandono irresponsável ou utilização, em outras igrejas, de modo inconveniente, porque em desacordo com seu estilo peculiar, de numerosas peças do edifício (altar, órgão, bancos e via-sacra);

3. louvor unânime suscitado pelo conjunto do exterior;

4. valor excepcional do monumento 107

Durante anos acirram-se os conflitos entre diversos grupos divergentes: as autoridades clericais contrárias à consagração; as diversas gestões que passaram por Belo Horizonte, de posicionamento variável; e a opinião pública, favorável ao projeto. Somente em 11 de abril de 1959, a Igreja de São Francisco de Assis da Pampulha é consagrada como templo católico.

Lauro Cavalcanti comenta que a resistência em consagrar a Igreja de São Francisco não impediu seu reconhecimento internacional. Segue trecho do autor:

O arrojo das formas livres da igreja de São Francisco provocou espanto nas autoridades locais e a recusa do arcebispo de Belo Horizonte a consagrá-la. Ainda que fechada durante anos, as curvas harmoniosas e variadas da igreja da Pampulha foram, internacionalmente, ungidas à condição de símbolos da liberdade de criação dos arquitetos, um verdadeiro antídoto contra a mesmice que rondava o funcionalismo arquitetônico ortodoxo (CAVALCANTI 2006:200, grifo nosso).

Pampulha exemplifica o produto sensível de uma mente que considera a liberdade como instrumento fundamental para a ação criadora. Mas talvez, de todos os edifícios do Conjunto da Pampulha, considerando suas individualidades, o único que atinge o sentido de monumento é a Igreja de São Francisco de Assis. A idéia de monumento, definitivamente, não se refere à escala, mas aos significados e aos valores simbólicos e estéticos que conferem ao edifício a condição de obra de arte.

A experiência precursora de Niemeyer traduz com estilemas modernos os atributos litúrgicos de uma construção religiosa típica do período colonial. Ao sintetizar, em forma e superfície, as alegorias e a ambiência do lugar da oração, Niemeyer confere o sentido moderno a um programa ainda pouco explorado pela arquitetura do período.

O exemplo da Igreja da Pampulha não se reduz a mera aplicação moderna dos motivos

106. In FABRIS, Annateresa. Fragmentos Urbanos. p. 187.

107. Idem. p. 188.

297 | o encontro de 1936: formação 
eclesiásticos. Niemeyer, ao interpretar o imaginário barroco, confere a arquitetura moderna o sentido lúdico e simbólico do lugar de fé e oração, que não provém da forma moderna, mas da forma sensivel que se constitui moderna em sua essencialidade, e em sua capacidade de sintetizar, em um único traço contínuo, a tensão do excesso e do êxtase das volutas e contra-volutas do Barroco Mineiro.

Compreendemos que a mensagem contida das curvas da Igreja da Pampulha é oposta daquelas contidas nas curvas de Aleijadinho. Ambos os arquitetos detém o domínio da curva a serviço de uma lógica individual. Enquanto Aleijadinho concebe a curva como instância particular que se multiplica em profusão radiante, Niemeyer age de maneira diametralmente inversa, distendendo em um gesto livre a racionalidade moderna.

Invariavelmente, Niemeyer inicia suas conferências com a indefectível frase: "De modo que minha arquitetura começou em Pampulha". Simultaneamente a verbalização dessas poucas palavras, Niemeyer desfere um movimento contínuo e firme, empunhando a caneta contra o papel preso no cavalete, e arremata dizendo: “(...) e resolvi cobrir a igreja de curvas(...)".

Ao eleger Pampulha como o marco inicial de sua carreira, Niemeyer, de maneira proposital, relega ao esquecimento aqueles projetos realizados durante a segunda metade da década de 1930. Esses projetos representam o seu período de formação profissional, e sintetizam os ensinamentos tanto de Lucio Costa como de Le Corbusier: Ministério da Educação e Saúde e a Universidade do Brasil (1936/1937); a Obra do Berço e a Maternidade (1937); o Grande Hotel de Ouro Preto e o Pavilhão do Brasil em Nova York (1938/1939).

Para Lauro Cavalcanti, na igreja de São Francisco de Assis: “(...) Niemeyer rompe com dois importantes pontos de sua formação anterior: o racionalismo do modernismo corbusiano e a permanente dialética com o passado, propugnada por Lucio Costa." (CAVALCANTI 2006:199).

Quando Niemeyer diz “minha arquitetura começou em Pampulha”, o arquiteto simplesmente não assimila os projetos realizados na segunda metade da década de 1930 como sendo "seus projetos". Colocação, aliás, que faz todo o sentido. Em todas das tentativas que antecedem a experiência da Pampulha, Niemeyer esbarra em fatores externos que condicionam a solução final: os projetos realizados em equipe (MES e Pavilhão do Brasil); os projetos tributários a um corbusianismo ortodoxo (Obra do Berço e Maternidade) e os projetos dirigidos pela incorporação da linguagem da arquitetura tradicional e vernacular (Grande Hotel de Ouro Preto).

Os edifícios do conjunto da Pampulha, principalmente a Igreja de São Francisco de Assis, representam o exato instante em que Niemeyer processa os ensinamentos vinculados a modernidade Le Corbusier e a tradição de Lucio Costa a partir de uma experiência caracterizada pelo seu elevado teor de liberdade presente nas escalas da superfície, da forma e do espaço.

A igreja da Pampulha, obra-prima de Oscar Niemeyer, sintetiza no traço e na matéria o maior desafio enfrentado pela arquitetura moderna brasileira: legitimar seu valor e seu sentido através de um diálogo bi-lateral com a cultura nacional e com a vanguarda, fundindo em um único arranjo construtivo-pictórico essencial, os ideais de tradição e modernidade. 




\section{o encontro de 1947: contra-influência}





\section{Sede da Organização das Nações Unidas em Nova York}

"Muito lidei com Le Corbusier. Só em Nova Iorque, quando trabalhamos no projeto das Nações Unidas, passamos lado a lado vários meses. Conversa diária, almoçamos juntos todos os dias, sentindo suas angústias e esperanças de arquiteto.” (NIEMEYER, 1998:90).

Passados onze anos do projeto para a sede do Ministério da Educação e Saúde e da Universidade do Brasil, em fevereiro de 1947, Oscar Niemeyer reencontra Le Corbusier em Nova York, cidade que, em 1939 já havia acolhido o projeto de Niemeyer e Lucio Costa para o Pavilhão do Brasil em sua Feira Internacional realizada naquele ano.

A incumbência que uniria novamente "mestre" e "discípulo" seria o projeto para a sede da Organização das Nações Unidas.

Termina a II Guerra Mundial e, em junho de 1945, representantes de cinqüenta e um paises instituem a criação de uma nova organização mundial com o objetivo de garantir os interesses de paz e os valores humanitários do planeta. Uma das condições para a implantação dessa organização era que a mesma deveria ser implantada em território norte-americano, dado o reconhecimento da nova geografia política e econômica que se descortinava no pós-guerra.

Várias cidades americanas candidatam-se à sede das nações unidas, tais como São Francisco, Boston e Nova York. Para a escolha do sítio definitivo, organiza-se uma comissão de profissionais de diversas partes do mundo, entre eles Le Corbusier ${ }^{108}$. A dúvida pairava entre a escolha de um terreno implantado em um contexto urbano ou em uma área desocupada, que poderia inclusive servir de base não apenas do projeto de um conjunto de edifícios, mas de uma nova cidade projetada segundo os preceitos da arquitetura e do urbanismo modernos. Até que uma oferta de doação da família Rockefeller de uma imensa propriedade ao norte do estado de Nova York redireciona o foco das escolhas. Apesar do inestimável valor da doação propostas pelos Rockefeller, o arquiteto americano Wallace Harrison aponta para a comissão incumbida da escolha do local (da qual fazia parte Le Corbusier) as qualidades de um generoso terreno situado à margem do East River, no centro da ilha de Manhattan, entre as ruas 42 e 48 . Tratava-se

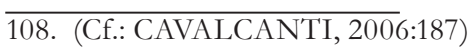

303 o encontro de 1947: contra-influência 
de uma área ocupada por armazéns desocupados e galpões abandonados. Nesse mesmo terreno havia a previsão de se erigir um projeto batizado como "Cidade X", de autoria do próprio Wallace Harrison, onde seriam implantados edifícios de escritórios, complexos comerciais, teatros e conjuntos de habitação. Após as evidências de que realmente estavam diante do terreno ideal para a implantação da sede da ONU, John Davison Rockefeller compra o lote equivalente a cinco quarteirões e, em seguida, doa à ONU.

Em um primeiro momento, não havia sido aventada a hipótese de se realizar um concurso para a sede da ONU. Wallace Harrison tinha como incumbência coordenar um grupo de arquitetos que desenvolveriam o projeto da ONU em conjunto.

Em seu livro Moderno e Brasileiro: A bistória de uma nova linguagem na arquitetura (1930-1960) Lauro Cavalcanti discorre sobre as qualidades que levaram Harrison a assumir a coordenação do projeto da ONU e relaciona os arquitetos convocados para a realização do projeto.

Wallace Harrison foi nomeado para dirigir um grupo de arquitetos que se reuniriam para, juntos, elaborar a sede definitiva. O fato de ser norte-americano, íntimo dos Rockefeller, experiente em coordenar tarefas institucionais como o departamento cultural do OCIAA e a arquitetura da Feira Mundial de 1939, além de já haver projetado para o terreno entre as ruas 42 e 48 East, faziam de Harrison alguém talhado para a tarefa. Dez outros arquitetos forma convocados: Le Corbusier (França), Sven Markelius (Suécia), Howard Robertson (Reino Unido), Liang Ssu-ch'heng (China), Oscar Niemeyer (Brasil), Gustave Brunfaut (Bélgica), Gyle Soulleux (Austrália), Nikolai Bassov (União Soviética), Ernest Cormier (Canadá) e Julio Vilamajo (Uruguai). (CAVALCANTI 2006:189).

Apesar de se tratar de um projeto em "equipe", Wallace Harrison, exigiu que, em uma primeira fase, fossem entregues propostas individuais. Ao término da primeira fase, três trabalhos assumiram nítido papel de destaque: os projetos de Sven Markelius, de Le Corbusier e de Oscar Niemeyer.

As vésperas da apresentação do projeto final de cada um dos participantes, Niemeyer recebe a visita de Le Corbusier no hotel em que estava hospedado. O "mestre" tentava persuadir o "discípulo" a desistir de apresentar sua proposta individual e colaborar no desenvolvimento de sua proposta. O projeto de Niemeyer despontava como a melhor solução para a sede da ONU e Le Corbusier, receoso em assimilar mais uma derrota que, ao que tudo indicava, seria certa, decide convencer o "discípulo" a abrir mão de sua proposta. Só assim Le Corbusier teria alguma chance de ter seu projeto escolhido pela comissão presidida por Wallace Harrison.

Com a ocasional desistência de Niemeyer, Le Corbusier eliminaria um fator que se configurava como um potencial obstáculo na estratégia traçada por ele mesmo para a realização de seu projeto particular para a sede da ONU.

Ao saber da tentativa de Le Corbusier de cooptar Oscar Niemeyer, Harrison é enfático em cobrar de Niemeyer sua proposta individual e anuncia ao arquiteto brasileiro o desejo em adotar a sua proposta como base para o projeto definitivo da sede da ONU.

Segue trecho em que o próprio Oscar Niemeyer descreve os acontecimentos que cercaram o projeto da ONU: 
Em 1947, Wallace Harrison convidou-me para fazer parte da equipe de arquitetos que deveria projetar a sede das Nações Unidas. E no mesmo dia em que cheguei a Nova Iorque, Le Corbusier telefonou para o hotel pedindo que o encontrasse numa esquina da Quinta Avenida.

Fazia muito frio. Solícito, ele me colocou seu capote sobre o meu, dizendo: 'Vou fazer como São Franscisco'.

E, como a casa de Oscar Nitzke ficava perto, caminhamos até lá, ele contando sua história.

Seu projeto começava a ser criticado e ele queria que eu ficasse a seu lado, colaborando no seu trabalho. Aceitei. E durante alguns dias procurei ajudá-lo, quando Wallace Harrison me convocou a seu gabinete: 'Oscar, convidei você para, como todos os outros arquitetos, apresentar seu projeto e não para trabalhar com Le Corbusier'. Avisei a Le Corbusier o ocorrido e ele logo respondeu: 'Você não pode ir, vai criar confusão'. Mas, dias depois, aconselhou-me: 'É melhor você ir. Estão esperando seu projeto'.

Em uma semana elaborei meu estudo. Confesso que não gostava do projeto de Le Corbusier. Penso ter sido feito para outro local, e o bloco da grande Assembléia e dos Conselhos, no centro do terreno, o dividia em dois.

Mantive, no meu projeto, o bloco indispensável das Nações Unidas e separei os Conselhos da grande Assembléia, colocando o primeiro num bloco extenso embaixo, junto ao rio, e ela no extremo do terreno. Tinha criado a Praça das Nações Unidas.

Budainsky, assessor de Le Corbusier, foi o primeiro a vê-lo: 'Você fez melhor que Le Corbusier'. E este, que apareceu em seguida, depois de examiná-lo detidamente, comentou: 'É um projeto elegante!'.

Wallace Harrison convocou-me outra vez: 'Oscar, todos preferem seu projeto, vou propô-lo na próxima reunião'.

Nesse dia, subi no elevador com o arquiteto que representava a China, que me disse: 'Hoje vou ficar ao seu lado'.

Ao iniciar a reunião, Le Corbusier tentou mais uma vez defender o seu projeto: 'Não fiz desenhos bonitos, mas é a solução cientifica de todo o programa das Nações Unidas'. E eu compreendi que ele se referia aos meus desenhos.

A reunião começou, Wallace Harrison propôs o meu projeto, aceito por unanimidade. Todos me cumprimentaram. Até a secretária veio me abraçar. Meu projeto estava escolhido (NIEMEYER, 1998:105-106, grifo nosso).

A proposta de Niemeyer ${ }^{109}$, conhecida como projeto 32, era caracterizada por uma implantação aberta que dispunha todos os componentes do programa na periferia do grande terreno retangular voltado para o East River. O arquiteto preserva desobstruído o lado do terreno defronte a Primeira Avenida, configurando um espaço de chegada dado por uma grande praça que ocupa todo o comprimento do lote. A lâmina mais alta do conjunto (edifício do Secretariado) está alinhada ao limite leste do lote, paralelo a margem do East River. O edifício do Secretariado encontra-se sobreposto a uma plataforma horizontal, cujo comprimento ocupa mais da metade da face leste do lote e avança, em balanço, em direção ao rio. Nos pavimentos inferiores desse embasamento horizontal estão abrigados os salões de conferência e as Câmaras do Conselho da ONU, no último pavimento encontram-se os salões de exposições, na cobertura, o arquiteto desenha um restaurante abrigado sob laje de contorno recortado e voltado para um generoso terraço voltado inteiramente para o East River. [427]

Paralelo ao conjunto formado pelo edifício do Secretariado e seu embasamento (Confe-

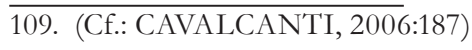

305 o encontro de 1947: contra-influência 

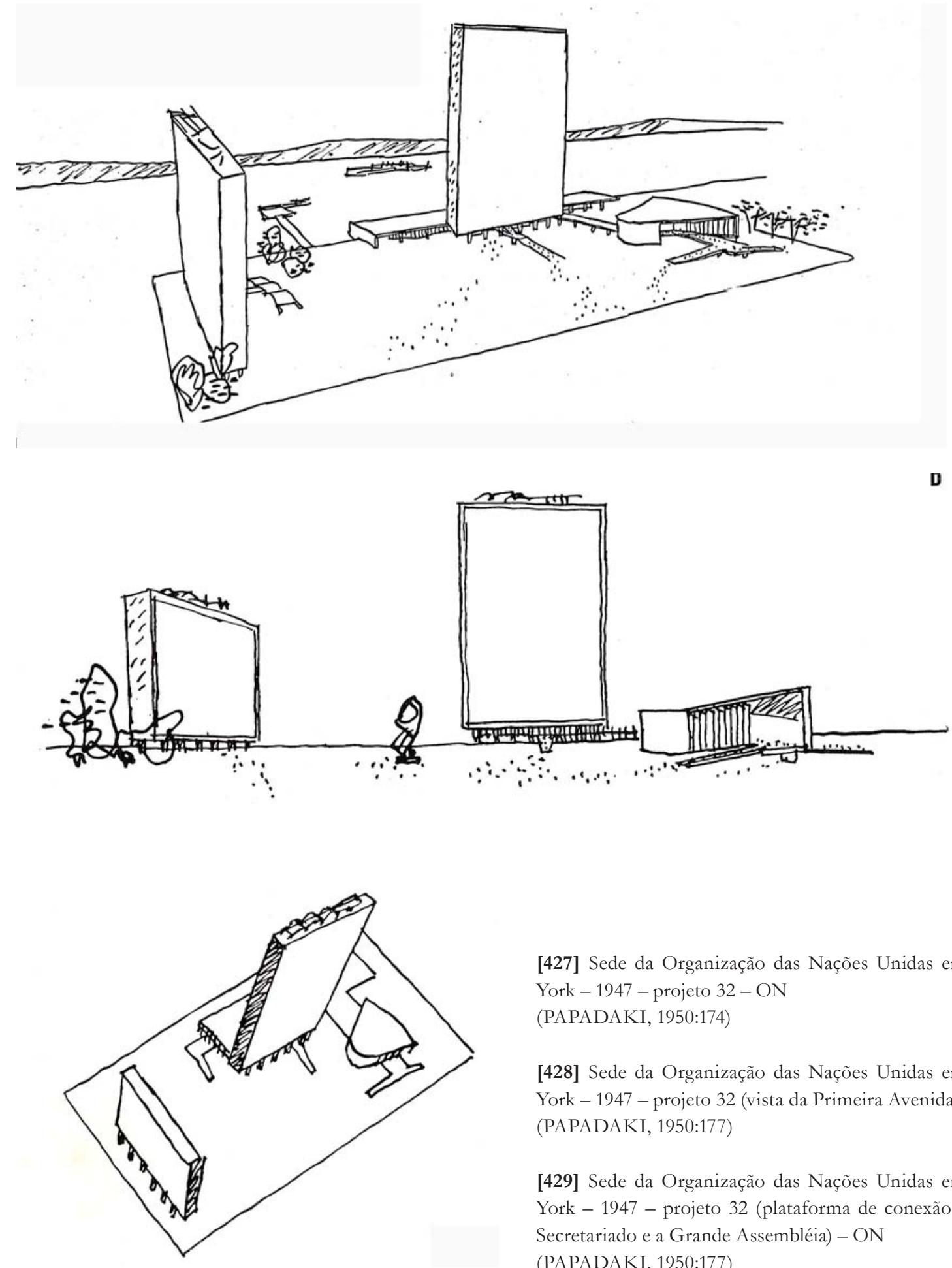

[427] Sede da Organização das Nações Unidas em Nova York - 1947 - projeto 32 - ON

(PAPADAKI, 1950:174)

[428] Sede da Organização das Nações Unidas em Nova York - 1947 - projeto 32 (vista da Primeira Avenida) - ON (PAPADAKI, 1950:177)

[429] Sede da Organização das Nações Unidas em Nova York - 1947 - projeto 32 (plataforma de conexão entre o Secretariado e a Grande Assembléia) - ON (PAPADAKI, 1950:177) 
rência, Conselho, exposições e restaurante) e alinhado ao limite sul do terreno, encontra-se a Grande Assembléia, volume de matriz trapezoidal conectado por passarela coberta ao volumeplataforma paralelo ao Rio. Na face da Grande Assembléia voltada para a Primeira Avenida, estão localizadas duas rampas gêmeas (alinhadas a passarela coberta do lado oposto) que levam até a grande praça central. [428], [429]

$\mathrm{Na}$ face norte do terreno, paralelo à Rua 48, em frente a Grande Assembléia e perpendicular ao conjunto do Secretariado, está implantado o Pavilhão das Delegações que preserva as dimensões em planta do edifício do Secretariado, porém apresenta altura que ultrapassa em poucos metros a metade da altura do edifício do Secretariado. [430]

No projeto 32, estão presentes as soluções formais que já vinha sido manipuladas por Niemeyer desde Pampulha e que seriam adotadas pelo arquiteto nos projetos realizados nos primeiros anos da década de 1950. As abóbadas sucessivas sobrepostas a apoios inclinados se encontram não apenas nas coberturas das lâminas maiores (Grande Assembléia e Pavilhão das Delegações) como estão implantadas sobre a própria praça, demarcando o acesso para o Pavilhão das Delegações. As rampas gêmeas que ascendem ao foyer da Grande Assembléia lembram as ruas elevadas propostas pelo arquiteto para o Teatro Municipal de Belo Horizonte (1943). O contorno trapezoidal em arcos côncavos da Grande Assembléia retoma a solução adotada por Niemeyer para o auditório do Pavilhão do Brasil da Feira Internacional sediada nessa mesma cidade oito anos antes.

O conjunto formado pelo bloco retangular sobreposto ao volume-plataforma horizontal seria retomado por Niemeyer em projetos como o Conjunto JK em Belo Horizonte (1953).

A proposta de Niemeyer para a sede da ONU sintetiza uma organização das formas no espaço que assimila a idéia de unidade arquitetônica a partir de um arranjo onde o vazio é o componente articulador que possibilita a percepção do projeto como um conjunto nitidamente hierarquizado pelos diferentes gradientes de expressão que caracterizam cada um dos edifícios.

Para Niemeyer, o vazio é a instância fundamental para que os seus conjuntos arquitetônicos sejam apreendidos de maneira integral, desfragmentada. Em uma mesma visada é possível a leitura de todo o conjunto. O conceito de unidade reside na possibilidade de se perceber todos os edifícios conjuntamente. Será exatamente esse fator que diferirá as propostas de Niemeyer e de Le Corbusier para a sede da ONU. Enquanto Niemeyer elege o vazio como elemento estruturador do espaço, Le Corbusier escolhe o objeto construído - a grande assembléia - como personagem protagonista do conjunto.

As diferentes propostas de Niemeyer e Le Corbusier para a sede a ONU não representam apenas dois projetos de características distintas, mas sintetizam as divergentes concepções de espaço e conjunto presentes no raciocínio de ambos os arquitetos.

De todos os arquitetos encarregados de elaborar o plano para a sede da ONU, Le Corbusier foi o primeiro a chegar a Nova York, e com mais de um mês de antecedência. Em 25 de janeiro de 1947, o arquiteto inicia seus trabalhos no $21^{\circ}$ andar do edifício RKO em Nova York. Tratava-se um grande estúdio de projeto montado por Wallace Harrison para receber

307 | o encontro de 1947: contra-influência 



[430] Sede da Organização das Nações Unidas em Nova York - 1947 - projeto 32 - maquete - ON (PAPADAKI, 1950:181)

[431] Sede da Organização das Nações Unidas em Nova York - 1947 - projeto 23 (vista do East River) - LC (BOESIGER, 1953:52)

[432] Sede da Organização das Nações Unidas em Nova York - 1947 - projeto 23 (intersecção entre o volume retangular das Comissões e o volume trapezoidal da Grande Assembléia) - LC (BOESIGER, 1953:53) 
os arquitetos integrantes da "equipe" que elaboraria o plano para a sede da Organização das Nações Unidas.

Os volumes separados que caracterizam a proposta de Le Corbusier coincidem com a versão apresentada por Niemeyer: a torre retangular do Secretariado; o volume trapezoidal da Grande Assembléia; o volume baixo que abriga as Comissões; e a lâmina retangular de menor altura, separada do conjunto principal que abriga as "agências especiais".

As semelhanças entre as propostas de Le Corbusier e Niemeyer não residem apenas na natureza formal dos objetos e nos programas que abrigam. Na proposta de Le Corbusier, assim como na de Niemeyer, a torre do Secretariado encontra-se alinhada a margem do East River, deslocada à direita de quem chega a praça pela Primeira Avenida. O edifício das "agências especiais", na proposta de Le Corbusier, possui a mesma disposição no espaço e a mesma solução formal adotada por Niemeyer: implantada na porção lateral esquerda da praça, paralelo a $48^{a}$ avenida. [431]

O ponto de discordância entre as propostas de Le Corbusier e Oscar Niemeyer é o posicionamento do conjunto formado pelo volume baixo das Comissões e o volume trapezoidal da Grande Assembléia. Assim como Niemeyer, Le Corbusier também implanta a Grande Assembléia paralela a torre do Secretariado, porém, diferentemente do arquiteto brasileiro, Le Corbusier desloca o conjunto plataforma-trapézio para o centro do terreno.

Na proposta de Le Corbusier, o volume baixo e retangular das salas de Comissões "abraça” o volume trapezoidal da Grande Assembléia aos moldes da solução adotada pela equipe brasileira na versão definitiva para o projeto do MES (1936), na qual o salão de exposições também intercepta o volume trapezoidal do auditório em sua base menor. [432]

Para Lauro Cavalcanti "Dois problemas pareciam evidentes nessa disposição: a ocupação maciça do solo e a operacionalidade dificultada pelo gigantismo do bloco mais baixo." (CAVALCANTI 2006:190).

É certo que Niemeyer teve acesso a proposta de Le Corbusier antes de dar início a sua proposta individual para a sede da ONU. A ida antecipada de Le Corbusier para Nova York, com mais de um mês de antecedência com relação aos demais arquitetos participantes do projeto, certamente foi providencial para que o arquiteto desenvolvesse com absoluta autonomia um plano para a sede da ONU que, segundo seu desejo, seria adotado como base para os demais arquitetos estrangeirosque, a partir de fevereiro de 1957, desembarcariam em solo norte-americano. A estratégia de Le Corbusier não seria vista com bons olhos por Wallace Harrison, arquiteto organizador do projeto que, a todo instante, declarava que todos os arquitetos estavam ali em condições profissionais idênticas.

Em outro trecho, Lauro Cavalcanti diz que a atitude de Le Corbusier

(...) era a de alguém que acreditava estarem os outros arquitetos participando como auxiliares na definição de seu projeto definitivo. (...) Abrindo os trabalhos em fevereiro de 1947, Harrison fixou o prazo de cinco meses, fez algumas recomendações gerais para a implantação do conjunto e deixou claro que os dez profis-

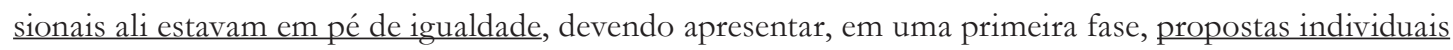

309 o encontro de 1947: contra-influência 


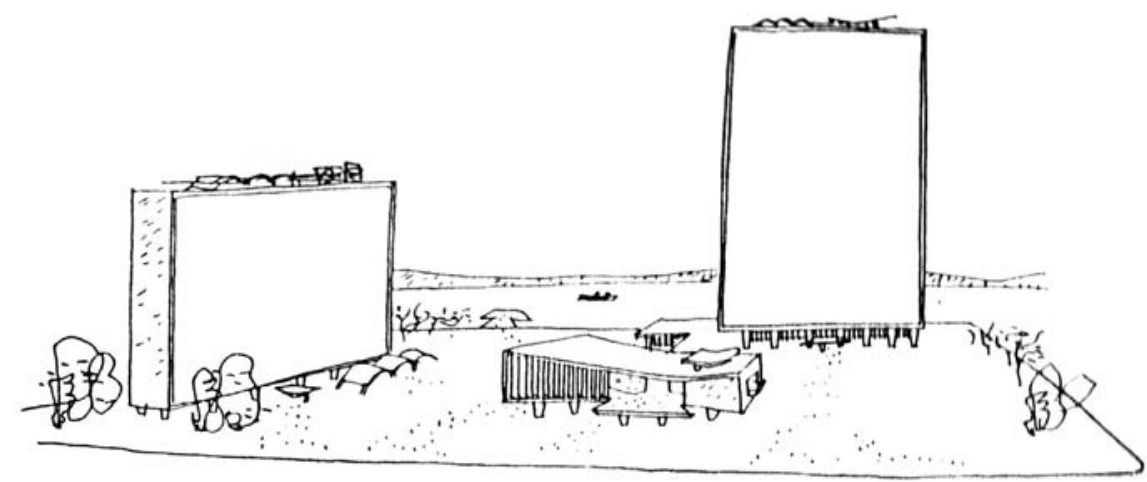

[433] Sede da Organização das Nações Unidas em Nova York - 1947 - projeto 23-32 (o retorno da Grande Assembléia para o centro da Praça das Nações Unidas) - ON e LC

(CORONA, 2001:102) 
(Idem:189, grifo nosso).

Se, no Conjunto da Pampulha (1940-1943), Oscar Niemeyer transgride o modelo corbusiano nas dimensões da superfície e da forma ${ }^{110}$, no projeto para a sede da ONU Niemeyer subverte sua lógica de espaço, justamente no instante em que adota o vazio como instrumento de articulação dos componentes do conjunto.

Na proposta de Le Corbusier, a Praça das Nações Unidas é ocupada por um edifício de grandes proporções que centraliza o foco de atenção de todo o conjunto, ao passo que Niemeyer, ao afastar tanto a plataforma como a Grande Assembléia para as laterais do terreno concebe uma espacialidade aberta que permite a assimilação do projeto como um todo único, como um conjunto. Porém, assim como a proposta de Le Corbusier, a proposta de Niemeyer também é caracterizada por uma relação figura-fundo, na qual o volume trapezoidal da Grande Assembléia assume nítido papel de destaque.

Em que pese as evidentes diferenças entre as propostas de Le Corbusier e de Niemeyer, devemos atentar para o fato de que o arquiteto brasileiro lança mão de um vocabulário formal e de um partido de implantação que se remete diretamente à proposta de Le Corbusier que, como vimos, já estava sendo desenvolvida antes mesmo de Niemeyer desembarcar em Nova York.

No projeto para a sede da ONU, Niemeyer estabelece um enfrentamento das soluções corbusianas com a mesma ambigüidade caracterizada pela reverência e subversão presente nos projetos da sede do MES (1936), do Pavilhão do Brasil (1938) e do Conjunto da Pampulha (1940-1943). Apesar dos projetos citados possuírem características distintas entre si, podemos interpretá-los como conseqüência de um raciocínio único que, nas três escalas (superfície, forma e espaço), potencializa ao extremo a brecha de liberdade poética que Le Corbusier, até então, preservava enclausurada no interior de seus esquemas reguladores, seja na escala do objeto isolado ou na escala do conjunto arquitetônico.

Assim como o Cassino da Pampulha representa o instante em que Niemeyer torna exterior a liberdade que Le Corbusier mantem interiorizada em suas casas puristas, o projeto de Niemeyer para a sede da ONU simboliza o momento em que o arquiteto reordena a organização clássica que caracteriza os conjuntos arquitetônicos de Le Corbusier, como o Palácio Centrosoyus (1928) e o seu projeto para a sede da ONU.

Ao interpretar a solução de Le Corbusier, movendo tanto a plataforma como a Grande Assembléia para as laterais leste e sul respectivamente, Niemeyer não apenas intervém no projeto do "mestre" como inverte sua lógica espacial.

Quando substitui o objeto pelo vazio como componente estruturador do conjunto arquitetônico, Niemeyer rompe com a condição primordial que caracteriza o espaço corbusiano. Ao eliminar o objeto do centro da composição, Niemeyer não apenas desenha o vazio como também sugere a necessidade do afastamento fundamental para a apreensão do conjunto. Em diversos projetos de conjuntos arquitetônicos, como a Universidade de Constantine na Argélia

110. Seja pela adoção das superfícies opacas (pedra apicoada) e vitrificadas (cerâmica pintada), ou pela ruptura do volume cubista que caracteriza os projetos de residência de Le Corbusier da década de 1920.

311 o encontro de 1947: contra-influência 
(1969) e o Memorial da América Latina em São Paulo, Niemeyer incorpora esse senso compositivo arejado lançado em sua proposta para a sede da ONU.

Após o anúncio do projeto de Oscar Niemeyer como proposta-base para o projeto definitivo da ONU, Le Corbusier intervem novamente junto ao arquiteto brasileiro. Dessa vez o "mestre" especularia a possibilidade de realizar um novo projeto em parceria com Oscar Niemeyer. Na verdade, Le Corbusier desejava deslocar o volume trapezoidal da Grande Assembléia novamente para o centro do terreno e, assim, retomar sua proposta original, mesmo que em parceria como o "discípulo".

Segue trecho em que Niemeyer relata esse segundo momento do projeto da ONU:

Mas, na saída [da reunião que definiu o projeto de Niemeyer como o ponto de partida para o projeto definitivo], Le Corbusier pediu-me: 'Quero falar como você, amanhã cedo'.

Atendi-o. O que ele queria era mudar a posição da grande Assembléia, levando-a para o centro do terreno: 'É o elemento hierarquicamente mais importante, e lá é o seu lugar'. Eu não estava de acordo. Liquidaria com a Praça das Nações Unidas, dividindo de novo o terreno.

Mas Le Corbusier insistiu, e tão preocupado me parecia que resolvi aceitar. E juntos apresentamos um novo estudo, o projeto 23-32 (23 era o número de seu projeto e 32 o meu).

Wallace Harrison não gostou da minha decisão. Afinal, tinha me consultado antes.

E os trabalhos prosseguiram. Pequenas modificações foram feitas e, na realidade, o prédio construído corresponde, nos seus volumes e espaços livres, ao projeto 23-32 apresentado.

Mas devo considerá-lo como um trabalho de equipe; nossa tarefa foi apenas definir o partido arquitetônico. $\mathrm{O}$ resto, todos os detalhes, foi elaborado por Wallce Harrison, Abramovitz e seus colaboradores. Esses foram os fatos dos quais participei. Deles, Wallace Harrison e Abramovitz, só lembro correção e amizade.

Quanto a Le Corbusier, nunca comentou, nem falou sobre o projeto 23-32, mas recordo-o muitos anos depois, almoçando em seu apartamento, fitando-me longamente, e afirmando: "Você é generoso".

E senti que, um pouco mais tarde sem dúvida, ele estava lembrando aquela manhã em Nova Iorque, quando, para atendê-lo, deixei de lado meu projeto, já escolhido pela comissão de arquitetos.

Seria natural, diante dos fatos relatados, que guardasse uma certa reserva ao falar de Le Corbusier. Mas isso não ocorreu. Lembro-o, hoje, com o mesmo entusiasmo com que 40 anos atrás fomos recebê-lo no aeroporto. $\mathrm{O}$ arquiteto genial que naquele dia nos parecia descer do céu.

E se, por vezes, exagerou sua ânsia de realizar sua arquitetura, por outro lado, sempre o senti como um ser humano que trazia dentro de si uma mensagem, um canto de beleza que não podia calar. E aceitá-lo e compreendê-lo foi o que sempre procurei fazer (NIEMEYER 1998:106-108, grifo nosso).

No relato acima, Niemeyer descreve a modificação ocorrida em seu projeto após a intervenção sugerida por Le Corbusier que, por sua vez, era fundamentada nos princípios que regeram a proposta inicial do arquiteto franco-suíço. Ao propor a recondução do volume trapezoidal da Grande Assembléia novamente para o centro do terreno, Le Corbusier não apenas desmantela a Praça das Nações Unidas desenhada por Niemeyer, como aniquila com a concepção de espaço arquitetural presente na proposta do jovem arquiteto para a ONU. [433]

Essa passagem do episódio do projeto para a sede da ONU ilustra muito mais do que a simples intervenção do "mestre" sobre o projeto do "discípulo". Ao realinhar a Grande 
Assembléia para o centro do terreno, Le Corbusier demonstra sua absoluta incompreensão com relação as concepções de espaço, de unidade arquitetônica e de conjunto embutidas na proposta de Niemeyer.

Para Ricardo Ohtake,

A discussão é interessante, pois revela como Le Corbusier via a questão da arquitetura limitada em si mesma, ao dar relevância a Assembléia do centro do terreno e dividindo este em dois, ao contrário de Niemeyer que leva em conta a existência da cidade, ao criar uma grande praça, local de encontro e de reunião livre das pessoas e onde a urbe respira. (OHTAKE 2007:26)

Do ponto de vista da seqüência dos fatos, os episódios da Organização das Nações Unidas e do Ministério da Educação e Saúde no Rio de Janeiro possuem algumas semelhanças. Em ambas as ocasiões Le Corbusier descarta a proposta em andamento, formula uma alternativa diferente e convence Niemeyer a abandonar sua proposta original e reiniciar os estudos a partir de uma nova concepção.

A diferença crucial entre as duas situações é que, no MES, Le Corbusier indica para Niemeyer uma nova perspectiva tanto para a forma arquitetônica, como para a sua configuração urbana, enquanto que, na ONU, Le Corbusier não reconhece os avanços apresentados por Niemeyer e retrocede, preferindo a permanência do objeto como centro da organização no sítio ao invés de incorporar a sugestão proposta pelo "discípulo". Nesse exato instante, a relação "mestre/discípulo" se dilui, é equalizada. O sentido do percurso da influência de Le Corbusier sobre Oscar Niemeyer se abranda.

Quando reafirma a importância da Grande Assembléia no centro do terreno, Le Corbusier coloca em prática a mesma estratégia de organização do espaço que resultou na configuração de projetos como o Palácio dos Centrosoyus em Moscou (1928-1929), onde o volume trapezoidal da Grande Assembléia, assim como no caso da ONU, localizado no centro da composição, desenhava-se como o elemento estruturador do espaço.

Ao se contrapor à proposta de Niemeyer, Le Corbusier exterioriza sua predileção pelas concepções que caracterizaram seus "grands travaux" da década de 1920 que, por sua vez, já estavam superadas dentro dos procedimentos de projeto de Oscar Niemeyer.

Se o projeto do Cassino da Pampulha representa o instante em que Niemeyer rompe a estanqueidade da forma regular que caracteriza os exemplares puristas de Le Corbusier, a proposta do arquiteto brasileiro para a sede da ONU sintetiza o momento em que essa mesma intenção de ruptura transporta-se da dimensão da forma para a dimensão do espaço. E será nesse instante que "mestre" e "discípulo", agora em pé de igualdade, apresentam, um ao outro, revelações distintas.

Se por um lado, Le Corbusier reluta em assimilar a nova concepção de espaço presente na proposta de Niemeyer, preferindo a permanência do objeto como instância estruturadora desse espaço, por outro lado, ao ser apresentado pelo próprio arquiteto brasileiro aos seus projetos realizados durante o final da década de 1930 e os primeiros anos da década de 1940, o "mestre"

313 | o encontro de 1947: contra-influência 
não vê apenas a obra de um "discípulo" atento, mas também uma perspectiva para sua própria trajetória pós-1947.

Segundo Kenneth Frampton:

A essa altura é difícil saber que estava influenciando quem. O mesmo pode ser dito sobre suas propostas para a sede da ONU em Nova York em 1947, com o projeto 32 de Niemeyer e o projeto 23 de Le Corbusier equivalendo-se no partido. (...) Pode ser mais correto, entretanto, ver esse período como de mútua e enriquecedora troca entre mestre e discípulo (FRAMPTON apud BRILLEMBOURG, 2004:47, tradução do autor).

A seguir, analisaremos o encontro entre Niemeyer e Le Corbusier em 1947 como um momento de alteração do trânsito da influência "mestre/discípulo", no qual o jovem arquiteto apresenta a Le Corbusier uma obra que, ao extrapolar a contensão do raciocínio purista, encontra um novo nexo entre modernidade e liberdade. 


\section{A Igreja de São Francisco de Assis de Oscar Niemeyer, a Capela em Ronchamp de Le Corbusier e o crustáceo apanhado na praia de Long Island}

\footnotetext{
No meu caderno de croquis eu tenho uma casca de um crustáceo que apanhei na praia de Long Island em 1947. Dessa experiência nasceu a cobertura da capela [de Ronchamp]: duas membranas de concreto armado de seis centímetros.

(...) A concha está implantada sobre as pesadas paredes, porém apoiada sobre colunas embutidas nos fechamentos.

A concha repousará sobre as colunas, mas não toca as paredes, há uma fresta de dez centímetros, entre a concha e a parede, o que permite a entrada de luz, criando um efeito espetacular (LE CORBUSIER, 1960: s.n., grifo nosso).
}

No parágrafo acima, Le Corbusier descreve a circunstância que envolveu os esboços iniciais da capela de Notre-Dame du Haut em Ronchamp na França. Segundo o próprio arquiteto, os primeiros desenhos para o projeto para a capela de Ronchamp foram realizados em Nova York, no período em que, curiosamente, passados onze anos do episódio do MES (1936), Le Corbusier reencontra Oscar Niemeyer por ocasião do projeto para a sede da Organização das Nações Unidas.

Lucio Costa aponta o primeiro encontro entre Niemeyer e Le Corbusier em 1936 no Rio de Janeiro, como o momento da "revelação" do "gênio encubado" do jovem arquiteto brasileiro. Ao interpretar os pressupostos corbusianos presentes nos estudos do "mestre" para o MES, Niemeyer fundamenta uma perspectiva para uma arquitetura que se desenhava, ao mesmo tempo, moderna e brasileira, não apenas no agenciamento das superfícies ligadas a nossa tradição colonial, mas no traçado e na organização de seus componentes formais, que incorporam o vocabulário formal de Le Corbusier a partir de um raciocínio que inverte sua lógica estanque. No MES, Niemeyer configura um novo desenho ao objeto moderno que deixa de ser hierarquizado em si mesmo e assume o seu papel de instante arejado em meio a configuração urbana existente.

Essa "revelação" diagnosticada por Costa no episódio do MES em 1936 só será apresentada e assimilada por Le Corbusier em seu segundo encontro com Niemeyer, em 1947 na cidade de Nova York. Será nessa ocasião que Le Corbusier se defrontará com a obra do "discípulo atento" realizada no período pós-MES.

Certamente, publicações como o periódico L'Architecture d'Aujourd'bui e o livro Brazil Buil-

315 o encontro de 1947: contra-influência 

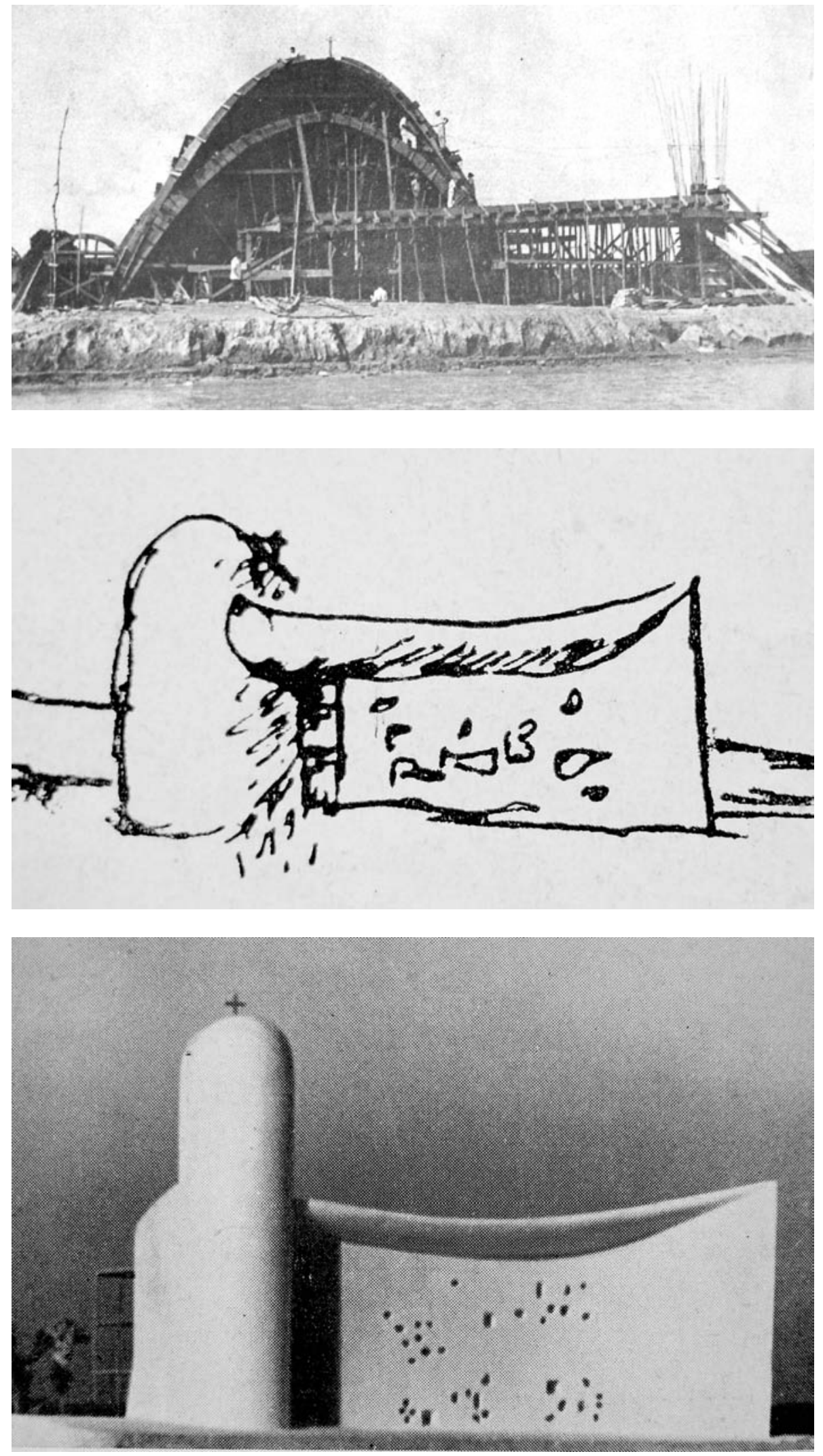

[434] Igreja de São FranciscodeAssis-Pampulha - 1943 - em construção - ON

(GOODWIN, 1944:sn)

[435] Capela de NotreDame du-Haut em Ronchamp - 1947/1953 (estudo inicial) LC

(BOESIGER, 1953:91)

[436] Capela de NotreDame du-Haut em Ronchamp - 1947/1953 (maquete - versão preliminar) LC

(BOESIGER, 1953:91) 
$d s$ (catálogo da exposição itinerante que levou o mesmo nome) organizado por Philip Goodwin, mantiveram Le Corbusier informado sobre as experiências realizadas por Niemeyer posteriores ao projeto do MES. Mas o reencontro de ambos os arquitetos em Nova York para o concurso do projeto da sede da ONU fará com que Le Corbusier seja apresentado, pelo próprio arquiteto brasileiro, àquele projeto que não se configurava apenas como um desdobramento libertador dos cânones corbusianos, mas como a gênese do vocabulário formal de Oscar Niemeyer: o conjunto arquitetônico da Pampulha.

Tanto o livro-catálogo da exposição Brazil Builds: architecture new and old 1652-1942 lançado em 1943 como o primeiro número monográfico da revista L'Architecture d'Aujourd'bui dedicado à arquitetura moderna brasileira, publicado em setembro de $1947^{111}$, não apresentavam na íntegra o conjunto na Pampulha.

No livro Brazil Builds estão presentes apenas os edifícios do Cassino, da Casa de Baile e do Iate Clube e, mesmo assim, apenas o Cassino estava concluído. Nas fotografias da Casa de Baile é possível observar a presença do cimbramento de madeira que sustenta a laje circular que cobre o salão de dança e restaurante, enquanto que, no Iate Clube, os pilares internos ao salão social ainda encontram-se revestidos com uma camada de papelão. Nessa publicação não há qualquer menção, nem textual, nem em imagem, à Igreja de São Francisco de Assis.

Em 1944 é lançado um complemento ao livro-catálogo Brą̧il Builds, dessa vez, dedicado exclusivamente ao conjunto da Pampulha. Essa publicação, editada pela Imprensa Nacional, assim como o livro-catálogo Brazil Builds, foi prefaciada por Phillip Goodwin. Porém, tanto o texto intitulado "Arquitetura" como o memorial que acompanha cada um dos projetos é de autoria de Oscar Niemeyer. Mesmo nessa publicação especial, o conjunto da Pampulha não se apresenta inteiramente completo. A Igreja de São Francisco de Assis é apresentada ainda em fase de execução, com as formas de madeira nas abóbadas e o andaime em frente ao painel de Portinari, ao passo que os demais edifícios do conjunto já estavam devidamente concluídos. [434]

Assim como as duas publicações prefaciadas por Phillip Goodwin, o número monográfico de L'Architecture d'Aujourd'hui lançado em setembro de 1947 também não publica na íntegra o projeto da Igreja de São Francisco de Assis. Há apenas uma fotografia junto ao texto que apresenta a edição.

Niemeyer percebe que o encontro com Le Corbusier em Nova York poderia ser o momento oportuno para apresentar seus projetos ao "mestre", principalmente o conjunto da Pampulha. Devido os hiatos presentes nas publicações americana e francesa, é das mãos do próprio Niemeyer que Le Corbusier será apresentado, através de fotografias, ao conjunto completo dos edifícios da Pampulha, principalmente à Igreja de São Francisco de Assis.

Julio Katinsky, em seu texto Técnica e Arte na obra de Oscar Niemeyer discorre sobre o instante em que Niemeyer apresenta a Le Corbusier as fotografias da Igreja de São Francisco de Assis. Segue trecho do autor:

111. Seja pela adoção das superfícies opacas (pedra apicoada) e vitrificadas (cerâmica pintada), ou pela ruptura do volume cubista que caracteriza os projetos de residência de Le Corbusier da década de 1920.

317 | o encontro de 1947: contra-influência 
(...) E justificou também a construção da igreja como inspirada na estrutura de um caranguejo encontrado na praia de Long Island. Mas a relação de Ronchamp com as igrejas proto-cristãs parece tão artificial quanto a presença barroca na atitude projetual do arquiteto brasileiro, tão exaltada nos anos 50 .

(...) A insistência de Le Corbusier em ligar a cobertura de sua igreja com a estrutura de um caranguejo é por si só reveladora de que ele pensava em uma igreja com uma estrutura especial, justamente quando conheceu, através de fotos, a Capela de Pampulha (KATINSKY 1996:13, grifo nosso).

No trecho acima, Julio Katinsky não apenas revela que Le Corbusier é apresentado ao projeto da Igreja de São Francisco de Assis, através de fotografias, pelas mãos do próprio Niemeyer, como reafirma a explicação de Le Corbusier sobre o "crustáceo apanhado na praia de Long Island" como fonte de inspiração para a "estrutura especial" da Capela de Ronchamp.

Em um de seus textos, Oscar Niemeyer relata o exato momento em que apresenta as fotografias de seus projetos para Le Corbusier em Nova York:

(...) Não sei por quê, lembrei-me de outro encontro que tivemos em 1947 - em Nova York, quando Le Corbusier, examinando fotografias de meus trabalhos, comentou: 'Você faz o barroco com o concreto armado', acrescentando indulgente: 'Mas o faz muito bem' (NIEMEYER apud XAVIER, 2003:248, grifo nosso).

Diagnosticamos no trecho acima que Le Corbusier percebe, nas fotografias apresentadas por Niemeyer, a presença de uma incontestável liberdade plástica e a qualifica como "barroco com o concreto armado", reconhecendo o valor do trabalho do arquiteto brasileiro em um elogio: "Mas o faz muito bem".

O elogio do "mestre" é um primeiro sinal de que Le Corbusier recebe com simpatia o ímpeto de liberdade presente no projeto da Igreja de São Francisco de Assis. Le Corbusier está diante daquela obra que representa o exato instante que o "discípulo atento", ao desvincular-se dos pressupostos do esquema Dom-ino ${ }^{112}$, abre caminho para aquilo que chama de "forma livre".

Em outro texto, Niemeyer descreve o instante em que Le Corbusier, em Nova York, mostra para ele seus primeiros esboços para a Capela de Ronchamp:

Lembro-me, por exemplo, de um episódio passado em Nova Iorque, quando trabalhávamos nos planos do edifício das Nações Unidas. Estudávamos as fachadas do bloco principal e então Le Corbusier chegou com um croqui da marquise [da capela de Ronchamp], figurando uma grande placa de concreto armado, apoiada em monumental cariátide. Mostrou-me o desenho, dizendo, numa espécie de desculpa: 'você vai perdoar esse pequeno pecado mortal'. Era, já nesse tempo, uma reação incontida contra os dogmas arquitetônicos que recusavam como falso tudo que não se ligasse intimamente aos problemas técnicos e funcionais e que a imaginação do artista por vezes custava a suportar. Confesso que recebi a sugestão sem surpresa, pois sempre considerei a arquitetura uma obra de arte e somente

112. Por mais que os edifícios a Pampulha representem sucessivas rupturas e transgressões com relação ao legado purista de Le Corbusier, tanto o Cassino, como a Casa de Baile e o Iate Clube ainda preservam sua filiação corbusiana na utilização das lajes sucessivas, da estrutura independente, dos pilotis de seção circular. Nesses projetos, por mais que seja latente a liberdade na forma e no agenciamento dos espaços, as lições aplicadas por Le Corbusier no esquema Dom-ino ainda são obedecidas, ao passo que na Igreja de São Francisco de Assis a idéia de estrutura reticular e da extrusão vertical planta é sublimada em um conjunto de abóbadas conseqüência de um único gesto.

o encontro de 1947: contra-influência 318 
como tal capaz de subsistir(NIEMEYER, 1998:97-grifo nosso).

No trecho acima, Niemeyer relata o exato momento em que o "mestre" decide experimentar da liberdade do "discípulo" e, ao mostrar a esse "discípulo" a sua audaz incursão na forma livre, pede perdão pelo "pequeno pecado mortal".

Trata-se de um perdão compreensível. Devemos lembrar que todo o vocabulário formal de Niemeyer foi constituído a partir da leitura atenta dos exemplares corbusianos realizados durante a década de 1920, todos eles caracterizados por uma lógica que flertava com o racionalismo purista. No instante em que Le Corbusier apresenta o desenho da "monumental cariátide" da capela de Ronchamp para Niemeyer, o "mestre" se desculpa pela contradição que se descortinava diante dos olhos do "discípulo".

O mesmo arquiteto que, em 1936 no Rio de Janeiro, "como um Moisés, entrega as tábuas da 'modernidade' a Oscar Niemeyer" (CAVALCANTI, 1995:73), passados onze anos, em Nova York, depara-se com as imagens de Pampulha, e compreende que a obra de Niemeyer está longe de ser a simples produção de um "discípulo" atencioso. Ao contrário, formaliza um raciocínio que, mesmo tributário ao vocabulário corbusiano, apresenta um novo contorno para a forma moderna.

O impacto desse encontro com Niemeyer e as imagens de Pampulha transparece nos primeiros esboços para a Capela de Ronchamp que Le Corbusier insiste em associar a casca de um crustáceo apanhado na praia de Long Island.

É um dado significativo a informação de que Le Corbusier apresenta a Niemeyer os primeiros esboços para a Capela de Ronchamp exatamente no mesmo período em que é apresentado, pelo próprio Niemeyer, aos edifícios do conjunto da Pampulha, principalmente à Igreja de São Francisco de Assis.

Ao diluir o raciocínio purista de Le Corbusier, o projeto de Niemeyer para a Igreja de São Francisco de Assis funda uma perspectiva para a arquitetura moderna, com soluções de forma e espaço sem qualquer precedente na obra do "mestre". Sendo assim, Le Corbusier não encara a Igreja da Pampulha apenas como um exemplar que exprime o redesenho transgressor de seus pressupostos mas, principalmente, como uma nova perspectiva para sua própria obra que, justamente a partir do projeto da Capela de Ronchamp, inicia uma incursão no universo do simbólico e do monumental.

Quando Niemeyer percebe nos esboços do "mestre" para a capela de Ronchamp uma tentativa de especular sobre o tema da forma livre, reconhece seu grau de participação nesse evento crucial e inclusive recebe "a sugestão sem surpresa".

A dimensão plástica da obra de Le Corbusier sempre foi um dado que chamou a atenção de Niemeyer, que soube com extrema sensibilidade apoiar-se justamente nessa mesma dimensão plástica para legitimar sua própria obra. Basta lembrarmos do próprio conjunto da Pampulha, onde, no projeto do Cassino, Niemeyer não só extravasa como confere um contorno arejado aos componentes curvilíneos internos à Casa Savoye (1929).

Segundo Kidder-Smith, Oscar Niemeyer não assimila os ensinamentos de Le Corbusier como simples "clichês" versáteis e adaptáveis aos mais diversos projetos. Tratava-se de uma

319 | o encontro de 1947: contra-influência 

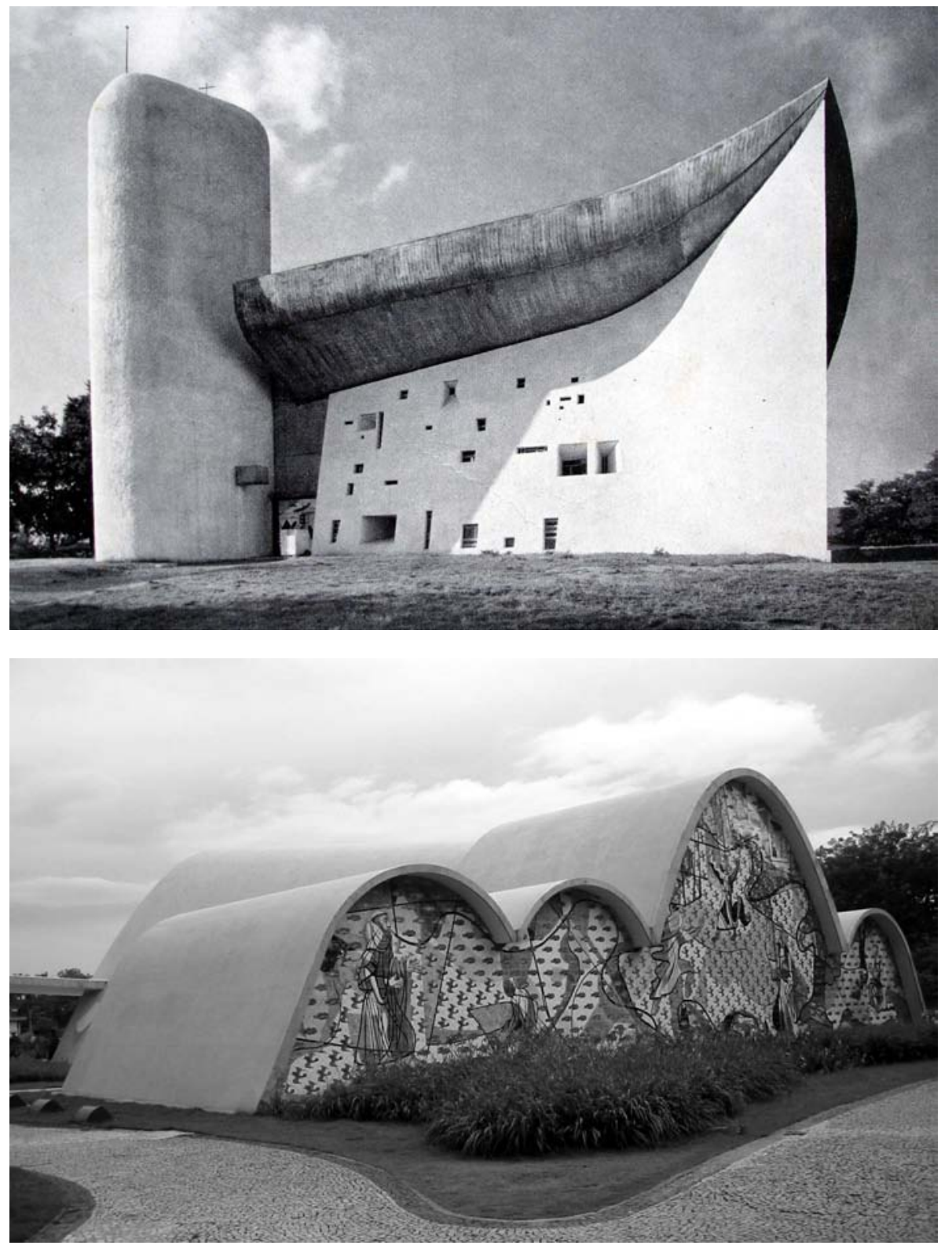

[437] Capela de Notre-Dame du-Haut em Ronchamp - 1947/1953 - LC (BOESIGER, 1957:23)

[438] Igreja de São Francisco de Assis - Pampulha - 1943 - abóbadas sucessivas - ON (foto: Rodrigo Queiroz) 
“inspiração de ideais” e não de meras transposições de soluções formais.

Porém, não se deve crer que ele deixou aos brasileiros um álbum de modelos que eles possam copiar cuidadosamente. A influência de Le Corbusier foi imensa, especialmente em Niemeyer, mas foi uma inspiração de ideais, não de clichês. O produto sempre foi especialmente brasileiro (SMITH 1944, apud TINEM, 2002:62, grifo nosso).

Será justamente esse diálogo que transita na dimensão dos ideais, do desejo, que caracterizará a relação de influência e contra-influência entre Le Corbusier e Oscar Niemeyer.

Assim como Pampulha não representa a simples adoção literal de soluções apregoadas por Le Corbusier, o projeto da Capela de Ronchamp nem de longe se expressa como um redesenho direto da Igreja de São Francisco de Assis. Estamos diante de um diálogo que se estabelece muito mais na dimensão da intenção, do que na dimensão da forma em si.

Em Ronchamp, Le Corbusier interpreta não a forma que caracteriza a Igreja de São Francisco de Assis, mas a intenção e o desejo de liberdade que constitui a experiência de Niemeyer em Pampulha que, por sua vez, adota justamente esse mesmo procedimento de raciocínio ao reinterpretar a dimensão plástica presente nos exemplares puristas de Le Corbusier. Como podemos observar, trata-se de um diálogo onde tanto "mestre" como "discípulo" incorporam a obra "do outro" a partir de uma percepção que não reproduz o modelo alheio, mas assimila sua essência. [435], [436]

A leitura dos fatos ocorridos em 1947 na cidade de Nova York (da apresentação das fotografias da Pampulha aos primeiros esboços de Le Corbusier para a Capela de Ronchamp) fornece algumas pistas sobre uma suposta influência da arquitetura de Oscar Niemeyer na formulação do experimento de Ronchamp. Por outro lado, a Igreja de São Francisco e a Capela de Ronchamp estão longe de possuírem características formais comuns entre si. As semelhanças existem muito mais em uma ambiência religiosa moderna configurada pelas formas curvas que se tangenciam e mal se tocam (sejam as coberturas côncavas de Niemeyer ou a casca convexa de Le Corbusier) do que na forma arquitetônica propriamente dita.

A grande casca curva que se apóia sobre os fechamentos e se projeta para o exterior está presente tanto na Capela de Ronchamp como na Igreja da Pampulha. Porém Le Corbusier conceberá o arranjo entre cobertura e fechamento vertical de maneira diversa daquela presente no projeto de Niemeyer. Em Ronchamp observamos a casca convexa disposta sobre os paramentos curvos, mas apoiada apenas sobre os pilares, mantendo uma fresta entre a parede e a cobertura. $\mathrm{Na}$ Igreja da Pampulha, as sucessivas membranas convexas envolvem todo o conjunto e também se projetam para além dos limites do fechamento. Mas nesse caso a fresta é decorrência do encontro de duas abóbadas. [437], [438]

Em ambos os projetos, observamos uma emancipação da cobertura com relação aos fechamentos e será o desenho dessas coberturas que caracterizará os projetos enquanto imagem.

Ao prever a fresta entre a cobertura e o fechamento, Le Corbusier deseja a mesma luz ritualística presente no projeto de Niemeyer, mas nem por isso os desenhos que originam a luz

321 o encontro de 1947: contra-influência 

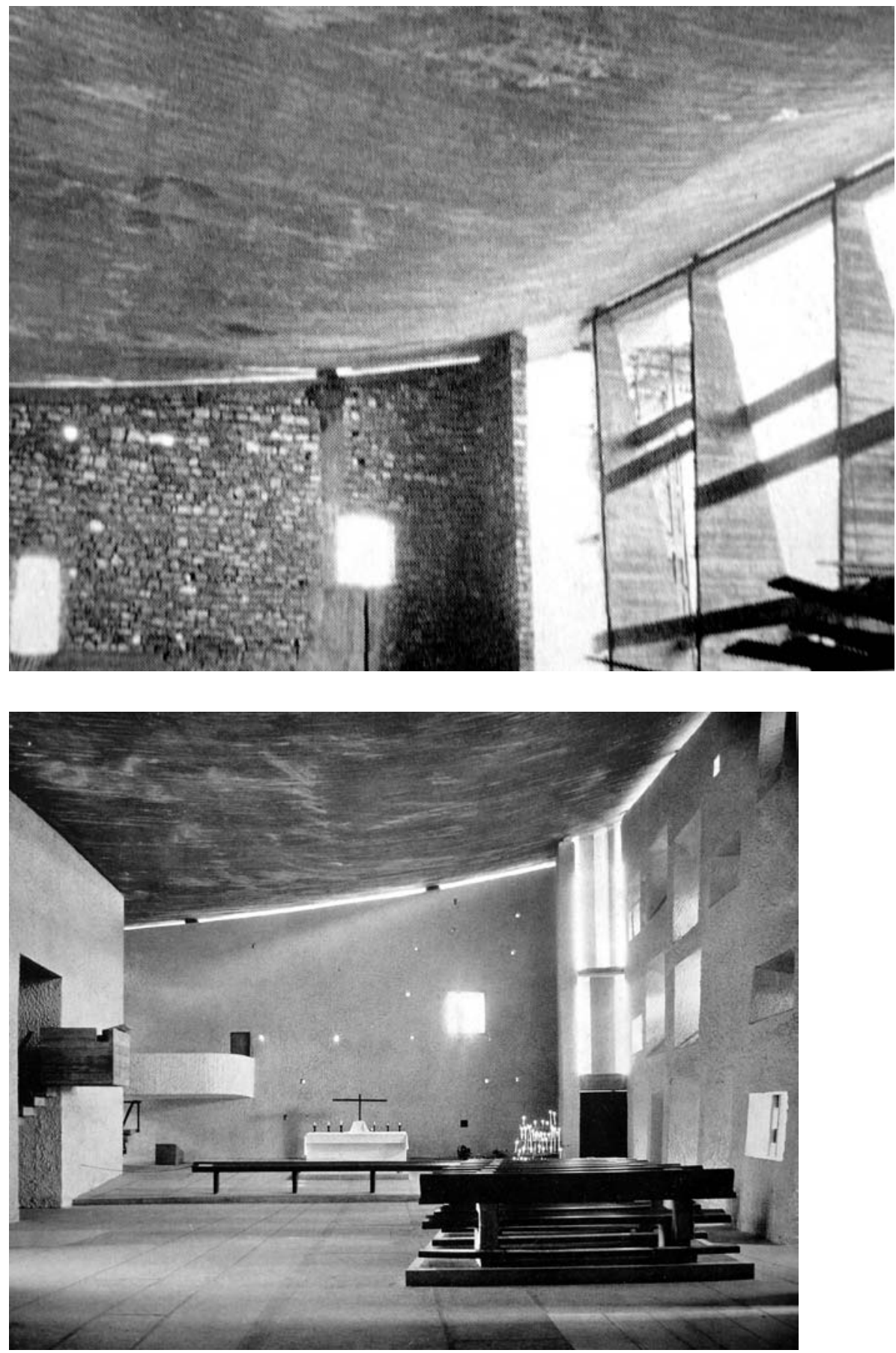

[439] Capela de Notre-Dame du-Haut em Ronchamp - 1947/1953 (interior em construção) - LC (BOESIGER, 1957:38)

[440] Capela de Notre-Dame du-Haut em Ronchamp - 1947/1953 (interior) - LC

(BOESIGER, 1957:33) 
serão semelhantes. A proximidade entre os projetos reside muito mais na intenção do que na forma em si.

Julio Katinsky considera a existência de uma "aproximação possível" entre as luzes que banham os templos de Oscar Niemeyer e Le Corbusier. Segundo o autor

(...) há uma aproximação possível entre a luz indireta, refletida nas capelas de Ronchamp, e a luz que banha o retábulo de São Francisco, também no altar da capela da Pampulha.

(...) É verdade que Le Corbusier justifica a sua solução como uma referência a soluções proto-cristãs. E não podemos deixar de anotar essa aproximação, pois também os barrocos abusaram de luz vinda de locais imaginados, mas nunca perfeitamente entrevistos (KATINSKY 1996:13, grifo nosso).

O efeito da luz indireta que banha as três pequenas capelas de traçado espiral aberto presentes no interior do templo de Le Corbusier é diverso daquele presente na Igreja de Niemeyer. Devemos lembrar que não há um fechamento curvo se quer na Igreja da Pampulha, as únicas ocorrências da curva em planta são percebidas nos elementos interiores: escada helicoidal, recorte curvo da laje do coro, batistério e púlpito, ao passo que em Ronchamp, inversamente, inexistem paramentos regulares, o caráter escultórico é tanto externo como interno. Em ambos os templos a luz se desenha quando encontra a curva, que é parede em Ronchamp e cobertura em Pampulha. [439], [440]

O projeto de Le Corbusier para a Capela em Ronchamp sintetiza a inclinação ao arcaico, ao vernáculo primitivo, de um arquiteto descrente da perspectiva de uma arquitetura que, para afirmarse como moderna, deveria assumir as condições estéticas e técnicas da sociedade industrial.

No projeto para a Capela de Ronchamp, Le Corbusier especula sobre a possibilidade de se estabelecer um diálogo entre os espaços sacros e a sua conduta pautada pelo agenciamento da plástica moderna. A substituição dos elementos e da ambiência religiosa tradicional por uma intenção plástica dinâmica que intenta traduzir a atmosfera litúrgica em um gesto contínuo e curvo aproxima as experiências de Le Corbusier e Oscar Niemeyer.

Entendemos que a proximidade entre a Igreja da Pampulha e a Capela de Ronchamp reside muito mais na intenção plástica do que na suposta semelhança literal entre os elementos formais comuns aos projetos. Ambos os arquitetos possuem um problema comum: desenvolver o projeto de um templo que represente a afirmação da fé de uma comunidade condicionada aos valores religiosos enraizados no lugar e sedimentados com o passar dos séculos: o lugar de meditação dos peregrinos na Borgonha de Le Corbusier e a casa da religiosidade mineira de Niemeyer.

Os pontos em comum presentes nos dois projetos não estão apenas no problema encontrado, mas principalmente na maneira como os arquitetos enfrentam a forma do abrigo que envolve a fé e a concepção do espaço moderno que, nesse instante, promove momentos de oração e contemplação.

A adoção da forma livre é característica comum entre as soluções de Le Corbusier e Oscar Niemeyer, que enfrentam o problema do templo a partir da flexibilização da linguagem moderna que, agora, se presta como invólucro de um programa simbólico, ritualístico, oposto à perspectiva pragmática do funcionalismo utilitário que se formaliza a partir de especulações puristas.

323 o encontro de 1947: contra-influência 


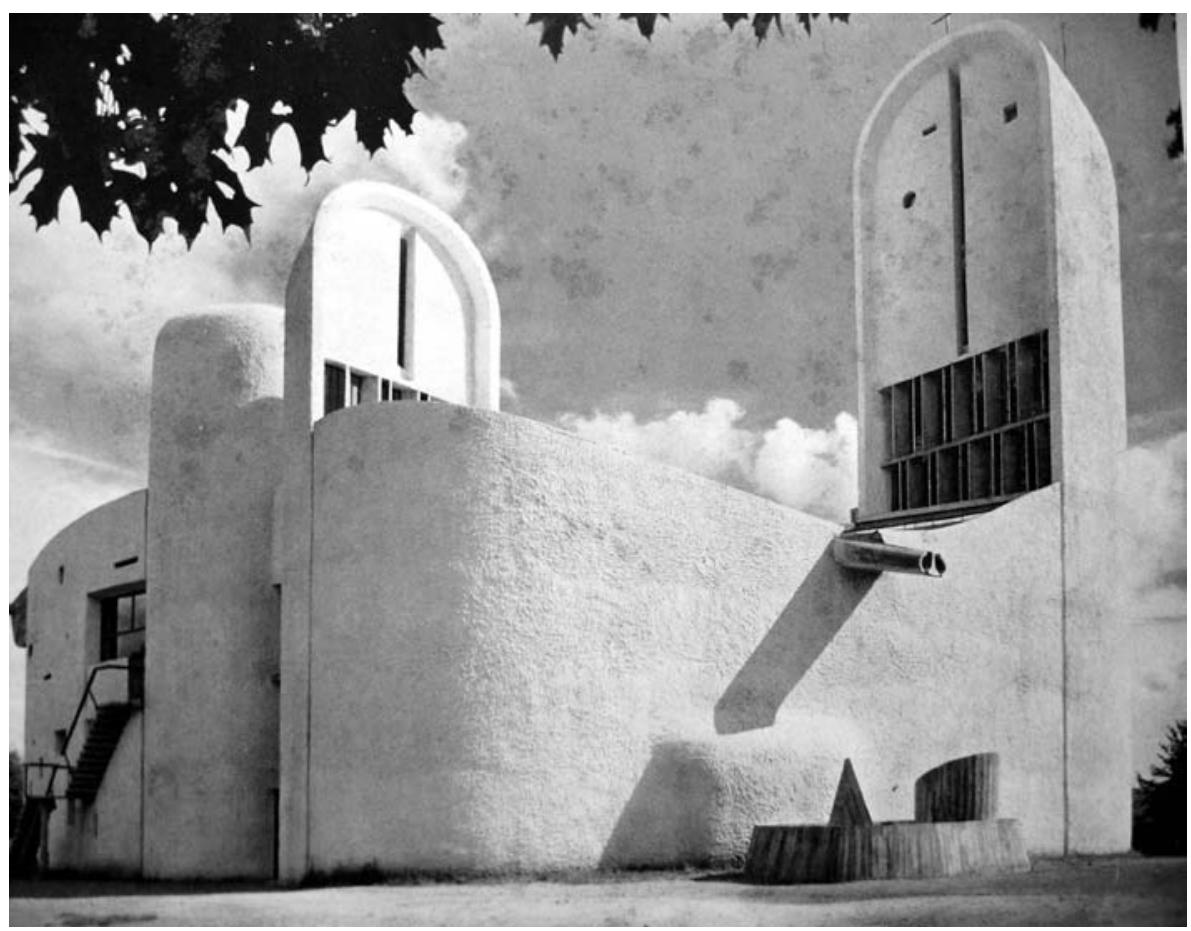

[441] Capela de Notre-Dame du-Haut em Ronchamp - 1947/1953 (fachada oeste) - LC (BOESIGER, 1957:27) 
Dentro das experiências de Le Corbusier onde figuram esquemas organizacionais hierarquizadores da intensidade da linguagem, a Capela de Ronchamp surge como um exemplar que comprova a predileção do arquiteto por soluções expressivas para abrigar programas de dimensão coletiva que evoquem o alimento ao espírito, tais como museus, assembléias e templos. Essa inclinação de Le Corbusier não aproxima apenas a Capela de Ronchamp à Igreja da Pampulha, mas também indica as direções parecidas que tomam as obras de ambos os arquitetos. $\mathrm{Na}$ arquitetura de Niemeyer é possível perceber esse mesmo procedimento: os programas flexíveis assumem a dimensão expressiva e gestual do conjunto, enquanto o programa pragmático e repetitivo, invariavelmente, está abrigado sob contornos regulares.

Quando compara a Capela de Ronchamp às obras puristas de Le Corbusier, Giulio Carlo Argan compreende a gestualidade da capela como um "golpe de força":

A premissa permanece a mesma, a busca de uma relação entre o espaço construído e o ambiente natural; aqui, porém, ela não se resolve com a definição de uma "proporção áurea", e sim com um golpe de força, isto é, tornando o edifício um núcleo plástico duro e compacto, pleno de força expansiva contida, que, no entanto, revela-se na anomalia geométrica da planta, na saída brusca de esporões edificados, no volume em forma de barco na cobertura exageradamente grande, na força dos contrastes de luz (ARGAN, 1993:387388, grifo nosso).

Argan define a Capela de Ronchamp como um "núcleo plástico duro e compacto, pleno de força expansiva contida”. Para o autor, a forma construída, apesar de plástica, se apresenta compacta como uma escultura plena na paisagem. Sólida, mas ao mesmo tempo perfurada por rasgos retangulares e seteiras verticais.

A "força expansiva contida" a que se refere Argan provem justamente desse jogo de opostos entre o enbrutecimento da matéria e da superfície e a maleabilidade de seu contorno: o concreto aparente rústico da cobertura e os fechamentos externos revestidos de uma massa grossa bombeada com mangueira contrastam com as quatro paredes curvas (duas côncavas e duas convexas) que se tocam em apenas um ponto. [441]

As definições de Argan para a Capela de Ronchamp reforçam o distanciamento entre os templos de Le Corbusier e Oscar Niemeyer. Na Igreja da Pampulha inexiste a introspecção presente no "núcleo plástico duro e compacto" de Ronchamp. Ao contrário, a luz em Pampulha é filtrada pelos brises verticais que revestem o trecho encaixilhado que abriga o coro e é absorvida pelo forro de madeira que cobre a nave.

Na Igreja de São Francisco de Assis, a articulação entre os planos verticais de fechamento e a as abóbadas sucessivas que ascendem em diagonal do solo dilui a idéia de volume. É como uma fina espessura que materializa a tensão delicada de um desenho que se implanta na paisagem.

Os templos de Le Corbusier e Oscar Niemeyer representam delicadezas distintas. Le 
Corbusier expressa uma gestualidade embrutecida, estanque e excessivamente movimentada que reverbera aquilo que Kenneth Frampton ${ }^{113}$ chama de "acústica visual” (FRAMPTON 1997:275). Niemeyer concebe um arranjo cuja sintonia entre fechamentos e abóbadas desmaterializa seu próprio volume, seja no sutil avanço das abóbadas com relação aos fechamentos; na esbelta espessura das abóbadas; no uso do pano de vidro nos fechamentos verticais voltados para a Lagoa da Pampulha; e no painel de Portinari pintado sobre cerâmica esmaltada, cuja sutil reflexão realça a opacidade do granito apicoado que reveste as espessuras das abóbadas que desenham um percurso autônomo com relação aos fechamentos.

Os distintos agenciamentos da liberdade presentes na Capela de Ronchamp e na Igreja de Pampulha ilustram os diferentes posicionamentos de Le Corbusier e Oscar Niemeyer com relação aos desenhos da curva e do espaço. A introspecção tectônica de Le Corbusier contrasta com as sutilezas das espessuras aéreas de Niemeyer.

A modelagem da Capela de Ronchamp assume uma condição plástica auto-suficiente que, para atingir a forma e o aspecto desejado pelo arquiteto, preserva a estrutura de concreto armado embebida em uma solução ao mesmo tempo fluida e bruta. Esse diálogo contraditório travado entre a forma e a técnica transparece também em outros projetos tardios de Le Corbusier como os Palácios para Chandigarh, onde mais uma vez a dimensão plástica contradiz o partido estrutural adotado: palácios monumentais e suas gigantescas marquises côncavas, estruturados em retículas de tessituras pequenas.

A liberdade plástica exteriorizada tanto em Ronchamp (1947) como em Chandigarh (1951) ecoa uma sinuosidade em curvas e contra-curvas de amplitude fechada, ao passo que, em Niemeyer, a curva se desenha em um gesto aberto. Tanto as delgadas abóbadas da Igreja de São Francisco como os pilotis parabólicos dos palácios de Brasília representam interpretações suavizadas da plástica corbusiana. Trata-se de um diálogo entre "mestre" e "discípulo" que ocorre em uma via de mão tripla: em um primeiro momento no MES (1936), no Pavilhão do Brasil (1938) e em Pampulha (1940-1943), Niemeyer extravasa a dimensão plástica que Le Corbusier preserva refreada dentro de uma estrutura de raciocínio purista presente nos projetos compreendidos entre a casa Monol (1919) e a casa Savoye (1929). Ao reconhecer na obra do "discípulo" não apenas um redesenho de sua fase purista, mas uma perspectiva para sua própria obra, Le Corbusier especula sobre a forma livre em diferentes intensidades, em projetos como a Capela de Ronchamp (1947/1951), os palácios de Chandigarh (1951), o Carpenter Center em Harvard (1961), o edifício estudantil em Firminy (1956/1963), o Palácio de Estrasburgo (1964) e o Centro Tecnológico da Olivetti em Milão (1963). Alguns projetos, como a própria Capela de Ronchamp e os Palácios de Chandigarh, encontrarão ecos nos edifícios de Niemeyer em Brasília, como nos palácios e nas capelas do Palácio do Alvorada (1956/1957) e de Nossa Senhora de Fátima (1957). ${ }^{114}$

113. (...) as formas crustáceas que compõem o conjunto - o telhado em concha, com sua gárgula gigantesca, as capelas laterais e o altar - estavam precisamente ajustadas de modo a responder à "acústica visual" de uma paisagem ondulante.

114. A análise da influência dos palácios de Chandigarh sobre a arquitetura dos palácios de Brasília encontra-se no capítulo Chandigarh e Brasília.

o encontro de 1947: contra-influência| 326 
Tanto Le Corbusier como Oscar Niemeyer sujeitam essa referência exterior aos procedimentos particulares que garantem a individualidade das obras de ambos os arquitetos.

Quando processa a plástica corbusiana, Niemeyer transgride o raciocínio de matriz cubista presente nas "casas brancas". O arquiteto brasileiro dilui em um movimento sinuoso, aéreo e vazado, aquelas formas estanques e regulares que, para Le Corbusier, se prestavam como suporte para a ação de um raciocínio pictórico que compreende o objeto como uma base suscetível à subtrações e adições das mais diversas, mas que, mesmo assim, não perde o caráter de volume.

Por sua vez, Le Corbusier, quando incorpora a plástica de Niemeyer, não assimila nem a leveza das sutis espessuras que desmaterializam o volume, nem a construção geométrica da curva dada pela concordância entre segmentos de reta e segmentos de arco (característica que confere a precisão ao gesto). O arquiteto franco-suíço absorve a liberdade de Niemeyer, mas a compreende e a formaliza como uma mera conseqüência da ductilidade do concreto, o que resulta em arranjos que exprimem um contorcionismo jamais visto na obra de Niemeyer.

Le Corbusier assimila a liberdade de Niemeyer a partir do vetor de uma plástica meramente escultórica, quase barroca. Por mais que a Capela de Ronchamp represente um momento de ruptura e renovação, Le Corbusier continua fiel a alguns de seus procedimentos estéticos que remontam a sua fase purista. $\mathrm{O}$ arquiteto preserva a idéia do objeto como um volume integral que sofre sucessivas e diferenciadas subtrações, mas que não chegam a intervir em sua identidade volumétrica e visual.

A seguir, abordaremos o projeto de Le Corbusier para a Capela de Ronchamp, não mais como fruto do encontro com Niemeyer em Nova York, mas como um exemplar que fará com que o "discípulo", novamente, volte o olhar sobre a obra do "mestre". 



\section{A capela de Le Corbusier em Ronchamp e os templos de Oscar Niemeyer em Brasília}

Apesar de reconhecer o papel de sua arquitetura nas transformações ocorridas na obra de Le Corbusier a partir do projeto da Capela de Ronchamp, Niemeyer ressalta a importância da Capela de Ronchamp no redirecionamento da obra do "mestre" que, a partir desse instante, inaugurava um "movimento de libertação" que encontra "o equilíbrio indispensável entre forma e função". Segue trecho do texto em que Niemeyer comenta o projeto de Le Corbusier para a Capela de Ronchamp:

A Capela de Ronchamp representa uma nova e decisiva etapa na vida artística de Le Corbusier. É como que um movimento de libertação há muito desejado, e que se afirma agora com o ímpeto criador do seu talento e da sua invulgar personalidade. É, em síntese, a predominância da forma plástica, sugerindo e dirigindo todo o planejamento, a imaginação do artista se expandindo pura e espontânea em busca de beleza e harmonia.

Desta característica decorre precisamente a importância que a Capela de Ronchamp representa na obra do grande arquiteto francês, durante anos disciplinada em princípios arquitetônicos por ele mesmo instituídos e que muitas vezes condicionavam a beleza plástica a conveniências técnico-funcionais. (...)

Pouco a pouco, porém, foi a arquitetura encontrando o equilíbrio indispensável entre forma e função, de maneira a perder o aspecto frio e científico dessa fase fria e transitória para assumir, novamente, as características superiores e eternas da verdadeira obra de arte. E se examinarmos, nesses períodos de evolução, a obra de Le Corbusier, verificaremos que dentro dos conceitos limitadores que cada um estabelecia, nela como em nenhuma outra, se manifesta um desejo latente de maior liberdade de criação e poesia. (...)

Agora, com a Capela de Ronchamp realizada, sabemos que o velho mestre atingiu seu objetivo, e que hoje, mais jovem do que nunca, a todos oferece o poder criador do seu talento e da sua fantasia (NIEMEYER apud CORONA, 2001:50, grifo nosso).

A Capela de Ronchamp não sintetiza apenas um dos instantes em que o "mestre" volta sua atenção sobre a obra do "discípulo". O projeto de Le Corbusier exercerá uma clara influência sobre os projetos de templos realizados por Niemeyer após a experiência em Nova York. Os exemplares mais significativos dessa influência serão os projetos da Capela do Palácio da Alvorada (1956-1957) e da Capela de Nossa Senhora de Fátima (1957), ambos em Brasília.

Em uma capela projetada por Niemeyer em 1955, observamos um claro desdobramento do raciocínio presente em Ronchamp. O projeto consiste do arranjo de duas superfícies verticais

329 o encontro de 1947: contra-influência 

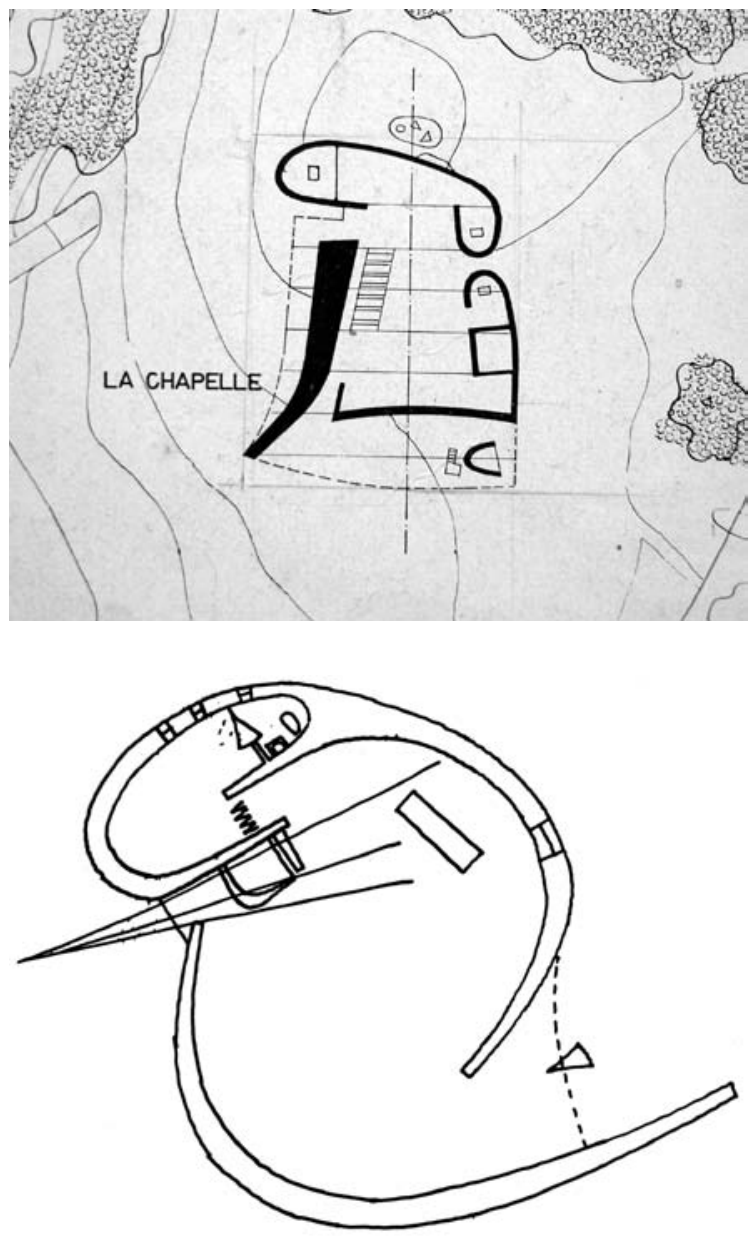

[442] Capela de Notre-Dame du-Haut em Ronchamp planta $(1947 / 1951)$ - LC

(BOESIGER, 1971:258)

[443] Capela - planta (1955) - ON

(PAPADAKI, 1956:117)
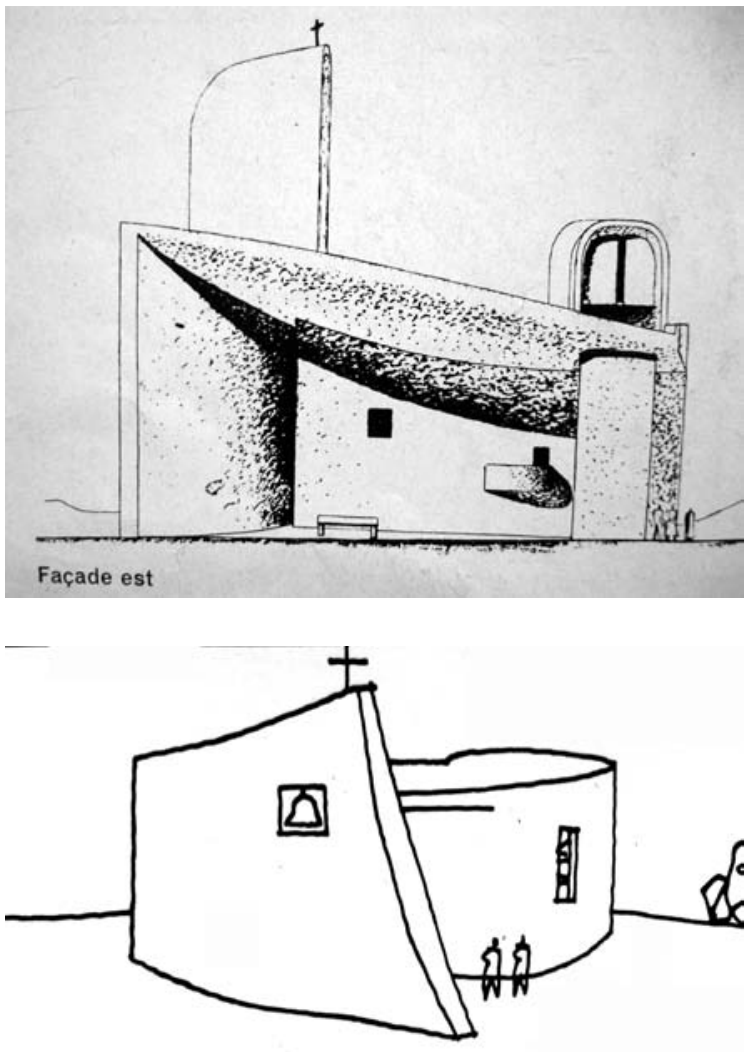

[444] Capela de Notre-Dame du-Haut em Ronchamp fachada leste - versão preliminar (1947/1951) - LC (BOESIGER, 1953:98)

[445] Capela - perspectiva (1955) - ON

(PAPADAKI, 1956:116) 
encurvadas e encaixadas: uma abriga a nave e outra abriga o altar e uma pequena sacristia com banheiro. O tratamento da iluminação natural segue os mesmos princípios expressos por Le Corbusier em Ronchamp: seteira vertical oriunda do encontro dos dois paramentos curvos em caracol que não se tocam e os recortes retangulares sobre a superfície encurvada. [442], [443]

O traçado em caracol aberto da capela de Niemeyer parafraseia as curvaturas ora fechadas, ora abertas presentes na planta da capela de Le Corbusier.

A capela projetada por Niemeyer em 1955, ao mesmo tempo em que se inspira na Capela de Ronchamp, assume uma nítida depuração de seus contornos excessivamente movimentados. Niemeyer assimila a plástica corbusiana - caracterizada quase como uma escultura oca - no desenho em curva fechada da sacristia, que se assemelha às capelas internas de Ronchamp. Por outro lado, a capela de Niemeyer substitui a profusão de curvas e contra-curvas da Capela de Ronchamp por membranas elementares, cujos traçados distendem tanto o gesto como a plástica corbusiana presente em Ronchamp.

A curvatura aberta da capela de Niemeyer ascende em espiral e a espessura dos fechamentos arqueados se afunila na medida em que se aproxima das extremidades. Enquanto Le Corbusier em Ronchamp reafirma sua predileção pelo volume, ao conceber espessas paredes opacas e rústicas, Niemeyer especula a dissolução da massa volumétrica bruta, elaborando fechamentos de traçado aberto que, apesar de curvos, terminam em segmentos de reta nas extremidades.

Ao suprimir a cobertura como um elemento adicional que abriga o volume que parece emergir do chão (procedimento presente em Ronchamp) e reduzir os fechamentos a apenas duas paredes encurvadas, Niemeyer desbasta tanto a plástica como a espacialidade de Ronchamp.

O espaço interno do pequeno templo projetado pelo arquiteto brasileiro é conseqüência da disposição sensível de dois traços curvos que não se tocam. A espiral ascendente, em seu ponto mais alto, contém um pequeno rasgo quadrado que abriga o sino. É o campanário que, na intenção de manter a integridade da forma, não se apresenta como um apêndice (como na Igreja de São Francisco de Assis e na Capela de Ronchamp). Ao contrário, se configura como uma porção vazia da própria forma. [444], [445]

O projeto da capela de 1955 inspirará Niemeyer no projeto da igreja presente no primeiro estudo para o centro cívico de Brasília (1956), realizado antes mesmo do concurso para o Plano Piloto.

Em um trecho da margem do Lago Paranoá onde, futuramente, se instalou o Palácio da Alvorada, Niemeyer elaborou um conjunto arquitetônico que continha o Palácio Governamental, a Residência Presidencial, um hotel e uma igreja.

A igreja presente no primeiro projeto para o centro cívico de Brasília apresenta-se como uma versão depurada e ampliada da capela de 1955. Na igreja de Brasília Niemeyer suprime a curvatura interna que abriga a sacristia e o fechamento em espiral aberta inexiste. O projeto se reduz a apenas duas paredes em forma de "U", uma de frente para a outra, porém, desencontradas.

A supressão da curvatura da sacristia não será a diferença principal entre os dois projetos. O que mais chama a atenção é a diferença de escala. O templo de 1955 se presta ao uso

331 | o encontro de 1947: contra-influência 



[446] Igreja - primeira versão para o Centro Cívico de Brasília - planta (1956) - ON

(Revista Módulo n. 06 dezembro/1956:21)

[447] Igreja - primeira versão para o Centro Cívico de Brasília - maquete (1956) - ON

(Revista Módulo n.06 dezembro/1956:20)
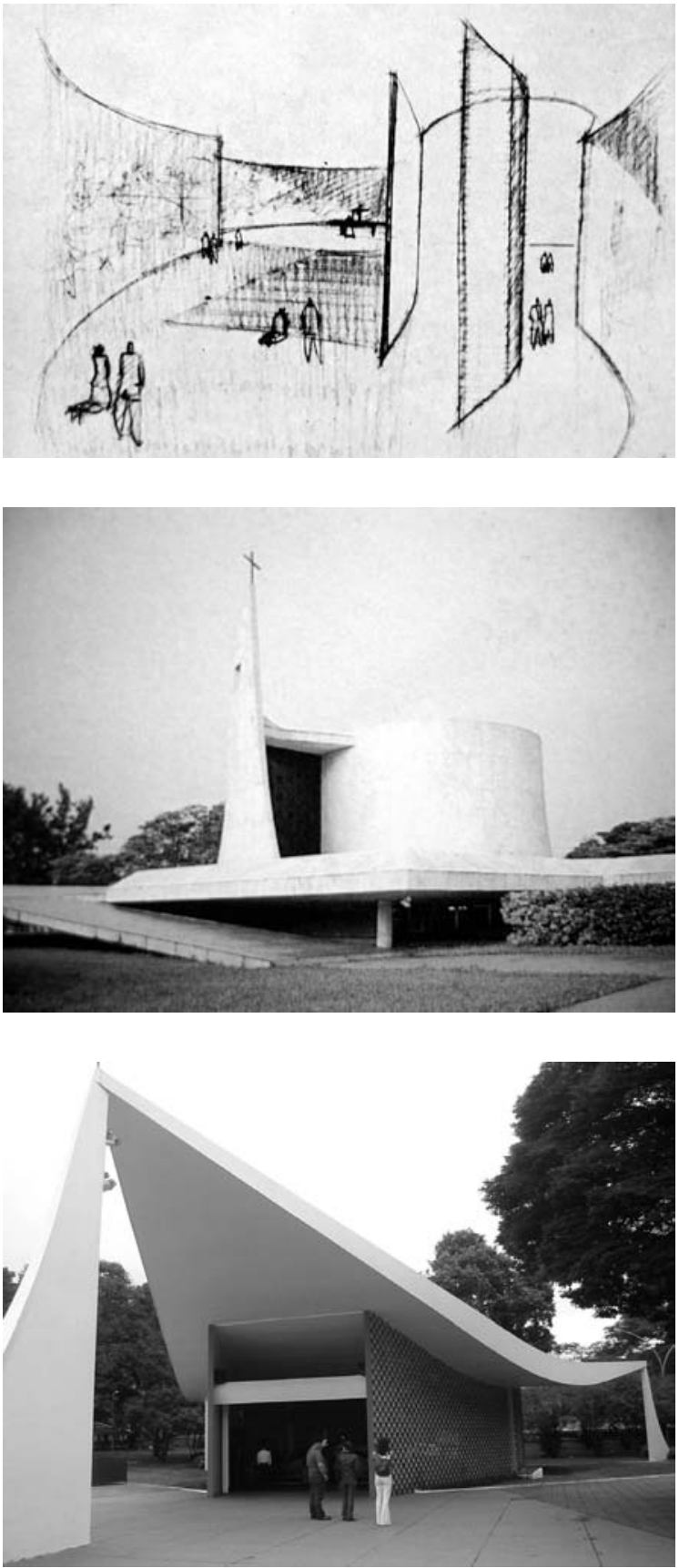

[448] Igreja - primeira versão para o Centro Cívico de Brasília - interior (1956) - ON

(Revista Módulo n.06 dezembro/1956:21)

[449] Capela do Palácio da Alvorada (1957) ON (BOTEY, 1996:163)

[450] Igreja de Nossa Senhora de Fátima - Brasília (1957) ON

(foto: Rodrigo Queiroz) 
de uma capela e possui dimensões inferiores aquelas presentes no projeto da igreja de Brasília. Essa mudança dimensional era inevitável, afinal tratava-se da adequação do projeto de uma capela para o projeto de uma igreja implantada no, até então, centro cívico da nova capital do Brasil. [446], [447], [448]

É sabido que o projeto para o centro cívico de Brasília à margem do Lago Paranoá não foi levado a diante, porém o projeto da igreja (que provém da capela de 1955) será aproveitado e se transformará na capela do Palácio da Alvorada, construído, juntamente com o hotel, na área onde o primeiro projeto de centro cívico havia sido proposto, enquanto o Palácio Governamental transfere-se para a Praça do Três Poderes e recebe o nome de Palácio do Planalto. ${ }^{115}$

No projeto da capela do Palácio da Alvorada, Niemeyer retoma a escala da capela de 1955, porém preserva a planta da igreja presente no primeiro estudo para centro cívico de Brasília.

A imprevisibilidade das curvas da Capela de Ronchamp sintetiza-se sob o traço de Niemeyer que, primeiramente, a abranda no projeto da capela de 1955, torna a simplificar no projeto para a igreja do centro cívico de Brasília próximo ao Lago Paranoá e que, posteriormente, transfere-se, em uma versão sutilmente reduzida, para a lateral esquerda do Palácio da Alvorada. [449]

A composição, ao mesmo tempo orgânica e bruta, elaborada por Le Corbusier em Ronchamp, derivada de espirais abertos e irregulares, encontra nas experiências de Niemeyer algumas variações que sintetizam sua profusão de curvas e contra-curvas.

Assim como o templo de Le Corbusier, os três templos de Niemeyer pós-Ronchamp ${ }^{116}$ são caracterizados por um hiperbolóide que se dilata em seu eixo vertical, no sentido do chão. A pronunciada dilatação do hiperbolóide no momento em que toca o solo reforça a sensação de repouso, de estabilidade.

$\mathrm{Na}$ Capela de Rochamp, Le Corbusier contrapõe o aspecto estático dos fechamentos em caracol, ao adotar uma cobertura de concreto côncava que não se apóia diretamente sobre as paredes, mas repousa sobre os pilares que estruturam as espessas paredes e avançam em poucos centímetros a altura dos fechamentos, configurando uma fresta entre a cobertura conchóide e as paredes do templo.

Tanto no projeto capela de 1955 como na Igreja projetada para o primeiro centro cívico da Capital Federal e na Capela do Palácio da Alvorada, inexiste a cobertura como uma forma sobreposta ao corpo do templo em si (hiperbolóide aberto). Nesses três projetos, Niemeyer incorpora e redesenha apenas a plástica dos fechamentos da Capela de Ronchamp, suprimindo a cobertura como um volume côncavo sobreposto ao corpo da edificação.

No projeto da Igreja de Nossa Senhora de Fátima (1957), Niemeyer lança mão dos dois elementos principais da composição de Le Corbusier em Ronchamp: os paramentos encurvados e a cobertura côncava.

A cobertura côncava triangular da Igreja de Nossa Senhora de Fátima está apoiada em

115. A análise dos projetos dos Palácios de Brasília será realizada no capítulo Chandigarh e Brasilia.

116. A Capela de 1955, a Igreja presente no primeiro projeto do centro cívico de Brasília, e a Capela do Palácio da Alvorada.

333 o encontro de 1947: contra-influência 

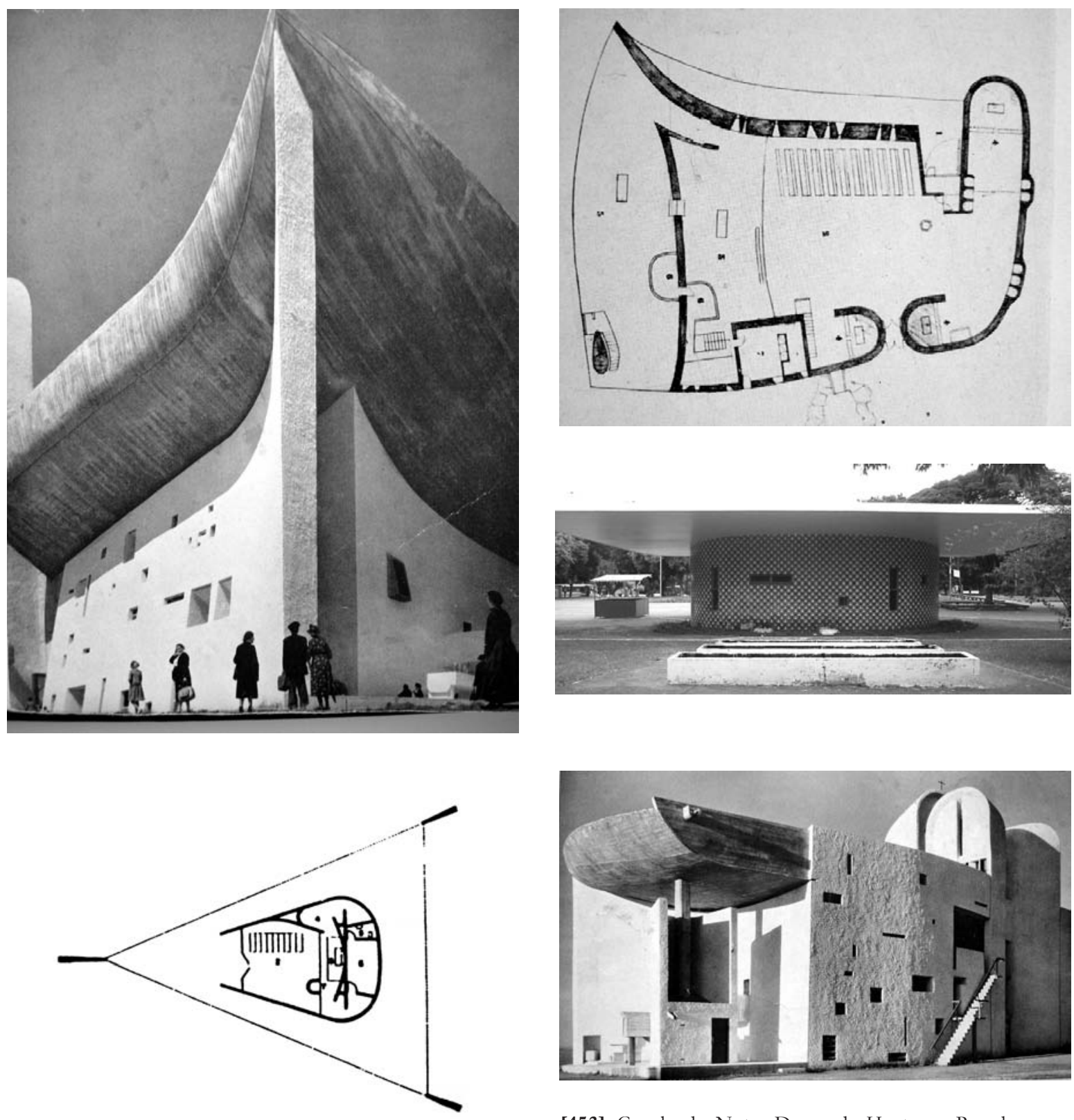

[453] Capela de Notre-Dame du-Haut em Ronchamp planta (1947/1951) - Le Corbusier

(BOESIGER, 1953:92)

[451] Capela de Notre-Dame du-Haut em Ronchamp (1947/1951) - Le Corbusier

(BOESIGER, 1957:24)

[452] Igreja de Nossa Senhora de Fátima - Brasília (1957) planta-ON

(FROLICH, 1982:144)

[454] Igreja de Nossa Senhora de Fátima - fundos - aberturas variadas (1957) ON

(foto: Rodrigo Queiroz)

[455] Capela de Notre-Dame du-Haut em Ronchamp - aberturas variadas - fachada norte (1947/1951) LC (BOESIGER, 1971:259) 
três colunas, uma em cada vértice do triângulo. As colunas alargam-se em curva na medida em que se aproximam do chão, conferindo à composição o mesmo movimento visual presente em Ronchamp: a base que se alastra em direção ao solo é antítese à cobertura côncava que ascende. $\mathrm{Na}$ medida em que se aproxima de seu ponto mais baixo, a cobertura se alarga, artifício que enfatiza a dinâmica plástica do movimento que confere um sentido de leveza a cobertura côncava. [450], [451]

A planta em forma de ferradura, contida sob a projeção da cobertura triangular, abriga a nave, o altar, a sacristia e a secretaria. Assim como na capela de 1955, na Igreja de Nossa Senhora de Fátima, Niemeyer resolve os espaços da sacristia a partir da adoção de segmentos curvos internos, porém concordantes com a curvatura do fechamento exterior do templo. A porta de entrada, recuada com relação às extremidades da "ferradura", configura um nártex, ao mesmo tempo abrigado e aberto para a praça defronte à Igreja. [452], [453]

Assim como na Igreja de São Francisco de Assis na Pampulha, na capela de Nossa Senhora de Fátima Niemeyer estabelece a mesma relação de contraste entre as superfícies: o perfil exterior opaco e alvo e os fechamentos revestidos em cerâmica esmaltada.

Se Portinari colabora com Niemeyer no MES e no Conjunto da Pampulha, Athos Bulcão será seu parpictórico em Brasília. A composição proposta por Athos Bulcão para a Igreja de Nossa Senhora de Fátima será sua única experiência figurativa em Brasília, onde estão representados a Estrela do Divino e a Pomba da Natividade.

A difusa reflexão colorida das cerâmicas estampadas por Athos Bulcão encontra-se abrigada sob a projeção da cobertura triangular côncava. A espessura opaca e branca da cobertura enfatiza a própria imaterialidade, em sutil penumbra, do fechamento externo, cuja sombra reproduz o desenho do perfil exterior da cobertura. Trata-se de uma adaptação do mesmo raciocínio presente da Igreja de São Francisco de Assis na Pampulha, onde o fechamento que recebe o painel de Portinari encontra-se sutilmente recuado com relação as abóbadas sucessivas revestidas de granito apicoado que, assim com a cobertura da Capela de Nossa Senhora de Fátima, destaca-se da superfície revestida de cerâmica sombreada pelo desenho autônomo da cobertura, seja convexa no templo de Belo Horizonte ou côncava no templo de Brasília.

Ao dispor as aberturas na face posterior da igreja de Nossa Senhora de Fátima em uma composição propositalmente ocasional, Niemeyer faz eco à organização movimentada das obstruções retangulares presentes na Capela de Ronchamp. [454], [455]

Para Vincent Scully Jr., a suposta aleatoriedade das aberturas dispersas da Capela de Ronchamp correspondem à própria condição escultórica do edifício.

Mais uma vez, suas janelas dispersas têm de ser como são para permitir que atue como uma força escultural. Se fossem grandes demais, ou alinhadas horizontalmente, indicando andares, ou em painéis verticais, indicando que a parede era uma tela, a sua unidade e escala puramente escultural - portanto o seu poder de ação - se perderiam (SCULLY, 2002:99-100, grifo nosso).

335 | o encontro de 1947: contra-influência 

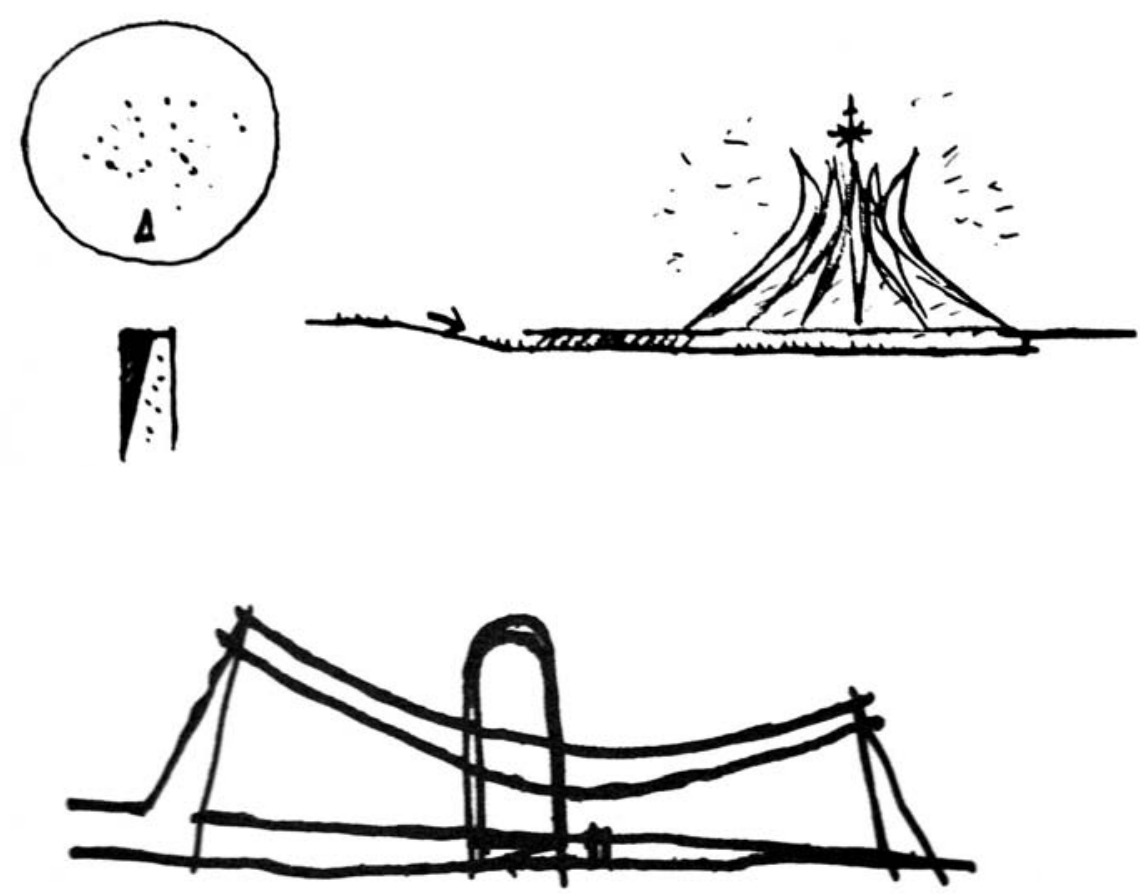

[456] Catedral Metropolitana de Brasília - esboços (1958) - ON (Revista Módulo n.11 dezembro/1958:sn)

[457] Templo Batista no Caminho Niemeyer em Niterói - croqui (1997/2003)

(NIEMEYER, 2004: s. n.) 
Segundo Scully, ao substituir a composição de aberturas organizadas sobre traçados ortogonais, Le Corbusier não assilima a superfície da forma como uma tela, isto é, o arquiteto transcende o raciocínio pictórico que caracterizou as elevações dos projetos tributários aos cinco pontos. No instante em que se liberta desses condicionantes reguladores, a dimensão pictórica da forma pura dá lugar a dimensão escultórica da forma livre.

Podemos situar os projetos dos templos de Niemeyer como um franco diálogo com a experiência de Le Corbusier em Ronchamp. As experiências dos templos de Niemeyer derivados do projeto de Le Corbusier em Ronchamp culminarão no projeto da Catedral de Brasília: um hiperbolóide regular, produto da multiplicação radial de seu perfil exterior.

Para Niemeyer, o perfil hiperbolóide que originalmente caracterizava-se como um redesenho sintético das movimentadas curvaturas presentes na planta de Ronchamp transforma-se em uma solução tipológica para os seus projetos de templos em Brasília.

Porém, o projeto para a Catedral de Brasília não deve ser compreendido apenas como um redesenho sintético dos templos de Niemeyer pós-Ronchamp. O volume hiperbolóide concebido por Le Corbusier para abrigar a Câmara da Assembléia de Chandigarh (1951) ${ }^{117}$ encontrará rebatimento em projetos de Niemeyer como a própria Catedral de Brasília (1958) e o Centro Cultural em Le Havre (1972). [456]

Para Julio Katinsky, a capela de Oscar Niemeyer projetada em 1955 se inspira em Ronchamp, ao passo que a Catedral de Brasília faz eco ao hiperbolóide que abriga a Assembléia em Chandigarh.

Há uma capela projetada por Oscar Niemeyer [a capela de 1955] publicada em "Works in Progress" que parece inspirada em Ronchamp, assim como a Catedral de Brasília, e o teatro no Havre parecem inspirados na Assembléia de Chandigarh (KATINSKY 1996:13).

Do projeto da capela de 1955 ao projeto da Catedral Metropolitana de Brasília (1958), Niemeyer depura os estilemas propostos por Le Corbusier em Ronchamp. Na medida em que os projetos são realizados, Niemeyer se afasta paulatinamente da plástica presente em Ronchamp, mas o referencial corbusiano permanecerá no imaginário do arquiteto brasileiro, como podemos atestar no projeto para o Templo Batista no Caminho Niemeyer em Niterói (2003), onde o arquiteto não apenas revisita a solução da cobertura côncava da Igreja de Nossa Senhora de Fátima como acopla ao volume da nave um campanário vertical de cobertura convexa, aos moldes das capelas verticais que extravazam a cobertura côncava no projeto templo corbusiano.

Esse jogo de contraposição e complementariedade entre a instabilidade dinâmica da cobertura e a serena solidez das capelas verticais que caracteriza a composição exterior em Ronchamp será incorporado por Niemeyer no Templo Batista em Niterói. [457]

A análise desses exemplares de templos pós-Ronchamp projetados por Niemeyer abre uma

117. No capitulo Chandigarh e Brasília, veremos que essa não será a única semelhança entre os projetos dos centros cívicos realizados pelos arquitetos. vide figura 597

337 | o encontro de 1947: contra-influência 
outra perspectiva para a compreensão do posicionamento do arquiteto brasileiro sobre seu referencial corbusiano.

Da mesma maneira que em Pampulha Niemeyer incorpora e redesenha o vocabulário purista presente nos projetos de Le Corbusier da década de 1920, nos templos pós-Ronchamp o "discípulo" se debruça novamente sobre a obra do "mestre". Nesse segundo momento, não caberá ao arquiteto brasileiro extravasar a liberdade estancada no interior das casas brancas de Le Corbusier. Ao contrário, nos templos de Brasília, Niemeyer desbasta a intensidade plástica de Ronchamp.

Se em Pampulha Niemeyer potencializa a vocação expressiva de componentes formais que Le Corbusier preserva enclausurados em um raciocínio de matriz pictórica, nos templos pós-Ronchamp o arquiteto brasileiro assumirá um posicionamento inverso: ao invés de encontrar a liberdade plástica na sintese purista de Le Corbusier, como fez em Pampulha, irá encontrar a sintese na liberdade plástica de Le Corbusier em Ronchamp.

Como vimos, Le Corbusier esboça os primeiros desenhos para a Capela de Ronchamp no mesmo período em que toma contato com os projetos de Niemeyer para os edifícios da Pampulha, mais precisamente a Igreja de São Francisco de Assis. Ao se deparar com a obra do “discípulo atento", Le Corbusier não apenas reconhece nesses exemplares uma interpretação seu período purista, mas vislumbra, na dimensão plástica da obra de Niemeyer, uma perspectiva para sua obra futura.

Niemeyer reconhece sua parcela de importância no feito do "mestre" e, quando adota a Capela de Ronchamp como um referencial de projeto, se coloca na posição de quem corrige os exageros cometidos por aquele que se aventurou no universo da forma livre.

Nos templos pós-Ronchamp, ao abrandar a ginástica escultórica do projeto de Le Corbusier, Niemeyer recupera a precisão do gesto presente em sua própria arquitetura. Isto é, o arquiteto brasileiro ajusta a liberdade corbusiana aos seus próprios parâmetros através de um nítido processo de reconversão.

Nesses projetos, Niemeyer não interpreta o referencial corbusiano dos cinco-pontos ou do Esquema Dom-ino. Ao contrário, como quem vê sua própria imagem distorcida no espelho, Niemeyer executa o redesenho de uma obra do mestre que faz eco à sua própria arquitetura. 


\section{Os projetos de Le Corbusier e Oscar Niemeyer para os padres Dominicanos em Sainte-Baume}

No ano de 1948, Le Corbusier realiza os projetos de uma basílica, de um hotel e de uma cidade permanente em Sainte-Baume, região montanhosa onde acredita-se que viveu Maria Madalena, tendo chegado a essa região vinda da Palestina em uma pequena embarcação. Reza a lenda que todas as manhãs anjos carregavam Maria Madalena até o cume da montanha (Le Pilon) que possui duzentos metros de altura.

A lenda fez de Sainte-Baume um lugar sagrado que passou a ser guardado pelos Dominicanos, onde se encontra a Basílica de São Maximiliano, que abriga o crânio de Maria Madalena em uma urna de ouro.

Le Corbusier recebe o convite para o projeto em Sainte-Baume de seu amigo Eduard Trouin, que possuía uma grande porção de terra infértil na região e queria encontrar um meio de resguardar a paisagem de Sainte-Baume da especulação imobiliária.

A partir de um croqui do próprio Edward Trouin, um geômetra e admirador da arquitetura e da construção, Le Corbusier concebe a Basilica da Paz e do Perdão como uma arquitetura invisivel, incrustada na montanha. [458], [459]

O projeto consiste de um túnel que invade o maciço rochoso do Le Pilon em rampa ascendente e se abre em um espaço de meditação e recolhimento iluminado por uma perfuração oriunda da continuidade do túnel em rampa. Com essa solução, Le Corbusier faz uma alusão direta à caverna onde Maria Madalena viveu.

Além da Basílica abrigada no interior da montanha, o projeto de Le Corbusier para SainteBaume comtemplava um conjunto de habitações implantadas na Cidade Permanente e um hotel.

As residências agrupadas propostas por Le Corbusier para a Cidade Permanente em SainteBaume faziam eco aos seus projetos de habitações de matriz vernacular, como as casas Errazuris (1930), Mme. Mandrot (1932), Mathes (1935) e La Celle Saint Cloud (1935).

No projeto para Sainte-Baume, Le Corbusier elabora um conjunto de habitações enfileiradas sem recuos laterais, com gabarito variável entre dois e três pavimentos. Cada lote possui desenho retangular, sendo que sua largura reduzida está voltada para a frente do terreno. Devido a pouca largura dos lotes, mesmo as unidades com dois pavimentos possuem nítida proporção

339 | o encontro de 1947: contra-influência 

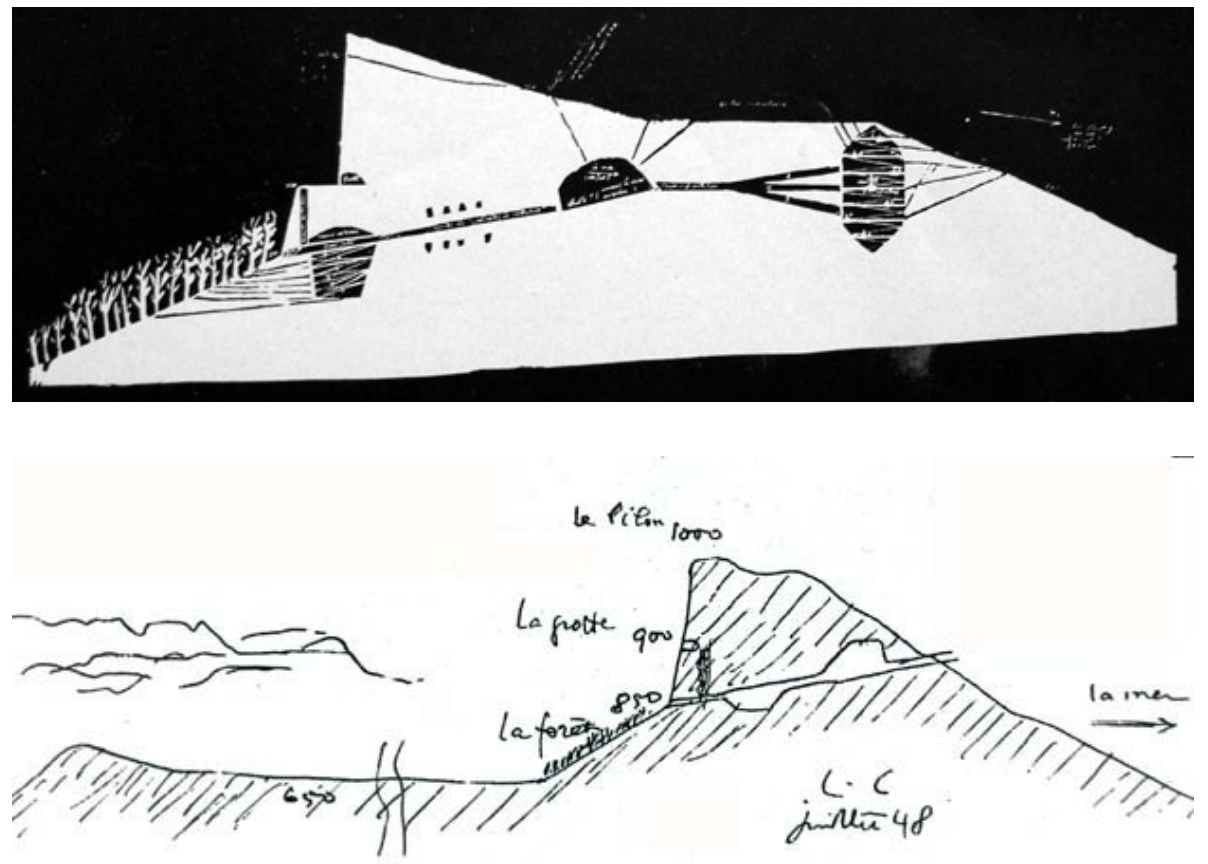

[458] Basílica de SainteBaume - corte no mon-

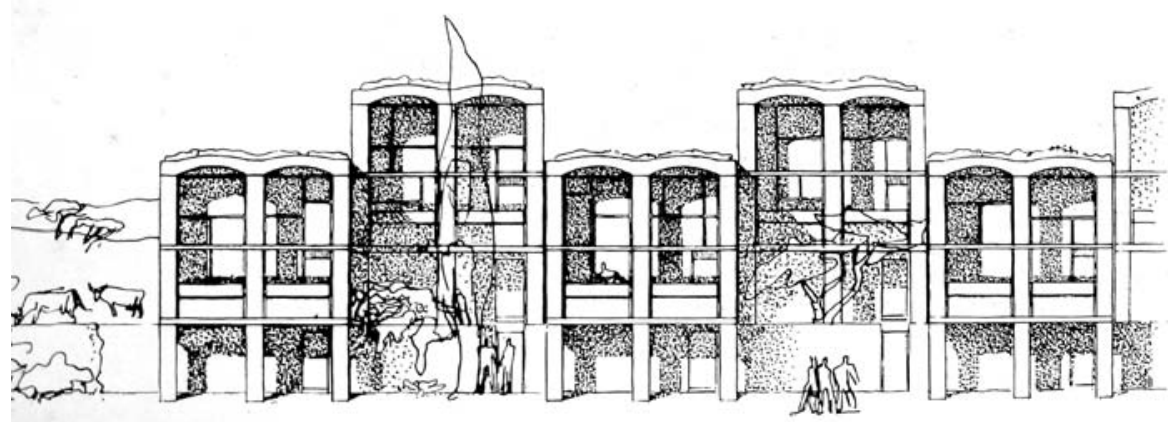
te Le Pilon - projeto de Edward Trouin (1948) (BOESIGER, 1953:29)

[459] Brasílica de SainteBaume - corte no monte Le Pilon (1948) LC (BOESIGER, 1953:30)

[460] conjunto de habitações da Cidade Permanente em SainteBaume- elevação (1948) LC

(BOESIGER, 1953:33)

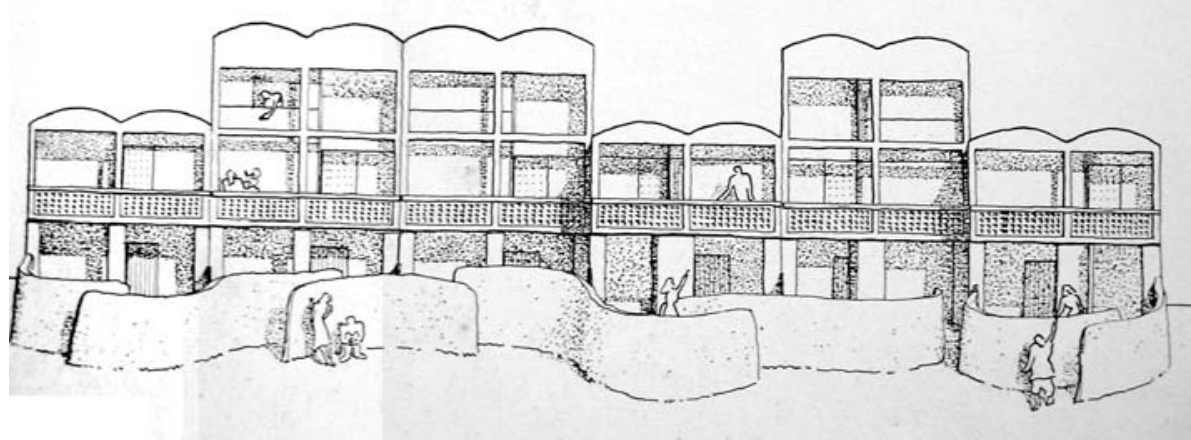

[461] conjunto de habitações da Cidade Permanente em SainteBaume- projeto para a primeira etapa da construção - elevação (1948) LC

(BOESIGER, 1953:36) 
vertical. As paredes laterais são construídas com a técnica da taipa de pilão com uma mistura de terra e palha. A cobertura consiste de uma abóbada abatida apoiada diretamente sobre os fechamentos, aos moldes da casa de fim-de-semana em La Celle Saint Cloud (1935). [460]

Em um pequeno grupo de casas, projetado para a primeira etapa de construção da Cidade Permanente, Le Corbusier preserva o partido adotado nas demais habitações, porém divide os jardins individuais com um muro de traçado orgânico - sua construção em pedra remete às próprias ruínas presentes na região. [461]

Le Corbusier estabelece uma relação de contraposição entre a gestualidade ondulante dos fechamentos que dividem os jardins abertos e a regularidade dos volumes que abrigam as habitações. Apesar do caráter austero do projeto, que evoca nas linhas, na matéria e na superfície a retidão e a simplicidade do lugar, Le Corbusier propõe um jogo compositivo entre a totalidade regular e ritmada verticalmente das habitações e o apêndice liberto e ondulante dado pelos fechamentos encurvados que dividem os jardins. [462]

Nas habitações de Sainte-Baume, o arquiteto especula um princípio inverso da machine d’habiter. A idéia de síntese também está presente, mas não é conseqüência da técnica moderna ou dos estilemas da arte abstrata, mas dos recursos materiais naturais que transparecem apenas a dignidade vernácula da construção.

O hotel de Sainte-Baume que, nas primeiras propostas de implantação, assumia a forma de dois anéis, em um segundo estudo, se caracteriza como duas lâminas curvas espelhadas, lembrando a forma de um olho. A partir dos centros de ambas as curvas, o arquiteto divide em fatias os apartamentos duplex cujas divisões internas lembram um fragmento da solução tipológica adotada para a Unité d'Habitation: no pavimento inferior encontra-se o corredor de distribuição, cozinha e estar com trecho em pé-direito duplo. O pavimento superior abriga os dormitórios além de um generoso terraço que repete a mesma largura do apartamento. [463], [464]

Devemos lembrar que o partido formal adotado por Le Corbusier para o hotel em SainteBaume (1948), caracterizado pela lâmina em arco suspensa sobre pilotis, já havia sido proposto por Niemeyer no projeto para o Hotel Resort da Pampulha (1942-1943) definido por uma barra encurvada de proporção horizontal de dois pavimentos sobre pilotis e sobreposta a uma plataforma de contorno sinuoso. [465]

Em 1967, passados dezenove anos do projeto de Le Corbusier, curiosamente, Oscar Niemeyer também realiza um projeto em Sainte-Baume. Trata-se do Centro Espiritual dos Padres Dominicanos.

Se Le Corbusier encrava a arquitetura no interior da pedra, Niemeyer procederá de maneira inversa: refará a própria pedra através da arquitetura.

Para conceber o pavilhão dos apartamentos dos religiosos, Niemeyer cria uma arquitetura a partir da reprodução construtiva do princípio da escavação presente na idéia de Le Corbusier para Sainte-Baume. Ambos os arquitetos reproduzem o ambiente de recolhimento dos ambientes paleo-cristãos, tanto na forma como na superfície.

O bloco distendido e curvo dos apartamentos proposto por Niemeyer é produto de uma

341 o encontro de 1947: contra-influência 



[462] conjunto de habitações da Cidade Permanente em Sainte-Baume - projeto para a primeira etapa da construção - planta térreo (1948) LC(BOESIGER, 1953:37)

[463] Hotel de Sainte-Baume - implantação (1948) LC (BOESIGER, 1953:39)

[464] Hotel de Sainte-Baume - corte (1948) LC (BOESIGER, 1953:39)
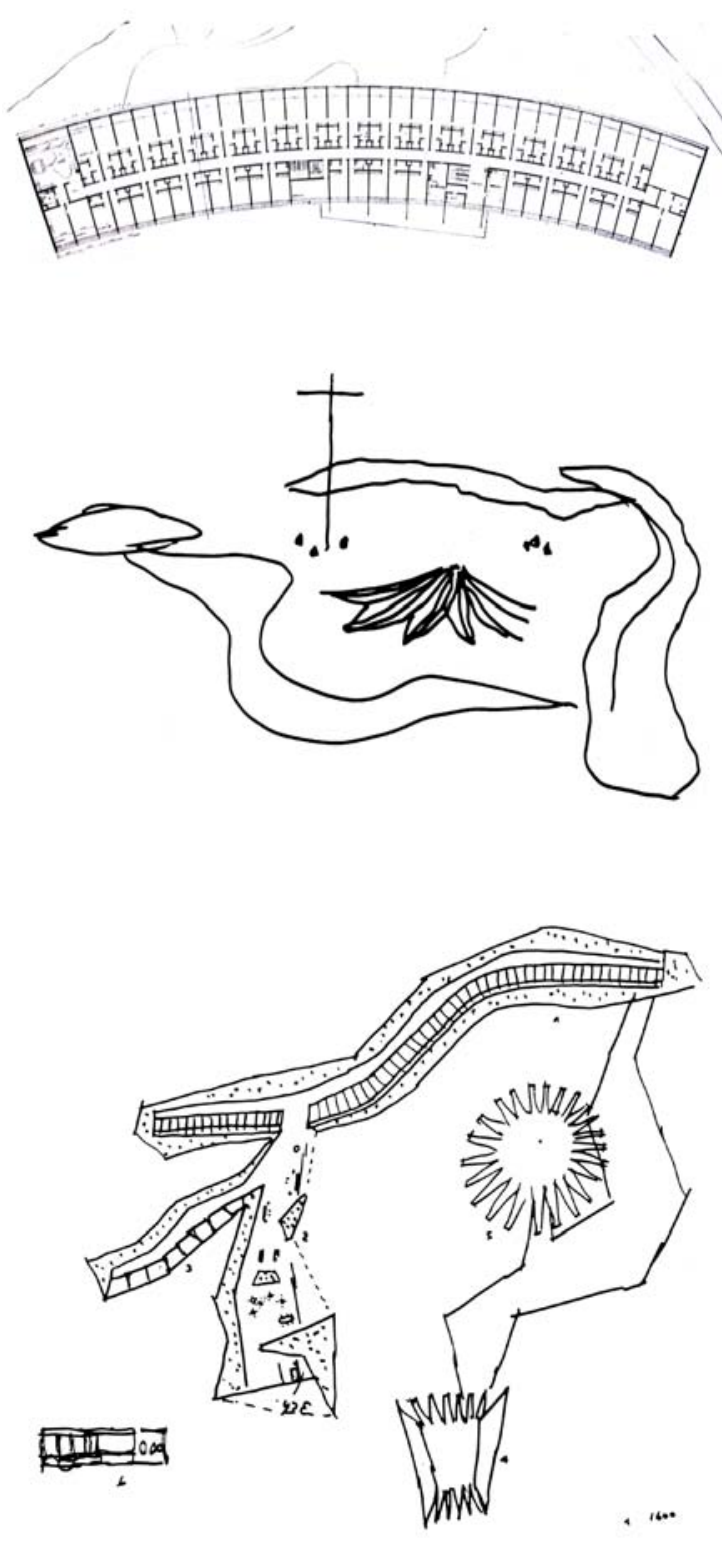

[465] Hotel Resort da Pampulha - planta apartamentos (1943) ON

(GOODWIN, 1944:sn)

[466] Centro Espiritual dos Padres Dominicanos em Sainte-Baume - croqui (1967) ON (BOTEY, 1996:169)

[467] Centro Espiritual dos Padres Dominicanos em Sainte-Baume - planta (1967) ON (BOTEY, 1996:169) 
lógica construtiva curiosa: primeiramente seria criado o volume do edifício horizontal em uma única corcova linear encurvada de terra natural e sobre esse morrote contínuo seria realizada uma concretagem que garantiria à construção a rusticidade formal e material da terra natural. Após a concretagem, seria retirada toda a terra contida no interior dessa casca esparramada no terreno. Como resultado, surge uma caverna construída a partir de um molde que é a própria terra.

Enquanto Le Corbusier oculta a arquitetura no interior da geografia da região, Niemeyer refaz essa geografia, utilizando como molde a própria terra. [466], [467], [468], [469]

Mais uma vez, Niemeyer parafraseia Le Corbusier a partir de um raciocínio que exterioriza a forma contida no interior. Ao reproduzir em forma arquitetônica a perfuração de Le Corbusier, Niemeyer dá continuidade as suas interpretações sobre os temas religiosos enfrentados pelo "mestre". Basta lembrarmos das relações presentes entre a Capela de Ronchamp e as capelas de Brasília.

Segue trecho em que Niemeyer explica o projeto de Sainte-Baume:

A primeira idéia que me ocorreu ao projetar o Centro Espiritual dos Padres Dominicanos de SainteBaume foi a de encontrar uma forma diferente de alcançar os requintes da civilização e que me lembram as cavernas onde no passado os cristãos se reuniam para a meditação e a oração.

Assim, pensei em uma grande cobertura de silhueta simples e variada, sugerindo uma forma natural que abrigará as salas, o restaurante, as celas, etc.... Perto dessa cobertura se encontrará a sala de conferências e a capela na qual a forma requintada e quase barroca acentuará, pelo contraste, o critério plástico do conjunto.

Eis, portanto, a solução inicial, que em 15 dias de trabalho, se impôs definitivamente, porque ela exprime o espírito e as conveniências do programa e se harmoniza com a tradição e a beleza grandiosa do maciço de Sainte-Baume (NIEMEYER in Revista Acrópole n.362 junho/1969:31)

Em Sainte-Baume, Niemeyer ensaia versões cruas de configurações formais já consagradas. A própria capela se apresenta como uma versão embrutecida da Catedral Metropolitana de Brasília. O arquiteto lança mão do mesmo esquema do perfil estrutural curvo que se multiplica em ritmo radial. Porém, em Sainte-Baume, o caixilho é uma estreita fresta e a coluna assume a materialidade de um volume que se expande em direção ao solo. Se o esquema estrutural é semelhante, o sentido plástico é oposto àquele presente na Catedral de Brasília, onde os apoios apenas tocam o solo e a porção envidraçada envolve a maioria da superfície exterior do volume, fazendo com que seu interior receba luz natural em abundância. [470]

Em um dos desenhos para a própria Catedral de Brasília, Niemeyer dispõe um volume de planta encurvada que envolve parcialmente a Catedral, muito semelhante com a construção orgânica e bruta proposta para Sainte-Baume. Em Brasília, esse morrote artificial funciona apenas como um fundo à edificação protagonista do conjunto, ao passo que, em Sainte-Baume, o volume do templo, apesar de sua expressão pronunciada, comporta-se como um componente de um conjunto maior. [471]

Esse conjunto de croquis de Niemeyer para a Catedral de Brasília não corresponde aos desenhos realizados entre 1958 e 1959. Certamente foi elaborado após a construção da estrutura

343 o encontro de 1947: contra-influência 



[468] Centro Espiritual dos Padres Dominicanos em Sainte-Baume - corte (1967) ON (BOTEY, 1996:169)

[469] Centro Espiritual dos Padres Dominicanos em Sainte-Baume - perspectiva interna do salão de refeições (1967) ON

(BOTEY, 1996:169)



[470] Centro Espiritual dos Padres Dominicanos em Sainte-Baume - maquete (1967) ON (BOTEY, 1996:168)

[471] Catedral Metropolitana de Brasília (1958) ON (Revista Acrópole n.362 - junho/1969) 
do templo que esperou por mais de dez anos pelos fechamentos com os vitrais de Marianne Peretti.

No livro Minha Arquitetura, Niemeyer relata outros aspectos do projeto para Sainte-Baume:

Um dia fui procurado pelos dominicanos de Sainte-Baume. Queriam que projetasse um conjunto compreendendo dormitório, capela, locais de encontro - e falavam de coisas antigas, antiqüíssimas, de abrigos naturais onde a religião cristã começou a surgir. E isso me levou a uma arquitetura tão diferente que vale a pena lembrá-la. Primeiro, seria construir com terra os volumes desejados. Depois cobri-los com uma laje de concreto. E, com a retirada da terra, a construção estaria concluída. E dentro desse princípio, em função do programa, o conjunto que os desenhos explicam melhor, foi projetado (NIEMEYER 2000:55, grifo nosso).

No projeto para os Dominicanos de Sainte-Baume, Niemeyer, assim como Le Corbusier, expressa através da arquitetura o ambiente primitivo da reclusão e da devoção dos rituais protocristãos.

Na maquete do projeto de Niemeyer para Sainte-Baume nota-se a presença de um volume caracterizado pela adoção das abóbadas sucessivas aos moldes da Igreja de São Francisco de Assis. Apesar da incorporação de uma plástica que remete ao ambiente primitivo das "cavernas onde no passado os cristãos se reuniam para a meditação e a oração", Niemeyer não abandona seu repertório de formas consagradas e incorpora tanto o hiperbolóide fracionado pelos pilares encurvados presentes na Catedral Metropolitana de Brasília como as abóbadas sucessivas que abrigam a Igreja de São Francisco de Assis na Pampulha.

O projeto de Niemeyer para o Instituto de Teologia da Universidade de Brasília, realizado em 1963, nos mostra que o arquiteto já havia experimentado a manipulação dos atributos litúrgicos que estarão presentes em seu projeto para o Centro Espiritual dos Padres Dominicanos de Sainte-Baume (1967) e sinaliza mais uma vez para uma nova interpretação do projeto de Le Corbusier para Sainte-Baume.

O projeto para o Instituto de Teologia é dividido em dois corpos distintos: o volume retangular que abriga os apartamentos dos padres e dos estudantes, além da biblioteca e das capelas na cobertura, e a igreja (não construída), implantada na lateral direita do volume retangular. [472]

Niemeyer utiliza elementos pré-fabricados no volume dos apartamentos. São grandes peças côncavas de proporção vertical em forma de gigantescas calhas que funcionam, ao mesmo tempo, como fechamento e pilar. As janelas dos apartamentos estão localizadas entre as colunasparedes pré-fabricadas, funcionando como uma sutil fresta entre as peças verticais de contorno convexo. [473]

O terraço na cobertura é abrigado por uma estrutura independente ao edifício. Trata-se de uma cobertura que se lança transversalmente ao comprimento do edifício - seus pilares não tocam o edifício, apóiam-se diretamente do solo. A face inferior da viga da cobertura do terraço possui desenho em arco abatido. $\mathrm{O}$ volume de planta retangular está contido no interior a uma seqüência de elementos verticais autônomos. Com esse artifício o arquiteto cria uma espacialidade vazada entre o ambiente externo e o objeto retangular, reproduzindo em elementos

345 o encontro de 1947: contra-influência 

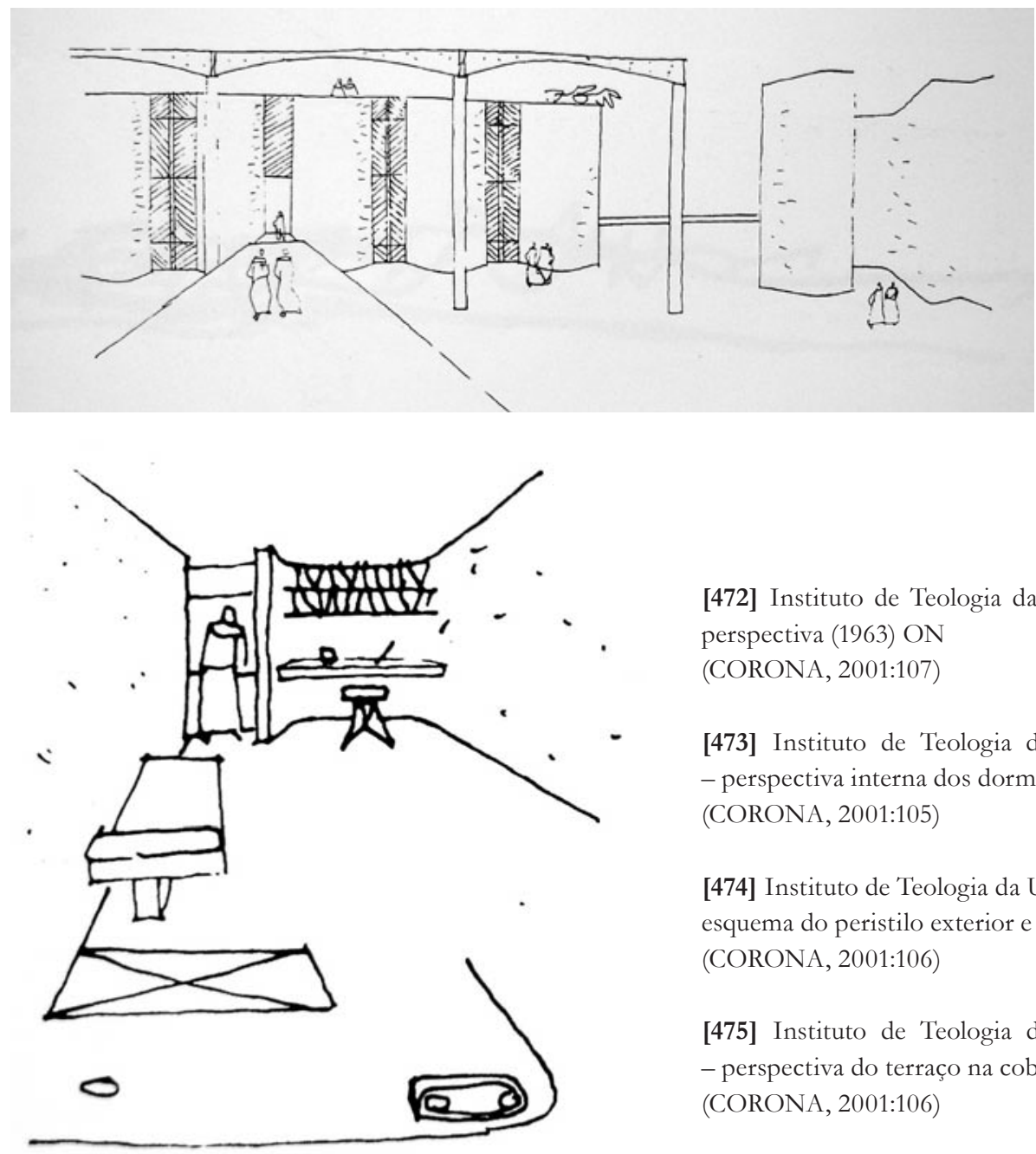

[472] Instituto de Teologia da Universidade de Brasília perspectiva (1963) ON (CORONA, 2001:107)

[473] Instituto de Teologia da Universidade de Brasília - perspectiva interna dos dormitórios (1963) ON (CORONA, 2001:105)

[474] Instituto de Teologia da Universidade de Brasília esquema do peristilo exterior e corte transversal (1963) ON (CORONA, 2001:106)

[475] Instituto de Teologia da Universidade de Brasília - perspectiva do terraço na cobertura (1963) ON (CORONA, 2001:106)
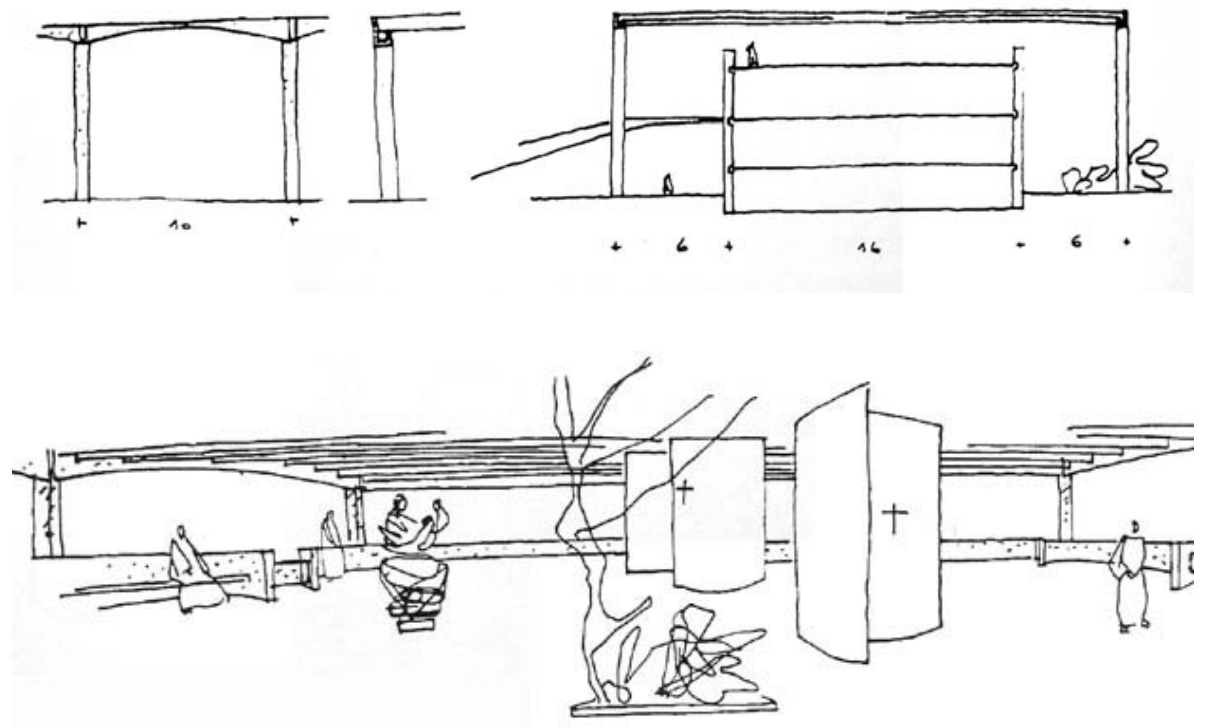
pré-fabricados, a regra tipológica dos Palácios de Brasília: a caixa regular envolvida por peristilo de pilares delgados. [474], [475], [476]

Niemeyer explica o projeto do Instituto de Teologia:

O Instituto de Teologia terá característica arquitetônica diferente - barroca se o desejarem - mas será também simples, sóbrio e recatado. Seus acabamentos respeitarão a austeridade necessária - quase tudo de tijolo e concreto aparentes - harmonizando-se assim com a filosofia de pobreza e humildade dos que o deverão habitar. Nele será mantido, embora num sentido mais amplo e flexível, o critério de pré-fabricação adotado na Universidade de Brasília. O bloco principal caracterizado por suas colunas-paredes (10 x 5) recurvadas, sobre as quais se apoiarão as placas nervuradas dos pisos $(16 \times 5)$ por meio de pinos de concreto armado. A cobertura, também pré-fabricada, representa elemento independente no conjunto estrutural. $\mathrm{Na}$ igreja conventual prevaleceu, porém, o aspecto plástico com suas formas imprevistas, visando a iluminação interna e o ambiente de recolhimento e mistério procurado (NIEMEYER in Revista Acrópole n.362 junho/1969:17).

Na igreja conventual do Instituto de Teologia, Niemeyer estabelece o contraponto gestual à volumetria rígida dos elementos pré-fabricados presentes no bloco dos apartamentos. A igreja configura-se quase como um emaranhado de fechamentos verticais de ondulação recortada que não se tocam. A nave e o altar são iluminados por uma luz filtrada pelas frestas entre os fechamentos soltos. O traçado irregular dos fechamentos repete-se em sub-solo que abriga quinze pequenas capelas nos trechos onde o desenho orgânico gera espaços com certo grau de isolamento. [477]

Assim como Le Corbusier em Ronchamp, na Igreja do Instituto de Teologia Niemeyer concebe uma planta a partir de paredes ondulantes e recortadas que não se tocam e abrigam as pequenas capelas em seus trechos côncavos internos.

A maneira como Niemeyer articula a relação de contraste entre a concisão do edifício dos apartamentos e a liberdade gestual da igreja indica um princípio de hierarquização das formas que adota um gradiente de expressão próximo daquele presente no projeto do conjunto de habitações de Le Corbusier em Sainte-Baume, caracterizado pela composição formada pelo volume regular encimado por seqüência de arcos abatidos que se contrapõe a um conjunto de fechamentos verticais de curvatura ondulante que não se tocam. Esse procedimento se repete no projeto de Niemeyer para o Instituto de Teologia na Universidade de Brasília.

Enquanto Le Corbusier cobre as habitações de Sainte-Baume com abóbadas abatidas, Niemeyer encaixa uma estrutura vazada - com arcos presentes apenas na face inferior das vigas da cobertura - ao corpo principal do Instituto de Teologia. Esse tipo de operação nos mostra que, mais uma vez, o "discípulo" manipula as soluções do "mestre" com um aguçado senso de espacialidade e leveza que sublima o peso e a estanqueidade das experiências de Le Corbusier, em um conjunto de traços e formas depurados justamente por essa reflexão que abranda tanto o excessivo contorcionismo como a condição de volume escultórico que caracteriza projetos como a Capela em Ronchamp e o conjunto em Sainte-Baume. [478], [479]

Seja em Pampulha, ou nos templos e nos Palácios de Brasília, ou mesmo no próprio

347 | o encontro de 1947: contra-influência 

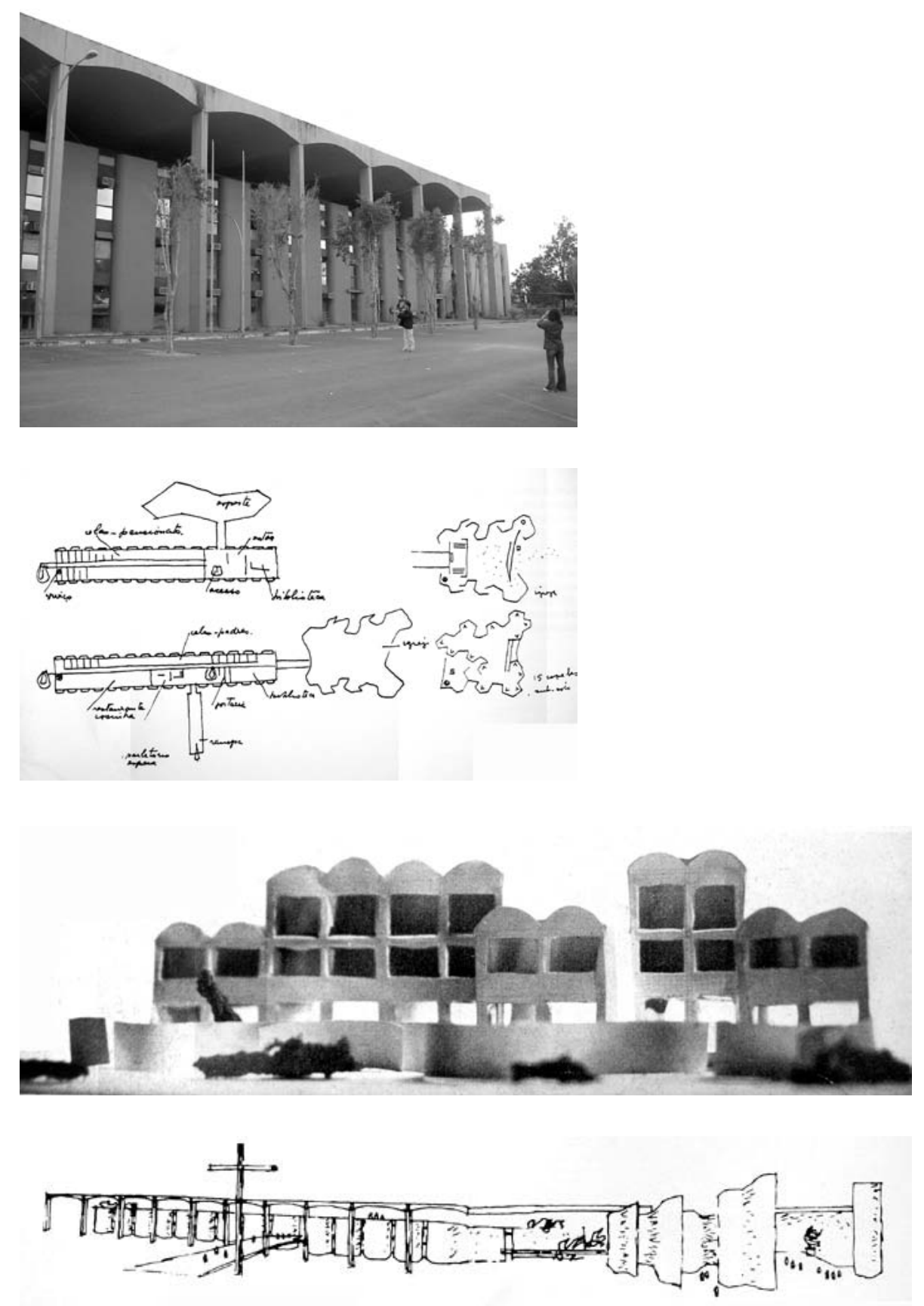

[476] Instituto de Teologia da Universidade de Brasília (1963) ON (foto: Rodrigo Queiroz)

[477] Instituto de Teologia da Universidade de Brasília - plantas (1963) ON (CORONA, 2001:107)

[478] conjunto de habitações da Cidade Permanente - projeto para a primeira etapa da construção - maquete (1948) LC (BOESIGER, 1953:36)

[479] Instituto de Teologia da Universidade de Brasília - perspectiva do conjunto (1963) ON

(CORONA, 2001:104) 
projeto do Instituto de Teologia, Niemeyer interpreta o vocabulário corbusiano a partir de uma estratégia que transgride os pressupostos do "mestre" no instante em que dilui e extravasa a plástica volumétrica de Le Corbusier.

A estratégia de Niemeyer, apesar de não esconder sua filiação corbusiana, rompe com a condição física que caracteriza os projetos de Le Corbusier. Se em projetos como o Pavilhão do Brasil na Feira Internacional de Nova York (1938) Oscar Niemeyer desmonta a lógica do volume presente nos projetos puristas de Le Corbusier realizados durante a década de 1920, em projetos como a Capela do Palácio da Alvorada e o Instituto de Teologia Niemeyer desbasta a plasticidade rústica aparente em Ronchamp e em Sainte-Baume.

A análise dos projetos dos templos de Niemeyer e de Le Corbusier clarificam as direções alternadas dos diálogos travados entre os arquitetos.

A Igreja de São Francisco de Assis na Pampulha funde em um traço contínuo, a superfície material barroca ao desenho dos arcos presentes nos projetos de Le Corbusier para a casa Monol e para seu atelier particular.

Le Corbusier, em Ronchamp, realiza um objeto escultural que adota a materialidade crua como revestimento para a técnica moderna. $\mathrm{O}$ arquiteto busca essa inspiração, por uma coincidência "tempo/espaço", nas cascas dos crustáceos apanhados na praia de Long Island em 1947, justamente no instante em que é apresentado pelo próprio Niemeyer, ao conjunto da Pampulha, em especial a Igreja de São Francisco de Assis. Por outro lado, os templos de Niemeyer em Brasília podem ser compreendidos como redesenhos abrandados do contorno movimentado dos fechamentos "em caracol" presentes em Ronchamp.

As experiências de Le Corbusier e Oscar Niemeyer em Sainte-Baume registram um instante único: ambos os arquitetos se debruçam sobre o mesmo problema e interpretam o tema da religiosidade dos dominicanos a partir do significado arquitetônico da reclusão e do claustro. Mas, nem por isso, as soluções se assemelham. Ao contrário, os arquitetos concebem idéias que se contrapõem pela própria materialidade, mas que se aproximam na intenção de conceber um simulacro do recolhimento incrustado nas próprias montanhas de Sainte-Baume.

Como podemos observar, as aproximações entre os projetos de templos de ambos os arquitetos reafirmam a hipótese da existência de um contínuo diálogo entre as obras de Le Corbusier e Oscar Niemeyer. O trânsito de influências entre "mestre" e "discípulo" é uma constatação que não ilustra a mera citação à obra do “outro". Em nenhum dos projetos é possível observar transposições literais da obra alheia. Os arquitetos incorporam a influência nas dimensões da idéia e do desejo.

Ao influenciar-se pela obra de Niemeyer, Le Corbusier assimila a liberdade do aspecto plástico, mas não transpõe para seus projetos a sutileza das esbeltas espessuras suspensas que, por sua vez, em Niemeyer, cumpriram o papel de, justamente, diluir a condição eminentemente volumétrica dos exemplares corbusianos da década de 1920. Sendo assim, Le Corbusier, ao debruçar-se sobre a obra de Niemeyer, compreende a forma livre apenas em sua dimensão escultórica, pois ainda preserva o sentido de volume integral que sempre caracterizou sua arquitetura,

349 | o encontro de 1947: contra-influência 
por mais que, a partir de Ronchamp, sua obra assuma contornos cada vez mais expressivos.

Do outro lado, nos templos pós-Ronchamp, Niemeyer, apesar de influenciado pela Capela de Ronchamp, não se seduz pela mera plástica escultórica de Le Corbusier, justamente pelo fato de que o "mestre", ao se enveredar no universo da liberdade em que transita o "discípulo", não assimila suas estratégias de ruptura com a idéia de volume, e ainda se mantém fiel a sua máxima que define arquitetura como o "jogo sábio, correto e magnífico de volumes reunidos sob a luz" (LE CORBUSIER apud LIMA, 2006:111). 


\section{Le Corbusier e a ruptura com a membrana purista: O Carpenter Center e o Pavilhão de Congressos em Estrasburgo}

O projeto do Cassino (1940), como já observado no capítulo Pampulha, representa o exato instante em que Oscar Niemeyer enfrenta os estilemas puristas manipulados por Le Corbusier, em seus projetos residenciais durante a década de 1920. Nesse projeto, Niemeyer incorpora o referencial corbusiano, ao mesmo tempo em que rompe com uma de suas condições principais: a idéia do volume integral como suporte para uma intervenção compositiva de cunho pictórico, seja em planta ou em elevação.

Em projetos de Le Corbusier como as casas Stein (1927) e Savoye (1929), a expressão plástica das formas curvas permanece estancada no interior de um esquema regulador dado pela ortogonalidade dos fechamentos exteriores. Neles, a composição gráfica em planta assume o mesmo senso de organização presente na pintura do mesmo autor, onde objetos do cotidiano como livros, garrafas e violões - destituídos dos atributos gráficos da perspectiva cônica - são dispostos em eixos paralelos ao alinhamento da moldura. No salão de jogos do Cassino, Niemeyer preserva a matriz de um raciocínio que faz eco com a pureza e a suspensão da casa Savoye (1929); já no salão de dança, assume uma posição oposta no instante em que extravasa um volume de traçado curvilíneo.

Nas "casas brancas" da década de 1920, Le Corbusier transpõe a dimensão pictórica da arte purista não só para a concepção gráfica da planta, como também para a dimensão plástica da arquitetura. A volumetria do edifício representa uma "extrusão vertical" da pintura, onde a moldura do quadro se transforma na membrana exterior da arquitetura e o contorno sinuoso e parabólico dos objets types representados na tela assume a condição de fechamento que divide os ambientes - seja a parede da sala de jantar na casa Stein ou no caixilho semi-circular, na escada em "U" e nos pára-ventos na cobertura da casa Savoye ${ }^{118}$

Para a análise de projetos de Le Corbusier como o Carpenter Center (1961) e o Palácio de Congressos em Estrasburgo (1964) faz-se necessária uma breve retomada da leitura das vilas puristas de Le Corbusier projetadas durante a década de 1920.

118. A análise sobre a relação entre a pintura e a arquitetura de Le Corbusier encontra-se no texto O Cassino da Pampulha e a ruptura com o raciocinio pictórico de Le Corbusier.

351 o encontro de 1947: contra-influência 
No texto intitulado O Cassino da Pampulha e a ruptura com o raciocinio pictórico de Le Corbusier abordamos a maneira como Niemeyer, no projeto do Cassino da Pampulha, transgride a dimensão pictórica dos exemplares puristas de Le Corbusier ao romper com a membrana/moldura que delimita o campo da composição.

É oportuna uma análise complementar do desenho de Le Corbusier intitulado "Quatro Composições" para clarificarmos as estratégias adotadas pelo arquiteto na concepção dos quatro projetos de residência ilustrados em seqüência: a casa La Roche-Jeanneret (1923), a casa Stein (1927), a casa Baizeau (1928) e casa Savoye (1929).

A ordem dos desenhos indica o percurso trilhado por Le Corbusier nos projetos de suas moradas puristas da década de 1920, nos quais os "cinco pontos da nova arquitetura" a manipulação da forma e da superfície. [480]

Se, na casa La Roche-Jeanneret, a organização do programa é conseqüência de uma articulação de volumes conectados entre si por ligações estreitas, na casa Stein o arquiteto assume um posicionamento inverso, condicionando no interior de um volume puro os diferentes recintos do programa, entrevistos pelas janelas em fita.

No projeto da casa Baizeau na Tunísia, Le Corbusier elimina parte das faces do volume retentor. Os paramentos ortogonais e encurvados estão dispostos no interior de uma estrutura de planos horizontais e apoios reticulados que faz eco ao esquema Dom-ino. Com a subtração dos fechamentos exteriores a idéia de volume absoluto é fragilizada. Nesse caso, a superfície pura como suporte para a fenêtre en loungeur (como na casa Stein) é substituída pela simples sucessão de lajes que abrigam os fechamentos no interior de suas projeções.

Apesar da ruptura com o volume integral, Le Corbusier preserva o raciocínio de matriz pictórica ao assimilar os planos horizontais das lajes como limite da composição formada pelos fechamentos internos, dispostos em sintonia com os alinhamentos da projeção da construção.

Le Corbusier encerra as "Quatro Composições" com um croqui da casa Savoye, cujo conjunto de soluções se apresenta como uma síntese depurada dos três primeiros esboços. Ao invés de eliminar as faces verticais do volume, como fez na casa da Tunísia, na casa Savoye, Le Corbusier subtrai trechos do plano horizontal de cobertura, fazendo com que, nesse caso, tanto a superfície opaca e branca dos fechamentos exteriores, como a fenêtre en loungeur, além de abrigarem os elementos do programa protegidos pela laje de cobertura, delimitem um terraço logo no primeiro pavimento ${ }^{120}$.

De todos os quatro projetos, a casa Savoye é o único em que Le Corbusier expõe as formas curvilíneas para além da contensão do volume puro. No solário da cobertura, os pára-ventos em segmento de elipse e semi-círculo extravasam a altura do volume, assumindo uma nítida presença exterior. O caixilho semi-circular do térreo, por sua natureza geométrica e material, enfatiza a pureza do paralelepípedo horizontal suspenso pela trama reticular de pilotis. [481]

119. "Les 5 points d'une architecture nouvelle: les pilotis; les toits-jardins; le plan livre; la fenêtre en loungeur; la façade libre." (LE CORBUSIER apud BOESIGER, xx:128).

120. (Cf.: SBRIGLIO, 2005:172) 
Se em planta a relação entre fechamentos internos e membrana exterior da casa Savoye (assim como nas casas Stein e Baizeau) ainda ecoa o raciocínio pictórico presente na organização dos objets types na pintura purista, sua volumetria indica uma emancipação com relação aos outros três exemplares das "casas brancas” representados nas "Quatro Composições”. Tanto os páraventos da cobertura como o caixilho semi-circular no pavimento térreo correspondem a índices curvilíneos exteriores, cuja intensidade plástica não possui precedentes nos projetos anteriores.

Diferentemente da casa Stein, na casa Savoye a forma pura, alva e rasgada pelas " janelas em fita" não corresponde a totalidade exterior que abriga dentro de si um arranjo compositivo dado pelas retas e curvas alinhadas aos fechamentos ortogonais. O volume regular é parte integrante de uma organização caracterizada pela sobreposição de formas: o semi-círculo transparente no térreo, o volume regular de planta quadrada no primeiro pavimento e os pára-ventos encurvados na cobertura. No projeto da casa Savoye ocorre uma gradativa emancipação da forma curva que, em projetos como a casa Stein, ainda permanecia enclausurada no interior do volume puro.

No Cassino da Pampulha, Niemeyer dá prosseguimento à paulatina libertação da forma livre com relação a forma regular presente na seqüência de projetos de Le Corbusier representados nas "Quatro Composições” (La Roche-Jeanneret, Stein, Baizeau e Savoye) que claramente apontavam para uma expansão da dimensão plástica das formas curvilíneas, mesmo que ainda estancadas pelo perímetro purista. [482]

Apesar da casa Savoye representar uma evolução na emancipação da forma curva com relação a forma pura, devemos observar que Le Corbusier, pelo menos na planta, preserva intacta a concepção pictórica da composição. A membrana/moldura exterior ainda representa um limite ortogonal que retém e organiza o arranjo dos paramentos, mesmo com a exposição exterior das formas curvas no térreo e na cobertura.

Mesmo em projetos que apontam para uma direção diversa dos exemplares puristas da década de 1920, como a Unité d'Habitation (1947) e a Assembléia de Chandigarh (1951), Le Corbusier se mantém fiel aos estilemas plásticos aplicados na casa Savoye.

$\mathrm{Na}$ Unité d'Habitation, os volumes encurvados do ginásio e do reservatório de água dispostos na cobertura da lâmina retangular - apesar de suas pronunciadas curvaturas - preservam o mesmo princípio compositivo da casa Savoye: o perímetro ortogonal da planta é o limite físico e gráfico que condiciona a organização das formas curvas na cobertura. [483]

O volume hiperbolóide que extravasa a cobertura da Assembléia de Chandigarh incorpora o mesmo senso de organização preconizado na casa Savoye e assimilado na Unité d'Habitation. Ainda que esses projetos representem uma suposta fidelidade ao raciocínio presente na casa Savoye, a expressão escultórica das formas que aparecem na cobertura não lembrarão o traçado geométrico das formas curvas em semi-círculo e elipse presentes na cobertura da casa Savoye.

O contorno ondulante da caixa d'água da Unité d'Habitation e a expansibilidade dinâmica do hiperbolóide da Assembléia de Chandigarh mostram que Le Corbusier preserva o esquema da casa Savoye como uma estrutura de raciocínio, e não como um parâmetro formal.

Para Sophia Telles, a "liberdade poética" dos elementos encurvados, presentes tanto na

353 | o encontro de 1947: contra-influência 

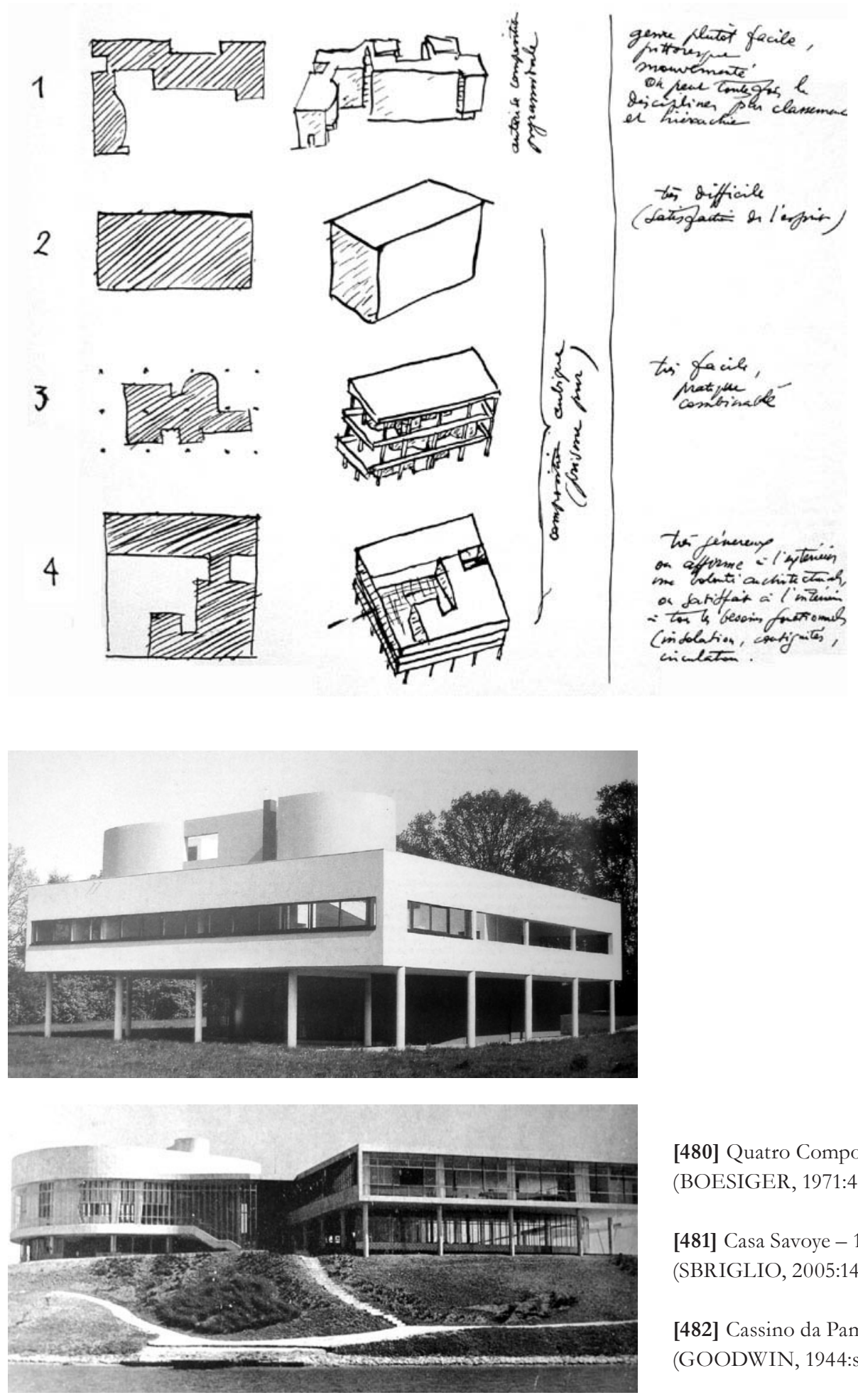

[480] Quatro Composições - LC

(BOESIGER, 1971:45)

[481] Casa Savoye - 1929 - LC

(SBRIGLIO, 2005:14-15)

[482] Cassino da Pampulha - 1940 - ON (GOODWIN, 1944:sn) 
cobertura como no interior do volume, representam o contraponto com a pureza abstrata da arquitetura. Segue trecho da autora:

\begin{abstract}
Arma assim uma dualidade que é reconhecida em seus projetos, entre a lógica do raciocínio e o que chama de liberdade poética, que deve operar por contraponto à emoção intelectual produzida pela abstrata proporção arquitetônica. Daí a série de "objets à réacton poétique", quase surrealistas, que desenha para elementos do cotidiano como a chaminé ou playground, alocados em geral nos tetos jardim, mas presentes também nas curvas inusitadas de um prosaico banheiro (TELLES 1988:22, grifo nosso).
\end{abstract}

Poderíamos classificar o projeto de Oscar Niemeyer para o Cassino da Pampulha (1940) não apenas como um desdobramento das transformações diagnosticadas nos projetos de Le Corbusier ilustrados nas "Quatro Composições" (1923-1929), mas também como uma perspectiva para a continuidade das transformações paulatinas presentes nesses mesmos projetos representados nas "Quatro Composições". Como seria a suposta configuração de uma "quinta composição" que sucedesse a casa Savoye?

Da estanqueidade rasgada pelas "janelas em fita" da casa Stein à sobreposição de formas da casa Savoye, Le Corbusier trilha um percurso onde a forma curva assume um nítido papel de autonomia a independência com relação a forma pura que a abriga.

Embora as transformações presentes em cada um dos exemplares representados nas "Quatro Composições” sinalizem para uma gradativa emancipação da forma livre e conseqüente diluição da idéia de volume puro, Le Corbusier não abre mão da membrana exterior reguladora que abriga em seu interior os fechamentos internos, sejam eles curvilíneos ou ortogonais.

Diferentemente da casa Savoye, no Cassino da Pampulha, a forma regular do salão de jogos não se presta como suporte exterior que abriga os elementos encurvados. Ao contrário, Niemeyer transforma o volume de matriz purista em um elemento integrante de um conjunto, pois, ao conceber o salão de baile como um volume curvilíneo, autônomo com relação ao volume regular do salão de jogos, Niemeyer "exterioriza" o gesto curvo que Le Corbusier preserva contido no interior de suas composições puristas. [484], [485]

A ruptura com a moldura do modelo purista - que caracteriza o projeto de Niemeyer para o Cassino - se configurará como um procedimento tardio na obra de Le Corbusier. Projetos como o Museu de Arte de Ahmedabad (1954) e o Museu de Arte Ocidental de Tókio (1957), apesar de terem sido concebidos em um período da obra de Le Corbusier caracterizado pela intensa plasticidade das formas (vide Ronchamp e Chandigarh), preservam tanto a identidade tipológica dos "cinco-pontos" como a aparência ortogonal do volume exterior de planta quadrada.

Essa resistência em romper com a superfície exterior dos projetos de volumetria ortogonal é conseqüência de uma incompatibilidade plástica entre a idéia de forma livre e os instrumentos adotados pelo arquiteto como parâmetros projetuais. A própria adoção irrestrita da retícula uniforme de pilares como instância reguladora do raciocínio compositivo limitaria uma possível maleabilidade da forma arquitetônica. Seja nas vilas puristas da década de 1920 ou nos museus da década de 1950, o campo de ação se restringe a malha estrutural que, ortogonal aos fechamentos

355 o encontro de 1947: contra-influência 

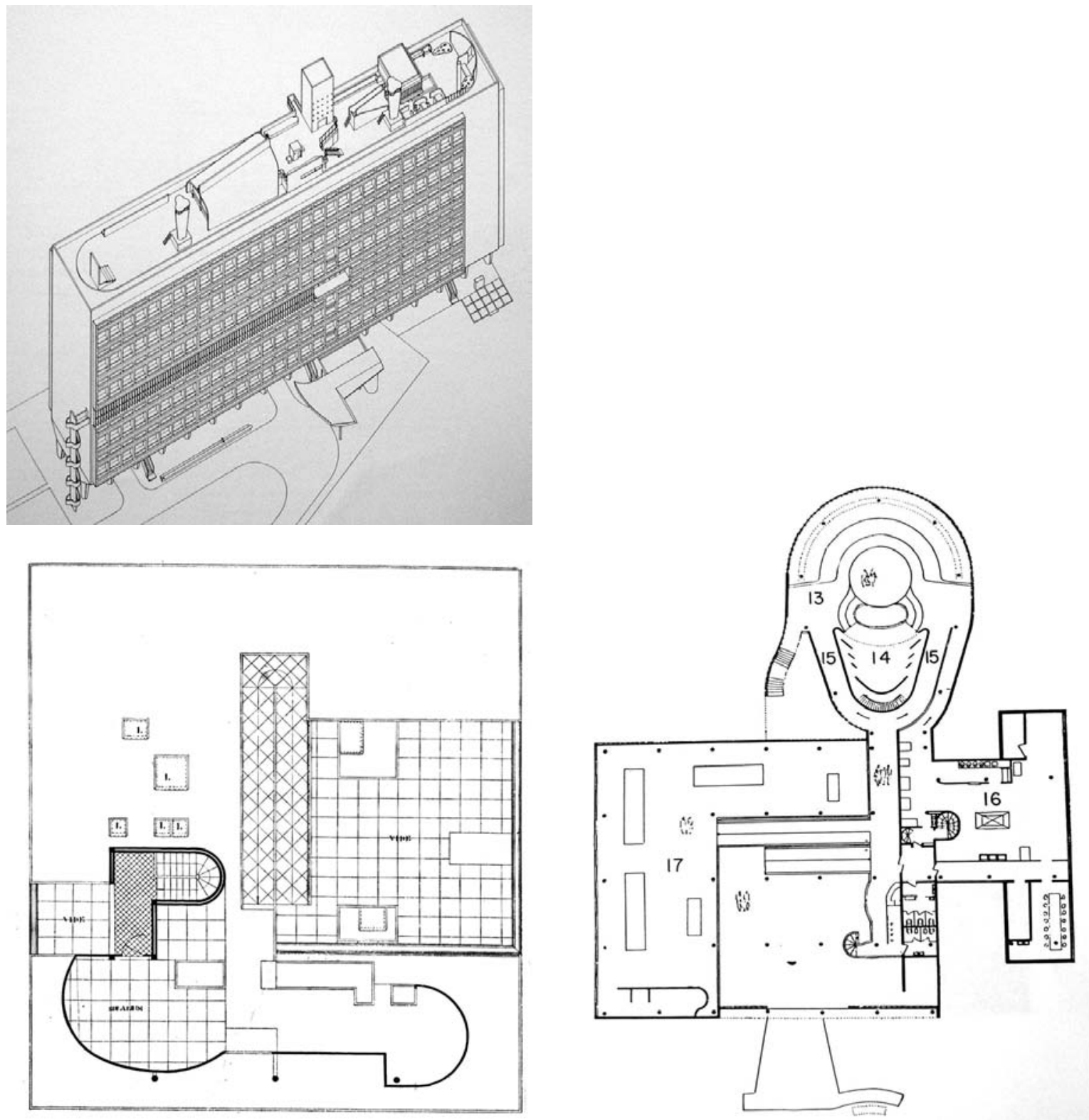

[483] Unité d'Habitation em Marselha - perspectiva - 1947/1952 - LC (JENKIS, 1993:sn)

[484] Casa Savoye - planta cobertura - 1929 - LC (BOESIGER, 1971:59)

[485] Cassino da Pampulha - planta pav. superior - 1940 - ON (PAPADAKI, 1950:73) 
internos e externos, baliza a organização das formas e dos espaços.

No Cassino na Pampulha, ao expor a forma curvilínea como um objeto pleno com relação a forma de matriz regular, Niemeyer abre mão da retícula retangular do salão de jogos e adota uma trama radial que corresponde a própria forma do salão de dança.

Ao se desvincular da retícula ortogonal, Niemeyer viola um postulado que Le Corbusier preservará intacto durante quase toda sua obra. Isto é, Niemeyer compreende que, para transgredir a dimensão pictórica presente no esquema purista de Le Corbusier, não basta apenas romper com a membrana ortogonal que delimita o campo regulador da composição, é necessária a criação de uma nova retícula, cuja tessitura corresponda à forma que a abriga.

Somente em 1961, no projeto para o Centro de Artes Visuais para a Universidade de Harvard, conhecido como Carpenter Center, é que Le Corbusier especula a possibilidade da ruptura lateral dos limites do volume regular de modelos caracterizados pela planta de feição quadrada.

Situado em um pequeno terreno envolvido por edifícios de estilo georgiano, o Carpenter Center quase não possui divisões internas. Os espaços interiores funcionam como generosos ateliês abertos aos estudantes da Universidade de Harvard que são convidados a utilizar os espaços através de duas rampas em sutil "S" que desenham um percurso que cruza o edifício de um lado a outro, no sentido de seu comprimento. [486]

O projeto do Carpenter Center sofre clara influência de algumas das soluções aplicadas por Le Corbusier no projeto para o edifício da Associação dos Fiandeiros de Ahmedabad, na Índia (1954).

Tanto no Carpenter Center como na Associação dos Fiandeiros de Ahmedabad, Le Corbusier substitui a superfície pura rasgada pelas "janelas em fita" pela grelha de brises de concreto. O plano alvo e homogêneo das "casas brancas" dá lugar a espessas membranas vazadas que configuram um "plano ativado por luz e sombra" (TELLES, 1988:25) que, em ambos os projetos, é perfurado por uma rampa exterior que ascende ao primeiro pavimento em posição perpendicular a face do edifício. As rampas encurvadas e rebatidas do Carpenter Center parafraseiam a rampa retilínea que invade o edifício da Associação dos Fiandeiros. [487], [488]

A expressiva maleabilidade dos fechamentos internos da Associação dos Fiandeiros não lembra a rigidez geométrica das curvas interiores aos modelos puristas da década de 1920, mas Le Corbusier ainda preserva intacto o mesmo raciocínio pictórico da planta, onde o fechamento perimetral ortogonal é o campo gráfico e volumétrico que limita a expansibilidade dos fechamentos encurvados contidos em seu interior. [489]

Para Kenneth Frampton, as formas ovais que estravazam o volume retangular do Carpenter Center representam uma “dilatação” (FRAMPTON 2001:216) das formas encurvadas contidas no interior do edifício de Ahmedabad. Segundo Frampton, o diálogo entre o orgânico e o ortogonal, contraído no interior do edifício em Ahmedabad, assume uma configuração inédita no Carpenter Center, justamente no instante em que são expelidas as formas curvilíneas que, desde as "Quatro Composições", permaneciam confinadas no interior da projeção do volume de feição ortogonal.

357 | o encontro de 1947: contra-influência 

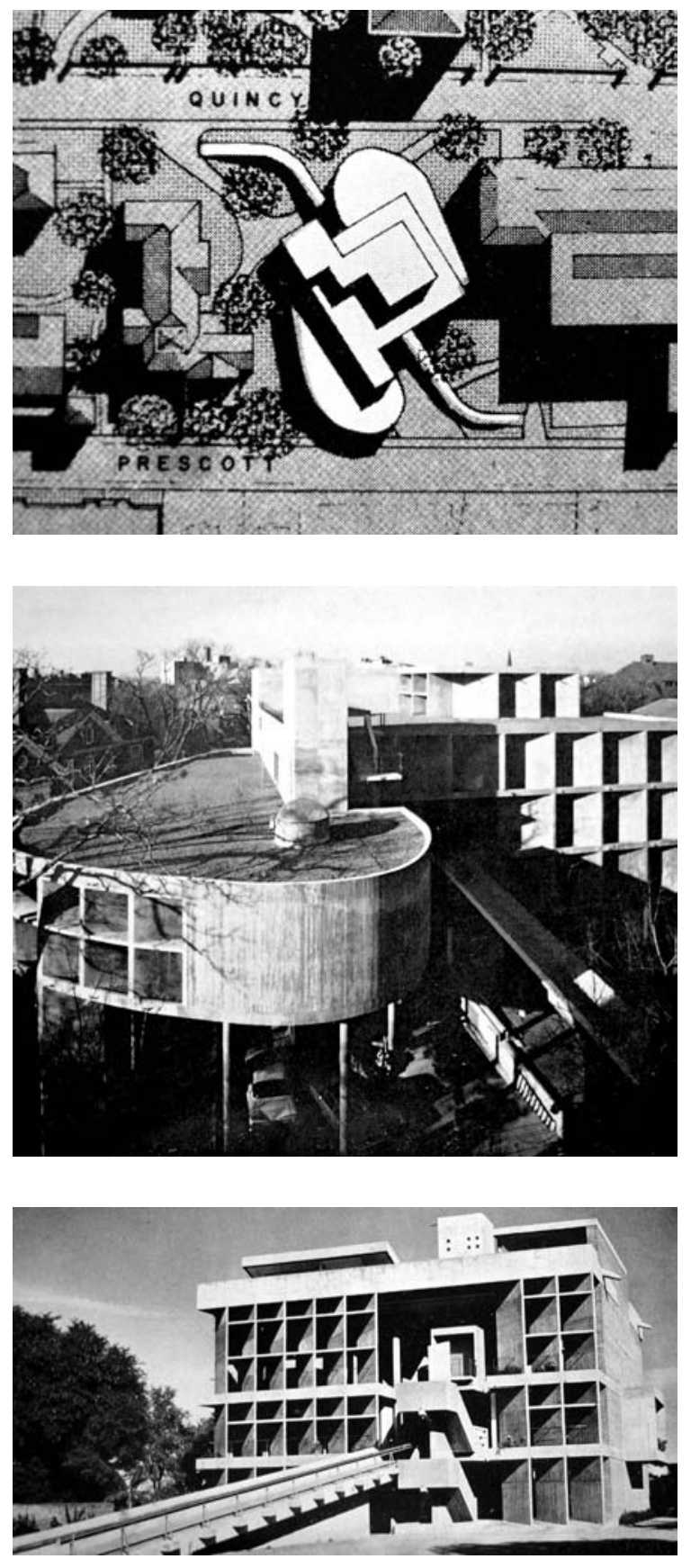

[486] Carpenter Center - implantação (1961/1964) LC (BOESIGER, 1965:55)

[487] Carpenter Center (1961/1964) LC

(BOESIGER, 1965:57)

[488] Palácio da Associação dos Fiandeiros em Ahmedabad (1954) LC

(BOESIGER, 1957:145)
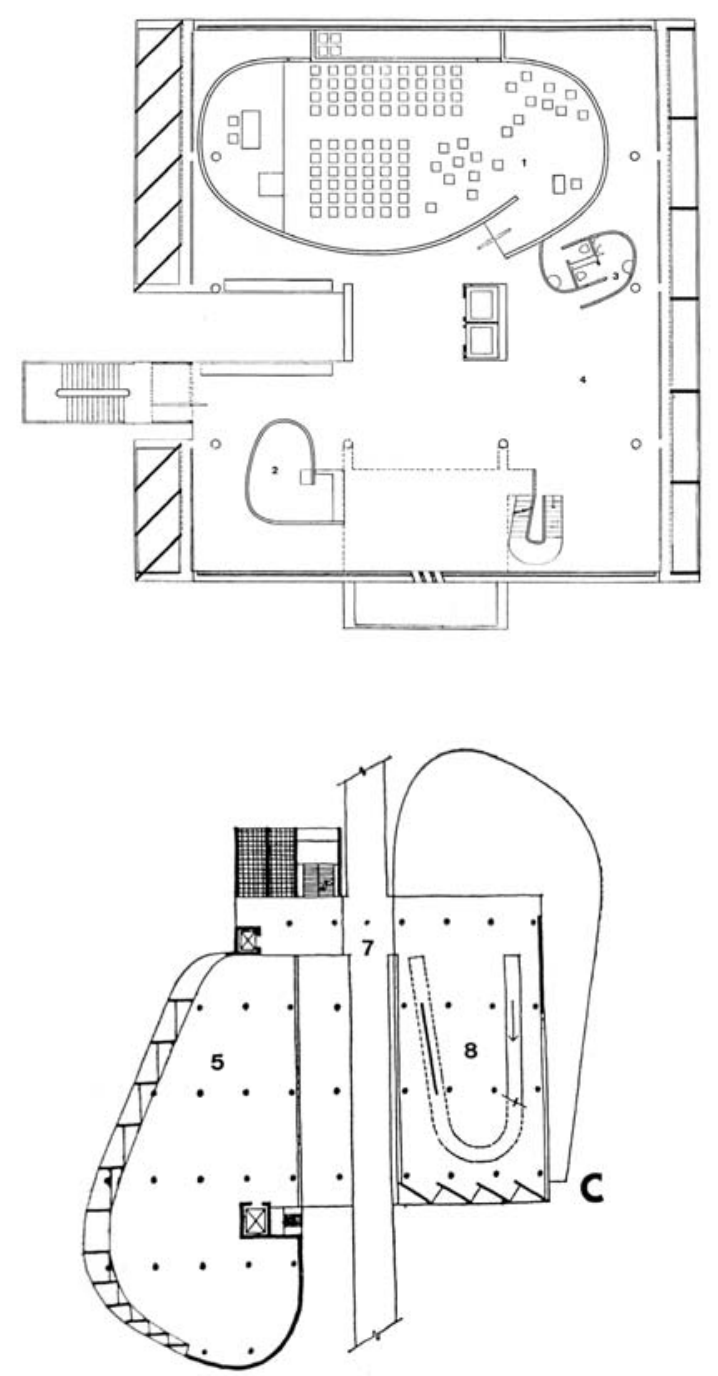

[489] Palácio da Associação dos Fiandeiros em Ahmedabad - planta quarto pavimento (1954) LC (BOESIGER, 1957:150)

[490] Carpenter Center - planta segundo pavimento (1961/1964) LC

(BOESIGER, 1965:55) 
Frampton elege o arranjo em curvas espelhadas que define o contorno dos sanitários localizados no interior do edifício da Associação dos Fiandeiros como a solução embrionária que inspiraria as formas ovais de "aspecto pulmonar" dos auditórios rebatidos que se expandem para além dos limites da forma regular que abriga os ateliês.

Corroboramos com Frampton: a correspondência entre o edifício da Associação dos Fiandeiros em Ahmedabad (1954) e o Carpenter Center na Universidade de Harvard (1961) é inquestionável, mas o procedimento de exteriorização da forma livre com relação a forma regular adotado por Le Corbusier em Harvard se aproxima daquele utilizado por Niemeyer em 1940 no projeto do Cassino da Pampulha.

Quase vinte anos separam o projeto de Niemeyer para o Cassino da Pampulha e o projeto de Le Corbusier para o Carpenter Center. Não cabe a essa pesquisa afirmar de maneira categórica que o projeto de Le Corbusier em Harvard é fruto da influência do projeto do Cassino da Pampulha. Preferimos alinhavar semelhanças que apontem para procedimentos de projeto e intenções estéticas que se aproximam.

Por mais que Le Corbusier demonstre uma inegável habilidade na manipulação e na modelação das formas encurvadas presentes nos projetos caracterizados pela adoção da retícula de pilares, seu campo de ação sempre se limita a um perímetro retentor de contorno ortogonal.

O edifício do Carpenter Center será o primeiro projeto em que Le Corbusier promove a curva como elemento de ruptura com o conjunto formado pela membrana exterior de contorno retangular e pela trama de pilares.

Projetos de períodos tão distintos como a Casa Savoye (1929), a Assembléia de Chandigarh (1951) e a Associação dos Fiandeiros de Ahmedabad (1954), independentemente de suas evidentes diferenças, possuem a mesma lógica compositiva caracterizada pela presença da organização em retícula de um campo delimitado por um perímetro retangular que abriga em seu interior os fechamentos encurvados que estabelecem uma relação de contraste com a própria ortogonalidade da membrana exterior.

Será justamente essa rígida estrutura de raciocínio - que Le Corbusier preserva intacta por mais de trinta anos - que será transgredida por Niemeyer no projeto do Cassino da Pampulha.

Ao extrapolar a forma curvilínea para além dos limites da forma regular, Niemeyer adianta em pelo menos vinte anos o procedimento adotado por Le Corbusier no Carpenter Center. Como já foi dito anteriormente, no Cassino Niemeyer rompe com dois dogmas corbusianos: a membrana purista e a retícula ortogonal de pilares.

Niemeyer não apenas expõe para o meio externo as formas curvas que Le Corbusier mantém enclausuradas no interior da forma regular, como também abre mão da retícula ortogonal de pilares como suporte do volume curvo, adotando uma trama radial que acompanha o contorno ovalado do salão de baile.

As intervenções de Niemeyer sobre o esquema corbusiano transcendem a mera dimensão formal, Niemeyer infrige o postulado da forma que segue a função ao condicionar a configuração da trama estrutural à forma do edifício. $\mathrm{O}$ arquiteto brasileiro inverte a lógica forma/ função e, pelo

359 | o encontro de 1947: contra-influência 

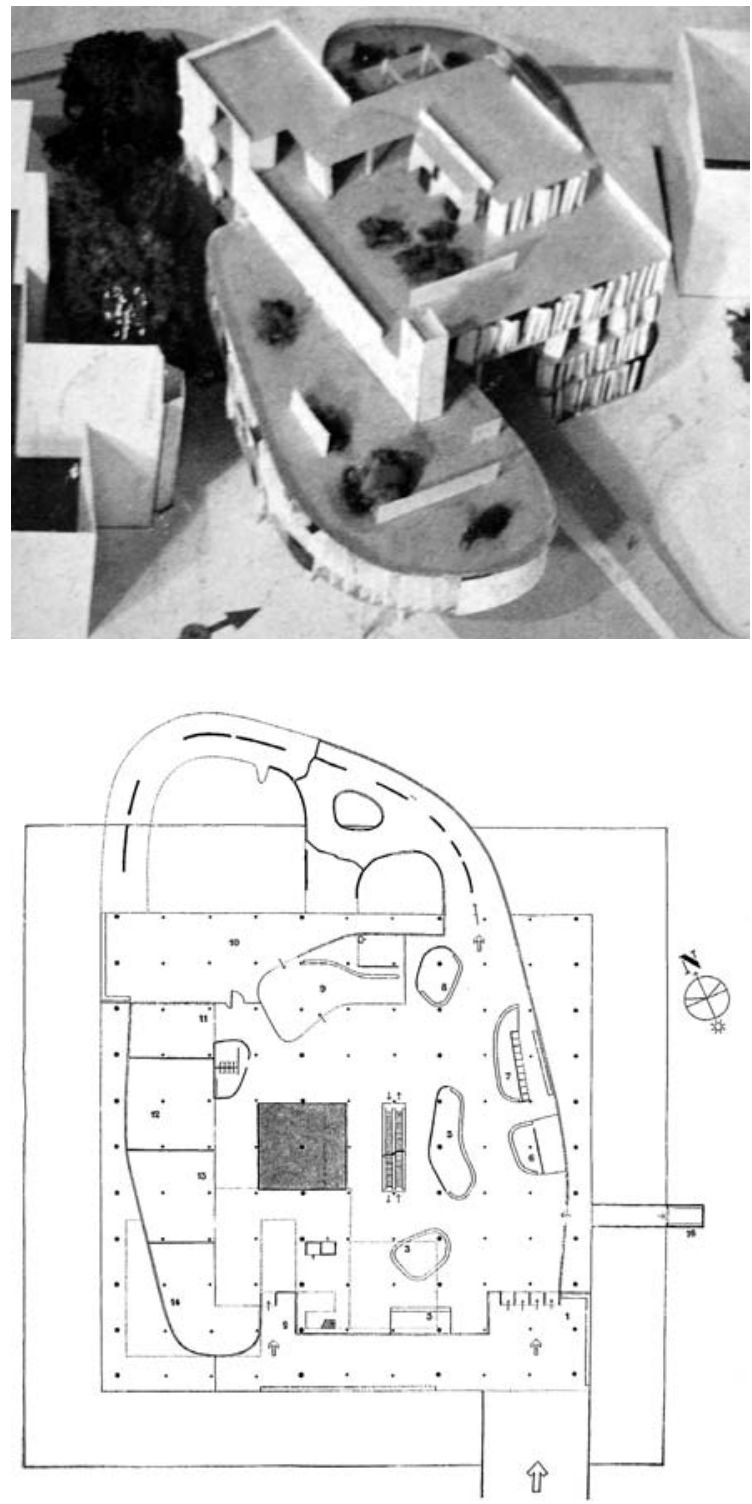

[491] Carpenter Center - maquete (1961/1964) LC (BOESIGER, 1965:56)

[492] Palácio de Congressos em Estrasburgo - planta terceiro pavimento (1964) LC (BOESIGER, 1965:156)
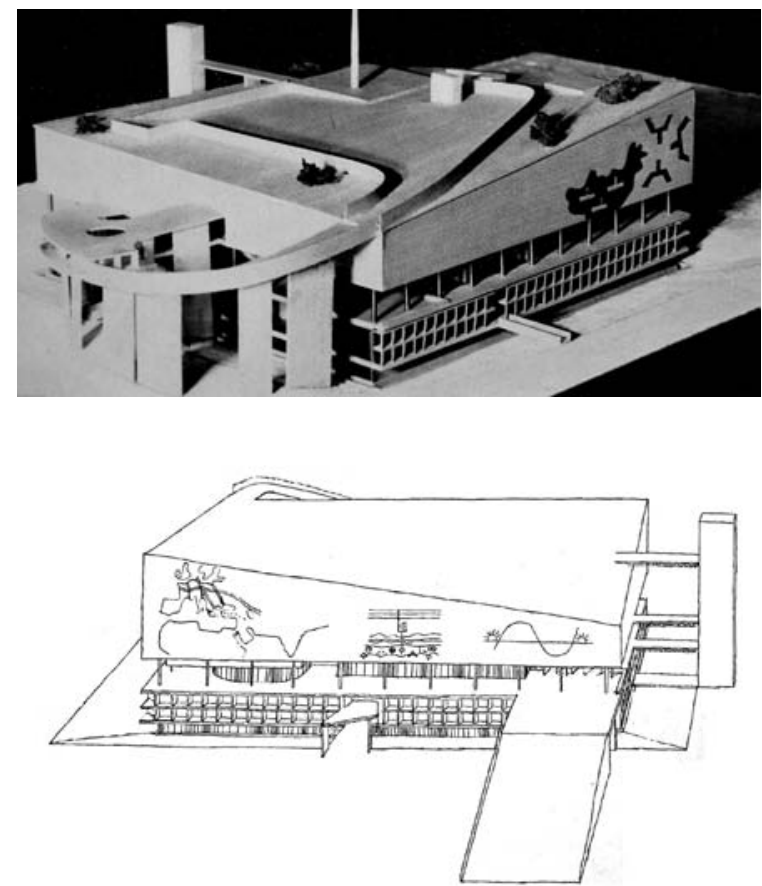

[493] Palácio de Congressos em Estrasburgo - maquete (1964) LC

(BOESIGER, 1965:158)

[494] Palácio de Congressos em Estrasburgo - perspectiva (1964) LC

(BOESIGER, 1965:153) 
menos no salão de baile do Cassino, a função segue a forma.

No projeto do Carpenter Center, Le Corbusier rompe com a membrana ortogonal reguladora, mas preserva a mesma retícula retangular em todo o projeto, inclusive nas formas ovaladas e rebatidas que extravasam o volume puro. Em Le Corbusier a forma se adapta a trama estrutural, ao passo que em Niemeyer ocorre o procedimento inverso: a trama estrutural se adapta à forma. [490]

Mesmo com a manutenção da retícula uniforme, o projeto de Le Corbusier em Harvard representa uma inegável ruptura com seu modelo de concepção pictórica (moldura/figura). Poderíamos dizer que, no Carpenter Center, o campo estruturador da composição deixa de ser a forma pura, como na casa Savoye, e passa a ser a própria modulação da estrutura que, apesar de inflexível, se expande para estruturar a "forma livre" que se dilata para além dos limites da planta quadrada.

O sentimento dialético de aproximação e repulsão entre a forma dinâmica e a forma pura é comum aos projetos do Cassino da Pampulha e do Carpenter Center. Porém, enquanto Niemeyer conecta a forma curva a forma ortogonal com um estreito corredor de ligação solução que preserva intacta a integridade formal dos dois volumes - Le Corbusier interseciona um volume ao outro. [491]

Nos projetos do Cassino da Pampulha e do Carpenter Center, as intenções de Oscar Niemeyer e Le Corbusier se aproximam. Em que pese as evidentes diferenças plásticas entre os projetos, quando rompe o esquema regulador da forma pura no Carpenter Center, o "mestre" lança mão do mesmo raciocínio que o "discípulo" havia adotado com vinte anos de antecedência no projeto do Cassino da Pampulha.

Kenneth Frampton não nega a influência da arquitetura de Niemeyer nos projetos tardios do arquiteto europeu, mas, curiosamente, o autor elege o projeto de Le Corbusier para o Palácio de Congressos em Estrasburgo (1964/1965) como sendo o exemplar mais evidente dessa "contra-influência". O autor define o projeto de Estrasburgo como "um prisma grandioso interceptado por uma larga rampa em curva. Inspirado na arquitetura de Oscar Niemeyer, esse é o projeto mais brasileiro realizado por Le Corbusier." (Idem:222, grifo nosso).

No texto Le Corbusier e Oscar Niemeyer: Influência e Contra-Influência, 1929-1965, Kenneth Frampton reafirma a ascendência da arquitetura de Niemeyer sobre projetos de Le Corbusier como Palácio de Congressos em Estrasburgo.

A flexibilidade brilhante nos planos de Niemeyer durante esse período parece vir a tona quinze anos depois no projeto de Le Corbusier para o Salão do Congresso em Estrasburgo (1963/1964) que, com suas rampas sinuosas, expostas para fora do edifício, além do planejamento dinâmico e orgânico interno é, com certeza, o trabalho mais brasileiro de toda a carreira de Le Corbusier (FRAMPTON apud BRILLEMBOURG, 2004:47).

Não negamos que a curvatura aérea das rampas do Palácio de Congressos em Estrasburgo faz eco à liberdade plástica de Niemeyer. Porém, no projeto de Le Corbusier a superfície

361 | o encontro de 1947: contra-influência 

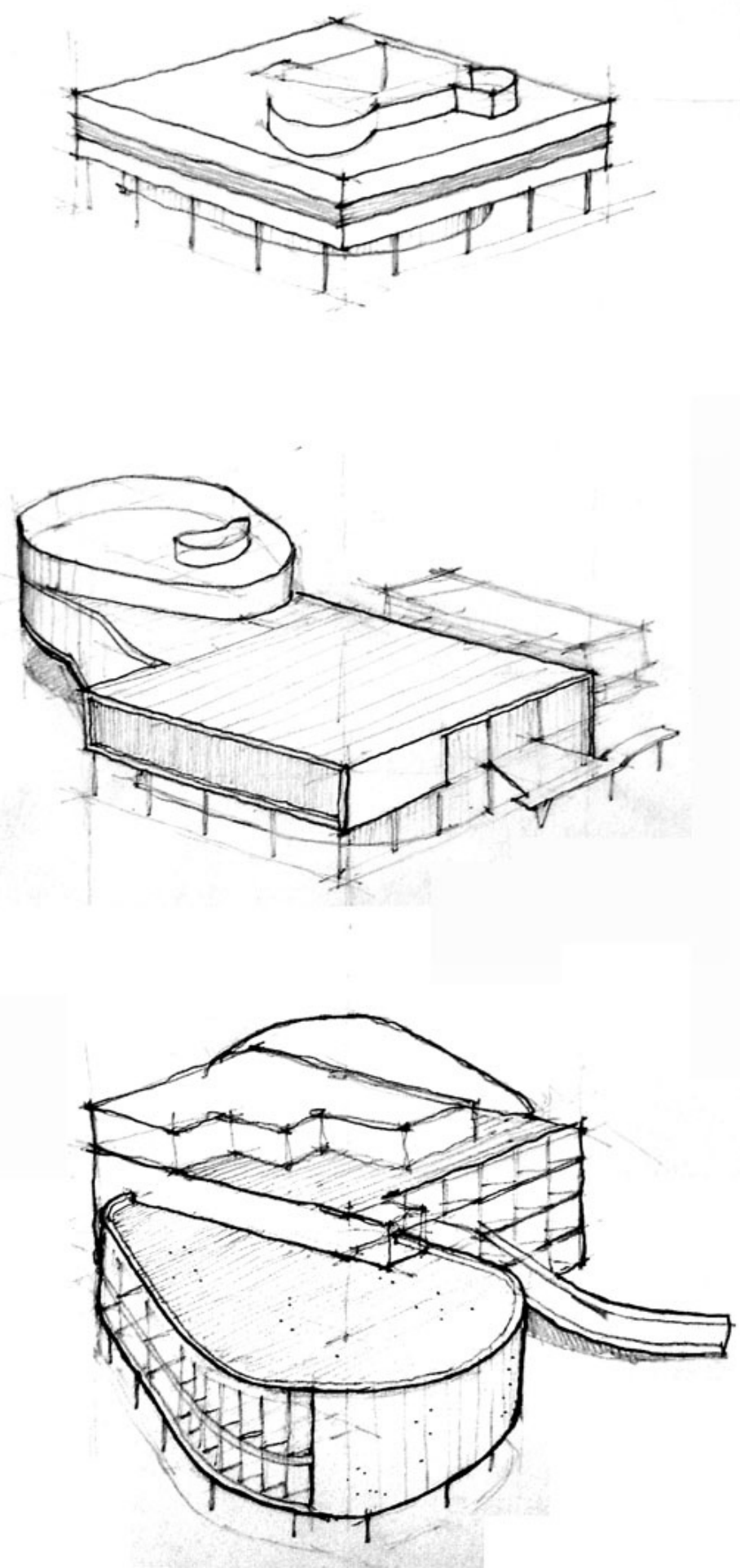

[495] Emancipação da forma livre - comparativo: Casa Savoye (1929-LC); Cassino da Pampulha (1940-ON) e Carpenter Center (1961-1964LC)

desenho: Rodrigo Queiroz 
inclinada e encurvada do piso da rampa se repete em sua cobertura, configurando não um plano de curvatura ascendente, mas um volume de planta ovóide com perfurações em planta. Nos projetos de Niemeyer, as rampas se configuram como elementos suspensos e delgados, não como volumes. Para Niemeyer, a esbeltez das sutis espessuras das rampas serve de contraponto a própria volumetria do edifício. [492], [493]

O acesso principal para o Palácio de Estrasburgo é dado por uma rampa retangular representada por um sólido raso em forma de cunha. Essa solução já havia sido especulada por Le Corbusier no Projeto para a Embaixada da França em Brasília (1962).

Para Glauco Campello, é inevitável a associação das rampas "em cunha” de Le Corbusier com as rampas de Niemeyer para os Palácios de Brasília. Mas o autor ressalta as diferenças entre as rampas de Niemeyer e de Le Corbusier. Enquanto Niemeyer concebe planos inclinados quase "soltos no ar", Le Corbusier se mantém fiel ao volume, mesmo em uma rampa de baixa inclinação, rente ao chão. Segue trecho em que Campello compara as rampas de Le Corbusier e Niemeyer.

(...) Lançando o olhar sobre as fotos do projeto [Embaixada da França em Brasília] não podemos deixar de ser atraídos pelas duas rampas que servem o palácio residencial. Elas nos intrigam e despertam uma viva curiosidade estética. Que papel desempenham esses grandes e sólidos volumes em forma de cunhas? Não podemos olhar essas rampas sem pensar nos planos inclinados de arquiteturas do passado. É quase inevitável, por outro lado, relacioná-las com as rampas dos palácios da Praça dos Três Poderes. As rampas dos palácios de Niemeyer se alçam do chão, quase soltas no ar. Algumas são marcadas por uma pausa que lhe acentua a leveza no Palácio do Congresso, após o primeiro trecho divide-se num ramo que segue em nível, enquanto o outro se lança audaciosamente para galgar o teto da esplanada. As rampas das esplanadas de Le Corbusier são planos maciços, como terraplenos que descem do pavimento elevado, ligando o edifício à campina a sua volta. Elas nos parecem tão arcaicas que somos tentados a imaginá-las cobertas de pós e das folhas secas do cerrado. (CAMPELLO 1987:35, grifo nosso)

As evidentes diferenças entre as rampas de ambos os arquitetos simbolizam justamente a diferença seminal entre as arquiteturas de Le Corbusier e Oscar Niemeyer. Para Le Corbusier a dimensão plástica da arquitetura está indissociável da idéia de volume, ao passo que Niemeyer confere uma autonomia para sua própria obra justamente no instante em que rompe com o raciocínio purista de Le Corbusier, e dilui em plano e sombra o volume regulador das casas puristas (vide o projeto para o Pavilhão do Brasil em Nova York - 1938). [494], [495]

Se por um lado, os projetos de Le Corbusier pós-Ronchamp assumem uma intensidade plástica cada vez maior - fator que aproxima sua arquitetura da de Niemeyer - por outro lado, o arquiteto conserva intacta a integridade volumétrica de suas obras. Em projetos como o a Capela de Ronchamp, o Carpenter Center e o Palácio de Estrasbrugo, Le Corbusier dilui a estrutura purista em formas mais "maleáveis", mas ainda assimila a arquitetura como volume, como massa.

A valorização da arquitetura como um volume que sofre ocasionais subtrações, desbastes e adições é um dado que está presente em toda a obra de Le Corbusier, mesmo naqueles projetos que demonstram uma liberdade plástica pronunciada. Nesse sentido, poderíamos dizer que Le Corbusier, mesmo em seus projetos tardios, mantém intacto um pensamento de matriz cubista

363 o encontro de 1947: contra-influência 
que assimila a forma como um suporte físico para a intervenção compositiva do artista.

Ainda que nossa leitura estabeleça relações de proximidade entre os projetos do Cassino da Pampulha e o Carpenter Center, para Elizabeth Harris, o projeto de Le Corbusier em Harvard sofre grande influência do projeto de Oscar Niemeyer e Lucio Costa para o Pavilhão do Brasil na Feira Internacional de Nova York (1938). Seguem trechos em que a autora descreve as supostas semelhanças entre os projetos:

No Carpenter Center, construído entre 1961 e 1964, Le Corbusier pôs em prática vários dos motivos do Pavilhão Brasileiro de 1939; os conceitos básicos, entretanto, foram originalmente adaptados pelos brasileiros, a partir dos princípios corbuserianos. Antes de tudo, os edifícios partilhavam de um propósito comum por que continha áreas para exposições e auditório (...) algumas semelhanças eram inegáveis. Primeiro, a entrada para o Carpenter Center ficava no segundo andar e o acesso se dava por uma rampa que era reta na frente da fachada principal e curva na parte de trás, permitindo fácil circulação através do edifício. Cada prédio também incorporava um uso variado de quebra-sois.

No Carpenter Center, Le Corbusier alternou grandes quebra-sóis com “ondulatoires” assimetricamente colocados, que proporcionavam uma vista, apesar de controlar e dirigir a entrada da luz. O Pavilhão Brasi-

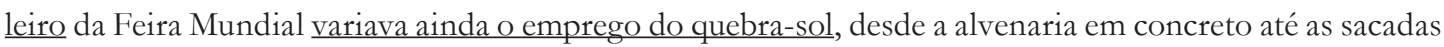
suspensas. Outro ponto era a incorporação de um auditório definido no exterior e contido no interior, que conservava o seu aspecto geral trapezoidal, enquanto permanecia dentro do corpo da estrutura.

No Carpenter Center, uma das formas semelhantes a pulmões delineava um auditório no primeiro andar. Finalmente as vigas "I" pintadas que formavam os pilotis do pavilhão brasileiro apresentavam a mesma característica espinhal dos finos pilotis que sustentavam o Carpenter Center. Uma indicação de que Le Corbusier estaria pensando nos brasileiros quando projetou esse edifício foi o fato de ter empregado um padrão curvo no piso, reminiscência da pedra portuguesa - as calçadas curvas em branco-e-preto que or-


a relação de Le Corbusier com os brasileiros pode ter sido reciprocamente inspiradora (HARRIS 1987:197, grifo nosso).

As comparações feitas por Harris expressam muito mais um desejo de encontrar relações de "contra-influência" do que constatações que atestem as similaridades efetivas entre os projetos.

Para justificar supostas afinidades, a autora agrupa semelhanças que são comuns, não apenas aos dois projetos, mas que caracterizam diversos projetos tanto de Oscar Niemeyer como de Le Corbusier, fator que fragiliza a afirmação da autora.

O auditório do Carpenter Center é um volume ovóide que interseciona um volume prismático, diferente do auditório do Pavilhão do Brasil que está inserido no interior da projeção de um terraço aberto resultado de um prolongamento em "L" do bloco de exposições. Quando a autora aponta a retícula de perfis se secção "I" do Pavilhão como fonte de inspiração para os "finos pilotis" do Carpenter Center, assume como parâmetro de mensuração dessa suposta semelhança um elemento recorrente em inúmeros projetos de ambos os arquitetos.

Elizabeth Harris fundamenta uma suposta relação de "contra-influência" ao elencar afinidades genéricas entre o Pavilhão de Costa e Niemeyer e o Carpenter Center de Le Corbusier. As semelhanças apontadas por Harris são comuns a inúmeros projetos de ambos os arquitetos, justamente por pertencerem ao vocabulário formal corbusiano que, por sua vez, fundamenta o 
próprio vocabulário formal de Oscar Niemeyer.

Os elementos de projeto que, segundo Harris, Le Corbusier incorpora do Pavilhão do Brasil e utiliza no Carpenter Center, na verdade são redesenhos que Costa e Niemeyer realizam sobre a própria arquitetura de Le Corbusier: rampa, quebra-sol fixo, auditório trapezoidal e piloti.

No texto $O$ clássico, o poético e o erótico: método, contexto e programa na obra de Oscar Niemeyer, Edson Mahfuz inicia sua análise crítica sobre a obra de Oscar Niemeyer, afirmando que

(...) até certo ponto, toda análise ou crítica de arte é uma obra de ficção. É possível que nada do que será dito a seguir corresponda a idéia que Oscar Niemeyer tem de sua própria arquitetura, e que muitas das características de sua obra apontadas aqui só existam na mente de quem a analisa. A verdadeira obra de arte possui uma densidade tal que permite várias interpretações, às vezes até conflitantes entre si (MAHFUZ 2002:122).

A delicada tarefa de clarificar aproximações entre as obras de dois artistas, inevitavelmente, se sujeita ao filtro crítico de quem a realiza. Ao cotejarmos o projeto de Oscar Niemeyer para o Cassino da Pampulha com o projeto de Le Corbusier para o Carpenter Center, apontamos uma série de semelhanças de procedimentos de projeto que sinalizam para um diálogo recíproco entre os arquitetos. Esse diálogo emerge nas sucessivas transformações atestadas na obra do "mestre" que, enquanto exercício de libertação com relação aos cânones puristas, faz eco à obra do próprio “discípulo”. [495] 



\section{Le Corbusier e "as premissas de um Novo Barroco vindo de fora" ${ }^{121}$}

Em duas passagens de seu livro intitulado A Forma na Arquitetura, Oscar Niemeyer aborda o tema da "contra-influência" e relata a importância de sua arquitetura no redirecionamento plástico da obra de Le Corbusier pós-1947. Para legitimar o argumento de sua influência sobre Le Corbusier, Niemeyer prefere alicerçar-se nas palavras de Amedée Ozenfant, em vez de construir uma lógica de raciocínio que ateste de maneira literal sua ascendência sobre a obra de Le Corbusier. Seguem trechos do autor:

De Ozenfant, amigo de Le Corbusier, recolhi, no seu livro de memórias, este trecho claro, de destino inconfundível: 'Le Corbusier, depois de ter defendido a disciplina purista e a lealdade ao ângulo reto, pelo qual pretendia direitos particulares, parece ter decidido abandoná-lo, ao sentir no vento as premissas de um novo barroco, vindo de fora, que faz justiça a ele mesmo e, como sempre, com um imenso talento'. (...)

Já não caminhávamos sozinhos. Os últimos projetos de Le Corbusier denunciavam, como disse Ozenfant, um alheamento ostensivo ao ângulo reto que sempre defendera. Não mais se limitava a jogar com os volumes, a fazer os apoios mais robustos do que o concreto armado propunha ou projetar fortes vigamentos de cobertura onde uma simples laje bastaria, mas a procurar deliberadamente a forma arquitetural: gratuita para os neo-funcionalistas, funcional para nós que, como ele, a compreendíamos como o caminho da beleza arquitetural (Ronchamp, Olivetti, etc.). E aplaudíamos intimamente o velho mestre. Fazíamos o mesmo, embora num sentido diferente, procurando a leveza arquitetônica (NIEMEYER 1978:29-40, grifo nosso).

Segundo Niemeyer, "as premissas de um novo barroco vindo de fora", denunciadas por Ozenfant na obra de Le Corbusier fazem menção a sua própria arquitetura - que foi devidamente apresentada e assimilada pelo "mestre" em seu segundo encontro com o arquiteto brasileiro em Nova York, por ocasião do projeto para a Sede da Organização das Nações Unidas em 1947.

Um outro indício de que Ozenfant se refere à arquitetura de Niemeyer está no trecho final de sua colocação, quando aponta esse "novo barroco" como uma obra que "faz justiça" a própria arquitetura de Le Corbusier "com um imenso talento". Esse trecho atesta que Ozenfant não apenas identifica a influência de Le Corbusier na arquitetura de Niemeyer, como reconhece

121. Termo utilizado por Amedée Ozenfant ao se referir a influência da arquitetura de Oscar Niemeyer sobre Le Corbusier (apud NIEMEYER, 1978:20-30)

367 | o encontro de 1947: contra-influência 
o talento do arquiteto brasileiro na livre apropriação dos estilemas arquitetônicos do arquiteto franco-suíço. E seria, justamente, essa liberdade na manipulação do vocabulário formal corbusiano, por parte do "discípulo", um fator que apontaria uma nova direção para a própria obra do "mestre".

Na segunda citação que faz a Ozenfant, Niemeyer revela que o "alheamento ostensivo ao ângulo reto", aparente nos últimos projetos de Le Corbusier, era um claro sinal de que "já não caminhávamos sozinhos" na especulação de uma nova dimensão plástica para a arquitetura moderna. Em um primeiro instante do texto, Niemeyer reconhece uma relação de sintonia entre sua arquitetura e os projetos de Le Corbusier caracterizados por uma maior liberdade formal. Mas no trecho final, Niemeyer deixa claro que, apesar da reciprocidade entre os arquitetos na procura da "forma arquitetural", há uma diferença crucial entre suas intençôes: "E aplaudíamos intimamente o velho mestre. Fazíamos o mesmo, embora num sentido diferente, procurando a leveza arquitetônica".

Com essa colocação, Niemeyer traz a tona uma questão crucial para a compreensão das diferentes liberdades presentes nas obras de ambos os arquitetos. Niemeyer assume que "a procura deliberada pela forma arquitetural" tornou-se um condicionante comum entre sua obra e a de Le Corbusier mas, por outro lado, o arquiteto brasileiro aponta que sua arquitetura caminhava "num sentido diferente".

O que Niemeyer quer dizer com essa afirmação? Que Le Corbusier não procurava a leveza arquitetônica? Algumas informações coletadas em uma entrevista ${ }^{122}$ realizada com Oscar Niemeyer podem clarificar as colocações feitas pelo arquiteto no livro A Forma na Arquitetura.

Quando perguntado sobre a existência de uma influência de sua arquitetura em projetos de Le Corbusier, como os palácios de Chandigarh, Niemeyer reage afirmativamente, mas salienta a presença da excessiva racionalidade nos palácios indianos, mesmo que ainda dotados de uma evidente plasticidade. Segue trecho da entrevista:

Rodrigo Queiroz: Mas, por exemplo, os Palácios de Chandigarh de Le Corbusier, será que eles não têm uma influência de sua arquitetura?

Oscar Niemeyer: Ah! Alí ele já procurou a curva, não é? Muito, não é? Mas a arquitetura dele, você vê, naqueles outros Congressos que ele fez: é linha reta.

RQ: Sobre meu próximo trabalho, você acha que tem fundamento defender essa tese sobre a sua influência sobre Le Corbusier?

ON: Não posso dar palpite, mas eu digo que tem influência sim, ele ficou mais sensível, com a coisa mais movimentada, mais leve.(...)

Isso é que é esquisito... ele [Le Corbusier] não seguiu a técnica, aqueles projetos de Chandigarh têm muitas colunas, não sei se ele quis fazer um negócio meio indiano... (...)

Para mim, o melhor projeto do Le Corbusier é aquele auditório que ele fez para Moscou, lembra? Tem um arco.

RQ: O Palácio dos Sovietes.

ON: Isso! Eu me lembro que naquele momento ele devia estar ligado com essa coisa dos tirantes, daí para

122. Entrevista realizada com Oscar Niemeyer em seu escritório no Rio de Janeiro em 02 de outubro de 2003. 
adiante ele esqueceu o progresso da técnica, continuou com os vãos pequenos.

A técnica permite mudar a arquitetura, os vãos que hoje a sociedade reclama, são os vãos que o concreto pode resolver. Lembre-se que, antigamente, se você tinha que fazer uma cúpula, no tempo da Renascença, fazia uma cupulazinha de vinte e cinco metros, hoje a gente faz de quase cem metros. O museu de Brasília tem uma cúpula de oitenta metros (NIEMEYER apud QUEIROZ, 2003:s.n, grifo nosso).

Nesse trecho da entrevista, Niemeyer não nega a influência de sua arquitetura sobre Le Corbusier, que naquele instante "procurou a curva". Entretanto, nessa mesma frase, o arquiteto denuncia uma suposta inconsistência na "busca pela beleza arquitetônica" na obra de Le Corbusier, ao apontar a presença da "linha reta" como condicionante dos demais edifícios do centro cívico de Chandigarh.

Na opinião de Niemeyer, será justamente essa incompatibilidade entre a evolução da plástica e o progresso da técnica que refreará a busca da "leveza arquitetônica" em projetos de Le Corbusier como os palácios do centro cívico de Chandigarh. Ele reafirma seu ponto de vista ao dizer que, naquela obra, "não seguiu a técnica", salientando a contradição entre as "muitas colunas" do palácio e a sua pronunciada intenção plástica ${ }^{123}$. Mais uma vez, o arquiteto brasileiro reitera seu estranhamento sobre a incoerência entre forma e técnica diagnóstica na obra de Le Corbusier.

Em seguida a crítica à incoerência entre partido formal e estrutura diagnosticada na obra de Le Corbusier, Niemeyer arremata dizendo que o projeto daquele arquiteto que mais lhe agrada é o Palácio dos Sovietes em Moscou (1932). Isso se dá justamente pela sublimação entre forma e técnica em um mesmo desenho, referindo-se ao arco parabólico que sustenta a cobertura do auditório com tirantes metálicos.

A escolha de Niemeyer não é aleatória. O projeto de Le Corbusier para Moscou atende à síntese entre forma e técnica reclamada por Niemeyer nos palácios de Chandigarh. Mas em seguida, ele arremata dizendo que, após o projeto para o Palácio dos Sovietes, Le Corbusier “esqueceu o progresso da técnica, continuou com os vãos pequenos”.

Após a análise dos trechos de A Forma na Arquitetura e da entrevista com Niemeyer, podemos concluir que, para o arquiteto brasileiro, a "leveza arquitetônica" deve estar intimamente ligada ao "progresso da técnica". Vem daí sua restrição com relação à liberdade plástica percebida nos projetos tardios de Le Corbusier, nos quais a expressividade da forma se apresenta como uma sobreposição a um esquema estrutural pré-definido, quase como um dispositivo aplicado $a$ posteriori. Nesse sentido, compreendemos o que Niemeyer quer dizer quando afirma que caminha num "sentido diferente" daquele diagnosticado em Le Corbusier.

Niemeyer evidencia os diferentes "caminhos da beleza arquitetural" assumidos por ele e por Le Corbusier para distinguir condutas opostas na proposição da forma livre. Enquanto Le Corbusier encontra uma nova plasticidade, que aflora de um modelo que remonta a um raciocínio ainda tributário ao esquema Dom-ino e aos cinco-pontos, Niemeyer confere uma autonomia à forma

123. Certamente, Niemeyer se referia ao Palácio da Assembléia de Chandigarh.

369 o encontro de 1947: contra-influência 

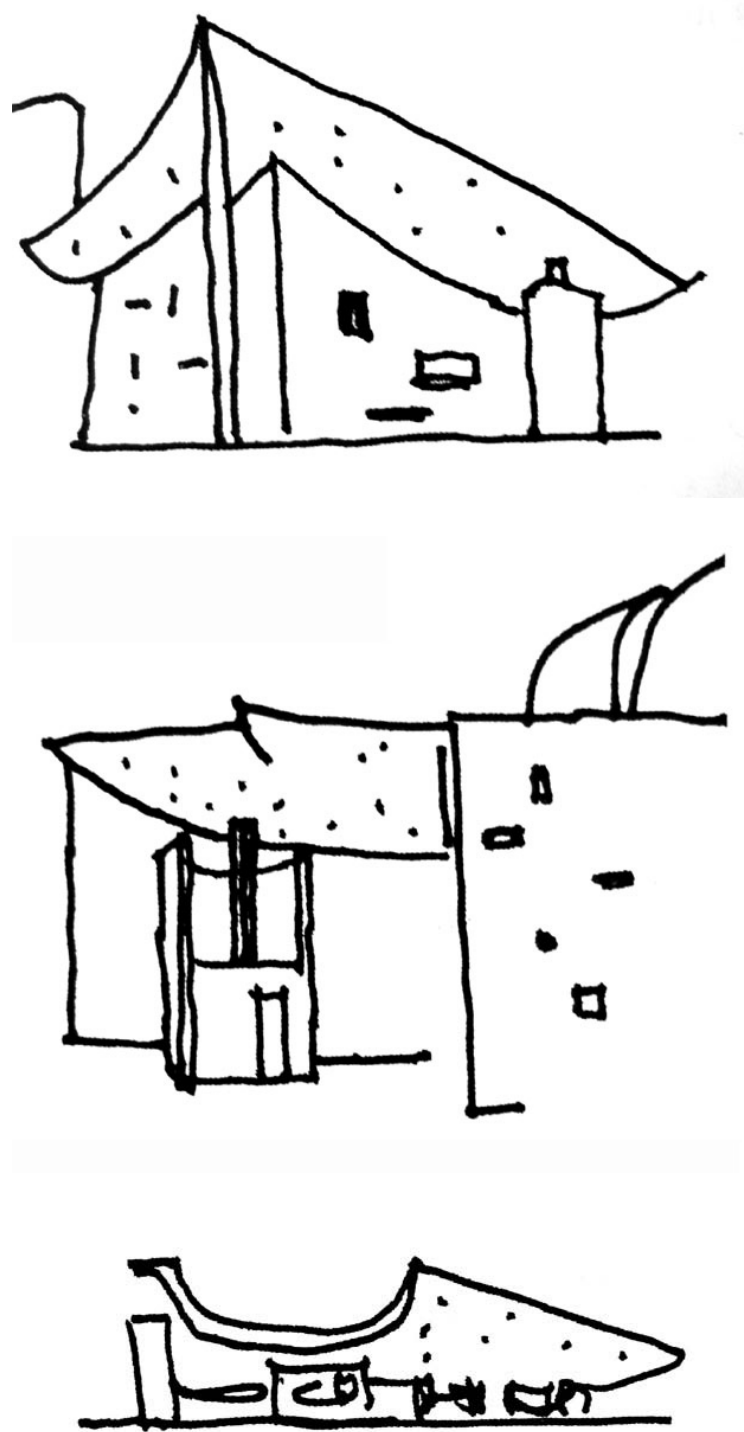

[496] Capela de Notre-Dame du-Haut em Ronchamp (1947/1951) projeto de Le Corbusier - croqui de Oscar

Niemeyer

(NIEMEYER, 1978:41)

[497] Capela de Notre-Dame du-Haut em Ronchamp (1947/1951) projeto de Le Corbusier - croqui de Oscar

Niemeyer

(NIEMEYER, 1978:41)

[498] Assembléia de Chandigarh (1951) projeto de Le Corbusier - croqui de Oscar Niemeyer

(NIEMEYER, 1978:41)


[499] Centro de Cálculos Eletrônicos da Olivetti em

Milão (1963) projeto de Le Corbusier - croqui de Oscar Niemeyer

(NIEMEYER, 1978:41)

[500] Centro de Cálculos Eletrônicos da Olivetti em Milão - maquete (1963) LC

(BOESIGER, 1965:129) 
livre, justamente no instante em que se desvincula daqueles procedimentos de projeto caracterizados como um redesenho do vocabulário purista de Le Corbusier.

O próprio projeto do Conjunto da Pampulha exemplifica, com precisão, esse itinerário que ilustra a paulatina libertação dos códigos formais corbusianos. Se no Cassino, na Casa de Baile e no Iate Clube, Niemeyer ainda preservava intacta a idéia da forma como extrusão vertical da planta (em que pese a evidente liberdade presente nos edifícios), na Igreja de São Francisco de Assis ele substitui os estilemas puristas de Le Corbusier por uma solução onde a forma é resultante de um gesto de movimento contínuo, que sublima arquitetura e estrutura em um mesmo perfil.

Em A Forma na Arquitetura, Niemeyer afirma que, em seus últimos projetos, Le Corbusier "não se limitava mais a jogar com os volumes" e que procurava "deliberadamente da forma arquitetural (...) como caminho da beleza”. Ao final dessa colocação, Niemeyer cita os projetos de Le Corbusier para a Capela de Ronchamp (1947/1951) e para o Centro de Cálculos Eletrônicos da Olivetti em Milão (1963) como exemplares da nova fase do arquiteto franco-suíço. Para ilustrar o comentário, o próprio Niemeyer faz um conjunto de croquis onde estão representados os dois projetos de Le Corbusier mencionados no texto, além do projeto do Palácio da Assembléia de Chandigarh (1951). [496], [497], [498], [499]

No projeto para o Centro de Cálculos Eletrônicos da Olivetti (1963), Le Corbusier lança mão de um partido arquitetônico e de uma solução formal que fazem eco a alguns projetos de Niemeyer realizados durante a primeira metade da década de 1950: conjunto de blocos suspensos (encurvados ou retilíneos) conectados por marquise sinuosa.

O projeto é constituído por duas lâminas suspensas, uma regular e outra curva, ambas com nítida proporção horizontal, interligadas por um corpo baixo distendido de contorno orgânico sobreposto a um embasamento ortogonal. Ao observarmos esse projeto, vêm à tona, em um primeiro instante, algumas soluções propostas por Niemeyer em projetos como o Conjunto Arquitetônico do Parque Ibirapuera (1951-1953) ou as diferentes versões para Hotel Quitandinha em Petrópolis (1950). A lembrança da obra de Niemeyer pós-Pampulha parece um movimento de raciocínio natural. O projeto de Le Corbusier, entretanto, possui uma corporalidade volumétrica sem precedentes na obra de Niemeyer. [500], [501], [502], [503], [504]

O projeto de Le Corbusier para a Olivetti, localizado em um terreno à margem da rodovia que liga Milão a Turim, é constituído da sobreposição de três componentes distintos do programa: oficinas de montagem; circulações/vestiários e laboratórios de pesquisa. O embasamento é formado por três pavilhões quadrados, com 105 metros de lado cada um, que abrigam as oficinas de montagem. A entrada principal consiste em uma rampa que ascende à cobertura dos pavilhões das oficinas. O corpo da rampa prolonga-se em um volume raso de contorno orgânico, que contém as circulações de distribuição e os vestiários dos 4000 funcionários, sobreposto aos pavilhões das oficinas de montagem. Suspensas sobre o conjunto formado pelo embasamento e pelo volume de circulações encontram-se duas lâminas de 10 pavimentos, que abrigam os laboratórios de pesquisa. A própria curvatura de uma das lâminas, constituída pela concordância

371 o encontro de 1947: contra-influência 



[501] Centro de Cálculos Eletrônicos da Olivetti em Milão - maquete (1963) LC

(BOESIGER, 1965:129)

[502] Hotel Quitandinha - Petrópolis - fotomontagem (1950) ON

(PAPADAKI, 1956:39)

[503] Conjunto arquitetônico do Parque Ibirapuera -

maquete (1951/1953) ON

(PAPADAKI, 1956:128)

[504] Centro de Cálculos Eletrônicos da Olivetti em Milão - implantação (1963) LC

(BOESIGER, 1965:117)


[505] Hotel Quitandinha em Petrópolis - croqui (1950) $\mathrm{ON}$

(PETIT, 1995:96)

[506] Conjunto arquitetônico do Parque Ibirapuera croqui (1951/1953) ON

(PETIT, 1995:91)

[507] Conjunto arquitetônico do Parque Ibirapuera (1951/1953) ON

(Revista Módulo n.01, março de 1955:22) 
de dois segmentos de reta às extremidades de um arco, aproxima-se do desenho empregado por Niemeyer no Hotel de Petrópolis.

Tanto a organização dos três elementos principais do projeto de Le Corbusier, como as suas respectivas propriedades plásticas apontam um distanciamento com relação à "procura pela leveza arquitetônica", tida por Niemeyer como seu diferencial com relação aos projetos tardios de Le Corbusier.

Em projetos como o Conjunto Arquitetônico do Parque Ibirapuera e o Hotel Quitandinha, Niemeyer estabelece uma relação de contraste entre as superfícies planares e suspensas das marquises e os volumes simplificados dos edifícios. Em ambos os projetos, as marquises sinuosas representam índices bidimensionais de recorte ondulante, que enfatizam a própria serenidade dos blocos laminares e vice-versa.

Niemeyer estabelece um senso compositivo que equaciona os diferentes gradientes formais dos componentes do conjunto em uma organização clara e objetiva. Não há o ruído da sobreposição de volumes presente na proposta de Le Corbusier para Milão. Niemeyer manipula os componentes do projeto com um evidente sentido de hierarquização da forma arquitetônica.

Para o arquiteto brasileiro, as marquises sinuosas representam plataformas delgadas e suspensas, que abrigam os percursos no nível do chão e servem de embasamento para a lâmina sobreposta a ela. O sentido da "leveza arquitetônica" tão apregoada por Niemeyer reside justamente nessa sensível relação entre planos e volumes.

No Conjunto Arquitetônico do Parque Ibirapuera, Niemeyer opera uma composição cujo campo material se reduz a uma gigantesca superfície horizontal suspensa e ondulante cujas extremidades desembocam nos térreos de blocos retangulares, ao passo que, no projeto para a Olivetti, Le Corbusier estabelece uma organização onde os componentes formais do projeto fundem-se entre si. O corpo horizontal e sinuoso que nos projetos de Niemeyer se reduz a uma esbelta marquise suspensa com relação ao chão, na versão de Le Corbusier apresenta-se como corpo maleável, espesso e orgânico acomodado diretamente sobre a plataforma de contorno ortogonal.

Por mais que as formas encurvadas, presentes em projetos como a sede da Olivetti em Milão, façam alusão a expressividade formal de Niemeyer, Le Corbusier assimila uma noção de liberdade da forma que incorpora um sentido de maleabilidade dúctil jamais visto na obra de Niemeyer. Se, para Niemeyer, a liberdade da forma é conseqüência de um redesenho paulatino do próprio vocabulário formal corbusiano, nos últimos projetos de Le Corbusier a forma livre assume uma configuração plástica de feição escultórica, preservando uma predileção pelo volume que sempre esteve presente em sua obra desde os exemplares puristas da década de 1920.

Enquanto no Conjunto Arquitetônico do Ibirapuera, ou no Hotel Quitandinha, Niemeyer preserva o caráter bidimensional da marquise sinuosa, contrapondo essa às massas suspensas dos edifícios, na Olivetti Le Corbusier justapõe volumes. A aparência de "massa" do corpo sinuoso da Olivetti, como um fluido viscoso esparramado diretamente sobre a cobertura dos pavilhões, atesta a denúncia de Niemeyer publicada em A Forma na Arquitetura. [505], [506], [507], [508]

373 o encontro de 1947: contra-influência 

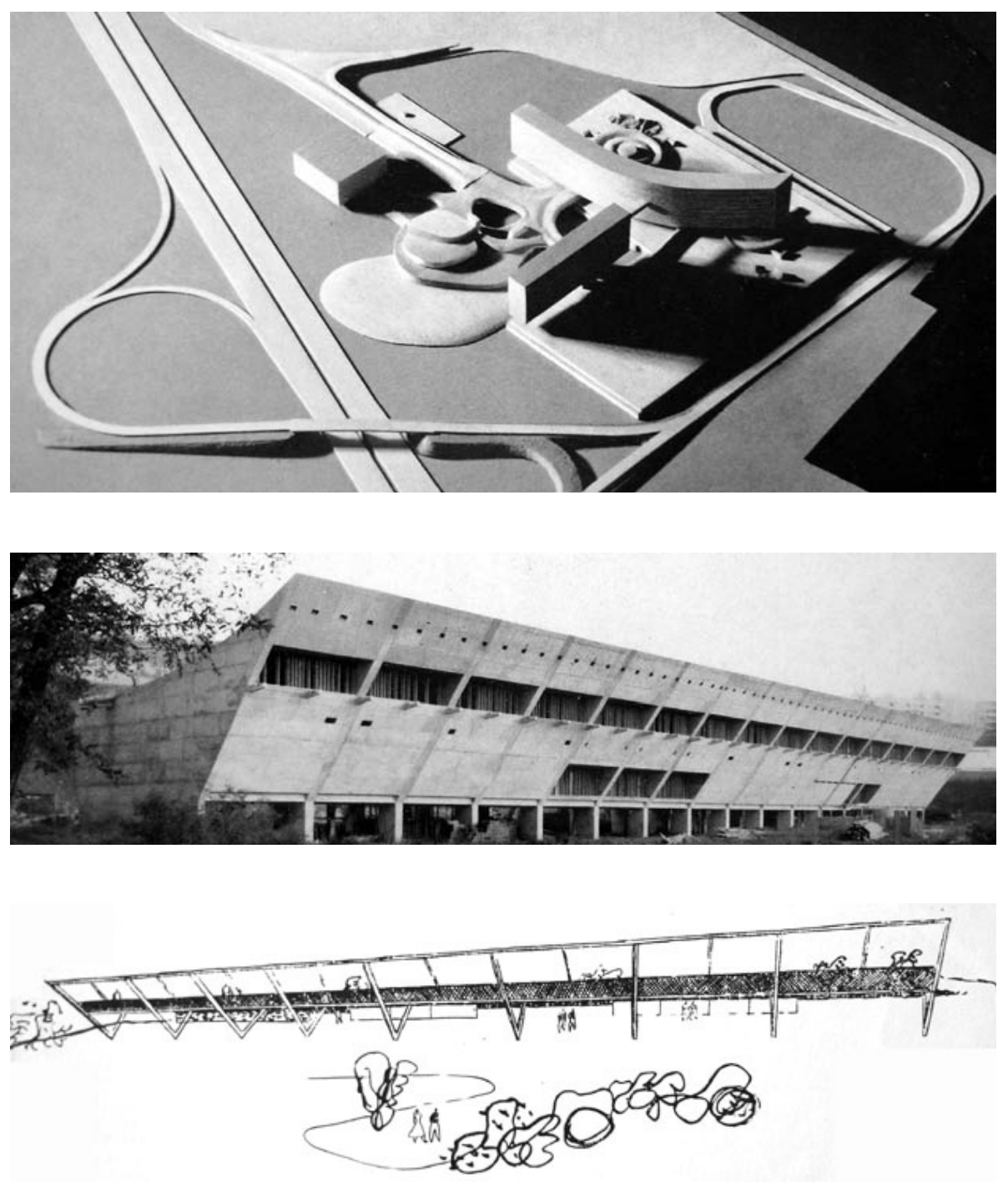

[508] Centro de Cálculos Eletrônicos da Olivetti em Milão - maquete (1963) LC

(BOESIGER, 1965:125)

[509] Casa dos Jovens e da Cultura em Firminy (1956-1963) LC

(BOESIGER, 1965:131)

[510] Hotel Tijuco em Diamantina - perspectiva (1951) ON

(PAPADAKI, 1956:101) 
Niemeyer reconhece o papel de sua arquitetura nas alterações ocorridas nos projetos tardios do "mestre". Entretanto, após a leitura da liberdade plástica de Le Corbusier no Centro de Cálculos da Olivetti, reconhecemos a precisão dos apontamentos de Niemeyer ao afirmar que, apesar das condutas semelhantes, "caminhava num sentido diferente, buscando a leveza arquitetônica".

Alguns projetos de Niemeyer realizados durante a primeira metade da década de 1950, como o próprio Conjunto Arquitetônico do Parque Ibirapuera e o Hotel Quitandinha, encontram rebatimentos em projetos de Le Corbusier realizados a partir da segunda metade da década de 1950. Devemos lembrar que esses projetos de Niemeyer são posteriores tanto à exposição e ao catálogo Brazil Builds (1943) como ao encontro com Le Corbusier em Nova York em 1947. A obra de Niemeyer pós-Pampulha tem como seu principal meio de divulgação os dois volumes organizados por Stamo Papadaki, respectivamente The Work of Oscar Niemeyer (1950) e Oscar Niemeyer: works in progress (1956).

O primeiro livro organizado por Stamo Papadaki, The Work of Oscar Niemeyer, cobre as fases iniciais da trajetória do arquiteto brasileiro (1937-1950), desde os antecedentes à Pampulha, como a Obra do Berço (1937) e o Grande Hotel de Ouro Preto (1938), até aqueles projetos caracterizados pela utilização indiscriminada do vocabulário formal lançado em Pampulha, como o Fluminense Iate Clube (1945) e o Hotel em Nova Friburgo (1945).

Em Oscar Niemeyer: Works in Progress estão presentes os projetos realizados pelo arquiteto brasileiro durante o período compreendido entre 1950 e 1955: dos grandes projetos urbanos como o Edifício Copan em São Paulo (1951) e o Conjunto JK em Belo Horizonte (1951) aos projetos que já apontavam para uma revisão elementarista do uso exaustivo do vocabulário formal da Pampulha, como o Conjunto da Fundação Getúlio Vargas no Rio de Janeiro (1955) e o Museu de Arte de Caracas (1955), passando por sua experiência em Diamantina, com os projetos para o Clube Municipal (1950), a Escola Julia Kubitschek (1951), o Hotel Tijuco (1951) e o Aeroporto Municipal (1954).

Em carta enviada para Oscar Niemeyer, datada de 15/07/1956, Le Corbusier elogia os projetos que integram o segundo volume editado por Papadaki: Oscar Niemeyer: Works in Progress. Segue trecho da carta:

(...) Escrevi-lhe outro dia, quando recebi o livro de Papadaki, para dizer-lhe o quanto acredito que você possua o senso arquitetônico inato. Resta ainda a experiência dos homens, que se realiza ao longo da vida e que pode trazer luzes a certos pontos imprevisíveis (LE CORBUSIER apud SANTOS, 1987:287, grifo nosso).

Ao reconhecer o "senso arquitetônico inato" dos projetos de Niemeyer, presentes no segundo volume de Stamo Papadaki, Le Corbusier revela sua admiração pelos projetos pósPampulha realizados pelo "discípulo". Os projetos de Niemeyer, que encontram rebatimento na proposta de Le Corbusier, para o Centro de Cálculos da Olivetti, como o Conjunto Arquitetônico do Parque Ibirapuera e o Hotel Quitandinha, integravam a edição Oscar Niemeyer: Works

375 o encontro de 1947: contra-influência 

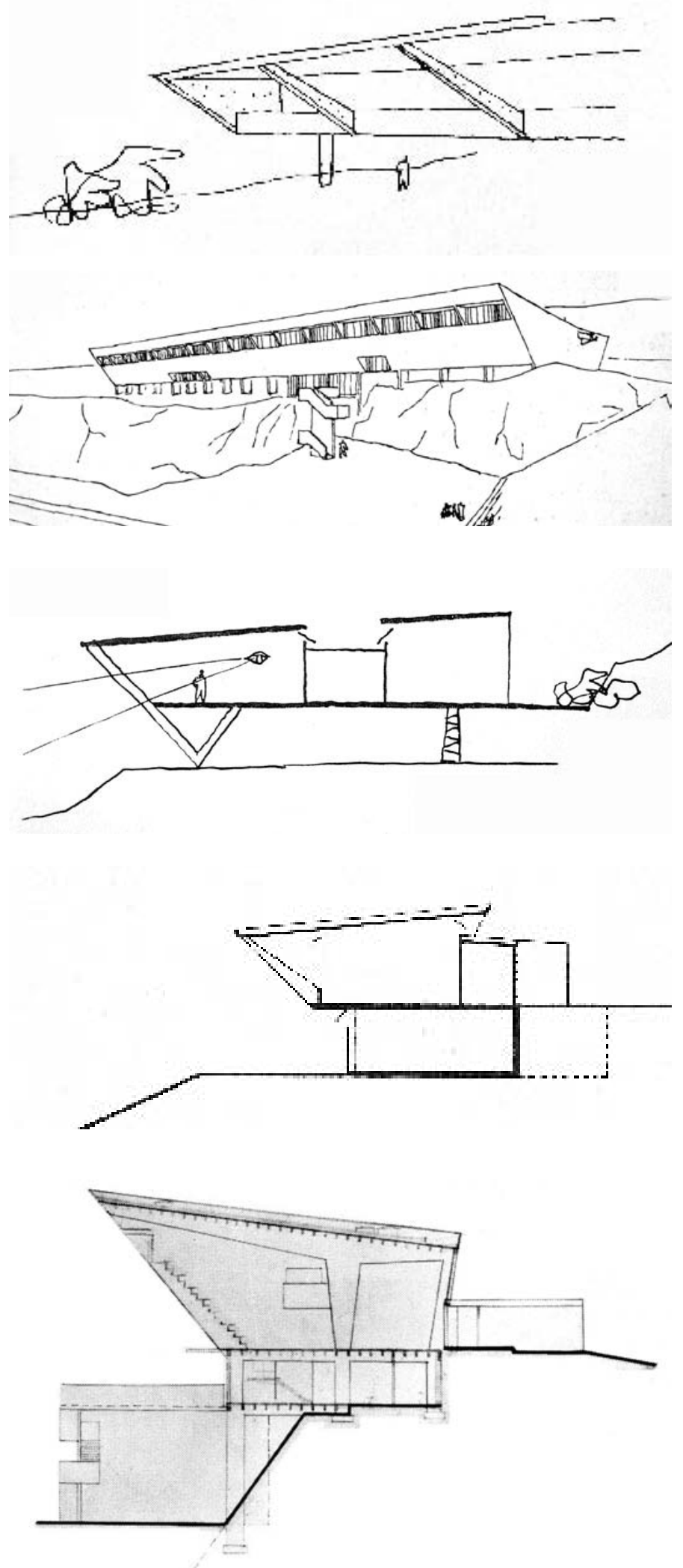

[511] Escola Julia Kubitschek em Diamantina - perspectiva (1951) ON (PAPADAKI, 1956:105)

[512] Casa dos Jovens e da Cultura em Firminy (1956-1963) LC

(BOESIGER, 1965:131)

[513] Hotel Tijuco em Diamantina - corte (1951) ON

(PAPADAKI, 1956:100)

[514] Escola Julia Kubitschek em Diamantina - corte (1951) ON

(PAPADAKI, 1956:107)

[515] Casa dos Jovens e da Cultura em Firminy (1956-1963) LC

(BOESIGER, 1970:35) 
in Progress. Mas esses não serão os únicos projetos de Niemeyer publicados por Papadaki que ecoarão nos projetos tardios de Le Corbusier.

O projeto de Le Corbusier para a Casa dos Jovens e da Cultura em Firminy (1956-1963) consiste de um bloco horizontal suspenso, de seção transversal trapezoidal, com sua face principal debruçada sobre topografia inclinada. Originalmente, esse edifício incorporaria a ruína de uma arquibancada existente no local. Mesmo com a alteração do local da implantação, Le Corbusier manteve o partido formal do edifício. [509]

Um olhar atento sobre o projeto de Niemeyer para a Escola Julia Kubitschek em Diamantina (1951), publicado em Oscar Niemeyer: Works in Progress, nos permite estabelecer algumas aproximações com o projeto de Le Corbusier para a Casa dos Jovens e da Cultura em Firminy.

$\mathrm{Na}$ escola de Diamantina, Niemeyer torna aérea a seqüência modular de pórticos sucessivos, com apoios inclinados que emergiam diretamente do solo, presentes em projetos como o bloco de habitação estudantil do Centro Tecnológico da Aeronáutica, em São José dos Campos (1947), e o próprio Hotel Tijuco em Diamantina (1951). [510], [511], [512]

O bloco inferior da Escola de Diamantina apresenta-se como um embasamento recolhido no interior da projeção do volume suspenso. O recuo dos fechamentos transparentes e do painel vazado por perfurações circulares no pavimento térreo enfatiza a expressividade plástica do próprio volume suspenso, cuja inclinação configura-se como um rebatimento da própria topografia. O arranjo dado pelo volume de fachada inclinada, sobreposto ao embasamento recuado, presente em Diamantina, repete-se no projeto de Le Corbusier em Firminy, cuja forma, assim como no projeto de Niemeyer, é definida como a extrusão linear de um contorno trapezoidal que espelha o perfil do terreno. [513], [514], [515]

Enquanto Niemeyer dilui o sentido volumétrico do edifício, ao recuar os fechamentos no interior da projeção dos planos exteriores, Le Corbusier assume um comportamento inverso, ao enfatizar a plasticidade da forma como um volume.

Assim como Niemeyer em Diamantina, em Firminy, Le Corbusier dispõe os caixilhos do bloco suspenso na posição vertical, recuados com relação ao plano inclinado da fachada. Porém, para Le Corbusier, a forma é suporte para uma intervenção subtrativa, ao passo que, para Niemeyer, a abertura não se comporta como uma supressão de parte da superfície da fachada. Ao contrário, a abertura expande-se ao limite físico do volume. Ao preservar apenas as espessuras da forma, Niemeyer distancia-se do raciocínio escultórico de matriz purista presente nos exemplares de Le Corbusier. Essa conduta de Niemeyer remonta a projetos como o Clube dos Estudantes da Universidade do Brasil (1937) e o Pavilhão do Brasil em Nova York (1938), onde a lógica da abertura como uma intervenção no volume, presente em projetos de Le Corbusier como o Pavilhão L'Esprit Nouveau (1925) ou a casa Stein (1927), é substituída por um raciocínio que substitui a simples obstrução da fenêtre longeur corbusiana por uma abertura cuja dimensão é a própria face do objeto.

No projeto de Niemeyer para a Escola Julia Kubitschek, a tão almejada leveza é conseqüência desse procedimento que inverte a concepção de volume, presente nos projetos de Le

377 | o encontro de 1947: contra-influência 

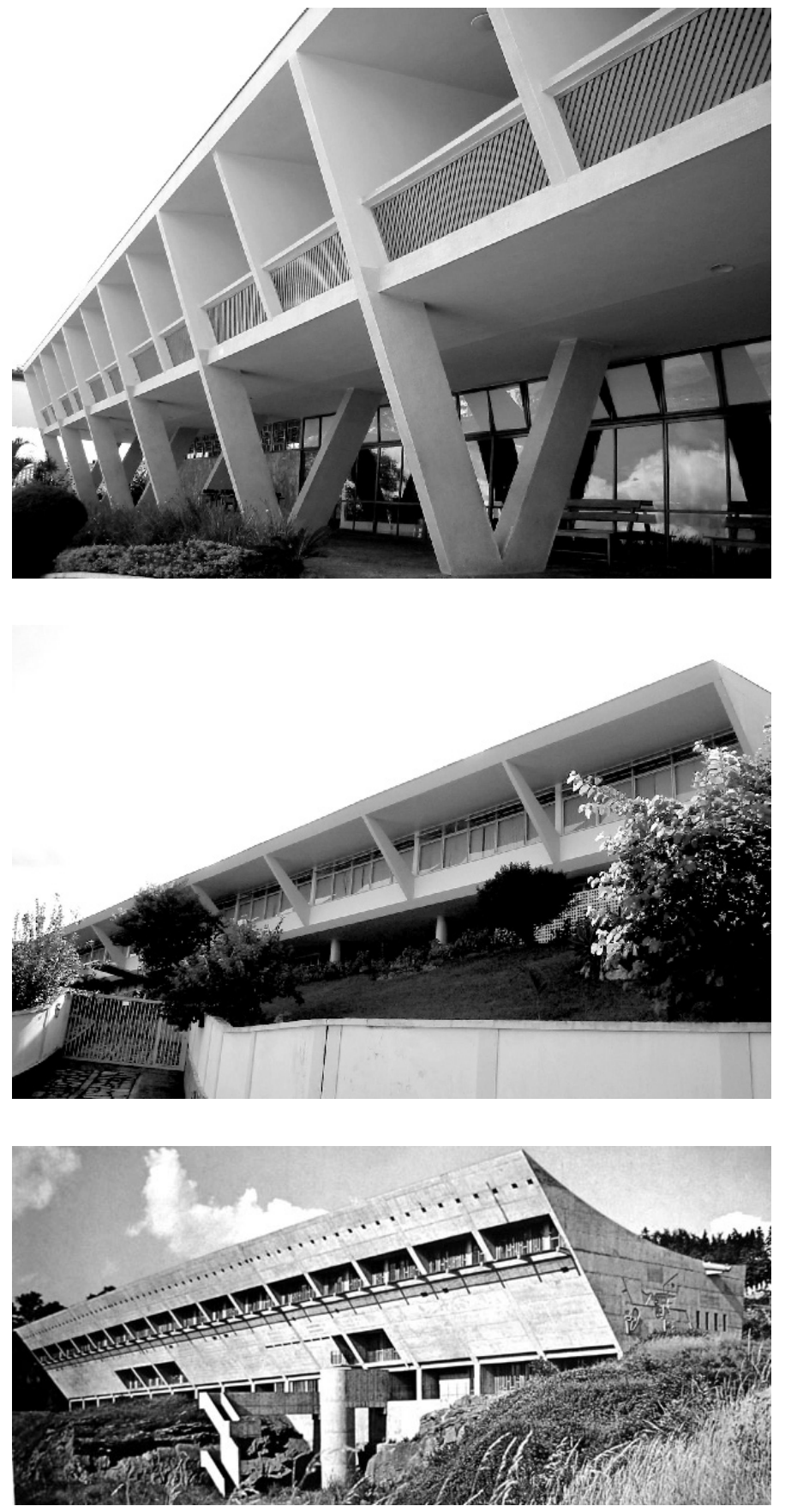

[516] Hotel Tijuco em Diamantina (1951) ON (foto: Rodrigo Queiroz)

[517] Escola Julia Kubitschek em Diamantina (1951) ON

(foto: Rodrigo Queiroz)

[518] Casa dos Jovens e da Cultura em Firminy (1956-1963) LC

(BOESIGER, 1970:31) 
Corbusier, preservada inclusive no próprio Centro de Jovens e Cultura em Firminy. Para Le Corbusier, a liberdade formal que caracteriza seus projetos tardios está relacionada muito mais a um sentido de plasticidade da forma do que ao sentido de leveza apregoado por Niemeyer. [516], [517], [518]

A liberdade presente na arquitetura de Niemeyer representa, antes de tudo, um exercício de autonomia com relação ao próprio vocabulário formal corbusiano. Nesse sentido, poderíamos dizer que Le Corbusier não se seduz pela "premissa de um novo barroco vindo de fora" como algo estranho à sua própria arquitetura. Ao contrário, o "mestre" vislumbra uma perspectiva estética na arquitetura do "discípulo", justamente por reconhecer a "paternidade" naquilo que Niemeyer ${ }^{124}$ chama de "invenção” (NIEMEYER apud QUEIROZ, 2003:sn).

124. Em entrevista concedida ao autor dessa tese em 02 de outubro de 2003, Niemeyer declara que “(...) A única coisa que recebi e aceito como uma influência dele [Le Corbusier] foi aquele dia em que ele me disse que 'arquitetura é invenção' e é”. 

o encontro de 1955: síntese e monumentalidade 



\section{Do Museu de Arte de Caracas a Brasília}

Os quatro anos compreendidos entre 1954 e 1958 representam o período de revisão crítica de Oscar Niemeyer, no qual soluções de projeto vinculadas ao arranjo de elementos formais presentes no conjunto arquitetônico da Pampulha (1940/1943), gradativamente, perdem espaço para propostas simples e concisas.

O projeto para o Museu de Arte de Caracas, realizado em 1955, ilustra um período de amadurecimento que culmina nos projetos para os Palácios de Brasília (1956/1957) e em seu Depoimento, publicado em fevereiro de 1958, onde Niemeyer esclarece os motivos que levaram à sua revisão crítica.

Os projetos de Oscar Niemeyer que sucedem sua experiência em Pampulha, em sua imensa maioria, versam sobre um conjunto de soluções que possuem como matriz formal os recursos utilizados em cada um dos edifícios da Pampulha: planta circular e marquise sinuosa na Casa de Baile; marquise sinuosa e pilar em "V" e planta circular irregular no Cassino; telhado invertido e plataforma no Iate Clube; abóbada e telhado invertido no Golfe Clube; bloco em curva, fachada inclinada e laje sinuosa/plataforma no Hotel Resort; abóbadas sucessivas e pilar em "V" na Igreja de São Francisco de Assis. ${ }^{125}$

Os projetos de Niemeyer realizados no período posterior a Pampulha podem ser considerados como variações, em diferentes intensidades, das soluções formais do projeto mineiro. Entretanto, devemos atentar para o fato de que as soluções presentes no conjunto da Pampulha não são conseqüência da mera "invenção", e sim variações sobre temas já abordados por Le Corbusier em projetos realizados entre 1919 e 1930, tais como: o pilar em "V", a marquise inclinada e o cilindro do Exército da Salvação (1929); as abóbadas sucessivas da Casa Monol (1919) e de seu estúdio particular (1929); o cilindro transparente e o paralelepípedo suspenso por um reticulado de pilares presente na casa Savoye (1929); a marquise arqueada da Liga das Nações em Genebra (1927) e do Centrosoyus (1929); o telhado invertido da casa Errazuris (1930), entre outros.

Nos projetos realizados entre 1942 e 1954, cada uma das soluções formais elencadas

125. (Cf.: VALLE, 2000).

383 o encontro de 1955: Síntese e Monumentalidade 
acima sofrerá transformações de escala, proporção e desenho. A organização dos diversos componentes desse conjunto de formas é conseqüência de estratégias compositivas onde, em alguns casos, um único projeto pode conter todas as soluções presentes em Pampulha.

Projetos como o Fluminense Iate Clube (1945), o Hotel Regente na Gávea (1949), o Restaurante e Garagem de Barcos da Lagoa Rodrigo de Freitas (1944), o Hotel em Nova Friburgo (1945) e a Residência Burton-Tremaine na Califórnia (1947) são exemplares que se constituem a partir da manipulação de todos os componentes formais presentes no conjunto da Pampulha.

Esses componentes se relacionam conforme uma estratégia que estabelece padrões de hierarquia entre as formas expressivas - consideradas como apêndices ornamentais - e as formas simplificadas derivadas de volumetrias prismáticas.

É evidente que a produção de Niemeyer posterior à experiência em Pampulha não se resume apenas às variações originais sobre os temas formais lançados no projeto de Belo Horizonte. E, certamente, o raciocínio de Niemeyer não deve ser compreendido como uma mera equação combinatória. O repertório formal de Pampulha representa a gênese criativa de uma obra calcada, antes de tudo, na sensibilidade.

Entre os projetos dos edifícios da Pampulha (1940-1943) e os projetos que ilustram sua revisão crítica, realizados a partir de 1954, Niemeyer executa algumas obras-chave para o desenvolvimento de sua pesquisa pessoal, tais como os projetos em Diamantina para a Escola Julia Kubitschek e para o Hotel Tijuco (1951), o Conjunto do Parque Ibirapuera (1951-1953) e sua residência particular na estrada de Canoas no Rio de Janeiro (1953).

Os projetos de Niemeyer que sucedem a experiência em Pampulha não serão reconhecidos pelo ineditismo de suas formas, mas serão compreendidos como uma variação sobre um original, ou seja, a própria matriz que contém a gênese criadora de Niemeyer: Pampulha.

Niemeyer se arrisca ao tornar subjetivo e meramente ornamental aquilo que, pelo menos em Pampulha, tinha a força suficiente para caracterizar o edifício como um todo.

Quando um único objeto configura-se como o arranjo de diversos elementos formais diferentes, oriundos do gesto que concebeu os sete edifícios da Pampulha, a solução formal que antes caracterizava o perfil do edifício assume a condição de ornamento.

A exaustiva manipulação das soluções formais consagradas em Pampulha fragilizará o valor e o sentido arquitetônico de projetos constituídos a partir de uma formulação sobre um repertório conhecido. O visível desgaste de uma linguagem que se estabelece sobre um conjunto restrito de soluções formais é um sintoma diagnosticado em textos como os de Luis Saia e de Max Bill.

No artigo intitulado " $A$ fase beróica da arquitetura contemporânea brasileira”, publicado no jornal paulista A Folha da Manhã no dia 31 de marco de 1954, Luis Saia afirma que a arquitetura moderna brasileira seduziu-se pela simpatia de soluções formais elegantes que, ao serem reproduzidas e redesenhadas indiscriminadamente, reduzem-se ao mero estilo, onde “(...) muito arquiteto já maduro e experimentado pratica impunemente o mais desbragado academicismo modernista." (SAIA apud XAVIER, 2003:228). 
Segundo Saia, quando a reflexão sobre nossa produção moderna se restringe a "discussão bizantina de pormenores formais”, faz-se necessária uma “(...) revisão incômoda das verdades que atualmente se impingem aos incautos, mas que não resistem a menor crítica (...)” (Idem, grifo nosso).

Quando o autor refere-se à necessidade de uma "revisão incômoda", admite que, para tanto, seriam necessários alguns sacrifícios que penalizariam diretamente a arquitetura que encerra na forma seu debate.

Ao apontar os estilemas formais lançados por Niemeyer e adotados pelos arquitetos modernos como modelo, Saia relativiza a vigência de uma produção nacional que adota como regra um sistema de formas que teve um duplo papel: alçar Pampulha ao status de obra-prima e, em virtude disso, ser transformado em modelo polivalente.

Em seu artigo, Saia elege um rol de soluções mágicas que, segundo o autor, restringiram a discussão da produção nacional ao universo meramente plástico. Saia diz que

as cartas do atual 'baralhão' são poucas e fáceis, eficientes e redondas: meia dúzia de soluções formais e algumas palavras de poder mágico: 'brise-soleil', 'colunas em v', 'pilotis', 'amebas', 'panos contínuos de vidro', 'moderno', 'funcional', etc. (Idem, grifo nosso).

As "cartas do baralhão" eleitas por Saia coincidem com os elementos formais que Niemeyer lança em Pampulha e que, em seus projetos seguintes, assumem o papel de modelo. Ao elencar e condenar os elementos típicos de uma arquitetura da "forma livre", Luis Saia coloca à tona algumas verdades oportunas, apontando a necessidade de uma revisão crítica sobre uma produção em crise de significado, onde a subjetividade do gosto e a síndrome da originalidade não teriam a densidade suficiente para legitimar essa arquitetura por muito tempo.

Segundo Luis Saia, estamos ainda “(...) aprisionados no rabo do foguete estético” (Ibid.:230) fator que impede que se realize um a reflexão crítica mais franca e isenta sobre o papel do arquiteto na sociedade.

Para legitimar seu ponto de vista, Saia corrobora com as críticas realizadas pelos especialistas estrangeiros que "(...) não deixam de ter procedência quando encaradas de um ponto de vista criterioso.” (Ibid.:228).

O teor da crítica internacional transitará entre a benevolência de Siegfried Giedion em "O Brasil e a arquitetura contemporânea" - que é prefácio de Arquitetura Moderna no Brasil de Henrique Mindlin, o que explica o caráter enaltecedor do texto - e a severidade extremada de Max Bill em $O$ arquiteto, a arquitetura, a sociedade, onde o autor desfere um ponto de vista “(...) franco e desimpedido de formalidades. Ficaria desgostoso comigo mesmo se não afirmasse que a arquitetura brasileira corre o risco de cair em um perigoso academicismo anti-social." (BILL apud XAVIER,2003:159).

As preocupações de Max Bill aproximam-se daquelas presentes no texto de Luis Saia. O fascinante jogo das formas livres havia reduzido a produção nacional às infinitas variações combinatórias cujo tema é comum tanto às formas que Niemeyer elege posteriormente à

385 o encontro de 1955: Síntese e Monumentalidade 
experiência de Pampulha quanto às soluções que Luis Saia condena em seu texto.

Max Bill identifica, em quatro elementos presentes na arquitetura brasileira, aquilo que, segundo o autor, “(...) materializam o que chamarei de espírito acadêmico modernizado": forma livre, cortina de vidro, brise-soleil e piloti, esse último, "nos últimos anos variou um pouco, conforme a 'última moda parisiense', ditada pelo escritório de Le Corbusier." (Idem, grifo nosso)

Em seu texto, Max Bill indica uma espécie de tragédia anunciada, onde o fascínio pela liberdade da forma sedutora impede os avanços na esfera social e urbana. Após visitar as obras do edifício da Galeria Califórnia na cidade de São Paulo, projeto de Oscar Niemeyer, o autor acredita que

(...) caso não reflitam cuidadosamente sobre as responsabilidades do arquiteto para com o homem e a sociedade, vocês podem incorrer em erros semelhantes, pois, de fato, à primeira vista, tal arquitetura pode parecer revolucionária e ser festejada como obra de arte." (Ibid.161, grifo nosso).

$\mathrm{Na}$ tentativa de redirecionar o foco de um debate embasado pelo primado da forma livre, Max Bill pontua questões cruciais que visam a revisão do juízo de valor que recai sobre a produção nacional: "Mas qual a forma estruturadora que estamos procurando? Seria aquela caracterizada pela forma livre, pilotis, brise-soleils e cortina de vidro? Tem que ser tão fotogênica e espetacular assim? Não creio.” (Ibid.162, grifo nosso).

Em entrevista concedida a revista Habitat em setembro de 1953, Max Bill não poupa de suas críticas nem o projeto para a sede do MES, e diz que “(...) os azulejos quebram a harmonia do conjunto, são inúteis e, como tal, não deveriam ter sido colocados. (...) Aliás, a arquitetura moderna brasileira padece um pouco desse amor ao inútil, ao simplesmente decorativo." (BILL, 1953:34, grifo nosso) .

Para Max Bill, a arquitetura moderna brasileira, ao seduzir-se pela forma livre, desconsidera o seu compromisso social. Sobre Pampulha, o artista e crítico é enfático:

Niemeyer, apesar de seu evidente talento, projetou-o por instinto, por simples amor à forma pela forma; elaborou-o em torno de curvas caprichosas e gratuitas, cujo sentido arquitetural apenas para si mesmo é evidente. $\mathrm{O}$ resultado disso é um barroquismo excessivo que não pertence à arquitetura nem à escultura. (Idem, grifo nosso).

Devido ao ponto de vista racionalista de Max Bill, que postula que “(...) em arquitetura tudo deve ter sua lógica, sua função imediata” (Idem), poucos exemplares da produção nacional estariam ilesos de comentários agudos. Apenas o Conjunto de Pedregulho de Affonso Eduardo Reidy inspira elogios por parte de Bill.

É evidente que os arquitetos brasileiros não verão com bons olhos as opiniões cristalinas e pouco diplomáticas de Max Bill, que será alvo da réplica arguta de Lucio Costa em seu texto Desencontro de 1953: 
(...) Quase me envergonho de abordar tais pormenores para rejeitar uma crítica viciosa e carregada de velhos recalques pueris contra os princípios básicos da doutrina de Le Corbusier. O edifício do Ministério, malgrado o desamor com que é tratado pelo crítico e pelos encarregados da sua conservação, há de ser sempre considerado, pela opinião profissional isenta de prevenção, um dos marcos fundamentais da arquitetura contemporânea (...) (COSTA 1995:202, grifo nosso).

Sobre Pampulha, Lucio Costa (idem) rebate a crítica de Max Bill argumentando que o conjunto de Niemeyer não tinha como premissa o compromisso com a coletividade, bastando uma análise sobre o programa proposto:

Trata-se de um conjunto de edificações programadas para a burguesia capitalista - um cassino, um iateclube, uma casa de baile. Cada qual foi traduzido arquitetonicamente com seu caráter próprio inconfundível, a belíssima entrada, a sábia conexão das salas de jogos e do teatro, tudo agenciado com maestria; no iate a linha distendida puríssima; no baile, o dengue gracioso que lhe convém. Nada disto coube na visão estreita do mestre de Ulm, (...) (Idem).

Niemeyer, em seu livro Minha Arquitetura corrobora com as colocações de Costa sobre as críticas enérgicas desferidas por Max Bill:

Às vezes surge o indesejável, e um intruso é levado a exibir sua pretensão descabida. Foi o que aconteceu com Max Bill, que, de passagem pelo Rio, se permitiu criticar Pampulha. Lucio Costa, pelos jornais, deu-lhe a resposta adequada: 'Sem Pampulha, Pedregulho não existiria.' E, de longe - como as coisas se propagam! - Alvar Aalto me escreveu: 'Niemeyer, hoje pus a última pá de cal em cima de Max Bill.' E o trêfego homenzinho voltou a sua insignificância (NIEMEYER 2000:24).

Em Pretextos para uma crítica não formalista, Ernesto Nathan Rogers destila uma crítica severa sobre a arquitetura moderna brasileira e sobre parte das obras de Niemeyer, e reconhece tanto os exageros agressivos de Max Bill como a condescendência de Siegfried Giedion (ambos suíços). Acredita ainda que "Observar a arquitetura brasileira sob um ângulo particular (por exemplo, suíço) é, de qualquer forma um erro de abstração que - por ilação - conduz a excessivas e condenáveis polaridades da crítica formalista.” (ROGERS apud XAVIER, 2003:166).

Rogers compreende como formalista uma crítica que utiliza o aporte do gosto ou da crença pessoal como parâmetro de julgamento.

Segundo o autor:

É um erro crítico que ousaria incluir na categoria de formalismo o fato de comparar com as próprias preferências poéticas o resultado estético que um artista alcança por ser fiel à poética que lhe é inata. Não menos do que outro erro bastante freqüente, de julgar um artista por seus imitadores. Pois se, de fato, os inúmeros imitadores compatriotas de Niemeyer são muitas vezes um desastre e há tolos que transplantam a semente dele para territórios impróprios, como fazem alguns charlatães,(...) (Ibid.168, grifo nosso).

Ao eximir de Niemeyer a responsabilidade pelo tortuoso caminho tomado pela arquitetura moderna brasileira, Rogers aponta a obra do arquiteto brasileiro como modelo para toda uma

387 | o encontro de 1955: Síntese e Monumentalidade 
geração desprovida da mesma habilidade, essa sim, responsável pela proliferação de um caos estético provocado pela manipulação indiscriminada das cartas do "baralhão" apontado por Saia.

Mas, certamente, Rogers também percebeu que a obra de Niemeyer não é modelo apenas para uma legião de arquitetos doutrinados na arte do arranjo das formas, mas é modelo para si mesmo.

Ao transformar as soluções formais de Pampulha em componentes de um procedimento de projeto, Niemeyer estrutura sua obra a partir da manipulação de modelos que assumem perfis e arranjam-se entre si conforme infinitas configurações. Essa capacidade de diversificar-se a partir da organização de um repertório restrito de formas dará o fôlego suficiente para uma produção que perdurará, no mínimo, por quatorze anos (1940/1954).

Os diagnósticos de Luis Saia, Max Bill e Ernesto Nathan Rogers correspondem ao de Giulio Carlo Argan que, em seu texto Arquitetura Moderna no Brasil aponta que “(...) o problema que mais urgentemente se coloca para o desenvolvimento moderno brasileiro, para além dos seus limites atuais, é justamente a superação do formalismo técnico." (ARGAN apud XAVIER, 2003:173-174, grifo nosso).

Argan indica que o rigor técnico e estético presente nos exemplares da arquitetura moderna brasileira não encontram paralelo no desenho urbano e entende que o grande desafio para os arquitetos brasileiros reside muito mais na questão urbana do que no refinamento estilístico de um modelo sacralizado.

Segundo o autor, faz-se necessária uma revisão do foco e da escala do problema, que não se encerra no objeto, mas que deve enfrentar a cidade. Segue trecho em que Argan coloca como fundamental a inserção da problemática urbana no debate da arquitetura:

É evidente que a posição pela qual a arquitetura moderna brasileira pôde alcançar o atual nível de especialização técnica e estética não é mais adequada para enfrentar, em toda sua extensão, o problema essencialmente social de um grande programa urbanístico (Idem, 174).

Argan acredita que a arquitetura moderna brasileira só terá condições de evoluir quando tiver a autonomia suficiente e a maturidade para "sacrificar algumas das fórmulas venturosas" (Idem). As fórmulas que Argan se refere correspondem às cartas eleitas por Saia em seu "baralhão":

(...) talvez seja necessário sacrificar algumas das 'fórmulas' venturosas que lhe permitiram alcançar o alto grau de qualificação técnica e estilística (...); mas será também por essa via que a nova arquitetura brasileira poderá conseguir, como caracterização histórica concreta e não apenas como inovação formal, uma originalidade profunda e autêntica." (idem, grifo nosso).

Marco do Valle, em sua tese "Desenvolvimento da Forma e procedimentos de projeto na arquitetura de Oscar Niemeyer (1935-1998)" aponta para o fato de que os mesmos atributos que durante a década de 1940 conferiram notoriedade internacional à arquitetura moderna brasileira, a partir de meados da década de 1950, cumprem o papel inverso: serão o tema da crítica internacional.

Segue trecho do autor: 
A polêmica gerada pela crítica internacional especializada, que reverberou em um debate da arquitetura brasileira, que estava sendo criticada exatamente pela mesma característica que a projetara internacionalmente, qual seja, a demonstração das capacidades semânticas e programáticas do estilo e a revelação de possibilidades formais até então inexploradas. Tratadas como barroquismo excessivo que não pertenciam nem à arquitetura nem à escultura, (...) (VALLE 2000:15, grifo nosso).

Devemos lembrar que os artigos de Saia, Bill, Rogers e Argan foram publicados em 1954, ano que, não por mera coincidência, deflagra um evidente redirecionamento plástico na obra de Oscar Niemeyer, como podemos observar em projetos como a TV-Rio (1954), o Museu de Arte de Caracas (1955) e a residência Cavanelas (1954). [519]

Nesses projetos inexistem as soluções condenadas por Luis Saia e Max Bill. O jogo entre marquises sinuosas, abóbadas e pilotis escultóricos dá lugar a soluções nitidamente simplificadas e concisas, onde o programa não mais se organiza a partir da justaposição compositiva de formas livres, mas abriga-se sob um traço rigoroso e elementar.

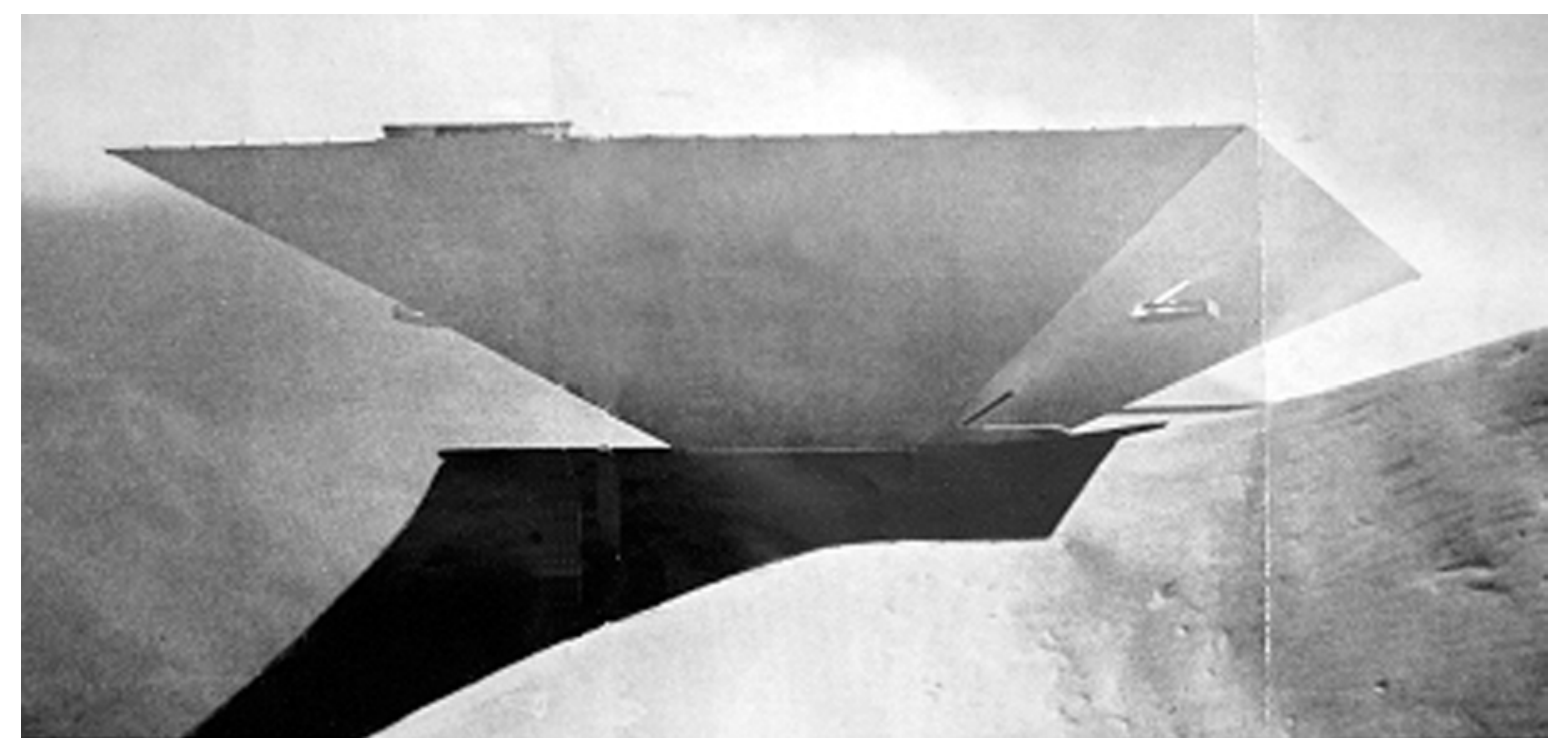

[519] Museu de Arte de Caracas - maquete (1955) ON (Revista Módulo n.04 - março/1956:sn) 



\section{Revisão crítica de Oscar Niemeyer: dos projetos realizados a partir de 1954 ao "Depoimento" de 1958}

Apesar do desagrado e do mal estar provocados pelas severas críticas sofridas a partir de 1953, os projetos de Niemeyer realizados a partir de 1954 mostram um realinhamento que coincide com a perspectiva presente nos ataques dos críticos. As "cartas do baralhão" colocadas em cheque por Luis Saia serão revistas nos projetos de Niemeyer, que já indica um abandono paulatino da metodologia compositiva e organizacional sobre o vocabulário da Pampulha presente nos projetos realizados entre 1942 e 1953.

O fato de Niemeyer não receber com bons olhos as críticas desferidas a partir de 1953, não significa que, no ofício da profissão, na prancheta, o arquiteto não as considere como parâmetro para legitimar uma nova fase que depura a profusão da forma livre em perfis elementares.

Entre as críticas sofridas entre 1953 e 1954 e seu aclamado Depoimento de 1958, Niemeyer realiza uma série de projetos que se alinham aos preceitos de unidade, simplicidade e pureza presentes no relato pessoal ${ }^{126}$ do arquiteto. E será somente após a manipulação de programas distintos sob a perspectiva de uma linguagem concisa, a partir da fusão entre forma e estrutura, que Niemeyer se sentirá preparado para elaborar um texto que explique o desgaste da originalidade subjetiva e que anuncie sua nova fase.

O projeto para o Museu de Arte de Caracas (1955) não representa apenas a reação de Niemeyer às críticas sofridas, mas simboliza um novo período que culminará nos projetos para Brasília: o primeiro estudo para o centro cívico - à margem do Lago Paranoá (1956) - e no projeto definitivo dos Palácios, após a realização do concurso para o Plano Piloto (1957).

No projeto para a TV-Rio (1954), Niemeyer concebe um conjunto a partir da manipulação de volumetrias simplificadas que se articulam através de marquise estreita e linear, indicando um apuro tanto no desenho como na forma. Os objetos constituem-se de massas praticamente cegas e de contornos sintéticos: um volume ovóide achatado de planta circular - próximo da solução do batistério da Catedral Metropolitana de Brasília - que se conecta a um volume de planta quadrada e de distendida proporção horizontal; e um volume prismático de seção triangular com

126. O texto intitulado Depoimento foi publicado na revista Módulo n.09 em fevereiro de 1958.

391 o encontro de 1955: Síntese e Monumentalidade 

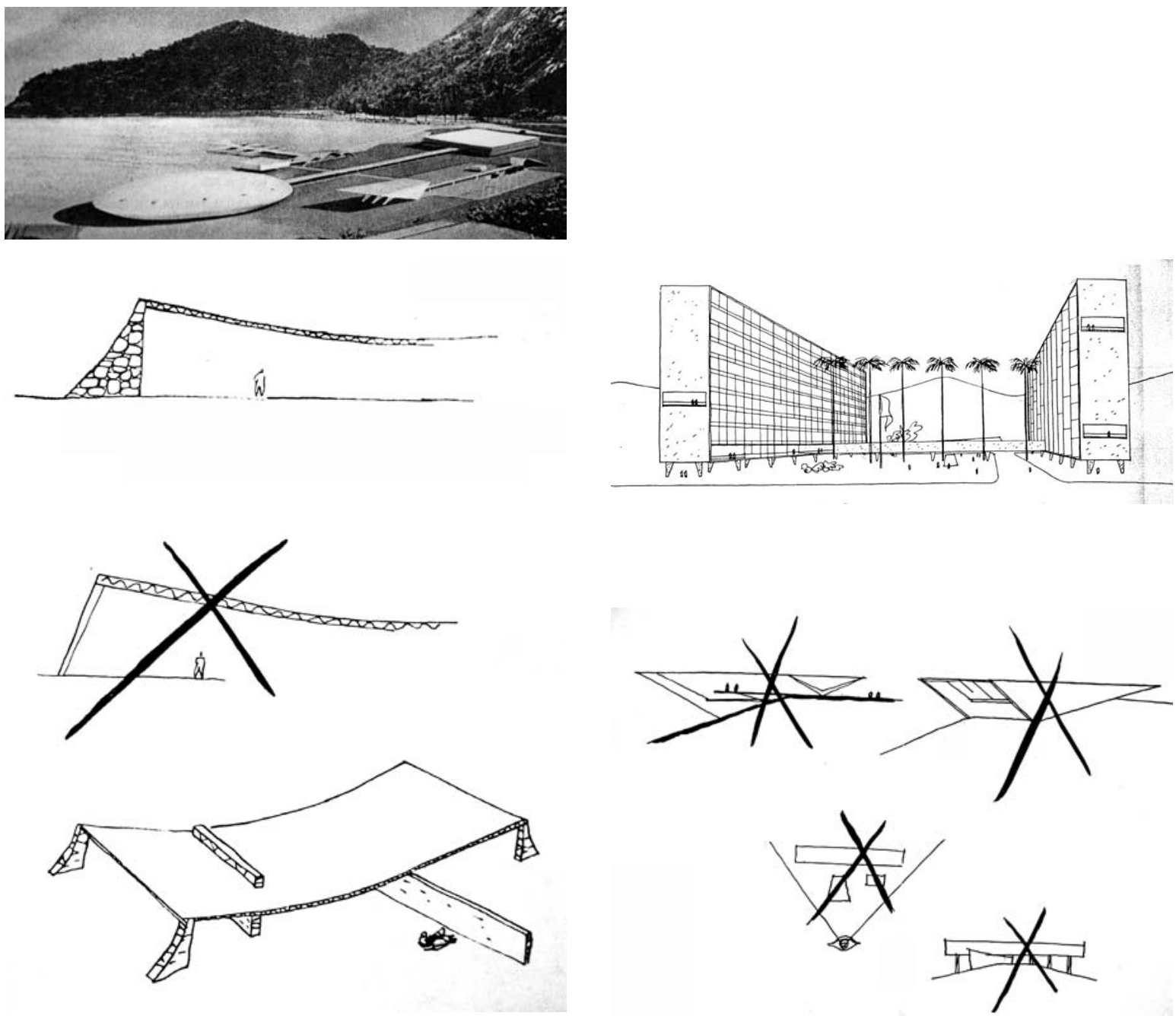

[520] Estação da TV Rio - Rio de Janeiro - 1954 - ON (PAPADAKI, 1956:191)

[521] Residência Cavanelas - 1954 - ON

(PAPADAKI, 1956:79)

[522] Fundação Getúlio Vargas - Rio de Janeiro, 1954 $\mathrm{ON}$

(PAPADAKI, 1956:168)

[523] Museu de Arte de Caracas - estudos - 1955 - ON (Revista Módulo n.04, p.38)

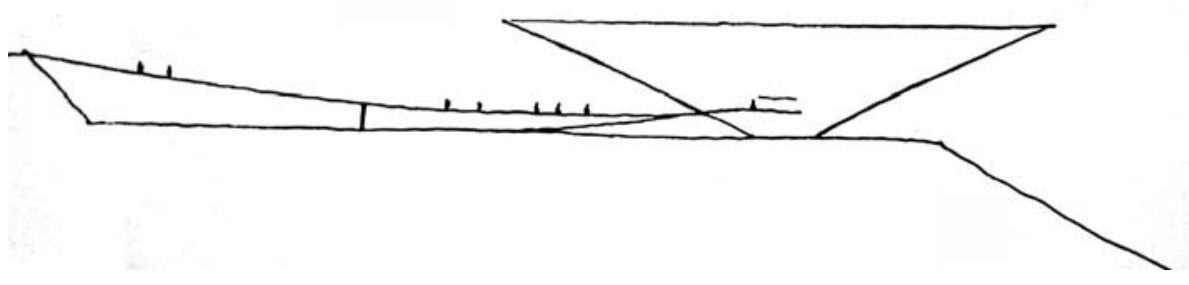

[524] Museu de Arte de Caracas - croqui - 1955 - ON (Revista Módulo n.04, p.38) 
um de seus vértices voltados para o solo - solução já utilizada no auditório para o Parque Ibirapuera em São Paulo (1951) - conectado por marquise a uma abobadada aberta. [520]

Enquanto a maioria das residências projetadas por Niemeyer até 1954 ainda versavam sobre uma apropriação doméstica dos elementos formais empregados no conjunto da Pampulha, seu projeto para a residência Cavanelas (1954) ilustra um momento em que o programa da moradia se resume a uma generosa espacialidade miesiana abrigada por uma cobertura em catenária de sutil curvatura apoiada em quatro pilares que se alargam em direção ao solo, cujo desenho é a plena antítese da própria catenária. [521]

No projeto para a Fundação Getúlio Vargas no Rio de Janeiro (1955 - versão preliminar), as lâminas que constituem o conjunto possuem feição elementar, sintética, indicando um claro distanciamento daquelas soluções em que as lâminas vinham acompanhadas de apêndices expressivos caracterizados pelas abóbadas vazadas e lajes sinuosas, presentes em projetos como o Hotel Quitandinha (1951) e o Hospital Sul América (1952). [522]

A objetividade flagrante na pirâmide invertida do Museu de Arte de Caracas (1955) aponta para a nova posição adotada por Niemeyer. Em uma seqüência de pequenos croquis, o arquiteto descreve o percurso até a solução final. Nos croquis iniciais ainda observa-se a presença de soluções aplicadas em projetos anteriores como o volume prismático sobre pilotis, o pilar em "V" e a fachada inclinada. Esses desenhos não são registros originais de um processo de raciocínio, certamente foram elaborados posteriormente à solução final. Ao fazer essa seqüência de croquis e publicá-los, Niemeyer torna pública uma autocrítica ilustrada onde se observa uma clara busca pela síntese.

A seqüência de croquis para o projeto do Museu de Caracas não representa apenas a evolução de uma idéia de projeto, mas contém a densidade de uma pesquisa pessoal que objetiva a unidade e, para tanto, deverá se desvencilhar das soluções sedutoras e fotogênicas que já haviam percorrido um longo caminho: da experimentação à consagração, culminando em um inevitável desgaste. [523], [524]

Ao refinar o desenho em busca da forma simples e essencial, Niemeyer parece atender aos conselhos de Saia e Argan e, pelo menos naquele momento, desvincula-se do modelo paradigmático representado pelo conjunto de formas de Pampulha.

Apesar dos projetos de Niemeyer realizados a partir de 1954 já ilustrarem um evidente redirecionamento de sua postura projetual, será apenas em seu celebrizado Depoimento, publicado em fevereiro de 1958 na revista Módulo, que o arquiteto explicará uma conduta vigente desde 1954.

Em seu Depoimento de 1958, Niemeyer realiza uma severa auto-crítica sobre seus procedimentos de projeto e sua postura profissional, condenando seu ponto de vista anterior, que compreendia a arquitetura

como um exercício que se deve praticar com espírito esportivo - e nada mais. E isso permitia certa negligência - facilitada pelo meu feitio displicente e boêmio - e fazia com que aceitasse trabalhos em demasia,

393 | o encontro de 1955: Síntese e Monumentalidade 
executando-os às pressas, confiante na habilidade e na capacidade de improvisação que me julgava possuidor (NIEMEYER 1958:04, grifo nosso).

Em entrevista publicada na edição inaugural da revista Módulo ${ }^{127}$, além de rebater o bombardeio da crítica internacional, Niemeyer antecipa em pelo menos três anos algumas colocações presentes em seu Depoimento. As colocações de Niemeyer na entrevista de 1955 reafirmam a condição de seu Depoimento de 1958 não como um marco que inaugura uma nova fase, mas como uma explicação cristalina de uma nova postura de projeto presente nos projetos realizados desde 1955.

Segue trecho da entrevista de Niemeyer publicada em março de 1955:

Sobre estas críticas, meu amigo, nada tenho a dizer; nem me interessa mesmo contestá-las. Somos um povo jovem, com uma tradição de cultura ainda em formação - o que nos expõem naturalmente mais à crítica daqueles que se julgam representantes de uma civilização superior. Mas também, somos simples e confiantes em nossa obra. O suficiente pelo menos para apreciar essa crítica, ainda quando parta de homens que não possuem, profissionalmente, as credenciais necessárias. (...)

Um dos aspectos mais objetivos das críticas é a deficiência de bons acabamentos nos nossos edifícios. Isso é compreensível, uma vez que se leve em conta ser a nossa industria ainda pobre; além disso e, principalmente, muitos dos arquitetos brasileiros, executaram trabalhos em demasia, o que não lhes permitiu, às vezes, dar a todos uma fiscalização apurada - ao contrário da maioria dos arquitetos europeus, que se dedicam meses a fio a um só projeto.

Aliás - e esta pequena ressalva também não deixa de ser importante - nada se conhece no Brasil, dos Srs. Rogers e Max Bill, a não ser pequenos e inexpressivos projetos (NIEMEYER 1955:47, grifo nosso).

Para legitimar sua nova fase, Niemeyer recorre a uma estratégia surpreendente e improvável: no Depoimento realiza uma severa crítica sobre o entendimento de projeto como conseqüência do arranjo de soluções formais que interagem entre si, presente em seus projetos posteriores à Pampulha. Segundo Niemeyer, seriam esses elementos os culpados por uma suposta síndrome da originalidade que permeava a produção nacional. Niemeyer reconhece que "chegou a descuidar de certos problemas e adotar uma tendência excessiva para a originalidade." (Idem-grifo nosso).

Ao questionar sua "tendência excessiva para a originalidade", Niemeyer retira a autoridade daquelas soluções formais lançadas em Pampulha e condenadas por Luis Saia. Em outro trecho, o arquiteto entende o papel fundamental de seus projetos para a arquitetura moderna brasileira, com um sincero sentimento de "missão cumprida":

Não pretendo, naturalmente, com esses comentários, iniciar um processo de autodestruição, nem atribuir aos meus trabalhos feição depreciativa. Vejo-os, pelo contrário, como fatores positivos dentro do movimento arquitetural brasileiro, ao qual deram, na ocasião oportuna, por seu élan e seu sentido criador, uma contribuição efetiva que até hoje caracteriza esse movimento. (Idem, grifo nosso).

Mario Pedrosa, em seu artigo Depoimento de Oscar Niemeyer, publicado no Jornal do Brasil

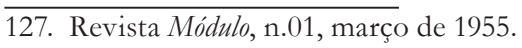

o encontro de 1955: Síntese e Monumentalidade 394 
em duas partes, nos dias 24 e 25 de julho de 1958, sintetiza de maneira precisa a importância de Oscar Niemeyer e de seu Depoimento para a arquitetura moderna brasileira:

Assim iria caber a Niemeyer, o mais fecundo inventor de formas de nossa arquitetura, o inesgotável improvisador de soluções, o 'playboy' endiabrado, reagir primeiro que todos contra o demônio da originalidade e a faceirice da improvisação (PEDROSA apud XAVIER, 2003:243, grifo nosso).

A partir da colocação de Pedrosa, podemos concluir que Niemeyer teve um duplo papel na formação do ideário formal da arquitetura moderna brasileira: o mesmo arquiteto que em 1940, no projeto do conjunto da Pampulha, lança as soluções formais e as estratégias compositivas que figurarão nas pranchetas de toda uma geração de arquitetos, a partir de 1954 com seus projetos e, em 1958 com seu Depoimento, contradiz a primazia da originalidade, apresentando soluções de extremo rigor geométrico e estrutural, onde forma e estrutura plasmam-se em um objeto que passa a abrigar o desejo da síntese, da concisão, da pureza e da simplicidade.

Ao assumir novamente a responsabilidade de conferir uma direção para a reflexão no campo da arquitetura, Niemeyer revigorará um debate, então esvaziado pelo fascínio coletivo por um "corbusianismo tropical".

Vilanova Artigas, em seu artigo Revisão crítica de Niemeyer, publicado na Revista Acrópole em julho de 1958 (contemporâneo ao artigo de Pedrosa) saudará o Depoimento de Oscar Niemeyer como um “(...) ponto de partida para uma nova fase do desenvolvimento da arquitetura nacional (...)” (ARTIGAS apud XAVIER, 2003:240, grifo nosso).

Artigas encontra no Depoimento de Niemeyer "sugestões para a análise da atual etapa do desenvolvimento da arquitetura brasileira” (Idem).

Ao compreender o texto de Niemeyer quase como um manual que sinaliza para uma nova direção para o debate interno, Artigas indica um comprometimento com relação ao discurso de Niemeyer que, segundo o próprio autor, “define com segurança o significado de certos aspectos decorativos que imaginamos que, de certa forma, envolviam nossas expressões arquitetônicas, traçando rumo certo para evitá-los.” (Idem).

Devemos salientar que grande parte dos projetos de Vilanova Artigas realizados até meados da década de 1950 versavam sobre o conjunto de soluções sacralizadas de Pampulha e que, posteriormente, assumiram a condição de modelo.

Alguns projetos de Artigas são exemplos sintomáticos de redesenhos do vocabulário formal de Niemeyer: o telhado invertido com a adoção de mezanino na porção mais alta do volume na segunda residência do arquiteto em São Paulo(1949) e a fusão do telhado invertido a seqüência de abóbadas sucessivas suspensas na Rodoviária de Londrina (1950).

Segundo Artigas, após o Depoimento de Niemeyer, "A arquitetura brasileira abandona os aspectos de submissão ao imobiliário, que vinha exibindo, para se projetar com pureza no plano da manifestação cultural, única forma de ser compreendida." (Idem).

A colocação de Artigas, ao mesmo tempo em que diz respeito ao texto de Niemeyer, corresponde à mudança presente em sua própria trajetória profissional que, a partir da metade da

395 | o encontro de 1955: Síntese e Monumentalidade 
década de 1950, se desvincula de soluções tributárias a um corbusianismo que flerta com o repertório celebrizado por Niemeyer e migra para a formulação de uma obra onde a forma é conseqüência do rigor presente na técnica que aflora e fica aparente, sendo registro da matéria desnudada que revela o objeto não mais como mera composição original, mas como construção.

Para Niemeyer, a tensão intelectual dessa revisão crítica não reside na mera dimensão plástica da arquitetura, mas no novo foco presente em seus procedimentos de projeto.

A partir de 1954, Niemeyer não apenas considera o conteúdo das críticas sofridas desde 1952, como formula um novo raciocínio a partir de uma severa revisão sobre suas formulações especuladas desde Pampulha.

A partir do projeto para o Museu de Arte de Caracas (1955) e de seu Depoimento (1958), Niemeyer não apenas revê a dimensão plástica de sua obra, como antevê uma nova perspectiva para sua arquitetura: a condição de monumento. 


\section{A viagem de Niemeyer à Europa e o encontro com Le Corbusier em Paris}

Em seu Depoimento, Niemeyer diz que "As obras de Brasília marcam, juntamente com o projeto para o Museu de Caracas, uma nova etapa no meu trabalho profissional. Etapa que se caracteriza por uma procura constante de concisão e pureza, (...)" (NIEMEYER, 1958:03)

Niemeyer elege o Museu de Arte de Caracas (1955) e os Palácios de Brasília (1956-1957) como dignos exemplares dessa nova fase de sua carreira. Ambos os projetos sucedem à seqüência de críticas sofridas por Niemeyer durante o ano de 1954.

Apesar do evidente redirecionamento plástico de Niemeyer ocorrer posteriormente a publicação das críticas incisivas ao seu trabalho, não será esse o fato alegado por Niemeyer como crucial para a legitimação de sua revisão profissional.

O arquiteto aponta sua primeira viagem a Europa, realizada no início de 1955, como fato fundamental para sua mudança de conduta: "Realmente, depois que voltei da Europa, após haver - atento aos assuntos do ofício - viajado de Lisboa a Moscou, muito mudou minha atitude profissional." (Idem).

Segundo Yves Bruand:

O fato decisivo foi a viagem à Europa feita nessa data; Niemeyer percorreu o então o Velho Continente, de Lisboa a Moscou, e o que viu, foi para ele uma revelação.(...) O contato direto com a Europa e seus monumentos modificou radicalmente seu ponto de vista; de repente ele compreendeu o significado das construções do passado enquanto símbolo do estágio de uma civilização e, principalmente, o valor permanente de sua beleza,(...) (BRUAND 1999:181).

A viagem de Niemeyer à Europa antecede em praticamente oito meses o projeto para o Museu de Arte de Caracas ${ }^{128}$, o que nos permite compreender o projeto para Caracas não apenas como conseqüência de uma revisão de sua conduta profissional, mas também como reflexo de sua viagem à Europa.

A primeira experiência de Niemeyer na Europa é conseqüência de dois compromissos dis-

128. Os esboços realizados por Niemeyer para o Museu de Arte de Caracas foram assinados e datados pelo arquiteto com a data de 03/10/55.

397 | o encontro de 1955: Síntese e Monumentalidade 

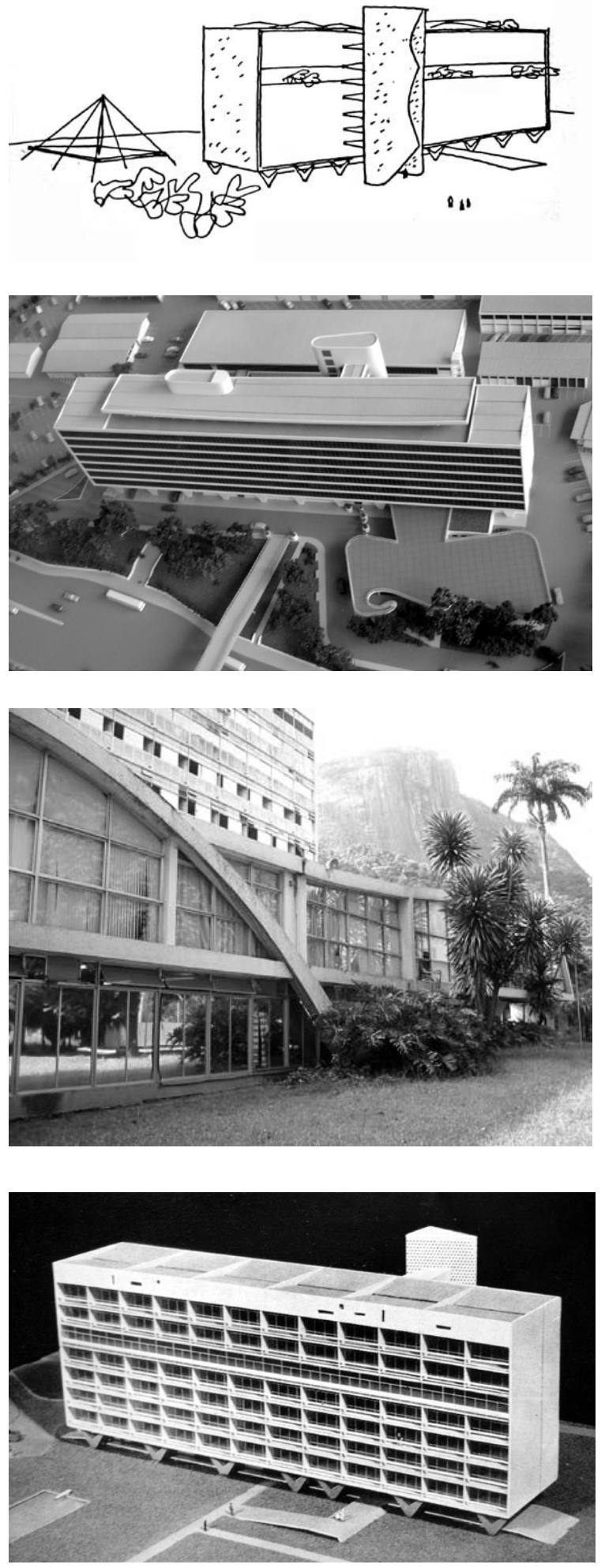

[525] Edifício de Habitação em Berlim - perspectiva (1955) ON (PAPADAKI, 1956:170)

[526] Palácio da Agricultura - conjunto arquitetônico do Parque Ibirapuera - maquete (1951/1953) ON (foto: Rodrigo Queiroz)

[527] Hospital Sul América - volume anexo (1952) ON (foto: Rodrigo Queiroz)

[528] Edifício de Habitação em Berlim - perspectiva (1955) ON

(Revista Módulo n.04, março de 1956:57) 
tintos: a realização de um projeto de edifício de habitação no bairro Hansa em Berlim ${ }^{129}$, e uma palestra ${ }^{130}$ na União de Arquitetos da então URSS em Moscou. [525]

Em seu livro de memórias As Curvas do Tempo, Niemeyer descreve o itinerário de sua primeira viagem a Europa:

Gostava de olhar, cada dia diferente. Mar intenso a lembrar eternidade. Gostava daqueles dias de ócio, sem fazer nada, a ler, conversar, estirado nas cadeiras de bordo.

Numa dessas viagens fui a Moscou. Levava Annita e o meu amigo Eça. Queria que eles conhecessem o Velho Mundo.

Descemos na Itália. Fomos a Roma, Florença, Veneza e Lisboa, daí partimos para Paris, onde Vinícius de Moraes nos esperava na estação. Ficamos três dias em Paris, uma semana na Tchecoslováquia, um mês em Berlim e, finalmente, Moscou (NIEMEYER, 1998:54).

No projeto para Berlim, Niemeyer utiliza o mesmo partido formal caracterizado pela lâmina estreita de proporção horizontal sobreposta aos apoios em "V", presentes em projetos como o Palácio da Agricultura em São Paulo (1951) e o Hospital Sul América no Rio de Janeiro (1952).

O projeto alemão é caracterizado pela barra suspensa e autônoma, os volumes adjacentes não estão interligados ao bloco de apartamentos, estão soltos no jardim. Já os projetos do Palácio da Agricultura e do Hospital Sul América possuem elementos conectados ao volume principal, seja o belvedere/plataforma sinuosa presente no Palácio paulista, seja o volume formado pelo encontro entre a abóbada rasa e a cobertura inclinada que está ligado ao sólido retangular do hospital implantado à margem da Lagoa Rodrigo de Freitas. [526], [527], [528]

Essa estratégia compositiva, baseada na elaboração de um gradiente hierárquico que separa os programas em corpos distintos a partir de suas potencialidades expressivas - presente nos três projetos citados acima - é um recurso presente em inúmeros projetos de Niemeyer, no qual, a forma racional é abrigo do programa pragmático e inflexível (apartamentos, escritórios) e a forma expressiva contém o elemento do programa que abriga funções de uso esporádico e coletivo, com programa adaptável a solução formal (salões de exposição, auditórios).

No Depoimento de 1958, Oscar Niemeyer fala sobre os perigos do uso indiscriminado dos apêndices expressivos:

Dentro do mesmo objetivo, passei a evitar as soluções recortadas ou compostas de muitos elementos, difíceis de se conterem numa forma pura e definida; os paramentos inclinados e as formas livres que, desfigurados pela incompreensão e inépcia de alguns, se transformam muitas vezes, em exibição ridícula de sistemas e tipes diferentes (Ibid.:05, grifo nosso).

129. Em uma perspectiva concebida por Niemeyer para ilustrar o projeto no bairro Hansa, o arquiteto assina "Berlim, 15/02/1975", dado que comprova que a primeira viagem de Niemeyer à Europa foi realizada durante os primeiros meses de 1955 e anteriormente ao projeto de Caracas.

Uma breve nota publicada na revista Módulo de dezembro de 1955 (n.03, s.n.) comprova que a viagem à Europa ocorre antes do projeto para Caracas.

"O projeto do novo Museu de Arte Moderna de Caracas, na Venezuela, foi elaborado pelo arquiteto brasileiro Oscar Niemeyer, que acaba de regressar daquela cidade. Trata-se de obra patrocinada por um grupo de incentivadores de arte

399 | o encontro de 1955: Síntese e Monumentalidade 
A revisão crítica de Niemeyer não deve ser compreendida como mera conseqüência do amadurecimento de uma linguagem lançada em Pampulha e exercitada nos projetos seguintes. Um conjunto de fatores fará com que Niemeyer reveja a condição da forma plástica em seus projetos:

- a recepção (mesmo que de mal grado) das críticas internas e externas;

- o reconhecimento do desgaste da formulação que se apóia no vocabulário formal do conjunto da Pampulha;

- a necessidade da formulação de uma nova estrutura de linguagem para sua obra, caso contrário, os projetos (de dimensões cada vez maiores) estariam condenados a subjetividade;

- em sua primeira viagem ao continente Europeu, Niemeyer toma contato com as construções históricas que, pelos seus atributos arquitetônicos e simbólicos, atingem a condição de monumento, de obra de arte;

- A incumbência de projetar os Palácios e a praça cívica da nova Capital Federal fez com que Niemeyer refletisse sobre novos significados que deveriam estar presentes em suas obras: o caráter simbólico e o sentido de monumento.

Uma peça-chave para a compreensão do redirecionamento plástico de Niemeyer a partir da segunda metade da década de 1950 ocorre durante sua primeira viagem a Europa: o encontro de Oscar Niemeyer com Le Corbusier em 1955, em seu atelier na rue Sèvres 35, em Paris.

A visita de Oscar Niemeyer ao atelier de Le Corbusier em 1955 marca o terceiro encontro entre os arquitetos. O primeiro deles acontece no ano de 1936, na cidade do Rio de Janeiro, para a realização dos projetos para a sede do Ministério da Educação e Saúde e da Universidade do Brasil. O segundo encontro ocorre onze anos depois, em 1947, na cidade de Nova York, ocasião em que ambos os arquitetos participaram do concurso para o projeto da sede da Organização das Nações Unidas.

Nesse terceiro encontro, Niemeyer depara-se com um arquiteto que, resignado das investidas em macro-escala não executadas, enfrenta a arquitetura não como intervenção urbana de escala monumental, mas como monumento em si, a partir da adoção da tríade matéria/expressão/significado simbólico presente em projetos como a Capela de Notre-Dame du-Haut em Ronchamp (1947/1951), o Convento dos Monges Dominicanos em La Tourette (1957) e os Palácios do Capitólio de Chandigarh (1952-1955).

Em Paris, Niemeyer encontra um “outro” Le Corbusier, diverso daquele presente no primeiro e no segundo encontro.

\footnotetext{
venezuelanos e deverá compreender uns quatro mil metros quadrados de construção. O projeto de Niemeyer prevê a construção de um bloco de cinco pavimentos, de dezesseis metros de altura. Está situado em uma elevação de terreno - o que determinou suas características especiais. Em seu próximo número, MÓDULO apresentará todos os detalhes do projeto - o segundo realizado pelo arquiteto patrício, em 1955, no estrangeiro (o primeiro: prédio em Berlim). (...)” in Módulo n.03 - grifo nosso.

130. A palestra de Niemeyer em Moscou foi noticiada em nota publicada na revista Módulo de agosto de 1955 - n.02, p.07. Além da palestra, a sede da União dos Arquitetos da U.R.S.S. foi sede da exposição dos projetos de Niemeyer (Conjunto da Pampulha, Hotel Quitandinha, Residência do arquiteto na estrada de Canoas, Conjunto JK em Belo Horizonte, entre outros).
}

o encontro de 1955: Síntese e Monumentalidade $\mid 400$ 
Em 1955, tanto Le Corbusier como Oscar Niemeyer encontravam-se em um momento de transformação de suas trajetórias: Niemeyer substitui a profusão radiante de elementos tributários à Pampulha por formas simplificadas e elementares que expressam alto grau de síntese. Enquanto Le Corbusier - após passar pelas vilas puristas (Cook, Stein e Savoye), pelos planos urbanísticos a rendent da década de 1920 e realizar uma incursão no universo vernáculo, quiçá primitivo, nas casas da década de 1930 (Errazuris, Mathes e Mandrot) - a partir da década de 1950 funde memória e monumento em projetos de intensa carga simbólica.

Mas afinal, qual o significado do terceiro encontro entre Oscar Niemeyer e Le Corbusier?

Em 1936, no Rio de Janeiro, no primeiro encontro entre os arquitetos, Niemeyer absorve as soluções e os procedimentos de Le Corbusier e a partir daí constrói sua própria linguagem que encontra seu exemplo máximo nos edifícios que constituem o conjunto arquitetônico da Pampulha, caracterizados como redesenhos do próprio repertório corbusiano. Nesse instante o “discípulo atento" absorve os estilemas canônicos de Le Corbusier ${ }^{131}$.

No ano de 1947, na cidade de Nova York, Le Corbusier é apresentado à arquitetura de Niemeyer através de fotografias, sejam aquelas presentes no livro Brazil Builds: Architecture New and Old 1652-1942, ou sejam aquelas levadas pelo próprio arquiteto brasileiro à Nova York.

Os projetos de Niemeyer, principalmente o Conjunto da Pampulha, alavancam os apêndices expressivos de Le Corbusier presentes em projetos de seu período purista (década de 1920) ao patamar de objeto exterior pleno (a marquise sinuosa, o cilindro transparente e a abóbada integral) além de subverterem a estanqueidade cubista da relação dentro/fora a partir da adoção de espaços generosos abertos para o meio externo.

Ao mesmo tempo em que podem ser compreendidos como uma interpretação da obra de Le Corbusier, os projetos de Niemeyer desempenharão um impacto sobre o "mestre" que pode ser aferido em diversos projetos, como o Carpenter Center (1961/1963), o Pavilhão de Estrasburgo (1964), Centro Tecnológico da Olivetti (1963), o Conjunto de Firminy (1961), e a própria Capela de Notre-dame du Haut em Ronchamp, cujos primeiros esboços, curiosamente, foram realizados em 1947 em Nova York durante o período em que Le Corbusier esteve junto com Oscar Niemeyer.

No encontro de 1955, Niemeyer não se depara nem com a pedagogia dos cinco pontos presente no encontro de 1936 e nem encara o momento como a chance de apresentar ao "mestre" sua obra inovadora, mesmo que inspirada nos temas corbusianos, como no encontro de 1947.

O ano de 1955, além de marcar o encontro entre Niemeyer e Le Corbusier em Paris, também marca o início da auto-crítica de Niemeyer, que culminará nos projetos dos Palácios de Brasília em seu Depoimento de 1958. Ambos os eventos estão intimamente ligados a sua viagem à Europa.

131. O fato de Niemeyer ter tido o seu primeiro contato pessoal com Le Corbusier em 1936 não significa que o arquiteto brasileiro não conhecia a obra e os textos do arquiteto europeu que eram estudados como "sagrado catecismo". Devemos lembrar que o ano de 1929 não apenas marca o projeto de Le Corbusier para a casa Savoye como também o ingresso de Oscar Niemeyer na Escola Nacional de Belas Artes do Rio de Janeiro.

401 o encontro de 1955: Síntese e Monumentalidade 
Tanto no encontro de 1936, como no encontros de 1955, Niemeyer está em busca de um sentido para sua obra. No primeiro e no terceiro encontro com Le Corbusier, Niemeyer se reporta ao "mestre" como alguém em busca de uma direção. Caberá a Le Corbusier indicar as postulações que balizarão os dois itinerários distintos de Niemeyer: em 1936, quando compreende o legado purista de Le Corbusier como inspiração para a elaboração de um repertório formal que se multiplica em diversas estratégias compositivas, e em 1955, quando, reconhecendo o desgaste da formulação gestada em 1936, o "gênio da forma livre" se vê novamente no papel de "discípulo atento" e se reporta novamente ao "mestre" na tentativa de encontrar a direção para uma obra que já perdia parte de seu viço.

Le Corbusier, aquele que em 1936 apresenta os elementos necessários à consagração de Niemeyer em Pampulha (1940-1943), em 1955 se encontra em situação parecida: caberá a ele mostrar uma possibilidade concisa e essencial - mas, principalmente, monumental - para um modelo que, apresentado havia dezoito anos, entrava em declínio.

O simbolismo e a monumentalidade monolítica e geométrica presentes nos estudos de Le Corbusier para Chandigarh indicam para Niemeyer uma possibilidade que redefine sua obra e institui um novo repertório formal que não substitui aquele presente em Pampulha, mas o incorpora, culminando nos Palácios de Brasília. 


\section{Chandigarh e Brasília}

Os trabalhos de Le Corbusier realizados a partir do projeto da Unité d'Habitacion (1947) formalizam um discurso que parecia não crer mais na validade do objeto arquitetônico como instância extensível, idéia presente em projetos como o Immeuble Villa, a Villa Radieuse, ou o Pavilhão l'Esprit Nouveau, caracterizado como uma experiência prototípica e modelar que fundia o aspecto quantitativo - dado pela sua serialidade - a preceitos de ordem qualitativa, que preservavam uma generosidade espacial mesmo sob o objetivo da estandardização.

A partir da segunda metade da década de 1940, o caráter da arquitetura de Le Corbusier desloca-se da proposta de uma modulação multiplicável, presente principalmente nos projetos da década de 1920, para a compreensão da arquitetura como símbolo.

Segundo Allan Colquhoun, os projetos de Le Corbusier realizados posteriormente a II Guerra Mundial apresentam

(...) uma nova ênfase sobre o edifício isolado como um monumento singular estabelecido na natureza - não mais a natureza artificialmente 'natural' dos primeiros planos para cidades, mas uma natureza já humanizada pelo cultivo e que continha evidencias de uma tradição construtiva vernácula (COLQUHOUN, 2004:175, grifo nosso).

Para Le Corbusier, a idéia de monumento pode ser conseqüência de uma especulação eminentemente formal que traduz sua experiência pessoal no universo da forma plástica, como no caso do projeto da Capela de Ronchamp (1947/1951), ou, como nos Palácios da Assembléia e da Justiça em Chandigarh (1951/1955), onde o arquiteto encontrará em arranjos tipológicos da antiguidade clássica a direção para a caracterização do monumento.

Para exemplificar a transposição de Le Corbusier do universo de um purismo estilizado para uma verdade vernácula e expressiva, Colquhoun utiliza como meio de comparação as diferentes 'unidades métricas' utilizadas pelo arquiteto em duas fases tão distintas: a proporção áurea aplicada nas fachadas das moradias da década de 1920 e o Modulor que, nos projetos que flertam com a matéria e técnica artesanais, assume a condição, ao mesmo tempo, de escala e de medida. Segue trecho do autor:

403 o encontro de 1955: Síntese e Monumentalidade 
(...) enquanto na década de 20 o interesse de Le Corbusier por sistemas proporcionais havia assumido a forma de uma verificação a posteriori de superfícies regulares, após a guerra ela se tornou, com a publicação do Modulor, uma escala numérica que poderia conferir validade platônica aos menores detalhes e às formas mais irregulares (Idem, grifo nosso).

No projeto de Le Corbusier para Chandigarh, tanto o Palácio da Assembléia como o Palácio da Justiça possuem o partido da caixa vazada. Porém, a operação que rege o experimento em Chandigarh é oposta àquela presente nas casas projetadas por Le Corbusier durante a década de 1920 que, em tese, também podem ser compreendidas como caixas vazadas.

Em Garches e Poissy, Le Corbusier escava o volume alvo e opaco, e com essa intervenção torna visível a separação entre a estrutura - cuja retícula está contida no interior do volume e o prisma suspenso e rasgado.

Ao retirar matéria do volume suspenso, Le Corbusier exterioriza uma organização contida na forma pura que se define, em síntese, por trama de apoios e paramentos encurvados sem função estrutural, ora retilíneos, ora encurvados.

Em Chandigarh, a idéia de volume não nasce da eleição do objeto puro, manipulado, penetrado e subtraído de sua própria matéria. A aparência do objeto é conseqüência do ordenamento de uma retícula que não está mais contida no interior de bólidos puristas, mas assume uma organização tramada vertical que configura o próprio volume. Abole-se assim a idéia da membrana reguladora. O que delimita visualmente o volume não é a massa pura, mas a disposição dos apoios eqüidistantes e alinhados e, em alguns edifícios, combinados com quebra-sóis que assumem a configuração de peças monumentais contidas nos vãos entres os pilares escultóricos.

A relação entre para-sóis gigantes e apoios monumentais será um recurso corrente nos projetos tardios ${ }^{132}$ de Le Corbusier. Com o advento dessa solução, o arquiteto evita um retorno aos rasgos nos volumes puros e opacos da década de 1920, ao mesmo tempo em que indica uma solução criativa para substituir a monotonia dos gigantescos panos de vidro.

Segundo Sophia Silva Telles, "A enfática solução do brise-soleil, por outro lado é um recurso funcional que atinge forte expressividade ao transformar a superfície em um plano ativado por luz e sombra." (TELLES, 1988:25).

A adoção de extensas superfícies vazadas, conseqüência da relação apoio/quebra-sol, permite ao arquiteto exercer um trabalho quase gráfico nas fachadas de projetos como o Palácio da Justiça de Chandigarh e o Palácio dos Fiandeiros de Ahmedabad (1954). As diferentes divisões e subdivisões presentes nessas superfícies culminam em um arranjo que enriquece a espessa peça contínua. [529]

O drástico efeito lumínico dado pelas peças de concreto que refletem a luz e preenchem o interior de penumbra enfatiza o caráter gráfico dessas composições. Não há meios-tons: ou o concreto reflete, ou está sob sombras densas.

A solução do Palácio da Justiça, da Assembléia de Chandigarh e do Palácio dos Fiandeiros

132. Tais como: Centro de Artes Visuais da Universidade de Cambridge - Carpenter Center (1961/1963) e o Palácio de Congressos em Estrasburgo (1964).

o encontro de 1955: Síntese e Monumentalidade| 404 
de Ahmedabad consiste em uma sobreposição de volumes: um menor - ora a caixa transparente, ora um fechamento opaco e curvilíneo - contido no interior de outro volume maior, cuja configuração exterior é dada pelo ordenamento de um peristilo de pilares escultóricos associado à quebra-sóis com largura idêntica ao vão entre os pilares.

Para Colquhoun:

(...) o brise-soleil era mais que um artifício técnico; introduzia um novo elemento arquitetônico na forma de uma parede grossa e permeável (...) cuja superfície podia ser manipulada, criando uma hierarquia de escalas, proporcional tanto ao ser humano como ao edifício como um todo (COLQUHOUN, 2004:177).

Nos Palácios de Chandigarh observamos a inversão da lógica interior/exterior presente nos projetos de Le Corbusier realizados durante a década de 1920. Ao inverter a relação entre volume e estrutura, Le Corbusier aproxima as experiências de Chandigarh dos exemplares canônicos do classicismo greco-romano.

A partir da adoção do intermez:o de pilares entre o meio externo e o interior do palácio, Le Corbusier configura um monumento que usa como molde a tipologia do templo grego. Com esse artifício, a monumentalidade não está associada exclusivamente à escala, mas vincula-se a um significado de monumento que, resgatado da antiguidade, é colocado novamente à tona: construção coerente e proporcional que expressa sua lógica estética e matemática a partir das relações métricas presentes entre a totalidade da construção - vista em elevação - e o desenho do pilar, monumento individual quando observado de perto. Porém, quando contemplado à distância, o apoio é artefato integrante de um conjunto responsável pelo desenho da elevação, juntamente com uma peça de proporção horizontal que arremata o limite vertical e emoldura o conjunto, seja a marquise côncava da Assembléia ou os arcos escultóricos da Suprema Corte de Chandigarh.

Nos estudos de Le Corbusier para o Palácio da Assembléia de Chandigarh, há a fusão do peristilo de pilares à idéia de arcos parabólicos sucessivos. Incorpora-se em um mesmo objeto as duas características primordiais da arquitetura clássica: o pilar e o arco.

$\mathrm{Na}$ intenção de conferir uma expressividade ao desenho dos pilares escultóricos ${ }^{133} \mathrm{da}$ Assembléia de Chandigarh, Le Corbusier opera um desbaste, esculpe um arco tridimensional de desenho parabólico. [530], [531]

Os primeiros estudos de Le Corbusier para a Assembléia de Chandigarh datam de 1951. Esses estudos são publicados no quinto volume de sua Obra Completa ${ }^{134}$, que compreende os projetos realizados entre 1946 e 1952, editado e publicado no ano de 1953.

Oscar Niemeyer nunca escondeu que acompanhou a trajetória de Le Corbusier a partir da apreciação de seus textos e seus projetos publicados: "De Le Corbusier, lembrava os projetos que publicou, os textos que tão bem definiam as suas idéias sobre arquitetura e urbanismo (...)"

133. Preocupação presente em sua obra desde o Pavilhão Suíço da Universidade de Paris (de secção oblonga que varia em cada par de pilares), passando pelos apoios trapezoidais de planta oval presentes na Unité d'Habitacion.

134. BOESIGER, Willy. Le Corbusier - oeuvre complète 1946-1952, v.05. Switzerland, Girsberger-Zurich, 1953.

405 o encontro de 1955: Síntese e Monumentalidade 

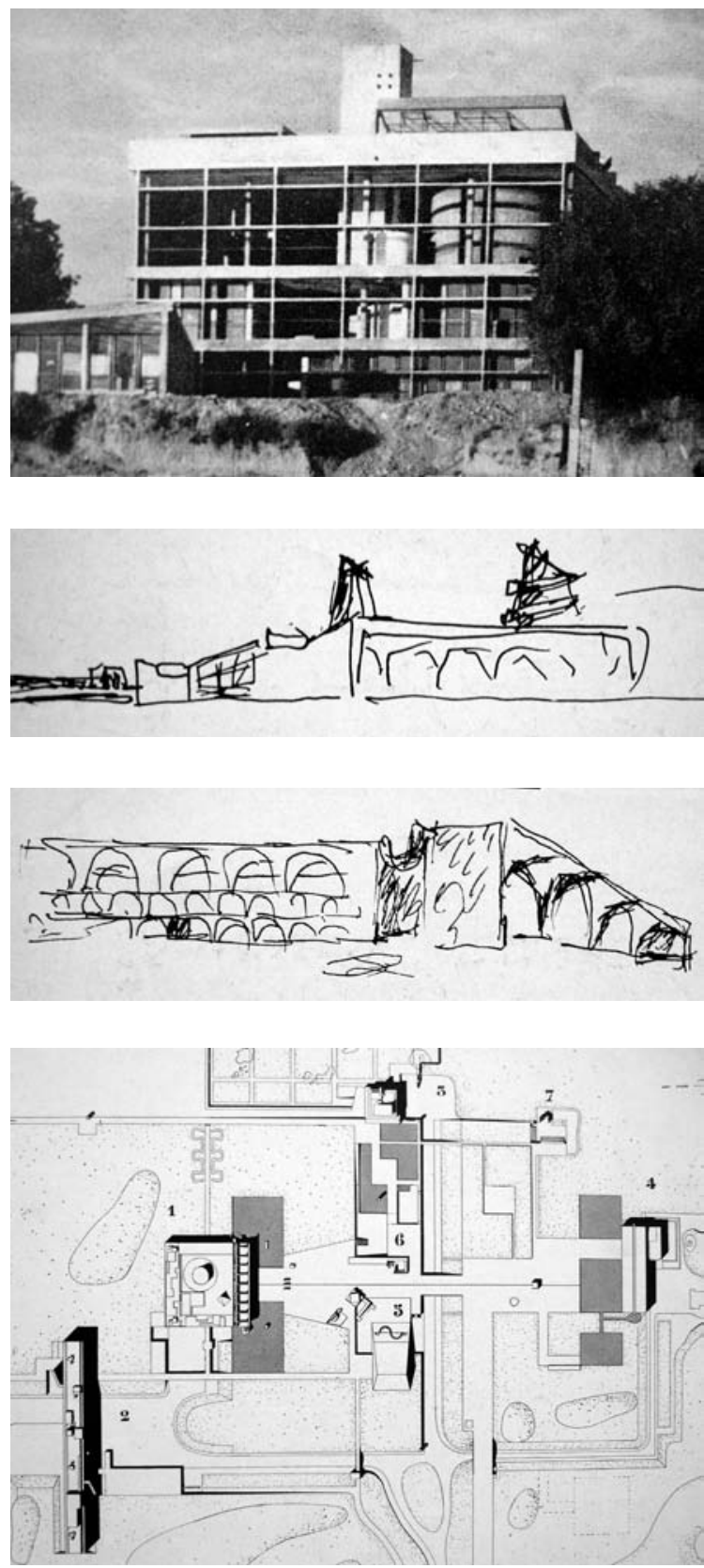

[529] Palácio dos Fiandeiros em Ahmedabad - 1954 Le Corbusier (BOESIGER, 1957:145)

[530] Assembléia de Chandigarh - 1951 - croqui - Le Corbusier (BOESIGER, 1953:145)

[531] Assembléia de Chandigarh - 1951 - croqui - Le Corbusier (BOESIGER, 1953:145)

[532] Centro Cívico de Chandigarh (1951) LC

(BOESIGER, 1971:198)


[533] Centro cívico de Brasília - primeira versão - 1956 $-\mathrm{ON}$.

Da esquerda para a direita: Residência do Presidente; Igreja; Palácio Governamental e Hotel.

(Revista Módulo n.06, dezembro/1956:13)

[534] Centro cívico de Brasília - primeira versão - 1956 $-\mathrm{ON}$

(Revista Módulo n.06, dezembro/1956:sn)

[535] Centro cívico de Brasília - primeira versão - 1956 $-\mathrm{ON}$

(Revista Módulo n.06, dezembro/1956:23) 
(NIEMEYER, 2000:15). Em outro trecho: “Lembrava Rodrigo" ${ }^{135}$ a me dizer: 'Oscar, leia os gregos e os clássicos portugueses'. E li, li muito. Li como quem nada sabe e tudo quer aprender. Li com a devoção com que lera, anos antes, a obra de Le Corbusier.” (NIEMEYER, 1998:61).

Em um artigo, intitulado Le Corbusier, publicado em 1963, Niemeyer, mais uma vez, valoriza o papel dos escritos e dos projetos de Le Corbusier em sua formação:

Começamos a tomar contato com a obra de Le Corbusier nos bancos da Escola Nacional de Arquitetura do Rio de Janeiro. Aí a estudamos, manuseando seus álbuns, procurando sentir suas intenções, tentando descobrir em cada traço, em cada curva, o objetivo arquitetural. Mesmo depois de formados há vários anos sua obra permaneceu como uma espécie de guia, de tira-dúvidas, que consultávamos com freqüência (NIEMEYER 1963:23, grifo nosso).

Poderíamos considerar a hipótese de que Niemeyer, antes mesmo de encontrar Le Corbusier em seu atelier em Paris, já havia tomado conhecimento dos estudos do arquiteto francosuíço para os Palácios que constituem o Capitólio de Chandigarh.

Em passagens presentes em diversos relatos e entrevistas, Oscar Niemeyer revela o instante em que Le Corbusier, em seu atelier em Paris, apresentou para ele as fotografias da Assembléia de Chandigarh: 'Lembro-o a dizer, certa vez: 'Oscar, você faz o barroco, mas o faz muito bem'. E vários anos depois: 'Dizem que faço o barroco. Veja aquela fotografia da marquise do Congresso de Chandigarh, não é qualquer um que pode fazer isso." (NIEMEYER 1998:96, grifo nosso).

Provavelmente, se tratavam de imagens de modelos ou da obra ainda em fase inicial, pois a construção da Assembléia de Chandigarh não consta sequer do sexto volume ${ }^{136}$ de sua Obra Completa, onde estão publicados os projetos realizados entre 1952 e 1957 . Nesse volume, o Palácio da Justiça já aparece concluído, o edifício do Secretariado ainda em obras, e a Assembléia de Chandigarh está representada apenas em desenhos e fotografias de modelos tridimensionais. Tanto os desenhos como os modelos não correspondem a solução definitiva.

Niemeyer, ao relatar esse episódio, indica nas "entrelinhas" que Le Corbusier solidarizavase a ele na experiência da forma livre, e ressalta a constante incompreensão do senso comum que insiste em conferir atributos barrocos à liberdade formal presente em Niemeyer e também em Le Corbusier, nos projetos pós-1947.

Corroboramos com o ponto de vista de Niemeyer. O redirecionamento plástico de Le Corbusier é evidente e em alguns casos possui uma clara afinidade com as soluções preconizadas por Niemeyer nos projetos realizados entre 1940 e 1954. Porém, gostaríamos de acrescentar a hipótese de que tantos os estudos como as versões definitivas para os edifícios que compõem o Capitólio de Chandigarh, além de registrarem a incursão de Le Corbusier no universo da forma livre, desempenharão uma influência crucial no processo de desenvolvimento de projeto de

135. Referência a Rodrigo Melo Franco de Andrade: criador e primeiro diretor do Serviço do Patrimônio Histórico e Artístico Nacional (SPHAN), hoje Instituto (IPHAN).

136. BOESIGER, Willy. Le Corbusier et son atelier rue de Sèvres 35 - oeuvre complète 1952-1957, v.06. Switzerland, Girsberger-Zurich, 1957.

407 | o encontro de 1955: Síntese e Monumentalidade 
Oscar Niemeyer para os Palácios de Brasília.

Por mais que o Museu de Arte de Caracas (1955) represente o projeto que inaugura uma nova fase na obra de Niemeyer, caracterizada pelo rigor geométrico e pela simplicidade das formas, não podemos negar que a pirâmide invertida de Caracas também pode ser compreendida como uma conseqüência lógica de alguns experimentos do arquiteto realizados anteriormente, como os volumes que se afunilam conforme se aproximam do solo, exemplificados pelo primeiro projeto de Niemeyer para o auditório do conjunto arquitetônico do Parque Ibirapuera em São Paulo (1951/1953), caracterizado por um volume de secção triangular com um de seus vértices apontado para o solo.

O projeto para o Museu de Arte de Caracas não representa apenas um redirecionamento evidente na obra de Niemeyer, mas também pode ser considerado como a síntese arquitetônica que sucede a primeira experiência de Niemeyer na Europa.

O arquiteto brasileiro toma contato com o caráter simbólico dos monumentos e das diferentes arquiteturas das cidades européias, encontra-se com Le Corbusier em 1955, é apresentado a uma obra que flerta, ao mesmo tempo, com o vernáculo, com o monumental e com o simbólico.

Em outubro de 1955, no projeto para Caracas, Niemeyer revê sua linguagem vigente entre 1940 e 1953 e descarrega todo o novo arcabouço absorvido na Europa, concebendo um objeto desprovido dos efeitos ornamentais caracterizados pelo vocabulário formal da Pampulha, realizando sua primeira síntese entre arquitetura e monumento.

É certo que os Palácios de Brasília exemplificam o conceito da "concisão e simplicidade" apregoado por Niemeyer em seu Depoimento de 1958. Os Palácios de Brasília podem ser compreendidos como a continuação de uma obra que caminha em direção à síntese. Porém, devemos atentar para o fato da inexistência, nos projetos de Niemeyer realizados entre 1940 e 1955, do partido tipológico adotado nos Palácios de Brasília, caracterizado pela caixa de vidro suspensa por plataforma e recuada no interior da projeção da cobertura plana, envolvida por peristilo de pilares escultóricos.

Nos Palácios de Brasília, ao exteriorizar a estrutura e recuar os fechamentos transparentes, Niemeyer inverte a condição estanque dos exemplares puristas de Le Corbusier, onde o objeto preserva uma volumetria homogênea por conter em seu interior toda a retícula de pilares.

Ao manipular o canônico Esquema Dom-ino de Le Corbusier, em Brasília Niemeyer concebe volumetrias virtuais onde a idéia de volume não é dada pelo fechamento em si, mas pela presença de um renque de pilares parabólicos alinhados ao limite da cobertura.

Mas, não será esse o partido tipológico dos Palácios de Chandigarh?

Le Corbusier, o mesmo indivíduo que institui os cinco pontos, elabora o Esquema Dom-Ino e exercita diferentes configurações sobre esse tema nas casas de 1925 a 1929, em Chandigarh subverterá sua regra concebendo um tipo que, em tese, pode ser compreendido como o avesso das suas especulações puristas.

Com o advento da exteriorização da estrutura, o significado de "fachada livre" muda de sentido. Nesse instante, a fachada "está" livre para receber uma intervenção que confere um 
tratamento gráfico à arquitetura. Trata-se, na verdade, da criação de uma nova fachada a partir da adoção de uma membrana tramada que se sobrepõe a um volume transparente contido em seu interior.

Em Chandigarh, observamos o tratamento que beira um abstracionismo geométrico, onde a estrutura saliente e os pára-sóis monumentais assumem a condição de grelha vertical tecida por diferentes retículas que se sobrepõem.

Tanto a regra tecnicista do Esquema Dom-ino como a singularidade quase artesanal das investigações de Chandigarh serão compreendidas por Niemeyer como modelo: em um primeiro momento, como estrutura de um raciocínio em formação - Pavilhão do Brasil em Nova York (1938) e Cassino da Pampulha (1940) - e em um segundo período caracterizado pela revisão crítica e pelo amadurecimento ilustrado nos Palácios de Brasília (1956).

Essas considerações reafirmam o caráter pedagógico presente nas obras de Le Corbusier. Tanto os exemplares puristas que consideravam os "cinco pontos", como a tipologia inversa presente em Chandigarh, são projetos que podem ser compreendidos como uma sucessão de operações que, por serem didáticas e elementares, assumem a dimensão de tipo: ao mesmo tempo em que permitem interpretações das mais variadas, preserva-se o nexo entre a matriz e suas variações.

Tanto no primeiro como no terceiro encontro, Le Corbusier indicará para Niemeyer uma direção a seguir: em 1936, quando mostra uma idéia de arquitetura como conseqüência de uma experiência compositiva entre partes que constituem um todo e em 1955, quando, no sentido inverso dos apontamentos de 1936, mostra a necessidade da síntese, mas que não abre mão da expressão e da liberdade. [532]

Em 1956, após sua viagem a Europa e a sua experiência no atelier de Le Corbusier em Paris, mas teve contato com os estudos do arquiteto europeu para a cidade de Chandigarh, Niemeyer inicia os estudos para os Palácios de Brasília.

Paralelamente a realização do concurso para o Plano Piloto da nova Capital Federal, Niemeyer concebe o projeto de um conjunto arquitetônico implantado à margem do Lago Paranoá, onde posteriormente foi construído o Palácio da Alvorada. Com esse projeto estava garantida a Niemeyer a autoria dos edifícios componentes do centro cívico da futura capital, independentemente no resultado do concurso para o Plano Piloto. Esse primeiro projeto era constituído de Palácio Governamental, Residência Presidencial, Igreja e Hotel. [533], [534], [535]

Em entrevista para a revista Módulo, publicada em sua sexta edição, de dezembro de 1956, Niemeyer explica o projeto da praça cívica:

Os prédios, cuja construção está sendo iniciada na nova capital federal, localizam-se nos limites da área a ser destinada propriamente à futura sede do Govêrno Federal. Ficarão situados junto a grande represa, cujos trabalhos já se acham em andamento. Este simples fato mostra a preocupação da Companhia Urbanizadora em não criar limitações àqueles que estão concorrendo ao concurso para o Plano Diretor da nova capital.

409 o encontro de 1955: Síntese e Monumentalidade 
Os prédios serão: um hotel, um palácio, uma residência permanente para o presidente da República, e uma igreja. De todos, apenas o palácio, que está sendo detalhado, aguardará a escolha da localização adequada, em meio a um grande parque, pois a construção dos demais está praticamente iniciada. (...)

Quanto aos dados específicos dos projetos referidos, posso adiantar o seguinte: o hotel compreenderá cerca de 300 quartos e terá todo o conforto moderno, como amplos salões, restaurantes, salas de estar e pontos de diversões.

A residência oficial, que terá caráter definitivo, será a residência definitiva do presidente da República, tendo sido projetada, tomando-se em conta essa circunstância. O palácio será constituído por amplos salões envidraçados, com divisões facilmente removíveis, de forma a poder servir a outros fins, caso se torne necessário. Além dessas construções, como foi dito, está prevista a edificação de uma igreja, segundo a tradição de todas as cidades do Brasil. (...)

No projeto do palácio, por exemplo, procurei encontrar nos apoios da estrutura o elemento plástico que o deverá enriquecer e definir, dando-lhe as características de pureza e dignidade desejadas sem prejuízo de suas funções construtivas.

Em arquitetura, na minha opinião, o arquiteto, além de solucionar a parte técnica, precisa dar sua contribuição própria, pessoal. Doutra forma, a Arquitetura se transforma num trabalho de compilação em que praticamente não existe aspecto criador (NIEMEYER in Módulo n.06 pp.12-15 - grifo nosso).

No projeto para a praça cívica à margem do Lago Paranoá, Niemeyer flerta com as soluções presentes em seus projetos da primeira metade da década de 1950, ao mesmo tempo em que antevê algumas propostas para o projeto definitivo da praça cívica, futura "Praça dos Três Poderes" presente no Plano Urbanístico de Lucio Costa.

Os projetos do Hotel e da Residência Presidencial são caracterizados pelo uso do paralelepípedo horizontal sobreposto à marquise, seja ela recortada, no caso da Residência Presidencial, ou retangular, no caso do Hotel.

Essa solução pode ser diagnosticada no projeto para os palácios laminares que integram o conjunto arquitetônico do Parque Ibirapuera em São Paulo (1951/1953), caracterizados pela lâmina retangular suspensa de proporção horizontal, com marquise de traçado livre que demarca o acesso no pavimento térreo.

No projeto paulista, três extremidades da grande marquise situam-se sob a projeção do volume retangular suspenso dos palácios. Enquanto que, tanto no Hotel como na Residência Presidencial, a marquise não se caracteriza como um plano horizontal autônomo, mas é a continuidade da laje de piso do primeiro pavimento.

As marquises presentes na primeira proposta de Niemeyer para a praça cívica da nova capital não se apresentam como aquelas derivadas da ondulatória preconizada na Casa de Baile e redesenhada em projetos como o Hotel Quitandinha, a Fábrica Duchen, ou o Conjunto do Parque Ibirapuera. Em seu primeiro projeto para a nova capital, Niemeyer substitui a sinuosidade pelo recorte anguloso. Esse tipo de solução já estava presente na marquise de cobertura do Museu de Arte de Caracas (1955).

No primeiro estudo para o centro cívico de Brasília, ao substituir a sinuosidade pela angulosidade, Niemeyer compreende que a curva, antes "componente protagonista", dificilmente cumpriria o papel de "apêndice compositivo". 
Como os edifícios se aproximam cada vez mais de uma geometria pura e simplificada, seu contraponto expressivo, no caso dado pelas marquises, assume uma importância que desvia o foco que, agora, deve dirigir-se a geometria do edifício em si.

As marquises, tanto da cobertura do Palácio Governamental como do embasamentoplataforma da Residência Presidencial, apresentam-se como planos recortados que, por natureza geométrica (a reta), aproximam-se da linguagem dos volumes retangulares suspensos.

Ao sublimar a sinuosidade das marquises através do uso recortes angulosos, Niemeyer diminui a intensidade expressiva desses elementos que, apesar de simplificados, ainda estão presentes. Nesse instante, Niemeyer ainda não havia compreendido que talvez fosse necessário eliminar totalmente esses apêndices. Tal subtração ocorre nos projetos definitivos dos Palácios.

Em uma das imagens da maquete do Palácio Governamental observa-se a presença de uma abóbada com uma das extremidades em espiral implantada na laje de cobertura, juntamente com a marquise recortada. Trata-se, claramente, de um elemento remanescente de projetos anteriores como o edifício de apartamentos em Berlim (1955) e o próprio Museu de Caracas, cuja cobertura também possui uma peça em abóbaba, aos moldes daquela presente na cobertura do Palácio Governamental.

É curioso notar que a abóbada presente na cobertura do Palácio Governamental consta apenas na maquete em que o Palácio está implantado sobre a praça cívica que abriga todo o conjunto. Na maquete em escala maior, onde apenas o Palácio é representado, a abóbada na cobertura foi suprimida. Esse é um claro indício de que Niemeyer desvencilhava-se paulatinamente daqueles elementos meramente compositivos e de feição ornamental. Tal processo de busca por uma síntese culminaria no projeto para o Palácio da Alvorada.

No projeto para o Hotel, a sinuosidade, antes presente na própria marquise (Hotel Resort da Pampulha -1943), transpõe-se para o contorno dos fechamentos dos salões contidos sob a projeção da marquise, agora retangular.

No conjunto à margem do Lago Paranoá, Niemeyer realiza uma severa revisão de seus procedimentos de projeto e percebe que, caso queira realizar uma obra caracterizada pela concisão e simplicidade, será obrigado a se desvencilhar daqueles elementos que anteriormente conferiam o sentido expressional aos seus projetos. E será exatamente essa eliminação da dimensão compositiva presente nos projetos realizados entre 1940 e 1954 que caracterizará os projetos definitivos dos Palácios de Brasília.

A primeira versão para os palácios de Brasília representa o exato instante em que Niemeyer especula procedimentos presentes em projetos anteriores, ao mesmo tempo em que insinua uma nova proposição que revigoraria sua obra, baseada nos contornos simplificados e monumentais.

O projeto para o Palácio Governamental - edifício que corresponde ao Palácio do Planalto - representa a primeira experiência de Niemeyer tributária à tipologia da caixa de vidro contida na caixa de pilares escultóricos, preconizada por Le Corbusier no projeto da Assembléia de Chandigarh.

411 | o encontro de 1955: Síntese e Monumentalidade 

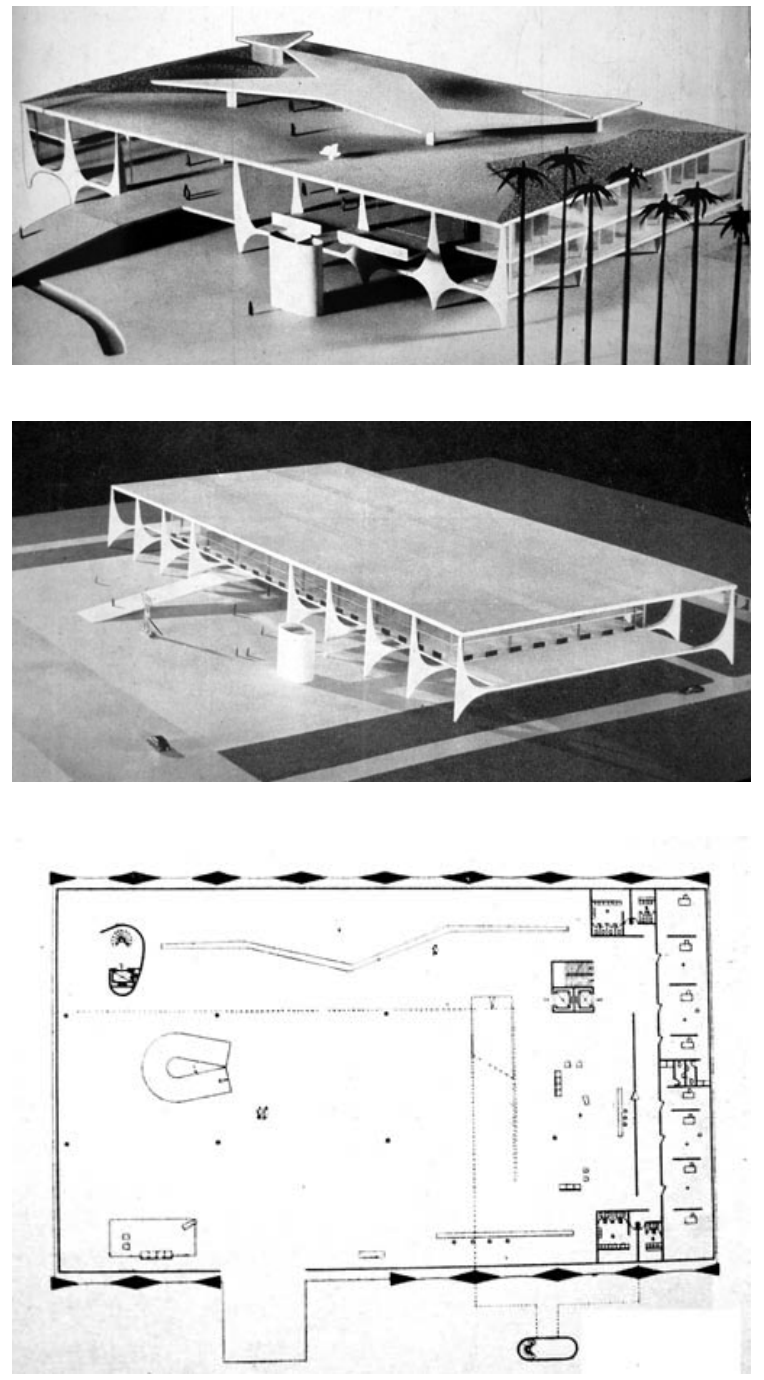

[536] Palácio Governamental - 1956 - ON

(Revista Módulo n.06, dezembro/1956:capa)

[537] Palácio do Planalto - 1958 - ON

(Revista Módulo n.10, agosto/1958:10)

[538] Palácio Governamental - planta - 1956 - ON (Revista Módulo n.06, dezembro/1956:19)
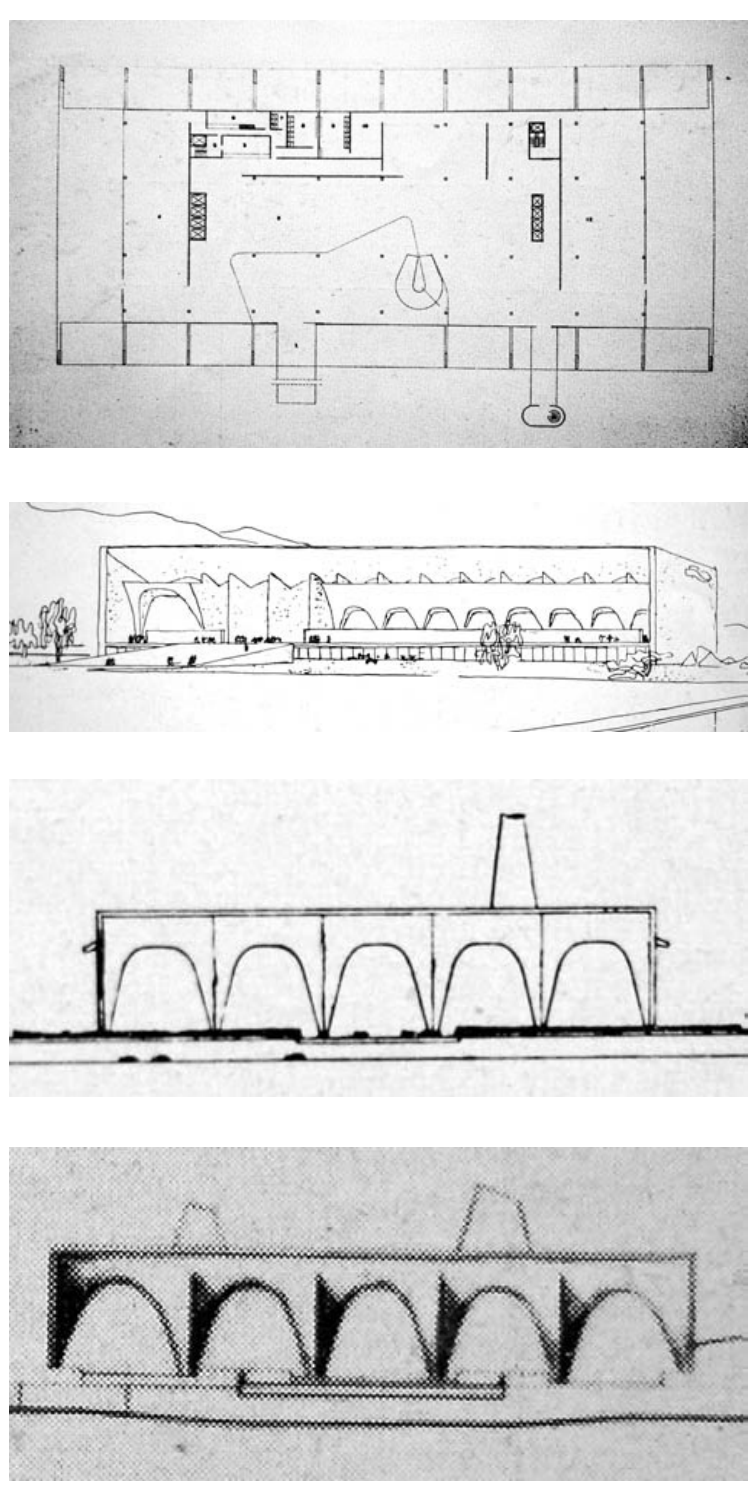

[539] Palácio do Planalto - planta - 1958 - ON (Revista Módulo n.10, agosto/1958:12)

[540] Assembléia Chandigarh - estudo elevação - 1951 - LC (BOESIGER, 1953:137)

[541] Assembléia Chandigarh - estudo elevação - 1951 - LC (BOESIGER, 1953:137)

[542] Assembléia Chandigarh - estudo elevação - 1951 - LC (BOESIGER, 1953:137) 
À primeira vista, um olhar menos atento associará o Palácio Governamental ao Palácio da Alvorada, devido à presença da seqüência de pilares em parábola que caracteriza ambos os projetos.

$\mathrm{Na}$ verdade, o Palácio Governamental trata-se de uma versão preliminar do Palácio do Planalto revestida com uma versão primitiva das colunas que caracterizariam, futuramente, o Palácio da Alvorada.

As plantas do Palácio Governamental e do Palácio do Planalto são extremamente parecidas $^{137}$. Com uma análise mais minuciosa, percebe-se que em nenhum instante o projeto do Palácio Governamental dá margem a uma interpretação que o vincule à residência presidencial. [536], [537], [538], [539]

Apesar das evidencias, Yves Bruand, em Arquitetura Contemporânea no Brasil, trata o Palácio Governamental como uma versão preliminar para o Palácio da Alvorada. Segue trecho do autor:

A idéia de Niemeyer era erigir um verdadeiro palácio nobre e monumental, dividido pelas estruturas que lhe dariam leveza e dignidade. Já no ante-projeto de 1956, havia fixado o tema fundamental a ser desenvolvido e o tinha esboçado em linhas gerais: a moradia propriamente dita, seria constituída por uma caixa de vidro retangular, presa entre duas lajes salientes, sustentadas por uma colunata, cuja audaciosa novidade formal iria caracterizar plasticamente o edifício. Mas tratava-se apenas de um esboço que iria amadurecer nos meses seguintes para ir desembocar na obra-prima que se conhece. De fato, basta comparar as primeiras propostas com a construção final para apreender a amplitude das mudanças feitas:

a) a capela, inicialmente muito afastada e totalmente separada, veio integrar-se no prolongamento Palácio, de modo a formar com ele um só corpo, ao mesmo tempo em que guarda uma inegável independência. b)as proporções gerais foram radicalmente modificadas devido ao prolongamento considerável das fachadas principais e à concomitante diminuição da largura e da altura do edifício.

c) A colunata assumiu significado totalmente diverso depois da adoção de uma nova disposição: seu distanciamento dos panos de vidro permitiu que fossem feitas galerias externas, que trazem uma contribuição decisiva à expressão geral; além disso, o desenho dos suportes foi desenvolvido numa sucessão rítmica contínua, ocultando totalmente a laje de piso, o que reforça o caráter aéreo da composição.

d)Desapareceu a tribuna oficial, bem como a marquise do telhado, recortada em ângulos agudos e obtusos como uma escultura abstrata.

e) $\mathrm{O}$ riacho artificial que serpenteava na esplanada que fica em frente do Palácio foi suprimido a fim de eliminar uma nota pitoresca, deslocada num contexto solene e majestoso.

f) $\mathrm{O}$ arranjo interno, somente esboçado na proposta original, foi totalmente modificado num edifício de proporções inteiramente diferentes.

A passagem do anteprojeto para o projeto definitivo é das mais instrutivas; nela revela-se claramente o novo estilo de Niemeyer. No plano estético, constata-se que as operações efetuadas correspondiam a uma dupla preocupação: aumentar a unidade formal do conjunto e reduzir o número de efeitos inicialmente previstos, a fim de concentrar toda a força expressiva num motivo principal, digno de caracterizar um verdadeiro palácio (BRUAND, 1981:184-186 - grifo nosso).

Como podemos observar, Bruand entende o Palácio que Niemeyer projeta para abrigar a sede do Governo Federal como sendo a Residência do Presidente da República. Em diversas

137. Diversos componentes são comuns em ambas as plantas, tais como: a compartimentação periférica para uso de salas e gabinetes; salão de entrada com mezanino e uso da rampa em "U”.

413 | o encontro de 1955: Síntese e Monumentalidade 

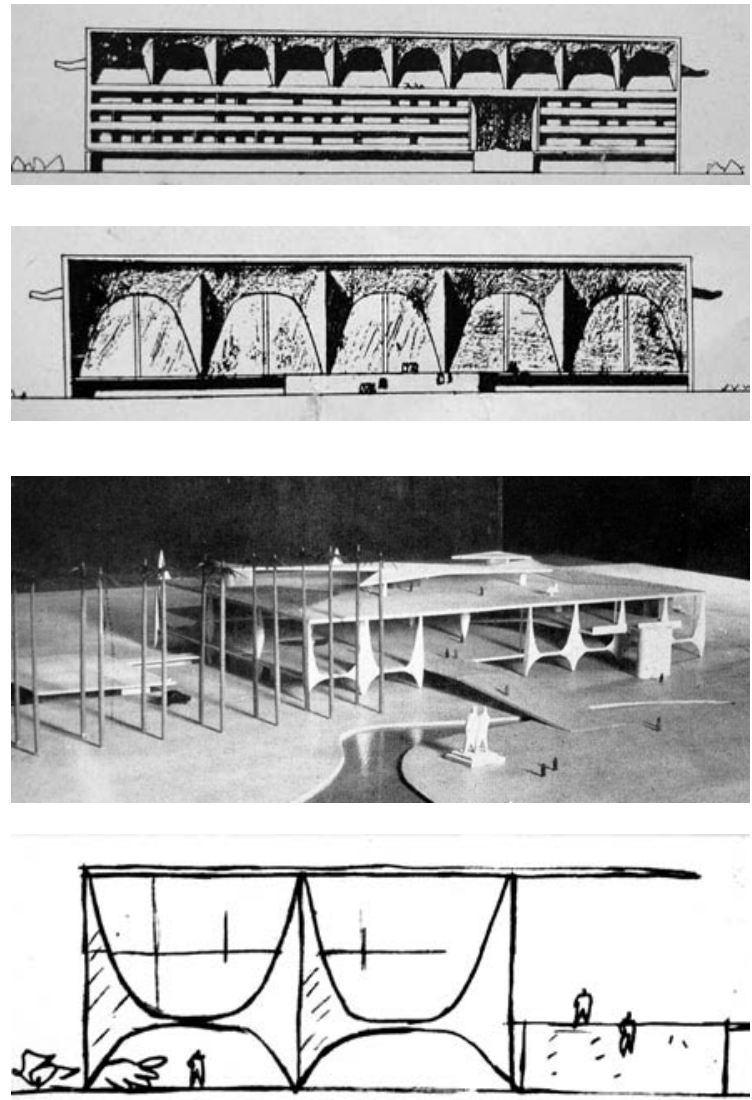

[543] Assembléia Chandigarh - estudo elevação - 1951 $-\mathrm{LC}$

(BOESIGER, 1953:137)

[544] Assembléia Chandigarh - estudo elevação - 1951 $-\mathrm{LC}$

(BOESIGER, 1953:137)

[545] Palácio Governamental - 1956 - maquete - ON (Revista Módulo n.06, dezembro/1956:19)

[546] Palácio Governamental - 1956 - perspectiva - ON (Revista Módulo n.06, dezembro/1956:19)


[547] Pavilhão das Industrias do Parque Ibirapuera (atual sede da Fundação Bienal de São Paulo) rampa interna $-\mathrm{ON}$

(PETIT, 1998:35)

[548] Colégio de Meninos - Cataguases - 1946 - marquise de acesso - ON

(PAPADAKI, 1950:153) 
passagens de sua explicação o autor vincula o projeto do Palácio Governamental ao projeto do Palácio da Alvorada. Tal é o engano que Bruand entende a igreja projetada por Niemeyer como sendo a capela, que no projeto para o Palácio da Alvorada migrará para sua lateral esquerda.

É evidente que, a primeira vista, seja quase que inevitável a associação do Palácio Governamental ao Palácio da Alvorada, devido a presença dos apoios em parábola. Conseqüentemente, quando observamos o volume conchóide da igreja, o relacionamos com o projeto da capela do Palácio da Alvorada. A semelhança entre os templos é flagrante. A diferença reside na escala. No projeto do Palácio da Alvorada, para conferir a feição de capela à igreja, Niemeyer reduz consideravelmente a tamanho do templo.

No projeto para o centro cívico à margem do Lago Paranoá, a igreja ultrapassa com folga a altura do próprio Palácio Governamental que, por sua vez, é consideravelmente mais alto que o Palácio da Alvorada: possui praticamente a mesma altura da capela situada a sua esquerda. Com essa aferição, concluímos que a capela do Palácio da Alvorada corresponde a uma versão reduzida da igreja implantada na praça cívica que abrigava, além do templo religioso, o Hotel, a Residência Presidencial e o Palácio Governamental.

A planta do Palácio Governamental indica que a caixa de vidro transparente está rente à seqüência de pilares parabólicos. Nesse instante, Niemeyer ainda se mantém fiel a formulação do volume horizontal, transparente e suspenso, presente em projetos como o Pavilhão das Indústrias e o Pavilhão dos Estados, constituintes do Conjunto do Parque Ibirapuera. O arquiteto simplesmente envolve seu "pavilhão prototípico" com a seqüência de parábolas.

Nos Palácios de Brasília, o apoio expressivo, antes configurado em "V” e presente no embasamento das barras suspensas ${ }^{138}$, assume a altura do próprio edifício, cujo corpo transparente encontra-se recuado e sombreado sob a laje de cobertura, efeito que torna o pilar responsável pelo reconhecimento do edifício enquanto imagem.

O primeiro estudo de Niemeyer para os palácios de Brasília, representado pelo projeto do Palácio Governamental, ainda não é um redesenho pleno da tipologia presente nos palácios de Chandigarh, caracterizada pela caixa de vidro contida na caixa de pilares expressivos.

Esse estudo de Niemeyer é um registro exato do instante em que o arquiteto, em um mesmo projeto, especula sobre seu repertório vigente entre os anos de 1940 e 1955 e flerta com as soluções postuladas por Le Corbusier em Chandigarh.

Ao mesmo tempo em que o Palácio Governamental preserva características dos projetos anteriores de Niemeyer - não enfrentando a espacialidade vazada dos Palácios de Chandigarh - demonstra um evidente fascínio pelo novo desenho monumental de Le Corbusier, expresso na feição das colunas parabólicas.

No Palácio Governamental de 1956, a influência dos Palácios de Chandigarh não reside ainda na tipologia propriamente dita, mas é diagnosticada no desenho dos apoios parabólicos. Em um primeiro momento a referência à Chandigarh é plástica. Somente nos projetos dos

138. Presente em projetos como o Hospital Sul América e o Palácio da Agricultura.

415 o encontro de 1955: Síntese e Monumentalidade 

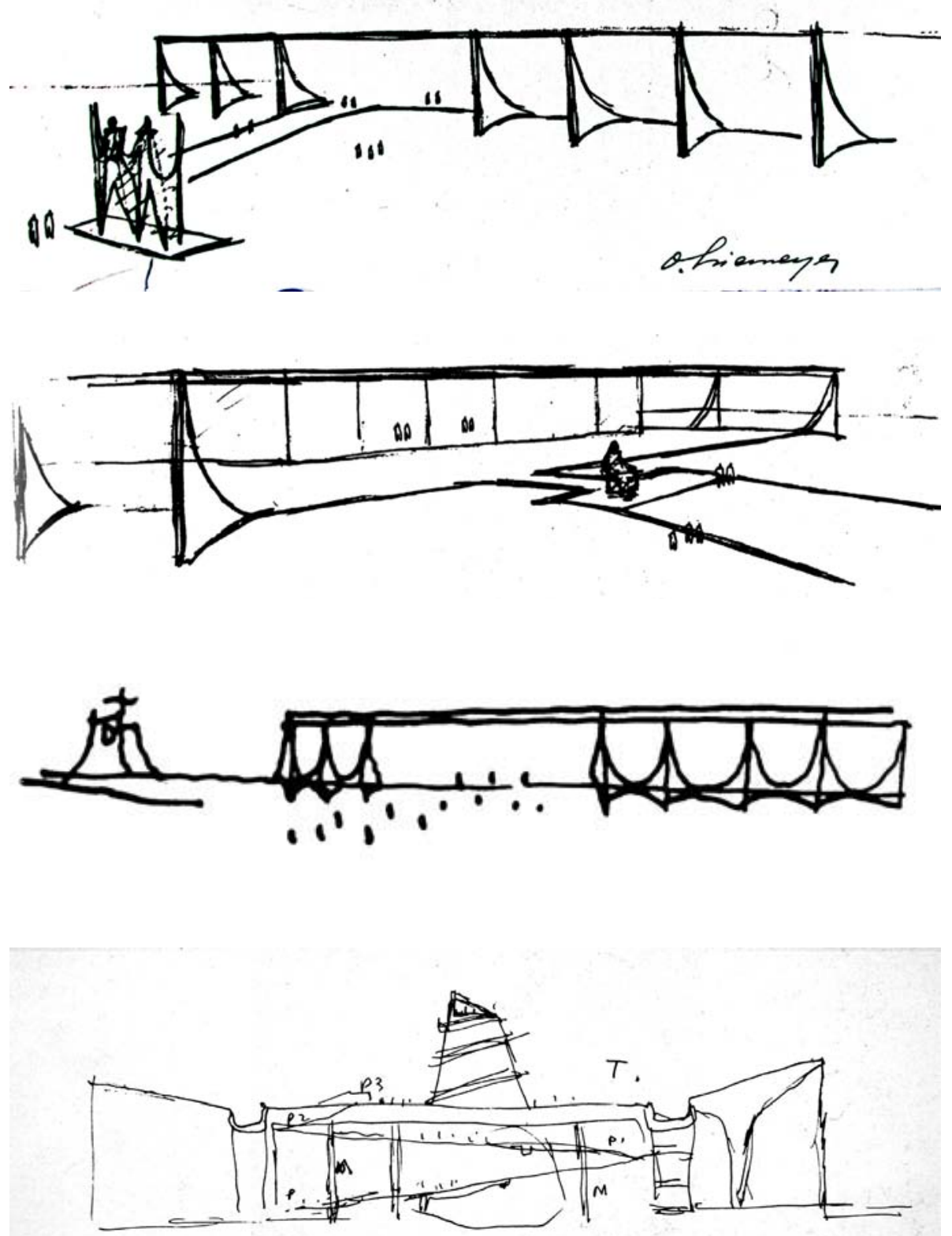

[549] Palácio do Planalto - 1958 - croqui - ON

(Revista Módulo n.10, agosto/1958:09)

[550] Supremo Tribunal Federal - 1958 - croqui - ON

(Revista Módulo n.10, agosto/1958:09)

[551] Palácio da Alvorada - 1957 - croqui - ON

(CORONA, 2001:75)

[552] Assembléia de Chandigarh - croqui - 1951 - LC

(BOESIGER, 1965:80) 
Palácios implantados sobre o Plano Piloto de Lucio Costa, na Praça dos Três Poderes, é que poderemos observar a filiação tanto tipológica como formal.

O desenho dos apoios em parábolas do Palácio Governamental de Niemeyer possui uma clara afinidade com os apoios em arcos parabólicos presentes em diversos estudos de Le Corbusier para a Assembléia de Chandigarh. No Palácio Governamental, Niemeyer inverte o arco parabólico da Assembléia de Chandigarh, que ganha feição em forma de "U" e transformase em parábola. [540], [541], [542], [543], [544], [545], [546]

Ao inverter o arco de Le Corbusier, Niemeyer vincula o apoio do Palácio Governamental à lógica presente em seus apoios em "V": o vértice afunila-se ao se aproximar do chão, enquanto cada perna do "V" afina-se ao se aproximar da laje ou do volume sobre ela.

Niemeyer, no Palácio Governamental, rebate o trecho encurvado da parábola na porção do vazio compreendido entre o chão e a face inferior do volume transparente suspenso. Com essa operação, suspende-se a parábola que apenas toca a laje de cobertura, preservando a idéia de apoio afunilado que toca o chão.

Os pilares do Palácio Governamental e do Palácio da Alvorada não devem ser interpretados como mera inversão dos apoios parabólicos presentes nos estudos de Le Corbusier para a Assembléia e para a Suprema Corte de Chandigarh. O apoio da marquise do Colégio de Meninos em Cataguases (1946) e o pilar escultórico que apoia a rampa em "U” no interior do Pavilhão da Bienal do Parque Ibirapuera (1951) são exemplares que já prenunciam o rebatimento das parábolas ascendentes presente nos pilares dos Palácios de Brasília. [547], [548]

Além da inversão do arco parabólico de Le Corbusier que se transforma em parábola em "U" no exemplar de Niemeyer, há um outro fator que aproxima os arcos parabólicos dos estudos da Assembléia de Chandigarh dos pilares em parábola do Palácio Governamental: o tratamento volumétrico dados aos apoios, caracterizado como um desbaste que confere um sentido ósseo à volumetria dos arcos. Esse tratamento é extremamente semelhante entre os Palácios de Le Corbusier e de Oscar Niemeyer.

Em síntese, podemos considerar que a idéia do apoio em parábola suspensa, presente no Palácio Governamental e, posteriormente, nos Palácios da Alvorada, do Planalto e no Supremo Tribunal Federal, é uma interpretação que inverte a solução que caracteriza conjunto de estudos de Le Corbusier para a Assembléia de Chandigarh.

Ao inverter o arco de Le Corbusier, Niemeyer vincula o desenho do pilar às suas pesquisas sobre os apoios escultóricos em "V" de extremidades afinadas. Exemplares que, exatamente nesse instante, desaparecem da obra de Niemeyer.

O redesenho dos pilares de Chandigarh presente nos Palácios de Brasília não deve ser compreendido como um procedimento isolado na obra de Niemeyer. Trata-se do fragmento de uma pesquisa maior que elabora um repertório pessoal a partir da interpretação das soluções de Le Corbusier, sejam elas de seu período purista (casas brancas e os grands travaux) ou de sua fase que flerta com o vernáculo e com o monumento (Chandigarh).

Devido a intensa profundidade da volumetria do arco escultórico presente nos estu-

417 | o encontro de 1955: Síntese e Monumentalidade 

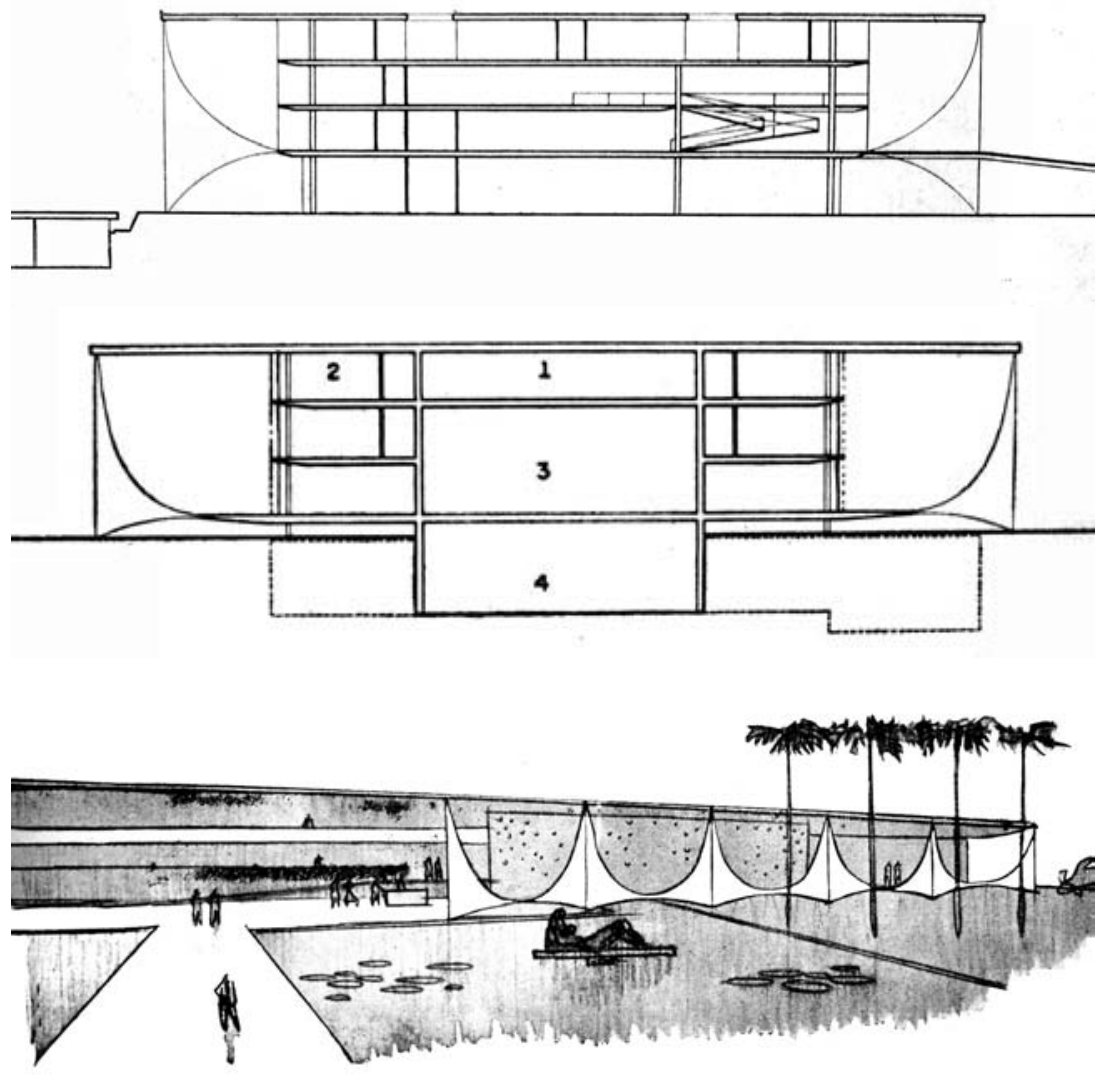

[553] Palácio do Planalto - 1958

- corte - ON

(Revista Módulo n.10, agosto/1958:10)

[554] Supremo Tribunal Federal - 1958 - corte - ON

(Revista Módulo n.10, agosto/1958:13)

[555] Palácio da Alvorada perspectiva - 1957 - ON

(Revista Módulo n.07, fevereiro/1957:24-25)

[556] Palácio Governamental - perspectiva - 1956 - ON

(Revista Módulo n.06, dezembro/1956:16-17)

[557] Palácio da Alvorada maquete - 1957 - ON (Revista Módulo n.07, fevereiro/1957:21)

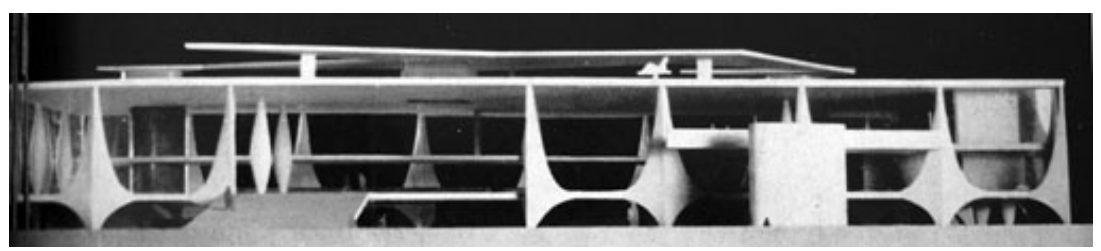

[558] Palácio Governamental - maquete - 1956 - ON (Revista Módulo n.06, dezembro/1956:16-17) 
dos de Le Corbusier para a Assembléia de Chandigarh, seu corte transversal resulta em um perfil em meia-parábola, perpendicular ao arco, que se alarga conforme ascende verticalmente. Com esse artifício, Le Corbusier concebe o apoio como uma escultura vazada que, vista de frente, representa uma seqüência de arcos parabólicos e, vista de lado - em corte - descreve uma meia-parábola, perpendicular e afastada do corpo principal do projeto.

A operação visual múltipla que Le Corbusier concebe em um único projeto será interpretada por Niemeyer nos três projetos definitivos para os Palácios de Brasília: o Palácio do Planalto, o Supremo Tribunal Federal e o Palácio da Alvorada - residência oficial do Presidente da República implantada à margem do Lago Paranoá, no mesmo lugar onde alguns meses antes Niemeyer havia projetado o centro cívico que continha o Palácio Governamental, Residência Presidencial, hotel e igreja. [549], [550], [551]

Enquanto no Palácio da Alvorada Niemeyer realiza a inversão da elevação da Assembléia de Chandigarh, no Palácio do Planalto, ao posicionar os apoios perpendiculares à fachada, Niemeyer inverte o pilar, não mais da elevação, mas do corte transversal presente nos estudos de Le Corbusier para a Assembléia de Chandigarh, caracterizado pela meia-parábola em curva que ascende verticalmente.

Tanto no Palácio do Planalto como no Supremo Tribunal Federal, de maneira inversa, a meia-parábola alarga-se conforme se aproxima da plataforma suspensa e se afulina novamente no trecho abaixo da plataforma suspensa, até, quase tocar o solo em um único ponto. [552], [553], [554]

No projeto para o Palácio da Alvorada, Niemeyer utiliza a solução plástica das parábolas integrais presentes no projeto do Palácio Governamental, cuja planta é utilizada como modelo para o Palácio do Planalto.

A parábola presente na fachada principal do Palácio da Alvorada representa uma versão depurada da parábola do Palácio Governamental que é caracterizada por uma curvatura interrompida pela laje de piso do primeiro pavimento, rompendo-se assim a continuidade da parábola.

A diferença entre as modenaturas que desenham cada parábola é flagrante, esse é um exemplo cristalino da evolução do desenho de Niemeyer. Ao observarmos a precisão, tanto da parábola quanto da proporção do Palácio da Alvorada, entendemos o projeto para o Palácio Governamental como uma versão primitiva, quase uma caricatura, porém necessária para a compreensão do percurso até o Palácio da Alvorada. [555], [556], [557], [558]

Nos projetos do Palácio da Alvorada, do Palácio do Planalto e do Supremo Tribunal Federal, Niemeyer se desvincula por completo do princípio do volume retangular, transparente e suspenso presente nos Palácios do Conjunto do Parque Ibirapuera, mas que ainda reverbera no projeto do Palácio Governamental.

No Palácio da Alvorada, a inversão do arco parabólico não será a única interpretação que Niemeyer realiza sobre o a Assembléia de Chandigarh. Em dois cortes transversais do Palácio do Alvorada - o croqui de Niemeyer e o desenho instrumentado - observamos a presença de um beiral côncavo, rebatido em ambas as faces e que abriga a varanda. O volume envidraçado é

419 | o encontro de 1955: Síntese e Monumentalidade 

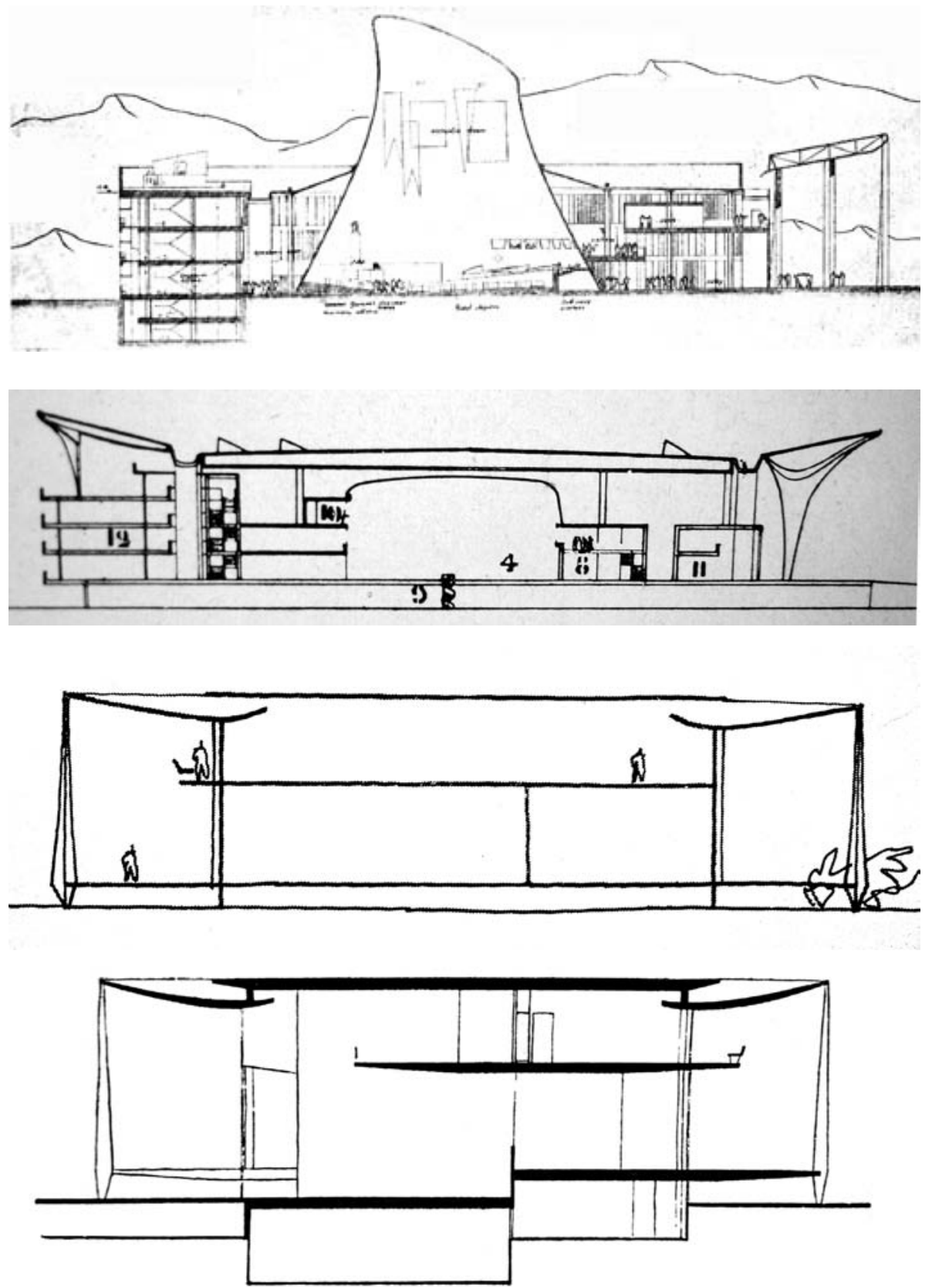

[ 559] Assembléia de Chandigarh - corte - 1955 - LC (BOESIGER, 1957:99)

[560] Assembléia de Chandigarh - corte - 1951 - LC (BOESIGER, 1953:137)

[561] Palácio da Alvorada - corte - versão preliminar - 1957 (Revista Módulo n.07, fevereiro/1957:27)

[562] Palácio da Alvorada - corte - projeto definitivo - 1957 (BOTEY, 1996:126) 
coberto por laje plana que se sobrepõe sutilmente aos beirais côncavos. Esse tipo de solução já estava presente nos estudos de Le Corbusier para a Assembléia de Chandigarh, onde se nota o beiral côncavo na extremidade do volume regular, como no exemplar de Niemeyer. [559], [560], [561], [562]

O projeto de Niemeyer para o Palácio da Alvorada indica um refinamento não apenas do desenho dos apoios parabólicos de Le Corbusier, mas da própria marquise côncava presente nos estudos para a Assembléia de Chandigarh.

Essa operação de Niemeyer que abranda e suaviza o gesto de Le Corbusier, presente no Palácio da Alvorada, não ilustra uma mera interpretação, mas uma conduta que depura em sutis perfis, as embrutecidas curvaturas de Le Corbusier para Chandigarh.

Será justamente o desenvolvimento do desenho desse beiral côncavo que fará com que Le Corbusier encontre a solução definitiva para a Assembléia que, nem de longe, lembrará a sucessão de arcos parabólicos presente nos estudos preliminares, solução que migrará para outro Palácio de Chandigarh: a Suprema Corte.

Nos três projetos definitivos de Palácios (Alvorada, Planalto e Supremo), Niemeyer assume de maneira contundente o partido tipológico adotado por Le Corbusier para os Palácios do Capitólio de Chandigarh na medida em que evidencia o recuo dos fechamentos verticais transparentes para o interior das lajes de cobertura e de piso, mantendo-os resguardados pelo peristilo de pilares de perfil parabólico. Com esse procedimento, a laje de cobertura vira beiral e a laje de piso, daquele que até então era um volume retangular suspenso, torna-se plataforma.

Ao recuar o fechamento transparente, Niemeyer subverte a estanqueidade de um volume que perde suas faces. O plano da fachada, compreendido pelo espaço entre a borda da cobertura e a borda da plataforma suspensa, é agora ritmado pelos pilares parabólicos, sejam eles alinhados à fachada, em parábola inteira como no Palácio da Alvorada, ou perpendiculares, em meia-parábola como no Supremo Tribunal Federal e no Palácio do Planalto.

Com essa operação que desmembra o volume em campos bidimensionais autônomos (laje de cobertura, plataforma e planos verticais transparentes) Niemeyer aproxima a solução espacial dos Palácios de Brasília à concepção de espaço de Mies van der Rohe, onde o ambiente é conseqüência da articulação de componentes autônomos representados pelos planos horizontais de piso e cobertura e os planos verticais opacos e transparentes presentes em projetos como o Pavilhão da Alemanha para a Feira Internacional de Barcelona (1929) e a casa Farnsworth (1947).

Niemeyer, ao afastar-se da tectônica corbusiana, aproxima-se da essencialidade etérea de Mies van der Rohe que dissolve a materialidade do objeto no instante em que elimina as arestas do volume, e o suspende.

Nesses três Palácios (Alvorada, Planalto e Supremo), podemos diagnosticar com clareza a tipologia da caixa de vidro contida no interior da caixa de pilares vazados, aplicada por Le Corbusier nos Palácios de Chandigarh. [563], [564], [565]

Apesar das semelhanças, não encontramos nos estudos de Le Corbusier para os Palácios de Chandigarh a idéia de suspensão presente nos Palácios de Brasília. O chão em Le Corbusier

\footnotetext{
421 o encontro de 1955: Síntese e Monumentalidade
} 



[563] Palácio da Alvorada - 1957 - maquete - ON (Revista Módulo n.07, fevereiro/1957:27)

[564] Palácio do Planalto - 1958 - maquete - ON (Revista Módulo n.10, agosto/1958:01)

[565] Supremo Tribunal Federal - 1958 - maquete $-\mathrm{ON}$

(Revista Módulo n.10, agosto/1958:10) 
se transforma em plataforma em Niemeyer.

Enquanto os Palácios de Chandigarh emergem vigorosos como se brotassem do chão, os Palácios de Brasília levitam, como se quisessem apenas tocar o solo. A sombra maciça da plataforma sobre o chão enfatiza essa sensação de suspensão.

A diferença entre as concepções de Le Corbusier e Oscar Niemeyer é conseqüência da interpretação dos modelos referenciais que cada arquiteto utiliza para conceber seu projeto. Os Palácios de Le Corbusier são tributários a configuração canônica dos templos da antiguidade clássica, enquanto os Palácios de Niemeyer representam uma evolução dos modelos de pavilhões ${ }^{139}$ presentes em sua própria obra (volume retangular, horizontal, transparente e suspenso) ao mesmo tempo em que podem ser compreendidos como interpretação das soluções corbusianas para Chandigarh.

Em alguns croquis para os Palácios de Brasília, Niemeyer desenha o percurso do indivíduo que, segundo o traço do arquiteto, deve descobrir passo a passo as diferentes visuais que se revelam em cada mirada.

Nos Palácios de Brasília, Niemeyer inverte a materialidade purista de Le Corbusier ${ }^{140}$, concebendo grandes espaços vazados e generosas galerias cobertas que possuem como limite físico e visual com o meio externo apenas o peristilo de pilares em parábola.

Em Brasília, a relação interior/exterior assume outra caracterização. Por mais que os edifícios que constituem o conjunto arquitetônico da Pampulha representem uma evolução que rompe com a estanqueidade do "objeto moderno", devemos observar que todos eles, sem exceção, estabelecem um diálogo com a paisagem através de uma decomposição da forma, só possível a partir da adição e da subtração de elementos. Por exemplo, a plataforma do Iate Clube da Pampulha - diferentemente das plataformas dos Palácios de Brasília - configura-se como algo externo ao volume trapezoidal suspenso, que é caracterizado pela cobertura em forma de telhado invertido.

Niemeyer em Brasília, ao eliminar a matéria que reveste a face do volume, revela um esqueleto esculpido que rompe com o código "dentro/fora". A paisagem, antes instância que emoldurava o objeto, invade os vazios dos alpendres suspensos que resguardam o volume envidraçado que, na penumbra, se pretende incógnito, se esconde na sombra que contrasta com a alvura das esbeltas espessuras das lajes de piso e de cobertura e dos pilares. Conforme nos movemos, esses peristilos de pilares desenham novas molduras para uma paisagem que é tão presente quanto a própria matéria. [566], [567], [568]

Para Sofia Telles, a relação entre a caixa de vidro suspensa e resguardada no interior da projeção dos planos horizontais de cobertura e plataforma dos palácios, e os perfis parabólicos dos apoios localizados do limite desse campo retangular indicam uma "anulação da superfície"

139. O próprio projeto para o Pavilhão do Brasil na Feira Internacional de Nova York de 1939 contém informações sobre a solução do prisma retangular suspenso que posteriormente assume escala monumental nos palácios do Conjunto arquitetônico do Parque Ibirapuera em São Paulo (1951).

140. Exemplificada nos projetos de residências realizados da década de 1920: casa Cook, casa Stein, casa Savoye, entre outros.

423 o encontro de 1955: Síntese e Monumentalidade 

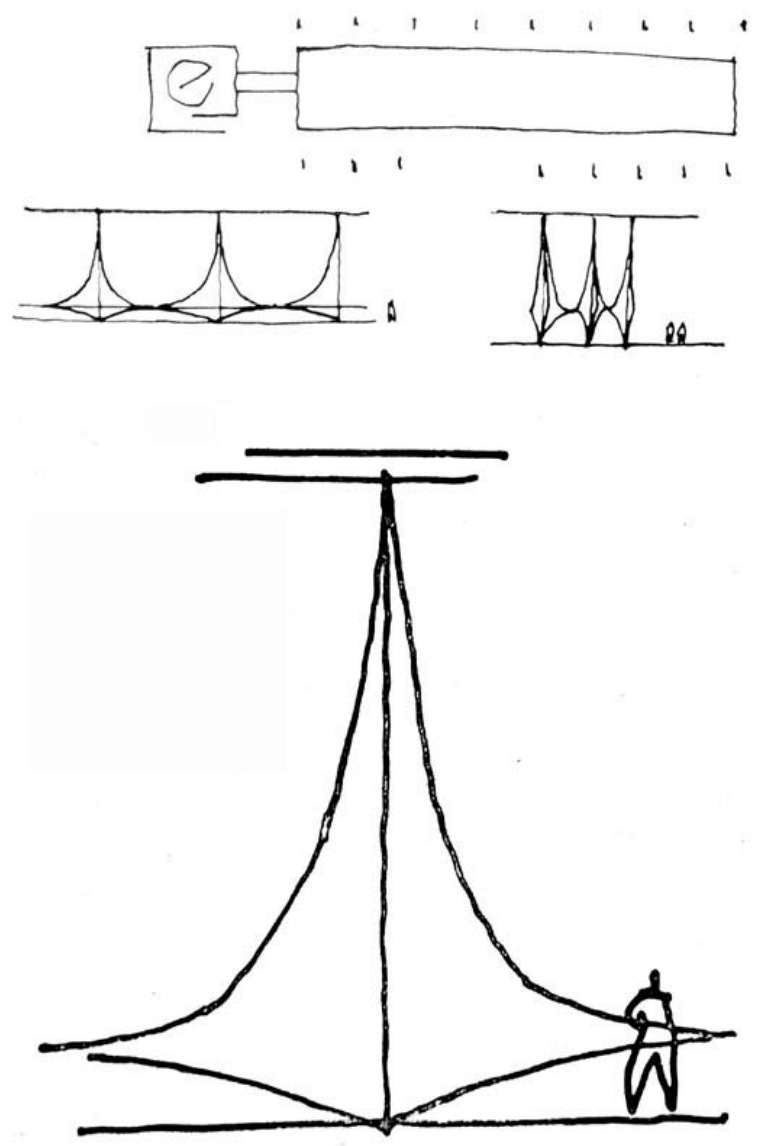

[566] Palácio da Alvorada - 1957 - croquis - ON (Revista Módulo 15 p.12)
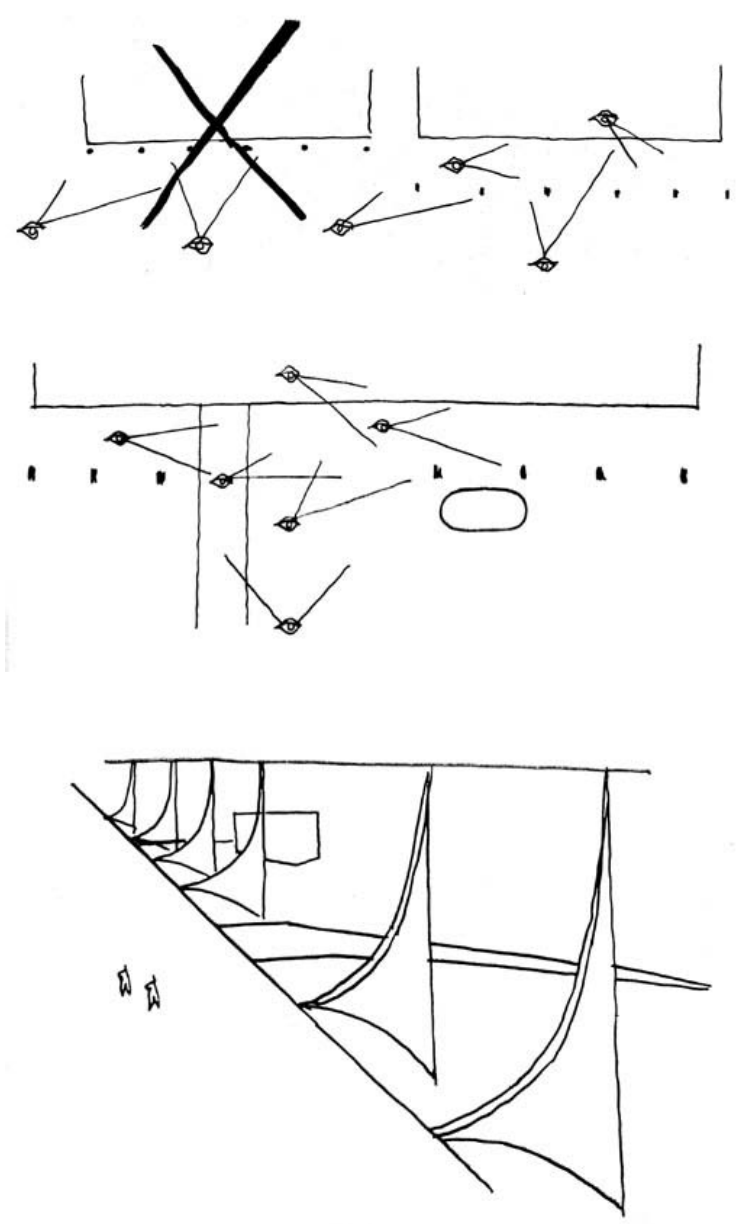

[567] Palácio do Planalto - 1958 - croqui - ON (Revista Módulo 15 p.08-09) 
preenchida pela penumbra, conseqüência da sombra projetada pelo generoso beiral. O efeito lumínico que, ao mesmo tempo, produz sombras densas no alpendre entre o peristilo de pilares e a caixa de vidro, irradia a alvura dos pilares revestidos de mármore branco. Segue trecho da autora:

A questão é que, de um lado, Niemeyer afasta de tal maneira o corpo envidraçado do edifício para o interior da laje que a sombra que produz é na verdade a anulação da superfície, o que por sua vez dissolve o volume. De outro lado, o uso do mármore branco que reveste as colunas acaba por funcionar como um rebatedor luminoso que dissolve a sua própria materialidade. (TELLES, 1988:77)

Se os Palácios da Alvorada, do Planalto e o Supremo Tribunal Federal representam uma interpretação livre, alva e aérea do partido tipológico e plástico presente nos estudos de Le Corbusier para os Palácios de Chandigarh, o mesmo não pode ser dito sobre o Ministério das Relações Exteriores (Palácio do Itamaraty - 1962) e o Palácio da Justiça (1962).

No projeto para o Palácio do Itamaraty observa-se uma relação mais estreita com os Palácios de Chandigarh que foram construídos, que diferem dos esboços integrantes dos estudos de Le Corbusier.

Assim como Le Corbusier em Chandigarh, Niemeyer no Itamaraty concebe um edifício nitidamente caracterizado pela caixa de vidro contida no interior da caixa de pilares escultóricos. No Itamaraty inexiste a plataforma: tanto o volume transparente, como o peristilo de pilares emergem diretamente do chão, isto é, da água. Com o advento do espelho d'água, por reflexão, duplica-se a altura do edifício, que se rebate na lâmina d'água.

No caso do Palácio do Itamaraty, não será apenas o partido tipológico e plástico que o aproximará da Suprema Corte de Chandigarh, mas também o tratamento da superfície, com a adoção do concreto aparente, que impregna na forma arquitetônica não só o sentido de verdade, mas o caráter artesanal presente no relevo que registra a marca deixada pela fôrma de madeira. [569], [570], [571]

O desenho do arco, presente em diversos estudos de Le Corbusier para a Assembléia de Chandigarh e concretizado na Suprema Corte, será assumido por Niemeyer em apenas dois edifícios de Brasília, que são, justamente, o Palácio do Itamaraty e o Palácio da Justiça.

No Palácio da Justiça, o arco em semi-círculo, aparece apenas em sua face principal, e é caracterizado por um corte simples no plano vertical de concreto aparente, diferentemente do tratamento em desbaste que caracteriza o Palácio do Itamaraty.

Na elevação principal do Palácio da Justiça, Niemeyer dispõe lado a lado meios-arcos irregulares que não possuem a mesma materialidade escultórica do Palácio do Itamaraty. O arquiteto contrasta a aspereza do tratamento da superfície com a presença de gárgulas gigantes localizadas no vão entre cada meio-arco. [572], [573], [574]

O Palácio do Itamaraty representa uma versão arejada e delgada da solução presente na Suprema Corte de Le Corbusier caracterizada por arcos excessivamente espessos e embrutecidos.

Devemos salientar o fato de que tanto o Palácio do Itamaraty como o Palácio da Justiça foram projetados em 1962, sendo posteriores a inauguração de Brasília que data de 20 de abril

425 o encontro de 1955: Síntese e Monumentalidade 

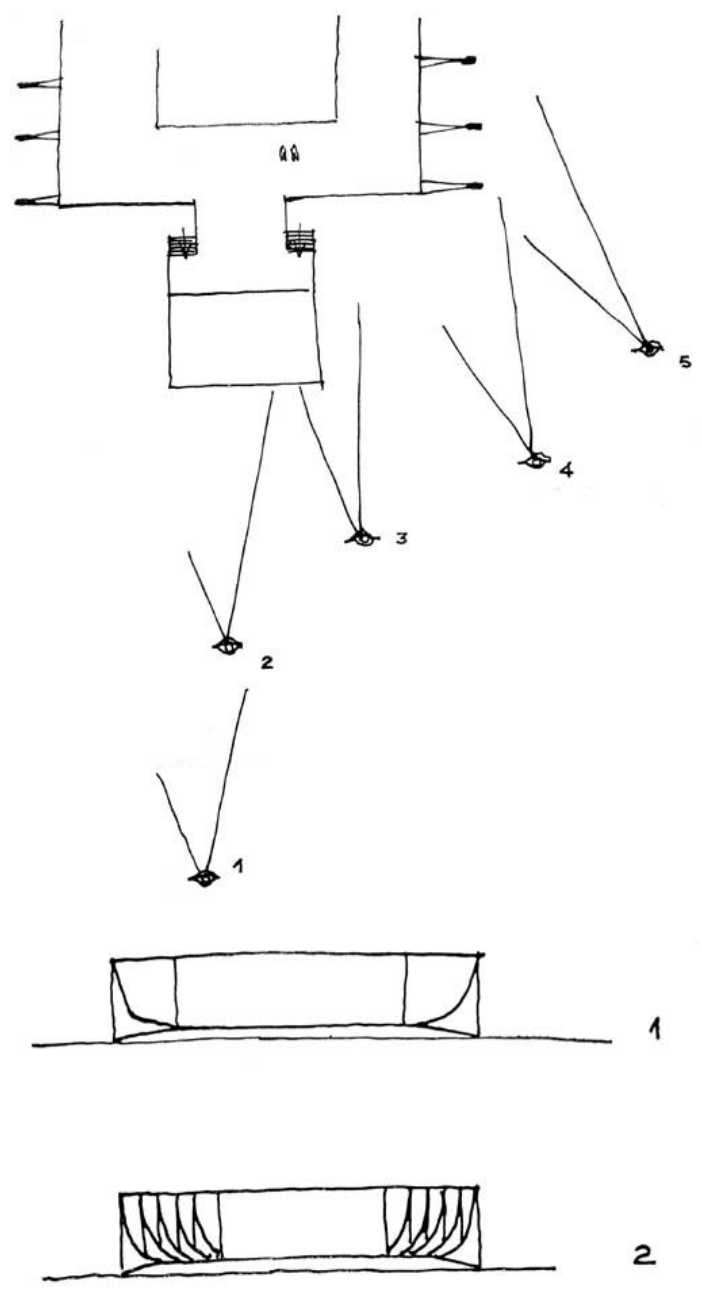

2


[568] Supremo Tribunal Federal - 1958 - ON (Revista Módulo 15 p.10-11)
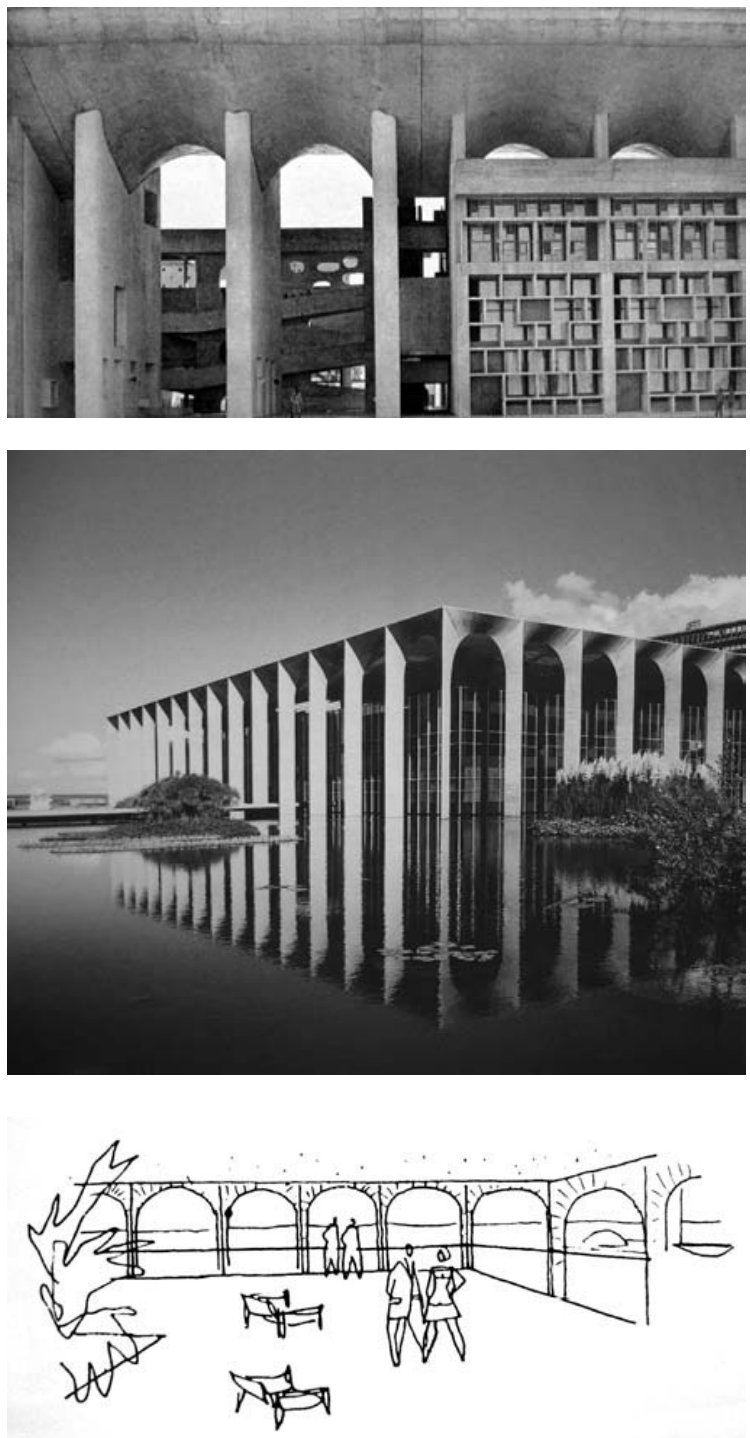

[569] Suprema Corte de Chandigarh (BOESIGER, 1957:59)

[570] Palácio do Itamaraty (Ministério das Relações Exteriores) - 1962 - ON

(UNDERWOOD, 2002:97)

[571] Palácio do Itamaraty (Ministério das Relações Exteriores) - 1962 - ON

(CORONA, 2001:74) 
de 1960, enquanto os demais Palácios de Brasília, incluindo a versão primitiva do Palácio Governamental, foram concebidos entre 1956 e 1957.

O processo de projeto de Niemeyer nos Palácios de Brasília, ao invés de afastar-se das propostas de Le Corbusier para Chandigarh, ao contrário, irá aproximar-se cada vez mais do modelo do "mestre". Aquilo que, à primeira vista, pode parecer estranho e contraditório, possui uma explicação: tanto o Palácio Governamental ${ }^{141}$, como o Palácio da Alvorada, o Palácio do Planalto e o Supremo Tribunal Federal, são formulações que levaram em conta os estudos de Le Corbusier para Chandigarh e não tinham como referência os Palácios construídos, até por que, em 1956, os Palácios de Chandigarh ainda estavam em construção. Nesse sentido, podemos considerar esse primeiro "lote” de Palácios projetados por Niemeyer entre 1956 e 1957 como um desdobramento dos estudos de Le Corbusier em constante modificação e distantes da solução final. Exatamente o contrário ocorre no caso do Palácio do Itamaraty, que se aproxima muito mais da versão definitiva e construída para a Suprema Corte de Chandigarh do que dos estudos elaborados por Le Corbusier.

Em síntese, poderíamos intuir um diálogo contínuo na linha do tempo entre as experiências dos centros cívicos das capitais de Le Corbusier e de Oscar Niemeyer: enquanto os Palácios de Niemeyer projetados entre 1956 e 1957 faziam referência a uma Chandigarh presente na prancheta de Le Corbusier, já passados alguns anos, o Palácio do Itamaraty encontrava como interlocutor não mais o desenho de Le Corbusier, mas Chandigarh construída, pronta.

A experiência projetual dos Palácios de Brasília representa o ponto máximo da auto-crítica de Niemeyer que se inicia em 1954, onde o arquiteto revê os procedimentos e as soluções formais de seus projetos anteriores mas não os abandona por completo, os reorganiza a partir da fusão entre forma e estrutura.

Nessa revisão, Niemeyer preserva as soluções formais preconizadas em Pampulha, porém, os elementos presentes em seu repertório formal perderão o caráter de apêndice e a feição compositiva, assumindo a escala e o perfil de todo o objeto que agora é conseqüência de um traço vigoroso, contínuo e sintético. As vibrações malemolentes dão lugar à serenidade de um gesto pleno, único, ao mesmo tempo simples e monumental.

O processo de desenvolvimento de projeto presente nos conjunto de croquis do arquiteto para o projeto do Congresso Nacional de Brasília ilustra com extrema clareza e precisão a transição entre a diversidade compositiva de elementos secundários e a síntese da forma que aglutina partido formal e partido estrutural.

Nos estudos para o Congresso Nacional de Brasília, Niemeyer lançará mão de diversos elementos integrantes de seu conjunto de soluções formais experimentadas em Pampulha e adotadas como modelo na maioria de seus projetos realizados entre 1940 e 1954.

Apesar do projeto definitivo para o Congresso Nacional não possuir o peristilo de pilares parabólicos presentes nos Palácios da Alvorada, Planalto e Supremo, encontramos em vários

141. Versão preliminar do Palácio do Planalto. Projeto realizado antes mesmo do concurso para o Plano Piloto.

427 | o encontro de 1955: Síntese e Monumentalidade 

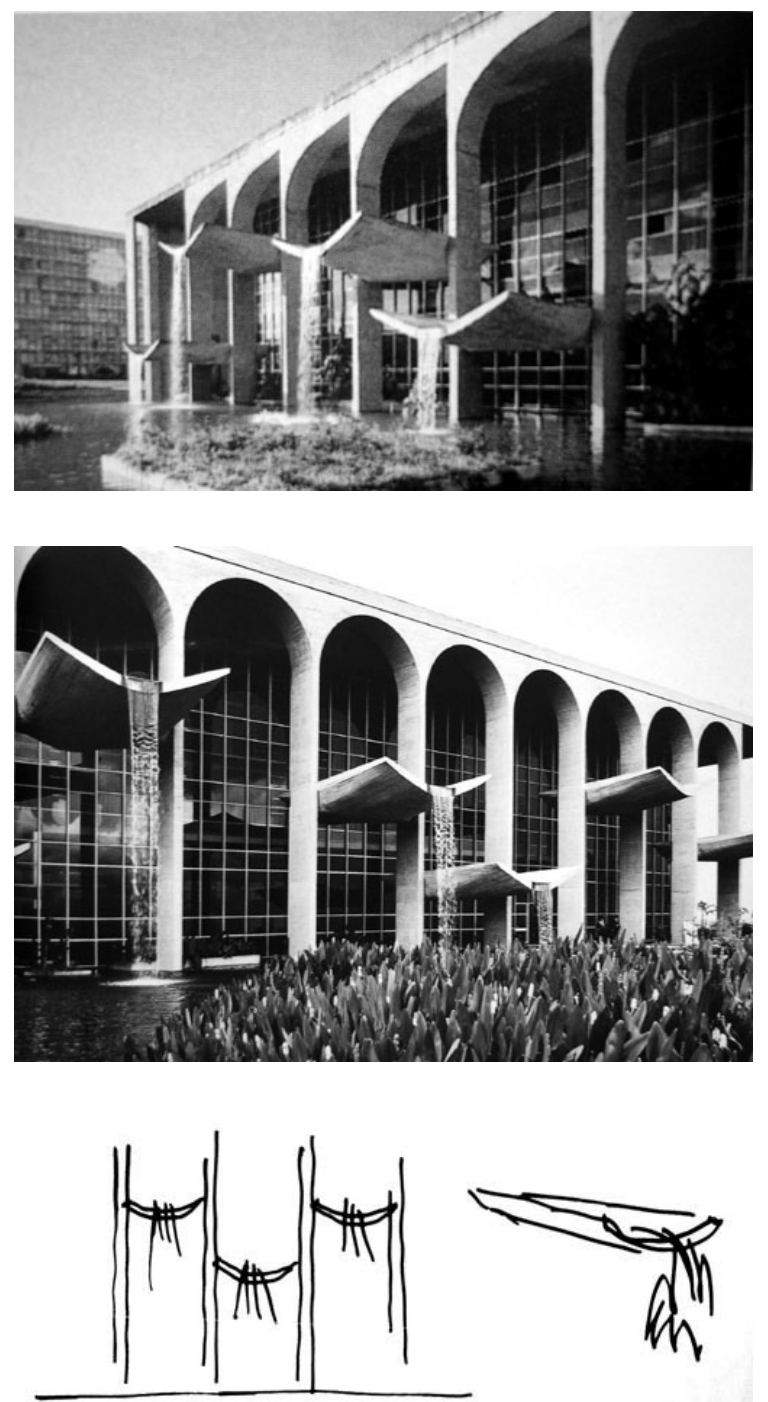

[572] Palácio da Justiça - fachada principal - 1962 - ON (BOTEY, 1996:140)

[573] Palácio da Justiça - fachada posterior - 1962 - ON (BOTEY, 1996:140)

[574] Palácio da Justiça - croqui gárgulas - 1962 - ON (CORONA, 2001:122) 
estudos do arquiteto para o Congresso especulações e variações sobre o tema presente no pilar do Palácio da Alvorada.

Em alguns estudos para o Congresso, Niemeyer elabora os plenários da Câmara dos Deputados e do Senado na forma de volumetrias trapezoidais, solução recorrente em projetos de Le Corbusier como o Palácio Centrosoyus (1929) e o Palácio dos Sovietes (1931) e incorporada no projeto para a sede do MES (1936). O próprio Niemeyer, tanto em seus projetos anteriores como nos posteriores à Brasília, nunca se furtou de lançar mão da solução trapezoidal para objetos que tinham a função de abrigar auditórios, assembléias e teatros, como por exemplo no Teatro Municipal de Belo Horizonte (1943) ou no auditório do Centro Tecnológico da Aeronáutica em São José dos Campos (1947).

Em alguns esboços para o Congresso Nacional, Niemeyer funde os volumes trapezoidais das tribunas às extremidades de uma barra horizontal, cuja fachada é sobreposta pelo renque de pilares parabólicos que caracterizam o Palácio da Alvorada.

A própria idéia da barra horizontal que se conecta a um volume trapezoidal, presente nesses estudos, pode ser diagnosticada na solução do projeto definitivo do MES, onde o Salão de Exposição, de planta retangular e proporção horizontal, conecta-se ao volume trapezoidal do auditório. [575], [576], [577], [578]

Independentemente das inúmeras variações e versões que Niemeyer elabora para o Congresso Nacional, a "coluna do Alvorada” é um denominador comum entre os estudos. Niemeyer parecia estar decidido em imprimir para o Conjunto Arquitetônico de Brasília um sentido de unidade a partir do desenho da coluna parabólica.

$\mathrm{Na}$ pesquisa de Niemeyer, a própria coluna assumirá as mais diversas feições: migrará para um dos pavimentos da torre dos gabinetes, preenchendo todo o trecho de um dos andares-tipo, ou, como em outro estudo, preencherá toda a proporção vertical da torre, sobrepondo uma coluna a outra em prumo vertical. [579], [580]

O arranjo da seqüência de colunas parabólicas em ritmo vertical já havia sido aventada por Le Corbuiser em um dos seus estudos para a Assembléia de Chandigarh. Mesmo quando comparamos a disposição vertical da coluna escultórica em Le Corbusier e em Niemeyer, notamos a existência da mesma operação de inversão, onde Niemeyer transforma em parábola o arco de Le Corbusier.

Enquanto o croqui de Le Corbusier representa a sobreposição de arcos escultóricos, um sobre o outro, o desenho de Niemeyer ilustra uma continuidade vertical dada por um empilhamento de meias parábolas rebatidas, fragmento evidente do "pilar do Alvorada" que caracterizase como uma inversão - com caráter escultórico abrandado - dos arcos de Le Corbusier para a Assembléia de Chandigarh. [581], [582]

Em um dos esboços para o Congresso Nacional, Niemeyer concebe o plano vazado de pilares na fachada com arcos parabólicos, aos moldes dos estudos de Le Corbusier para a Assembléia de Chandigarh. Nesse estudo não há a típica inversão do arco parabólico de Le Corbuiser que se transforma em parábola suspensa em Niemeyer. Ao especular o arco parabólico,

429 o encontro de 1955: Síntese e Monumentalidade 

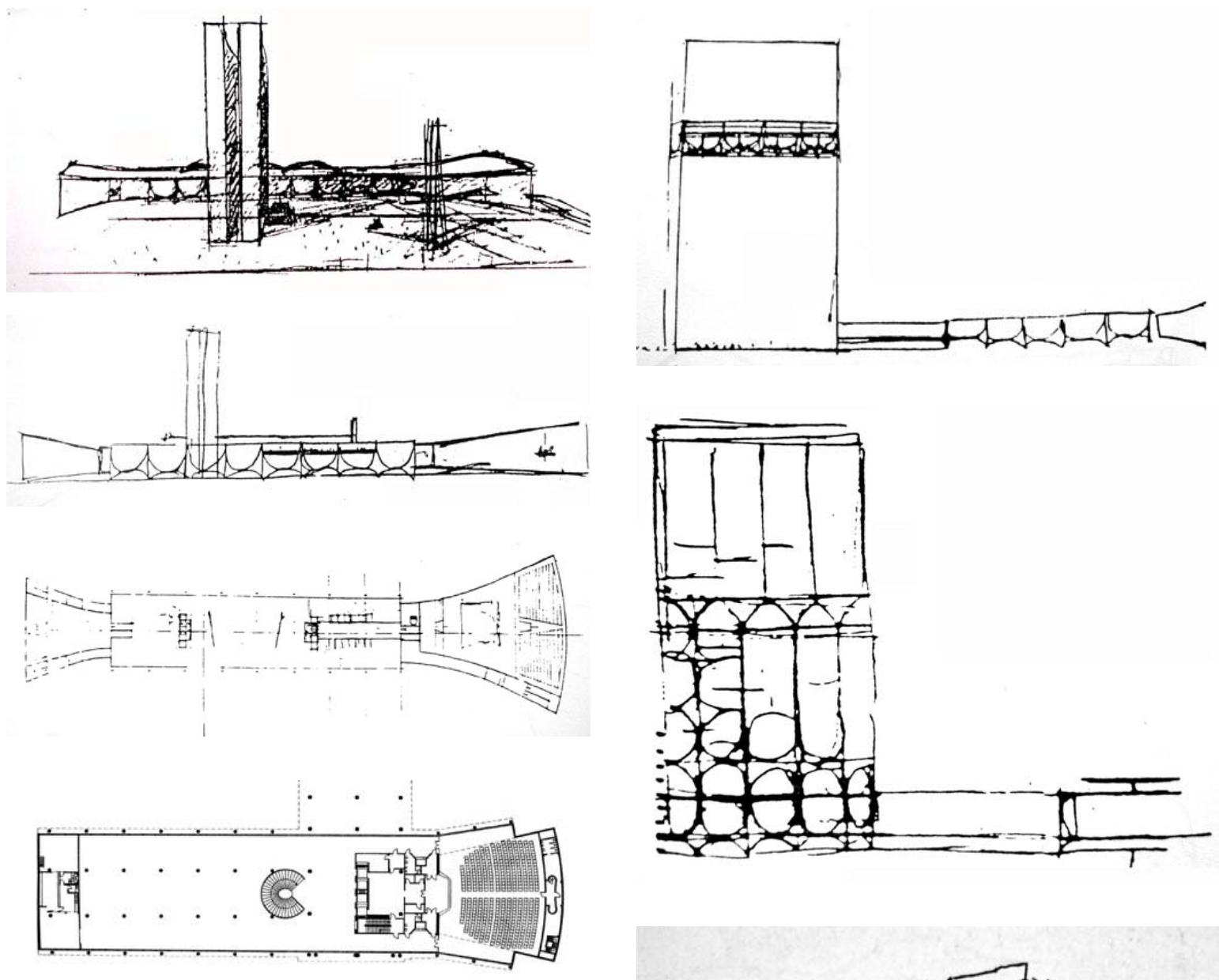

[575] Congresso Nacional - estudos - 1957 - ON (KATINSKY, 1990:sn)

[576] Congresso Nacional - estudos - 1957 - ON (KATINSKY, 1990:sn)

[577] Congresso Nacional - estudos - 1957 - ON (KATINSKY, 1990:sn)

[578] Ministério da Educação e Saúde - planta salão de exposições - 1936 - Lucio Costa, Oscar Niemeyer, Affonso Eduardo Reidy, Jorge Moreira, Carlos Leão e Ernani Vasconcelos

(UNDERWOOD, 2002:39)

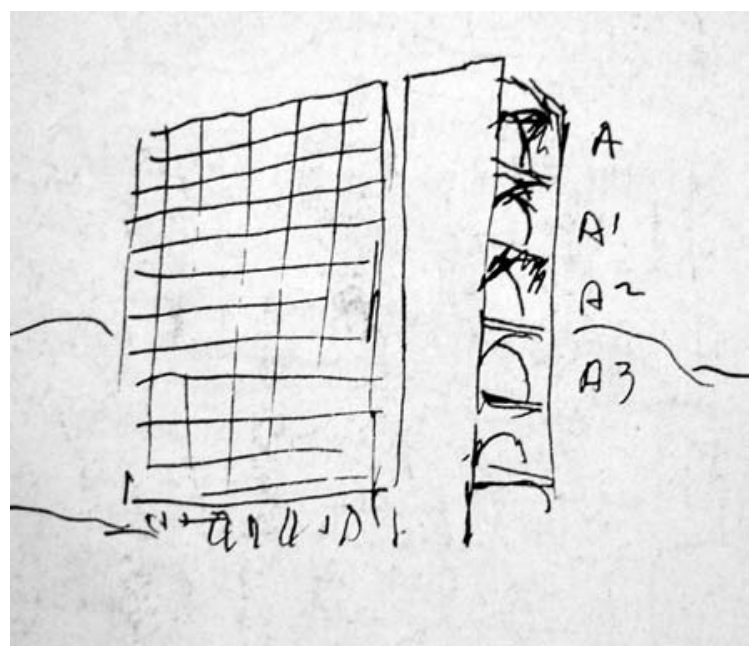

[579] Congresso Nacional - estudos - 1957 - ON (KATINSKY, 1990:sn)

[580] Congresso Nacional - estudos - 1957 - ON (KATINSKY, 1990: sn)

[581] Assembléia de Chandigarh - estudo - 1951 - LC (BOESIGER, 1953:136) 
Niemeyer, mais uma vez, nos dá pistas de que sua experiência em Brasília guarda uma relação de partido e de forma com as propostas arquitetônicas de Le Corbusier para Chandigarh. [583]

Os estudos para o Congresso Nacional atestam que Niemeyer migra do partido da barra horizontal interligada a volumes trapezoidais em suas extremidades para soluções onde os plenários são representados por recintos de planta circular. Niemeyer substitui os volumes trapezoidais por cúpulas que, ora estão sobre a barra horizontal revestida pelos "pilares do Alvorada", ora estão dispostas diretamente sobre o solo.

Nos estudos para o Congresso Nacional de Brasília, a tipologia prototípica do volume trapezoidal como abrigo para assembléias e auditórios dá lugar a solução do volume de planta circular contido no interior do perímetro do embasamento retangular. Os volumes correspondentes às plantas circulares dos plenários afloram do plano de cobertura do volume-plataforma, sob a forma de dois objetos antagônicos: uma cúpula (Senado) e uma cúpula invertida (Câmara dos Deputados).

Em alguns estudos de Niemeyer para o Congresso Nacional, os volumes dos plenários em forma de cúpula estão dispostos sobre o volume horizontal. Paulatinamente, esse embasamento horizontal perde o sentido de sólido e assume o caráter de plataforma de aparência bidimensional.

Niemeyer acomoda o embasamento do Congresso Nacional na cota mais baixa do Eixo Monumental e nivela sua laje de cobertura às duas avenidas laterais que - em cota mais alta com relação ao térreo do Congresso - rumam em direção a Praça dos Três Poderes. O trecho em declive de ambas as vias se inicia após a passagem pelo Congresso Nacional. Com esse artifício, a partir de um arranjo primoroso de diferentes terraplenos, Niemeyer elimina a volumetria do embasamento do Congresso para quem olha em direção da Praça dos Três Poderes. A real altura da plataforma só é percebida quando já estamos na Praça dos Três Poderes e nos voltamos para o Congresso Nacional. [584], [585]

Ao rebaixar o nível do embasamento do Congresso, Niemeyer resolve a equação da espacialidade cívica de Brasília. O arquiteto libera a perspectiva do Eixo Monumental para a Praça dos Três Poderes e mantém em evidencia os perfis rigorosos dos volumes que abrigam os plenários, que nesse instante, apresentam-se como dois bólidos suspensos sobre uma delgada plataforma.

Até o momento, o nexo arquitetônico entre as soluções de Le Corbusier e Oscar Niemeyer baseia-se em dois aspectos significativos: o partido tipológico da caixa de vidro contida no interior da caixa vazada compreendida pelo peristilo de pilares, e o desenho expressivo dos apoios caracterizado por um perfil parabólico e pela materialidade escultórica, escavada.

Ao analisarmos os estudos de Niemeyer para o Congresso Nacional de Brasília, podemos eleger um terceiro componente significativo e comum tanto aos ensaios como as soluções finais dos projetos de ambos os arquitetos. Os estudos para o Congresso Nacional evoluem em uma direção que aponta para a solução dos plenários em duas formas circulares contidas no interior da planta retangular ${ }^{142}$.

142. Que culminará na solução definitiva do Congresso Nacional de Brasília.

431 o encontro de 1955: Síntese e Monumentalidade 



[582] Congresso Nacional - estudos - 1957 - ON (KATINSKY, 1990:sn)

[583] Congresso Nacional - estudos - 1957 - ON (KATINSKY, 1990:sn)

[584] Congresso Nacional de Brasília - 1958 - ON (foto: Rodrigo Queiroz)

[585] Congresso Nacional de Brasília - 1958 - ON (foto: Rodrigo Queiroz)




A solução das formas circulares contidas no interior do pavilhão de perímetro regular, aproxima os estudos de Niemeyer das especulações de Le Corbusier para a Assembléia de Chandigarh.

Nos estudos iniciais de Le Corbusier para a Assembléia de Chandigarh, a planta é claramente caracterizada por duas formas arredondadas abrigadas no interior de um perímetro retangular, assim como o projeto do Congresso de Niemeyer. [586], [587]

Conforme os estudos de Le Corbusier evoluem, as duas formas arredondadas são substituídas por um único volume de planta circular.

As formas de feição circular contidas no interior de plantas de perímetros retangulares e quadrados é recorrente na obra de Le Corbusier. Basta lembrarmos das plantas de projetos como a casa Savoye (1929) ou a casa Stein (1927) onde diversos paramentos como lavabos e escadas estão representados por formas arredondadas contidas no interior de um perímetro ortogonal.

Essa estratégia compositiva não é exclusividade dos projetos de arquitetura de Le Corbusier. Suas pinturas puristas utilizavam o mesmo código gráfico das plantas das casas: um limite puro, regular, que abriga em seu interior elementos de traçado curvo organizados a partir de eixos ortogonais que reproduzem o alinhamento do limite físico da composição, seja ele a moldura da tela ou o volume exterior da residência desenhado em planta. Podemos dizer que tanto para a pintura como para a arquitetura, Le Corbusier utiliza-se de parâmetros pictóricos.

Não bastassem as semelhanças gráficas presentes nos estudos das plantas da Assembléia de Chandigarh e do Congresso Nacional, é oportuno salientar o fato de que, em Le Corbusier, assim como em Niemeyer, essa mesma forma de traçado circular aflorará sobre a cobertura do volume regular, seja o hiperbolóide de Le Corbusier ou as cúpulas antagônicas de Niemeyer.

Enquanto no projeto de Le Corbusier o objeto dinâmico de planta circular extravasa verticalmente e rompe com o plano de cobertura do volume de planta regular, no Congresso Nacional, Niemeyer manipulará a dualidade extrema entre o plenário do Senado em cúpula, que se configura como mera saliência, e o plenário da Câmara dos Deputados, como um elemento quase exterior, que pousa na plataforma. [588], [589]

A plataforma horizontal do Congresso Nacional de Brasília, pelo seu conteúdo programático, aproxima-se da Assembléia de Chandigarh. Ambos os projetos reduzem seus programas a grandes salões circulares para os plenários e generosos espaços vazios e abertos para abrigá-los. Esse dado isolado não pode ser considerado como fator de semelhança intrínseca aos projetos, pois se trata do programa elementar destinado a espaços de assembléias e de convenções.

Os projetos se aproximam no instante em que percebemos que as estratégias de articulação do programa em planta são as mesmas, isto é: o plenário corresponde a uma forma circular solta no vazio necessário ao equilíbrio do conjunto.

O raciocínio comum que rege os espaços em planta da Assembléia de Chandigarh e do Congresso Nacional de Brasília também pode ser diagnosticado na manipulação da forma. Tanto Le Corbusier como Oscar Niemeyer elegem justamente o recinto do plenário como índice expressivo

433 o encontro de 1955: Síntese e Monumentalidade 

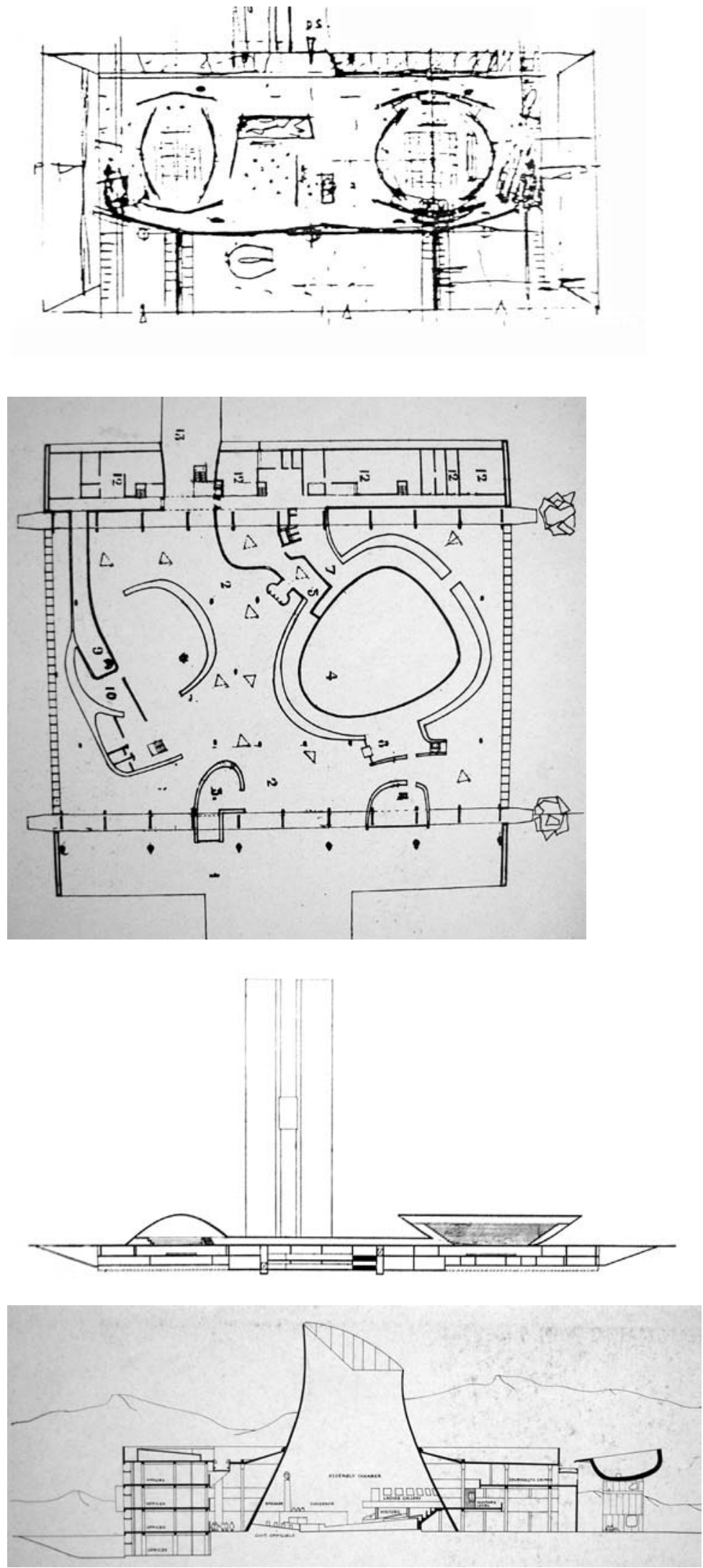

[586] Congresso Nacional - estudos - 1957 - ON

(KATINSKY, 1990:sn)

[587] Assembléia de Chandigarh - versão preliminar - 1951 - LC (BOESIGER, 1953:137)

[588] Congresso Nacional de Brasília - corte longitudinal - 1958 - ON (Revista Módulo 09, fevereiro/1958:19)

[589] Assembléia de Chandigarh - projeto definitivo - corte - 1955 - LC

(BOESIGER, 1965:90) 
do conjunto que estabelecerá uma relação de contraste com volume regular que em Le Corbusier é abrigo, membrana envoltória, mas em Niemeyer é plataforma, embasamento. [590], [591]

Da mesma maneira que em Pampulha - quando Niemeyer rompe com a estanqueidade cubista do Le Corbusier das "casas brancas" - em Brasília, Niemeyer depura os componentes elementares de Chandigarh: a caixa de pilares escultóricos que abriga a caixa do programa propriamente dito e o plenário circular que emerge de dentro da caixa de pilares.

Ao reorganizar esses elementos, Niemeyer subverte a condição formal dos projetos de Le Corbusier. Esse tipo de intervenção remonta à experiência do MES, quando o jovem arquiteto brasileiro desmembra em elementos puros aquilo que, nas propostas de Le Corbusier, era conseqüência da interseção de volumes que estavam longe de serem completamente independentes.

Em seu projeto para o Centro Cultural em Le Havre ${ }^{143}$ (1972), conhecido pelos franceses como "Le Volcan”, Niemeyer retoma a solução dos dois volumes circulares internos ao limite regular, só que, dessa vez, ao invés das cúpulas, utilizará o sólido que deriva da matriz hiperbólica presente na Assembléia de Le Corbusier.

No projeto em Le Havre, a contensão do perímetro regular que abriga os dois volumes de planta circular - de maneira oposta da Assembléia de Le Corbusier - é constituída por uma subtração. Os dois volumes hiperbolóides emergem de uma praça rebaixada quatro metros com relação ao entorno. Aquilo que em Chandigarh é um volume retangular e vazado em Le Havre é apenas o contorno de uma escavação. [592], [593]

A solução da forma livre como elemento dinâmico que aflora da cobertura de volumes puros permeará diversos projetos de Le Corbuiser: os para-ventos na cobertura da casa Savoye (1929); os volumes de traçado irregular na cobertura do projeto para o MES (1936 - versão para o terreno a beira mar); o reservatório de água de planta amebóide que emerge ascendente e o ginásio em abóbada presentes na Unité d’Habitation (1947).

O Palácio do Governo de Chandigarh (não construído) possui a cobertura "coroada" com uma peça com curvatura côncava em catenária. A própria idéia da cobertura côncava permeia o imaginário de Le Corbusier em seu período tardio: as coberturas da Capela de Ronchamp e do Pavilhão dos estudantes em Firminy e a marquise do projeto definitivo da Assembléia de Chandigarh.

Segundo Kenneth Frampton,

A estrutura dominante de concreto em forma de concha de Ronchamp repetia o perfil do telhado em catenária em lona e cabo do pavilhão de 1937 (Pavillon des Temps Nouveaux). A repetição desse perfil no Capitólio de Chandigarh e em outros momentos de sua obra posterior dá a impressão de que Le Corbusier estava tentando estabelecer essa forma como equivalente, no século XX, à cúpula renascentista, isto é, como um signo do sagrado (FRAMPTON, 1997:276).

Em outras situações presentes nos estudos de Le Corbusier para o Capitólio de Chandigarh



435 o encontro de 1955: Síntese e Monumentalidade 



[590] Assembléia de Chandigarh - projeto definitivo planta - 1955 - LC

(BOESIGER, 1965:88)

[591] Congresso Nacional de Brasília - planta - projeto definitivo - $1958-\mathrm{ON}$

(Revista Módulo 09, fevereiro/1958:21)


[592] Centro Cultural em Le Havre - França - implantação - 1972 - ON

(UNDERWOOD, 2002:115)

[593] Centro Cultural em Le Havre - França - 1972 - ON (UNDERWOOD, 2002:114) 
encontramos a matriz gráfica e formal de outros elementos concebidos por Niemeyer para Brasília.

O monumento para Chandigarh caracterizado por um "T" simétrico de proporção horizontal e com balanços proeminentes encontrará rebatimento no projeto de Niemeyer para o Museu da Fundação de Brasília, cuja solução também é baseada em “T”' horizontal, porém assimétrico. Esse tipo de solução pode ser diagnosticada em um outro projeto de monumento de Le Corbusier: o Monumento à memória de Vaillant-Couturier em Paris, cujo projeto data de 1937. [594], [595], [596]

A própria concepção do volume hiperbolóide, tão investigada por Le Corbusier nos estudos para a Assembléia de Chandigarh, encontrará paralelo em outra experiência de Niemeyer em Brasília: a Catedral Metropolitana, caracterizada por um volume hiperbolóide que resulta da extrusão radial em dezesseis peças com perfil encurvado.

O arranjo radial de Niemeyer para a Catedral contraria a volumetria opaca do hiperbolóide da Assembléia de Chandigarh e confere um sentido vazado àquilo que, em Le Corbusier, assume a condição eminente de volume.

Apesar do evidente contraste entre a Catedral de Niemeyer e a Assembléia de Le Corbusier, devemos lembrar que em algumas publicações do arquiteto europeu, a maquete de estudo referente ao volume hiperbólico da Assembléia não se apresenta como uma volumetria cega, como observamos no projeto concluído, mas é completamente permeável e vazada, por conseqüência da utilização de varetas tramadas umas as outras e sutilmente torcidas.

Nesses estudos de modelos de Le Corbusier, observamos uma transparência que não estará presente no projeto definitivo para a Assembléia, mas em compensação se aproximará da solução de Niemeyer para a Catedral de Brasília. [597], [598]

A maquete do volume hiperbolóide da Assembléia de Chandigarh, caracterizada pela superfície vazada, foi publicada no sétimo volume da Obra Completa de Le Corbuiser. A fotografia publicada não fazia referência ao projeto para Chandigarh, mas tinha o objetivo de mostrar o ambiente de trabalho de Le Corbusier. Trata-se de uma fotografia do atelier do arquiteto em Paris. Podemos intuir que Niemeyer não apenas apreciou o modelo de Le Corbusier presente em uma das páginas do sétimo volume de sua obra completa, como, provavelmente, deve ter observado esse modelo no próprio atelier parisiense.

Em um estudo para a elevação do edifício do Secretariado de Chandigarh, Le Corbusier suspende a lâmina com a adoção de uma seqüência de pilares que se afunilam em direção ao solo. Niemeyer, em uma versão preliminar para a lâmina padrão dos edifícios ministeriais (relação forma/programa que corresponde ao Secretariado de Le Corbusier) procederá de maneira semelhante ao propor o edifício solto, apoiado sobre pilares facetados e pontiagudos voltados para o solo. [599], [600]

A análise proposta reforça o ponto de vista que atribui aos estudos de Le Corbusier para o Capitólio de Chandigarh - principalmente aqueles publicados nos volumes de sua Obra Completa - um papel fundamental para as decisões de Niemeyer em Brasília.

Assim como o Conjunto da Pampulha representa a construção de um repertório formal

437 | o encontro de 1955: Síntese e Monumentalidade 

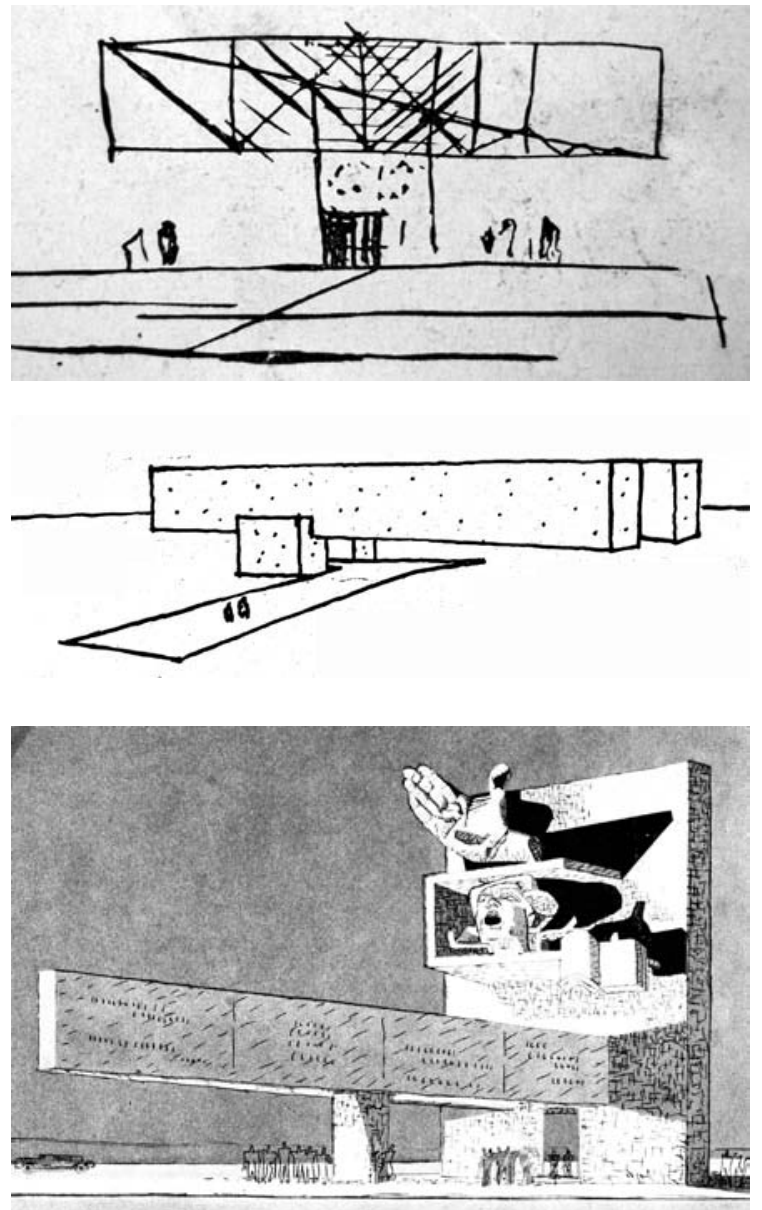

[594] Monumento em Chandigarh - 1952 - LC (BOESIGER, 1953:149)

[595] Museu da Fundação de Brasília - 1958 - ON (Revista Módulo 12, fevereiro/1959:36)

[596] Monumento à memória de Vaillant-Couturier Paris - 1937 - LC

(BOESIGER, 1946:11)
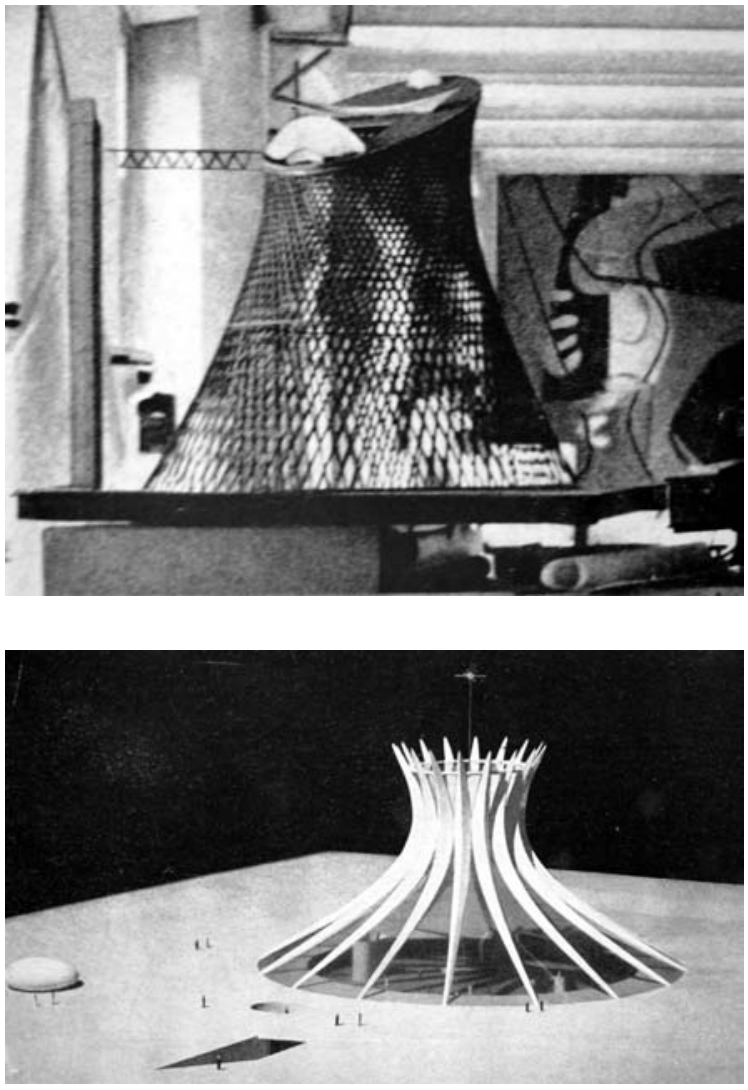

[597] Assembléia de Chandigarh - maquete - 1955 - LC fotografia do atelier de Le Corbusier: 35, rue de Sèvres, à Paris.

(BOESIGER, 1965:13)

[598] Catedral Metropolitana de Brasília - maquete $1958-\mathrm{ON}$

(Revista Módulo n.11, dezembro/1958:14) 
elaborado a partir da interpretação dos elementos presentes nos projetos de Le Corbusier realizados até 1930, Brasília também é conseqüência de uma interpretação, não mais dos projetos de Le Corbusier realizados nas primeiras décadas do século XX, mas de sua experiência em Chandigarh com as formas monumentais, simbólicas e solenes implantadas em um vazio que reforça a sua condição de monumento. Nesse instante, Niemeyer não apenas revê seus procedimentos, mas formula um segundo rol de soluções formais.

Em dois momentos distintos, Niemeyer encontra em Le Corbusier a direção para legitimar sua produção. Os encontros de 1936 e 1955 representam os dois instantes em que Niemeyer, ao interpretar as soluções corbusianas, define o conjunto de estratégias que caracterizará sua obra.

A partir de 1955, a leitura de Niemeyer sobre a obra de Le Corbusier se aproximará daquela realizada quinze anos antes, em 1940, quando o arquiteto brasileiro assimila os estilemas puristas presentes nos projetos de Le Corbuiser realizados até 1930, e os transforma em protagonistas da experiência de Pampulha. Nessa ocasião, Niemeyer reverterá, em linha e gesto, a espacialidade estanque presente nos exemplares das casas brancas de 1925 e 1929, projetos que, apesar de expressarem um evidente desejo de expansão, encontram seu limite na membrana exterior exata.

Em Pampulha, Niemeyer expõe ao meio externo as formas encurvadas que Le Corbusier, invariavelmente, preservava contidas no interior de volumes de matriz purista. Com essa operação, Niemeyer transforma o componente plástico no próprio edifício.

Em Brasília, Niemeyer continua a interpretar os modelos de Le Corbusier. Só que, nesse caso, o modelo purista alicerçado no esquema Dom-Ino é substituído pelas experiências que fundem memória e simbolismo.

Devemos lembrar que esse raciocínio de Niemeyer - que transforma os modelos de Le Corbusier em sutis perfis que incorporam superfície, forma e espaço - não teve sua origem no projeto do conjunto da Pampulha, mas nasceu das intervenções cruciais de um jovem arquiteto sobre a proposta de "Jeová"144 para a sede do MES.

Em ambos os casos - Pampulha e Brasília - Niemeyer discute os estilemas presentes na obra de Le Corbusier: seja a condição de apêndice expressivo, inerente aos fechamentos encurvados presentes nas "casas brancas" da década de 1920, seja a ordem clássica, embrutecida e monumentalizada em Chandigarh.

Sem se desvencilhar dos códigos de uma arquitetura moderna de filiação corbusiana, Oscar Niemeyer institui uma possibilidade de liberdade a uma arquitetura caracterizada pela tensão entre o apelo plástico da abstração pictórica e a revolução da técnica.

Enquanto Le Corbusier rompe com a face do volume para demonstrar uma liberdade só possível graças à técnica, Niemeyer rompe com a integridade física do próprio volume.

Em Chandigarh e Brasília, tanto Le Corbusier como Oscar Niemeyer concebem os palácios a partir da adoção de perímetros regulares. Le Corbusier elabora superfícies vazadas, conseqüência do peristilo de pilares preenchido por brises, enquanto Niemeyer, ao recuar os fechamentos

144. "Oscar, que se revelou de repente - depois de sua partida - a estrela do grupo, é o principal responsável e espera, comovido, certamente - como todos nós aliás o OK de Jeová.”(COSTA apud LISSOVSKY, 1996:137)

439 | o encontro de 1955: Síntese e Monumentalidade 

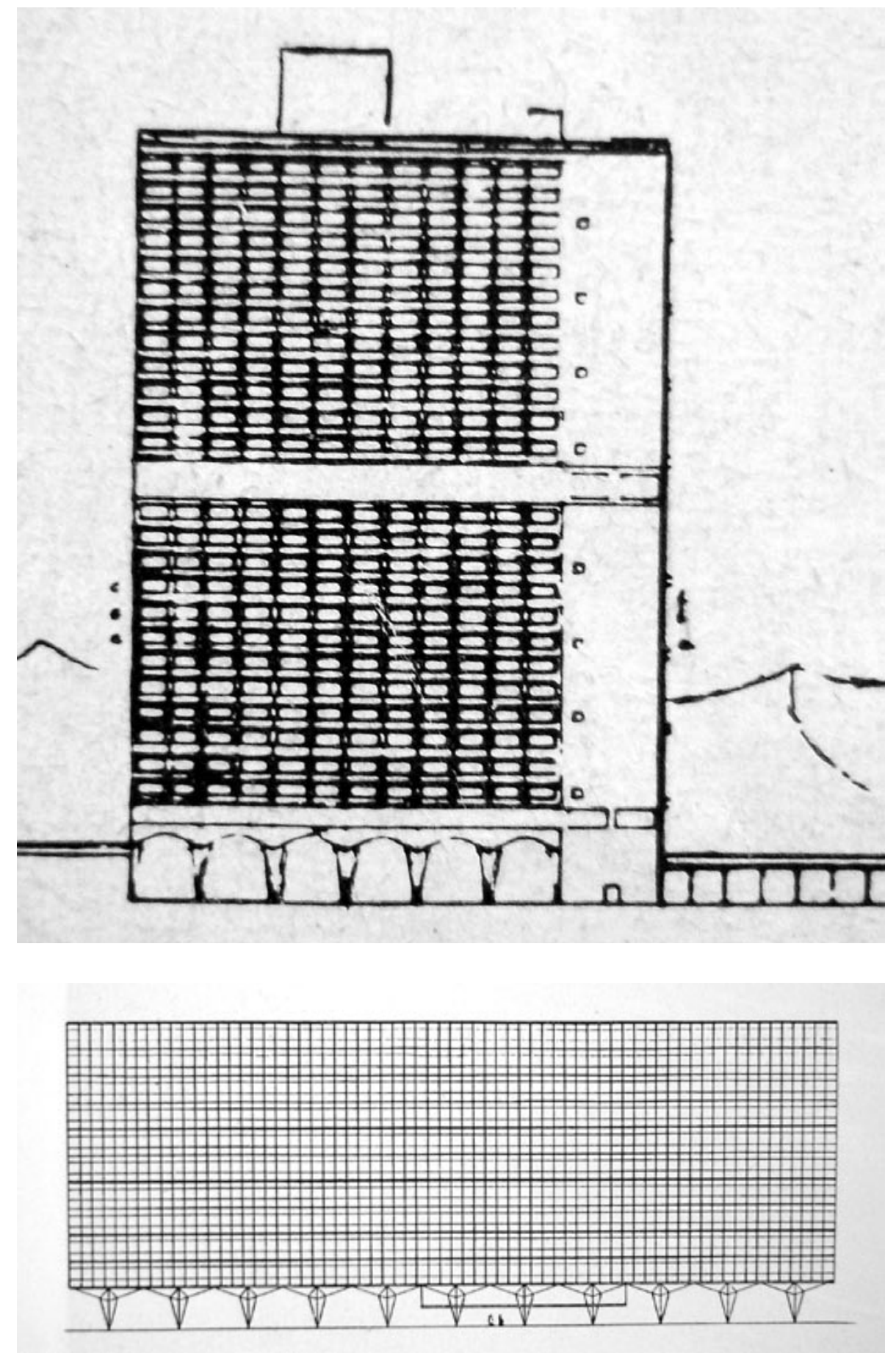

[599] Secretariado - Chandigarh - 1951 - LC

(BOESIGER, 1953:134)

[600] Edifício Ministerial - Esplanada dos Ministérios - 1958 - ON

(BOTEY, 1996:138) 
transparentes para o interior das lajes de piso/plataforma e cobertura, não evidencia o volume, mas apenas os perfis encurvados dos apoios e as espessuras dos grandes planos horizontais.

Nos Palácios de Brasília, a espessura vira linha, e a obra construída corresponde exatamente àquilo que a originou: o desenho. 



\section{considerações finais}

Ao término desse trabalho, com o qual se procurou estabelecer uma leitura comparativa entre os projetos de Oscar Niemeyer e Le Corbusier, podemos afirmar que os encontros entre os arquitetos desempenharam um papel fundamental nas transformações ocorridas em suas trajetórias pessoais.

A leitura comparada das obras de Oscar Niemeyer e Le Corbusier nos permite situá-las em um contexto espaço/tempo compreendido como suporte para um trânsito de conhecimentos que ocorre em uma via de mão-dupla, de onde emerge uma relação de influência e contra-influência configurada pelos encontros de 1936, 1947 e 1955.

Em seus estudos para o projeto da Sede do Ministério da Educação e Saúde no Rio de Janeiro, realizados em 1936, Le Corbusier aponta para uma direção que funde as dimensões técnica e plástica em uma nova configuração formal que supera o aparente pragmatismo de seus grands travaux da década de 1920 (que foram adotados como referência pela equipe de jovens arquitetos para a realização do primeiro estudo para o MES, antes da chegada de Le Corbusier, batizado de "múmia" pelo mestre franco-suíço).

Ao debruçar-se novamente sobre o projeto do MES, após o retorno de Le Corbusier para Paris, Oscar Niemeyer transfere o foco do referencial corbusiano aplicado na "múmia" - tributário a projetos como a Liga das Nações em Genebra (1927) e o Palácio dos Sovietes em Moscou (1929), caracterizados pela organização ortogonal entre lâminas retangulares e o volume trapezoidal da assembléia - para uma nova perspectiva que aponta para uma relação dialética de respeito e ruptura com códigos arquitetônicos como o esquema Dom-ino e os cinco-pontos.

A livre interpretação de Niemeyer sobre os postulados de Le Corbusier no MES, ainda que sutilmente transgredidos, ${ }^{1}$ assume um maior grau de autonomia e independência no projeto para o Pavilhão do Brasil na Feira Internacional de Nova York (1938/1939), realizado em parceria com

1. Como podemos observar no afrouxamento da retícula de pilares do bloco de exposição para o encaixe do volume trapezoidal do auditório e nas curvaturas ondulantes dos volumes da casa-de-máquinas na cobertura do vestiário no térreo.

$443 \mid$ considerações finais 
Lucio Costa, onde o corpo horizontal suspenso e transparente do salão de exposições representa um desdobramento ondulante da trama reticular levemente esgarçada presente no bloco de exposições do MES.

Tanto a delicada curvatura do bloco de exposições do Pavilhão, como as divisões internas e os pequenos volumes encurvados presentes no jardim interno e na entrada do Pavilhão representam uma versão prototípica daquelas formas que seriam utilizadas por Niemeyer no projeto do Conjunto arquitetônico da Pampulha (1940/1943), em edifícios como o Cassino, a Casa de Baile e o Hotel Resort.

No Pavilhão do Brasil e em Pampulha, Niemeyer promove à condição de edifício àquelas formas que Le Corbusier preserva como instância gestual interna a um esquema compositivo purista, onde as formas encurvadas dos lavabos, escadas, pára-ventos e reservatórios na cobertura, expressam, em planta, uma organização que dialoga com suas próprias pinturas, onde o perímetro da forma - seja a moldura da pintura ou o limite exterior da arquitetura - retém a composição curvilínea. A aparência volumétrica da construção é conseqüência de um procedimento de extrusão, tanto do perímetro ortogonal da planta, como dos contornos curvilíneos presentes na cobertura e nos fechamentos internos.

Nos projetos posteriores à experiência do MES, Niemeyer dilata a escala e torna exterior aquelas volumetrias que Le Corbusier mantém como índice gráfico e formal interno a um esquema ortogonal maior, cujo aspecto exterior atesta a predileção de Le Corbusier pelo volume como suporte para intervenções subtrativas e aditivas que, por mais inusitadas que possam parecer, preservam a identidade volumétrica da forma.

Em 1947, na cidade de Nova York, no segundo encontro entre Le Corbusier e Oscar Niemeyer, o "mestre" toma contato não apenas com a obra de um "discípulo atento" mas, principalmente, com uma arquitetura que apontava para a possibilidade de uma nova vertente para sua própria trajetória que, a partir desse ano, passaria por um nítido processo de transformação, onde tanto os esquemas puristas como aqueles que dialogam com o vernáculo dão lugar a uma obra cuja dimensão plástica apresentaria um nítido teor escultórico.

Os projetos de Niemeyer que sucedem seu encontro com Le Corbusier no Rio de Janeiro em 1936, apesar de representarem um esgarçamento poético dos estilemas puristas presentes nos projetos de Le Corbusier realizados durante a década de 1920, preservam um evidente nexo de linguagem com a obra do "mestre".

Em Nova York, ao ser apresentado à obra de Niemeyer pós-MES, Le Corbusier não apenas reconhece a presença de sua arquitetura nos projetos realizados pelo "discípulo", como também, assimila as transgressões sobre o modelo purista como uma possível direção para uma obra que assumiria um novo grau de expressividade e liberdade plástica já em 1947, na própria cidade de Nova York, onde Le Corbusier concebe os primeiros esboços para a Capela de Ronchamp. Nesse instante a direção da influência "mestre/discípulo" muda de sentido.

Os edifícios que integram o Conjunto Arquitetônico da Pampulha, além de representarem a emancipação plástica de soluções formais presentes nos projetos de Le Corbusier, fundam um 
vocabulário formal que será disseminado por Niemeyer em todos os projetos que sucedem a experiência mineira. As abóbadas sucessivas, os pilotis e as coberturas em "V", as marquises sinuosas e as lâminas encurvadas transformam-se em componentes versáteis que se adaptam as mais diferentes escalas, abrigando todo tipo de programa. A utilização exaustiva desses componentes formais torna previsível aquilo que, em Pampulha, possuía o frescor da novidade.

A transposição da obra-prima à condição de modelo não passará desapercebida nas críticas de Luis Saia e Max Bill, que acusam uma certa previsibilidade subjetiva naquilo que Niemeyer chama de "invenção".

A partir de 1955, Oscar Niemeyer inicia um processo de revisão crítica de sua própria obra. A utilização desmedida do já desgastado vocabulário formal lançado em Pampulha dá lugar à soluções formais concisas e simplificadas que fundem o partido formal à concepção da estrutura.

O início da auto-crítica de Niemeyer coincide com sua primeira viagem à Europa onde, além de realizar um projeto de edifício habitacional em Berlim, faz palestras e abre uma exposição sobre arquitetura brasileira em Moscou. Nessa mesma viagem, Niemeyer visita Le Corbusier em seu escritório em Paris, onde toma contato com os estudos do arquiteto franco-suíço para os palácios de Chandigarh.

A fusão entre síntese plástica, monumentalidade e simbolismo, presente nos edifícios do capitólio de Chandigarh, será transformada por Niemeyer em um palácio tipológico que, já a partir de 1956, será aplicado e redesenhado nos projetos para os palácios de Brasília.

Tanto em 1936, no Rio de Janeiro, como em 1955 em Paris, Le Corbusier sinaliza para Niemeyer perspectivas projetuais distintas que se prestarão como um arcabouço formal elementar que será especulado pelo arquiteto carioca nos projetos que sucedem os encontros com o "mestre".

Em 1936, Niemeyer assimila o vocabulário formal corbusiano como instrumento para a elaboração de uma arquitetura que rompe com a aparente estanqueidade tributária ao purismo, justamente no instante em que dilata à escala do edifício aquelas formas que Le Corbusier preserva enclausuradas no interior de raciocínio de matriz pictórica. Será esse procedimento de transfiguração da plástica corbusiana, associado a estratégias de organização dessas formas no espaço que caracterizará a arquitetura de Niemeyer pré-Brasília.

O oportuno encontro com Le Corbusier em 1955, em Paris, clarifica uma direção para a trajetória de Niemeyer que sinalizava para uma suposta crise ilustrada pela exaustiva utilização do vocabulário formal lançado em Pampulha, diagnosticado por Luis Saia como "meia dúzia de soluções formais" associadas a "algumas palavras de poder mágico: 'brise-soleil', 'colunas em 'V', 'pilotis', 'amebas', 'panos contínuos de vidro', 'moderno', 'funcional', etc.” (SAIA apud XAVIER, 2003:228)

Em 1955, a direção do trânsito da influência entre "mestre" e "discípulo" retoma o sentido do encontro de 1936. No encontro em Paris, assim como no encontro do Rio de Janeiro, o "discípulo" busca na obra do "mestre" uma direção para sua própria obra. Enquanto no primeiro encontro, Niemeyer estrutura sua própria linguagem no instante em que transporta a dimensão compositiva de componentes formais corbusianos à escala do edifício, no terceiro encontro, o

$445 \mid$ considerações finais 
arquiteto brasileiro encontra novamente na obra de Le Corbusier a perspectiva para uma obra que passava por um necessário processo de revisão, onde a noção de edifício como conseqüência do arranjo dos elementos integrantes do vocabulário formal lançado em Pampulha dá lugar a soluções simplificadas, cujo sentido de síntese e pureza, permite conduzi-las à condição de monumento.

O paulatino processo de autonomia de Niemeyer com relação ao referencial corbusiano é conseqüência de um livre procedimento de interpretação que subsidia a formulação de uma linguagem arquitetônica singular. Niemeyer nunca encarou tal interpretação como um exercício de mimetismo. Ao contrário, para Niemeyer, a matriz corbusiana se presta como um tema a ser transgredido.

Ao desmembrar a lógica estanque da volumetria corbusiana, Niemeyer, não apenas estrutura sua própria linguagem, como funda uma idéia de forma moderna e brasileira. Por outro lado, a pronunciada liberdade plástica que delineia toda a obra de Niemeyer não deve ser compreendida apenas como conseqüência de uma operação de contraponto com o legado racionalista das vanguardas modernas. Le Corbusier nunca se furtou de conferir um caráter plástico a suas obras, mesmo que, em um primeiro momento, estivessem subordinadas a um raciocínio de matriz cubista, no qual a expressividade da forma é conseqüência tanto do diálogo como do enfrentamento entre rąão e liberdade, de onde, justamente, emana do caráter plástico de sua arquitetura. Nesse sentido, poderíamos dizer que Niemeyer não estrutura sua própria linguagem apenas a partir de um procedimento de contraposição à aparente configuração purista dos projetos de Le Corbusier, mas apreende da arquitetura do "mestre" o potencial plástico contido em um esquema que conjuga a contensão ortogonal da forma exterior à gestualidade compositiva dos elementos de traçado curvilíneo.

Poderíamos intuir que o processo de assimilação da liberdade plástica como instância de tensionamento entre forma e paisagem e a conseqüente adoção da noção de forma livre não deve ser considerado como privilégio de um ideário impregnado na arquitetura de Oscar Niemeyer.

A bordo do navio Lutétia, que o levava de volta a Europa de sua primeira experiência latinoamericana em dezembro de 1929, Le Corbusier relata suas impressões sobre o território americano no texto Precisões: sobre um estado presente da arquitetura e do urbanismo. Em uma de suas passagens, Le Corbusier discorre sobre a "lei do meandro". Segue trecho do autor:

Aqui está a "lei do meandro":

Desenho um rio. O objetivo é preciso: ir de um ponto a outro, rio ou idéia. Surge um incidente ínfimo - as incidências do espírito: na seqüência um pequeno cotovelo que mal se nota. A água desvia para a esquerda e faz com que a margem desmorone; de lá, por causa do incidente, a água desvia para a direita. Então a linha reta deixa de existir. À esquerda, à direita, sempre mais fundo, a água corrói, escava, causa desmoronamentos, cada vez mais alargada, a idéia reconhece o campo. A linha reta tornou-se sinuosa; a idéia está provida de incidentes. A sinuosidade caracteriza-se, o meandro se desenha (...). O ímpeto inicial foi respeitado: chegou-se ao objetivo final, mas através de que caminhos! (LE CORBUSIER, 2004:143, grifo nosso) $)^{2}$

2. In Precisões: sobre um estado presente da arquitetura e do urbanismo / Le Corbusier. Edição original 1930 - Edição atual: Cosac Naify, 2004. 
Le Corbusier adota o percurso sinuoso de um rio como metáfora para justificar a forma livre como configuração mediadora entre arquitetura e lugar. A conseqüência mais eloqüente desse enfrentamento espontâneo entre o edifício e o território, se traduz no plano urbanístico de Le Corbusier para a cidade do Rio de Janeiro - realizado nessa mesma "expedição" de 1929 pelo continente americano - onde o contorno gestual das lâminas sinuosas, conseqüência da concordância entre curvas e retas, desenha o encontro da plissada topografia carioca com o mar, aglutinando em um mesmo gesto os projetos do objeto e da cidade, fato que torna difuso o limite entre escalas da arquitetura e do urbanismo.

Segundo Kenneth Frampton,

Em 1929, antes de concluir seus projetos para a "cidade radiosa", Le Corbusier visitou a América do Sul, onde, transportado pelos aviadores pioneiros Mermoz e Saint-Exupéry, teve a estimulante experiência de admirar uma paisagem tropical vista do ar. A partir desse vantajoso ponto de observação, o Rio de Janeiro impressionou-o como uma cidade linear natural, colocada como uma estreita faixa ao longo de sua "corniche", com o mar de um lado e, do outro, rochas vulcânicas íngremes. A forma desse terreno urbano parece ter sugerido espontaneamente a idéia da cidade-viaduto, e Le Corbusier imediatamente esboçou uma extensão do Rio em forma de uma via costeira de cerca de seis quilômetros de comprimento, cem metros acima do solo e compreendendo quinze andares de "lugares artificiais" para uso residencial (...). (FRAMPTON, 1997:218, grifo nosso)

Essa noção de projeto de arquitetura urbana que rompe com o pragmatismo da trama ortogonal como campo invisível para a organização da forma, presente no projeto de Le Corbusier para a cidade do Rio de Janeiro, abre uma nova perspectiva para a relação entre forma e paisagem na arquitetura moderna brasileira ao fundir o aprendizado de quem especula o território ainda desconhecido, agora visto de cima, à idéia de ocupação contundente e gestual, quase como uma nova "conquista" do continente americano a partir de um diálogo poético entre arquitetura e geografia.

Assim como na "lei do meandro", na primeira experiência carioca de Le Corbusier, "a linha reta deixa de existir (...) tornou-se sinuosa". Ao enfrentar uma paisagem de exuberância ofuscante, apreendida a partir de uma perspectiva aérea, Le Corbusier abre mão da regularidade ortogonal nos blocos à rendent, presentes em projetos como a Cidade para três milhões de habitantes (1922), e realiza um projeto onde a curva não se comporta como componente integrante de uma totalidade pura, mas caracteriza o projeto em sua própria gênese formal.

Segundo Le Corbusier, a liberdade impregnada nessa relação de aderência quase corpórea entre o projeto do edifício e o lugar é conseqüência de uma partida jogada "a dois, uma partida 'afirmação-homem' contra ou com a 'presença-natureza”. (LE CORBUSIER, 2004:236)

Em que pese a afirmação do presente trabalho, que aponta para a arquitetura de Niemeyer como conseqüência de um exaustivo redesenho do legado purista de Le Corbusier, devemos salientar que o novo grau de expressão formal resultante do franco diálogo homem/natureza, presente no projeto de arquitetura urbana concebido por Le Corbusier em 1929 no Rio de Janeiro (realizado sete anos antes do primeiro encontro com o arquiteto brasileiro) também pode ser compreendido

447 | considerações finais 
como uma chave estética para a construção do ideário formal presente na própria arquitetura de Niemeyer, que encontra na curva o nexo gráfico e formal com a paisagem brasileira.

Assim como Le Corbusier na "lei do meandro", Oscar Niemeyer, em seu "poema da curva", discorre sobre os atributos da paisagem brasileira como sua fonte de inspiração:



Após a leitura comparada das obras de ambos os arquitetos, realizada dentro de uma cronologia linear, somos induzidos a acreditar que um dos grandes legados deixados por Le Corbusier para a arquitetura moderna brasileira tenha sido a própria obra de Oscar Niemeyer.

Quando interpreta os procedimentos projetuais de Le Corbusier, através de um redesenho de seu próprio vocabulário formal, Niemeyer não apenas estrutura sua própria linguagem, como desvenda a abrangência pedagógica da obra do "mestre" e a assimila como "escola". Por outro lado, é evidente que a obra de Niemeyer não deve ser encarada como uma mera tradução pessoal dos estilemas formais corbusianos. Niemeyer encontra a direção de sua obra no instante em que inverte as dimensões da superfície, da forma e do espaço impregnadas no ideário de Le Corbusier. E será justamente esse exercício de "inversão" que legitimará aquilo que Niemeyer chama de "invenção".

Acreditamos que efetiva contribuição da obra de Niemeyer para a arquitetura moderna brasileira não resida apenas em sua contundente proficiência plástica, cujo vocabulário se disseminou aos quatro cantos. Talvez o grande ensinamento por trás da "invenção" apregoada por Niemeyer não seja a forma em si, mas o raciocínio gerador de um gesto que assimila arquitetura e paisagem como uma mesma "construção", onde as superfícies, do chão e do horizonte incorporam-se ao perfil da arquitetura como uma continuidade única, sem interrupção. Nesse sentido, poderíamos dizer que a arquitetura de Niemeyer frutifica um desejo que brota de seu próprio desenho, cujo campo é um só, papel ou paisagem.

Quando inverte a lógica estanque da arquitetura de Le Corbusier, Niemeyer desfigura a objetividade volumétrica da forma, transpondo-a para um outro patamar de complexidade, onde a abertura não representa uma operação subtrativa sobre o volume, mas expande-se ao limite físico da forma. Com essa operação, Niemeyer transforma o volume corbusiano em uma sutil membrana, cuja fisicalidade esbelta se adere ao desenho do arquiteto, onde a linha não confere um limite à forma, mas representa a espessura da própria forma. Tal procedimento ilustra uma pedagogia de 
construção do espaço conseqüência da dissolução da noção cubista impregnada na forma corbusiana. No instante em que expande a abertura ao limite da forma, Niemeyer deixa aparente apenas os planos envoltórios, cuja espessura, quando vista de longe, é reduzida a mera linha, ora paralela, ora tangente a linha do horizonte, exatamente como em seus desenhos.

Ao desvelarmos o ofício da arquitetura que se oculta à sombra do mito, em parte, construído pelo próprio Niemeyer, iniciamos uma simples tentativa de compreensão da obra de nosso maior arquiteto. Mas afinal, seria possível inscrever uma obra pautada pela "invenção" como um instrumento de aprendizado com a capacidade de apontar uma perspectiva para o legado moderno da arquitetura brasileira? Isso é assunto, quem sabe, para uma próxima reflexão. 



\section{bibliografia}

ANDREOLI, Elisabetta, FORTY, Adrian. Arquitetura Moderna Brasileira. Nova York: Phaidon, 2004. ARANTES, Otília Beatriz Fiori. Mário Pedrosa. Itinerário Crítico. São Paulo: Cosac Naify, 2004. ARGAN, Giulio Carlo. Arte Moderna. São Paulo: Companhia das Letras, 1993. . Projeto e Destino. São Paulo: Ática, 2001.

ARTIGAS, João Batista Vilanova. Revisão crítica de Niemeyer. In: Acrópole, 1958.

BACON, Mardges. Le Corbusier in América. Massachusetts: MIT Press, 2003.

BAKER, Geoffrey H. Le Corbusier - The Creative Search: the formative years of Charles-Edonard Jeanneret. Londres: E \& Spon, 1996.

. Le Corbusier: uma análise da forma. São Paulo: Martins Fontes, 2002.

BALTANAS, José. Le Corbusier: Promenades. Barcelona: Gustavo Gili, 2005.

BARBARA, Fernanda. Duas tipologias habitacionais: o conjunto Ana Rosa e o Edifício Copan - contexto e análise de dois projetos realizados em São Paulo na década de 1950. Dissertação de Mestrado. FAUUSP, 2004.

BARDI, Pietro Maria. Lembrança de Le Corbusier. São Paulo: Nobel, 1984.

BARNABÉ, Marcos. A poética da luz natural na obra de Oscar Niemeyer. Dissertação de Mestrado. FAU-USP, 2000.

BILL, Max. (entrevista) Max Bill, o inteligente iconoclasta. In: Habitat n.12, pp.34-35, set.1953.

. Le Corbusier et Pierre Jeanneret: oeuvre complète - 1934/1938, v.03. Switzerland, Les éditions d'architecture Erlebach-Zurich, 1947.

BENEVOLO, Leonardo. História da Arquitetura Moderna. São Paulo: Pespectiva, 1976.

BOESIGER, Willy. Le Corbusier et Pierre Jeanneret: oeuvre complète - 1910/1929, v.01. Switzerland, Les éditions d'archicteture Erlebach-Zurich, 1946 (quatrième édition).

. Le Corbusier et Pierre Jeanneret: oeuvre complète - 1929/1934, v.02. Switzerland, Les éditions d'architecture Erlebach-Zurich, 1935.

. Le Corbusier: oeuvre complète - 1938/1946, v.04. Switzerland, Les éditions d'architecture Erlebach-Zurich, 1946.

. Le Corbusier - oeuvre complète 1946-1952, v.05. Switzerland, Girsberger-Zurich, 1953.

. Le Corbusier et son atelier rue de Sèvres 35 - oeuvre complète 1952-1957, v.06. Switzerland, Girsberger-Zurich, 1957.

. Le Corbusier et son atelier rue de Sèrres 35 - oeuvre complète 1957-1965, v.07. Switzerland, Girsberger-Zurich, 1965.

. Le Corbusier: les dernières oeuvres - oeuvre complète, v.08. Switzerland, Artemis-Zurich, 1970.

451 
. Le Corbusier 1910-1965. Barcelona: Gustavo Gili, 1971.

. Le Corbusier. São Paulo: Martins Fontes, 1994.

BONDUKI, Nabil Georges. Affonso Eduardo Reidy. São Paulo/Lisboa: coleção Arquitetos Brasileiros, Instituto Lina Bo e P.M. Bardi / Editora Blau, 1999.

BORDA, Luis Eduardo. O Nexo da Forma - Oscar Niemeyer: da Arte Moderna ao debate contemporâneo. Tese de doutorado. ECA-USP, 2003.

- Vinculo da Forma: investigações sobre a interface da obra de Niemeyer com a Arte Moderna.

In: Nossa América n. 25. São Paulo: Memorial da América Latina, 2007.

BOTEY, Josep Maria. Oscar Niemeyer: works and projects. Barcelona. Gustavo Gilli, 1996.

BRILLEMBOURG, Carlos (org.). Latin American Architecture: 1929-1960. Reino Unido: Monacelli Press, 2004.

BROOKS, H. Allen. Le Corbusier's formative years. Chicago: The Universitiy of Chicago Press, 1997.

BRUAND, Yves. Arquitetura Contemporânea no Brasil. São Paulo. Perspectiva, 1999 (3a ed.).

CABRAL, Fernando Frank. À Procura da Beleza: Aprendendo com Oscar Niemeyer. Dissertação de Mestrado. São Paulo: FAU-USP, 2002.

- Auditório Simon Bolivar: A Beleza na Síntese. In: Nossa América n. 25. São Paulo: Memorial da América Latina, 2007.

CABRAL, Maria Cristina. Espaços expositivos e a emergência do novo. In: Nossa América n. 25. São Paulo: Memorial da América Latina, 2007.

CAMPELLO, Glauco. O projeto para a Embaixada da França em Brasília. In: Módulo n.96, pp.31-41, nov.1987.

CAMPOFIORITO, Ítalo. Os anos 60: Brasilia revisitada. In: Módulo n.96, nov.1987.

CAPPELLO, Maria Beatriz Camargo. Arquitetura em revista: arquitetura moderna no Brasil e sua recepção nas revistas francesas, inglesas e italianas (1945-1960). Tese de Doutorado. FAU-USP, 2005.

CARRILHO, Marcos José. Lucio Costa: Patrimônio Histórico e Arquitetura Moderna. Tese de Doutorado. São Paulo: FAUUSP, 2002.

CARVALHO, Claudia S. Rodrigues de. Edifícios modernos: preservação e restauração. Tese de Doutorado. FAU-USP, 2005.

CASANOVA, Maria; MENOR, Maria Victoria. Da Antropofagia a Brasília: Brasil 1920/1960. São Paulo: Cosac Naify, 2002.

CASTRO, Mariângela; FINGUERUT, Silvia (org.). Igreja da Pampulha: restauro e reflexões. Rio de Janeiro: Fundação Roberto Marinho, 2006.

CAVALCANTI, Lauro. Visita à arquitetura brasileira de boje. In: Módulo n.96, pp.46-57, nov.1987. - As preocupações do belo. Rio de Janeiro: Taurus, 1995.

—. (org.) Modernistas na repartição. 2a ed. Rio de Janeiro, Editora UFRJ / MinC-IPHAN, 2000.

no, 2001 . - (org) Quando o Brasil era moderno: guia de arquitetura - 1928/1960. Rio de Janeiro, Aeropla; LAGO, André Correa do. Ainda Moderno? arquitetura brasileira contemporânea. Rio de Janeiro: 
Nova Fronteira, 2005.

. Moderno e Brasileiro: a história de uma nova linguagem na arquitetura (1930-1960). Rio de Janeiro. Jorge Zahar, 2006.

- Oscar Niemeyer: Alguns projetos das duas ultimas décadas. In: Nossa América n. 25. São Paulo: Memorial da América Latina, 2007.

COLQUHOUN, Allan. Modernidade e Tradição Clássica: ensaios sobre arquitetura. São Paulo. Cosac Naify. 2004.

CORONA, Eduardo. Oscar Niemeyer: uma lição de arquitetura (apontamentos de uma aula que perdura bá sessenta anos). São Paulo: FUPAM, 2001.

CORRÊA, Marcos Sá. Oscar Niemeyer. Rio de Janeiro: Relume Dumará, 1996.

COSTA, Lucio. Lucio Costa: registro de uma vivência. São Paulo: Empresa das Artes, 1995.

- Lucio Costa: documentos de trabalho (coord. José Pessoa). Rio de Janeiro, Edições do Patrimônio, Iphan/Ministério da Cultura, 1999.

- Arquitetura. Rio de Janeiro: José Olympo, 2002.

. Lucio Costa: sôbre arquitetura (org. Alberto Xavier). Porto Alegre: Editora UniRitter, 2007.

COSTA, Maria Elisa (org.). Com a palavra, Lucio Costa. Rio de Janeiro: Aeroplano, 2001.

. (org.). Lucio Costa: 1902-2002 (catálogo da exposição). Rio de Janeiro: Paço Imperial, 2002.

CURTIS, William. J. R. Le Corbusier: Ideas and Forms. Londres: Phaidon, 2003.

CZAJKOWSKI, Jorge (org.). Jorge Machado Moreira. Rio de Janeiro: Centro de Arquitetura e Urbanismo do Rio de Janeiro, 1999.

DARLING, Elizabeth. Le Corbusier. tradução Luciano Machado. São Paulo: Cosac Naify, 2000.

DECKER, Zilah Quezado. Brazil Built: the architecture of the modern movement in Brazil. Nova York: Spon Press, 2001.

EULALIO, Alexandre. A aventura brasileira de Blaise Cendrars. São Paulo: EDUSP, 2001.

FABRIS, Annateresa. Fragmentos Urbanos: representações culturais. São Paulo: Studio Nobel, 2000.

FICHER, Sylvia e ACAYABA, Marlene Milan. Arquitetura moderna brasileira. São Paulo: Projeto, 1982.

FRAMPTON, Kenneth. Homenagem a Niemeyer. In: AU n.15, pp.58-59, 1987.

. História crítica da arquitetura moderna. São Paulo: Martins Fontes, 1997.

. Le Corbusier. Londres: Thames \& Hudson, 2001.

FREITAS, Grace de. Brasilia e o projeto construtivo brasileiro. Rio de Janeiro: Jorge Zahar, 2007.

FROLICH. Allan. Oscar Niemeyer: Selbstdarstellung Kritiken Oewre. Berlim, 1982.

GIEDION, Sigfried. O Brasil e a arquitetura contemporânea. In: MINDLIN, Henrique E. Arquitetura Moderna no Brasil. Rio de Janeiro. Aeroplano, 1999.

GIMENEZ, Luis Espallargas. Arquitetura paulistana da decada de 1960: técnica e forma. Tese de Doutorado. FAU-USP, 2004.

GOODWIN, Philip L. Brazil bulds: architecture new and old, 1652-1942. New York. The Museum of Modern Art, 1943.

. Pampulha. Rio de Janeiro: Imprensa Nacional, 1944.

GORELIK, Adrián. Das vanguardas a Brasilia: cultura urbana e arquitetura na América Latina. Belo 
Horizonte: Editora UFMG, 2005.

GOROVITZ, Matheus. Brasilia: uma questão de escala. São Paulo: Projeto/CNPq, 1985.

- Os Riscos do Projeto: contribuição à análise do juíro estético na arquitetura. São Paulo: Studio Nobel: Brasília: Editora Universidade de Brasília, 1993.

GUERRA, Abílio. Lucio Costa: modernidade e tradição - montagem discursiva da arquitetura moderna brasileira. Tese de Doutorado. IFCH-UNICAMP, 2002.

HARRIS, Elizabeth. Le Corbusier: Riscos brasileiros. São Paulo, Nobel, 1987.

HESS, Alan. Oscar Niemeyer Houses. Nova York: Rizzoli, 2006.

IMBRONITO, Maria Isabel. Monumentalidade e Programa. Revista Nossa América n. 25. São Paulo: Memorial da América Latina, 2007.

JENCKS, Charles. Le Corbusier and the continual revolution in Architecture. Nova York: Monacelli Press, 2001.

JENKIS, David. Unité d'Habitation Marseilles - Le Corbusier. Londres: Phaidon, 1993.

KATINSKY, Julio Roberto. Leituras de Arquitetura, viagens, projetos. São Paulo, Texto submetido a concurso público para a obtenção do título de livre-docente. FAU-USP, 1990.

. Brasilia em três tempos. Rio de Janeiro: Revan, 1991.

- Técnica e Arte na obra de Oscar Niemeyer. São Paulo: produção acadêmica FAUUSP, 1996.

LAGO, André Correa do. Oscar Niemeyer: uma arquitetura da sedução. Rio de Janeiro: BEI, 2007.

LE CORBUSIER. The Chapel at Ronchamp. Londres: The Architectural Press, 1960.

. Por uma arquitetura; trad. Ubirajara Rebouças. Sao Paulo: Perspectiva, 1977.

. Os três estabelecimentos humanos. São Paulo: Perspectiva, 1979.

. A Carta de Atenas. São Paulo: HUCITEC EDUSP, 1993.

. Precisões. trad. Carlos Eugênio Marcondes de Moura. São Paulo: Cosac Naify, 2004.

. A Viagem do Oriente. São Paulo: Cosac Naify, 2007.

LIMA, Evelyn Furquim Werneck. Das Vanguardas à Tradição: arquitetura, teatro e espaço urbano. Rio de Janeiro: 7Letras, 2006.

LISSOVSKY, Maurício; MORAES DE SÁ, Paulo Sérgio. Colunas da Educação: a construção do Ministério da Educação e Saúde (1935-1945). Rio de Janeiro: MinC-IPHAN-FGV-CPDOC, 1996.

LUIGI, Gilbert. Oscar Niemeyer: une esthétique de la fluidité. Marseille: Editions Parenthéses, 1987.

MAHFUZ, Edson. O Clássico, o Poético e o Erótico. Porto Alegre: Editora das Faculdades Integradas do Instituto Ritter dos Reis, 2002.

MALARD, Maria Lúcia (org.). Cinco textos sobre arquitetura. Belo Horizonte: Editora UFMG, 2005. . As Aparências em Arquitetura. Belo Horizonte: Editora UFMG, 2006.

MINDLIN, Henrique E. Arquitetura Moderna no Brasil. Rio de Janeiro: Aeroplano, 1999.

MONTANER, Josep Maria. A Modernidade Superada: arquitetura, arte e pensamento do século XX.

Barcelona: Gustavo Gili, 2001.

NIEMEYER, Oscar. Entrevista.In: Módulo n.01, março de 1955, p.47.

. A Capela de Ronchamp. In: Módulo n.05, p.45, setembro, 1956, p.45.

. Depoimento. In: Módulo n.09, pp.03-06, fev.1958. 
- Minha Experiência em Brasilia. Rio de Janeiro: Avenir, 1961.

. Le Corbusier. In: Módulo n.32, p.23, março. 1963.

- Quase memórias, viagens. Rio de Janeiro: Civilização Brasileira, 1968.

- A Forma da Arquitetura. Rio de Janeiro: Revan, 1978.

- Parque do Tietê: Plano de Reurbanização da Margem do Rio Tietê. São Paulo: ALMED, 1987.

- Meu Sósia e Eu. Rio de Janeiro: Revan, 1992.

- Conversa de Arquiteto. Rio de Janeiro: Revan, 1993.

- As Curvas do Tempo. Rio de Janeiro: Revan, 1998.

. Diálogo pré-socrático. São Paulo: Instituto Lina Bo e P. M. Bardi, 1998.

. Museu de Arte Contemporânea de Niterói. Rio de Janeiro: Revan, 1998.

- Minha Arquitetura. Rio de Janeiro: Revan, 2000.

- Serpentine Gallery Pavilion 2003. Londres: Serpentine Gallery and Trolley, 2003.

. Minha Arquitetura: 1937-2004. Rio de Janeiro: Revan, 2004.

- Casas onde morei. Rio de Janeiro: Revan, 2006.

. Universidade de Constantine. Rio de Janeiro: Revan, 2007.

OHTAKE, Ricardo. Oscar Niemeyer (Coleção Folha Explica). São Paulo: Publifolha, 2007.

OZENFANT, Amedée; JEANNERET, Charles Edouard. Depois do Cubismo. São Paulo: Cosac Naify, 2005.

PAPADAKI, Stamo. The work of Oscar Niemeyer. New York: Rheinhold Publishing, 1950.

. Oscar Niemeyer: works in progress. New York, Rheinhold Publishing, 1956.

. Oscar Niemeyer. New York: George Braziller, 1960.

PEDROSA, Mario. Dos Murais de Portinari aos espaços de Brasília. São Paulo: Perspectiva, 1981.

PEREIRA, Miguel Alves. Arquitetura, texto e contexto: o discurso de Oscar Niemeyer. Brasília: Editora UnB, 1997.

PESSOA, José; VASCONCELOS, Eduardo; REIS, Elizabete; LOBO, Maria (organizadores).

Moderno e Nacional. Niterói: Editora da Universidade Federal Fluminense, 2006.

PETIT, Jean. Niemeyer: Poeta da Arquitetura. Milão: Fidia Edizioni D’Arte, 1998.

PUPPI, Lionello. A Arquitetura de Oscar Niemeyer. Rio de Janeiro: Revan, 1988.

QUEIROZ, Rodrigo C. O Desenho de um processo: os estudos de Oscar Niemeyerpara o edifício do Congresso Nacional de Brasília. São Paulo, Dissertação de Mestrado, ECA-USP, 2003.

. O Encontro com Oscar Niemeyer. Entrevista com Oscar Niemeyer realizada em 11 de outubro de 2003 (original).

- Memorial da América Latina: Concisão e Monumentalidade. Nossa América n.23. São Paulo: Memorial da América Latina, 2006.

. (org.) Oscar Niemeyer: 100 anos. Revista Nossa América n.25. São Paulo: Memorial da América Latina, 2007.

- A Igreja de São Francisco de Assis na Pampulha: o traço moderno como abrigo da fé. In: Nossa América n.25. São Paulo: Memorial da América Latina, 2007.

. Oscar Niemeyer: forma, superfície e luz. In: L+D International Lighting Magazine n.13. São 
Paulo, 2007.

RECAMÁN, Luiz Antônio. Oscar Niemeyer: forma arquitetônica e cidade no Brasil Moderno. Tese de Doutorado. FFLCH-USP, 2002.

SALVAING, Matthieu. Oscar Niemeyer. Madrid: H Kliczkowski, 2002.

SANTOS, Cecília Rodrigues dos; PEREIRA, Margareth Campos da Silva; PEREIRA, Romão Veriano da Silva; SILVA, Vasco Pereira da. Le Corbusier e o Brasil. São Paulo: Tessela/Projeto, 1987.

SBRIGLIO, Jacques. Le Corbusier: La Villa Savoye. Madrid: Abada Editores, 2005.

SCULLY, Vincent. Arquitetura Moderna. São Paulo: Cosac Naify, 2002.

SEGAWA, Hugo. Arquiteturas no Brasil 1900-1990. São Paulo: EDUSP, 1997.

SODRÉ, Nelson Werneck. Oscar Niemeyer. Rio de Janeiro: Graal, 1978.

SPADE, Rupert; FUTAGAWA, Yukio. Oscar Niemeyer. Simon and Schuster: Nova York, 1971.

TELLES, Sophia S. Arquitetura moderna no Brasil: o desenho da superfície. São Paulo, Dissertação de Mestrado, FFLCH-USP, 1988.

. Oscar Niemeyer: técnica e forma. In: Óculum n.02. Campinas: PUCCAMP, 1992.

. O Desenho: Forma \& Imagem. In: AU n.55, 1994.

TINEN, Nelci. O alvo do olhar estrangeiro: o Brasil na historiografia da arquitetura moderna. João Pessoa: Manufatura, 2002.

TIRAPELI, Percival. Patrimônios da Humanidade no Brasil. Metalivros: São Paulo, 2000.

- Niemeyer e o Patrimônio. In: Revista Nossa América n. 25. São Paulo: Memorial da América Latina, 2007.

TSIOMIS, Yannis. Le Corbusier - Rio de Janeiro: 1929-1936. Rio de Janeiro: Centro de Arquitetura e Urbanismo do Rio de Janeiro - Prefeitura da Cidade do Rio de Janeiro, 1998.

TZONIS, Alexander. Le Corbusier: The Poetics of Machine and Metaphor. Nova York, Rizzoli, 2001.

VALLE, Marco Antonio Alves do. Desenvolvimento da forma e procedimentos de projeto na arquitetura de Oscar Niemeyer (1935-1998). Tese de Doutorado. FAU-USP. 2000.

VASQUES, Fernando. Mies Van der Rohe 1886-1969. Lisboa: BLAU, 1999.

WISNIK, Guilherme. Lucio Costa. São Paulo: Cosac Naify, 2001.

. Copan: uma cidade em São Paulo. In: Revista Nossa América n.25. São Paulo: Memorial da

América Latina, 2007.

XAVIER, Alberto (org). Depoimentos de uma geração. São Paulo: Cosac Naify. 2003.

ZEIN, Ruth Verde. O lugar da crítica: ensaios oportunos de arquitetura. Porto Alegre: Editora das Faculdades Integradas do Instituto Ritter dos Reis, 2001.

ZEVI, Bruno. Saber ver a arquitetura. São Paulo: Martins Fontes, 2000.

. Linguagem moderna da arquitectura. Lisboa: Edições 70, 2002. 
